\title{
De Idylle voorbij : verbeelding van moederschap in Nederlandse literatuur 1980 tot 2010.
}

Citation for published version (APA):

Weusten, J. L. (2011). De Idylle voorbij : verbeelding van moederschap in Nederlandse literatuur 1980 tot 2010. [Doctoral Thesis, Maastricht University]. Universitaire Pers Maastricht. https://doi.org/10.26481/dis.20111125jw

Document status and date:

Published: 01/01/2011

DOI:

10.26481/dis.20111125jw

Document Version:

Publisher's PDF, also known as Version of record

\section{Please check the document version of this publication:}

- A submitted manuscript is the version of the article upon submission and before peer-review. There can be important differences between the submitted version and the official published version of record.

People interested in the research are advised to contact the author for the final version of the publication, or visit the DOI to the publisher's website.

- The final author version and the galley proof are versions of the publication after peer review.

- The final published version features the final layout of the paper including the volume, issue and page numbers.

Link to publication

\footnotetext{
General rights rights.

- You may freely distribute the URL identifying the publication in the public portal. please follow below link for the End User Agreement:

www.umlib.nl/taverne-license

Take down policy

If you believe that this document breaches copyright please contact us at:

repository@maastrichtuniversity.nl

providing details and we will investigate your claim.
}

Copyright and moral rights for the publications made accessible in the public portal are retained by the authors and/or other copyright owners and it is a condition of accessing publications that users recognise and abide by the legal requirements associated with these

- Users may download and print one copy of any publication from the public portal for the purpose of private study or research.

- You may not further distribute the material or use it for any profit-making activity or commercial gain

If the publication is distributed under the terms of Article $25 \mathrm{fa}$ of the Dutch Copyright Act, indicated by the "Taverne" license above, 
De idylle voorbij 



\title{
De idylle voorbij Verbeelding van moederschap in Nederlandse literatuur 1980 tot 2010
}

\author{
PROEFSCHRIFT
}

ter verkrijging van de graad van doctor aan de Universiteit Maastricht, op gezag van de Rector Magnificus, Prof. Mr. G.P.M.F. Mols

volgens het besluit van het College van Decanen

in het openbaar te verdedigen

op vrijdag 25 november 2011 om 12.00 uur

door

Jos Leonarda Weusten 
PROMOTOR

Prof. dr. M.J.H. Meijer

COPROMOTOR

Dr. E. Wesseling

BEOORDELINGSCOMMISSIE

Prof. dr. J.H.W. Kusters (voorzitter)

Dr. A. Andeweg

Prof. dr. R.L. Buikema, Universiteit Utrecht

Prof. dr. G.J. Dorleijn, Rijksuniversiteit Groningen

Dr. A.M.C. Swinnen 


\section{Inhoudsopgave}

DANKWOORD

INTRODUCTIE

ONGELUK VERSUS GELUK: DE VERBEELDING VAN MOEDERSCHAP

IN LITERATUUR EN MAATSCHAPPIJ

Inleiding

De opzet van dit boek

Literaire fictie: een afbakening

New Historicism: een plaatsbepaling

\section{HOOFDSTUK 1}

DE MAATSCHAPPELIJKE IDEALISERING VAN MOEDERSCHAP 29

Inleiding 29

Populaire opvoedkundige adviesboeken $\quad 34$

Vrouwenweekbladen: Margriet en Libelle 43

Opvoedkundige tijdschriften: Ouders van Nu$\quad 47$

Reclame voor babyproducten $\quad 51$

Bredere maatschappelijke ontwikkelingen $\quad 57$

Probleemvertogen $\quad 64$

$\begin{array}{ll}\text { Conclusie } & 69\end{array}$

HOOFDSTUK 2

DE PRODUCTIE VAN FICTIONEEL PROZA OVER MOEDERSCHAP 73

Inleiding 73

$\begin{array}{ll}\text { Materiële productie } & 76\end{array}$

$\begin{array}{ll}\text { Dataverzameling } & 76\end{array}$

Thema's $\quad 83$

Sekse $\quad 99$

Genre 105

Symbolische productie 120

Opzet van de analyse $\quad 120$

Vermelding in vijf dagbladen, sekse en genre 122

Conclusie 142 


\section{HOOFDSTUK 3}

THEORETISCHE OVERWEGINGEN

Een ontmoeting tussen romaninterpretatie en literatuursociologie $\quad 145$

$\begin{array}{ll}\text { De keuze voor de vier romans } & 147\end{array}$

$\begin{array}{ll}\text { Methode } & 151\end{array}$

\section{HOOFDSTUK 4}

HET SPROOKJE VAN GENIETEN VOORBIJ? DE REIS NAAR HET KIND (1989) VAN VONNE VAN DER MEER

Inleiding

Een fantastische leeshouding

Een kwestie van kiezen

Hedonistisch moederschap

Maakbaarheidskritiek

De zichzelf opofferende moeder

\section{HOOFDSTUK 5}

ZWANGER VAN HERKENBARE SPANNING. NIEUWE BUREN (2006) VAN SASKIA NOORT

Inleiding

Seks, drugs en rock' $n$ roll in een Vinexwijk

I want it all, and I want it now...?

Een thrilleresque a-heroïsche misdaadroman

De suspense van de Vinexwijk

Coda

\section{HOOFDSTUK 6}

EEN HORMONALE TRAGEDIE. EEN HART VAN STEEN (1998) VAN RENATE DORRESTEIN

Inleiding

Een gotiek gebrek aan controle

Vergissingen en keuzes met tragische gevolgen

Een straf van God? 


\section{HOOFDSTUK 7}

EEN POËTISCHE (DE)CONSTRUCTIE VAN KINDERMOORD. MET ONBEKENDE BESTEMMING (2000) VAN MAYA RASKER

Biologische bestemmingen van moeders en vaders $\quad 229$

Schrijven en moederschap: een moeizame combinatie $\quad 231$

$\begin{array}{ll}\text { Fotografie en vaderschap: een plezierige verrijking } & 237\end{array}$

$\begin{array}{ll}\text { Poëtische meerduidigheid } & 238\end{array}$

$\begin{array}{ll}\text { Conclusie } & 244\end{array}$

$\begin{array}{lr}\text { CONCLUSIES } & 247\end{array}$

BIBLIOGRAFIE $\quad 253$

SUMMARY $\quad 271$

CURRICULUM VITAE $\quad 281$

PUBLICATIEOVERZICHT 



\section{Dankwoord}

Velen 'moederden' in de meest positieve zin van het woord mee over dit boek en over mij als promovendus. Ik wil iedereen die mij in de afgelopen vier jaar heeft geïnspireerd, geholpen en gesteund hier bedanken, waarvan ik er enkelen bij naam wil noemen.

Ten eerste gaat mijn waardering uit naar mijn promotor Maaike Meijer en copromotor Lies Wesseling. Ik kon me geen betere begeleiders wensen, waarbij ik de kunst van de interpretatie, van het schrijven en van interdisciplinair onderzoek kon afkijken. Ik kon de afgelopen jaren altijd rekenen op "gratis advies van tante Lies". In Maaike vond ik soms zelfs twee begeleiders, zo bleek wanneer ze haar mails ondertekende met 'Ciao, Vasalis' toen ze haar biografie over Vasalis schreef. Maaike, Lies, ik prijs me gelukkig dat ik getuige mocht zijn van jullie passie voor onderzoek en bedank jullie voor de geweldige kansen die jullie me hebben geboden.

Jan Willem Duyvendak ben ik erkentelijk voor zijn sociologische inbreng toen de eerste opzet van dit onderzoeksproject gestalte kreeg. De leden van de promotiecommissie, Agnes Andeweg, Rosemarie Buikema, Gilles Dorleijn, Wiel Kusters en Aagje Swinnen, bedank ik voor hun bereidheid zich in mijn proefschrift te verdiepen.

Daarnaast wil ik al mijn huidige en voormalige collega's van de Faculteit der Cultuur- en Maatschappijwetenschappen (FdCMW) bedanken, in het bijzonder van het Centrum voor Gender en Diversiteit (CGD) en van de capaciteitsgroep Letteren en Kunst (L\&K). Agnes Andeweg, Ineke Boerefijn, Mineke Bosch, Jos van Cann, Arjan van Dixhoorn, Carina Furnée, Marli Huijer, Roel van den Oever, Ruth de Kanter, Ineke Klinge, Kyoko Shinozaki, Aagje Swinnen en Yvonne Winants voorzagen verschillende hoofdstukken van commentaar. Mineke en Lies wil ik bovendien bedanken voor het feit dat zij mij voor het eerst lieten kennismaken met gender studies. Hans Schmeets, Rik Linssen en Tessa Fox hielpen me bij kwantitatieve analyses. De gerichte vragen van onder meer Karin Bijsterveld, Ulrike Brunotte, Marietje Kardaun, Wiel Kusters, Jack Post, Jan de Roder en Renée van de Vall en de leden van het facultaire Overleg Team Onderzoek hielpen mij verder op weg. Met collega's Nico Baakman, Eefje Cleophas, Phillipp Dorstewitz, Elena Fronk, Annette Hendrikx, Annnelies van der Horst, Karin de Kroes, Chris Leonards, Wiebe Nauta en Akke Visser had ik verhelderende gesprekken over het doen van onderzoek en carrière en de minder verheven zaken van het leven. Wilma Lieben was een cruciale steun en toeverlaat. Bij haar kon ik altijd terecht voor een bemoedigende opmerking. Wilma, jij maakte het schrijven van dit proefschrift door je warme belangstelling absoluut leuker en gemakkelijker. Ook wil ik de promovendi, de coördinator (Geert Somsen) en de vorige en huidige directeur (Rein de Wilde, Thomas Conzelmann en Tsjalling 
Swierstra) van de facultaire Graduate School hier vermelden, net als de promovendi van de AIO-soep. Verder ben ik de docenten en aio's van de Nederlandse Onderzoekschool Vrouwenstudies (NOV), de Onderzoeksschool Literatuurwetenschap (OSL) en de Amsterdamse School for Social Science Research (ASSR) erkentelijk. Daarnaast wil ik Dorel Netherlands, het Fonds Psychische Gezondheid en de redacties van Margriet en Ouders van $\mathrm{Nu}$ bedanken voor het beschikbaar stellen van beeldmateriaal en informatie over hun producten.

De studenten van het University College Maastricht (UCM) hielden mij bij de les met hun enthousiasme en vragen over mijn onderzoek. De samenwerking met de collega's van het CGD, FdCMW en van UCM maakte het geven van onderwijs bovendien zeer plezierig en leerzaam. Van mijn voormalige collega's bij de afdeling Marketing and Communications van de UM en Observant leerde ik veel over het schrijversvak. Vaardigheden die bij het maken van dit boek goed van pas kwamen.

Ook wil ik mijn (schoon)familie en vrienden noemen. Mijn moeder Tiny Gulpers nam een groot deel van de tekstredactie voor haar rekening en mijn zus Loes Weusten en haar vriend Bob hielpen me aan toegankelijke boeken en artikelen over statistiek. Liefste mama, het is zo fijn om met jou de liefde voor literatuur, kunst en taal te kunnen delen. Je leerde me op mijn creativiteit en mezelf te vertrouwen en daarvoor ben ik je enorm dankbaar. Lieve Loes, jou dank ik in het bijzonder voor jouw relativeringsvermogen en inzicht in mensen waar ik van mocht profiteren. Mijn geweldige broer Rein Weusten, die helaas al enkele jaren niet meer bij ons is, heeft mij via zijn leven geïnspireerd om onderzoek te gaan doen. Dit geldt ook over mijn dierbare, overleden grootouders, Jan en Bertha Gulpers. Zij leerden mij te volharden. Mijn vader Leo Weusten stierf voordat ik dit onderzoek kon afronden. Mijn relatie met hem was zeer moeizaam. In een bepaald opzicht heeft dat een rol gespeeld bij mijn keuze voor een onderzoek naar familierelaties. Ik weet dat hij trots op me was en ik wil hem daarom noemen. Mijn schoonmoeder Lilly Theunissen en schoonbroer en -zus Lars Theunissen en Susanne Tijssen toonden steeds interesse in mijn onderzoek. Joselien Rampen bleek de liefste onthaalmoeder die ik voor mijn dochter Veerle kon wensen. Ze maakte het mogelijk om me met een gerust hart aan dit boek te wijden. Van mijn vrienden verdienen Ralph Crützen en Ellen Rohaan het om apart genoemd te worden. Zij hielpen me met de statistische kant van het onderzoek. Met Patrick Wenmakers kon ik mijn interesse in Nederlands en literatuur delen. Hij hielp me bovendien bij het vinden van recensies. Bij mijn goede vriendin Ynke Feenstra vond ik onderdak, als ik in het westen van het land een conferentie bezocht. Het was daardoor altijd extra plezierig om naar zo'n conferentie te gaan. Alle andere niet genoemde vrienden en familieleden die mij op een of andere manier hebben gesteund, bedank ik hier eveneens.

Tot slot, wil ik de twee belangrijkste mensen in mijn leven noemen: mijn echtgenoot Noud Theunissen en mijn dochter Veerle Theunissen. Lieve Noud, jij zorgde er voor dat ik me er bewust van bleef dat er meer is in het leven dan het proef- 
schrift. Je bleef er bovendien altijd in geloven dat het boek er zou komen en dat het goed zou zijn. Je enthousiasme was groot: je las alle versies. Zelfs na het lezen van de hoofdstukken over literaire werken waarin gezinnen ontsporen, durfde je het avontuur van het ouderschap gelukkig nog steeds met me aan te gaan. Veerle, toen ik de romans na jouw geboorte opnieuw las, waren hun betekenissen intenser. Zonder jou, liefste meid, had dit proefschrift er dan ook anders uitgezien. Jij hebt het, net als mijn leven, rijker gemaakt. Ik draag dit boek aan jou op.

Josje Weusten

Kanne (B), zomer 2011 



\section{Introductie}

\section{Ongeluk versus geluk: de}

\section{verbeelding van moederschap}

\section{in literatuur en maatschappij}

\section{Inleiding}

In het in 2003 verschenen Het duister dat ons scheidt van Renate Dorrestein is de relatie tussen een moeder en haar kind ontspoord. De roman draait om Loes en haar moeder, die verder niet bij name wordt genoemd. Zij wonen in "de oude, krakende pastorie" van een dorp onder de wind van Amsterdam, samen met Ludo en Duco, "twee vriendelijke mannen van wie iedereen aanneemt dat het kamerhuurders zijn" (Dorrestein, 2003, cover). In werkelijkheid zijn het de minnaars van de moeder van Loes. Ludo en Duco denken beiden dat een van hen de biologische vader van Loes is. De zesjarige Loes zit op school en is bevriend met haar klasgenootje Thomas. Aanvankelijk lijkt alles pais en vree tussen Loes en haar moeder, maar dat tij keert snel wanneer de vader van Thomas in een stormachtige nacht wordt vermoord met een rood tekenpotlood. De moeder van Loes bekent de moord en haalt Loes er toe over om voor haar te liegen in de hoop op strafvermindering. Ze instrueert Loes om de politie te vertellen dat de vader van Thomas haar seksueel heeft misbruikt. Ondanks de leugens wordt de moeder van Loes tot twaalf jaar gevangenisstraf veroordeeld, waarvan ze er zes moet uitzitten. Loes blijft achter bij Ludo en Duco, die de permanente voogdij over haar krijgen.

Loes verkeert jarenlang in de veronderstelling dat haar moeder onterecht de schuld op zich heeft genomen. Ze meent dat zijzelf de misdaad heeft gepleegd. In de nacht van de moord is Loes namelijk stiekem uit haar huis weggeglipt om naar haar vriendje Thomas te gaan. Onderweg komt ze Thomas' vader tegen, die haar moeder blijkt te haten. Bang van hem, valt Loes hem aan met een rood kleurpotlood dat ze bij zich heeft. Ludo en Duco treffen haar op dat moment met de vader van Thomas op de grond aan, waarop zij haar naar huis sturen. Pas wanneer Loes achttien jaar is, komt ze door een confrontatie met haar eigen herinneringen en haar moeder achter de waarheid. Niet haar moeder noch zijzelf, maar Ludo en Duco hebben de vader van Thomas uit jaloezie het leven benomen. De vader van Thomas blijkt een minnaar van de moeder van Loes en de verwekker van Loes te zijn geweest. Ludo en 
Duco komen hier in de nacht dat ze de moord plegen achter. Omdat de moeder van Loes vindt dat ze de moord door haar seksuele escapades indirect heeft veroorzaakt, heeft ze er voor gekozen schuldig te pleiten en zo Ludo en Duco buiten schot te houden. Alle tussenliggende jaren wordt de relatie tussen Loes en haar moeder getekend door deze gebeurtenissen en de geheimzinnigheid die er omheen betracht wordt. De titel van roman, Het duister dat ons scheidt, verwijst naar de moord en de geheimen die tussen moeder en dochter instaan. Hieraan wordt bij herhaling gerefereerd in de roman. Een voorbeeld hiervan is de beschrijving - vanuit het perspectief van Loes - van de verhouding tussen Loes en haar moeder nadat deze haar gevangenisstraf heeft uitgezeten: "[Z]e voelde zich niet meer op haar gemak, met mij in de buurt. Er hing iets duisters en onuitspreekbaars tussen ons in dat ons als een muur scheidde" (Dorrestein, 2003, p. 241).

Niet alleen Loes en haar moeder bevinden zich in moeilijk vaarwater, ook de op het eerste oog 'normale' relaties tussen de klasgenoten van Loes en hun moeders worden vanaf het eerste hoofdstuk van een uiterst scherp randje voorzien. Deze kinderen groeien, anders dan Loes, op in 'klassieke', heteroseksuele, blanke, middenklasse kerngezinnen. De vaders verdienen in de stad de kost en de moeders zorgen thuis, in een afgelegen dorp, voor kroost en het huishouden. Die moeders zijn lang niet altijd even gelukkig met deze rolverdeling en daardoor wringt het tussen hen en hun kinderen. Dit blijkt bijvoorbeeld uit de volgende passage waarin de ruzies tussen de vaders en moeders over die situatie, vanuit de klasgenootjes van Loes, worden beschreven:

\footnotetext{
'Jij bent de hele dag weg en ik zit hier met de kinderen opgesloten!'

Dwars door de muur heen hoorden we hoe boos onze mama's waren. Ze wilden laten zien wie ze waren, aan het universum, aan onze vaders, misschien zelfs aan ons. Ze waren verdomme toch uniek, ze hadden allerlei mogelijkheden en talenten, o, meer dan gemiddeld zelfs! Na zo'n uitbarsting kon je er donder op zeggen dat ze de volgende ochtend met strakke lippen en een beschuldigende blik in hun ogen onze Liga's zouden smeren: door ons immers waren zij aan handen en voeten gebonden. (...) Wij waren het kruis dat zij te dragen hadden, dag in dag uit.

Terwijl zij binnensmonds op ons foeterden, hielden wij ons muisstil. Als je beseft iemands kruis te zijn, kreeg je de droge Liga-kruimels bijna niet doorgeslikt, en ging je hart steeds banger hameren. Door je geboorte bracht je blijkbaar een onvermoede kettingreactie op gang. Mama cijferde zich voor je weg! Zij offerde zich voor je op! Ze had een hele waslijst van moederuitdrukkingen die maakten dat je kleurpotloden nog uren later bevend uitschoten. (Dorrestein, 2003, p. 20)
}

De verwijzing naar de kleurpotloden in dit citaat versterkt het idee dat de verhouding tussen de klasgenootjes van Loes en hun moeders, net zo goed als die van Loes en haar moeder, moeizaam zijn. We kunnen deze immers als een vooruitwijzing naar het uiteindelijke moordwapen opvatten en zo dringt deze parallel over de aard van de verhouding tussen Loes en haar moeder enerzijds en die tussen de klasgenoten en hun moeders anderzijds zich op. In Het duister dat ons scheidt (Dorrestein, 
2003) zijn moeder-kindrelaties dus vrijwel altijd een mijnenveld, of er nu wel of geen moord is gepleegd.

Het bijna zonder uitzondering problematiseren van verschillende soorten moederschap is typerend voor het oeuvre van Dorrestein (zie ook Rosemarie Buikema en Elisabeth Wesseling (2006)). In haar roman Ontaarde moeders (1992) maken bijvoorbeeld verschillende generaties moeders het leven van hun dochters zuur. En in Een hart van steen (1998) gaat een moeder zelfs zo ver dat ze haar kinderen en man vermoordt. Een recent voorbeeld van Dorresteins literaire interesse in moeders en gezinnen die in moeilijkheden verkeren, is het tweeluik Zolang er leven is (2008) en Is er hoop (2009). Daarin verdwijnt een baby door de onoplettendheid van de ouders. Dorrestein staat hierin als romanschrijfster vandaag de dag niet alleen. Literatuurwetenschapster Gerti Wouters en psychoanalyticus Patrick Gyselen (2007) komen na het lezen van een "honderdtal" Nederlandstalige romans, waarvan ze er helaas slechts enkele noemen, tot de conclusie dat "moderne fictie een keur biedt aan extreme moeders" (p. 120). Afgaand op de romans die ze bespreken, lijken vooral vrouwelijke auteurs over ontspoorde moeder-kindrelaties schrijven. Ze noemen onder meer het werk van Dorrestein en Hannes Meinkema. Van Meinkema behandelen zij onder andere de verhalen Dochter en Reparatie uit de bundel Het kind en de rekening (1988). Het eerste verhaal gaat over een moeder die haar dochter haat, omdat haar man ontluikende seksuele gevoelens voor hun dochter ontwikkelt. Zij heeft haar man, van wie ze veel houdt, daardoor samen met haar dochter moeten verlaten. In Reparatie (1988) staat een moeder oogluikend toe dat haar dochter door haar vader wordt misbruikt. De dochter hoopt dat haar moeder haar te hulp zal schieten, maar wanneer dit bij herhaling niet gebeurt, verminkt ze haar vagina met een gebroken glazen fles om het misbruik te stoppen. Uit het artikel van Wouters en Gyselen (2007) blijkt dat Meinkema en andere auteurs in hun verhalen over hedendaags moederschap vaak op een premodern repertoire teruggrijpen. In een aantal romans wordt bijvoorbeeld gerefereerd aan de eeuwenoude Griekse mythe over de oogst- en vruchtbaarheidsgodin Demeter en haar dochter Persephone, die tot het verdriet van haar moeder door Hades, de god van de onderwereld, werd ontvoerd. Ook in de lijvige roman De speeltuin van Teiresias (1994) van Hannes Meinekema, over een door misbruik gekleurde relatie tussen drie generaties moeders en kinderen, wordt teruggegrepen op de Griekse mythologie. Dorrestein lijkt eveneens een voorkeur voor het premoderne te hebben wanneer ze over moderne vormen van moederschap schrijft. Ze staat er om bekend uit het genre van de gothic novel te putten. Dit is weliswaar zelf een modern genre, maar het wordt gekenmerkt door het gebruik van premoderne elementen (Andeweg, 2010, 2011; Buikema \& Wesseling, 2006).

We kunnen stellen dat het moederschap in de contemporaine fictionele Nederlandse literatuur dikwijls in zwaar weer lijkt te verkeren. Daar staat tegenover dat moederschap - en tot op zekere hoogte ook vaderschap - in de maatschappelijke, 
dat wil zeggen niet-fictionele, context, waarin deze literatuur sinds de jaren zeventig en zeker het begin van de jaren tachtig is gepubliceerd, vaak op een specifieke normatieve wijze wordt geïdealiseerd. ${ }^{1}$ Het moederschap wordt daarbij in zeer moderne termen verbeeld. Dit in tegenstelling tot de archaïsche of premoderne elementen die in hedendaagse literaire fictie dikwijls lijken te worden ingezet. Moederschap wordt beschouwd als iets waarvoor je mede dankzij de introductie van de anticonceptiepil bewust kunt kiezen en dat, als er eenmaal voor gekozen is, maakbaar is. In deze context moet het moederschap wel leuk zijn. Het is in tegenstelling tot vroeger immers niet langer iets dat je zomaar overkomt, maar waaraan je zelf naar eigen goeddunken vorm kunt geven. Het moederschap wordt onder andere op deze manier geïdealiseerd in opvoedkundige adviesboeken voor ouders (Wubs, 2004), vrouwenbladen (Knijn \& Verheijen, 1991), tijdschriften voor jonge ouders en in reclames voor babyproducten (Buikema \& Wesseling, 2000, 2006). Hierin wordt doorgaans een bepaald type moeder verheerlijkt en dit is de blanke, welgestelde middenklasse moeder, van wie de kinderen nog jong zijn - meestal nog in de luiers of in ieder geval niet ouder dan twaalf jaar - en die deel uitmaakt van een heteroseksueel kerngezin, waarin de vader kostwinner is en zij hoofdzakelijk voor de kinderen zorgt. Van deze moeder wordt verwacht dat ze van het moederschap geniet en dat ze een symbiotische relatie met haar kind heeft. Als er zich onverhoopt problemen voordoen, dan moet ze die zo snel mogelijk met hulp van professionals oplossen. Haar geluk is haar eigen verantwoordelijkheid; als ze niet gelukkig is dan heeft ze daarover enkel zichzelf iets te verwijten.

De dwingende aanwezigheid van dit geïdealiseerde beeld van moederschap, maakt dat veel moeders het niet als vanzelfsprekend ervaren om over onplezierige kanten en ervaringen van het moederschap te spreken. Het taboe op de minder rooskleurige aspecten van het moederschap blijkt uit peilingen door TNS NIPO in 2005 door de meerderheid van de Nederlandse bevolking te worden ervaren (Maassen \& Oosterwijk, 2006, pp. 209-211). De breed gedeelde norm is dat je met je kind wordt "geacht blij te zijn en te blijven, zelfs al groeit het op voor galg en rad" (Maassen \& Oosterwijk, 2006, pp. 209). ${ }^{2}$ Deze norm lijkt haaks te staan op concrete ervaringen van het prille ouderschap. Recent onderzoek onder 1.130 Duitse ouders tussen 1984 en 2005 wijst hier op (Pouwels, 2011). Zowel vaders als moeders geven aan ongelukkiger te zijn na de geboorte van hun eerste kind dan ervoor. Dit onge-

\footnotetext{
${ }^{1}$ Daarmee is overigens niet gezegd dat de neiging om het moederschap te idealiseren dan historisch gezien een noviteit is, maar wel dat er dertig jaar geleden een specifiek rooskleurig vertoog dominant wordt dat afwijkt van eerdere heersende, idyllische verbeeldingen van moederschap. In hoofdstuk 3 kom ik hier op terug.

${ }^{2}$ We zwijgen ook over deze gevoelens omdat we onze kinderen niet willen kwetsen; hen niet het gevoel willen geven dat zij ongewenst zijn. Het feit dat hier ook met andere volwassenen niet openlijk over gepraat kan worden, wijst er echter op dat er meer aan de hand is.
} 
lukkigere gevoel houdt jaren na de geboorte aan en wordt zelfs sterker. Pas na vijftien jaar neemt het geluksgevoel van de moeders weer toe, bij vaders gebeurt dit 'al' na zeven-en-een-half jaar (Pouwels, 2011). Het taboe op het openlijk uitspreken van negatieve gevoelens, betekent niet dat deze door moeders helemaal niet voor het voetlicht worden gebracht. In de media kunnen we zeker persoonlijke verhalen aantreffen over problemen die moeders ervaren. Maar het heeft er alle schijn van dat die verhalen geregeld door een bepaald ideaalbeeld van moederschap worden ingeperkt en bepaald.

Een voorbeeld van dit mechanisme zien we in december 2006 aan het werk in de speciale bijlage Taboe van het Nederlandse glossy vrouwenmaandblad Jan. Daarin staat het persoonlijke relaas van de 36-jarige Laura die bekent jarenlang niet van haar prille moederschap te hebben genoten (Laura, 2006). De nachtenlange huilbuien van haar babydochter Sophie werden haar vaak te veel en toen Sophie wat ouder was, had zij grote moeite met de woedeaanvallen van de peuter. Laura vertelt hoe zij uitvluchten verzon om niet bij Sophie hoeven te zijn. Zo ging ze "[o]nnodige boodschapjes doen" (Laura, 2006, p. 66). Een van de belangrijkste verklaringen waarom het moederschap haar zo slecht beviel, is volgens Laura dat zij en haar man de keuze voor een kind niet bewust genoeg hadden gemaakt. Desondanks loopt het goed af met Laura. Ze zoekt hulp bij een pedagoog om op een andere manier met haar dochter om te leren gaan en nu geniet zij eindelijk van het moederschap: "Voor het eerst geniet ik van mijn dochter en zie ik wat een schatje ze is" (Laura, 2006, p. 66).

De publieke bekentenis van Laura is veelzeggend over hoe er in Nederland tegenwoordig vaak tegen pril moederschap wordt aangekeken. Het feit dat Laura haar relaas anoniem doet - haar achternaam blijft onbekend en bij het artikel staat geen foto van haar - onderstreept dat er niet openlijk over ronduit negatieve ervaringen van moederschap kan worden gesproken. Tegelijkertijd illustreert dit artikel dat er in het maatschappelijke domein ook mogelijkheden bestaan om in negatieve termen over het moederschap te spreken, maar dat deze door de idyllische norm van moederschap worden gereguleerd. De anonimiteit van Laura is hier een voorbeeld van en dit geldt ook voor het gelukkige einde van het verhaal. Laura weet op die manier ruimte voor zichzelf te creëren om over het moederschap te klagen, maar het ideaalbeeld blijft uiteindelijk intact.

Wanneer we deze dwingende moderne idealisering van het moederschap afzetten tegen de voorkeur voor negatieve kanten van het moederschap in fictionele literatuur, dan rijst de vraag hoe beiden zich tot elkaar verhouden. De vraag naar deze verhouding is de centrale kwestie in dit boek. Hierbij dringt de bredere vraag naar de relatie tussen literatuur en maatschappij zich op. Dit proefschrift richt zich in de eerste plaats op de betekenissen van fictionele literatuur. Het gaat vooral om de wijze waarop het type moederschap dat in de maatschappij doorgaans wordt geï- 
dealiseerd, wordt behandeld in de literatuur: het bewust gekozen, blanke, middenklasse moederschap in de context van een heteroseksueel kerngezin met jonge kinderen. Daarbij ligt de nadruk op fictionele Nederlandse literatuur die van 1980 tot 2010 is gepubliceerd. Het begin- en eindpunt van het onderzoek zijn om precies te zijn 1 januari 1980 en 31 december 2009. Het jaar 1980 geldt als het beginpunt van dit onderzoek, omdat het beschreven geïdealiseerde beeld van moederschap vanaf dat moment aantoonbaar dominant is in de Nederlandse samenleving. Dat blijft zo tot eind 2009, het laatste jaar dat gezien de duur van dit project volledig kon worden meegenomen. Meer in het bijzonder omvat dit proefschrift een interpretatie van de volgende vier romans: De reis naar het kind (1989) van Vonne van der Meer, Een hart van steen (1998) van Renate Dorrestein, Met onbekende bestemming (2000) van Maya Rasker en Nieuwe buren (2006) van Saskia Noort.

\section{De opzet van dit boek}

$\mathrm{Er}$ is nog niet veel onderzoek gedaan naar moederschap in Nederlandse literaire romans van na 1980. Naast Wouters en Gyselen (2007) hebben Buikema en Wesseling $(2000,2006)$ de verbeelding van moederschap in twee romans van Renate Dorrestein bestudeerd. Daarnaast heeft Hilde van Belle (1997) onder meer over de verbeelding van de moeder in de roman Rituelen (1980) van Cees Nooteboom geschreven. Aagje Swinnen heeft zich in haar boek Het slot ontvlucht. De vrouwelijke Bildungsroman in de Nederlandse literatuur (2006) onder andere over de verbeelding van moederschap in De wetten (1991) van Connie Palmen gebogen. Jaap Goedegebuure (2004) heeft daarnaast een artikel over de verbeelding van de geboorte van Jezus in de Nederlandse literatuur van de twintigste eeuw gepubliceerd, waarin hij ingaat op de figuur van de moeder Maria. Ook het proefschrift over Nederlandse streekromans van literatuurwetenschapster Johanna Maria van Buuren (2005) moet genoemd worden. Al gaat het hier niet om een genre dat doorgaans als literatuur wordt gezien, het is een van de weinige studies waarin de verbeelding van moederschap in hedendaagse romans aan bod komt. Naast literatuurwetenschappelijke werken, zijn er enkele artikelen van de hand van cultuurwetenschappers, antropologen en psychiaters verschenen waarin de verbeelding van moederschap in contemporain Nederlands proza, al dan niet literair, aan bod komt. Zo bestudeert cultureel antropoloog Henk Driessen (2004) de representatie van barenspijnen in Nederland aan de hand proza, poëzie en etnografische beschrijvingen van het baren van een kind, waarbij De procedure (1998) van Harry Mulisch de revue passeert. In de bundel De taal van het gevoel. Essays over literatuur en psychiatrie (Olderwald, Meulenberg \& Van Tilburg, 2003) vinden we onder andere een artikel van psychiater Bram Bakker over de verbeelding van het krijgen van een kind in De gelukkige huisvrouw (2000) van Heleen van Royen. De bundel Ziektebeelden - essays over literatuur en geneeskunde (Meulenberg, Van der Meer \& Oderwald, 2002) bevat 
een bijdrage van huisarts Henriëtte van der Horst over de verbeelding van het lichamelijke en geestelijke verval van ouders op leeftijd in hedendaagse Nederlandse romans. In het merendeel van de hier genoemde literatuurwetenschappelijke en niet-literatuurwetenschappelijke artikelen staat de verbeelding van het moederschap echter niet centraal. Als dit wel het geval is, beperken de interpretaties zich meestal tot het werk van één of twee auteurs. Wanneer er wel meerdere auteurs worden besproken, worden de romans veelal fragmentarisch en schematisch besproken. Er worden slechts een of twee korte passages uit iedere roman belicht. Dit geldt bijvoorbeeld voor het artikel van Wouters en Gyselen (2007) en dat van Driessen (2004).

Bij mijn weten kwam de verbeelding van moederschap in de Nederlandse literatuur van na 1980 niet eerder zo uitgebreid aan bod als in dit proefschrift. De kwalitatieve interpretatie van vier romans waarin bewust gekozen, blank, middenklasse moederschap in de context van een heteroseksueel kerngezin problemen blijkt op te leveren, staat zoals gezegd centraal. Die interpretatie inden plaats in het licht van een normatief geïdealiseerd maatschappelijk beeld van moederschap. Het gaat er hier om de interactie van literatuur met dit beeld te onderzoeken. Daarom is het noodzakelijk om uitgebreid stil te staan bij de wijze waarop moederschap in de afgelopen dertig jaar in Nederland nu precies is geïdealiseerd. Dit gebeurt hoofdzakelijk in het eerste hoofdstuk. Daarnaast komt de maatschappelijke idealisering van moederschap aan bod bij de interpretaties van de geselcteerde

Voordat de vier romans aan de orde komen, wordt de algehele productie van romans over moederschap in het tweede hoofdstuk op literatuursociologische wijze onderzocht. Dit gebeurt via analyse van de inhoudsbeschrijvingen en recensies van romans over moederschap in de Nederlandse Centrale Catalogus. Daarbij worden niet alleen romans over bewust gekozen, blank, middenklasse moederschap in de context van een heteroseksueel kerngezin meegenomen, maar alle fictionele prozawerken over moederschap. Het belangrijkste doel van deze analyse is om de aanname die aan dit proefschrift ten grondslag ligt te toetsen. De centrale vraag is in dit hoofdstuk dan ook: wordt het moederschap in literaire fictie hoofdzakelijk geproblematiseerd? Daarnaast probeer ik de relatie tussen maatschappelijke en literaire verbeeldingen van moederschap hier al enigszins te doordenken. Ook wordt in dit hoofdstuk onderzocht of het inderdaad vooral vrouwelijke auteurs zijn die zich in hun werk met moederschap bezighouden. Ten slotte wordt de receptie van fictionele prozawerken over moederschap aan een kwantitatieve analyse onderworpen. Bij dit alles wordt ook naar andere fictionele prozawerken gekeken, dan boeken die volgens de Nederlandse Uniforme Rubrieksindeling [NUR] als literair kunnen worden beschouwd. Tevens worden boeken over vaderschap in de analyses betrokken. Zo krijgen we hopelijk zicht op de relatieve positie van literaire fictie over moederschap ten opzichte van andere genres en ten opzichte van de totale productie van romans over ouderschap. Daarnaast zijn we zo uiteindelijk ook beter in staat om de 
vier case studies in dit boek te situeren in relatie tot fictioneel proza en literaire fictie over moederschap en ouderschap in het algemeen. Waar in dit landschap horen ze thuis en hoe representatief zijn ze?

De interpretaties van deze vier boeken vormen een aanvulling op de uitkomsten van de kwantitatieve analyses. De verhouding tussen de kwantiatieve analyses en de individuele romaninterpretaties komt in hoofdstuk 3 aan de orde. Daarna volgen de tekstuele analyses van de geselecteerde cases zelf. In hoofdstuk 4 wordt De reis naar het kind (1989) van Vonne van der Meer behandeld. Hoofdstuk 5 gaat over Nieuwe buren (2006) van Saskia Noort. In hoofdstuk 6 komt Een hart van steen (1998) van Renate Dorrestein aan bod. In hoofdstuk 7 volgt ten slotte Met onbekende bestemming (2000) van Maya Rasker. In alle vier romans wordt bewust verkozen, blank, middenklasse moederschap in de context van een heteroseksueel kerngezin met jonge kinderen op de korrel genomen. In de eerste twee romans is ongewilde kinderloosheid een belangrijk thema, in de laatste twee staan moeders die hun kinderen vermoorden centraal. Bij de interpretatie van de romans gaat het steeds om de vraag hoe moederschap wordt verbeeld en hoe we deze verbeeldingen kunnen lezen in relatie tot de dwingende maatschappelijke idealisering ervan.

\section{Literaire fictie: een afbakening}

Dit boek begeeft zich in het spanningveld tussen de fictionele, literaire, problematiserende verbeeldingen van moederschap aan de ene kant en de maatschappelijke idealisering van moederschap aan de andere kant. Daarbij wordt literatuur als een verschijnsel beschouwd dat niet los staat van de samenleving waarin ze ontstaat en gelezen wordt. Alle representaties van moederschap worden bovendien als culturele constructen benaderd. Het uitgangspunt is dat moederschap geen vaste betekenis heeft, maar dat de betekenissen van moederschap tot stand komen via de interactie tussen de verschillende representaties ervan, waaronder literaire. Die betekenissen worden hier onderzocht, met bijzondere interesse voor de bijdrage van literaire teksten.

Het gaat in dit proefschrift dus niet zozeer om de esthetische waarde van de romans, om de vraag of ze 'hoge' of 'lage' literatuur zijn. Het doel is niet om vast te stellen dat ze literair uniek, vernieuwend of verrassend zijn en daarmee great works of art. Daarmee is niet gezegd dat zo'n onderscheid niet gemaakt zou kunnen worden en ook niet dat het niet interessant en relevant zou kunnen zijn. Het is echter niet wat er met dit onderzoek wordt beoogd. Het gaat hier om de betekenissen van romans in het licht van het geïdealiseerde beeld van moederschap; om de roman als betekenisvolle actor die participeert in het maatschappelijke krachtenveld. Vanuit deze veeleer sociologisch getinte visie op literatuur kan een populaire roman als die 
van Saskia Noort (2006), waarvan de literaire waarde nogal eens betwist wordt ${ }^{3}$, ook een interessant studieobject zijn.

In het verlengde hiervan wordt er een relatief brede definitie van literaire fictie gehanteerd. Literatuur verwijst in dit boek naar alle romans, verhalenbundels en novellen die volgens de codering van de NUR onder rubrieken vallen die tot literaire fictie voor volwassenen kunnen worden gerekend. Dit zijn: de 'literaire fictie algemeen' (code 300), de 'literaire roman, novelle' (code 301), de 'literaire thriller' (code 305) en de 'pockets literaire fictie' (code 311). Er is ten eerste voor deze afbakening gekozen, omdat de NUR-codes van invloed zijn op de perceptie van romans door hun lezers. De codes worden door de uitgeverijen toegekend en ze zijn mede bepalend voor hoe boekverkopers boeken aanprijzen en hun zaak inrichten. Ze hebben zo een effect op de wijze waarop boeken door consumenten worden gecategoriseerd, hoewel zij zich meestal niet bewust zijn van het bestaan van de codes (Nederlands Uitgeversverbond, 2009; Van Rees, Janssen \& Verboord, 2006). ${ }^{4}$ Daarnaast biedt de NUR belangrijke voordelen ten opzichte van andere genreafbakeningen voor de literatuursociologische analyses die hier worden gemaakt. Dit is de belangrijkste reden voor de keuze voor de NUR. In hoofdstuk 2 komt dit verder aan de orde, wanneer de aard van Nederlandstalige Uniforme Rubrieksindeling wordt besproken.

\section{New Historicism: een plaatsbepaling}

Omdat literatuur als een deel van de samenleving wordt benaderd en omdat de sociale functie van literatuur het centrale onderzoeksonderwerp is, zoek ik met dit proefschrift aansluiting bij het New Historicism. Deze literatuurwetenschappelijke stroming kwam op aan het begin van de jaren tachtig in de Verenigde Staten, in verzet tegen de tekstimmanente interpretaties van de New Critics en het werk van zogenaamde Old Historicists als E.M.W. Tillyard, Theodore Spencer, and John Dover Wilson. Deze zouden de literaire tekst volgens New Historicists als een illustratie van de historische context onderzoeken (Brannigan, 1998). Er bestaan naast enkele cruciale overeenkomsten, grote verschillen tussen de letterkundigen die onder het New Historicism worden geschaard (Brannigan, 1998; Pieters, 2007). Deze worden hier allebei besproken, om zo duidelijk te maken hoe dit onderzoek in deze onder-

\footnotetext{
${ }^{3}$ Zo is de kritiek van Connie Palmen op het werk van Saskia Noort op het boekenbal in 2009 notoir. Ze riep haar voor de camera van de NOS op zich uit het land van de literatuur "weg te scheren" (VARA, 2009).

${ }^{4}$ Dat ze dit effect op (potentiële) lezers hebben, blijkt bijvoorbeeld uit de verhitte discussie die zich in het programma De wereld draait door tussen Connie Palmen en Saskia Noort ontspon. Palmen ergerde zich aan het etiket 'literaire thriller' op Noorts romans, omdat de lezer daardoor de indruk zou krijgen dat het hier om literatuur zou gaan. Dit wenste Palmen te betwisten, omdat Noorts romans te clichématig zijn (VARA, 2009).
} 
zoekstraditie kadert. Daarbij is er ook aandacht voor het New Historicism in de Nederlandse literatuurwetenschap.

In zijn uiteenzetting over het New Historicism stelt John Brannigan (1998) dat de belangrijkste overeenkomst tussen New Historicists is, dat ze literaire teksten in verband met de historische context waarin deze teksten zijn geschreven en gelezen proberen te brengen, zonder de een tot de ander te reduceren (zie ook Jürgen Pieters (1996)). Het is een vorm van onderzoek die voornamelijk is toegepast bij de interpretatie van teksten uit de Renaissance, waaronder het werk van Shakespeare. In navolging van Michel Foucault veronderstellen New Historicists daarbij dat de werkelijkheid, zoals wij die kennen, sociaal geconstrueerd is (Brannigan, 1998). Universeel ware kennis van de wereld is volgens deze opvatting niet mogelijk, omdat kennis altijd van een specifieke sociale context afhankelijk is. Literaire en andersoortige teksten bepalen de betekenissen die wij aan de werkelijkheid toekennen (Brannigan, 1998; Van Gorp, Delabastita \& Ghesquiere, 2007). Deze betekenissen veranderen voortdurend (Brannigan, 1998; Pieters, 1996; Van Gorp, Delabastita \& Ghesquiere, 2007). De betekenissen van literaire teksten en de maatschappelijke context en het onderscheid tussen beiden, worden in interpretaties tot op zekere hoogte allebei door de onderzoeker geconstrueerd.

Met name het werk van Stephen Greenblatt is beeldbepalend voor het New Historicism. In essays zoals Invisible bullets (1981) en Murdering peasants: status, genre and the representation of rebellion (1983) laat Greenblatt zien dat allerlei soorten teksten en bronnen, ook literaire, als producten en producenten van historisch specifieke machtsrelaties kunnen worden beschouwd. Zijn belangrijkste punt is dat kunst, waaronder literatuur, niet autonoom of ideologisch neutraal is. Literatuur kan niet los van de ontwikkelingen en sentimenten in een specifieke samenleving worden gezien.

Aandacht voor genre is een essentieel element in Greenblatts werk. In Murdering peasants (1983) is de analyse van genrekenmerken een manier om de relatie tussen (literaire) teksten en de historische context te onderzoeken. De oorsprong, ontwikkeling en het gebruik van bepaalde genres vinden volgens hem altijd in relatie tot een specifieke historische context plaats. Hij beschouwt genres in feite als kunstzinnige metgezellen van maatschappelijke ontwikkelingen. Volgens Greenblatt (1983) begrenzen de voorschriften van genres namelijk wat er gezegd kan worden over een bepaald onderwerp; welke betekenissen er aan kunnen worden gegeven. Wanneer zich historische veranderingen voltrekken en een kunstenaar of schrijver wil deze verbeelden, dan kan dat meestal niet in de bestaande genres: er kan zich dan een "genre problem" (Greenblatt, 1983, p. 9) voordoen. Hét moment waarop nieuwe genres kunnen ontstaan of bestaande genres worden aangepast.

Een zeer goed, weliswaar niet-literair, voorbeeld hiervan treffen we volgens Greenblatt (1983) aan in het werk van de zestiende-eeuwse kunstenaar Albrecht Dürer. Hij ontwierp een overwinningszuil, die overigens nooit werd gebouwd, om de 
triomf van de Duitse adel over de opstandige boerenbevolking tijdens de bloedige Boerenoorlog in 1524 en 1525 te herdenken. Dürer zag zich daarbij, aldus Greenblatt (1983), voor een genreprobleem geplaatst. Volgens de heersende oorlogsnormen was er voor de overwinnende edelen weinig eer aan deze specifieke zege te behalen. In die tijd waren overwinningen alleen achtenswaardig, wanneer er sprak was van een conflict tussen edelen. Bij zo'n gevecht gingen de adelijke titels van de verliezer naar de overwinnaar. Overwinningszuilen waren er op gericht om dit soort gebeurtenissen te verbeelden. Daarbij werd niet alleen de hoge sociale, adellijke positie van de triomfator benadrukt, maar ook die van de verliezer. Hoe hoger de status van de verliezer, des te meer een overwinning namelijk tot de eer van de zegevierende edelman strekte. Deze vorm van verbeelding was niet geschikt om de ondergang van de boeren te herdenken. De lage sociale status van de boeren maakte het onmogelijk voor de adel om aan deze triomf op soortgelijke wijze status te ontlenen. De boeren golden niet als waardige opponenten. Dürer zag zich zodoende volgens Greenblatt (1983) genoodzaakt om het genre aan te passen. Greenblatt (1983) denkt dat de kunstenaar er daarom onder andere voor zou hebben gekozen om niet de edelen zelf af te beelden, maar om zich te beperken tot een beeld van een boer met een zwaard in zijn rug. Dit beeld zou volgens Greenblatt (1983) in die tijd onder meer gemakkelijk in verband zijn gebracht met de manier waarop misdadigers toen werden geëxecuteerd. Daarmee krijgt de overwinning op de boeren mogelijkerwijs dezelfde lading. De zege van de Duitse adel zou zo impliciet worden voorgesteld als een terechte bestraffing van misdadigers. Zo komt de eer van de edelen die de boeren hebben gedood niet in het geding.

Volgens Brannigan (1998) gaat Greenblatt er in zijn interpretaties vanuit dat een kunstwerk of literaire tekst vooral de (re)productie van de heersende orde dient. In Invisible bullets (1981) lijkt Greenblatt inderdaad te suggereren dat er nauwelijks ruimte voor werkelijk verzet tegen de heersende orde kan bestaan, ook niet binnen literatuur (zie Brannigan, 1998). Zo stelt hij over de van de norm afwijkende manifestaties in werken van Shakespeare dat deze de heersende machtsorde in stand houden, omdat ze als momenten dienen waarop macht zich kan laten gelden en zo versterken. Dit is Greenblatt wel eens op het verwijt komen te staan dat zijn theorie te monolithisch of zelfs totalitair is (Brannigan, 1998). Zijn interpretaties zouden er wellicht zelfs toe kunnen leiden dat we literatuur enkel als de bevestigende uitkomst van maatschappelijke ontwikkelingen gaan beschouwen en de interacties tussen beide domeinen uit het oog gaan verliezen. Wat niet de insteek van het New Historicism is (Brannigan, 1998).

Brannigan (1998) beschouwt de nadruk op literatuur als een normbevestigend product van de gevestigde sociale orde, zoals we die bij Greenblatt tegenkomen, als een algemeen kenmerk van het New Historicism. We mogen New Historicists op dit punt echter niet zomaar over een kam scheren. Er bestaan interpretaties van de hand van New Historicists waarin literatuur als een actieve kracht wordt belicht die 
sociale omstandigheden mede in het leven roept. Brannigan (1998) zelf noemt in dit verband het artikel Shaping fantasies (1983) van Louis Montrose over de machtspositie van de Britse koningin Elisabeth I. Volgens Montrose (1983) leverden theaterstukken een cruciale bijdrage aan het ontstaan van een cultus rondom de koningin, die haar status en een machtige positie verleende. In deze interpretatie van Montrose blijkt literatuur niet slechts het normbevestigende product van bepaalde sociale en politieke omstandigheden, maar draagt het juist actief bij aan die omstandigheden. Deze visie op literatuur treffen we ook aan in Sensational designs. The cultural work of American fiction, 1790-1860 (1985) van Jane Tompkins. Tompkins leest sentimentele romans van vier vrouwelijke auteurs in relatie tot sociaal-culturele context waarin ze zijn ontstaan. Daarbij behandelt ze de romans als actoren die op hun beurt ook hebben bijdragen aan culturele veranderingen. Zij laat zien hoe verschillende zogenaamd 'sentimentele' romans van vrouwelijke auteurs uit de achttiende en negentiende eeuw pogingen zijn om de bestaande sociale orde te ondermijnen en te herdefiniëren. In de hierna gepubliceerde studie van Amerikaanse Westerns, zowel romans als films, gaat Tompkins (1992) op dezelfde voet verder. ${ }^{5}$ Daarbij wordt bovendien zeer goed duidelijk dat fictie en maatschappij in haar ogen voortdurend met elkaar in dialoog zijn en elkaar (re)produceren. Literaire en maatschappelijke ontwikkelingen staan in een circulaire relatie met elkaar. Tompkins (1992) laat zien dat de opkomst van de Western aan het begin van de twintigste eeuw onder andere samenhangt met de secularisering van het wereldbeeld. Daarnaast blijkt het ontstaan van het genre een reactie op het succes van de negentiende-eeuwse "vrouwelijke' "domestic novel" en op de "cult of domesticity that dominated American Victorian culture" (Tompkins, 1992, p. 39). De Western is een manier om de vrouwelijke autoriteit die met de domestic novels en het huiselijkheidideaal samenhangt te ondermijnen. Mannen proberen via de Western volgens Tompkins (1992) cultureel terrein op vrouwen terug te veroveren. Het is niet voor niets een genre waarin het draait om een ruwe, harde, seculiere door mannen gedomineerde wereld, waarin vrouwen slechts een marginale rol spelen. Op zijn beurt draagt de Western volgens Tompkins (1992) weer bij aan de productie en verspreiding van specifieke beelden van mannelijkheid, geweld en de rol van vrouwen waar we ons in de werkelijkheid naar zijn gaan gedragen. "[T]he Western, and the larger cultural movements of which the Western is a part, have taught people to see the world in a certain way", aldus Tompkins (1992, p. 27).

In Nederland bestaat sinds het begin van de jaren tachtig voornamelijk in de historische letterkunde een rijke traditie van onderzoek naar Nederlandse literatuur die aandacht besteedt aan "de maatschappelijke inbedding van teksten en hun

\footnotetext{
${ }^{5}$ Het werk van Tompkins $(1985,1992)$ naar sentimentele romans en Westerns heeft een rol gespeeld in het uitbreiden van het onderzoeksveld van de Amerikaanse literatuurwetenschap naar genres die als 'lagere' literatuur te boek staan.
} 
'beeldvormende' functie" (Jensen, 2007). Zo heeft Marita Mathijsen (2000) literaire teksten onderzocht om meer te weten te komen over de belevingswereld van de tijd waarin deze teksten zijn ontstaan. Dit is volgens haar mogelijk, omdat literatuur als een "travestie" van de samenleving kan worden beschouwd. Daarmee bedoelt ze dat literatuur in staat is "de basale conflicten en obsessies van een samenleving weer te geven, zowel in de literaire vorm als in de inhoud" (Mathijsen, 2000, p. 12). Anders dan de New Historicists gaat Mathijsen (2000) hier niet in op de rol die literatuur mogelijk zelf speelt in het ontstaan en voortbestaan van deze conflicten en obsessies.

Aandacht voor meer contemporaine literaire teksten in relatie tot de maatschappelijke context waarin ze zijn geschreven, komen we onder andere tegen in het onderzoek naar het maatschappelijke engagement van contemporaine Nederlandse auteurs van de moderne letterkundige Thomas Vaessens (2009). Dit geldt ook voor verschillende meer cultuurwetenschappelijke studies waarin literatuur aan bod komt. Zo heeft literatuurwetenschapster Maaike Meijer (1996a) vanuit een gender studies-perspectief de betekenis van contemporaine literatuur, andere teksten en visuele bronnen in relatie tot de historische context geduid. Het gaat er Meijer (1996a) om, om te laten zien hoe de historische context ons kan helpen bij de interpretatie van literaire teksten en andere bronnen. Zij wijst tegelijkertijd ook op de vormende kracht van literatuur op onze opvattingen over mannelijkheid en vrouwelijkheid. Een andere hier te noemen cultuurwetenschappelijke studie is Waarom vrouwen van apen houden. Een liefdesgeschiedenis in literatuur en wetenschap (2002) van literatuurwetenschapster en filosofe Stine Jensen. In dit boek onderzoekt zij de geschiedenis van de wijze waarop de relatie tussen apen en vrouwen in de westerse cultuur is verbeeld en welke rol literatuur, film en wetenschap hierin spelen. Daarnaast kunnen de interpretaties van de filosofe Annelies van Heijst (1993) van romans van Renate Dorrestein en Anna Blaman niet ongenoemd blijven. Van Heijst (1993) leest deze boeken in het licht van heersende maatschappelijke opvattingen over lichamelijk lijden. Ook het werk van pedagoog Ido Weijers (1991) hoort in deze traditie thuis. Hij heeft romans uit de jaren vijftig in relatie tot dominante pedagogische en psychologische opvattingen uit die tijd bestudeerd.

Ondanks deze en andere initiatieven zijn er weinig studies van Nederlandse literatuur in de geest van het New Historicism gepubliceerd (Andeweg, 2010, 2011; Jensen, 2007). Daarin lijkt vanaf het begin van de eenentwintigste eeuw verandering te zijn gekomen. Zo hebben historisch letterkundigen Jürgen Pieters en Hans Vandevoorde (2003a, 2003b) een lans voor het New Historicism gebroken. In 2007 is er onder redactie van Pieters (2007) bovendien een themanummer van het online wetenschappelijke tijdschrift Neerlandistiek. $n /$ verschenen, met daarin verschillende artikelen van historische letterkundigen die expliciet op het New Historicism teruggrijpen. Zo is er een stuk van Mathijsen (2007) over de negentiende-eeuwse roman Het Huis Lauernesse (1980) van Geertruida Toussaint, waarin zij de voordelen van 
het New Historicism voor ons inzicht in de historische oorsprong en betekenis van romans belicht. Daarnaast kunnen we de invloed van het New Historicism onder andere waarnemen in onderzoek naar de gothic novel in Nederland door Agnes Andeweg $(2010,2011)$ en Buikema en Wesseling $(2000,2006)$. Zij richten zich in hun werk op contemporaine romans. Andeweg $(2010,2011)$ analyseert Nederlandse romans met gotieke elementen die na 1980 zijn gepubliceerd en Buikema en Wesseling $(2000,2006)$ richten zich op literatuur uit de tweede helft van de twintigste eeuw.

Dit proefschrift sluit vooral aan bij de visie op literatuur en de onderzoeksvragen zoals die door Andeweg (2010, 2011), Buikema en Wesseling (2006) in navolging van Tompkins $(1985,1993)$ zijn geformuleerd. Zij willen de vraag beantwoorden welk 'cultureel werk' romans verzetten, een term die zij aan Tompkins (1985) ontlenen. Met "cultural work" verwijst Tompkins naar de manier waarop literatuur zich op de samenleving bezint, "defining certain aspects of a social reality which their authors and their readers shared, dramatizing its conflicts, and recommending solutions" (1985, p. 200). Daarbij kan literatuur zowel normondermijnend als bevestigend zijn en zelfs ook de introductie van nieuwe normen behelzen. Wanneer Tompkins (1985) het culturele werk van romans bestudeert, is zij vooral geïnteresseerd in de betekenissen die romans bij hun lezers en critici (hoogstwaarschijnlijk) hebben opgeroepen. Andeweg $(2010,2011)$ en Buikema en Wesseling $(2000,2006)$ richten zich meer op het aanwijzen van mogelijke betekenissen van romans in relatie tot bepaalde maatschappelijke ontwikkelingen, door een minutieuze interpretatie van de werken zelf.

In dit boek gaat het vooral om interpretaties van romans zelf. De receptie komt ook aan bod, maar het is niet het doel om deze via receptieonderzoek volledig in kaart te brengen. Om verwarring te voorkomen spreek ik in dit verband liever van een onderzoek naar het culturele werkpotentieel van literatuur dan van een onderzoek naar het culturele werk. Bovendien geeft deze term beter uitdrukking aan het feit dat de onderzoeker onvermijdelijk een rol speelt in de betekenissen die aan teksten kunnen worden toegekend. Door bepaalde vragen aan literaire teksten en aan niet-literaire representaties over moederschap te stellen, wordt immers een bepaald cultureel potentieel geactiveerd dat in deze bronnen aanwezig is. Ze worden als het ware aan het werk gezet.

Dat literatuur en andere teksten, bronnen en praktijken als beeldvormende krachten worden opgevat die onze visie op het moederschap bepalen, betekent niet dat ze dit op dezelfde wijze doen. In dit boek probeer ik het unieke karakter van de verbeelding van moederschap in de onderzochte literaire teksten niet uit het oog te verliezen. Dit alles vraagt om een diepgaande interpretatie van romans, met aandacht voor details en nuances in de wijze waarop deze teksten werken. $\mathrm{Er}$ is daarom voor een klein corpus gekozen. Daarbij wordt veel aandacht besteed aan genreas- 
pecten. Dit omdat het ontrafelen van de genres die in een roman worden ingezet, de specifieke manier waarop een literaire tekst zich tot die maatschappelijke context verhoudt, kan blootleggen. Daarbij gaat de interesse onder meer uit naar het effect van premoderne genre-elementen die mogelijk in de romans aanwezig zijn. Juist vanwege het contrast met de maatschappelijke idealisering van moederschap die op een modern repertoire berust, is het interessant om ons af te vragen welk werk deze elementen precies kunnen verzetten. Bij het onderzoeken van dit werkpotentieel is het uitgangspunt, anders dan bij Greenblatt (1983), niet dat literaire teksten per definitie normbevestigend zijn. Ik probeer en hoop via dit onderzoek juist ook potentiële ondermijnende krachten van hedendaagse, fictionele, Nederlandse literatuur ten aanzien van de dominante rooskleurige verbeelding van moederschap, als die er zijn, te ontsluiten. De wijze waarop moederschap in Nederland de afgelopen dertig jaar op een specifieke manier is geïdealiseerd komt daartoe nu eerst aan de orde. 



\section{Hoofdstuk 1}

\section{De maatschappelijke idealisering van moederschap}

\section{Inleiding}

In 2001 stelt de Amerikaanse feministe en schrijfster Noami Wolf (2002) vast dat het grootste deel van de informatie in de Verenigde Staten over moederschap eenzijdig sentimenteel is. Het standaardbeeld dat (aanstaande) moeders in tekstuele en visuele bronnen wordt voorgeschoteld, is dat van een jonge, stralende moeder die haar baby gelukzalig omhelst. Voor het delen van ervaringen die hiervan afwijken is er volgens Wolf (2002) weinig ruimte. Door de kracht van dit beeld durven moeders namelijk nauwelijks te praten over problemen bij de zorg voor hun kinderen.

Wolf (2002) staat niet alleen in deze observaties. Verschillende al dan niet gepopulariseerde cultuurwetenschappelijke, sociologische en gezondheidswetenschappelijke studies met betrekking tot de Verenigde Staten, Groot-Brittannië, Australië en West-Europa laten zien dat moederschap vandaag de dag wordt geïdealiseerd (Barclay \& Kent, 1998; Barclay \& Lloyd, 1996; Chambers, 2001; Douglas \& Michaels, 2005; Hays, 1996; Johnston \& Swanson, 2003; Layne, 2004; Tincknell, 2005). Vooral de eerste maanden en jaren van het moederschap, voordat de kinderen gaan puberen, wordt vaak overgoten met een rooskleurig sausje. Daarbij staat gewoonlijk een blank, welgesteld, meestal middenklasse kerngezin centraal, bestaande uit een getrouwd, heteroseksueel koppel met gezonde kinderen (Barclay \& Kent, 1998; Barclay \& Lloyd, 1996; Chambers, 2001; Douglas \& Michaels, 2005; Hays, 1996; Tincknell, 2005). De moeder wordt doorgaans afgeschilderd als degene die tot haar genoegen het leeuwendeel van de zorg voor de kinderen en het huishouden op zich neemt, terwijl haar echtgenoot de kost wint. Zij vervult dan ook samen met haar kinderen een spilfunctie in de stroom rooskleurige representaties van het gezinsleven; de vader speelt slechts een bijrol. Dit beeld van het gezinsleven en de rol van de moeder is een van oorsprong negentiende-eeuws blank, middenklasse ideaal. $^{6}$

\footnotetext{
${ }^{6}$ De blanke "celebrity moms" (Douglas \& Michaels, 2005, p. 110) die zich omgeven met allerlei glitter en glamour met hun pasgeboren spruit laten afbeelden in de glossy magazines spelen in de verspreiding van dit van oorsprong middenklasse ideaal paradoxaal genoeg eveneens een rol (zie hierover bijvoorbeeld Lesley Barclay en Diane Kent (1998) en Susan Douglas en Meredith Michaels (2005)). Ondanks dat zij zelf
} 
Het gros van de geïdealiseerde verbeeldingen van moederschap die in de verschillende studies worden besproken, dient een commercieel doel. De beelden worden ingezet om moeders iets te verkopen: een opvoedkundig adviesboek, een glossy tijdschrift of een ander product. Door moeders een goed gevoel te geven en/of te beloven dat plezierig moederschap met de aankoop van bepaalde diensten en producten binnen handbereik ligt, worden dit soort producten veelal aan de vrouw gebracht. Daarbij staat logischerwijs de blanke, middenklasse moeder vaak centraal. Zij behoort immers tot de grootste klasse die financieel iets in de melk te brokkelen heeft. We mogen er, gezien de toenemende vercommercialisering van het moederschap in verschillende westerse landen, vanuit gaan dat deze commerciele beelden onze opvattingen over moederschap in toenemende mate hebben bepaald. Er is om de woorden van sociologe Arlie Hochschild te gebruiken in de afgelopen decennia immers een ware "mommy industry" (2004, p. 39) ontstaan. Allerlei aspecten van het gezinsleven die moeders vroeger alleen of met onbetaalde hulp van derden voor hun rekening hebben genomen, kunnen nu door bedrijven en instanties tegen betaling worden uitgevoerd. Daarnaast zijn er steeds meer producten te koop die de moeder bij het uitvoeren van haar taak beloven te ondersteunen en het moederschap aangenamer te zullen maken. Hoewel bedrijven in hun marketing vaak gebruik maken van het beeld van een moeder die zielsgelukkig alleen voor haar kindje zorgt, met haar man als steun op de achtergrond, interveniëren ze in de praktijk in de veronderstelde symbiotische relatie wanneer ze taken van de moeder overnemen. Dit gebeurt paradoxaal genoeg meestal juist onder het mom van de belofte dat moederschap met het inkopen van deze diensten (nog) fijn(er) zal zijn en dat het symbiotische ideaal er mee gerealiseerd zal worden.

Een aantal onderzoekers wijst er terecht op dat negatieve kanten en ervaringen van het moederschap ook worden besproken in de samenlevingen die zij bestuderen (zie bijvoorbeeld Chambers, 2001; Johnston \& Swanson, 2003; Tincknell, 2005). Het ideaal van moederschap blijft daarbij echter vaak in tact. Wanneer het over deze aspecten van het moederschap gaat, gaat het namelijk geregeld over moeders uit migrantengezinnen, uit 'lagere' sociaaleconomische klassen, over gescheiden moeders, alleenstaande tienermoeders, lesbische moeders en/of moeders van gehandicapte of ernstig zieke kinderen. Blanke, welgestelde, heteroseksuele moe-

niet tot de middenklasse behoren, dragen zij bij uitstek bij aan de verspreiding van dit specifieke idyllische plaatje van het kerngezin. Hoewel deze moeders er meestal een drukke werkagenda op na houden, wordt hun baan in de romantische verbeeldingen van hun moederschap bijvoorbeeld vaak weggepoetst, doordat bij herhaling wordt benadrukt hoeveel fijner en waardevoller ze het vinden om thuis bij hun kinderen te zijn (Douglas \& Michaels, 2005). 
ders die deel uitmaken van een kerngezin met gezonde, jonge kinderen worden aanzienlijk minder in termen van problemen besproken. ${ }^{7}$

In Nederland is dit alles niet zo heel anders. Uit verschillende onderzoeken blijkt dat moederschap ook hier vaak op normatieve wijze wordt geïdealiseerd. Niet voor niets heeft Marleen Castelein, journaliste en moeder, in 2009 een zelfde soort boek als dat van Wolf (2002) gepubliceerd, met de ironisch bedoelde titel De mooiste tijd van je leven (2009). Castelein (2009) stelt, net als Wolf, dat het niet geaccepteerd is om over tegenvallende ervaringen van het jonge moederschap te praten door de aanwezigheid van een dwingend, geïdealiseerd beeld van moederschap. Zij heeft bovendien het idee dat dit beeld zo sterk is, omdat het krijgen en hebben van kinderen vaak als een eenvoudig te plannen en organiseren project wordt gezien. Doorgaans wordt aangenomen dat vrouwen er vrijelijk voor kunnen kiezen of, wanneer en hoeveel kinderen ze krijgen, wat dankzij de beschikbaarheid van de anticonceptiepil tot op zekere hoogte inderdaad het geval is. Daarnaast wordt ook het moederschap zelf als een plooibare praktijk beschouwd. Doordat het krijgen en hebben van kinderen op deze manier als beheersbaar wordt voorgesteld, moet je volgens Castelein (2009) stevig in je schoenen staan om toe te geven dat het allemaal toch niet alleen maar zo fijn is. Je loopt dan immers het risico om als een loser versleten te worden die haar zaakjes niet goed op orde heeft.

In dit hoofdstuk wordt duidelijk dat Castelein (2009) gelijk heeft. De stelling is hier dat er in Nederland sinds het begin van de jaren zeventig een specifiek normatief vertoog over moederschap circuleert, dat zeker sinds het begin van de jaren tachtig tot een van de dominante voorstellingen van het moederschap behoort. Daarmee is niet gezegd dat het moederschap dan voor het eerst in de geschiedenis van Nederland wordt geïdealiseerd, maar wel dat we sinds het einde van de jaren zeventig te maken hebben met de opkomst van een voor die tijd specifieke idealsering van moederschap, waarin onder meer wordt benadrukt dat het krijgen van kinderen het gevolg van een bewuste keuze is en het moederschap zelf maakbaar. Onder vertoog wordt in navolging van Michel Foucault (2002/1972) een samenhangend geheel van regulerende ideeën, normen en categorieën verstaan, die de visuele en tekstuele representaties en handelingen rondom een bepaald onderwerp structureren. Volgens Sara Mills (2004) gebruikt Foucault de term vertoog op maar liefst drie verschillende manieren. Ten eerste om uitdrukking geven aan het idee dat de werkelijkheid zoals wij die kennen discursief, sociaal geconstrueerd, is. Wanneer Foucault bijvoorbeeld claimt dat er niets buiten het vertoog bestaat, bedoelt hij dat wij niet aan het sociaalgeconstrueerde karakter van de wereld, zoals wij die kennen,

\footnotetext{
${ }^{7}$ Uit een content analyse van populaire Amerikaanse weekbladen voor vrouwen door Deirdre Johnston en Debra Swanson (2003) blijkt bijvoorbeeld dat dit soort van representaties een kleine minderheid in de onderzochte tijdschriften is. In het merendeel van de verbeeldingen van moederschap wordt blank, middenklasse moederschap geassocieerd met geluk en plezier.
} 
kunnen ontsnappen. Een tweede manier waarop Foucault de term gebruikt is om te verwijzen naar het vertoog als "an individualizable group of statements" (Foucault, 2002/1972, p. 90). Daaronder verstaat hij het coherente geheel van 'uitspraken' en 'teksten' over een bepaald onderwerp in een specifieke sociale context, "which have some institutional force and which are thus validated by some form of authority", zoals Mills (2004, p. 61) het samenvat. Daaronder vallen niet alleen geschreven of gesproken woorden, maar bijvoorbeeld ook beelden, klanken en handelingen. De derde manier waarop Foucault de term inzet, is om te verwijzen naar "a regulated practice that accounts for a number of statements" (Foucault, 2002/1972, p. 90). Het gaat hem dan om de achterliggende mechanismen en structuren, die onze uitspraken en handelingen rondom een bepaald onderwerp in bepaalde specifieke sociaalhistorische context reguleren en (re)produceren; om de achterliggende normen, categorieën en ideeën. De definitie van vertoog die hier wordt gehanteerd, verwijst naar deze laatste invulling van de term.

In dit hoofdstuk wordt zichtbaar dat het geïdealiseerde vertoog over moederschap dat aan het begin van de jaren zeventig opkomt, uit de stilzwijgende aanname bestaat dat de ideale moeder blank is en bij voorkeur niet of weinig werkt. Verder behoort zij tot de middenklasse, heeft zij bewust voor kinderen gekozen en maakt ze deel uit van een heteroseksueel kerngezin met jonge, gezonde kinderen. Moeders die niet aan deze vereisten voldoen, worden binnen dit vertoog niet verondersteld de opvoeding plezierig te vinden. Voor een moeder die wel aan deze voorwaarden voldoet, is het dictaat echter dat het moederschap haar gelukkig moet maken. Ervaart ze het desondanks als onprettig, dan is dit geen ramp, mits ze hulp kan inroepen waarmee het moederschap alsnog tot geluk zal strekken; hulp die bedrijven en instanties maar al te graag tegen betaling willen leveren. Het idyllische vertoog bestaat al met al uit het idee dat het blanke, middenklasse, bewust gekozen moederschap in de context van een heteroseksueel kerngezin met jonge gezonde kinderen een beheersbare en uiteindelijk plezierige praktijk is. Genieten staat in dit vertoog dus centraal. Er zal daarom in dit boek ook wel van het vertoog van genieten worden gesproken.

Afgaand op het genoemde internationale onderzoek vinden we idealiseringen van het moederschap vooral terug in het commerciële domein. Dit hoofdstuk richt zich op dit domein, meer in het bijzonder op de verbeelding van moederschap in vier soorten bronnen: populaire opvoedkundige adviesboeken voor jonge ouders, commerciële tijdschriften voor vrouwen, tijdschriften voor (aanstaande) jonge ouders en reclame voor babyproducten. Deze worden aan de hand van bestaand onderzoek besproken. Deze bestaande studies worden aangevuld met nieuw onderzoek. Het doel van dit hoofdstuk is niet om de verbeeldingen van moederschap in opvoedkundige adviesboeken, tijdschriften en reclame in zijn geheel in kaart te brengen en evenmin om een uitputtend overzicht te geven van alle discursieve plekken waar moederschap wordt geïdealiseerd. Het doel is vooral om het dwin- 
gende karakter van het vertoog van genieten aannemelijk te maken. Daarnaast is het de intentie om licht te werpen op de historische oorsprong en ontwikkeling van dit vertoog. Met deze doelstelling in het achterhoofd, komen hier ook een aantal maatschappelijke ontwikkelingen aan bod die hoogstwaarschijnlijk hebben bijgedragen aan de opkomst en de voortdurende dominantie van het vertoog van genieten. Ook de Nederlandse samenleving is echter niet monolithisch. Moederschap wordt niet altijd geïdealiseerd. Aandacht voor maatschappelijke, politieke en wetenschappelijke probleemvertogen over moederschap mag in dit hoofdstuk daarom ten slotte niet ontbreken. Juist ook omdat dit het inzicht in de hedonistische benadering van moederschap kan vergroten. Dit komt in de laatste paragraaf aan de orde.

Eerst nog een korte toelichting op het gebruik van de term middenklasse in dit boek. In de genoemde internationale studies naar de verbeelding van moederschap wordt die term zelden expliciet gedefinieerd, zoals ook in veel van de onderzoeken naar moederschap in Nederland die hier later worden besproken. Over het algemeen worden er de huishoudens mee bedoeld die in hun levensonderhoud voorzien via het uitvoeren van redelijk goed tot hoog geschoold werk, dat een prettige economische levensstandaard mogelijk maakt. Wanneer het in de rest van dit boek over de middenklasse gaat, dan wordt daarmee naar deze definitie verwezen. Om preciezer te zijn wordt de middenklasse gedefinieerd als de gezinshuishoudens die tot de middelste vijftig procent van de inkomensverdeling in Nederland behoren ${ }^{\mathbf{9}}$ en die in hun levensonderhoud voorzien met een baan waarvoor minimaal een mbo-, havo- of vwo-diploma is vereist. Daarbinnen wordt er een onderscheid tussen een hogere en lagere middenklasse gemaakt. De hogere middenklasse bestaat uit de huishoudens uit de tweede helft van de middeninkomens, de hogere middeninkomens, en is werkzaam in banen waarvoor een opleidingsniveau van minimaal hbo is vereist. De lagere middenklasse wordt gevormd door de huishoudens die tot de eerste, lagere helft van de middeninkomens kunnen worden gerekend en die de lager geschoolde beroepen voor haar rekening neemt. ${ }^{10}$ In de praktijk kan iemand natuurlijk qua opleiding tot de hogere middenklasse behoren en economisch gezien tot de lagere middenklasse en omgekeerd. Dit komt echter weinig voor in Nederland. Een hoog opleidingsniveau geeft nog altijd meer kans op een hoog inkomen (Latten, 2005).

\footnotetext{
${ }^{8}$ Het gaat dan om de inkomens die tussen de $25 \%$ laagste en $25 \%$ hoogste inkomens in Nederland liggen.

${ }^{9} \mathrm{lk}$ ontleen het economische deel van deze definitie aan het werk van econoom Paul de Beer (2008).

${ }^{10}$ De onderverdeling in een hogere en lagere middenklasse op basis van opleiding komt van Margaret Nelson (2010).
} 


\section{Populaire opvoedkundige adviesboeken}

De contemporaine opvoedkundige adviesliteratuur in Nederland is bestudeerd door pedagogisch historica Janneke Wubs $(2000,2004)$. Zij heeft de populairste opvoedkundige adviesboeken voor (aanstaande) ouders die tussen 1945 en 1999 in Nederland zijn gepubliceerd aan een uitgebreid onderzoek onderworpen en stelt vast dat opvoedkundige auteurs van handboeken voor ouders in de loop van de jaren zeventig massaal een hedonistische benadering ${ }^{11}$ van ouderschap en opvoeden omarmen. Volgens Wubs (2004) is de vertaling van The common sense book of baby and child care (1946) van Benjamin Spock met afstand het best verkopende opvoedkundige boek in de hele door haar onderzochte periode. Een uitgebreide bespreking van Spocks werk is noodzakelijk voor ons inzicht in de aard van een ideaal van plezierig ouderschap, zoals dat in de opvoedkundige adviesliteratuur centraal komt te staan. Daarbij worden ook de versies van het boek die na 1999 zijn verschenen meegenomen, die Wubs $(2000,2004)$ in haar onderzoek niet heeft kunnen bespreken.

Spocks boek over de verzorging en opvoeding van kinderen tot elf jaar wordt in 1950 voor het eerst als Baby- en kleuterverzorging uitgegeven in Nederland en krijgt vanaf 1959 de titel Baby- en kinderverzorging en na 1984 de titel Baby- en kinderverzorging en opvoeding mee. Spock richt zich in zijn adviezen vooral op de middenklasse (Bigner, 1972), hoewel zijn werk in Nederland ook de lagere sociale klasse bereikt (Bakker, Noordman \& Rietveld-Van Wingerden, 2010). Tot 1978 staat de moeder als enige opvoeder centraal in de Nederlandse vertalingen van Spocks boek. Zij is volgens Spock (1950) verantwoordelijk voor de opvoeding van de kinderen en zou vanwege haar belangrijke rol thuis dan ook beter geen betaald werk buitenshuis verrichten. Daarbij gaat Spock (1950) er vanuit dat het 'klassieke' heteroseksuele kerngezin waarin de man kostwinner is en de vrouw huisvrouw en moeder, de beste plek is voor een opgroeiend kind. Andere gezinsvormen, waaronder gezinnen waarin de moeder werkt en eenoudergezinnen behandelt Spock veelzeggend genoeg in een sectie "Speciale problemen" (1950, p. 418) aan het einde van zijn boek. Hij onderschrijft daarmee een patriarchaal beeld over de verdeling van de taken tussen de seksen en de inrichting van het gezinsleven.

Spock (1950) combineert en populariseert inzichten over opvoeding uit verschillende ontwikkelingspsychologische theorieën ${ }^{12}$ die er vanuit gaan dat de ontwikke-

\footnotetext{
${ }^{11}$ Wubs $(2000,2004)$ gebruikt deze term en de term 'vertoog van genieten' zelf niet. Zij spreekt van de opkomst van een "ideaal" van "plezier" (2004, p. 164), een focus op "prettig opvoeden" (p. 77) of van centrale "idealen van gelukkige en volledig ontplooide ouders en kinderen" (2004, p. 217). Het gaat Wubs $(2000,2004)$ overigens expliciet niet om de analyse van de pedagogische wetenschappelijke discipline, maar om het gepopulariseerde opvoedkundige advies voor ouders. De publicatie van Wubs uit 2000 beperkt zich daarbij tot 1995, in de publicatie uit 2004 heeft ze haar analyse tot 1999 uitgebreid. De inzichten uit de publicatie uit 2000 komen overeen met die uit 2004.

${ }^{12}$ Wubs (2004) noemt Spocks visie op opvoeding daarom een ontwikkelingsgerichte benadering.
} 
ling van kinderen tot volwassenen verschillende fasen doorloopt, waaronder de psychoanalyse van Sigmund Freud, Jean Piagets cognitieve ontwikkelingspsychologie en de biopsychologische ontwikkelingsleer van Arnold Gesell (Bakker, Noordman \& Rietveld-Van Wingerden, 2010; Breeuwsma, 1999; Van Andel \& Van der Pol, 1997; Wubs, 2004). Spock ontdoet de psychoanalyse daarbij van haar scherpe kanten en hij benadrukt vooral dat opvoeden fijn is. Freud stelt onder meer dat de geestelijke ontwikkeling van kinderen vanaf de geboorte tot de volwassenheid vijf verschillende fasen doorloopt: de orale fase, de anale fase, de fallische fase, de latentiefase en de genitale fase (Verhulst, 2005, pp. 23-24). De vader en moeder spelen als identificatiefiguren van de twee verschillende seksen ${ }^{13}$ daarin een belangrijke rol. De meeste mensen zullen het werk van Freud vooral van het Oedipuscomplex kennen. Dit is de naam die Freud aan het proces geeft waarbij het kind in de fallische fase zijn seksuele identiteit ontwikkelt. Het kind wordt daarbij gedreven door een erotisch verlangen naar de ouder van de andere sekse. Een verstoring van deze geestelijke ontwikkeling in fasen kan volgens Freud tot neuroses op volwassen leeftijd leiden en de invloed van de ouders is daarbij niet te onderschatten. Bij veel psychoanalytisch geïnspireerde Nederlandstalige deskundigen resulteren de verwerkingen van Freuds opvattingen in handboeken voor ouders in de eerste jaren na de Tweede Wereldoorlog in bezorgde waarschuwingen. De ouder-kindrelatie zou "dé bron van neurotische stoornissen [zijn]. Relatief klein ongerief zwol aan tot grote proporties. Voorheen onbeduidende zaken als duimzuigen en nagelbijten werden symbolische expressies van een onopgelost innerlijk conflict" (Bakker, Noordman \& Rietveld-Van Wingerden, 2010, p. 332) waarvan de oorzaak meestal in het gedrag van de ouders zou liggen. Volgens Spock (1950) valt dit allemaal wel mee. Ook hij gaat er vanuit dat ouders als identificatiefiguren een belangrijke rol spelen in de ontwikkeling van kinderen en hoewel hij het typisch freudiaanse vocabulaire met woorden als Oedipuscomplex en castratieangst niet in de mond neemt, ontleent hij een deel van zijn beschrijving van de ontwikkeling van het kind duidelijk aan de psychoanalyse. Tegelijkertijd stelt hij ouders voortdurend gerust. "[A]nders dan de analytici en hun opvoedkundige navolgers maakte hij van allerlei - in hun ogen ongewenst - kindergedrag, zoals 'neurotisch' duimzuigen of masturberen, nauwelijks een probleem" (Bakker, Noordman \& Rietveld-Van Wingerden, 2010, p. 314). Volgens Spock

[zocht] [e]en duimzuigende peuter (...) troost en een kleuter die regelmatig zijn genitaliën betastte, deed iets wat heel gewoon was op een leeftijd waarop de seksuele gevoelens ontwaken. Ongezond was alleen wat afweek van de normale ontwikkeling van een kind. (Bakker, Noordman \& RietveldVan Wingerden, 2010, p. 314)

\footnotetext{
${ }^{13}$ Voor een toelichting van het gebruik van het woord sekse in dit boek zie hoofdstuk 3.
} 
Daarbij hanteert Spock (1950) een brede definitie van wat als normaal kan worden beschouwd. In navolging van Gesell stelt hij dat er geen vaste leeftijden zijn waarop nieuwe fasen zich aandienen (Bakker, Noordman \& Rietveld-Van Wingerden, 2010). Spock benadrukt de individualiteit en de grote verschillen tussen kinderen. leder kind doorloopt in zijn ontwikkeling weliswaar bepaalde fasen, maar het ontwikkelt zich daarbinnen op zijn eigen wijze. leder kind is met andere woorden uniek.

Een moeder dient de emotionele, cognitieve en fysieke ontwikkeling van haar kind vanwege het unieke karakter van die ontwikkeling wel minutieus te volgen en te ondersteunen. Dat maakt het moederschap, zoals Spock dat voor zich ziet, tot een zeer intensieve aangelegenheid, zowel wat betreft de tijdsinvestering als de emotionele investeringen die van een moeder worden gevraagd (zie ook Elly Singer, 1989). Daarover hoeft een moeder zich echter niet al te veel zorgen te maken, omdat zij volgens Spock (1950) immers min of meer van nature weet wat goed is voor haar kind. Zij handelt, als zij op haar gezonde verstand vertrouwt, daardoor bijna altijd juist. Niet voor niets begint zijn boek met de zinsnede: "Heb vertrouwen in Uzelf. U weet meer dan U zelf denkt" (Spock, 1950, p. 13). Dat Spock (1950) vervolgens toch een heel boek met adviezen vult en benadrukt dat de moeder vooral ook naar de adviezen van haar dokter moet luisteren, heeft iets paradoxaals. ${ }^{14}$ Daarbij benadrukt Spock (1950) dat opvoeden vooral warm en prettig moet zijn. Niet alleen omdat dit voor de moeder prettig is, maar ook en vooral omdat dit een goede ontwikkeling van het kind tot een gelukkig, zelfverzekerd volwassen persoon waarborgt. In het eerste hoofdstuk van zijn boek wordt deze opdracht expliciet verwoord in zinnen als "Heb plezier in Uw baby" (Spock, 1950, p. 28), "Wees natuurlijk en gewoon en geniet van uw kind" (Spock, 1950, p. 28) en "Houdt van uw kind en heb plezier in hem zoals hij is, zoals hij eruit ziet, zoals hij doet, en vergeet de eigenschappen die hij niet heeft" (Spock, 1950, p. 30). Niet voor niets is de op de ontwikkelingspsychologie gebaseerde benadering die we bij Spock (1950) terugvinden, als een fun morality getypeerd (Wolfenstein, 1955). Moeders (en vaders) moeten met ieder kind gelukkig zijn zoals het is en moeten er op die manier ook voor zorgen dat hun kind gelukkig is, omdat de ontwikkeling van het kind er anders onder lijdt.

Volgens Buikema en Wesseling $(2000,2006)$ pareert Spock (1950) zo een van de belangrijkste spanningen in de opvoedkunde van na de Tweede Wereldoorlog: die tussen de belangen van het kind en die van de moeder. In de naoorlogse psychologie, waardoor de naoorlogse opvoedkunde wordt beïnvloed, wordt veel waarde gehecht aan de bevordering van de ontplooiing van mensen tot authentieke autonome individuen. Wanneer het gaat om de opvoeding van kinderen doet zich de complicerende vraag voor om wiens zelfontplooiing en autonomie het in de eerste

\footnotetext{
${ }^{14}$ Zie naast Wubs (2004) ook Gerrit Breeuwsma (1999), Rosemarie Buikema en Elisabeth Wesseling (2000, 2006), Sharon Hays (1996) en Michael Zuckerman (1993) voor besprekingen van dit paradoxale aspect en van andere genoemde eigenschappen van Spocks werk.
} 
plaats moet gaan in de opvoeding: om die van de moeder of die van het kind? In Spocks visie op opvoeding is er geen sprake van een conflict tussen de belangen van de moeder en die van kind. Wat de moeder gelukkig maakt, is immers ook goed en fijn voor het kind (Buikema \& Wesseling, 2000, 2006). Moeder en kind worden zo als een symbiotische eenheid voorgesteld. De zelfontplooiing en het geluk van de moeder impliceren de zelfontplooiing en het geluk van het kind. Als de moeder van de opvoeding geniet, dan kunnen zowel moeder als kind zichzelf via de opvoeding verwezenlijken en ontplooien tot autonome subjecten. Zelfs in het geval van een moeder die er voor kiest om te werken omdat ze denkt anders echt niet gelukkig te kunnen zijn, is Spock (1950) er van overtuigd dat het beter voor het kind is als deze moeder, in beperkte mate(!) en mits ze adequate opvang heeft georganiseerd, gaat werken. Dit ondanks zijn bezwaren tegen werkend moederschap. Spock (1950) benadert de moeder zodoende paradoxaal genoeg in zijn hele werk in eerste instantie als iemand die zelf het beste naar eigen inzicht invulling kan geven aan de opvoeding, maar hij vlakt haar autonomie en die van het kind tegelijkertijd gedeeltelijk weer uit door de relatie tussen moeder en kind als symbiotisch voor te stellen.

Vanaf 1978 verschijnen er verschillende herziene versies van de Nederlandse vertaling van Spocks boek waarin dit allemaal net iets anders ligt (zie ook Wubs, 2004). In de eerste herziene versie heeft Spock (1978) paragrafen over de opvoedende taak van de vader toegevoegd en geeft hij de secties over kinderopvang een meer centrale plaats. Het idee dat het in de opvoeding om plezier draait, blijft in tact, maar Spock (1978) benadrukt nu dat de vader net zo goed als de moeder in staat is om voor de kinderen te zorgen. Meer dan dat: het zou zelfs goed voor de kinderen zijn als de vader ook een deel van de opvoeding voor zijn rekening neemt. Spock (1978) vindt het bovendien niet langer een probleem als moeders buitenshuis werken en juicht een gelijke verdeling van arbeid en zorg tussen vader en moeder zelfs toe. Wel meent hij dat de beste opvoeders nog altijd de ouders van het kind zelf zijn en in het meest ideale geval weten zij de taken zo te verdelen dat zij elkaar in de zorg voor het kind, zeker in de eerste drie levensjaren, kunnen afwisselen en geen andere vormen van opvang hoeven in te schakelen. Maar als het niet anders kan, zijn bepaalde vormen van opvang, waaronder een gastouder, niet ongeschikt. Daarnaast is er iets meer aandacht voor negatieve gevoelens die ouders bij het opvoeden van kinderen kunnen ervaren. Spock (1978) stelt dat deze normaal en van voorbijgaande aard zijn en dat ze weinig kwaad kunnen. Tegelijkertijd blijven cruciale dingen hetzelfde. Zo blijft het boek tussen de regels door in eerste instantie aan moeders gericht. ${ }^{15}$ Bovendien benadrukt Spock (1978) dat vrouwen en mannen in

\footnotetext{
${ }^{15}$ lets dat Wubs $(2000,2004)$ niet erkent. Dat moeders op impliciete wijze als voornaamste opvoeders worden beschouwd en aangesproken, blijkt bijvoorbeeld al op de eerste pagina van deze herziene versie van het boek, waar we het volgende lezen:
} 
essentie van elkaar verschillen en het heteroseksuele kerngezin is nog altijd de ideale plek voor een kind om op te groeien. In 1984 wordt de versie uit 1978 herdrukt. Hierin wordt een paragraaf van een halve pagina over "[g]eweld tegen kinderen" (Spock, 1984, p. 536) aan het boek toegevoegd. Spock (1984) gaat nu voor het eerst in op zaken als kindermishandeling en verwaarlozing. Daarmee stelt hij zijn geïdealiseerd beeld van het gezinsleven als een beheersbare, plezierige praktijk iets verder bij. Hij laat, weliswaar zijdelings, zien dat hij er zich van bewust is dat er zich ook grote problemen kunnen voordoen binnen een gezin, die niet altijd binnen dat gezin zelf zijn op te lossen. Aan de grote lijn van zijn verhaal verandert echter niets ten opzichte van de herziening uit 1978. In 2000 volgt met Steven Parker als coauteur weer een nieuwe versie. Wederom is er ten opzichte van 1978 weinig nieuws onder de zon. De paragraaf over kindermishandeling is in deze versie weliswaar met twee pagina's uitgebreid, maar het heteroseksuele kerngezin blijft de norm, getuige het volgende citaat:

\begin{abstract}
Op grond van mijn ervaring als kinderarts en psychiater vind ik dat het, indien mogelijk, de voorkeur verdient dat kinderen samenleven met een man en vrouw als vader en moeder. Het belangrijkste argument hiervoor is dat kinderen op die manier gelijke kansen hebben om zich met beide seksen te identificeren. Naast het vele, aan verandering onderhevig, maatschappelijk gedrag van mannen en vrouwen blijft er immers onderscheid tussen deze twee vormen van mens-zijn. In dit licht bezien is een bewuste keuze voor opvoeden zonder vader- of moederfiguur meer een behoefte van de volwassene dan die van het kind. (Spock \& Parker, 2000, p. 45)
\end{abstract}

Tegelijkertijd moet worden opgemerkt dat Spock en Parker (2000) positiever over andere gezinsvormen zijn. Voor het eerst wordt er in dit verband naast alleenstaand ouderschap ook over homoseksueel ouderschap gesproken. Deze vormen van ouderschap kunnen volgens Spock en Parker (2000) door de beugel, mits het kind de kans krijgt om zich met een ouderfiguur van de andere sekse dan de alleenstaande of homoseksuele ouders te identificeren. In de herdrukken van deze versie van het boek tot en met 2010 verandert er niet veel, maar vanaf 2007 kunnen we er een nieuwe paragraaf over co-ouderschap na echtscheiding aantreffen. Hiermee geven Spock en Parker $(2007,2010)$ in ieder geval toe dat het heteroseksuele kerngezin

Binnenkort zal uw baby geboren worden. Misschien is de baby er al. $U$ bent gelukkig en opgetogen, maar wanneer $u$ weinig ervaring heeft, zult $u$ zich afvragen of $u$ wel in staat zult zijn, het kind volgens de regels van de kunst te verzorgen. (...) Soms lijkt het allemaal erg ingewikkeld. U hoort over de vele vitaminen en inentingen die een baby nodig heeft. De ene moeder vertelt $u$, dat zij al vroeg met eigeel moest beginnen, omdat hierin zoveel ijzer zit. Een andere moeder, dat zij juist geen eieren mocht geven, omdat deze allergisch werken. (Spock, 1978, p. 17)

Dat in dit soort passages meestal niet expliciet over vaders wordt gesproken is veelzeggend. Impliciet ontstaat toch de indruk dat de aangesproken lezer, " $u$ ", net als de twee raadgevende moeders in de tekst een moeder is. 
zich in de praktijk niet altijd staande houdt en bieden ze ouders manieren aan om hier mee om te gaan.

Volgens Wubs (2004) is Spocks Baby- en kleuterverzorging (1950) tot 1970 een zeldzaamheid in het Nederlandse opvoedkundige advieslandschap. Daarna wordt zijn opvoedkundige, hedonistische moraal van een prettige opvoeding, zoals die in de eerste Nederlandse versie van zijn boek centraal staat, echter grotendeels en massaal overgenomen (zie ook Bakker, Noordman \& Rietveld-Van Wingerden, 2010). ${ }^{16}$ "Plezier in het grootbrengen van kinderen was tussen 1970 en 1999 het ideaal" (Wubs, 2004, p. 164). Binnen de ontwikkelingspsychologische benadering die vanaf dat moment populair wordt, is er aandacht voor de gevoelens en het geluk van de ouders, maar deze staan in de eerste plaats in relatie tot het welbevinden, geluk en de ontplooiing van het kind. Voorbeelden van de ontwikkelingspsychologische handboeken waarnaar Wubs (2004) verwijst wanneer ze de wijdverbreide opkomst van een plezierig opvoedingsideaal bespreekt, zijn Het tweelingenboek (1988) van Lenny Duijvelaar en Anjo Geluk, Kinderen grootbrengen (1991) van David Fontana, Kind, Kind...gedachten en adviezen over praktische opvoedingssituaties (1973) en Kind Toch, Een verzameling artikelen uit Ouders van Nu waarin ontwikkeling centraal staat (1980) van Rita Kohnstamm en Baby en kind (1979) van Penelope Leach. Vooral in het boek van Leach (1979) over de ontwikkeling van het kind in de eerste vijf levensjaren wordt een hedonistische moraal goed zichtbaar. Zo richt Leach in haar introductie als volgt het woord tot de ouders:

\footnotetext{
'Baby en Kind' is geschreven vanuit jouw baby of kind, omdat haar gezichtspunt het belangrijkst is en toch het meest over het hoofd gezien wordt, hoe de manier van kinderen grootbrengen ook verandert. (...) Het feit dat ik van de baby uitga, betekent dus niet dat jullie gezichtspunt, als ouders, over het hoofd wordt gezien. Jullie hebben dezelfde belangen. Jullie staan allemaal aan dezelfde kant: je wilt gelukkig zijn en plezier aan elkaar beleven. Als je ervoor zorgt dat zij gelukkig is, zal ze jullie gelukkig maken. Als zij ongelukkig is, zul je merken, dat je zelf ook ongelukkig bent, hóezeer je jouw gevoelens ook van de hare wilt scheiden. (Leach, 1979, p. 8)
}

Zo is dit hele boek gericht op jou en je kind als een twee-eenheid die elkaar gelukkig maakt. Als zij plezier heeft, heb jij het ook. Als jij er meer plezier in krijgt, wordt het voor haar weer leuker. Als je het allebei naar de zin hebt, zullen jullie minder problemen hebben. (Leach, 1979, pp. 13-14)

Leach (1979) benadrukt nog sterker dan Spock (1950, 1978, 1984, 2000, 2007, 2010) dat het geluk van de ouders en het geluk van het kind met elkaar samenhangt. Als het kind gelukkig is dan zijn de ouders dat ook en omgekeerd. Voor een geslaagde

\footnotetext{
${ }^{16}$ Wat overigens niet betekent dat dit vanaf dat moment de enige beschikbare visie op opvoeden is, hoewel deze ontwikkelingspsychologische benadering volgens Wubs (2004) wel dominant is. Andere visies op opvoeden zien we aldus Wubs (2004) terug in een klein aantal boeken met een christelijke inslag dat na 1970 wordt gepubliceerd en in een beperkt aantal boeken van deskundigen die beroepsmatig voornamelijk met probleemgezinnen te maken hebben, dat vanaf de late jaren tachtig verschijnt.
} 
ontwikkeling van het kind, is het volgens Leach (1979) zelfs van groot belang dat het kind en de ouders gelukkig zijn met elkaar. Een prettige ervaring van de opvoeding is bij Leach (1979) niet alleen mooi meegenomen voor ouders en kind, maar is een opvoedkundige norm die aan ouders wordt opgelegd. Daarbij spreekt ze indirect vooral de moeder aan.

Wubs (2004) stelt terecht dat de toenemende populariteit van het geluk van ouders en het kind als een opvoedkundig doel samenhangt met de opkomst van het idee dat het krijgen van kinderen een bewuste keuze is. "Voorlichters gingen er vanuit dat ouders kinderen kregen omdat zij die wilden en dat daarom genieten van hun kind voor ouders belangrijk was" (Wubs, 2004, p. 216). We kunnen in het verlengde van Wubs (2004) observatie stellen dat aan de basis van de wijdverspreide acceptatie van de ontwikkelingspsychologische benadering waarbinnen opvoeden prettig en warm moet zijn, een specifiek modern mensbeeld ten grondslag ligt. Aanstaande ouders worden namelijk als rationele, autonome, keuzemakende personen benaderd die hun eigen leven naar eigen inzicht kunnen en willen inrichten.

De verwachting van opvoedkundige experts in de handboeken dat ouders van hun kinderen willen en moeten genieten, geldt vooral voor moeders en in mindere mate voor vaders. Praktisch alle door Wubs $(2000,2004)$ onderzochte boeken richten zich op moeders als de belangrijkste opvoeders. Dat de opvoeding niet altijd vanzelfsprekend rimpelloos verloopt, daarvan zijn de auteurs van deze ontwikkelingpsychologische handboeken zich bewust (Wubs, 2004). Zij besteden in hun boeken volgens Wubs (2004) dan ook de nodige woorden aan mogelijke obstakels en problemen die moeders kunnen tegenkomen, zoals een baby die niet stil is te krijgen en maar blijft huilen of een krijsende peuter die niet doet wat zijn moeder hem vraagt. Gelukkig zijn, blijft echter het na te streven ideaal. De deskundigen bieden oplossingen aan, die moeders in staat moeten stellen om dit doel te realiseren en de aangesneden problemen worden zodoende van voorbijgaande aard beschouwd. Moederschap wordt voorgesteld als een beheersbare, prettige aangelegenheid. De meeste van de experts erkennen daarbij dat er geen perfecte opvoeders bestaan en dat opvoeden in de praktijk een compromis is tussen de behoeftes van het kind en wat de moeder naar best vermogen op kan brengen. Moeders mogen dus af en toe best aan hun eigen behoeftes toegeven, vooral ook omdat het beter zou zijn voor het kind wanneer zijn moeder hem dan ontspannen, positief en met liefde kan benaderen, terwijl ze dat anders misschien niet zou doen. Bovendien zijn moeders ook maar mensen en fouten maken hoort er gewoon bij.

In het grootste deel van de opvoedkundige adviesboeken die in de jaren zeventig worden gepubliceerd, worden de moeders daarbij zelf als de belangrijkste deskundige op het vlak van de opvoeding van hun kinderen beschouwd (Wubs, 2004). Individuele keuzevrijheid en autonomie van de moeder staan voorop en moraliserende uitspraken over de 'juiste' inrichting van het gezinsleven worden geschuwd. Belangrijker is het dat moeders zichzelf prettig voelen bij hun manier van opvoeden 
en dat ze authentiek blijven in hun benadering van het kind (Wubs, 2004). De vaak op de ontwikkelingspsychologie geïnspireerde adviezen zijn slechts een hulpmiddel, waarmee moeders opvoedingsproblemen kunnen oplossen als deze zich voordoen. Het algemene idee is dat opvoeding doorgaans spontaan goed plaatsvindt. Opvoedingsadviezen worden niet per definitie als noodzakelijk gezien, maar kunnen moeders wel ondersteuning bieden.

Vanaf de jaren tachtig wordt die vrijblijvendheid enigszins losgelaten. Het belang van de adviezen wordt meer geaccentueerd en het idee van de moeder die zelf intuïtief het beste weet hoe ze haar kind moet opvoeden, komt daardoor in zekere mate onder druk te staan (Wubs, 2004). In ieder geval lijkt de opvoedkundige literatuur op dit punt tegenstrijdiger te worden. Ondanks het streven van deskundigen om geen normerende uitspraken over de opvoeding te doen, gaat een groot aantal van hen vanaf dat moment explicieter in op wat naar hun mening goede en slechte opvoedingspraktijken zijn (Wubs, 2004). Een door ouders en het kind als plezierig ervaren opvoeding blijft het motto. De nadruk op genieten krijgt zelfs in toenemende mate een normatief karakter, doordat er meer aandacht voor de ontwikkelingspsychologische ontwikkeling van het kind komt. Die valt of staat immers met het plezier dat moeders aan hun kinderen beleven. Daarnaast wordt er in samenhang hiermee massaal en met klem gewezen op het belang van het stellen van grenzen en op een goede hechting tussen moeder en kind (Wubs, 2004). Vooral die hechting zou cruciaal zijn voor de ontwikkeling van het kind en de beschikbaarheid van de moeder zou hiervoor, zeker in de eerste levensjaren, noodzakelijk zijn. Een goede hechting wordt ook al in de jaren zeventig belangrijk gevonden, maar vanaf de jaren tachtig is dit nog sterker het geval (Wubs, 2004).

Hoewel veel opvoedkundigen het na 1970 in principe geen probleem vinden als moeders werken, mits zij er in slagen de opvoeding en het huishouden goed te organiseren, wordt er in de adviezen weinig aandacht besteed aan mogelijke vragen van werkende moeders, over kinderopvang bijvoorbeeld (Wubs, 2000, 2004). Volgens Wubs (2004) is het gebrek aan informatie over zulke kwesties niet het gevolg van een afkeurende houding van opvoedkundigen ten opzichte van werkende moeders. En het is ook niet zo dat opvoedkundigen denken dat de meeste moeders de hele dag bij hun kinderen zijn en daarom geen aandacht aan kinderopvang besteden. Zeker vanaf de jaren negentig is dit onwaarschijnlijk, vanwege het snel toenemend aantal kinderen dat door hun ouders naar de dagopvang wordt gebracht (Wubs, 2004). Opvoedkundigen gaan, aldus Wubs (2004), niet op de combinatie werk en zorg in, omdat zij zich niet willen bemoeien met de wijze waarop ouders het gezinsleven inrichten. Doordat in de boeken echter voornamelijk de moeder als de belangrijkste opvoeder wordt aangesproken en doordat het belang van de beschikbaarheid van de moeder in het kader van de juiste hechting wordt benadrukt, wordt zo impliciet en wellicht onbedoeld een bepaald normatief beeld van het gezin uitgedragen. Het normale gezin dat de opvoedkundigen als uitgangspunt nemen, is 
dan toch een gezin waarin de moeder de belangrijkste opvoeder is: "1950, 1970 of 1990, opvoedingsboeken gaan over kinderen die thuis wonen met een vader die de kost verdient en een moeder die voor ze zorgt en daar boeken over wil lezen" (Wubs, 2000). Opvoedkundigen vinden weliswaar in toenemende mate dat ook de vader een rol heeft te vervullen, maar het blijft zeker bij jonge kinderen vanzelfsprekend dat moeders de belangrijkste opvoeders zijn. De vader is meestal slechts een helpende hand.

Afgaand op de observaties van Wubs $(2000,2004)$ kunnen we stellen dat er vanaf 1970 een patriarchaal, heteroseksueel ideaal van een kerngezin naar voren wordt geschoven, waarin de moeder verantwoordelijk is voor de zorg van de kinderen en de vader kostwinner is. Dit ideaal heeft zijn historische wortels in de negentiende eeuw, toen de middenklasse zich in Nederland en andere westerse landen van de arbeidersklasse en hogere klasse ging onderscheiden door een specifieke inrichting van het gezinsleven (Schuurman, 1992). Het negentiende-eeuwse middenklasse gezin is idealiter een kerngezin waarin de vrouw moeder en huisvrouw is en de man kostwinner. Het van oorsprong blanke, middenklasse karakter van deze norm werkt tot op heden door in het vertoog van genieten, doordat het een gezinsideaal is dat een bepaalde levenstandaard vereist. Het moet immers in materiële zin ook mogelijk zijn voor de moeder om thuis te blijven. In Nederland is de overwegend blanke middenklasse de grootste groep die zich een dergelijke levensstijl kan veroorloven. ${ }^{17}$ En het is in eerste instantie vooral ook deze klasse die de gepopulariseerde ontwikkelingsgerichte benadering als ideaal heeft omarmd, hoewel zij in de praktijk hun leven wellicht anders inrichten.

De studie van Wubs (2004) houdt op in 1999, maar de op de ontwikkelingspsychologie geënte fun morality blijft tot op de dag van vandaag bon ton in Nederlandse opvoedkundige adviesliteratuur voor ouders. Dit blijkt uit het feit dat de meerderheid van de opvoedkundige adviesboeken die voor het eerst na 1970 zijn uitgegeven en die Wubs (2004) heeft bestudeerd, ook na 1999 worden verkocht, herdrukt en/of aangeraden aan ouders of andere opvoeders. ${ }^{18}$ Het grootste deel van

\footnotetext{
${ }^{17}$ Hoewel de middenklasse recent iets meer kleur heeft gekregen door de doorstroom van niet-westerse migranten op de arbeidsmarkt (Dagevos, Hoff \& Soede, 2006), blijft de middenklasse en ook de hogere klasse tot op heden grotendeels uit (overwegend blanke) autochtonen bestaan. De groep migranten die doorstroomt naar de middenklasse vormt een uitzondering op de regel. Jan Latten (2005) laat aan de hand van beschikbare cijfers van het Centraal Bureau voor de Statistiek over opleidingsniveau, inkomen en etnische achtergrond vanaf eind jaren negentig tot 2004 bijvoorbeeld overtuigend zien dat er sprake is van een etnische segregatie die samenvalt met de sociaaleconomische klassen in Nederland. Dit beeld wordt bevestigd door ander onderzoek (Bijl, Zorlu, Van Rijn, Jenissen \& Blom, 2005; Bos, 2009; Dagevos, 2005; Forum, 2010; Wetenschappelijk Onderzoek- en Documentatiecentrum van het Ministerie van Justitie, 2006).

${ }^{18}$ Wubs (2004) bekijkt in totaal 65 boeken die voor het eerst na 1970 zijn gepubliceerd. Door deze titels op te zoeken in de Nederlandse Centrale Catalogus, op de websites van uitgeverijen en door via Google na te gaan waar de boeken vandaag de dag circuleren, is duidelijk geworden dat ten minste 34 van deze
} 
deze boeken is na 1999 nauwelijks herzien. ${ }^{19}$ Zo zijn Het tweelingenboek (1988) van Duijvelaar en Geluk en Kinderen grootbrengen (1991) van Fontana nog steeds populair, waarvan de tweede in vrijwel dezelfde vorm als voor 1999. Dit geldt ook voor Baby en kind (1979) van Leach. Dit boek is in 2008 opnieuw uitgegeven, in nagenoeg dezelfde vorm als de versie uit 1979. Naast de door Wubs $(2000,2004)$ onderzochte boeken zijn er nog andere handboeken die het na 1999 goed doen en die aansluiten bij het ideaal van prettig opvoeden. Een goed voorbeeld is het in 1992 voor het eerst verschenen Oei, ik groei (2010) van het echtpaar Hetty van de Rijt en Frans X. Plooij (Breeuwsma, 1999). In 2010 is alweer de 56ste druk van dit handboek verschenen en het boek staat in ieder geval al sinds 2008 op de lijst met opvoedboeken die het Nederlands Jeugdinstituut, het landelijk kennisinstituut voor jeugd- en opvoedingsvraagstukken, aan ouders aanraadt (Nederlands Jeugdinstituut, 2008). Dit geldt overigens ook voor het boek van Leach (2003/1979). Daarnaast treffen we op deze lijst een boek van een auteur als Emmeliek Boost aan, met de titel Opvoeden...geniet ervan! Van baby tot en met puber. De meest gestelde vragen aan de Opvoeddesk (2006). Het doel van dit boek is om ouders tips aan te reiken waarmee ze de opvoeding van hun kinderen (weer) als aangenaam kunnen ervaren. Het is interessant dat Boost (2006) in dit boek juist een positief beeld van werkende moeders schetst. Ook bij de Opvoeddesk, een door Boost opgericht adviesbureau waar zowel ouders als bedrijven die ouders in dienst hebben, terecht kunnen met hulpvragen, staat de werkende moeder op deze manier centraal (De Opvoeddesk, 2010a). Dit kan er op wijzen dat de hedonistische visie op moederschap zich in de opvoedkundige handboeken in de loop van het eerste decennium van de twintigste eeuw wellicht meer is gaan richten op werkende moeders. Spock, die sinds 1978 al expliciet over werkend moederschap heeft geschreven, staat wat dat betreft nu minder alleen.

\section{Vrouwenweekbladen: Margriet en Libelle}

De auteurs van de adviesboeken die Wubs $(2000,2004)$ heeft onderzocht, hebben (delen van) hun werk gepubliceerd in de vrouwentijdschriften Margriet en Libelle en in het opvoedkundige tijdschrift Ouders van $\mathrm{Nu}$. Ook de hierboven genoemde opvoedkundige auteurs van na 1999 hebben in deze bladen gepubliceerd. Zo komt Boost bijvoorbeeld geregeld aan het woord in Margriet, Libelle en Ouders van $\mathrm{Nu}^{20}$

\footnotetext{
65 titels $(52,3 \%)$ na 1999 nieuw worden verkocht of dat ze worden genoemd op websites door en voor ouders en andere opvoeders. Niet alle 34 werken stellen een opvoedingsideaal van gelukkige ouders en kinderen centraal, maar in een aanzienlijk aantal is dit wel het geval.

${ }^{19}$ Slechts 6 van 34 boeken (zie noot 18 ) worden afgaand op de beschrijvingen van de boeken in de NCC en op websites van de uitgeverijen uitgebreid herzien.

${ }^{20}$ Voor een overzicht van deze artikelen zie De Opvoeddesk (2010b).
} 
en in november 2005 gaf Ouders van Nu ter gelegenheid van de verkoop van het 400.000ste exemplaar van Oei, ik groei (1992) een speciale bijlage over dit boek uit (Sanoma Uitgevers, 2005). Het is daarom niet verrassend dat er in deze tijdschriften wordt aangehaakt bij de moraal van een prettige opvoeding, zoals die in de opvoedkundige adviesliteratuur wordt geproduceerd of dat ze er op zijn minst mee resoneren. $^{21}$ Het ligt bovendien voor de hand dat dit soort glossy's vanwege hun winstoogmerk gelukkige mensen laat zien. Het idee is immers dat geluk verkoopt. Vanuit dit perspectief worden hier eerst de twee genoemde vrouwenweekbladen besproken. Daarna komt Ouders van Nu aan bod.

De doelgroep van Margriet en Libelle bestaat, afgaand op de beschikbare gegevens uit 2010, uit vrouwen tussen de dertig en vijfenvijftig jaar (Sanoma Uitgevers, 2010a, 2010b). Daarbij komt dat de doelgroep van Libelle qua inkomen en opleiding doorgaans tot de (hogere) middenklasse behoort (Sanoma Uitgevers, 2010a). Van Margriet ontbreken gegevens over de inkomenspositie van de lezersdoelgroep in de profielschets van de uitgever van het blad, maar qua opleiding bestrijkt Margriet de lagere middenklasse en een klein deel van wat we de arbeidersklasse zouden kunnen noemen. De doelgroep bestaat namelijk uit vrouwen met een mbo-, havo- of vwo-diploma, maar ook uit vrouwen die alleen de lagere school hebben afgemaakt (Sanoma Uitgevers, 2010a). Libelle is al jaren het grootste Nederlandse vrouwenweekblad. Met een oplage van 324.000 exemplaren en een bereik van 1,6 miljoen vrouwen per week in 2010 is ook Margriet een van de grotere wekelijkse tijdschriften voor vrouwen (Sanoma Uitgevers, 2010a, 2010b).

Afgaand op sociologisch onderzoek naar ideeën over moederschap in de artikelen uit de jaargangen 1960, 1970, 1980 en 1990 van Margriet en Libelle, werkt de hedonistische benadering vooral door in jaargang 1980 (Knijn \& Nievers, 1996; Knijn \& Verheijen, 1991; Verheijen, 1986). In 1960 en 1970 wordt moederschap voorgesteld als iets dat moeders overkomt en opvoeden als iets dat ze nu eenmaal moeten doen (Verheijen, 1986). In 1980 is dit anders. Moederschap wordt dan als een keuze beschouwd die indien bewust vormgegeven in plezier, individuele zelfontplooiing en persoonlijke verrijking voor de moeder resulteert (Knijn \& Verheijen, 1991; Verheijen, 1986). Daarbij wordt er vanuit gegaan dat de moeder het beste weet hoe zij die opvoeding kan inrichten.

Die vrijheid wordt in 1990 enigszins aan banden gelegd (Knijn \& Nievers, 1996). In deze jaargang is de moeder niet langer volledig vrij om te doen en laten wat zij wil op het gebied van opvoeding, maar wordt van haar verwacht dat zij het reilen en zeilen in het gezinsleven goed organiseert. Zelfontplooiing is niet meer iets wat in of via het moederschap plaats kan vinden, maar dat voorafgaand aan het krijgen van

\footnotetext{
${ }^{21}$ Buikema en Wesseling $(2000,2006)$ wijzen ook op de doorwerking van de fun morality uit het opvoedkundig advies in Ouders van $\mathrm{Nu}$.
} 
kinderen of naast het moederschap dient te worden gerealiseerd. Pas als het gezin op rolletjes loopt, kan en mag er ruimte zijn voor andere zaken zoals opleiding en werk. Er worden tips aangereikt waarmee de moeder de organisatie van haar gezinsleven kan laten slagen en organisatiestress kan voorkomen. $\mathrm{Er}$ is in tegenstelling tot de eerdere jaargangen onder meer aandacht voor de combinatie van een (deeltijd)baan en de zorg voor het gezin. Dit hangt waarschijnlijk samen met het feit dat moeders in die tijd meer zijn gaan werken. Dit zal ook voor de Libelle- en Margrietlezeressen met kinderen gelden. ${ }^{\mathbf{2 2}}$ Door de combinatie van werk en zorg te bespreken lijkt er in de tijdschriften in eerste instantie sprake te zijn van acceptatie van het feit dat moeders zijn gaan werken. De combinatie van werk en moederschap wordt echter vooral als een organisatorisch probleem voor de moeder beschreven. Bij de geopperde oplossingen voor dit probleem is er weinig aandacht voor de vader. De vader heeft in de uitgaven in 1990 nog steeds niet echt een actieve rol te vervullen in de opvoeding. Hij wordt net als in de voorgaande jaargangen voornamelijk als de kostwinner gezien. Weliswaar is er in 1990 sprake van een acceptatie van het feit dat een gezin verschillende verschijningsvormen heeft, maar men blijft er op normatieve wijze vanuit gaan dat de moeder in eerste instantie verantwoordelijk is voor de zorg voor de kinderen. Daarnaast is er een voorkeur voor een gezin met twee ouders boven alleenstaand moederschap.

De toenemende belangstelling voor de stressvolle kanten van de organisatie van het gezinsleven in 1990, betekent niet per definitie dat het vertoog van genieten zich niet langer laat gelden in deze vrouwenbladen. Het voert te ver om de tijdschriften hier zelf aan een uitgebreid onderzoek te onderwerpen, maar de vormgeving en inhoud van Margriet Kids, de special voor moeders van Margriet, wijst er op dat een hedonistisch moederschapsideaal voor de makers van het blad Margriet althans relevant blijft.

\footnotetext{
${ }^{22}$ Eind jaren zeventig blijft slechts $9 \%$ van de werkende vrouwen die voor het eerst moeder wordt werken, in 2006 is dit 89\% (Bekker, 2007). De toename van het aantal werkende moeders is onder andere mogelijk gemaakt door de toenemende beschikbaarheid van het aantal deeltijdbanen. Een deeltijdbaan is over het algemeen gemakkelijker te combineren met de zorg voor een gezin, waarvoor de moeder volgens de geldende publieke opinie nog altijd verantwoordelijk is. De stijging van het aantal moeders met een betaalde baan wordt lange tijd niet gefaciliteerd door overheidsbeleid (zie ook Elly Singer, 1989). Pas rond 1990 komen er regelingen die het voor een moeder gemakkelijker maken om deel te nemen aan de arbeidsmarkt: zoals de verlenging van het zwangerschap- en bevallingsverlof van twaalf naar zestien weken, de wettelijke invoering van ouderschapsverlof en de Stimuleringsmaatregel Kinderopvang die het aantal kinderopvangplekken voor kinderen tussen de nul en vier jaar moet vergroten. Vooral de arbeidsparticipatie van moeders van kinderen uit deze leeftijdscategorie krijgt door deze maatregelen in de jaren negentig een zetje in de rug (Niphuis-Nell \& De Beer, 1997).
} 


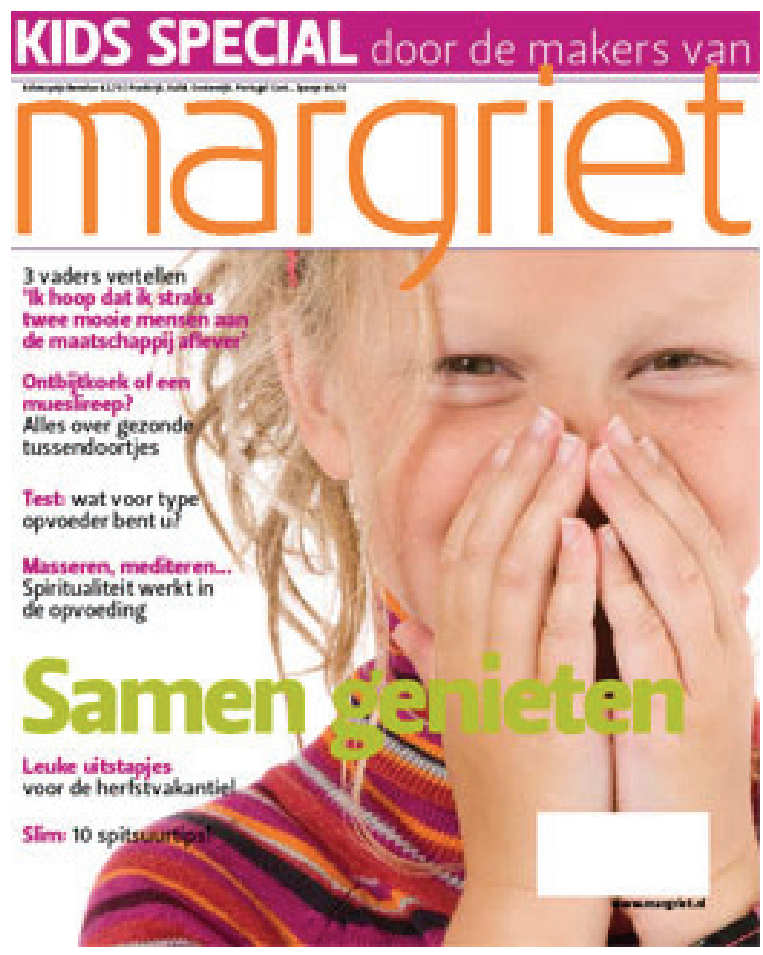

Afbeelding 1

Cover. Uit Margriet Kids Special door Sanoma Uitgevers, 2009. Geraadpleegd op 1 september, 2010, via www.zester.nl. Copyright 2009 Sanoma Uitgevers. Afgedrukt met toestemming.

Deze special "voor moeders van kinderen van 4 tot 12 jaar" (Sanoma Uitgevers, 2009) is volgens Jolanda Speelman van het Informatiecentrum Margriet tussen 2004 en 2009 één keer per jaar uitgegeven door Margriet en ziet vanaf 2010 twee keer per jaar het licht (Jolanda Speelman, e-mail, 31 augustus 2010). Het idee dat moederschap een prettige aangelegenheid is, manifesteert zich duidelijk op de cover van Margriet Kids uit 2009, waarop een lachend, blank jong meisje in een roze gestreepte koltrui staat, met daaronder de lichtgroen, vetgedrukte tekst "Samen genieten" (afbeelding 1). Een voor de hand liggende interpretatie van de betekenis van de cover aan de moeders op wie het blad zich richt is, is dat het bovenal plezierig is om samen met je jonge kind tijd door te brengen. Ook in het gros van de artikelen in dit nummer is geluk de belangrijkste maatstaf en leidraad, zoals blijkt uit de beschrijving van de inhoud door de uitgever van Margriet:

Verder in dit nummer: Spelen kun je overal. Op de boerderij, in de stad, vinexwijk of flat: kinderen (en hun moeders) vertellen over de plek waar zij wonen. Snoep verstandig...snoep af en toe (maar dan ook écht). De 10 leukste 'natuurlijke' herfstuitstapjes op een rij. Doe Een Wens laat dromen uit- 
komen. Dansen, zingen, koordlopen of gitaar spelen. Lekker naar school in je vrije tijd. (Sanoma Uitgevers, 2009)

Het gaat hoofdzakelijk om fijne dingen zoals spelen, dansen, zingen, dromen laten uitkomen en uitjes. Daarnaast wordt net als in jaargang 1990 van Margriet en Libelle de organisatie van het gezinsleven geaccentueerd, zoals in het artikel Slim: 10 spitsuurtips! dat op de cover wordt aangekondigd. Gezien de focus op het geluksgevoel van moeders en kinderen in de rest van het tijdschrift, ontstaat sterk de indruk dat de tips in dit artikel er op gericht zijn om het voor de moeder mogelijk te maken om het motto "Samen genieten" (afbeelding 1) te realiseren.

De Kids Special van Margriet is overigens niet de enige special van een vrouwentijdschrift voor moeders van jonge kinderen in Nederland. Verschillende vrouwenbladen hebben inmiddels glossy spin-offs over moederschap, zo geeft Viva de special Viva mama uit, publiceert Flair de glossy Flair Mama en van de makers van het blad Jan verschijnt Jantje. In al deze bladen wordt het moederschap zonder uitzondering op soortgelijke wijze geïdealiseerd. Hoewel er in deze tijdschriften eveneens aandacht wordt besteed aan eventuele problemen, lijken moeders en hun kinderen vooral uitbundig consumerend en gelukkig door hun succesvolle en aangename zelfgemaakte leven te gaan. Ook de visuele vormgeving werkt hieraan mee.

\section{Opvoedkundige tijdschriften: Ouders van $\mathrm{Nu}$}

Ouders van $\mathrm{Nu}$ is het eerste commerciële opvoedkundige blad voor ouders in $\mathrm{Ne}$ derland en is sinds haar oprichting in 1967 uitgegroeid tot een van de grootste en meest bekende populaire opvoedkundige tijdschriften. Andere bekende tijdschriften naast Ouders van Nu zijn onder meer Kinderen, opgericht in 1979 en het sinds 1997 verschijnend J/M Ouders (Wubs, 2004). Net als de door Wubs (2000, 2004) besproken opvoedkundige adviesboeken richt Ouders van $\mathrm{Nu}$ zich voornamelijk op (aanstaande) moeders, de neutrale titel ten spijt (Dijken \& Tavvechio, 1998; Van Lieshout, 1993). De doelgroep van het tijdschrift bestaat anno 2010 uit vrouwen, meestal met een (parttime) baan, die samen met een partner voor kinderen tussen de nul en vijf jaar zorgen of die op het punt staan om kinderen te krijgen (Sanoma Uitgevers, 2010c)..$^{\mathbf{2 3}}$ De sociale klasse van deze vrouwen wordt in 2010 omschreven als gemiddeld Nederland (Sanoma Uitgevers, 2010c). ${ }^{\mathbf{2 4}}$ Uit de spaarzame rubrieken in het blad waar de partner van de beoogde moeder aan het woord wordt gelaten,

\footnotetext{
${ }^{23}$ Uit marktonderzoek in 2007 blijkt dat 42\% van vrouwen met een kind van nul jaar Ouders van Nu lezen, voor moeders met een kind van een jaar is dit 34\%, voor vrouwen met een kind van twee jaar $28 \%$, voor moeders met een kind van drie jaar $20 \%$ en met een kind van vier jaar 16\% (Sanoma Uitgevers, 2008).

${ }^{24}$ Wat hiermee precies bedoeld wordt in termen van opleiding, beroep en inkomen, wordt niet nader gedefinieerd.
} 
blijkt dat er daarbij meestal vanuit wordt gegaan dat dit een man is. Zo kent het blad sinds 2007 een rubriek waarin vaders vertellen over de geboorte van hun kind (Van Gils, 2010). ${ }^{25}$ In 2004, 2005 en 2006/2007 is er bovendien een special voor vaders uitgegeven: Vaders van $\mathrm{Nu}^{26}$ Daarnaast blijkt uit steekproefsgewijs onderzoek dat er vooral blanke gezinnen worden afgebeeld in Ouders van $\mathrm{Nu}$ (Vereniging Samenwerkende Ouder- en Patiëntenorganisaties, 2003).

Een longitudinale historische studie naar de verbeelding van moederschap in Ouders van $\mathrm{Nu}$ ontbreekt ${ }^{27}$, maar wanneer we bij wijze van steekproef de covers van nummer zes van jaargang 1980, 1990, 2000 en 2009 bekijken (afbeelding 2, 3, 4 en 5) dan lijkt er in de visuele vormgeving in loop der jaren weinig te zijn veranderd.

\footnotetext{
${ }^{25}$ Tot het derde nummer uit 2010 heet de rubriek Meepuffen, daarna wordt de rubriek omgedoopt in Hoe bevalt 'ie? (Van Gils, 2010).

${ }^{26}$ Navraag bij de redactie van Ouders van Nu leert dat de productie van deze special wegens tegenvallende verkoopcijfers na deze drie uitgaven is stopgezet (Van Gils, 2010). Dat vaders blijkbaar niet geïnteresseerd zijn in het kopen van een opvoedkundig tijdschrift is indicatief voor de wijze waarop de zorg voor kinderen nog altijd wordt georganiseerd in de meerderheid van de Nederlands huishoudens: het zijn de moeders die het leeuwendeel van de zorg voor de kinderen op zich nemen (Cloïn, Van den Broek, De Haan \& Van der Klis, 2009; Cloïn \& Souren, 2009; Duijvendak \& Stavenuiter, 2004). Het is dan ook niet verrassend dat een tijdschrift zoals Ouders van $\mathrm{Nu}$ zich hoofdzakelijk en noodgedwongen op moeders blijft richten, omdat zij immers de belangrijkste afzetmarkt zijn.

${ }^{27}$ Er bestaat een onderzoek naar het tijdschrift door Ingrid van Lieshout (1993). Dit beperkt zich tot jaargang 1988 en richt zich op de vraag naar de wijze waarop ouders en deskundigen zich tot elkaar verhouden. Daarnaast is er onderzoek naar de berichtgeving over het gebruik van geneesmiddelen tijdens de zwangerschap in jaargang 1989 (Van Trigt, 1991).
} 


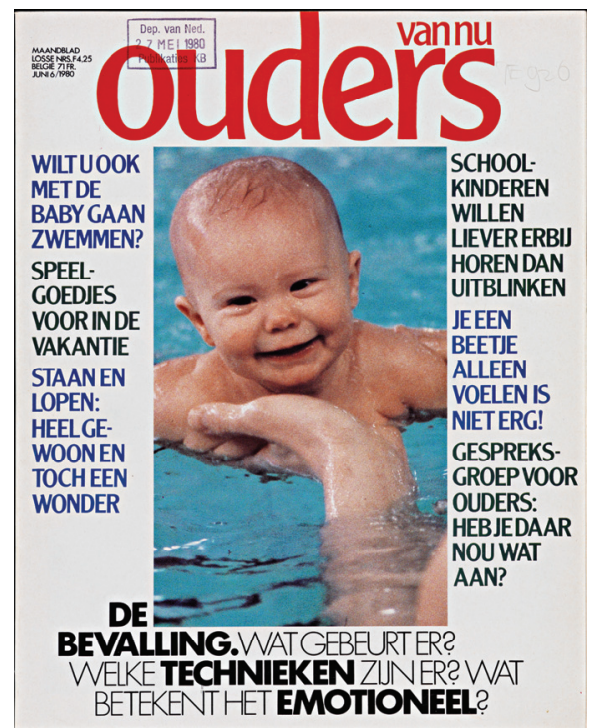

Afbeelding 2

Cover. Uit Ouders van nu, 1980, 6. Den Haag: Koninklijke Bibliotheek. Copyright 1980 Sanoma Uitgevers. Afgedrukt met toestemming.

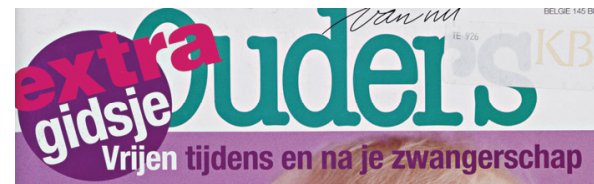

knder-gekibbel

begon, mam!

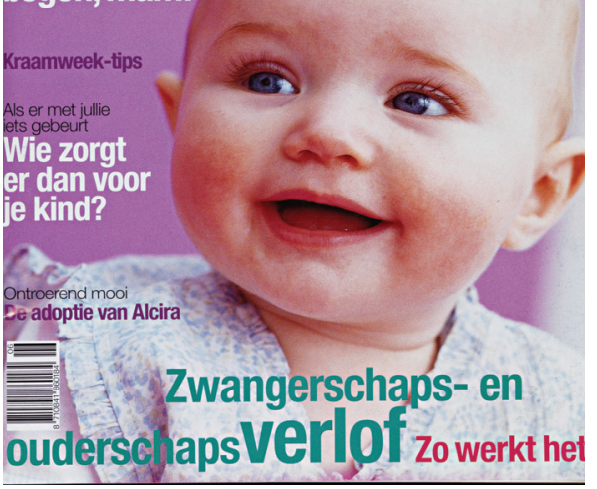

\section{Afbeelding 4}

Cover. Uit Ouders van nu, 2000, 6. Den Haag: Koninklijke Bibliotheek. Copyright 2000 Sanoma Uitgevers. Afgedrukt met toestemming.

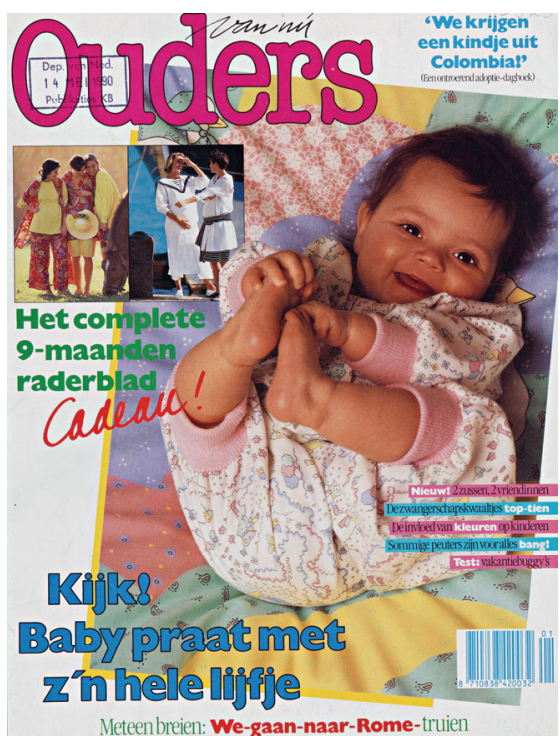

\section{Afbeelding 3}

Cover. Uit Ouders van Nu, 1990, 6. Den Haag: Koninklijke Bibliotheek. Copyright 1990 Sanoma Uitgevers. Afgedrukt met toestemming.

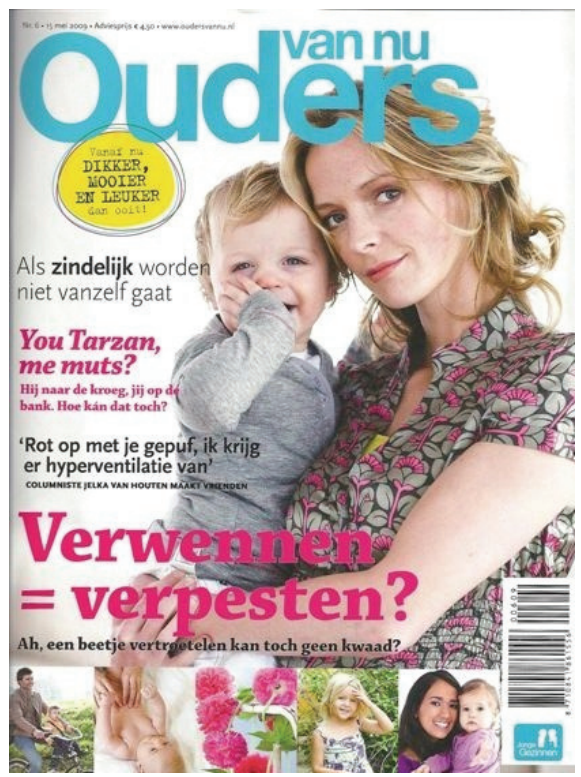

\section{Afbeelding 5}

Cover. Uit Ouders van $\mathrm{Nu}, 2009$, 6. Den Haag: Koninklijke Bibliotheek. Copyright 2009 Sanoma Uitgevers. Afgedrukt met toestemming. 
Op een cover van het maandblad staat doorgaans een foto van een lachende baby en/of een foto van een stralende, blanke, goedverzorgde, in de laatste mode gestoken moeder die haar baby innig gelukkig tegen zich aandrukt. De boodschap van de foto's op de covers is overduidelijk dat de zorg voor kleine kinderen fijn is. De foto van de moeder en haar kind op de cover uit 2009 heeft bovendien iets symbiotisch en als zodanig stelt deze afbeelding impliciet het belang van de beschikbaarheid van de moeder en van een innige band tussen moeder en kind op de voorgrond.

Daar staat tegenover dat de tekst op de vier covers lang niet altijd getuigt van het idee dat moederschap voornamelijk een warme en prettige ervaring is. Zo kunnen we op de cover uit 1980 de zin "Je een beetje alleen voelen is niet erg" lezen en op de cover uit 2000 staat "Kindergekibbel. Maar zíj begon, mam!". We komen in Ouders van Nu echter ook tekstuele idealiseringen van moederschap tegen. Zo staat er op de hier niet afgebeelde cover van het oktobernummer uit 2006 groot "Verliefd op je kind" (Sanoma Uitgevers, 2006, cover). Niettemin worden er juist ook allerlei opvoed- en bevallingsproblemen in Ouders van $\mathrm{Nu}$ bespreekbaar gemaakt, zoals de sociologe Van Lieshout (1993) in haar onderzoek naar jaargang 1988 ook al heeft laten zien. Artikelen over opvoedingsproblemen lijken het idee dat ouderschap iets plezierigs is en behoort te zijn te ondermijnen, maar dat is net als in de opvoedkundige adviesliteratuur waardoor het blad wordt beïnvloed niet per definitie of in ieder geval niet volledig het geval. Bij het bespreken van problemen staat het aandragen van oplossingen en het geruststellen van de ouders namelijk voorop (zie ook Van Lieshout, 1993). Dat dit de doelstelling is blijkt onder meer uit het profiel van Ouders van $\mathrm{Nu}$, zoals dat op de website van de uitgever in 2010 wordt beschreven:

\footnotetext{
Of het nu gaat om zwanger zijn, bevallen of opvoeden: de lezeres kan er op vertrouwen dat we goede, deskundige en getoetste informatie geven. Dat is voor een vrouw in die levensfase enorm belangrijk. Het krijgen van een kind verandert haar leven voor altijd en ze kan wel eens onzeker worden van al die nieuwe dingen die er op haar af komen. Wetend dat ze op Ouders van Nu kan vertrouwen, maakt ze zelf afgewogen keuzes. (...) Vrouwen die een kind hebben gekregen weer helemaal op de rails zetten: aan de buitenkant, maar, door middel van coaching, ook aan de binnenkant! Vervolgens het blad zo vormgeven dat het mooi en eigentijds is (en dus helemaal van nu). Allemaal zaken die ervoor zorgen dat lezers graag een Ouders van Nu oppakken, lezen en bekijken en waardoor ze er een prettig gevoel bij hebben. Omdat het hebben van een baby, dreumes of peuter ook leuk ís! (Sanoma Uitgevers, 2010)
}

Het accent ligt hier op het verstrekken van correcte informatie waarmee moeders de juiste keuzes kunnen maken en waarmee mogelijke onzekerheden die met het krijgen en zorgen voor kind kunnen samengaan, kunnen worden afgewend, waardoor moederschap een prettige aangelegenheid zal zijn. Besprekingen van problemen staan daardoor niet haaks op het idee dat moederschap een aangename ervaring is en vooral hóórt te zijn. 


\section{Reclame voor babyproducten}

Bij de marketing van babyproducten wordt moederschap eveneens geïdealiseerd, wat niet verrassend is. Om een zo groot mogelijke markt aan te spreken en vanwege haar sterk gecomprimeerde vorm, wordt er in reclame immers vaak geappelleerd aan culturele opvattingen die breed gedeeld worden (Spee, Lefever \& VanHoof, 1999; Van Zoonen, 2006). Sekse is bovendien, meer dan in andere moderne media, een centraal onderwerp in reclame (Van Zoonen, 2006). Reclame wordt daarom verondersteld een buitengewoon goede bron te zijn voor het verwerven van inzicht in heersende opvattingen over vrouwen waaronder moederschap (Van Zoonen, 2006). Voor hedendaagse reclame is het overigens niet ongewoon om zich op het geluk en het genot van de beoogde consumenten te richten. ${ }^{28}$ Daarnaast bestaat er in Amerikaanse reclame in ieder geval een langere traditie om het gezin te romantiseren (zie bijvoorbeeld Marchand, 1986). Nederland vormt daarop waarschijnlijk geen uitzondering. Het is daarom nog maar de vraag of hedendaagse idyllische voorstellingen van moederschap in reclame voor babyproducten één op één zijn terug te voeren op het rooskleurige ideaal van moederschap, zoals dat gestalte krijgt in opvoedkundig advies en tijdschriften voor vrouwen en ouders. Reclame is desondanks een belangrijke kracht die het vertoog zoals we het daar tegenkomen versterkt (Buikema \& Wesseling, 2000, 2006).

Hedendaagse reclame voor babyproducten brengt in Nederland opvallend vaak jonge moeders in beeld. Dat heeft een goede reden: moeders hebben doorgaans de beslissende stem in de aanschaf van de producten. ${ }^{29}$ Dat de moeder meestal centraal staat in reclame, wordt onder meer duidelijk bij een bezoek aan de Negenmaandenbeurs. Op deze beurs, die sinds 1985 jaarlijks wordt georganiseerd in de RAI in Amsterdam, presenteren bedrijven producten en diensten aan aanstaande en jonge ouders. Jaarlijks trekt de beurs tussen de veertigduizend en vijfenveertigduizend bezoekers en daarmee is dit het grootste commerciële evenement op het gebied van zwangerschap en baby's in Nederland (Amsterdam RAI, 2010). ${ }^{\mathbf{3 0}}$ Zowel de marketingstrategie van de bedrijven die zich op de beurs presenteren als de wijze waarop de beurs zelf wordt aangeprezen, is op moeders gericht. Dit laatste blijkt onder meer uit het logo van de beurs: een silhouet van een zwangere vrouw. Op de website van de Negenmaandenbeurs, www.negenmaandenbeurs.nl, worden

\footnotetext{
${ }^{28}$ Dit blijkt bijvoorbeeld uit Jean Kilbourne (1999) en Max Sutherland en Alice Sylvester (2000).

${ }^{29}$ De marketingafdeling van Maxi-Cosi, een producent van onder meer babyautozitjes, geeft bijvoorbeeld aan dat de moeder in $87 \%$ van de gevallen de aankopen voor de baby doet. Dit percentage neemt wel af naarmate de kinderen ouder worden; dan gaan vaders bij de aanschaf van producten een actievere rol spelen (Peters, telefonisch interview, 14 oktober, 2010).

${ }^{30}$ Een ander groot commercieel evenement in Nederland is de Jonge Gezinnen Beurs in Utrecht die jaarlijks ongeveer vijfentwintigduizend zwangere vrouwen en ouders van jonge kinderen, vooral moeders, trekt (Jonge Gezinnen BV, 2010).
} 
(aanstaande) moeders, en niet vaders, bovendien in eerste instantie als consumenten aangesproken en uitgenodigd om de beurs te bezoeken. De beurs wordt daarnaast tegelijkertijd met de op vrouwen gerichte Huishoudbeurs georganiseerd en een ticket voor de Negenmaandenbeurs geeft toegang tot de Huishoudbeurs en omgekeerd. In 2008 zijn er maar liefst 150 bedrijven die deelnemen aan de Negenmaandenbeurs. ${ }^{31}$ Slechts één bedrijf, IkVader Media BV, besteedt expliciet en alleen aandacht aan vaders als opvoeders. Het grootste deel van de bedrijven richt zich in hun promotiemateriaal en in de inrichting van hun stands vooral op moeders, onder meer door voornamelijk blanke moeders en kinderen af te beelden. Daarbij wordt jong moederschap en ook zwangerschap vaak geïdealiseerd. Een goed voorbeeld hiervan zijn de bedrijven die op de beurs de mogelijkheid aanbieden om een pretecho te laten maken van het ongeboren kind. Daarbij wordt er bij tijd en wijle ook ingespeeld op zorgen bij ouders over de veiligheid en de gezondheid van hun kroost. Bedrijven die ouders op deze manier aanspreken, benadrukken vaak impliciet dat het idyllische plaatje niet verstoord hoeft te worden mits ouders een bepaald product aanschaffen waarmee de veiligheid, gezondheid en toekomst van hun kroost bewaakt kan worden, zoals een sensormatje dat de ouders waarschuwt voor dreigende wiegendood. Uit de overweldigende hoeveelheid reclamemateriaal waarin moederschap wordt gerepresenteerd, wordt hier het promotiemateriaal van twee marktleiders op het gebied van babyproducten in Nederland besproken. Allebei bedrijven die zich op Negenmaandenbeurs 2008 presenteerden. Dit zijn Prénatal Moeder en Kind BV en Maxi-Cosi.

Prénatal Moeder en Kind BV, vanaf nu kortweg Prénatal genoemd, wordt in 1959 opgericht en is anno 2010 "de grootste speciaalzaak voor zwangere vrouwen, baby's en jonge ouders" met kinderen tot een jaar in Nederland (Prénatal Moeder en Kind BV, 2010a). In 1974 wordt er vanuit de winkelketen een aparte BV opgericht die de marketingactiviteiten van Prénatal op zich neemt: Wij Special Media (Wij Special Media BV, geen datum a; Prénatal Moeder en Kind BV, 2010b). Het belangrijkste doel van Wij Special Media is om Prénatal te promoten bij de (aanstaande) moeder, onder andere via cosampling. Een van de meest geslaagde marketingcampagnes zijn de twee gratis samplepakketten die Wij Special Media voor Prénatal vormgeeft, samenstelt en verstrekt: de blije doos en de baby doos. ${ }^{32}$ In de dozen zitten een

\footnotetext{
${ }^{31} \mathrm{Er}$ is ook een klein aantal stands van stichtingen en niet-commerciële instellingen aanwezig op de beurs.

${ }^{32}$ Wij Special Media houdt zich daarnaast onder andere bezig met het produceren van het gratis maandelijks tijdschrift Wij. Jonge Ouders voor aanstaande ouders en ouders van kinderen tot een jaar, van gratis jaarlijkse tijdschriftnummers over de zwangerschap, de geboorte en de eerste verjaardag van het kind en met de productie en vormgeving twee websites: www.babyinfo.nl en www.kinderinfo.nl (Wij Special Media BV, geen datum b).
} 
aantal gratis babyproducten zoals luiers, slabbers en spenen en informatie voor de moeder over het (aanstaande) moederschap (Wij Special Media BV, geen datum b). De blije doos en de baby doos zijn vaak de aanleiding voor het eerste contact van de (aanstaande) moeder met Prénatal. In ruil voor het verstrekken van haar contacten adresgegeven kan een aanstaande moeder de blije doos in de zevende maand van haar zwangerschap ophalen bij een Prénatal winkelfiliaal en de baby doos na de geboorte van het kind (Wij Special Media BV, geen datum a, geen datum b). Op die manier wordt de (aanstaande) moeder naar de winkel 'gelokt' en hebben Prénatal en Wij Special Media de beschikking over haar contactgegevens. ${ }^{33}$

Voor zover te achterhalen wordt de blije doos onder de huidige naam sinds omstreeks 1978 verstrekt. ${ }^{34}$ De naam van de blije doos is op zichzelf al veelzeggend over het idee van moederschap dat via beide dozen naar voren wordt geschoven: het krijgen en hebben van een kindje is fijn! Die interpretatie wordt bevestigd wanneer we naar de vormgeving van de dozen kijken zoals ze er tijdens het bezoek aan de Negenmaandenbeurs in 2008 uitzien. De dozen zijn lila en roze van kleur en laten een gelukkige op het eerste oog blanke moeder en haar baby zien. De moeder omhelst het kind. ${ }^{35}$ Alles aan deze dozen straalt uit dat moederschap prettig is en dit ideaal wordt gearticuleerd in relatie tot jonge kinderen en blank moederschap. Daarbij moet wel worden opgemerkt dat de baby doos enige ruimte laat voor de interpretatie van de huidskleur van de moeder. Deze zou met wat goede wil als nietblank kunnen worden beschouwd. De hedonistische visie op moederschap blijkt ook uit de folder met de antwoordkaart waarmee de dozen kunnen worden aangevraagd, die op de beurs wordt uitgedeeld. Er prijken zinnen op als: "Mama worden is leuker dan ooit!" en "Nog even en dan kan het echte genieten beginnen. Dan ben je moeder en ligt er een lief, klein kindje in je armen" (Prénatal Moeder en Kind BV, geen datum). De foto's op de dozen doen sterk denken aan die op de besproken cover van Ouders van Nu uit 2009. Door de sterke fysieke nabijheid tussen moeder

\footnotetext{
${ }^{33}$ Uit onderzoek van Wij Special Media in 2008 blijkt dat deze strategie zeer succesvol is: maar liefst 76\% van alle adressen van moeders van levend geboren kinderen wordt zo verzameld (Wij Special Media BV, geen datum a).

${ }^{34}$ De eerste vermelding van de doos in het online archief van het reclamearsenaal dateert uit dat jaar (Prints \& Proms, 1978). Het reclamearsenaal is in 2001 ontstaan uit een fusie van het Nederlandse reclamearchief en het Nederlandse reclame museum (Reclamearsenaal, geen datum a). Het reclamearsenaal heeft in haar archief circa veertigduizend reclame-uitingen vanaf 1850. In het online archief kan er in ruim dertigduizend uitingen gezocht worden (Reclamearsenaal, geen datum b). De marketingafdeling van Prénatal heeft na een bevestigingsreactie, niet meer gereageerd op vragen over de ontstaansgeschiedenis van de blije doos en de baby doos. De baby doos van Wij Special Media is overigens niet de enige, noch de eerste in zijn soort. In 1968 bestaat er al een soortgelijk initiatief van Happy Service Babyfelicitatiedienst BV (Ouwendijk, 1979).

${ }^{35}$ Een populaire bespreking van de marketing van Prénatal lijkt er echter op te wijzen dat de dozen er in 2004 nog anders uitzagen (Van Bel, Sander \& Verduin, 2007). Op de blije doos in dit boek staat namelijk een tekening van een ooievaar en op de baby doos staan twee bloemen.
} 
en kind wordt er ook hier een symbiotisch beeld van de moeder-kindrelatie gecreeerd en door de afwezigheid van andere opvoeders, zoals de vader, wordt de moeder als belangrijkste opvoeder naar voren geschoven. De hedonistische visie op moederschap blijkt ook uit de folder met de antwoordkaart waarmee de dozen kunnen worden aangevraagd, die op de beurs wordt uitgedeeld. Er prijken zinnen op als: "Mama worden is leuker dan ooit!" en "Nog even en dan kan het echte genieten beginnen. Dan ben je moeder en ligt er een lief, klein kindje in je armen" (Prénatal Moeder en Kind BV, geen datum).

Deze eenzijdige gerichtheid op de moeder en de idealisering ervan beperkt zich niet tot de blije doos en de baby doos. Ook in het bedrijfslogo, twee hartjes, zien we deze terugkeren. Het zijn volgens Prénatal namelijk "een moederhart met daarin een klein hartje, het hartje van haar baby" en ze staan voor "de onvoorwaardelijke liefde die er is tussen een moeder en haar kindje" (Prénatal Moeder en Kind BV, 2010c). Door moederliefde zo als iets onvoorwaardelijks voor te stellen krijgt het bovendien een 'natuurlijk' karakter. Moederliefde lijkt iets vanzelfsprekends, iets dat er altijd 'van nature' is. In de Prénatal catalogussen, waarin allerlei producten voor de zwangere vrouw en baby worden gepresenteerd, ligt de nadruk eveneens op aanstaand of jong moederschap en in combinatie daarmee op het idee dat de zorg voor een kind een genot is. In de 234 pagina's (inclusief de omslag) tellende catalogus van 2008-2009 (Prénatal Moeder en Kind BV, 2008) staat er bijvoorbeeld op maar liefst 73 pagina's een gelukkig (glim)lachende zwangere vrouw of een moeder met haar pasgeboren kind of peuter (31,7\% van het totaal aantal pagina's). Vaders of aanstaande vaders zijn daarentegen op maar 16 pagina's terug te vinden (6,8\% van het totaal aantal pagina's). De foto's van (aanstaande) vaders zijn over het algemeen ook aanzienlijk kleiner dan die van (aanstaande) moeders. De moeders worden meestal in de huiselijke sfeer afgebeeld. Er is in de catalogus maar één foto van een moeder op haar werk bij een artikel over de combinatie van carrière en moederschap. De in de catalogus afgebeelde baby's, moeders en vaders zijn doorgaans blank. Op maar liefst 121 pagina's (51,8\% van het totaal aantal pagina's) staat een blanke baby, een blanke (aanstaande) moeder en/of een blanke (aanstaande vader) vader, terwijl er echter op slechts zeventien pagina's ook enige kleur valt te ontwaren en er ook niet-blanke baby's en/of (aanstaande) moeders en vaders worden afgebeeld (7,3 \% van het totaal aantal pagina's). Een aantal van die foto's is echter wel net zo groot als die waarop blanke kinderen, en/of (aanstaande) ouders staan. Een foto met daarop een zwangere zwarte vrouw staat zelfs op de omslag van de catalogus, maar wel op de achterkant. Op de voorkant staat dan toch weer een zwangere blanke vrouw die glimlachend neerkijkt op haar opbollende buik. Het merendeel van de afgebeelde moeders wordt indirect voorgesteld als vrouwen die deel uitmaken van een heteroseksueel kerngezin, waarin de taken tussen moeder en vader klassiek zijn verdeeld. Dit komt doordat de spaarzame foto's waarop andere vormen van ouderschap staan, in een aparte sectie met de 
titel Verschillende vormen van ouderschap zijn opgenomen en daar expliciet zichtbaar zijn gemaakt. Daar vinden we een foto van twee lesbische moeders en hun kinderen, een afbeelding van een alleenstaande moeder en een foto van een tienermoeder. Ook vinden we in deze rubriek een afbeelding van een homoseksueel stel dat geregeld voor hun neefjes zorgt, van een oma die op haar kleinkinderen past en van een vader(!). Deze foto's wijken af van het gros van de afbeeldingen in de catalogus waarop de moeder in eerste instantie voor de kinderen zorgt. Dat dit de norm is, wordt bevestigd door hiervan afwijkende vormen van ouderschap in een aparte sectie in de catalogus op te nemen. Daarbij kan de kanttekening worden geplaatst dat de afbeeldingen van blanke moeders zonder vader in deze catalogus, en ook in de andere besproken media, ruimte laten voor een tegendraadse interpretatie die ingaat tegen deze hetero-normativiteit. Alleenstaande of lesbische moeders kunnen zich bijvoorbeeld met deze afbeeldingen gaan identificeren en ze als beelden van lesbisch en alleenstaand moederschap interpreteren.

Maxi-Cosi is een van oorsprong Nederlands en inmiddels wereldbekend merk op de markt voor babyproducten en is vooral bekend van haar babyautozitjes. In september 1984 heeft Maxi-Cosi als eerste het babyautozitje in Europa geïntroduceerd (Maxi-Cosi, 2009a). Op het gebied van babyautozitjes is Maxi-Cosi inmiddels een van de marktleiders. Jaarlijks worden er 1,4 miljoen van verkocht in 75 landen overal ter wereld. Volgens Vivian Peters, de internationale manager PR en communicatie van Dorel Netherlands waaronder Maxi-Cosi sinds 1994 valt, is Maxi-Cosi ook in Nederland marktleidend (Peters, telefonisch interview, 14 oktober, 2010). Naast kinderveiligheidsstoeltjes is Maxi-Cosi de afgelopen jaren ook babyfoons, wandelwagens en buggy's gaan produceren. Maxi-Cosi adverteert in Nederland al jaren in verschillende tijdschriften waaronder bijvoorbeeld Ouders van $\mathrm{Nu}$, Kinderen, Groter Groeien en Wij Jonge Ouders en in de catalogussen van speciaalzaken voor baby's en zwangere vrouwen, zoals Prénatal, Babypark en Baby-Dump. Daarnaast worden de producten van Maxi-Cosi sinds omstreeks eind 1998 via zogenaamde consumentenbrochures gepromoot (Peters, telefonisch interview, 14 oktober, 2010). Voor 2007 worden de consumentenbrochures via de retailers aan de consumenten verstrekt en is er weinig direct contact tussen de klant en Maxi-Cosi zelf. Na 2007 verandert dit en kunnen (potentiële) klanten de consumentenbrochures onder meer via de website van Maxi-Cosi downloaden (Peters, telefonisch interview, 14 oktober, 2010).

Maxi-Cosi heeft de vanaf 1999 gepubliceerde advertenties en de vanaf 2003 uitgegeven consumentenbrochures voor de Nederlandse markt bewaard. Ze mochten voor dit onderzoek worden ingezien. Het gaat in totaal om 62 advertenties en 14 consumentenbrochures. Op 54 van de 62 advertenties staan vrolijke of sereen slapende blanke, welvarende baby's, peuters, moeders en/of vaders $(87,1 \%)$. Meestal zien we alleen blanke kinderen: van de 54 advertenties geldt dit voor 33 stuks $(61,1 \%)$. Blanke moeders worden iets vaker afgebeeld dan blanke vaders, 
maar het verschil is niet enorm. Van de 54 advertenties zijn er 12 met blanke moeders $(22,2 \%)$ en 7 met blanke vaders $(13,0 \%)$. Op een klein deel van de advertenties kunnen we met goede wil ook niet-blanke mensen ontdekken. Het gaat dan om 5 van de 62 advertenties (8,1\%). Op slechts 1 advertentie staat een zwart persoon; een moeder. Het zwarte model wordt gebruikt om een speciale serie "Urban safari" aan te prijzen die uit Maxi-Cosi producten met jungleprints bestaat (Maxi-Cosi, 2006). Deze advertentie uit 2006 roept een racistisch stereotype op, waarbij zwarte mensen als primitief en dierlijk worden voorgesteld (Hall, 2002a). Op de resterende 3 van de 62 advertenties (4,8\%) staan alleen de autozitjes of wandelwagens van Maxi-Cosi en geen mensen afgebeeld. De producten van Maxi-Cosi worden via de advertenties door de jaren heen consequent verkocht door gelukkige, vrolijke blanke, welvarende kinderen, moeders en vaders te laten zien.

Bij de consumentenbrochures is dit niet anders. Vanaf de brochures voor de collectie van 2008 komt een positieve beleving van ouderschap niet alleen via de beelden, maar ook via de tekst van de brochures sterker tot uiting met slogans als "Create your moment!" (Maxi-Cosi, 2007), "Geniet Samen!" (Maxi-Cosi, 2008; 2009b) en "Geniet van elk moment" (Maxi-Cosi, 2010). Een representatief voorbeeld van de wijze waarop beeld en tekst gezamenlijk een specifiek geïdealiseerd beeld van ouderschap (re)produceren, vinden we terug in de brochure voor de collectie 2010 (Maxi-Cosi, 2009b). Deze brochure staat vol met foto's van gelukkig ogende, blanke gezinnen die er met Maxi-Cosi autozitjes en wandelwagens op uit trekken. De ouders zijn zichtbaar in goeden doen. Zij en hun kinderen zijn goed verzorgd en dragen modieuze kleding. Ze zien er zeker niet armlastig uit, maar veeleer alsof ze tot de middenklasse behoren. Op de eerste pagina die we tegenkomen als we de brochure openslaan, zien we de volgende, voor de brochure typerende foto.

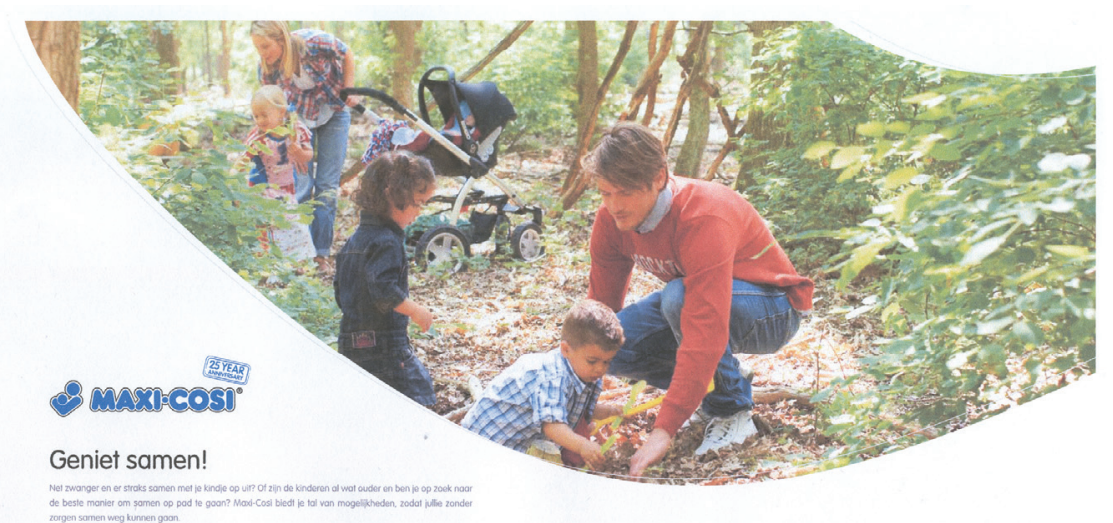

\section{Afbeelding 6}

Geniet samen! Uit Maxi-Cosi consumentenbrochure Collectie 2010 door Maxi-Cosi, 2009. Helmond: MaxiCosi/Dorel Netherlands. Copyright 2009 Maxi-Cosi. Afgedrukt met toestemming. 
Het bijschrift in afbeelding 6 luidt:

Geniet samen!

Net zwanger en er straks samen met je kindje op uit? Of zijn de kinderen al wat ouder en ben je op zoek naar de beste manier om samen op pad te gaan? Maxi-Cosi biedt je tal van mogelijkheden, zodat jullie zonder zorgen samen op weg kunnen gaan. (afbeelding 6)

Maxi-Cosi verkoopt haar producten in deze brochure door het gezinsleven als iets aangenaams neer te zetten. Door de toevoeging "zonder zorgen" (afbeelding 6) in het bijschrift wordt tegelijkertijd ook verwezen naar gedachten over potentiële gevaren die bij ouders zouden kunnen leven ten aanzien van de veiligheid van hun kroost. Een voor de hand liggende interpretatie van de betekenis van deze pagina uit de consumentenbrochure van Maxi-Cosi is dat deze met de aanschaf van een Maxi-Cosi product tot het verleden behoren. Ouders kunnen simpelweg plezier aan hun kroost beleven.

Maxi-Cosi richt zich in deze en andere brochures overigens net zo goed op moeders als op vaders en ook in de onderzochte advertenties zijn vaders redelijk goed vertegenwoordigd. Daarmee vormen ze een verfrissende uitzondering op de markt voor babyproducten. Dit hangt waarschijnlijk samen met het feit dat het gaat om de verkoop van producten die in de auto worden gebruikt. Auto's en mobiliteit worden in moderne westerse landen doorgaans met mannelijkheid geassocieerd en daardoor is het in deze specifieke context wellicht meer geaccepteerd om mannen in een zorgende rol af te beelden. Stereotiepe opvattingen over de rol van moeders en vaders in het gezin worden in de brochures en advertenties niettemin doorbroken. Moeders en vaders worden in hun rol als opvoeders op een gelijkwaardige manier aangesproken. Zo is het aantal moeders en vaders dat in de brochure voor de collectie 2010 wordt afgebeeld redelijk in evenwicht en worden zij op dezelfde manier afgebeeld. Er komen respectievelijk 17 moeders versus 13 vaders in beeld. Desondanks staat er op de cover alleen een moeder met kinderen. Het is hier zodoende toch de moeder die in eerste instantie worden aangesproken als potentiële consument en daarmee als de belangrijkste opvoeder. Dit geldt ook voor de brochures voor de collecties van 2008 en 2009. In de brochure van de collectie van 2011 is zelfs dat niet meer het geval. Op de cover van die brochure staat een blond, peutermeisje met daarachter uit focus en een beetje vaag een vader, geen moeder, met links daarvan de tekst "geniet van ieder moment" (Maxi-Cosi, 2010). Vaderschap kan vandaag de dag dus in een bepaalde context ook op een soortgelijke wijze als moederschap geïdealiseerd in beeld worden gebracht. Maar dat is de uitzondering.

\section{Bredere maatschappelijke ontwikkelingen}

De opkomst en de tot op heden voortdurende (re)productie van het vertoog van genieten kan worden gezien tegen de achtergrond van een aantal bredere maat- 
schappelijke ontwikkelingen. Soms lijken deze ontwikkelingen met elkaar of aspecten van het hedonistische discours over moederschap in strijd te zijn, maar ieder op zich kunnen ze als een vruchtbare voedingsbodem voor verschillende elementen uit dit vertoog worden beschouwd.

We zagen dat opvoedkundigen een ideaal van genieten zijn gaan omarmen, omdat ze er van overtuigd zijn geraakt dat het krijgen van een kind het gevolg van een bewuste keuze is. Er zijn een aantal ontwikkelingen aan te wijzen die er voor hebben gezorgd dat het idee dat het krijgen van een kind een keuze is, wijdverbreid verankerd is geraakt in de Nederlandse samenleving. Dit is allereerst de introductie van de anticonceptiepil in 1962 en de opname ervan in het ziekenfondspakket in 1971 (Verheijen, 1986; Knijn en Verheijen, 1991; Gupta, 2000). De introductie van de pil is op zichzelf niet voldoende om de acceptatie van het idee dat het krijgen van een kind een keuze is onder brede lagen van de Nederlandse bevolking te verklaren. Evenmin is de introductie van de pil het historische beginpunt van deze omslag van het denken over moederschap. Nelly Oudshoorn (2007) doet onderzoek naar de dynamiek van technologie in relatie tot de gezondheidszorg en wijst er terecht op dat de pil het product is van een sociale context waarin opvattingen over voortplanting al aan het veranderen waren. Vanaf de jaren vijftig nam de aandacht voor en het openlijk gebruik van voorbehoedsmiddelen al langzaam toe (Bakker, Noordman \& Rietveld-Van Wingerden, 2010). Aanvankelijk wordt de pil voornamelijk als een middel gezien waarmee het aantal kinderen kan worden beperkt en waarmee het moment waarop men kinderen krijgt, kan worden bepaald. Hoewel de opvoedkundigen dus al eerder het idee omarmden dat moederschap een keuze is, is dit in de Nederlandse samenleving pas grosso modo het geval aan het begin van de jaren tachtig. Pas dan wordt de pil wijdverbreid gezien als een middel om niet voor het moederschap te kiezen (Gupta, 2000). Naast de pil hebben de introductie van andere medische reproductietechnieken, zoals in vitro fertilisatie in 1983, hun steentje bijgedragen aan de verdere verspreiding en toenemende dominantie van het idee dat een kind iets is waarvoor bewust gekozen kan worden (Dykstra and Hagestad, 2007). ${ }^{36}$

\footnotetext{
${ }^{36}$ Sociologen Pearl Dykstra en Gunhils Hagestad (2007) merken in dit verband terecht op dat het overgrote deel van de Nederlandse bevolking zich door de beschikbaarheid van deze technieken niet bewust is van het feit dat er niet altijd zomaar voor het krijgen van kinderen gekozen kan worden. Onvruchtbaarheid of verminderde vruchtbaarheid kan, alle beschikbare technieken ten spijt, lang niet altijd verholpen worden. Dit heeft er volgens hen in de afgelopen decennia hoogstwaarschijnlijk toe geleid dat de traumatische gevoelens van verdriet over ongewilde kinderloosheid bij mannen en vrouwen heviger zijn geworden.
} 
Ook heeft de internationale feministische tweede golfbeweging ${ }^{37}$ in de jaren zestig en zeventig een rol gespeeld. Verscheidene feministen uit deze generatie hebben zich paradoxaal genoeg ingezet voor een relativering van een geïdealiseerd beeld van moederschap zoals dat in de jaren vijftig bestaat en zij hebben daarbij onder meer gevochten voor keuzevrijheid voor vrouwen bij de inrichting van hun leven (zie onder meer Meijer, 1996b; Pronk, 2006). ${ }^{38}$ Moederschap wordt in die tijd nog vaak als de enige 'natuurlijke' en daarmee ook moreel juiste levensinvulling voor vrouwen gezien en impliceert voor middenklasse vrouwen dikwijls fulltime huisvrouwenschap. Er wordt door verschillende feministen met succes geknaagd aan het taaie idee dat (gehuwd) moederschap de voorwaarde voor een geslaagd vrouwenleven zou zijn: vrouwen moeten zelf kunnen beslissen of ze wel of geen kinderen willen en als ze voor een leven zonder kinderen kiezen, dan geldt dit eveneens als een waardige optie voor vrouwen. Ook wordt de uitsluiting van moeders van de arbeidsmarkt bekritiseerd. ${ }^{39}$ Ondanks de verworvenheden van de tweede feministische golf, circuleert er tot op heden een idyllisch beeld van moederschap. Dit beeld komt in de besproken opvoedkundige adviesboeken zelfs juist op, tijdens en vlak na de feministische golf en lijkt paradoxaal genoeg verweven te zijn geraakt

\footnotetext{
${ }^{37}$ De term tweede feministische golf is niet onomstreden. De golvenretoriek wordt onder andere bekritiseerd, omdat ze zou suggereren dat er tussen de eerste en tweede feministische golf sprake zou zijn van een volledige radiostilte van feministische zijde. Sommige historici betwijfelen of dit het geval is (De Vries, 2006).

${ }^{38}$ Een blik op de beschikbare wetenschappelijke studies naar de tweede feministische golf van bijvoorbeeld Irene Costera Meijer (1996), Oudshoorn (1986), Anneke Ribberink (1998), Elly Singer (1989) en Liesbeth van Zoonen (1991) maakt in ieder geval duidelijk dat er veel verschillende stromingen binnen de beweging zijn geweest en dat de beweging dus als zeer divers is te beschouwen (De Vries, 2006). Dit blijkt ook uit het op het brede publiek gerichte boek van Vilan van de Loo (2005).

${ }^{39}$ In het essay Het onbehagen bij de vrouw (1967), dat als het startsein wordt gezien van de tweede feministische golf in Nederland (De Vries, 2006), gaat Joke Smit in op de sociale isolatie die vrouwen na het krijgen van kinderen ten deel valt en stelt ze de onderwaardering van huishoudelijk werk aan de kaak. Smit is samen met Heddy D'Ancona de oprichter van de Aktiegroep Man Vrouw Maatschappij in 1968 (De Vries, 2006). Deze actiegroep pleit onder andere voor "gelijke lonen, zwangerschapsverlof en vijf-urige [sic] werkdagen om een gelijke werkverdeling tussen mannen en vrouwen veilig te stellen" (Kennedy, 1995, p. 109) zowel in de zorg voor kinderen als op de werkvloer. Man Vrouw Maatschappij oefent succesvol druk uit op de overheid om de wetgeving op een aantal van deze punten aan te passen (Pronk, 2006). Daarnaast pleit Joke Smit (Kennedy, 1995) net als de radicalere feministische groepering Dolle Mina die in 1971 wordt opgericht (Pronk, 2006) voor de legalisering van abortus, waarbij ervan wordt uitgegaan dat moederschap de individuele keuze van een vrouw zou moeten zijn. Zij is "baas in eigen buik', zoals de bekende feministische leuze in die tijd klinkt. In 1976 culmineert een en ander onder andere in de uitgave van het Moederboek (Stroeve, Van der Meer, Meulebelt, Lambalk et al, 1967) door de feministische uitgeverij De Bonte Was waarin de belastende kanten van het heersende moederschapsideaal worden belicht. Ondanks deze geluiden, neemt de aandacht binnen de tweede feministische golf voor moederschap en in het bijzonder voor werkende moeders en voor de realisatie van kinderopvangregelingen, volgens Singer (1989) na het begin van de jaren zeventig snel weer af. Recent is het onderwerp weer een punt van aandacht geworden in feministische kringen.
} 
met het feministische idee dat moederschap een keuze is. Het lijkt er op dat feministische sentimenten deels zijn geïncorporeerd en daarmee bezworen in het hedendaagse rooskleurige idee van moederschap. Het contemporaine, geromantiseerde vertoog rondom moederschap lijkt daarmee al met al een voortzetting van een langer bestaande tendens in de Nederlandse, naoorlogse samenleving te zijn om moederschap in rooskleurige termen te verbeelden. De neiging om het moederschap te idealiseren gaat dus verder terug dan de jaren tachtig. In internationaal onderzoek worden de historische wortels van de huidige idealisering van het moederschap soms getraceerd tot in de negentiende eeuw (Nicolson, 1990). Anderen wijzen de jaren vlak na de tweede wereldoorlog als het startpunt aan (Romito, 1998). Men zou nog verder terug kunnen gaan, en bijvoorbeeld ook naar de Christelijke verheerlijking van het moederschap kunnen verwijzen die een stempel op de westerse cultuur, waaronder de Nederlandse, heeft gedrukt. Het voert hier te ver om alle verschillen tussen het huidige rooskleurige vertoog en deze oudere verbeeldingen te onderzoeken, maar een belangrijk onderscheid ligt onder meer in het idee dat moederschap een bewuste keuze is.

De hedendaagse nadruk op geluk en genot in relatie tot moederschap kunnen we ook in verband brengen met de opkomst van de hedonistische levenshouding. De populariteit van deze levensvisie, die in de tweede helft van de jaren zestig opkomt en waarbij het draait om het nastreven van aards geluk en plezier, is sinds eind jaren zeventig sterk toegenomen in Nederland (Felling, 2004; De Hart, 2005, 2007). Net als in andere moderne westerse samenlevingen is het idee dat het hoogste geluk na de dood in de hemel op ons wacht voor het grootste deel van de Nederlandse bevolking op de achtergrond geraakt en staat het hier en nu beleven van genot en vermaak voorop (Schnabel, 2007). De opkomst van deze waardeoriëntatie wordt onder meer verklaard vanuit de snelle uitbouw van de verzorgingsstaat en wederopbouw van de Nederlandse economie in de eerste twee decennia na de Tweede Wereldoorlog (zie bijvoorbeeld Felling, 2004). De gedachte is dat steeds meer mensen, wanneer de wederopbouw aan het begin van de jaren zestig is afgerond, van "de door hard werken en sober leven verworven welvaart" (Felling, 2004, p. 4) willen gaan genieten. Door de gelijktijdige uitbouw van de verzorgingsstaat is het bovendien voor een grotere groep mensen mogelijk om inderdaad van de gestegen welvaart te profiteren (Felling, 2004). Door de economische recessie in de tweede helft van de jaren zeventig en in de jaren tachtig wordt echter duidelijk dat welvaart niet vanzelfsprekend is (Felling, 2004). Vanwege de toenemende kosten van de verzorgingsstaat die de crisis veroorzaakt, vindt er een herziening van de verzorgingsstaat plaats en is ook sociale zekerheid iets minder vanzelfsprekend dan daarvoor. Dit doet echter niets af aan de populariteit van de hedonistische waardeoriëntatie, die daarna zelfs blijkt te zijn toegenomen (Felling, 2004; De Hart, 2005, 2007). Aards geluk is een leidraad geworden bij de wijze waarop we ons leven inrichten en de keuzes die we daarbij maken (Schnabel, 2007). 
Het verband dat in de opvoedkundige adviezen wordt gelegd tussen het idee dat moederschap vooral fijn is en het idee dat het krijgen van kinderen een keuze is, sluit goed aan bij de neiging in de politiek van de jaren tachtig tot heden om het individu en de markt centraal te stellen (Duyvendak, 1999, 2004; Duyvendak \& Hurenkamp, 2004; Tonkens, 2004). In deze jaren gaan verschillende regeringen - waaronder vooral de twee kabinetten Lubbers, de vier kabinetten Balkende en het in 2010 geïnstalleerde kabinet Rutte met zijn leuze Vrijheid en Verantwoordelijkheid (Kabinet Rutte, 2010) - uit van de individuele maakbaarheid van het leven, keuzevrijheid, eigen verantwoordelijkheid en zelfontplooiing. Bevoogding door kerk of staat wordt als passé beschouwd. ${ }^{40}$ De verzorgingsstaat wordt hervormd vanuit het idee dat de burger een consument is die zelf zijn keuzes kan maken en daarbij driften, behoeftes en verlangens rationeel tegen elkaar af kan wegen om zo naar eigen inzicht en tevredenheid zijn leven vorm te geven. De Nederlandse overheid positioneert zich in toenemende mate als een bedrijf dat een scala van mogelijkheden aanbiedt waaruit de burger kan kiezen (Tonkens, 2004). Volgens filosoof Tsjalling Swierstra en sociologe Evelien Tonkens (2004) verplicht de Nederlandse regering burgers zich zo als "kiezende consumenten" (p. 207) te positioneren. De keuzevrijheid brengt dus, paradoxaal genoeg, ook beperkingen met zich mee in de vorm van keuzedwang en individuele verantwoordelijkheid voor de gemaakte keuzes. Er móét gekozen worden. En mocht een keuze verkeerd uitpakken dan kan men daarvan enkel zichzelf de schuld geven, omdat men er immers zélf voor gekozen heeft (Breedveld \& Van Den Broek, 2003, p. 7). Deze ontwikkelingen in de politiek kunnen in het licht worden gezien van een algemene huldiging in moderne westerse samenlevingen van het idee dat het leven en geluk op individueel niveau maakbaar zijn, waarop Nederland geen uitzondering vormt. Met de Duitse sociologe Elisabeth Beck-Gernsheim (1996) kunnen we ook wel spreken van het bestaan van een psychology of choice, waarmee wordt verwezen naar een levensvisie, die is gebaseerd op het idee dat als er een individuele keuze is gemaakt, deze door individuele volharding gerealiseerd kan worden. Het is zodoende een kijk op het leven, die is gebaseerd op een moderne notie van de mens. Deze wordt beschouwd als autonoom en rationeel en in staat om zijn leven vrijelijk vorm te geven. ${ }^{41} \mathrm{Er}$ is geen besef van het bestaan van de mogelijkheid dat dit wel eens niet het geval zou kunnen zijn. Dit alles heeft het normatieve karakter van het idee dat moederschap plezierig is en behoort te zijn hoogstwaarschijnlijk verder versterkt. In deze context is het immers

\footnotetext{
${ }^{40}$ Hoewel keuzevrijheid en het individu belangrijke culturele ideeën zijn geworden in de politiek, betekent dit niet dat mensen in de praktijk volledig vrij zijn om hun levensloop te bepalen en dat we allemaal iets anders, eigens doen. Mensen kiezen opvallend vaak routinematig (Duyvendak, 2004; Duyvendak \& Hurenkamp, 2004).

${ }^{41}$ De historische wortels van dit moderne mensbeeld liggen in de zeventiende eeuw. De hier gehanteerde definitie van het moderne subject ontleen ik aan Jos De Mul, Elke Müller en André Nusselder (2001).
} 
moeilijk om toe te geven dat je als moeder niet gelukkig bent, omdat je dan min of meer aangeeft dat je bent tekortgeschoten. ${ }^{42}$ Bovendien zijn de moderne notie van het subject en moderne waarden als autonomie, keuzevrijheid en maakbaarheid ook instructief voor het ideaal van genieten, zoals dat in de opvoedkundige handboeken en tijdschriften wordt gearticuleerd. Zo worden mannen en vrouwen beschouwd als autonome individuen die er zelf voor kiezen of ze wel of geen kinderen krijgen. Aan de andere kant zagen we dat de verhouding van opvoedkundigen tot de autonomie van de moeder, als er dus eenmaal voor kinderen is gekozen, ambivalent is.

Daarnaast zijn er ook een aantal demografische veranderingen die het idee dat het krijgen van kinderen vooral fijn is, in de kaart hebben gespeeld. Om te beginnen worden er, mede door de introductie van de pil, steeds minder kinderen geboren (Garssen, Lalta \& Portegijs, 2009). In hun populairwetenschappelijk boek over veranderende relaties in Nederland stellen demograaf Jan Latten en politicologe Malou van Hintum dat kinderen daardoor niet langer meer 'gewoon' zijn, maar schaars en daarmee belangrijker zijn geworden. Deze hernieuwde waardering voor kinderen, die ook wordt ingegeven door een angst voor de ontgroenende en vergrijzende samenleving, zou weleens kunnen bijdragen aan de hedendaagse idealisering van het moederschap. Ook zijn huwelijksrelaties tussen volwassenen minder bestendig geworden. De kans op echtscheiding is vanaf eind jaren zestig tot aan het begin van de jaren negentig sterk toegenomen (Garssen, Beer, Cuyvers \& De Jong, 2001; Garssen, Lalta, Portegijs, 2009; Van Praag, 1997; Wobma \& De Graaf, 2009). ${ }^{43}$ Bovendien neemt het relatieve aantal huwelijken in dezelfde periode steeds verder af en kiezen mensen vaker voor samenwonen. De relaties van ongehuwd samenwonende koppels blijken vooralsnog minder stabiel dan huwelijken. De kans dat een samenwonend stel uit elkaar gaat, is tot op heden groter dan de kans op echtscheiding voor een gehuwd koppel (Wobma \& De Graaf, 2009). De Duitse sociologen Ulrich Beck en Elisabeth Beck-Gernsheim (1995) merken in verband met soortgelijke demografische ontwikkelingen in andere West-Europese landen op dat ouders als gevolg hiervan anders naar relaties met hun kinderen gaan kijken. Ouders gaan de relatie met hun kinderen als een ankerpunt in een "chaos of love" (Beck \& BeckGernsheim, 1995) ervaren, omdat de relaties tussen volwassen partners minder duurzaam zijn geworden. Ouderschap raakt zo "increasingly connected with hopes of being rooted, of life becoming meaningful, and with a 'claim to happiness', based on the close relationship with the child" (Beck \& Beck-Gernsheim, 1995, p. 105 cur-

\footnotetext{
${ }^{42}$ In een artikel in Trouw wordt een soortgelijke observatie door de filosofe Marli Huijer gemaakt (Otter, 2005).

${ }^{43}$ De grootste stijging vindt plaats tussen de jaren zestig en tachtig. Aan het begin van de jaren tachtig stabiliseert de kans op echtscheiding op een kans van 1 op de 4 huwelijken. Begin jaren negentig loopt die kans op tot 1 op 3, om vervolgens weer te stabiliseren (Garssen, Beer, Cuyvers \& De Jong, 2001; Garssen, Lalta, Portegijs, 2009).
} 
sivering door JW). Het is waarschijnlijk dat er in Nederland een soortgelijke ontwikkeling heeft plaats gevonden, zoals die door Beck en Beck-Gernsheim (1995) is beschreven.

Het feit dat het kerngezin met een gescheiden taakverdeling voor mannen (kostwinners) en vrouwen (opvoeders) vaak een impliciete norm is in de besproken bronnen, kan ten slotte worden gezien in het verlengde van een historisch lange en sterke traditie van dit gezinsideaal. Het is een, zoals al eerder opgemerkt, van oorsprong blank, middenklasse ideaal. Dit ideaal ontstaat in de negentiende eeuw in praktisch alle West-Europese samenlevingen en de VS, maar nergens anders dan in Nederland is men er beter in geslaagd om het in de praktijk te brengen. Het aantal Nederlandse moeders dat geen betaald werk verricht, behoort aan het begin van de twintigste eeuw immers relatief gezien tot de hoogste van Europa (Van Daalen, 2005). In de jaren daarna wordt de Nederlandse verzorgingsstaat ingericht met dit gezinsideaal in gedachten (Van Daalen, 2005). De Nederlandse overheid lijkt inmiddels ten dele afscheid te hebben genomen van het ideaal van het kerngezin met een seksespecifieke taakverdeling. Ten eerste door vanaf begin jaren tachtig het individu en niet het gezin als de hoeksteen van de samenleving te beschouwen. Ten tweede door vanaf de jaren negentig vrouwen en vooral moeders te stimuleren om aan de arbeidsmarkt deel te nemen. ${ }^{44}$ Niettemin is de erfenis van het op het ideaal van het kerngezin gerichte sociale stelsel nog altijd voelbaar in de politiek en maatschappij (Van Daalen, 2005; Peters, Bleijenbergh, Pas \& Gremmen, 2010). Collectieve voorzieningen die het voor ouders gemakkelijker maken om werk en zorg te combineren, zijn nog altijd niet optimaal en worden paradoxaal genoeg vaak weer uitgekleed onder het mom van de individuele verantwoordelijkheid van de ouders. ${ }^{45}$ Bovendien werken vrouwen in de eenentwintigste eeuw, waaronder moeders, relatief nog altijd weinig in Nederland (Van Daalen, 2005; Keuzenkamp, Hillebrink, Portegijs \& Pouwels, 2009). ${ }^{46}$ Hoewel het percentage van de vrouwen dat aan de arbeidsmarkt deelneemt, gestaag is toegenomen en in 2007 met $70 \%$ tot de hoogste van Europa behoort, is het aantal uren dat vrouwen gemiddeld per week werken met 25 uur juist een van de laagste van Europa (Keuzenkamp, Hillebrink, Portegijs \&

\footnotetext{
${ }^{44}$ Zie hierover ook noot 22 in dit hoofdstuk.

${ }^{45}$ Dit geldt bijvoorbeeld voor de bezuinigingen op de kinderopvangtoeslag van het Kabinet Rutte (Kabinet Rutte, 2010).

${ }^{46}$ Hierbij moet worden opgemerkt dat een groot deel van de moeders, ook wanneer de kinderopvang beter georganiseerd zou zijn, aangeeft niet aanzienlijk meer te willen werken. Ze willen de zorg voor hun kinderen niet uitbesteden (Portegijs, Cloïn, Keuzenkamp, Merens \& Stenvoorden, 2008). Goede kinderopvangvoorzieningen zijn wel een voorwaarde, maar lijken op zichzelf dus niet voldoende om de gedachten van moeders over hun rol in het gezin te veranderen.
} 
Pouwels, 2009). ${ }^{47}$ Vrouwen blijken onder meer in deeltijd te werken vanwege de zorg voor het huishouden en eventuele kinderen (Portegijs, Cloïn, Keuzenkamp, Merens \& Stenvoorden, 2008). ${ }^{48}$ Uit onderzoek van het Sociaal Cultureel Planbureau in 2008 onder vrouwen met kleine deeltijdbanen (minder dan 24 uur) in vijf verschillende arbeidssectoren, blijkt dat deze vrouwen wel vaak minderjarige, thuiswonende kinderen hebben (Portegijs, 2009). ${ }^{49}$ In huishoudens waar vrouwen een kleine deeltijdbaan hebben, zijn de taken veelal traditioneel verdeeld, overigens meestal naar tevredenheid van beide partners. Het inkomen van de vrouw wordt vaak gezien als een welkome aanvulling op het salaris van de man waarmee luxe uitgaven gefinancierd kunnen worden, maar niet als een noodzakelijke inkomstenbron (Portegijs, 2009).

\section{Probleemvertogen}

Hoewel het idee dat moederschap gepaard gaat met geluk wijdverspreid en normatief aanwezig is in de Nederlandse samenleving, worden bepaalde vormen van moederschap juist niet door een roze bril bekeken. In de inleiding van dit boek is er al op gewezen dat moederschap in literaire fictie bij uitstek in zwaar weer lijkt te verkeren.

Er bestaan echter ook niet-fictionele maatschappelijke, politieke en wetenschappelijke probleemvertogen over moederschap. Het moederschap van naar Nederland gemigreerde, niet-westerse vrouwen wordt bijvoorbeeld vaak negatief belicht. Uit een onderzoek naar beeldvorming rondom migranten in de Nederlandse dagbladen en onder leraren blijkt dat er in de afgelopen decennia een dominant negatief vertoog over migrantenouders circuleert, voornamelijk ten aanzien van niet-westerse migrantenmoeders en -vaders (Hermans, 2004). Deze moeders en vaders worden in de media vaak aangeduid als de belangrijkste oorzaak van het criminele gedrag, de slechte schoolresultaten en de falende integratie van hun kinderen. Vooral Marokkaanse ouders moeten het nogal eens ontgelden.

Ook over homoseksuele moeders doen veel negatieve vooroordelen de ronde (Warmerdam, 2007, 2010). Sinds 1980 is het aantal lesbische vrouwen dat bewust voor kinderen kiest toegenomen. Door veranderende wetgeving tussen 1998 en 2009 wordt homoseksueel en lesbisch co-ouderschap inmiddels ook wettelijk er-

\footnotetext{
${ }^{47}$ Ook de Nederlandse mannen werken volgens een vergelijking met andere Europese landen in 2008 vaker in deeltijd. Het zijn in Nederland echter vooral de vrouwen die in deeltijd werken (Keuzekamp, 2009).

${ }^{48}$ Andere factoren die meespelen is dat vrouwen tijd voor zichzelf en sociale contacten willen overhouden (Portegijs, Cloïn, Keuzenkamp, Merens \& Stenvoorden, 2008).

${ }^{49}$ In het onderzoek van het Sociaal Cultureel Planbureau hebben 3758 vrouwen tussen de dertig en zesenvijftig jaar met een kleine deeltijdbaan een vragenlijst ingevuld (Keuzekamp, 2009). Van deze groep heeft 77\% thuiswonende, minderjarige kinderen (Portegijs, 2009).
} 
kend en gelegitimeerd. Niettemin worden homoseksuele ouders en hun kinderen tot op heden met negatieve vooroordelen geconfronteerd. Lesbisch comoederschap wordt bijvoorbeeld geregeld bekritiseerd, omdat kinderen van lesbische moeders door het gebrek aan een mannelijk rolmodel niet zouden opgroeien tot volwaardige, heteroseksuele volwassenen. ${ }^{50}$

Ook werkende moeders zijn in Nederland in de afgelopen decennia nauwelijks geïdealiseerd (Wesseling, 2001). Sinds het begin van de jaren negentig worden werkend moederschap zelfs in toenemende mate expliciet in een negatief daglicht gesteld. Het probleemvertoog over werkend moederschap richt zich voornamelijk op goed tot hoog opgeleide, blanke, middenklasse moeders die fulltime werken of een grote deeltijdbaan hebben: op de zogenaamde carrièremoeders (Wesseling, 2001). De opkomst van dit vertoog hangt waarschijnlijk samen met de toenemende arbeidsparticipatie van moeders van jonge kinderen, die getuige de toename van het algemene opleidingsniveau van vrouwen in de jaren negentig steeds vaker hoger opgeleid zijn (Niphuis-Nell \& De Beer, 1997). In deze jaren is de publieke acceptatie van werkende moeders toegenomen (Niphuis-Nell \& De Beer, 1997), maar worden in de media vaak de belastende kanten van de combinatie van werk en moederschap belicht. Een goed voorbeeld van deze beeldvorming zagen we al de revue passeren in de wijze waarop de combinatie van werk en moederschap wordt neergezet in jaargang 1990 van Margriet en Libelle. Organisatiestress bleek in eerste instantie het centrale gegeven in artikelen die zich op de combinatie richten (Knijn \& Nievers, 1996). Zelfs in het feminisme is werkend moederschap volgens Elisabeth Wesseling (2001) nooit geïdealiseerd. Daarbij moet de kanttekening worden geplaatst, dat er sinds kort een nieuw feministisch geluid is te horen. Dit komt onder meer van econome, advocate en columniste Heleen Mees (2007) en journaliste en columniste Elma Drayer (2010). Zij bekritiseren hoogopgeleide moeders die niet werken en moeders met kleine deeltijdbanen. Ze nemen daarbij een economisch standpunt in: het is slecht voor de economische onafhankelijkheid van de moeders in kwestie en het zou de Nederlandse economie evenmin goed doen. Ook in de politiek is er sinds de jaren negentig meer aandacht voor het vergroten van de arbeidsparticipatie van vrouwen en moeders, met het oog op de toenemende vergrijzing van de samenleving (zie Singer, 1989). Het vergroten van de arbeidsparticipatie is bijvoorbeeld een expliciet doel in de kabinetsnota over emancipatie uit 2007 geweest. Opvallend genoeg richten dit soort economische discussies over opvoeding en arbeidsparticipatie zich bijna zonder uitzondering op de moeders, zonder dat daarbij wordt gekeken naar de rol van vaders op de arbeidsmarkt en op het gebied van opvoeden. In de emancipatienota uit 2007 wordt bijvoorbeeld bij herha-

\footnotetext{
${ }^{50}$ Verscheidene studies in Nederland hebben uitgewezen dat dit niet het geval is (Warmerdam, 2010). Het feit dat daar wel onderzoek naar wordt gedaan en niet naar de invloed van de heteroseksuele voorkeur van ouders op kinderen, wijst op een zekere hetero-normativiteit.
} 
ling gesteld dat het goed voor de onafhankelijkheid van vrouwen zou zijn als ze meer gaan werken, maar wordt niet gedacht aan de bijdrage die mannen hieraan zouden kunnen leveren door meer zorgtaken van vrouwen over te nemen (Plasterk, 2007). Overigens geldt de genoemde toename van de maatschappelijke acceptatie van werkende moeders vooral moeders van schoolgaande kinderen. Uit onderzoek van het Sociaal Cultureel Planbureau (Niphuis-Nell \& De Beer, 1997) onder Nederlandse vrouwen en mannen tussen de 17 en 70 jaar over de periode 1965-1995 blijkt dat in 1965 nog 81\% van de Nederlandse vrouwen en $87 \%$ van de Nederlandse mannen het bezwaarlijk vinden als een moeder van schoolgaande kinderen werkt. In 1995 is dit respectievelijk 13\% en 19\%. De acceptatie van werkende moeders met kinderen tussen nul en vier jaar is in mindere mate toegenomen. In 1965 ziet 100\% van de Nederlandse mannen en vrouwen dit als een probleem. In 1995 geldt dit voor $48 \%$ van de vrouwen en $50 \%$ van de mannen.

Andere moeders die in Nederland bij herhaling eenzijdig in verband worden gebracht met problemen zijn onder meer gescheiden moeders, alleenstaande moeders, arme moeders uit lagere sociale klassen, stiefmoeders, adoptiemoeders, moeders die hun kinderen op late leeftijd (na hun dertigste of vijfendertigste levensjaar) krijgen, drugs- of alcoholverslaafde moeders, moeders met een beperking of psychiatrische problemen, moeders van kinderen met een handicap en moeders met een postpartum depressie, ook wel bekend als een postnatale depressie. ${ }^{51}$ Ook is er sinds kort aandacht voor vrouwen die het moederschap mis dreigen te lopen, omdat ze het krijgen van kinderen uitstellen en daardoor verminderd vruchtbaar zijn of door andere vruchtbaarheidsproblemen hun keuze voor een kind niet kunnen realiseren. ${ }^{52}$ Daarnaast is er in de media veel aandacht voor moeders die hun kinderen op extreme wijze hebben mishandeld of vermoord of die mishandeling hebben toegelaten. Zo heeft de betreurenswaardige doodslag op de driejarige peuter Savanna door haar moeder en diens vriend de Nederlandse media in 2004 maanden bezig gehouden (zie over de zaak bijvoorbeeld Jos de Mul, 2006). Op een aantal van deze en andere probleemvertogen die in de Nederlandse maatschappij voorhanden zijn wordt nog teruggekomen in de interpretaties van de vier geselecteerde romans. ${ }^{53}$ Hier toch alvast twee algemene opmerkingen.

\footnotetext{
${ }^{51}$ Dat deze vormen van moederschap als problematisch worden beschouwd, blijkt uit de bijdragen aan de bundel Gezin (Autrique, Baggerman, Boer, Cuijpers, E.J. Knorth et al, 2010). In dit boek buigen verschillende onderzoekers uit Nederland en Vlaanderen zich over gezinsvormen waarvan wordt aangenomen dat ze problemen en risico's voor kinderen met zich meebrengen.

${ }^{52}$ Een goed voorbeeld hiervan is het boek Wie wil er nog moeder worden? (2006) van Christien Brinkgreve en Egbert te Velde.

${ }^{53}$ In hoofdstuk 4 ga ik aan de hand van de roman De reis naar het kind (1989) in op de beeldvorming rondom adoptie en vruchtbaarheidsproblematiek. In de analyse van Nieuwe buren (2006) in hoofdstuk 5 komt vruchtbaarheidsproblematiek eveneens aan bod. In hoofdstuk 6 en 7 ga ik aan de hand van respectievelijk Een hart van steen (1998) en Met onbekende bestemming (2000) verder in op de discussies over
} 
Ten eerste, lijkt een aantal van deze probleemvertogen het vertoog van genieten ex negativo te bevestigen, doordat ze zich op de andere vormen van moederschap richten dan het type dat doorgaans wordt geïdealiseerd. Voorbeelden hiervan zijn de probleemvertogen die zich expliciet focussen op migrantenmoeders, lesbische moeders, werkende moeders, alleenstaande en gescheiden moeders, en moeders uit lagere sociale klassen. Moeders dus die geen deel uitmaken van het geïdealiseerde blanke, middenklasse kerngezin. Wesseling (2001) beargumenteert bijvoorbeeld overtuigend dat de negatieve beelden van (praktisch) fulltime werkende, hoogopgeleide, blanke, middenklasse moeders parasiteren op opvattingen over opvoeding zoals die onder meer door de vroege Spock (1950) en Leach (1979; 1998; 2008) zijn gearticuleerd. ${ }^{54}$ Volgens haar is het gevolg van de wijdverspreide popularisering van hun opvattingen dat het niet evident wordt gevonden om moederschap met een carrière te combineren. Zij beschouwen moederschap immers als een intensieve en voor het welzijn van de kinderen bepalende bezigheid. Het hedendaagse idyllische vertoog over moederschap produceert zodoende de negatieve beeldvorming over fulltime werkende, hoogopgeleide, blanke, middenklasse moeders. Het is in dit verband interessant dat de combinatie van werk en vaderschap in een positiever licht staat. Voor mannen wordt de combinatie van opvoedende en verzorgende taken en een carrière zeker vanaf de jaren negentig juist steeds meer als een plezierige verrijking van hun leven gezien en niet zo zeer als een probleem (Wesseling, 2001). Een van de oorzaken hiervan is dat van mannen niet dezelfde overgave wordt verwacht als van vrouwen wanneer het om het opvoeden van kinderen gaat. Daarbij moet wel worden aangetekend dat bij het aanreiken van oplossingen voor de combinatie van werk en zorg in bladen als Margriet en Libelle ook het idee voorop lijkt te staan dat werkend moederschap uiteindelijk toch nog aangenaam kan worden. De besproken Margriet Kids is hier een ultiem voorbeeld van. In de opvoedkundige adviesliteratuur lijkt in het eerste decennium van de eenentwintigste eeuw ook zo'n ambigue geluid over werkend moederschap te ontstaan. Het probleemvertoog over werkende moeders heeft dus zo zijn rafelrandjes en dat zal hoogstwaarschijnlijk ook voor de andere hier genoemde vertogen gelden. Niettemin blijven Wesselings (2001) observaties grotendeels overeind.

Daarnaast valt op dat een aantal van de aangewezen probleemvertogen niet expliciet over specifieke klasse-, seksualiteit- of etniciteitgebonden vormen van moederschap gaat. Zij gaan over (aanstaand) moederschap in het algemeen, waaronder dus ook het moederschap dat vorm krijgt in een blank, middenklasse, heteroseksueel kerngezin. Ze lijken zodoende haaks op de hedonistische benadering van

werkende moeders en over moeders die hun kinderen vermoorden. In de bespreking van Een hart van steen (1998) speelt daarnaast ook het medisch-psychologische vertoog over postpartum depressie een rol.

${ }^{54}$ Wesseling (2001) gebruikt de term vertoog zelf niet. Zij spreekt van ideologie of moraal. 
moederschap te staan, zoals we die in de opvoedkundige handboeken, tijdschriften en reclame tegenkomen. Tot zulke vertogen behoren bijvoorbeeld het vertoog over vruchtbaarheidsproblemen en het medisch-psychologische vertoog over postpartum depressie. ${ }^{55}$ Uit interviews met Nederlandse vrouwen bij wie de diagnose postpartum depressie is gesteld, blijkt dat dit vertoog niet alleen de mogelijkheid biedt om het over mogelijk negatieve ervaringen van het moederschap te hebben, zonder dat vrouwen zich daarover schuldig hoeven te voelen. Het spoort sommige vrouwen ook aan om het idee van de "blije moeder" in twijfel te trekken (Cuisinier \& SmitWiersinga, 1998, p. 26). De relatie van het medisch-psychologische vertoog over postpartum depressie, en vooral haar biomedische variant, tot een rooskleurige norm van moederschap is echter ambigue. Hoewel dit medisch-psychologische vertoog moeders een veilige mogelijkheid biedt om negatieve gevoelens en ervaringen te verwoorden zonder het risico te lopen gestigmatiseerd te worden, blijkt uit verschillende internationale onderzoeken dat dit discours er in de eerste plaats juist is op gericht om (weer) gelukkige moeders van hen te maken (Oakley, 1979, 1980, 1984; Nicolson 1998; Romito, 1990). ${ }^{56}$ De negatieve gevoelens van de moeders worden daarbij vaak op enkelvoudige wijze teruggevoerd op een met antidepressiva en/of therapie eenvoudig te genezen ziekte met een hormonale en/of psychische oorzaak. ${ }^{57}$ De individuele verantwoordelijkheid van de moeder en een idee van beheersbaarheid zijn zodoende belangrijke ingrediënten van dit vertoog. De gedachtegang is dat de moeder er zelf voor kiest om zich wel of niet weer gelukkig te gaan voelen. Een gedeelde maatschappelijke verantwoordelijkheid voor de problemen van moeders is daardoor niet aan de orde. Door de ervaringen van de moeders op deze manier te medicaliseren worden ze in feite als individuele afwijkingen op het ideaalplaatje van moederschap voorgesteld en deze blijft zodoende intact. Dit normbevestigende karakter van het medisch-psychologische vertoog wordt goed zichtbaar in een advertentie waarmee het Fonds Psychische Gezondheid in 2005 aandacht vroeg voor postpartum depressie en die onder andere in het NRC Handelsblad verscheen en meer dan levensgroot in bushokjes langs de Nederlandse wegen hing (afbeelding 7).

\footnotetext{
${ }^{55}$ Over de historische opkomst van dit vertoog binnen de psychologische en medische wetenschap bestaat enige onduidelijkheid. Paula Nicolson (1998) stelt dat dit vertoog aan het einde van de negentiende eeuw opkomt, Patrizia Romito (1990) wijst de jaren zestig van de twintigste eeuw als het begin aan.

${ }^{56}$ Zie ook Natasha Mauthner (1999) voor een uitgebreid overzicht van studies naar de relatie tussen het medisch-psychologische vertoog over postpartum depressie en geïdealiseerde verbeeldingen van moederschap.

${ }^{57}$ Waarbij ik overigens niets wil afdoen aan het praktische belang van (medische) hulp voor moeders die zich ongelukkig of depressief voelen of met psychische problemen kampen.
} 


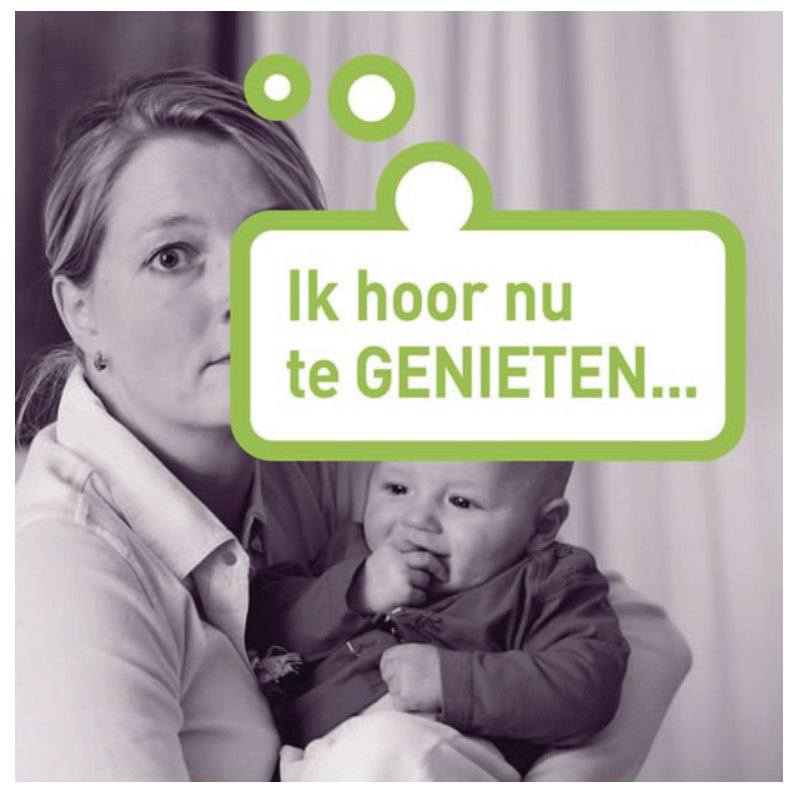

\section{Afbeelding 7}

Advertentie over postpartum depressie van het Fonds Psychische Gezondheid. Door Fonds Psychische Gezondheid. Geraadpleegd op 20 augustus, 2006, via www.depressiecentrum.nl/img/depressiecentrum/home/foto.jpg. Copyright 2005 Fonds Psychische Gezondheid. Afgedrukt met toestemming.

Op de advertentie zien we het gekwelde gezicht van een blanke, jonge, goedgeklede, waarschijnlijk tot de middenklasse behorende vrouw met een baby in haar armen, uit wier hoofd de tekstwolk "Ik hoor nu te GENIETEN . . ." opkomt. Deze zin geeft aan hoe we dit beeld moeten interpreteren en reproduceert het normatieve karakter van moederschap als een ervaring die prettig moet zijn. De woorden suggereren immers dat dit in grijstinten gevatte beeld van een mistroostig kijkende moeder niet is zoals het hoort te zijn. Dit maakt de moeder tot een uitzondering op de norm, tot een 'abnormale' moeder die met hulp van het Fonds Psychische Gezondheid in een 'normale' gelukkige moeder kan veranderen. ${ }^{58}$

\section{Conclusie}

Sinds de jaren zeventig circuleert in Nederland een specifiek vertoog van genieten, dat zeker vanaf het begin van de jaren tachtig tot een dominante voorstellingen van

\footnotetext{
${ }^{58}$ Dit geldt niet alleen voor postpartum depressie, maar ook voor het biomedische vertoog over depressie in het algemeen (Dehue, 2006).
} 
het moederschap behoort. Dit vertoog krijgt onder meer gestalte in populaire opvoedkundige adviesboeken voor ouders. Hierin komt een ideaal van een prettige opvoeding centraal te staan. Daarbij wordt niet alleen gedacht aan het welzijn van de ouders, dat de opvoeding voor hen fun is, maar ook en vooral aan het welzijn van het kind. Genieten moet, omdat dit goed is voor de kinderen. Dit normatieve ideaal richt zich voornamelijk op bewust gekozen moederschap in de context van een heteroseksueel kerngezin en heeft een blank, middenklasse karakter. Hoewel het hebben van een betaalde baan voor moeders niet expliciet wordt afgekeurd, wordt het niet als de norm beschouwd. Werken mag, maar impliciet wordt het idee uitgedragen dat het aantal uren noodzakelijkerwijs beperkt moet blijven. Dit kunnen we wijten aan de intensieve vorm van het moederschap die wordt gepropageerd. In het eerste decennium van de eenentwintigste eeuw lijkt deze norm overigens minder sterk te worden. Het idee dat een aanstaande moeder een autonoom individu is die rationeel en weloverwogen voor kinderen kiest, ligt aan de basis van de wijdverspreide opkomst van dit vertoog in de populaire opvoedkunde. Het krijgen van kinderen wordt zodoende als een maakbare aangelegenheid voorgesteld. Ook het moederschap zelf wordt als een controleerbare praktijk beschouwd, die de moeder naar eigen inzicht kan inrichten. De verantwoordelijkheid voor het welslagen van het moederschap ligt daarbij in eerste instantie bij de individuele moeder en niet bij de maatschappij. De boodschap is dat de moeder zich hierover echter geen zorgen hoeft te maken, omdat zij eigenlijk van nature wel weet wat het beste is voor haar kind. Het maken van fouten hoort er gewoon bij; dat is niet erg. Als ze gewoonweg op haar gezonde verstand vertrouwt, dan komt het wel goed. Mocht ze onverhoopt toch een keer problemen tegenkomen en ze weet niet meteen raad, dan bieden de adviezen in de handboeken een leidraad. De autonomie van de moeder staat anderzijds ook onder druk. Ten eerste, doordat er nauwelijks aandacht wordt besteed aan individuele verlangens van de moeder die niet in het verlengde van het belang van het kind liggen. Ten tweede, doordat bepaalde vormen van moederschap door de opvoedkundigen als beter worden beschouwd dan andere.

Verbeeldingen van moederschap in tijdschriften als Libelle, Margriet en Ouders van $\mathrm{Nu}$ en in reclame voor babyproducten dragen bij aan de kracht en reikwijdte van het hedonistische vertoog zoals we het in de opvoedkundige literatuur zijn tegengekomen. Hierdoor is het onderdeel geworden van de standaardvoorstellingen van moederschap. Zelfs moeders die geen opvoedkundig handboek openslaan, worden er hoogstwaarschijnlijk mee geconfronteerd. Uit de bespreking van de verschillende soorten bronnen bleek dat vaderschap doorgaans onzichtbaar is in dit vertoog. Dit neemt niet weg dat het discours zich soms ook uitstrekt naar vaders, wat in de advertenties en brochures van Maxi-Cosi het geval is.

Bij de discussie van de maatschappelijke context bleek onder meer dat het vertoog hoogstwaarschijnlijk een voedingsbodem vindt in de populaire hedonistische levensvisie en in de psychology of choice, waaraan een modern idee van maakbaar- 
heid en een daarmee samenhangend modern mensbeeld ten grondslag ligt. Ten slotte werd duidelijk dat de verschillende soorten besproken bronnen en de Nederlandse samenleving als geheel niet monolithisch zijn wanneer het gaat om de verbeelding van moederschap. Er bestaan ook maatschappelijke, politieke en wetenschappelijke plekken waar negatieve kanten van blank, middenklasse, bewust gekozen moederschap de ruimte krijgen. Soms komen we ook optimistische beelden tegen die van het ideaal 'afwijken'. Er wordt dus duidelijk ook aan het normatieve idyllische beeld van moederschap geknaagd. Daarbij is een slag om de arm echter op zijn plaats. Veel probleemdiscoursen over moederschap die voorhanden zijn, lijken namelijk vaak ingekapseld en beperkt te worden door datzelfde idyllische vertoog. In de besproken opvoedkundige adviesboeken en tijdschriften worden problemen bijvoorbeeld niet compleet verzwegen, maar ze lijken door rooskleurige vormgeving en opwekkende woorden relatief gemakkelijk te managen. De toon blijft zodoende optimistisch: het gaat nu misschien niet goed, maar maak je geen zorgen, voor je het weet is het moederschap iets dat je gelukkig maakt, mits je de juiste keuzes maakt. De normatieve invloed van het vertoog van genieten blijft zodoende zelfs dan voelbaar. Bij de bespreking van deze probleemvertogen wordt bovendien duidelijk dat er idealiseringen van bepaalde vormen van vaderschap bestaan die van het moederschap niet voor handen zijn. Zo wordt de combinatie van werk en zorg voor vaders vaak als een verrijking gezien, terwijl het voor moeders als een probleem wordt beschouwd.

Het is daarom niet opzienbarend dat Marleen Castelein het gevoel heeft dat ze als moeder niet vrijelijk kan praten over de "schaduwzijde van het moederschap" (2009). Problemen kunnen besproken worden in een context waarin ze meteen beheersbaar kunnen worden gemaakt. Simpelweg zeggen dat het allemaal bar tegenvalt, dat je het helemaal niet zo aangenaam vindt en misschien zelfs dat je er liever niet aan was begonnen, blijft moeilijk terrein. Ten eerste, heb je dan volgens de opvoedkundige handboeken als moeder eigenlijk toch gefaald ten opzichte van je kind. Als jij immers niet gelukkig bent, hoe kan je kind zich dan goed ontwikkelen? Daarnaast geef je dan volgens het geldende moderne mensbeeld toe dat je als mens tekort bent geschoten. Je bent immers niet in staat gebleken om de juiste keuzes te maken; keuzes die je gelukkig maken.

Hoe literaire fictie zich tot deze normatieve kracht van het idyllische vertoog over moederschap en tot beschikbare niet-fictionele probleemvertogen verhoudt, wordt in de volgende hoofdstukken uiteengezet. 



\section{Hoofdstuk 2}

\section{De productie van fictioneel proza over moederschap}

\section{Inleiding}

In dit hoofdstuk wordt op kwantitatieve wijze een beeld geschetst van de productie van Nederlandse, fictionele romans, novellen en verhalen over ouderschap die tussen begin 1980 en eind 2009 voor het eerst zijn gepubliceerd. Daarbij is er specifiek aandacht voor literaire werken over moederschap. Het belangrijkste doel van dit hoofdstuk is immers om de aanname te onderzoeken die aan dit onderzoek ten grondslag ligt: dat moederschap in literaire fictie in Nederland sinds 1980 voornamelijk wordt geproblematiseerd. Het net wordt echter verder uitgegooid. In tegenstelling tot de rest van dit proefschrift wordt hier al het fictionele proza over ouderschap meegenomen. Ten eerste, omdat het belangrijk is om ook aandacht aan vaderschap te besteden, ook al gaat dit onderzoek over moederschap. Betekenissen die aan moederschap en vaderschap worden toegekend, constitueren elkaar namelijk vaak (Chambers, 2001; Van Rijkswijk, 2006). Door ook romans over vaderschap mee te nemen, krijgen we inzicht in de bredere context waarin de boeken over moederschap kunnen worden geplaatst. Daarbij wordt er niet alleen gekeken naar werken die als literair te boek staan, waartoe de rest van dit onderzoek zich wel beperkt. Hier worden alle fictionele romans, novellen en verhalen voor volwassenen waarin ouderschap en in het bijzonder moederschap een thema is in de analyse betrokken, vanuit de hoop zo een betere indruk te krijgen van de relatieve positie van literaire genres ten opzichte van andere genres en fictioneel proza in het algemeen.

Voor de analyse is gebruik gemaakt van de Nederlandse Centrale Catalogus $[\mathrm{NCC}]^{59}$ Met behulp van deze database is ten eerste de publicatie van fictioneel proza over ouderschap en moederschap op kwantitatieve wijze in kaart gebracht. Daarbij is er ook aandacht voor de wijze waarop ouderschap en moederschap hierin worden verbeeld. Worden ze vooral geïdealiseerd of juist niet? Welke thema's komen er in het proza aan bod? Welke ontwikkelingen vinden er gedurende dertig jaar

\footnotetext{
${ }^{59}$ De Nederlandse Centrale Catalogus is toegankelijk via het portaal PiCarta. PiCarta is een service van het Ohio College Library Center (Ohio College Library Center, 2010).
} 
in die verbeelding plaats? En hoe verhouden die verbeeldingen zich tot de maatschappelijke norm van genieten en probleemvertogen over moederschap zoals die in het eerste hoofdstuk aan bod zijn gekomen?

Ten tweede, zal dit hoofdstuk inzicht verschaffen in de sekse van de auteurs die over ouderschap en over moederschap schrijven. Er is geopperd dat voornamelijk vrouwelijke auteurs zich met ouderschap en zeker met moederschap bezig houden. ${ }^{60}$ In een interview in Het Parool uit 1994 zegt schrijfster Hannes Meinkema, bekend van verschillende romans en verhalenbundels over moederschap, hierover bijvoorbeeld:

Het ouderschap ${ }^{61}$ is tegenwoordig een belangrijk thema in mijn boeken. In de Nederlandse literatuur $^{62}$ is dat tamelijk ongebruikelijk. De norm wordt hier vooralsnog bepaald door mannelijke schrijvers. En vaders schrijven niet veel over hun ouderschap, Nicolaas Matsier is een van de weinigen. Ik wijk af. Maar ik heb nooit anders gedaan; als schrijfster heb ik me altijd op de rand van het taboe begeven. (Van Brummelen, 1994, p. 36)

Meinkema verbindt haar keuze om over het moederschap te schrijven in dit citaat indirect aan haar vrouwelijke sekse. Niet iedereen deelt Meinkema's opvatting. In een artikel in NRC Handelsblad uit 2010 stelt recensente Yra van Dijk dat romans over het krijgen en hebben van kinderen al enkele decennia vooral door mannen worden geschreven. Vrouwen branden hun vingers volgens haar juist niet (meer) aan moederschap:

Overigens zijn het zelden vrouwelijke auteurs die daarover schrijven: juist zij lijken huiverig om hun vingers te branden aan deze materie. Zij kijken wel uit zich te voegen in een lange traditie waarin de baby het clichébeeld is voor ware zingeving, en waarin vrouwen niets anders scheppen dan kinderen. (Van Dijk, 2010)

Hoe zit het nu precies? Schrijven aan het eind van de twintigste eeuw en het begin van de eenentwintigste eeuw vooral vrouwelijke of mannelijke auteurs over ouderschap en moederschap? Is er iets veranderd in de loop van dertig jaar? Hoe ontwikkelt de verhouding tussen mannelijke en vrouwelijke auteurs zich?

$\mathrm{Na}$ het beantwoorden van deze vragen, wordt de relatieve positie van literaire fictie over ouderschap en moederschap ten opzichte van andere genres verder

\footnotetext{
${ }^{60}$ Deze aanname heeft een langere geschiedenis in de Nederlandse literatuurkritiek. Letterkundige Erica van Boven (1992) toont aan dat verscheidene literatuurcritici er tussen 1898 en 1930, volgens Van Boven onterecht, vanuit gaan dat onderwerpen als gezin en liefde enkel door vrouwelijke auteurs worden uitgewerkt. Cultuurhistoricus Leon Hanssen (2006a, 2006b) wijst overigens op het bestaan van dezelfde aanname bij critici in relatie tot twintigste-eeuwse, Nederlandse poëzie.

${ }^{61}$ Meinkema bedoelt hier het moederschap, maar ze geeft de voorkeur aan de meer sekseneutrale term ouderschap boven moederschap, "omdat er idealiter geen verschil is tussen de rol van de moeder en de vader" (Van Brummelen, 1994, p. 36).

${ }^{62}$ Wat Meinkema hier precies onder literatuur verstaat, is overigens onduidelijk.
} 
onderzocht, door de verschillende genres in kaart te brengen waartoe de romans volgens de Nederlandse Uniforme Rubrieksindeling [NUR] behoren. Daarbij wordt er ingegaan op de verbeelding van ouderschap en moederschap en het productieaandeel van vrouwelijke en mannelijke auteurs in verschillende genres. Daar komen we ook tot de kernvraag van dit hoofdstuk: of moederschap in literaire fictie voornamelijk wordt geproblematiseerd.

Ten slotte komt de culturele reikwijdte van fictionele prozawerken over ouderschap en moederschap aan de orde. Daarvoor wordt de aandacht voor een deel van de romans, novellen en verhalenbundels in vijf dagbladen in kaart gebracht. Daarnaast wordt de mogelijke invloed van de sekse van de auteur op de exposure in de kranten geanalyseerd. In debatten over de aandacht voor vrouwelijke en mannelijke auteurs kunnen we nog steeds het geluid horen dat vrouwen minder onder de aandacht worden gebracht dan mannelijke auteurs (Vos, 2008). Hier worden de verschillen in media-aandacht voor vrouwelijke en mannelijke auteurs van romans over ouderschap en moederschap onderzocht. Daarbij wordt er ook aandacht gevraagd voor de rol die genre mogelijk speelt.

Dit hoofdstuk houdt, om met Pierre Bourdieu te spreken, zich aldus hoofdzakelijk bezig met een literatuursociologisch onderzoek naar de "materiële" en "symbolische productie" (1994, p. 206) van fictioneel proza. Met de materiële productie verwijst Bourdieu (1994) naar het proces van het maken en uitgeven van boeken, met de symbolische productie bedoelt hij de processen waarbij er betekenissen en waarde aan boeken worden toegekend. ${ }^{63}$ In recent onderzoek naar de materiële en symbolische productie van proza worden "[u]itgevers, fondsredacteuren en boekhandelaren" bestudeerd als "sleutelfiguren in de materiële productie en distributie" (Van Rees, Janssen \& Verboord, 2006, p. 240). Het "gezamenlijke werk van auteurs, critici, leraren, (van literaire prijzen, festivals, wedstrijden) en redacteuren van literaire tijdschriften" wordt onderzocht als onderdeel van de symbolische productie (Van Rees, Janssen \& Verboord, 2006, p. 240). Voor het onderzoeken van deze twee vormen van productie wordt binnen de literatuursociologie vaak gebruik gemaakt van kwantitatieve methodes. Deze worden echter geregeld gecombineerd met kwalitatieve methodes. Zo brengt literatuursociologe Susanne Janssen (1994) in haar proefschrift de materiële productie van proza in 1978 en 1991 en de mate van

\footnotetext{
${ }^{63}$ Kees van Rees, Susanne Janssen en Marc Verboord (2006) merken op dat Bourdieu zich met het gebruik van deze termen afzette tegen de (ook nu nog) wijdverbreide opvatting dat de kunststatus van bepaalde cultuuruitingen primair berust op intrinsieke eigenschappen:
}

Ruim voor Beckers Art Worlds (1982), betoogde hij dat producten pas aanspraak kunnen maken op de status van kunstwerk, wanneer ze door gatekeepers - critici, galeriehouders, literaire uitgevers, een select publiek - binnen het bestaande kunstcircuit worden toegelaten en door de leden hiervan eigenschappen en waarde krijgen toegekend. (pp. 239-240) 
aandacht voor de in die jaren gepubliceerde werken met behulp van kwantitatieve methodes in kaart. Tegen de achtergrond van deze analyses onderzoekt ze vervolgens op kwalitatieve wijze de receptie van het werk van drie auteurs. In dit hoofdstuk worden er vooral kwantitatieve methodes ingezet.

In de praktijk zijn materiële en symbolische productieprocessen niet zo eenvoudig te scheiden. De uitgeverijen en boekhandelaren die zich op het eerste oog bezig houden met de materiële productie, spelen vaak ook een belangrijke rol in de classificatie van boeken en verzetten daarmee symbolisch werk (Van Rees, Janssen \& Verboord, 2006). De scheidslijn tussen symbolische en materiële productie is aan het eind van de twintigste eeuw bovendien diffuser geworden. Uitgeverijen en distributeurs zijn er namelijk in geslaagd een grotere rol in de symbolische productie te gaan spelen (Van Rees, 1987; Van Rees, Janssen \& Verboord, 2006). Waar de verwevenheid tussen materiële en symbolische productie een rol speelt, zal daar nader op worden ingegaan.

Hier begeven we ons bij tijd en wijle ook buiten de parameters van een literatuursociologische analyse van de productie van romans. Dit geldt voor de momenten waarop de verbeelding van ouderschap en moederschap in de romans zelf aan bod komt en wanneer de mogelijke betekenissen van die verbeeldingen worden doordacht in relatie tot de maatschappelijke context waarin ze zijn geproduceerd. Dit zijn onderwerpen die in literatuursociologische analyses van de productie van literatuur niet zo snel aan bod komen. Daar kom ik na dit hoofdstuk op terug.

\section{Materiële productie}

\section{Dataverzameling}

De NCC verschaft toegang tot de collecties van meer dan zeshonderd Nederlandse bibliotheken (Koninklijke Bibliotheek, geen datum), waaronder de (online) Nederlandse Bibliografie van de Koninklijke Bibliotheek. ${ }^{64}$ Volgens de Koninklijke Bibliotheek bevat de bibliografie alle publicaties die in Nederland sinds 1974 zijn uitgegeven (Koninklijke Bibliotheek, geen datum). ${ }^{65}$ Henk Voorbij en Pieter Douma (1996) concluderen in hun onderzoek naar de betrouwbaarheid van het Depot van Nederlandse Publicaties, waarop de Nederlandse Bibliografie is gebaseerd, dat 96,6\% van

\footnotetext{
${ }^{64}$ De Nederlandse Bibliografie wordt samengesteld door de Redactie Brinkman van de afdeling Depot van Nederlandse Publicaties \& Nederlandse Bibliografie van de Koninklijke Bibliotheek aan de hand van de publicaties die worden opgestuurd door Nederlandse uitgevers.

${ }^{65}$ Desondanks zal "een deel van de nieuw verschenen prozawerken" in de Nederlandse Bibliografie ontbreken, omdat er "uitgevers [zijn] die hun publikaties [sic] niet of niet altijd toezenden aan het Depot van de Koninklijke Bibliotheek" (Janssen, 1994, p. 43). Dat neemt niet weg dat de Nederlandse Bibliografie relatief volledig is.
} 
de uitgegeven boeken met een ISBN-nummer in het Depot is opgenomen. Ook bestaat er weinig achterstand met het invoeren van titels, ten opzichte van het moment waarop ze zijn uitgegeven. ${ }^{66}$ De NCC kent door de koppeling aan de Nederlandse Bibliografie minstens dezelfde volledigheid. Dit is een van de redenen geweest om voor de NCC te kiezen. De belangrijkste reden voor de keuze voor de NCC is echter dat deze de mogelijkheid biedt om gericht te zoeken naar fictionele prozawerken, waarin ouderschap en moederschap een thema is en om de inhoud van de boeken te beoordelen. In de NCC worden namelijk meerdere onderwerpsaanduidingen, "subject headings" (Ohio College Library Center, geen datum a), aan een boek toegekend. Sommige van deze aanduidingen zeggen iets over het land van oorsprong van het boek of geven aan of een boek fictie of non-fictie is. Weer andere aanduidingen zijn indicatief voor de thematische inhoud. Met behulp van de verschillende onderwerpsaanduidingen kan er binnen de NCC worden gezocht naar fictioneel, Nederlands proza over ouderschap en moederschap. Daarnaast bevat de NCC meestal korte beschrijvingen van de inhoud van de desbetreffende titels, "abstracts", en vaak zelfs korte recensies, "reviews" (Ohio College Library Center, geen datum a). Deze samenvattingen en recensies kunnen, in tegenstelling tot de titels en de onderwerpsaanduidingen, niet met behulp van de zoekmachine worden doorzocht. De via de titels en onderwerpsaanduidingen al gevonden fictionele prozawerken kunnen aan de hand van deze beschrijvingen en recensies wel verder worden gecategoriseerd en beoordeeld.

Over de onderwerpsaanduidingen, samenvattingen en recensies in de NCC een opmerking. We moeten ze als interpretaties van de prozawerken beschouwen. $\mathrm{Er}$ wordt bij het maken van deze categorieën en beschrijvingen gekozen voor het belichten van bepaalde elementen uit boeken, terwijl andere aspecten buiten beschouwing blijven. Dergelijke interpreterende keuzes zijn inherent aan het categoriseren, beschrijven of evalueren van een boek. Dat betekent niet dat de onderwerpsaanduidingen, samenvattingen en recensies volledig subjectief zijn en niets zeggen over de inhoud van de romans, verhalenbundels en novellen. Het interpretatieve aspect kan er echter bijvoorbeeld wel toe leiden dat bepaalde werken over ouderschap en moederschap in deze analyse buiten beschouwing blijven. Zo zou het wel eens zo kunnen zijn dat enkele romans waarin juist gelukkige ouders figureren niet als zodanig worden gecategoriseerd, omdat een ander, meer problematisch aspect in het boek de aandacht trekt. Het beeld dat met behulp van deze analyse van de productie van romans over ouderschap in het algemeen en moederschap in het bijzonder kan worden verkregen, is alleen daarom al onontkoombaar beperkt en gekleurd door interpretatie.

\footnotetext{
${ }^{66}$ Voorbij en Douma (1996) hebben een steekproef voor het jaar 1992 uitgevoerd en daaruit blijkt dat meer dan 90\% van de boeken die in 1992 zijn gepubliceerd vanaf week 16 van het jaar 1993 in de Nederlandse Bibliografie is opgenomen.
} 
Om de productie van fictioneel proza over ouderschap en moederschap in kaart te brengen, is de NCC met behulp van de volgende negen reeksen zoektermen doorzocht. De eerste hiervan bestaat uit de woorden 'moederschap', 'moeder', 'moeders', 'ma', 'mam', 'mama' en 'mama's'. De tweede serie omvat de termen 'vaderschap', 'vader', vaders, 'pa', 'pap', 'papa' en 'papa's', de derde 'ouderschap' en 'ouders' ${ }^{67}$ en de vierde 'baby', 'baby's', 'kind' en 'kinderen'. De vijfde reeks bestaat uit 'dochter' en 'dochters' en de zesde uit 'zoon', 'zoons' en 'zonen'. De zevende serie zoektermen omvat 'verwachting', 'bevalling', 'bevallingen', 'bevallen', 'zwangerschap', 'zwangerschappen', 'geboorte', 'geboorten' en 'geboortes' en de achtste serie bestaat uit de woorden 'familie', 'families', 'gezin' en 'gezinnen'. De negende en laatste reeks betreft de woorden 'opvoeding' en 'opvoeden'. Er is met deze zoektermen enkel gezocht naar werken die onder de onderwerpsaanduiding "romans en novellen; oorspr.-Nederlands" vallen en binnen de categorie "material selection" is "books" aangevinkt (Ohio College Library Center, geen datum a). Daarnaast is er alleen gezocht naar werken die in de periode tussen 1 januari 1980 en 31 december 2009 zijn gepubliceerd. De zoektermen zijn ingevuld in de zoekcategorie "all words" (Ohio College Library Center, geen datum a). Zo zijn zowel de titels als alle overige onderwerpsaanduidingen doorzocht, die naast 'romans en novellen; oorspr.-Nederlands' aan een boek zijn toegekend. Het op deze manier doorzoeken van de NCC heeft 2236 te analyseren hits opgeleverd. ${ }^{68}$

Aan de hand van deze resultaten zijn er twee verschillende datasets samengesteld. $\mathrm{Er}$ is ten eerste een algemene dataset gecreëerd op basis van de resultaten die met alle zoektermen zijn gevonden. Daarin staan dus alle gevonden titels over ouderschap. Daarnaast is er een aparte dataset aangelegd met de titels, 442 stuks, die alleen met de eerste reeks zoektermen, bestaande uit de woorden 'moederschap', 'moeder', 'moeders', 'ma', 'mam', 'mama' en 'mama's', zijn opgespoord. Deze dataset is dus beperkt tot de boeken die in de NCC op meest expliciete wijze met moederschap in verband zijn gebracht. Dit wil overigens niet zeggen dat moederschap geen thema kan zijn in de boeken, die met behulp van de andere zoektermen zijn gelokaliseerd.

Bij het opbouwen van deze twee datasets zijn de gevonden resultaten als volgt behandeld. Ten eerste is ieder boek slechts één keer opgenomen in iedere dataset, hoewel een titel vaak meerdere keren in de oorspronkelijke zoekresultaten voorkomt. Dit komt doordat boeken vaak opnieuw worden uitgegeven of doordat ze aan meer dan een van de gebruikte zoektermen zijn gekoppeld. Bij bundels van meerde-

\footnotetext{
${ }^{67}$ De zoekterm 'ouder' is ook overwogen. Omdat deze term in de NCC echter vooral treffers oplevert waarin ouderdom en niet ouderschap een belangrijk thema is, is deze niet gebruikt.

${ }^{68}$ Met betrekking tot de afzonderlijke reeksen zijn de aantallen als volgt verdeeld. Reeks een: 442 titels. Reeks twee: 490 titels. Reeks drie: 59 titels. Reeks vier: 407 titels. Reeks vijf: 296 titels. Reeks zes: 313 titels. Reeks zeven: 59 titels. Reeks acht: 164 titels. Reeks negen: 6 titels.
} 
re romans en novellen, zijn de titels van de afzondelijke werken die in deze bundels zijn opgenomen en dus niet de bundels zelf. De boeken die gebundeld worden, zijn namelijk vaak eerder al als op zichzelf staande boeken uitgegeven. Bij bloemlezingen van korte verhalen zijn juist wel de titels van de de bloemlezingen zelf ingevoerd en niet de aparte verhalen, omdat korte verhalen vaak niet afzonderlijk zijn gepubliceerd.

Omdat dit onderzoek zich op Nederland richt, zijn werken van auteurs die bij nader inzien niet Nederlands blijken te zijn uit de hierna overgebleven resultaten verwijderd. Hoewel er enkel is gezocht binnen de onderwerpsaanduiding 'romans en novellen; oorspr.-Nederlands' is deze verdere selectie noodzakelijk, omdat sommige boeken van bijvoorbeeld Vlaamse en Antilliaanse auteurs in de NCC ook onder Nederlandse romans worden geschaard. Alle auteurs die in de Nederlandse taal publiceren én in Nederland geboren zijn of in Nederland zijn komen wonen, worden hier als Nederlandse auteurs beschouwd. Auteurs uit de Nederlandse Antillen en Aruba die tot het Nederlands Koninkrijk behoren, zijn vanwege het bestaan van culturele en maatschappelijke verschillen met Nederland buiten beschouwing gelaten, tenzij ze in Nederland verblijven of verbleven. Ook Vlaamse auteurs zijn vanwege de eigenheid van het Vlaamse proza en maatschappij niet meegenomen ${ }^{69}$, tenzij zij in Nederland wonen of woonden en als zodanig onderdeel van de Nederlandse samenleving zijn. De informatie over de nationaliteit van de auteurs is, indien onbekend, achterhaald met behulp van de websites van uitgeverijen, van boekhandels en van schrijvers zelf en via de Digitale Bibliotheek voor de Nederlandse Letteren. Van de auteurs van een heel klein aantal prozawerken bleek de nationaliteit niet te achterhalen. ${ }^{70}$ Deze boeken zijn niet in de datasets opgenomen.

Van de overgebleven boeken zijn de volgende gegevens verzameld, op basis waarvan er een verdere selectie is gemaakt:

1). De titels van de boeken.

2). De namen van de auteurs of van de redacteurs als het om bloemlezingen van korte verhalen gaat. In de rest van dit hoofdstuk zal er voor de leesbaarheid van auteurs worden gesproken, maar daarmee worden ook de redacteurs bedoeld.

3). De sekse van de auteurs. De sekse van de auteurs is, indien niet bekend, op dezelfde wijze achterhaald als de nationaliteit van de schrijvers. Van een klein aan-

\footnotetext{
${ }^{69}$ Kees van Rees en Gilles Dorleijn (2006) wijzen eveneens op de aparte status van het Vlaams proza (p. 23).

${ }^{70}$ Voor de resultaten die met alle zoektermen zijn gevonden (dataset 1), gaat het hierbij om twee boeken. Voor de resultaten die alleen met de eerste reeks zoektermen zijn gevonden (dataset 2), gaat het om één boek. In één geval is dit het gevolg van het feit dat de auteur zich van een pseudoniem heeft bediend, waarvan de daarachter verscholen persoon op het moment van deze analyse niet bekend is. Dit is het pseudoniem Wladimir Arn.
} 
tal prozawerken bleek de sekse van de schrijvers niet te achterhalen. ${ }^{71}$ Deze werken zijn niet meegenomen in de datasets.

4). Het jaar waarin de boeken voor het eerst zijn gepubliceerd. Voor gebundelde romans en novellen is het oorspronkelijke jaar van uitgave van de afzonderlijke werken genoteerd, bij bloemlezingen van korte verhalen het jaar van uitgave van de bloemlezing. Boeken die bij nader inzien niet voor het eerst tussen 1 januari 1980 en 31 december 2009 zijn gepubliceerd, zijn niet opgenomen in de datasets.

$5)$. De samenvattingen en recensies van de boeken in de NCC. Van de romans en novellen die apart en gebundeld zijn uitgegeven, zijn zowel de beschrijvingen van de afzonderlijke boeken als die van de bundel zelf verzameld, om een zo compleet mogelijke indruk te krijgen van de inhoud van de boeken. Werken die op basis van de samenvattingen en recensies uiteindelijk toch helemaal niet over ouderschap blijken te gaan, zijn buiten beschouwing gelaten. In het zeldzame geval dat er van een boek geen samenvatting of recensie beschikbaar is, is dit boek niet meegenomen. Er kan dan immers op basis van de informatie in de NCC weinig tot niets over de thema's in dit werk gezegd worden.

6). De Nederlandstalige Uniforme Rubrieksindeling-codes [NUR-codes] van de boeken, zoals die zijn geregistreerd in het online ISBN-register van het Centrale Boekhuis. Voor de titels van romans en novellen uit bundels, zijn zowel de NURcode van het afzonderlijke boek als de code van de bundel zelf genoteerd. Ook enkele andere boeken kennen meerdere NUR-codes. Dat kan worden veroorzaakt doordat een boek door meerdere uitgeverijen is uitgegeven, die het boek elk een andere code hebben toegekend of doordat dezelfde uitgever heeft besloten om voor een boek meerdere codes te gebruiken. De NUR-code is een driecijferig code die door Nederlandse en Vlaamse uitgevers en het Centraal Boekhuis, de grootste distributeur van boeken in Vlaanderen en Nederland, wordt gebruikt om boeken naar genre te categoriseren (Janssen, 1994; Van Rees, Janssen \& Verboord, 2006). ${ }^{72}$ Zo verwijst de code 301 naar het genre 'literaire roman, novelle'. De NUR-codering is niet het enige gebruikte genreclassificatiesysteem. Individuele literatuurwetenschappers en critici hanteren vaak hun eigen genre-indelingen. De uniformiteit van de NUR is echter vanwege de onderlinge vergelijkbaarheid een belangrijk voordeel bij de onderhavige grootschalige, kwantitatieve analyse. Een ander bruikbaar uniform systeem is de Brinkman/Unesco-rubrieksindeling. Deze is echter minder ver-

\footnotetext{
${ }^{71}$ Het gaat hier bij de eerste dataset om drie boeken en bij de tweede dataset om twee boeken.

72 De NUR is in 2002 ingevoerd als een herziening van de Nederlandse Uniforme Genre Indeling [NUGI] die op haar beurt sinds 1986 in gebruik is. De NUGI is dan weer een herziening van de Uniforme Genre Indeling [UGI] die uit 1978 stamt (Janssen, 1994). In het ISBN-register zijn de oude UGI- en NUGI-codes omgezet naar NUR-codes. In de online Nederlandse Bibliografie en in de NCC staan geen UGI-codes meer, maar wel nog NUGI-codes. Deze NUGI-codes zijn niet geïndexeerd naar NUR-codes. Daarom is er voor het gebruik van de ISBN-register gekozen om de codes op te zoeken.
} 
fijnd dan de NUR (Janssen, 1994). Uit het bestaan van deze verschillende classificaties blijkt overigens dat ook het proces van het toekennen van de NUR-codes een interpretatieproces is. Het bepalen van het genre van een boek is altijd een kwestie van interpretatie, ingekaderd door de parameters van het desbetreffende boek en de gangbare definities van genres op dat moment. Het kan dus voorkomen dat een roman binnen de NCC als fictie of als literatuur wordt gecategoriseerd, terwijl dit in een andere database niet het geval is of dat verschillende literatuurwetenschappers en -critici datzelfde boek niet als fictie of als literatuur beschouwen. Binnen de NURindeling wordt er een onderscheid gemaakt tussen hoofdcategorieën, waarin de verschillende genres met hun codes zijn ingedeeld. Genres die we als Nederlands, fictioneel proza voor volwassenen kunnen beschouwen vallen onder de hoofdcategorie 'fictie \& literaire non-fictie' (Nederlands Uitgeversverbond, 2008). Onder deze hoofdcategorie worden ook een aantal non-fictionele genres geschaard. Dit geldt eveneens voor poëzie, strips, cadeauboeken, in het Nederlands vertaalde romans en teksten uit de klassieke oudheid. Deze en andere genres die niet tot Nederlands, fictioneel proza voor volwassenen gerekend kunnen worden, zijn hier buiten beschouwing gelaten. In Tabel 1 zijn de genres die wel naar Nederlands, fictioneel proza voor volwassenen verwijzen met hun codes weergegeven (Nederlands Uitgeversverbond, 2008). Afgaand op deze tabel worden de volgende vier rubrieken, hier vetgedrukt, tot literaire fictie gerekend: 'literaire fictie algemeen' (code 300), 'literaire roman, novelle' (code 301), 'literaire thriller' (code 305), 'pockets literaire fictie' (code 311). 
Tabel 1

Nederlandse Uniforme Rubriekscodes voor fictie voor volwassenen

\begin{tabular}{|c|c|}
\hline NUR-code & Genrebeschrijving \\
\hline 300 & literaire fictie algemeen \\
\hline 301 & literaire roman, novelle \\
\hline 303 & verhalenbundels \\
\hline 305 & literaire thriller \\
\hline 307 & Toneel-, theater- en filmteksten, ook scenario's \\
\hline 309 & bloemlezingen \\
\hline 310 & Pockets algemeen \\
\hline 311 & pockets literaire fictie \\
\hline 312 & pockets populaire fictie \\
\hline 313 & pockets spanning \\
\hline 330 & spannende boeken algemeen \\
\hline 331 & detective \\
\hline 332 & thriller \\
\hline 333 & science fiction \\
\hline 334 & fantasy \\
\hline 335 & griezel- en spookverhalen, horror \\
\hline 336 & avonturenroman \\
\hline 337 & oorlogs- en verzetsroman \\
\hline 338 & spionageroman \\
\hline 340 & populaire fictie algemeen \\
\hline 341 & esoterische en spirituele roman \\
\hline 342 & historische roman (populair) \\
\hline 343 & romantiek \\
\hline 344 & streek- en familieromans \\
\hline 345 & volkssprookjes, sagen en legenden \\
\hline 350 & fictie overig algemeen \\
\hline
\end{tabular}

Aangepaste versie van de NUR-lijst door de Nederlands Uitgeversverbond, 2008. Geraadpleegd op 24 November, 2009, via www.nuv.nl. Copyright 2008 Nederlands Uitgeversverbond.

Uit de verzamelde NUR-codes van de boeken uit de datasets blijkt dat zich tussen de inmiddels overgebleven resultaten nog titels bevinden die op basis van deze codes niet tot Nederlandse fictie kunnen worden gerekend, ondanks dat er in de NCC enkel binnen de onderwerpsaanduiding 'romans en novellen; oorspr.-Nederlands' is gezocht. Daarnaast blijken niet alle boeken van een NUR-code te zijn voorzien. Dit komt waarschijnlijk doordat aan deze boeken geen code is toegekend door uitgevers of het Centraal Boekhuis. ${ }^{73}$ Van deze boeken kan zodoende niet met zekerheid gezegd worden dat het volgens de NUR-codering om Nederlands, fictioneel proza gaat. Deze twee groepen boeken zijn daarom buiten beschouwing gelaten bij het samenstellen van de datasets.

\footnotetext{
${ }^{73}$ In 1996 kent 28\% van de uitgevers die zijn aangesloten bij de Koninklijke Vereniging ter bevordering van de belangen des Boekhandels [KVB] geen codes toe (Voorbij \& Douma, 1996).
} 
$\mathrm{Na}$ al deze selecties is het uiteindelijk aantal te analyseren boeken in de eerste dataset 549. Het aantal werken in de tweede dataset, die is beperkt tot de boeken die gevonden zijn met de zoektermen moederschap 'moeder', 'moeders', 'ma', 'mam', 'mama' en 'mama's', is 148.

De kwantitatieve analyses die volgen zullen zich beperken tot beschrijvende statistiek. Er wordt geen gebruik gemaakt van binnen de inductieve statistiek ontwikkelde testen om bijvoorbeeld verbanden tussen sekse van de auteurs en de aandacht voor hun boeken in de dagbladen te toetsen op significantie. De inductieve toetsen die gebruikt zouden kunnen worden om de genoemde verbanden te onderzoeken, vertrekken vanuit de aanname dat er sprake is van een aselecte streekproef. Zo'n steekproef is hier niet aan de orde. Daarom is legitiem om ons hier tot beschrijvende statistiek te beperken. Bovendien blijkt de beschrijvende statistiek in deze gevallen voldoende informatie over deze verbanden te verschaffen, zoals later duidelijk zal worden.

In de volgende drie paragrafen wordt de analyse van de twee datasets besproken, waarbij eerst de in de boeken aangesneden thema's worden behandeld en vervolgens de sekse van de auteurs en de NUR-genres van de boeken. Alle genreaanduidingen die in de rest van dit hoofdstuk worden gebruikt, zijn op de NURcodes van de boeken gebaseerd tenzij anders vermeld.

\section{Thema's}

De verzamelde samenvattingen en recensies vormden de basis voor de analyse van de inhoud van de romans, novellen en verhalenbundels en voor het beantwoorden van de vraag of ouderschap in het algemeen en in het bijzonder moederschap in Nederlands fictioneel proza doorgaans niet in rooskleurige termen wordt verpakt. Onder de noemer problematisering zijn alle boeken geschaard, waarin er zich problemen voordoen in relatie tot de verhoudingen tussen ouders en kinderen of bij het krijgen van kinderen. Deze problemen kunnen zowel vanuit het perspectief van kinderen, (aanstaande) ouders of andere personages worden waargenomen.

\section{Resultaten dataset 1: ouderschap}

Van de 549 boeken over ouderschap in de eerste dataset kunnen er 494 worden aangewezen waarin relaties tussen ouders en kinderen op een of andere manier van buiten af of van binnenuit worden bedreigd. Er zijn er slechts vier waarin ouderschap overduidelijk wordt geïdealiseerd zonder dat er een wolkje aan de lucht lijkt te zijn. Van 51 prozawerken kan niet worden vastgesteld of er zich wel of geen pro- 
blemen voordoen in het leven van ouders en hun kinderen. In Figuur 1 is die verdeling in percentages weergegeven. ${ }^{74}$

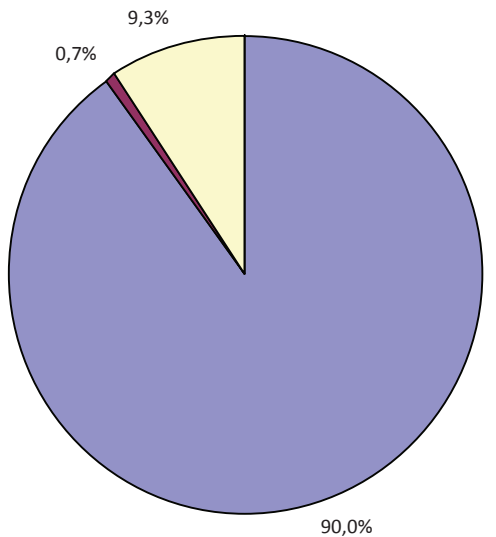

$\square$ Wel geproblematiseerd $\square$ Onduidelijk $\square$ Niet geproblematiseerd

\section{Figuur 1}

Problematisering van ouderschap in Nederlands, fictioneel proza over ouderschap in percentages (dataset 1)

$n=549$

Met betrekking tot de onderwerpen die worden aangesneden, kunnen er door het bestuderen van de samenvattingen en recensies een aantal centrale thema's ontdekt worden. Een veelvoorkomend thema is de ziekte of dood van een van de ouders. Dat kunnen zowel de biologische ouders zijn, maar ook adoptieouders of pleegouders. Het kan daarbij gaan om ouders van jonge kinderen; soms zelfs nog baby's wanneer de moeder in het kraambed het leven laat. Dit laatste gebeurt bijvoorbeeld in de 'streek- en familieromans' Mijn dochter Linda (1980) van Anke de Graaf en De verloren vader (2000) van Leida Verhagen. Maar niet alleen ouders van jonge kinderen sterven. In een groot aantal romans en novellen staat de dood of ziekte centraal van een moeder of een vader van volwassen kinderen. In deze boeken staat meestal het perspectief van het volwassen kind voorop, dat op de relatie met de desbetreffende ouder reflecteert. Deze relatie zelf verloopt niet altijd moeizaam, maar de ziekte of dood van de ouder werpt wel een schaduw over het leven van kind en ouder. Literaire romans als Winterjaar (1986) van Ton van Reen, De vader, de moeder en de tijd (1999) van Marijke Hilhorst en Uitdorsten (2003) van

\footnotetext{
${ }^{74}$ Alle percentages in dit hoofdstuk zijn op één decimaal afgerond.
} 
A.F.Th. van der Heijden zijn hier voorbeelden van. In deze romans is de relatie met de ouder liefdevol, maar wordt zij gecompliceerd door ziekte en dood. Er zijn ook romans waarin de relatie tussen zieke, stervende of dode ouders en hun volwassen kinderen verre van aangenaam is. In De huilende man (1984) van Ger Thijs bijvoorbeeld. De relatie tussen de stervende moeder en haar volwassen kinderen is in deze literaire roman zo slecht, dat de dochter het stervensproces opzettelijk probeert te versnellen. In het literaire boek Te kwader min (1984) van Hannes Meinkema komt er ondanks toenaderingspogingen van de volwassen dochter geen einde aan de vijandschap tussen de dochter en de stervende moeder. En in de literaire roman Aards bezit (1986) van Hilbert Kuik kampen twee broers met het feit dat ze tijdens zijn leven nauwelijks contact konden leggen met hun inmiddels overleden vader. De Politiek gevangene (2006) van Aukelien Weverling, ook een literair werk, laat zien hoe een volwassen zoon en dochter wraak nemen op hun dementerende, dominante moeder vanwege de moeilijke jeugd die zij hun heeft bezorgd. Om enkele voorbeelden te noemen.

Ouders sterven niet alleen, maar zijn ook om andere redenen afwezig in het leven van hun kind(eren). Er zijn aanzienlijk meer boeken over de afwezigheid van vaders dan van moeders. De afwezigheid van vaders wordt onder meer veroorzaakt, doordat zij niet altijd door de moeder op de hoogte zijn gebracht van het bestaan van hun kind, bijvoorbeeld wanneer het kind het resultaat is van een korte, buitenechtelijke affaire. De streek- en familieroman Geef je dromen niet op (2000) van Karin Peters en de literaire romans Anthon \& Anissa (2001) van Chandra Doest, Saternacht (2001) van Miriam Guensberg, Afkomst (2002) van Michiel Krielaars en Kid (2007) van Huub Beurskens zijn hier voorbeelden van. Een andere reden waarom een vader uit het leven van zijn kind verdwijnt, is het beëindigen van de relatie met de moeder waarna het contact met het kind verwatert of onmogelijk wordt gemaakt door de moeder of instanties. In de streek- en familieroman De roep van een kind (1994) van Anke de Graaf en de literaire romans Weg van Lila (2007) en Vaderstad (2009), beide van Patrick van Rhijn, is dit het geval. Er zijn ook vaders die er bewust voor kiezen om de vaderrol niet op zich te nemen, zoals in de streek- en familieroman Het bruidsboeket (1996) van Catelijn Claes en in de literaire roman En het dansen gaat door (1998) van Michiel Krielaars. Ook bij moeders zijn er uiteenlopende redenen voor hun afwezigheid. Zo worden moeders gedwongen om hun kind af te staan, omdat ze niet getrouwd zijn. Het gaat dan vaak om tienermoeders, zoals in de streek- en familieroman In de schaduw van een kind (1983) van Henny Thijssing-Boer en in het literaire werk Zuigend Moeras (1990) van Joanna Werners. Soms worden er vrouwen geïntroduceerd die er bewust voor kiezen om de moederrol de rug toe te keren, zoals in de literaire roman De bekoring (2006) van Hans Münstermann. Buitenechtelijke relaties, scheidingen en ongeplande zwangerschappen zijn over het algemeen onderwerpen die bij herhaling worden aangesneden in romans waarin een van de ouders afwezig is. Samen met de dood en de afwezigheid van 
ouders is adoptie-, stief- en pleegouderschap overigens vaak een thema in prozawerken. Dit geldt ook voor alleenstaand ouderschap en vooral voor alleenstaand moederschap. Daarnaast speelt religie meestal een rol in prozawerken waarin moeders worden gedwongen om hun buitenechtelijk kind af te staan. Zo spelen zulke boeken zich vaak af in een protestants-christelijk milieu, waarin juist het heteroseksuele kerngezin en het huwelijk belangrijke waarden zijn waaraan niet getornd mag worden. Religie, en niet alleen het protestantisme, is in het algemeen een veel voorkomend thema.

Niet alleen ouders worden ziek, gaan dood of zijn afwezig, ook kinderen. Hoewel in aanzienlijk minder grote getale dan ouders. De dood van een kind is onder meer een gegeven in de literaire romans De kleine blonde dood (1985) van Boudewijn Büch, Ontpopping (1992) van Berend Wineke, Koudvuur (2005) van Manon Uphoff en Koningswens (2005) van Christine Crütsen. Daarnaast zijn er een aantal romans waarin kinderen verdwijnen omdat ze van huis weglopen of worden ontvoerd, zoals in Dromen van kinderen (1989) van Roel Bossink en Kind Ontvoerd (1995) van Jackie Lourens. Allebei romans die volgens hun NUR-codes tot spannende boeken kunnen worden gerekend.

Een ander opvallend terugkerend thema is oorlog. De relaties tussen ouders en kinderen worden in verscheidene romans beschreven in een context waarin de bestaanszekerheid van een gezin wordt bedreigd door oorlog en geweld. Zoals in de literaire werken Bezonken rood (1981) van Jeroen Brouwers en Salka (2004) van Chaja Polak. Daarbij zijn er veel prozawerken die zich afspelen tegen de achtergrond van de Tweede Wereldoorlog, zoals het al genoemde Salka (2004). In deze boeken staat dikwijls een Joods gezin centraal dat wordt verscheurd door de Jodenvervolging. Ze gaan over kinderen en ouders die apart moeten onderduiken of die worden vermoord in concentratiekampen.

Daarnaast speelt, vaak in relatie tot het thema oorlog, migratie naar Nederland of naar een ander land in een deel van de romans een rol. Botsingen en ontmoetingen met andere culturen en personages die met hun nationale identiteit(en) worstelen, worden in dit soort romans beschreven. Voorbeelden van zulke boeken zijn de literaire romans Zij, mijn moeder mijn land (2000) van Shakib Sana en De stem van mijn moeder (2009) van Abdelkader Benali.

Enkele andere, iets minder vaak voorkomende thema's zijn: armoede, mishandeling of verwaarlozing van een kind, ouders en kinderen die in de criminaliteit belanden, kinderen die aan de drugs raken, problemen van moeders en vaders met de combinatie van betaald werk en de zorg voor kinderen, ongewilde kinderloosheid, bewuste kinderloosheid, miskraam, abortus, spijt van de keuze voor een kind en een moeilijke zwangerschap, bevalling of kraamtijd. Naast deze thema's speelt de homoseksuele geaardheid van een ouder of kind in een aantal prozawerken een rol. Bij de uitwerking van dit onderwerp wordt in enkele boeken gewezen op het bestaan van negatieve vooroordelen waarmee homoseksuele ouders geconfron- 
teerd worden: zij zouden hun kinderen niet goed kunnen opvoeden, omdat ze homoseksueel zijn.

Tabel 2 geeft een beeld van het absolute en relatieve aandeel van de thema's die in de samenvattingen en recensies zijn geïdentificeerd. De onderwerpen zijn zoals gezegd op basis van die informatie achteraf bepaald. De thema's zijn naar omvang van hun aandeel in de tabel geordend, waarbij het meest voorkomende onderwerp bovenaan staat en het minst voorkomende onderaan. Ik wil daarbij nog een keer opmerken dat in één roman vaak meerdere thema's zijn gecombineerd. 
Tabel 2

Productie van fictioneel proza over ouderschap per thema (dataset 1)

\begin{tabular}{|c|c|c|}
\hline Thema & $\begin{array}{l}\text { Absolute } \\
\text { productie }\end{array}$ & $\begin{array}{c}\text { Aandeel van de } \\
\text { totale productie van } \\
\text { fictioneel proza over } \\
\text { ouderschap in } \\
\text { percentages }\end{array}$ \\
\hline 1. Afwezigheid van een vader & 149 & $27,1 \%$ \\
\hline 2. Dood en/of ziekte van een vader & 131 & $23,9 \%$ \\
\hline 3. Dood en/of ziekte van een moeder & 126 & $23,0 \%$ \\
\hline 4. Religie & 118 & $21,5 \%$ \\
\hline 5. Adoptie-, stief-, of pleegouderschap & 114 & $20,8 \%$ \\
\hline 6. Alleenstaande moeder & 85 & $15,5 \%$ \\
\hline 7. Buitenechtelijke zwangerschap en/of kind & 74 & $13,5 \%$ \\
\hline 8. Oorlog & 73 & $13,3 \%$ \\
\hline 9. Afwezigheid van een moeder & 71 & $12,9 \%$ \\
\hline 10. Migratie & 61 & $11,1 \%$ \\
\hline 11. Scheiding & 55 & $10,0 \%$ \\
\hline 12. Dood van een kind & 42 & $7,7 \%$ \\
\hline 13. Overspel & 41 & $7,5 \%$ \\
\hline 14. Ziek, gehandicapt en/of gewond kind & 37 & $6,7 \%$ \\
\hline 15. Alleenstaande vader & 33 & $6,0 \%$ \\
\hline 16. Verdwijning van een kind & 31 & $5,6 \%$ \\
\hline 17. Armoede & 27 & $4,9 \%$ \\
\hline $\begin{array}{l}\text { 18. Mishandeling van een kind door iemand anders dan een moeder } \\
\text { of vader }\end{array}$ & 18 & $3,3 \%$ \\
\hline 19. Mishandeling of verwaarlozing van een kind door een vader & 17 & $3,1 \%$ \\
\hline 20. Tienerzwangerschap & 14 & $2,6 \%$ \\
\hline 21. Mishandeling of verwaarlozing van een kind door een moeder & 14 & $2,6 \%$ \\
\hline 22. Ongewilde kinderloosheid & 12 & $2,2 \%$ \\
\hline 23. Crimineel kind & 12 & $2,2 \%$ \\
\hline 24. Een moeilijke zwangerschap, bevalling en/of kraamtijd & 10 & $1,8 \%$ \\
\hline 25. Homoseksualiteit & 9 & $1,6 \%$ \\
\hline 26. Problemen met de combinatie van werk en moederschap & 7 & $1,3 \%$ \\
\hline 27. Criminele vader & 6 & $1,1 \%$ \\
\hline 28. Spijt van de keuze voor een kind & 5 & $0,9 \%$ \\
\hline 29. Abortus & 3 & $0,5 \%$ \\
\hline 30. Bewuste kinderloosheid & 3 & $0,5 \%$ \\
\hline 31. Problemen met de combinatie van werk en vaderschap & 3 & $0,5 \%$ \\
\hline 32. Drugsverslaafd kind & 3 & $0,5 \%$ \\
\hline 33. Miskraam & 2 & $0,4 \%$ \\
\hline 34. Criminele moeder & 1 & $0,2 \%$ \\
\hline
\end{tabular}


Om een beeld te krijgen van de ontwikkeling door de tijd heen, zijn het absolute en relatieve aandeel van de productie van boeken met de twee meest voorkomende thema's uit Tabel 2 in Tabel 3 en Figuur 2 en 3 per jaar weergegeven.

Tabel 3

Absolute productie van fictioneel proza over ouderschap met de twee grootste thema's per jaar (dataset 1)

\begin{tabular}{|c|c|c|c|}
\hline Jaar & $\begin{array}{c}\text { Thema: } \\
\text { Afwezigheid van een vader }\end{array}$ & $\begin{array}{c}\text { Thema: } \\
\text { Dood en/of ziekte } \\
\text { van een vader }\end{array}$ & $\begin{array}{c}\text { Totale productie van } \\
\text { fictioneel proza over } \\
\text { ouderschap }\end{array}$ \\
\hline 1980 & 1 & 0 & 15 \\
\hline 1981 & 2 & 0 & 8 \\
\hline 1982 & 1 & 1 & 6 \\
\hline 1983 & 1 & 1 & 7 \\
\hline 1984 & 3 & 4 & 13 \\
\hline 1985 & 2 & 2 & 10 \\
\hline 1986 & 3 & 4 & 13 \\
\hline 1987 & 1 & 4 & 12 \\
\hline 1988 & 2 & 3 & 13 \\
\hline 1989 & 4 & 0 & 12 \\
\hline 1990 & 1 & 2 & 10 \\
\hline 1991 & 3 & 5 & 12 \\
\hline 1992 & 4 & 4 & 25 \\
\hline 1993 & 6 & 8 & 25 \\
\hline 1994 & 5 & 7 & 25 \\
\hline 1995 & 8 & 3 & 28 \\
\hline 1996 & 7 & 7 & 25 \\
\hline 1997 & 6 & 6 & 17 \\
\hline 1998 & 6 & 5 & 18 \\
\hline 1999 & 11 & 2 & 26 \\
\hline 2000 & 6 & 3 & 17 \\
\hline 2001 & 6 & 5 & 21 \\
\hline 2002 & 8 & 12 & 32 \\
\hline 2003 & 7 & 6 & 23 \\
\hline 2004 & 5 & 11 & 27 \\
\hline 2005 & 7 & 6 & 25 \\
\hline 2006 & 11 & 6 & 22 \\
\hline 2007 & 8 & 5 & 18 \\
\hline 2008 & 7 & 7 & 30 \\
\hline 2009 & 7 & 2 & 14 \\
\hline
\end{tabular}




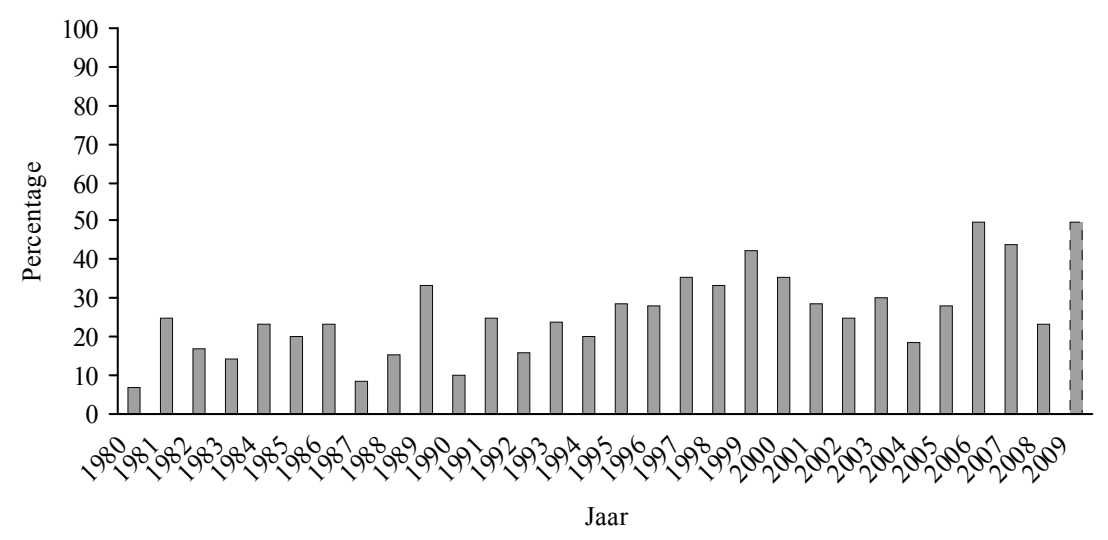

\section{Figuur 2}

Aandeel van fictioneel proza met de afwezigheid van een vader als thema van de totale productie van fictioneel proza over ouderschap in percentages per jaar (dataset 1)

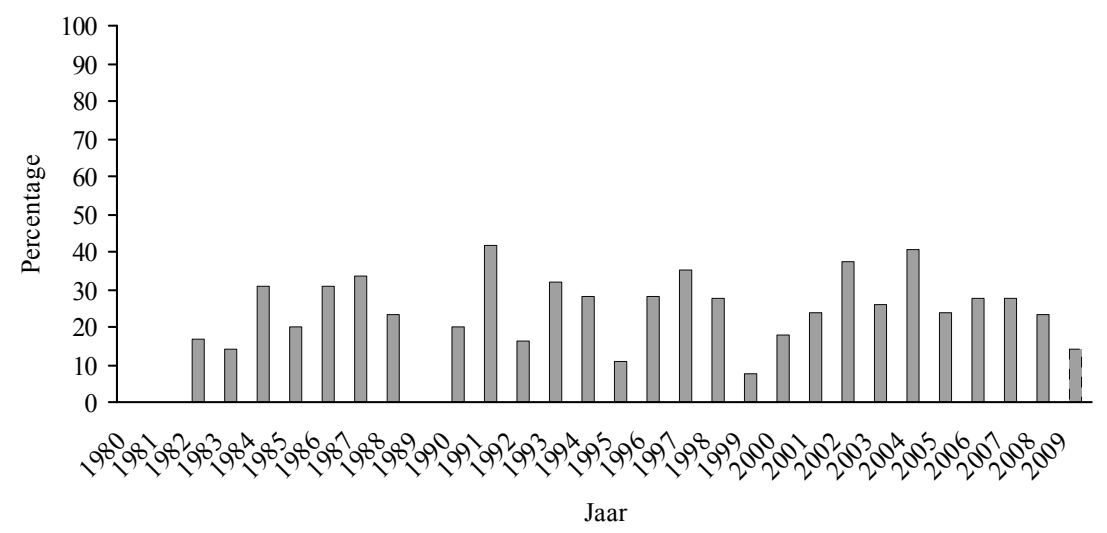

\section{Figuur 3}

Aandeel van fictioneel proza met de dood of ziekte van een vader als thema van de totale productie van fictioneel proza over ouderschap in percentages per jaar (dataset 1)

Op basis van Figuur 2 kan geconcludeerd worden dat de relatieve productie van werken met het eerste thema licht toeneemt vanaf medio jaren negentig. Figuur 3 toont dat dit bij het tweede thema niet het geval is.

Aan het eind van deze sectie een woord over de ontwikkeling van de totale productie van proza over ouderschap. Uit de derde kolom van Tabel 3 blijkt dat het totaal aantal prozawerken sinds 1992 een stuk groter is dan het aantal boeken dat in de periode daarvoor werd uitgegeven. Figuur 4 laat de absolute toename van het totaal aantal werken over ouderschap door de tijd heen goed zien. 


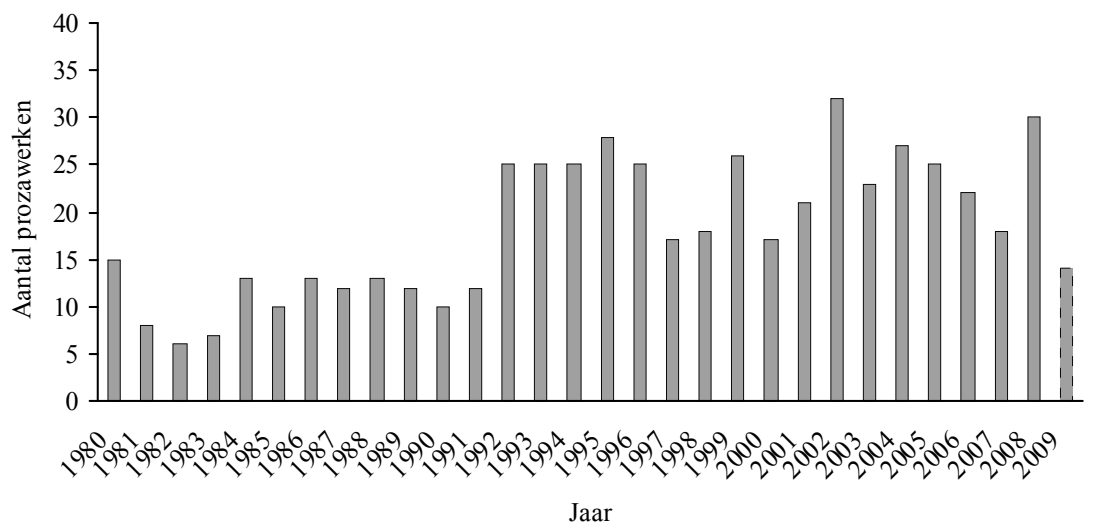

Figuur 4

Absolute productie van Nederlands, fictioneel proza over ouderschap per jaar (dataset 1)

In de periode tussen 1992 en 2009 is het gemiddeld aantal prozawerken 23,3. In de periode daarvoor is het gemiddeld aantal prozawerken 11,0. Het aantal romans, novellen en verhalenbundels varieert sterker in de periode 1992-2009 (SD =4,9) dan in de periode daarvoor $(S D=2,8)$. Dit lijkt voor een deel te wijten aan de plotselinge afname van de productie in 2009. Maar wanneer we het jaar 2009 buiten beschouwing laten, dan blijkt dit niet het geval. Het gemiddeld aantal werken voor de periode 1992-2008 blijkt dan namelijk 24 te zijn met een standaarddeviatie van 4,5. Dat wijst nog steeds op een grotere spreiding dan in de periode 1980-1991.

De daling in het jaar 2009 hangt overigens hoogstwaarschijnlijk samen met het moment waarop de data voor dit jaar werden verzameld. Dit is in januari 2010 gebeurd en het is goed mogelijk dat de in 2009 uitgegeven boeken op dat moment nog niet allemaal in de NCC waren opgenomen. Het beeld van de productie in 2009 is daardoor waarschijnlijk vertekend. Dit is visueel zichtbaar gemaakt door de cijfers in de tabellen voor het jaar 2009 in een lichtere kleur weer te geven en door de staaf in de grafieken van een stippellijn te voorzien.

\section{Resultaten dataset 2: moederschap}

Een analyse van de samenvattingen en recensies van de boeken over moederschap, levert slechts één werk op waarin er zich in het leven van moeders en kinderen of aanstaande moeders geen problemen voordoen. In het merendeel van de boeken is dit juist wel het geval. Figuur 5 geeft een goede indruk van de relatieve verdeling tussen prozawerken waarin de het leven van moeders wel of niet door problemen getekend is. 


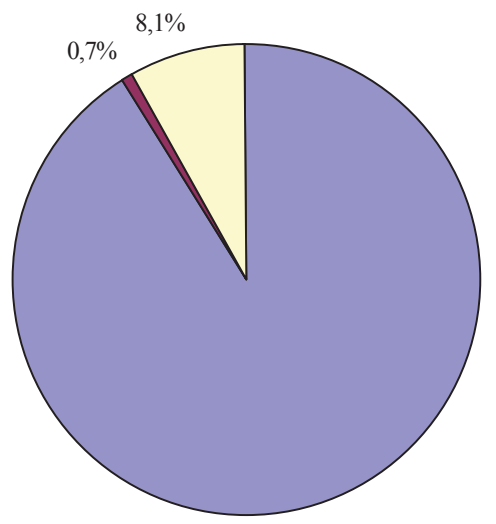

$91,2 \%$

$\square$ Wel geproblematiseerd $\square$ Niet geproblematiseerd $\square$ Onduidelijk

Figuur 5. Problematisering van moederschap in Nederlands, fictioneel proza over moederschap in percentages (dataset 2)

$n=148$

Aan de hand van de samenvattingen en recensies zijn er voor de tweede dataset eveneens een aantal thema's geïdentificeerd. Deze zijn weergegeven in Tabel 4. Ook hier moet worden opgemerkt dat een zelfde boek uit de dataset over meerdere van deze onderwerpen kan gaan. 
Tabel 4

Productie van fictioneel proza over moederschap per thema (dataset 2)

\begin{tabular}{|c|c|c|}
\hline Thema & $\begin{array}{l}\text { Absolute } \\
\text { productie }\end{array}$ & $\begin{array}{c}\text { Aandeel van de } \\
\text { totale productie van } \\
\text { fictioneel proza over } \\
\text { moederschap in } \\
\text { percentages }\end{array}$ \\
\hline 1. Dood en/of ziekte van een moeder & 59 & $39,9 \%$ \\
\hline 2. Afwezigheid van een vader & 44 & $29,7 \%$ \\
\hline 3. Religie & 31 & $20,9 \%$ \\
\hline 4. Alleenstaande moeder & 27 & $18,2 \%$ \\
\hline 5. Afwezigheid van een moeder & 26 & $17,6 \%$ \\
\hline 6. Adoptie-, stief-, of pleegouderschap & 25 & $16,9 \%$ \\
\hline 7. Oorlog & 25 & $16,9 \%$ \\
\hline 8. Buitenechtelijke zwangerschap en/of kind & 23 & $15,5 \%$ \\
\hline 9. Dood en/of ziekte van een vader & 22 & $14,9 \%$ \\
\hline 10. Migratie & 17 & $11,5 \%$ \\
\hline 11. Scheiding & 14 & $9,5 \%$ \\
\hline 12. Overspel & 8 & $5,4 \%$ \\
\hline 13. Tienerzwangerschap & 6 & $4,1 \%$ \\
\hline 14. Alleenstaande vader & 6 & $4,1 \%$ \\
\hline 15. Armoede & 6 & $4,1 \%$ \\
\hline 16. Crimineel kind & 6 & $4,1 \%$ \\
\hline $\begin{array}{l}\text { 17. Mishandeling van een kind door iemand anders dan een } \\
\text { moeder of vader }\end{array}$ & 6 & $4,1 \%$ \\
\hline 18. Dood van een kind & 5 & $3,4 \%$ \\
\hline 19. Mishandeling of verwaarlozing van een kind door een moeder & 5 & $3,4 \%$ \\
\hline 20. Ziek, gehandicapt, en/of gewond kind & 5 & $3,4 \%$ \\
\hline 21. Homoseksualiteit & 4 & $2,7 \%$ \\
\hline 22. Problemen met de combinatie van werk en moederschap & 4 & $2,7 \%$ \\
\hline 23. Verdwijning van een kind & 4 & $2,7 \%$ \\
\hline 24. Mishandeling of verwaarlozing van een kind door een vader & 3 & $2,0 \%$ \\
\hline 25. Abortus & 2 & $1,4 \%$ \\
\hline 26. Drugsverslaafd kind & 2 & $1,4 \%$ \\
\hline 27. Een moeilijke zwangerschap, bevalling en/of kraamtijd & 2 & $1,4 \%$ \\
\hline 28. Criminele moeder & 1 & $0,7 \%$ \\
\hline 29. Criminele vader & 1 & $0,7 \%$ \\
\hline 30. Ongewilde kinderloosheid & 1 & $0,7 \%$ \\
\hline 31. Problemen met de combinatie van werk en vaderschap & 1 & $0,7 \%$ \\
\hline 32. Spijt van de keuze voor een kind & 1 & $0,7 \%$ \\
\hline
\end{tabular}

Tabel 4 laat zien dat het meest voorkomende thema de dood en/of ziekte van een moeder is. Opmerkelijk genoeg handelen de boeken niet alleen over moederschap. Vaderschap komt ook aan bod, hoewel vaak indirect. Het tweede meest voorkomende onderwerp is bijvoorbeeld de afwezigheid van een vader. In Tabel 5 en Figuur 6 en 7 is te zien hoe de productie van boeken met deze twee meest voorkomende thema's zich ontwikkelen. 
Tabel 5

Absolute productie van fictioneel proza over moederschap met de twee grootste thema's per jaar (dataset 2)

\begin{tabular}{|c|c|c|c|}
\hline Jaar & $\begin{array}{c}\text { Thema 1: } \\
\text { Dood en/of ziekte van een } \\
\text { moeder }\end{array}$ & $\begin{array}{c}\text { Thema 2: } \\
\text { Afwezigheid van een } \\
\text { vader }\end{array}$ & $\begin{array}{c}\text { Totale productie van } \\
\text { fictioneel proza over } \\
\text { moederschap }\end{array}$ \\
\hline 1980 & 0 & 0 & 4 \\
\hline 1981 & 1 & 2 & 3 \\
\hline 1982 & 1 & 0 & 1 \\
\hline 1983 & 0 & 1 & 2 \\
\hline 1984 & 2 & 3 & 4 \\
\hline 1985 & 2 & 2 & 4 \\
\hline 1986 & 1 & 1 & 3 \\
\hline 1987 & 0 & 0 & 1 \\
\hline 1988 & 0 & 0 & 2 \\
\hline 1989 & 1 & 1 & 3 \\
\hline 1990 & 2 & 1 & 6 \\
\hline 1991 & 2 & 1 & 4 \\
\hline 1992 & 1 & 1 & 5 \\
\hline 1993 & 2 & 1 & 5 \\
\hline 1994 & 1 & 1 & 5 \\
\hline 1995 & 3 & 2 & 6 \\
\hline 1996 & 1 & 0 & 5 \\
\hline 1997 & 3 & 2 & 5 \\
\hline 1998 & 1 & 0 & 2 \\
\hline 1999 & 6 & 3 & 10 \\
\hline 2000 & 2 & 2 & 4 \\
\hline 2001 & 3 & 2 & 8 \\
\hline 2002 & 6 & 4 & 10 \\
\hline 2003 & 3 & 2 & 9 \\
\hline 2004 & 3 & 2 & 7 \\
\hline 2005 & 1 & 2 & 6 \\
\hline 2006 & 4 & 4 & 9 \\
\hline 2007 & 3 & 0 & 3 \\
\hline 2008 & 3 & 2 & 7 \\
\hline 2009 & 1 & 2 & 5 \\
\hline
\end{tabular}




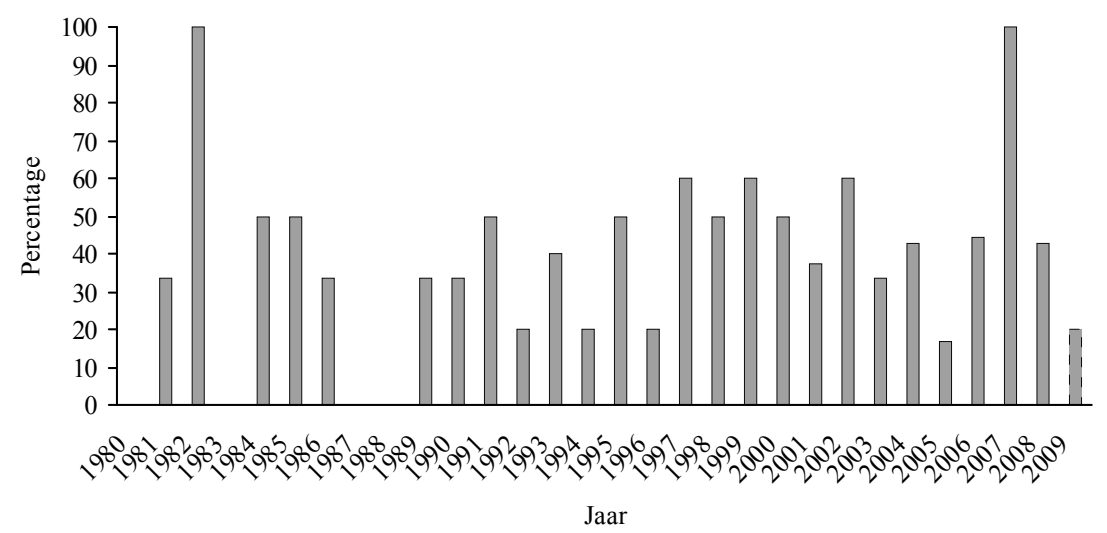

Figuur 6

Aandeel van fictioneel proza met de dood of ziekte van een moeder als thema van de totale productie van fictioneel proza over moederschap in percentages per jaar (dataset 2)

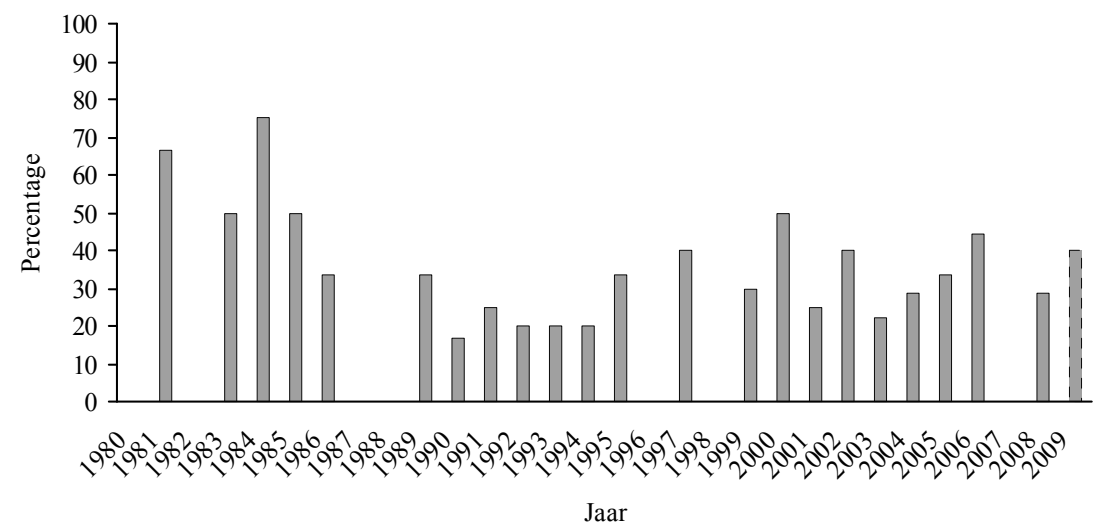

\section{Figuur 7}

Aandeel van fictioneel proza met de afwezigheid van een vader als thema van de totale productie van fictioneel proza over moederschap in percentages per jaar (dataset 2)

De aandacht voor beide thema's wisselt sterk gedurende de gehele periode, getuige Figuur 6 en 7.

Hier eveneens aandacht voor de ontwikkeling van de totale productie van fictioneel proza. Deze is weergegeven in Figuur 8. 


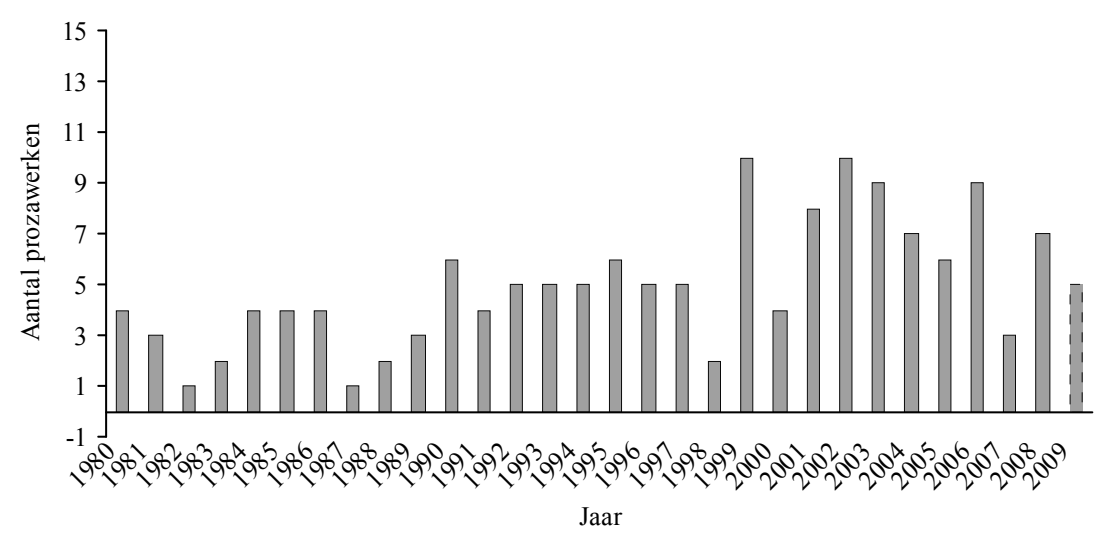

Figuur 8

Absolute productie van Nederlands, fictioneel proza over moederschap per jaar (dataset 2)

Het beeld dat hieruit naar voren komt is grillig. De productie neemt iets toe vanaf het begin van de jaren negentig, maar omdat het om kleine aantallen gaat kunnen we daaraan niet echt conclusies verbinden.

\section{Discussie resultaten dataset 1 en 2}

Bovenstaande analyse wijst er op dat ouderschap en moederschap in Nederlandse, fictionele roman, novellen en verhalenbundels vanaf 1980 tot en met 2009 doorgaans juist niet geïdealiseerd worden. Fictioneel proza lijkt inderdaad een discursief domein te zijn waarbinnen ouderschap en moederschap worden geproblematiseerd. Dat moederschap en ouderschap in relatie tot problemen worden verbeeld, hangt waarschijnlijk samen met het feit dat er in fictioneel proza in het algemeen een voorkeur voor problemen bestaat. Fictioneel proza is per definitie narratief. Uit verschillende onderzoeken blijkt dat strijd en problemen meestal belangrijke ingrediënten van narratieve teksten zijn (Porter Abbott, 2002). In het werk van literatuurwetenschapper Peter Brooks (1992) vinden we een plausibele verklaring voor de narratieve interesse in problemen. Volgens Brooks (1992) hebben narratieve teksten een bepaalde dynamiek nodig om lezers te kunnen boeien. Er moet een ontwikkeling plaats vinden, die lezers ernaar doet verlangen om verder te willen lezen (Brooks, 1992). Die dynamiek lijkt geluk te missen. Dat er zich problemen voordoen lijkt zodoende een belangrijke ongeschreven regel voor fictioneel proza te zijn. Problemen gelden als een essentieel ingrediënt voor een boeiende roman. Naar gelang het onderwerp dat centraal staat, kan de aard van deze problemen natuurlijk verschillen, net zoals wie er daarbij wordt belicht. Gelukkige vaders, moeders en kinderen zijn echter om de bovenstaande redenen wellicht minder interessant materiaal voor een fictionele roman waarin deze personages centraal staan. De observatie van de Russische schrijver Leo Tolstoy in zijn roman Anna Karenina dat 
"gelukkige families [op elkaar lijken], maar [dat] ongeluk door allen op eigen wijze [wordt] gedragen" (1960/1876, p. 7) om vervolgens de levenswandel van een ongelukkige familie uit de doeken te doen, is illustratief voor het bestaan van deze norm.

De resultaten van de analyse betekenen niet per definitie dat het hedendaagse, geïdealiseerde beeld van moederschap in het onderzochte proza ter discussie wordt gesteld. Problemen zijn in het geanalyseerde fictionele proza de regel, maar dat neemt niet weg dat sommige van deze romans met gelukkig ouderschap kunnen eindigen en zo de rooskleurige maatschappelijke norm toch in stand kunnen houden. Het feit dat een van de ouders in de boeken vaak afwezig of dood is en de relatief toch grote aandacht voor thema's als alleenstaande ouders en buitenechtelijke zwangerschappen, wijst er ook op dat het discours van genieten juist niet wordt doorbroken. Er staan hier namelijk vormen van moederschap centraal, die afwijken van het geïdealiseerde beeld van de moeder die deel uitmaakt van een heteroseksueel kerngezin. Dit geldt ook voor de vele boeken die over volwassen kinderen en hun ouders gaan. Vooral het moederschap van jonge kinderen wordt immers geïdealiseerd. Het moderne ideaalbeeld van moederschap lijkt in die gevallen intact te blijven. Op basis van de informatie in de NCC kunnen er echter geen definitieve uitspraken worden gedaan over de relatie van deze romans tot het vertoog van genieten over moederschap. De samenvattingen en recensies geven namelijk te weinig inzicht in de wijze waarop een thema wordt uitgewerkt in een roman. Kwalitatieve interpretaties van de romans zelf zijn daarvoor noodzakelijk.

Ook voor het aanwijzen van andere relaties tussen maatschappelijke ontwikkelingen in Nederland en de aandacht voor bepaalde thema's in fictioneel proza is er te weinig informatie. Het lijkt er op dat dergelijke verbanden bestaan. De aandacht voor onderwerpen als echtscheiding en alleenstaand ouderschap zou bijvoorbeeld kunnen samenhangen met de recente toename van het aantal echtscheidingen en eenoudergezinnen in Nederland (Centraal Bureau voor de Statistiek, 2009a). En ongewilde kinderloosheid wordt als fictief thema wellicht ontleend aan de dagelijkse praktijk waarin vrouwen en mannen het krijgen van kinderen steeds langer uitstellen (Centraal Bureau voor de Statistiek, 2009a). Zulk uitstelgedrag kan door verminderde vruchtbaarheid tot ongewilde kinderloosheid leiden. Dat de combinatie van werk en moederschap daarnaast vandaag de dag vaak in negatieve termen wordt verwoord ${ }^{75}$, zou ook kunnen doorwerken in de aandacht voor dit thema in het onderzochte corpus. Aan de andere kant lijkt het feit dat het aantal tienermoeders sinds het begin van de jaren zeventig in Nederland drastisch is afgenomen (Garssen, 2006), haaks te staan op de aandacht die het in fictioneel proza krijgt. De focus op christelijke religie in de romans, novellen en verhalenbundels strookt bovendien niet met de toenemende ontkerkelijking van Nederland. Daarbij moet wor-

\footnotetext{
${ }^{75}$ Zie hierover hoofdstuk 1 van dit boek.
} 
den opgemerkt dat de ontkerkelijking sinds de jaren negentig minder snel verloopt en dat veel Nederlanders, zelfs als ze onkerkelijk zijn, nog aan hun geloof hechten (Centraal Bureau voor de Statistiek, 2009b). Om meer gefundeerde uitspraken te kunnen doen over mogelijke verhoudingen tussen de aangesneden thema's en maatschappelijke ontwikkelingen, zouden de romans en novellen zelf aan nader kwalitatief onderzoek onderworpen moeten worden. ${ }^{76}$

Opvallend genoeg komt een bepaald onderwerp niet naar voren bij de analyse van de samenvattingen en recensies in de NCC en dat zijn ouders die hun kinderen vermoorden, oftewel infanticide. Infanticide is bij mijn weten sinds 1980 niet vaak het thema van Nederlandse romans geweest (Weusten, 2010a) en dat zou een verklaring zijn voor de afwezigheid van deze romans in de data. Het is het echter belangrijk om ze hier te noemen. Ten eerste, omdat recensenten en literatuurwetenschappers deze romans in verband brengen met geïdealiseerde beelden van moederschap. Ze beschouwen ze geregeld als een commentaar op deze beelden. ${ }^{77}$ Bovendien hebben deze romans vaak een grote reikwijdte. Ze worden veel gelezen, roepen bij lezers heftige emoties op en zijn onderwerp van literaire kritiek en debat. In het kader van dit onderzoek zijn ze dus uitermate interessant.

Tot slot nog een punt met betrekking tot de ontwikkeling van de totale productie. Op basis van de cijfers over de totale productie van proza over ouderschap en moederschap, zou de conclusie kunnen worden getrokken dat de relatieve aandacht voor ouderschap en moederschap binnen verhalende fictie in Nederland is toegenomen. Het is nog maar de vraag is of er daadwerkelijk sprake is van zo'n relatieve toename van aandacht. In de onderzochte periode is er in Nederland namelijk sprake van een algemene stijging van het aanbod van boeken, zowel van fictie als nonfictie (Van Rees, Janssen \& Verboord, 2006). Cijfers over de precieze ontwikkeling van het aanbod van alle fictionele prozawerken kunnen verder licht werpen op de vraag hoe de hier gepresenteerde resultaten kunnen worden geïnterpreteerd. Voor de hele periode zijn die niet voorhanden, maar voor de jaren tachtig geeft het werk van Janssen (1994) een indicatie. Zij laat zien dat de productie van fictioneel proza in de periode tussen 1978 en 1991 is toegenomen met 18\%. Janssen neemt ook poëzie en herdrukken mee in haar inventarisatie, maar zij laat duidelijk zien dat de stijging voornamelijk wordt veroorzaakt door de uitgave van nieuwe prozawerken (Janssen, 1994). Tegen de achtergrond van deze onderzoeken zijn de totaalaantallen in de derde kolom van Tabel 5 voor de periode 1980 - 1991 opvallend stabiel en

\footnotetext{
${ }^{76}$ Een kwantitatief onderzoek naar de ontwikkeling van thema's dat nog verder terugvoert, zou wellicht ook van toegevoegde waarde zijn. Op die manier kan onderzocht worden of de aandacht voor genoemde onderwerpen als echtscheiding en alleenstaand ouderschap tegen de achtergrond van bepaalde maatschappelijke ontwikkelingen al dan niet is toegenomen.

${ }^{77}$ Zie bijvoorbeeld Rosemarie Buikema en Elisabeth Wesseling (2000), Met onbekende bestemming. Persstemmen (geen datum) en Daniëlle Serdijn (2000).
} 
zouden we zelfs van een relatieve daling kunnen spreken van de aandacht voor ouderschap en moederschap.

\section{Sekse}

\section{Resultaten dataset 1: ouderschap}

Uit een analyse van de sekse van de auteurs van de werken uit de eerste dataset blijkt dat vrouwelijke auteurs aanzienlijk meer boeken over ouderschap publiceren dan mannen. Het aantal boeken van de hand van vrouwelijke auteurs is 329 tegenover 218 boeken van mannelijke auteurs. De resterende boeken zijn van een koppel auteurs dat uit een man en vrouw bestaat. De relatieve omvang van het verschillende aandeel van mannelijke en vrouwelijke auteurs is weergegeven in Figuur $9 .^{78}$

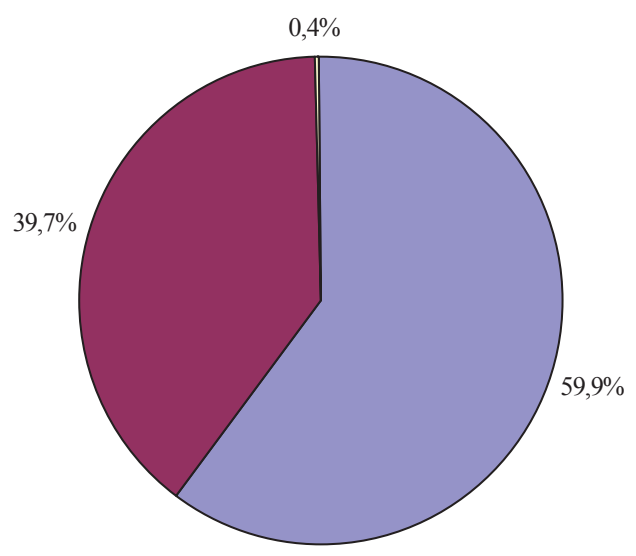

$\square$ Vrouw $\square$ Man $\square$ Man en vrouw

\section{Figuur 9}

Productie van fictioneel proza over ouderschap uitgesplitst naar sekse van de auteur in percentages (dataset 1)

$n=549$

\footnotetext{
${ }^{78}$ In een eerder artikel over dit onderwerp dacht ik op basis van een eerste analyse van de NCC nog dat het aantal vrouwelijke en mannelijke auteurs elkaar niet veel ontloopt (Weusten, 2009, 2010b). Het aantal zoektermen is bij deze eerste analyse echter veel beperkter geweest, dan bij de analyse zoals ik hem hier heb uitgevoerd. Dit geldt ook voor de onderzochte periode. Daarnaast heb ik voor deze eerste analyse de genreaanduidingen van de NCC zelf gebruikt en niet de NUR-codes. Op basis van de huidige analyse, die veel uitgebreider en verfijnder is, blijkt nu dat dit beeld moet worden bijgesteld.
} 
Tabel 6 en Figuur 10 laten zien dat de verdeling tussen mannelijke en vrouwelijke auteurs door de jaren heen weliswaar wisselt, maar dat vrouwelijke auteurs doorgaans de overhand hebben. Slechts in vier van de onderzochte dertig jaar zijn er meer prozawerken van mannelijke auteurs, respectievelijk in 1986, 1988, 1992 en 1998. In 1991 en 2008 is de bijdrage van mannelijke en vrouwelijke auteurs gelijk.

\section{Tabel 6}

Absolute productie van fictioneel proza over ouderschap uitgesplitst naar sekse van de auteur per jaar (dataset 1)

\begin{tabular}{|c|c|c|c|}
\hline \multirow[b]{2}{*}{ Jaar } & \multicolumn{3}{|c|}{ Sekse } \\
\hline & Man & Vrouw & Man en Vrouw \\
\hline 1980 & 4 & 11 & 0 \\
\hline 1981 & 3 & 5 & 0 \\
\hline 1982 & 2 & 4 & 0 \\
\hline 1983 & 3 & 4 & 0 \\
\hline 1984 & 5 & 8 & 0 \\
\hline 1985 & 4 & 5 & 1 \\
\hline 1986 & 7 & 6 & 0 \\
\hline 1987 & 4 & 8 & 0 \\
\hline 1988 & 7 & 6 & 0 \\
\hline 1989 & 5 & 7 & 0 \\
\hline 1990 & 3 & 7 & 0 \\
\hline 1991 & 6 & 6 & 0 \\
\hline 1992 & 13 & 12 & 0 \\
\hline 1993 & 12 & 13 & 0 \\
\hline 1994 & 9 & 16 & 0 \\
\hline 1995 & 8 & 20 & 0 \\
\hline 1996 & 11 & 14 & 0 \\
\hline 1997 & 8 & 9 & 0 \\
\hline 1998 & 10 & 8 & 0 \\
\hline 1999 & 9 & 17 & 0 \\
\hline 2000 & 5 & 12 & 0 \\
\hline 2001 & 9 & 12 & 0 \\
\hline 2002 & 15 & 17 & 0 \\
\hline 2003 & 8 & 15 & 0 \\
\hline 2004 & 8 & 19 & 0 \\
\hline 2005 & 6 & 19 & 0 \\
\hline 2006 & 7 & 15 & 0 \\
\hline 2007 & 6 & 11 & 1 \\
\hline 2008 & 15 & 15 & 0 \\
\hline 2009 & 6 & 8 & 0 \\
\hline
\end{tabular}

$n=549$. 


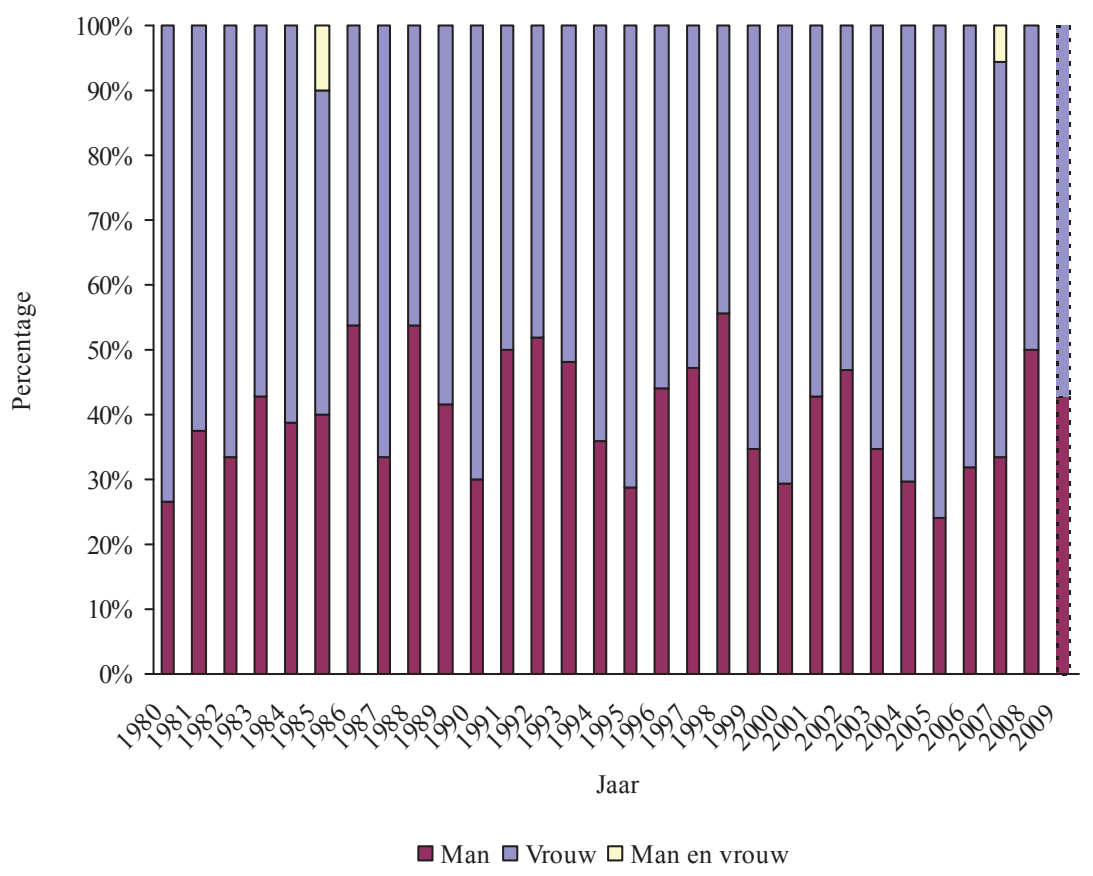

Figuur 10

Productie van fictioneel proza over ouderschap uitgesplitst naar sekse van de auteur in percentages per jaar (dataset 1)

\section{Resultaten dataset 2: moederschap}

Bij de auteurs van de werken uit de tweede dataset springt het verschil tussen de productie van mannelijke en vrouwelijke auteurs nog sterker in het oog. Van het totaal aantal van 148 boeken zijn er 101 van vrouwelijke auteurs tegenover 47 van mannelijke auteurs. Het aantal boeken van vrouwelijke auteurs is in deze dataset meer dan het dubbele van het aantal van mannelijke auteurs. Figuur 11 geeft de relatieve verdeling tussen mannelijke en vrouwelijke auteurs weer. 


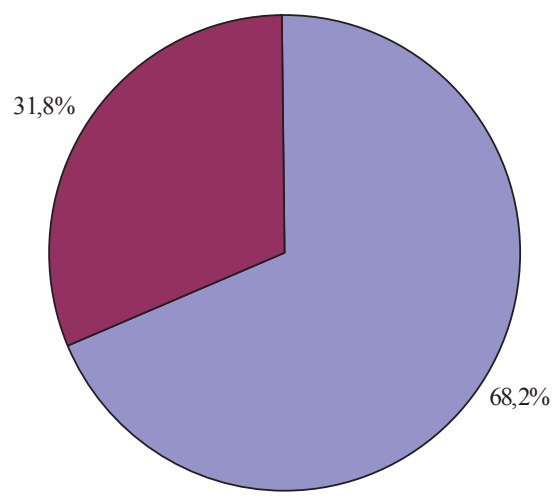

$\square$ Vrouw $\square$ Man

\section{Figuur 11}

Productie van fictioneel proza over moederschap uitgesplitst naar sekse van de auteur in percentages (dataset 2)

$n=148$

Uit Tabel 7 en Figuur 12 blijkt dat de productie van vrouwelijke auteurs in het merendeel van de dertig jaar groter is dan die van mannelijke auteurs. Slechts in vijf jaren is het aantal boeken van mannelijke auteurs in de meerderheid: in 1981, 1982, 1986, 1989 en 1992. In drie jaren, 1991, 1995, en 2001, is de afzet van boeken door mannelijke en vrouwelijke auteurs gelijk. 


\section{Tabel 7}

Absolute productie van fictioneel proza over moederschap uitgesplitst naar sekse van de auteur per jaar (dataset 2)

\begin{tabular}{|c|c|c|}
\hline \multirow[b]{2}{*}{ Jaar } & \multicolumn{2}{|c|}{ Sekse } \\
\hline & Man & Vrouw \\
\hline 1980 & 0 & 4 \\
\hline 1981 & 2 & 1 \\
\hline 1982 & 1 & 0 \\
\hline 1983 & 0 & 2 \\
\hline 1984 & 1 & 3 \\
\hline 1985 & 1 & 3 \\
\hline 1986 & 2 & 1 \\
\hline 1987 & 0 & 1 \\
\hline 1988 & 0 & 2 \\
\hline 1989 & 2 & 1 \\
\hline 1990 & 2 & 4 \\
\hline 1991 & 2 & 2 \\
\hline 1992 & 4 & 1 \\
\hline 1993 & 2 & 3 \\
\hline 1994 & 0 & 5 \\
\hline 1995 & 3 & 3 \\
\hline 1996 & 2 & 3 \\
\hline 1997 & 2 & 3 \\
\hline 1998 & 0 & 2 \\
\hline 1999 & 4 & 6 \\
\hline 2000 & 1 & 3 \\
\hline 2001 & 4 & 4 \\
\hline 2002 & 3 & 7 \\
\hline 2003 & 2 & 7 \\
\hline 2004 & 0 & 7 \\
\hline 2005 & 2 & 4 \\
\hline 2006 & 3 & 6 \\
\hline 2007 & 1 & 2 \\
\hline 2008 & 0 & 7 \\
\hline 2009 & 1 & 4 \\
\hline
\end{tabular}

$n=148$ 


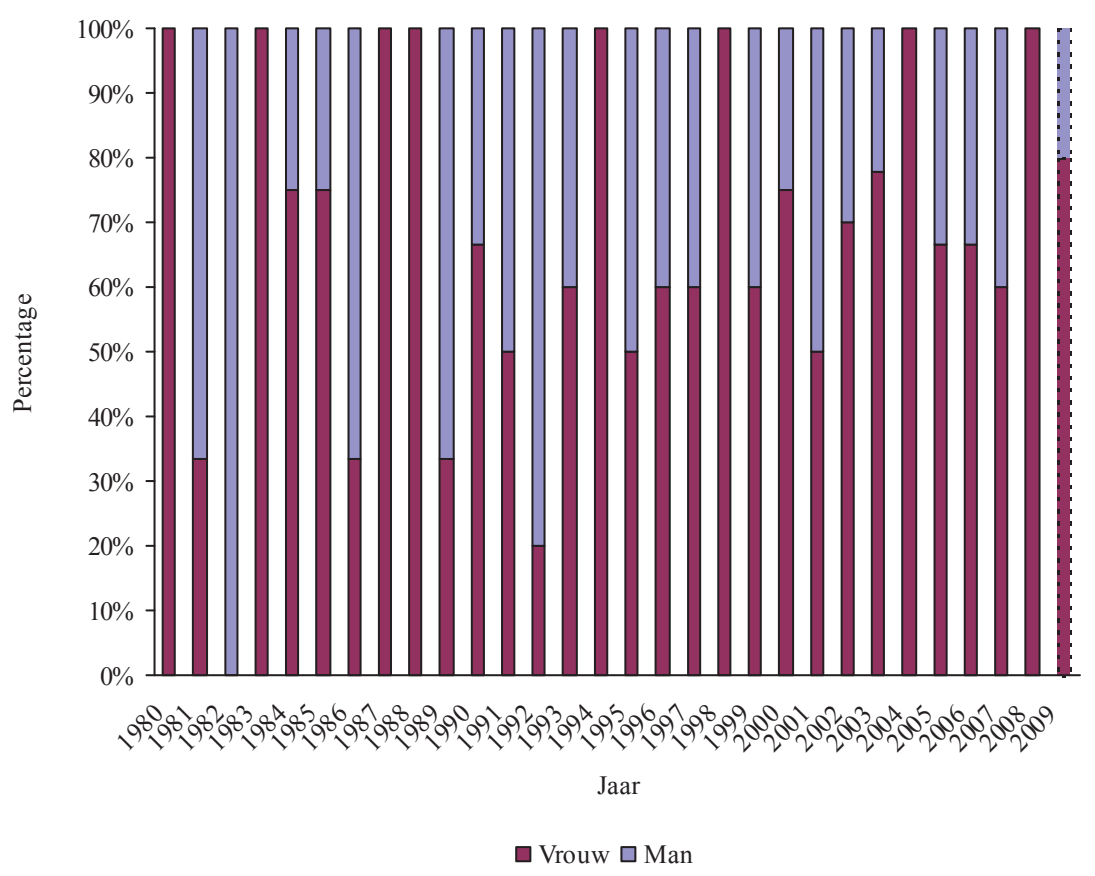

Figuur 12

Productie van fictioneel proza over moederschap uitgesplitst naar sekse van de auteur in percentages per jaar (dataset 2)

Discussie resultaten dataset 1 en 2

Met betrekking tot beide datasets kan er worden geconcludeerd dat er meer boeken over ouderschap en moederschap van vrouwelijke auteurs dan van mannelijke auteurs verschijnen. Het aandeel van de vrouwelijke auteurs is des te opmerkelijker, omdat mannen doorgaans een groter deel van de productie van fictioneel proza voor hun rekening nemen dan vrouwen. In 1987 was het percentage fictionele prozawerken van vrouwen bijvoorbeeld maar 27,0\% en in 1995 was dat met 29,0\% niet veel groter (Van Rees, Janssen \& Verboord, 2006). De door literatuursociologe Lenny Vos (2008) in kaart gebrachte ontwikkeling van de verdeling tussen mannelijke en vrouwelijke auteurs die bij Nederlandse uitgeverijen proza en poëzie publiceren met NUR-codes die naar een literair genre verwijzen, wijst ook in die richting. Hoewel daarbij de kanttekening moet worden geplaatst dat Vos (2008) ook nietfictionele romans en Vlaamse auteurs meeneemt in haar onderzoek. In 1947 vertegenwoordigen vrouwelijke auteurs $24,0 \%$ van het totaal aantal schrijvers, de rest van de auteurs zijn mannen. In 1987 is die situatie nagenoeg gelijk. Het percentage vrouwen is dan $27,0 \%$ en het percentage mannen $73,0 \%$. In 1997 blijkt het percen- 
tage vrouwelijke auteurs iets te zijn toegenomen. Ze vertegenwoordigen dan $35,0 \% .{ }^{79}$ Cijfers voor de periode na 1997 zijn bij mijn weten nog niet voor handen, maar de beschikbare gegevens wijzen er in iedere geval op dat vrouwen opvallend goed vertegenwoordigd zijn in de hier geanalyseerde dataset.

Hierbij moet wel de kanttekening worden geplaatst dat de bibliotheekmedewerkers die de samenvattingen en recensies schrijven, wellicht niet altijd oog hebben voor de aanwezigheid van deze thema's in het werk van mannen, terwijl ze die gevoeligheid wel aan de dag leggen bij het werk van vrouwelijke auteurs. Dat dit niet ondenkbaar is, blijkt uit het onderzoek van literatuurwetenschapster Erica van Boven (1992) naar literatuurkritiek in de periode van 1898 tot en met 1930. Zij toont aan dat mannen in deze periode net als vrouwen over het gezinsleven hebben geschreven, maar dat recensenten hier al dan niet bewust aan voorbij zijn gegaan.

\section{Genre}

\section{Resultaten dataset 1: ouderschap}

Met behulp van de NUR-codes is er een analyse gemaakt van het aandeel van de verschillende genres in de datasets. Tabel 8 geeft hier een overzicht van voor de eerste dataset, uitgesplitst naar de sekse van de auteurs. Wanneer aan een boek meerdere codes zijn toegekend, dan is dat boek onder een aparte 'combinatie'categorie geschaard.

\footnotetext{
${ }^{79}$ Voor Vlaanderen is de verhouding mannelijke en vrouwelijke auteurs voor de periode 1980-2001 apart in kaart gebracht (Lievens, 2007; Lievens, Demoor \& Saeys, 2004). Over de gehele periode genomen is het aantal mannelijke auteurs ook hier groter dan het aantal vrouwelijke auteurs. Respectievelijk $74,0 \%$ procent van de auteurs is man en $26,0 \%$ is vrouw (Lievens, 2007 ).
} 
Tabel 8

Productie van fictioneel proza over ouderschap per NUR-genre uitgesplitst naar sekse van de auteur (dataset 1)

\begin{tabular}{|c|c|c|c|c|c|}
\hline \multirow[b]{2}{*}{ NUR-genre } & \multicolumn{3}{|c|}{ Sekse } & \multirow[b]{2}{*}{$\begin{array}{c}\text { Totale } \\
\text { absolute } \\
\text { productie } \\
\text { per genre }\end{array}$} & \multirow[b]{2}{*}{$\begin{array}{c}\text { Aandeel van de totale } \\
\text { productie van fictioneel } \\
\text { proza over ouderschap in } \\
\text { percentages }\end{array}$} \\
\hline & Man & Vrouw & $\begin{array}{l}\text { Man en } \\
\text { Vrouw }\end{array}$ & & \\
\hline -literaire fictie algemeen & 4 & 5 & 0 & 9 & $1,6 \%$ \\
\hline -literaire roman, novelle & 153 & 132 & 1 & 286 & $52,1 \%$ \\
\hline -verhalenbundels & 2 & 4 & 0 & 6 & $1,1 \%$ \\
\hline -pockets algemeen & 1 & 0 & 0 & 1 & $0,2 \%$ \\
\hline -pockets literaire fictie & 1 & 0 & 0 & 1 & $0,2 \%$ \\
\hline -pockets spanning & 1 & 0 & 0 & 1 & $0,2 \%$ \\
\hline -spannende boeken algemeen & 4 & 2 & 0 & 6 & $1,1 \%$ \\
\hline -detective & 1 & 1 & 0 & 2 & $0,4 \%$ \\
\hline -thriller & 1 & 1 & 0 & 2 & $0,4 \%$ \\
\hline -fantasy & 3 & 0 & 0 & 3 & $0,5 \%$ \\
\hline $\begin{array}{l}\text {-griezel- en spookverhalen, } \\
\text { horror }\end{array}$ & 1 & 1 & 0 & 2 & $0,4 \%$ \\
\hline -populaire fictie algemeen & 0 & 5 & 0 & 5 & $0,9 \%$ \\
\hline -historische roman (populair) & 1 & 3 & 0 & 4 & $0,7 \%$ \\
\hline -romantiek & 0 & 22 & 0 & 22 & $4,0 \%$ \\
\hline -streek- en familieromans & 30 & 116 & 0 & 146 & $26,6 \%$ \\
\hline -fictie overig algemeen & 1 & 1 & 1 & 3 & $0,5 \%$ \\
\hline $\begin{array}{l}\text {-literaire fictie algemeen } \& \\
\text { literaire roman, novelle }\end{array}$ & 0 & 2 & 0 & 2 & $0,4 \%$ \\
\hline $\begin{array}{l}\text {-literaire roman, novelle \& } \\
\text { verhalenbundels }\end{array}$ & 1 & 0 & 0 & 1 & $0,2 \%$ \\
\hline $\begin{array}{l}\text {-literaire roman, novelle \& } \\
\text { verhalenbundels \& pockets } \\
\text { literaire fictie }\end{array}$ & 0 & 1 & 0 & 1 & $0,2 \%$ \\
\hline $\begin{array}{l}\text {-literaire roman, novelle \& } \\
\text { pockets literaire fictie }\end{array}$ & 9 & 5 & 0 & 14 & $2,6 \%$ \\
\hline $\begin{array}{l}\text {-literaire roman, novelle \& } \\
\text { streek- en familieromans }\end{array}$ & 0 & 1 & 0 & 1 & $0,2 \%$ \\
\hline $\begin{array}{l}\text {-verhalenbundels \& pockets } \\
\text { literaire fictie }\end{array}$ & 1 & 0 & 0 & 1 & $0,2 \%$ \\
\hline $\begin{array}{l}\text {-verhalenbundels \& streek- en } \\
\text { familieromans }\end{array}$ & 0 & 1 & 0 & 1 & $0,2 \%$ \\
\hline $\begin{array}{l}\text {-pockets spanning \& spannende } \\
\text { boeken algemeen }\end{array}$ & 1 & 0 & 0 & 1 & $0,2 \%$ \\
\hline $\begin{array}{l}\text {-populaire fictie algemeen \& } \\
\text { streek- en familieromans }\end{array}$ & 0 & 4 & 0 & 4 & $0,7 \%$ \\
\hline $\begin{array}{l}\text {-historische roman (populair) \& } \\
\text { streek- en familieromans }\end{array}$ & 0 & 1 & 0 & 1 & $0,2 \%$ \\
\hline $\begin{array}{l}\text {-romantiek \& streek- en } \\
\text { familieromans }\end{array}$ & 2 & 21 & 0 & 23 & $4,2 \%$ \\
\hline
\end{tabular}

$n=549$. 
Uit Tabel 8 blijkt dat de 'literaire roman, novelle' koploper is met 52,1\% van het totaal aantal prozawerken over ouderschap. Daarbij zijn de combinaties waarin dit genre voorkomt, om de categorie zo zuiver mogelijk te houden, buiten beschouwing gelaten. Zelfs dan is de 'literaire roman, novelle' met afstand het grootste literaire genre. De analyse van de relatieve positie van literaire fictie in dit hoofdstuk beperkt zich verder tot dit genre, omdat het aantal boeken in de andere literaire genres te klein is om er conclusies aan te verbinden. Er wordt ter vergelijking ook naar het grootste niet-literaire genre gekeken: de 'streek- en familieromans'. De andere nietliteraire genres zijn qua omvang zo klein, dat ze buiten beschouwing worden gelaten. De 'streek- en familieromans' zijn goed voor $26,6 \%$ van de totale productie. Wederom zijn de combinaties waarin dit genre voorkomt, daarbij niet meegerekend.

Aan de hand van Tabel 8 kunnen we concluderen dat mannen in het enkelvoudige genre 'literaire roman, novelle' iets sterker vertegenwoordigd zijn dan vrouwen $(53,5 \%$ versus $46,2 \%)$. Bij de 'streek- en familieromans' nemen vrouwelijke auteurs $79,5 \%$ van de productie voor hun rekening, tegenover een productie van $20,5 \%$ van mannelijke auteurs. Van de twee genres is er alleen bij de 'literaire roman, novelle' sprake van een auteurskoppel dat uit een man en vrouw bestaat. Dit koppel vertegenwoordigt slechts $0,3 \%$ van de productie in dit genre.

In Tabel 9 zijn de absolute en relatieve productie van de enkelvoudige genres 'literaire roman, novelle' en 'streek- en familieromans' per jaar uitgesplitst, om zo een beeld te krijgen van de ontwikkeling van de productie van deze genres. In Figuur 13 en 14 is de absolute productie van beide genres in de tijd visueel zichtbaar gemaakt. 
Tabel 9

Productie van fictioneel proza over ouderschap per NUR-genre per jaar (dataset1)

\begin{tabular}{|c|c|c|c|c|c|}
\hline Jaar & $\begin{array}{l}\text { Absolute } \\
\text { productie } \\
\text { van de } \\
\text { 'literaire } \\
\text { roman, } \\
\text { novelle' } \\
\text { over ouder- } \\
\text { schap }\end{array}$ & $\begin{array}{l}\text { Aandeel van de } \\
\text { productie van } \\
\text { de 'literaire } \\
\text { roman, novelle' } \\
\text { van de totale } \\
\text { productie van } \\
\text { fictioneel proza } \\
\text { over ouder- } \\
\text { schap in percen- } \\
\text { tages }\end{array}$ & $\begin{array}{c}\text { Absolute } \\
\text { productie van } \\
\text { de 'streek- en } \\
\text { familiero- } \\
\text { mans' over } \\
\text { ouderschap }\end{array}$ & $\begin{array}{l}\text { Aandeel van de } \\
\text { productie van } \\
\text { 'streek- en familie- } \\
\text { romans' van de } \\
\text { totale productie } \\
\text { van fictioneel } \\
\text { proza over ouder- } \\
\text { schap in percenta- } \\
\text { ges }\end{array}$ & $\begin{array}{l}\text { Absolute, totale } \\
\text { productie van } \\
\text { fictioneel proza } \\
\text { over ouder- } \\
\text { schap }\end{array}$ \\
\hline 1980 & 4 & $26,7 \%$ & 8 & $53,3 \%$ & 15 \\
\hline 1981 & 4 & $50,0 \%$ & 2 & $25,0 \%$ & 8 \\
\hline 1982 & 2 & $33,3 \%$ & 0 & $0,0 \%$ & 6 \\
\hline 1983 & 3 & $42,9 \%$ & 1 & $14,3 \%$ & 7 \\
\hline 1984 & 7 & $53,8 \%$ & 3 & $23,1 \%$ & 13 \\
\hline 1985 & 5 & $50,0 \%$ & 2 & $20,0 \%$ & 10 \\
\hline 1986 & 8 & $61,5 \%$ & 2 & $15,4 \%$ & 13 \\
\hline 1987 & 6 & $50,0 \%$ & 3 & $25,0 \%$ & 12 \\
\hline 1988 & 10 & $76,9 \%$ & 2 & $15,4 \%$ & 13 \\
\hline 1989 & 7 & $58,3 \%$ & 2 & $16,7 \%$ & 12 \\
\hline 1990 & 7 & $70,0 \%$ & 1 & $10,0 \%$ & 10 \\
\hline 1991 & 6 & $50,0 \%$ & 3 & $25,0 \%$ & 12 \\
\hline 1992 & 9 & $36,0 \%$ & 13 & $52,0 \%$ & 25 \\
\hline 1993 & 16 & $64,0 \%$ & 7 & $28,0 \%$ & 25 \\
\hline 1994 & 15 & $60,0 \%$ & 7 & $28,0 \%$ & 25 \\
\hline 1995 & 18 & $64,3 \%$ & 7 & $25,0 \%$ & 28 \\
\hline 1996 & 13 & $52,0 \%$ & 6 & $24,0 \%$ & 25 \\
\hline 1997 & 8 & $47,1 \%$ & 8 & $47,1 \%$ & 17 \\
\hline 1998 & 6 & $33,3 \%$ & 8 & $44,4 \%$ & 18 \\
\hline 1999 & 13 & $50,0 \%$ & 8 & $30,8 \%$ & 26 \\
\hline 2000 & 8 & $47,1 \%$ & 7 & $41,2 \%$ & 17 \\
\hline 2001 & 14 & $66,7 \%$ & 3 & $14,3 \%$ & 21 \\
\hline 2002 & 18 & $56,3 \%$ & 8 & $25,0 \%$ & 32 \\
\hline 2003 & 11 & $47,8 \%$ & 8 & $34,8 \%$ & 23 \\
\hline 2004 & 13 & $48,1 \%$ & 8 & $29,6 \%$ & 27 \\
\hline 2005 & 10 & $40,0 \%$ & 7 & $28,0 \%$ & 25 \\
\hline 2006 & 11 & $50,0 \%$ & 4 & $18,2 \%$ & 22 \\
\hline 2007 & 9 & $50,0 \%$ & 2 & $11,1 \%$ & 18 \\
\hline 2008 & 15 & $50,0 \%$ & 5 & $16,7 \%$ & 30 \\
\hline 2009 & 10 & $71,4 \%$ & 1 & $7,1 \%$ & 14 \\
\hline
\end{tabular}




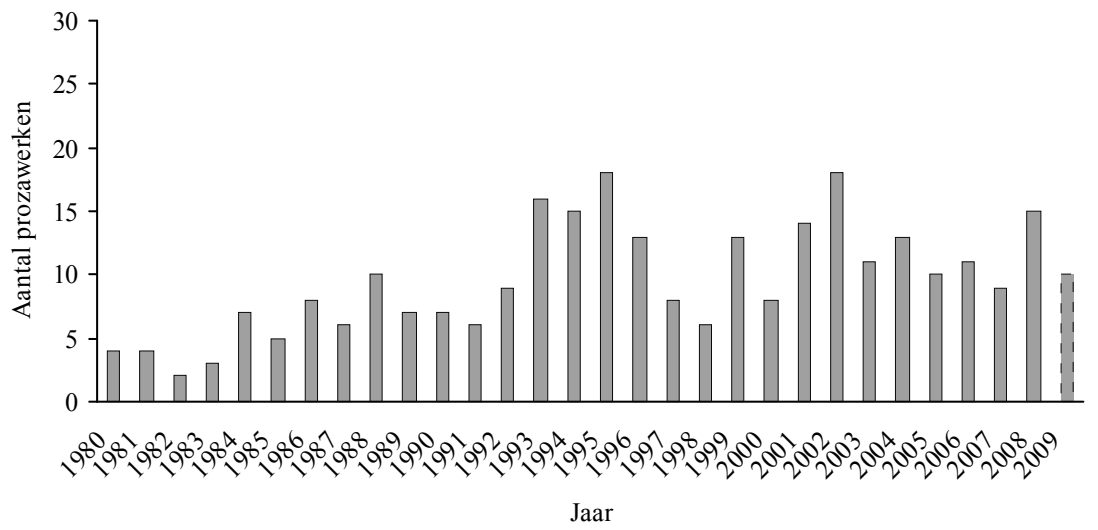

Figuur 13

Productie van de 'literaire roman, novelle' over ouderschap (dataset 1)

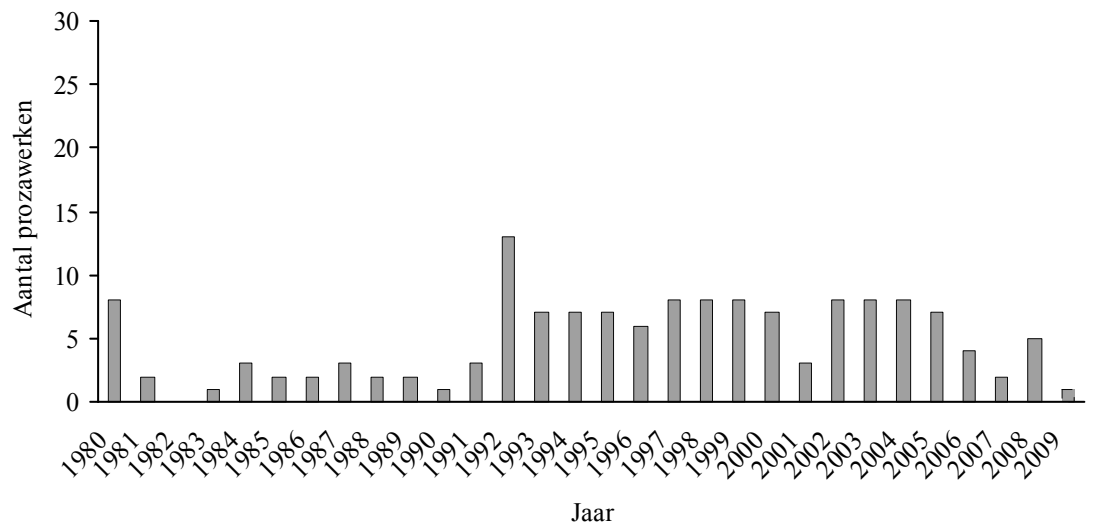

Figuur 14

Productie van 'streek- en familieromans' over ouderschap (dataset 1)

Uit Tabel 9 blijkt dat de productie van de 'literaire roman, novelle' absoluut gezien toeneemt na 1992; met uitzondering van een dip in 1997 en 1998. Ook bij de 'streek- en familieromans' kunnen we in ieder geval tot 2005 een stijging waarnemen in de productie. Dat de productie in beide gevallen stijgt, betekent niet dat de relatieve aandacht voor ouderschap in deze genres is toegenomen. Eerder genoemde cijfers wijzen er op dat er sprake is van een stijgende productie van proza in het algemeen in de afgelopen decennia en dit zal ook de hier waargenomen ontwikkelingen waarschijnlijk hebben veroorzaakt. Daarnaast kan de toenemende productie van de 'literaire roman, novelle' waarschijnlijk worden geweten aan het feit dat uitgeverijen in de loop der tijd steeds losser met dit genre zijn gaan omspringen. 
Vandaag de dag kennen zij de code 301 relatief vaker toe dan bijvoorbeeld twintig jaar geleden (Van Rees, Janssen \& Verboord, 2006).

Hoe zit het nu met de verbeelding van ouderschap in beide genres? Wordt ouderschap vaker in negatieve termen verbeeld in de 'literaire roman, novelle' dan in de 'streek- en familieromans' of omgekeerd? En komen er in beide genres andere of toch vooral dezelfde thema's aan bod? En hoe verhouden deze twee genres zich in dit opzicht tot het besproken beeld van fictioneel proza over ouderschap in het algemeen?

Wanneer we naar de werken kijken die onder de 'literaire roman, novelle' vallen, dan blijkt het ouderschap in $89,1 \%$ van die boeken allesbehalve rooskleurig te zijn. In 1,0\% van deze romans wordt ouderschap geïdealiseerd. Over de overige $9,9 \%$ valt op basis van de beschrijvingen niets te zeggen. Deze cijfers verschillen nauwelijks van de algemene cijfers over de problematisering van ouderschap in fictioneel proza. In de 'streek- en familieromans' is dit niet veel anders. In het gros van deze romans ligt de nadruk op negatieve aspecten en ervaringen van het ouderschap (92,5\%). Over de resterende werken uit dit genre vallen geen duidelijke conclusies te trekken (7,5\%). De beschrijvingen van de 'streek- en familieromans' wijzen er echter wel op dat deze romans, vaker dan boeken uit het genre 'literaire roman, novelle', een happy end hebben. Ouders en het gezin hebben aan het einde de problemen overwonnen en zijn (weer) gelukkig. Dit zou kunnen betekenen dat de 'streek- en familieromans' de rooskleurige norm uiteindelijk minder snel ter discussie stellen dan de 'literaire roman, novelle'. Op basis van de beperkte informatie over de inhoud van de boeken die in de NCC beschikbaar is, kunnen we hier echter geen definitieve uitspraken over doen.

Het aandeel van de verschillende thema's die in beide genres aan bod komen, is in Tabel 10 en 11 weergegeven. 
Tabel 10

Aandeel van verschillende thema's in het genre 'literaire roman, novelle' (dataset 1)

Thema

Absolute Aandeel van de totale

productie productie van de 'lite-

raire roman, novelle'

over ouderschap in

percentages

1. Dood en/of ziekte van een moeder

$24,5 \%$

2. Afwezigheid van een vader

$24,1 \%$

3. Dood en/of ziekte van een vader

$23,1 \%$

4. Oorlog

$16,8 \%$

5. Migratie

$16,1 \%$

6. Religie

$15,4 \%$

7. Alleenstaande moeder

$11,9 \%$

8. Afwezigheid van een moeder

$11,5 \%$

9. Adoptie-, stief-, of pleegouderschap

$9,4 \%$

10. Scheiding

$8,7 \%$

11. Overspel

$5,9 \%$

12. Dood van een kind

$5,6 \%$

13. Ziek, gehandicapt en/of gewond kind

$5,6 \%$

14. Buitenechtelijke zwangerschap en/of kind

$5,2 \%$

15. Alleenstaande vader

$4,5 \%$

16. Armoede

$3,1 \%$

17. Mishandeling van een kind door iemand anders dan een moeder

$3,1 \%$

of vader

18. Verdwijning van een kind

$2,8 \%$

19. Mishandeling of verwaarlozing van een kind door een vader

20. Crimineel kind

$2,8 \%$

21. Homoseksualiteit

$2,8 \%$

22. Mishandeling of verwaarlozing van een kind door een moeder

23. Een moeilijke zwangerschap, bevalling en/of kraamtijd

$1,7 \%$

24. Ongewilde kinderloosheid

$1,4 \%$

25. Tienerzwangerschap

26. Problemen met de combinatie van werk en moederschap

$1,0 \%$

27. Bewuste kinderloosheid

$1,0 \%$

$1,0 \%$

28. Drugsverslaafd kind

$1,0 \%$

19. Abortus

$0,3 \%$

30. Spijt van de keuze voor een kind

$0,3 \%$

31. Criminele vader

$0,3 \%$ 
Tabel 11

Aandeel van verschillende thema's in het genre 'streek- en familieromans' (dataset 1)

\begin{tabular}{|c|c|c|}
\hline Thema & $\begin{array}{l}\text { Absolute } \\
\text { productie }\end{array}$ & $\begin{array}{l}\text { Aandeel van de totale pro- } \\
\text { ductie van 'streek- en fami- } \\
\text { lieromans' over ouderschap } \\
\text { in percentages }\end{array}$ \\
\hline 1. Adoptie-, stief-, of pleegouderschap & 60 & $41,1 \%$ \\
\hline 2. Afwezigheid van een vader & 56 & $38,4 \%$ \\
\hline 3. Religie & 53 & $36,3 \%$ \\
\hline 4. Dood en/of ziekte van een vader & 43 & $29,5 \%$ \\
\hline 5. Alleenstaande moeder & 40 & $27,4 \%$ \\
\hline 6. Buitenechtelijke zwangerschap en/of kind & 41 & $28,1 \%$ \\
\hline 7. Dood en/of ziekte van een moeder & 35 & $24,0 \%$ \\
\hline 8. Afwezigheid van een moeder & 24 & $16,4 \%$ \\
\hline 9. Scheiding & 17 & $11,6 \%$ \\
\hline 10. Overspel & 17 & $11,6 \%$ \\
\hline 11. Ziek, gehandicapt en/of gewond kind & 16 & $11,0 \%$ \\
\hline 12. Dood van een kind & 14 & $9,6 \%$ \\
\hline 13. Alleenstaande vader & 14 & $9,6 \%$ \\
\hline 14. Verdwijning van een kind & 13 & $8,9 \%$ \\
\hline 15. Armoede & 12 & $8,2 \%$ \\
\hline 16. Oorlog & 8 & $5,5 \%$ \\
\hline $\begin{array}{l}\text { 17. Mishandeling van een kind door iemand anders dan een } \\
\text { moeder of vader }\end{array}$ & 7 & $4,8 \%$ \\
\hline 18. Tienerzwangerschap & 7 & $4,8 \%$ \\
\hline 19. Migratie & 6 & $4,1 \%$ \\
\hline 20. Mishandeling of verwaarlozing van een kind door een vader & 5 & $3,4 \%$ \\
\hline 21. Mishandeling of verwaarlozing van een kind door een moeder & 4 & $2,7 \%$ \\
\hline 22. Ongewilde kinderloosheid & 4 & $2,7 \%$ \\
\hline 23. Crimineel kind & 4 & $2,7 \%$ \\
\hline 24. Een moeilijke zwangerschap, bevalling en/of kraamtijd & 4 & $2,7 \%$ \\
\hline 26. Criminele vader & 3 & $2,1 \%$ \\
\hline 27. Miskraam & 2 & $1,4 \%$ \\
\hline 28. Problemen met de combinatie van werk en moederschap & 1 & $0,7 \%$ \\
\hline 29. Spijt van de keuze voor een kind & 1 & $0,7 \%$ \\
\hline 30. Problemen met de combinatie van werk en vaderschap & 1 & $0,7 \%$ \\
\hline
\end{tabular}

Wanneer we Tabel 10 met Tabel 2 in dit hoofdstuk vergelijken, dan valt op dat het meest voorkomende onderwerp in het genre 'literaire roman, novelle' niet hetzelfde is, wanneer we naar al het fictioneel proza kijken. In het laatste geval is het belangrijkste thema de afwezigheid van een vader, in de 'literaire roman, novelle' is dit de dood en/of ziekte van een moeder. Daarnaast blijkt een aantal thema's vaker in de 'literaire roman, novelle' te worden uitgewerkt. Zo prijken oorlog en migratie in Tabel 10 hoger op de ranglijst dan in Tabel 2. Ten slotte, wordt duidelijk dat een aantal thema's dat in Tabel 2 aan de orde is gekomen, in de 'literaire roman, novelle' niet aanwezig is. Dit zijn: problemen met de combinatie van werk en vaderschap, miskraam en een criminele moeder. 
Als we Tabel 11 naast Tabel 2 leggen dan springen er twee verschillen in het oog. Ten eerste is er bij de 'streek- en familieromans' eveneens sprake van een andere koploper dan in het fictioneel proza over ouderschap in het algemeen. Hier wordt de lijst aangevoerd door adoptie-, stief-, of pleegouderschap. Ten tweede, ontbreken er in Tabel 11 een aantal thema's uit Tabel 2. Bij de verzamelde data blijken geen 'streek- en familieromans' te zitten over homoseksualiteit, bewuste kinderloosheid, een drugsverslaafd kind, abortus en een criminele moeder. Uit een vergelijking van Tabel 10 en 11 blijkt dat de 'literaire roman, novelle' en de 'streeken familieromans' onder meer van elkaar verschillen in het meest voorkomende onderwerp dat in de genres wordt uitgewerkt. Er zijn daarnaast nuanceverschillen in de voorkeur voor bepaalde thema's tussen de twee genres aan te wijzen. In de 'literaire roman, novelle' doen oorlog en migratie het veel beter dan in de 'streeken familieromans', waarin religie en een buitenechtelijke kind/zwangerschap juist hogere plekken innemen.

\section{Resultaten dataset 2: moederschap}

In Tabel 12 zijn de prozawerken uit de tweede dataset uitgesplitst naar genre en sekse van de auteurs.

\section{Tabel 12}

Productie van fictioneel proza over moederschap per NUR-genre uitgesplitst naar sekse van de auteur (dataset 2)

\begin{tabular}{|c|c|c|c|c|}
\hline \multirow[b]{2}{*}{ NUR-genre } & \multicolumn{2}{|c|}{ Sekse } & \multirow[b]{2}{*}{$\begin{array}{c}\text { Totale } \\
\text { absolute } \\
\text { productie } \\
\text { per genre }\end{array}$} & \multirow[b]{2}{*}{$\begin{array}{c}\text { Aandeel van de } \\
\text { totale productie } \\
\text { van fictioneel } \\
\text { proza over moe- } \\
\text { derschap in } \\
\text { percentages }\end{array}$} \\
\hline & Man & Vrouw & & \\
\hline -literaire fictie algemeen & 0 & 4 & 4 & $2,7 \%$ \\
\hline -literaire roman, novelle & 39 & 60 & 99 & $66,9 \%$ \\
\hline -thriller & 0 & 1 & 1 & $0,7 \%$ \\
\hline -populaire fictie algemeen & 0 & 1 & 1 & $0,7 \%$ \\
\hline -historische roman (populair) & 1 & 0 & 1 & $0,7 \%$ \\
\hline -romantiek & 0 & 3 & 3 & $2,0 \%$ \\
\hline -streek- en familieromans & 5 & 24 & 29 & $19,6 \%$ \\
\hline -fictie overig algemeen & 0 & 1 & 1 & $0,7 \%$ \\
\hline $\begin{array}{l}\text {-literaire fictie algemeen \& literaire roman, } \\
\text { novelle }\end{array}$ & 0 & 2 & 2 & $1,4 \%$ \\
\hline $\begin{array}{l}\text {-literaire roman, novelle \& pockets literaire } \\
\text { fictie }\end{array}$ & 2 & 3 & 5 & $3,4 \%$ \\
\hline $\begin{array}{l}\text {-historische roman (populair) \& streek- en } \\
\text { familieromans }\end{array}$ & 0 & 1 & 1 & $0,7 \%$ \\
\hline -romantiek \& streek- en familieromans & 0 & 1 & 1 & $0,7 \%$ \\
\hline
\end{tabular}

$n=148$ 
Net als bij de eerste dataset nemen de 'literaire roman, novelle' en de 'streek- en familieromans' de leiding. De 'literaire roman, novelle' steekt als een enkelvoudige categorie met een aandeel van $66,9 \%$ van alle prozawerken met kop- en schouders boven de andere genres uit. Daarna volgt het genre 'streek- en familieromans' met $19,6 \%$. De combinaties waarin deze genres voorkomen zijn niet meegeteld in het aandeel dat ze vertegenwoordigen. De analyse van de relatieve positie van literaire fictie beperkt zich verder tot de 'literaire roman, novelle'. Daarbij wordt dit genre voortdurend met het grootste niet-literaire genre vergeleken: de 'streek- en familieromans'. De andere genres blijven buiten beschouwing, omdat hun aandeel zo klein is dat we op basis van de beschikbare data weinig kunnen zeggen over de kenmerken van deze genres.

Naast deze overeenkomst zijn er drie opvallende verschillen met de eerste dataset. Ten eerste is het totaal aantal geïdentificeerde genres een stuk kleiner. In de eerste dataset zijn de prozawerken verspreid over zestien verschillende genres en in de tweede dataset zijn dat er maar negen. Ten tweede is de verhouding tussen vrouwelijke en mannelijke auteurs anders. In de tweede dataset zijn vrouwelijke auteurs namelijk in beide enkelvoudige genres in de meerderheid. Van de 'literaire roman, novelle' is $60,6 \%$ van de hand van een vrouw, bij de 'streek- en familieromans' is dat $82,8 \%$. Een derde verschil is de historische ontwikkeling van de productie van beide genres. In tegenstelling tot de eerste dataset, blijft de productie van beide genres redelijk gelijkmatig gedurende dertig jaar. In Tabel 13 en Figuur 15 en 16 is de productie van de twee genres per jaar uitgesplitst. 
Tabel 13

Productie van fictioneel proza over moederschap per NUR-genre per jaar (dataset 2)

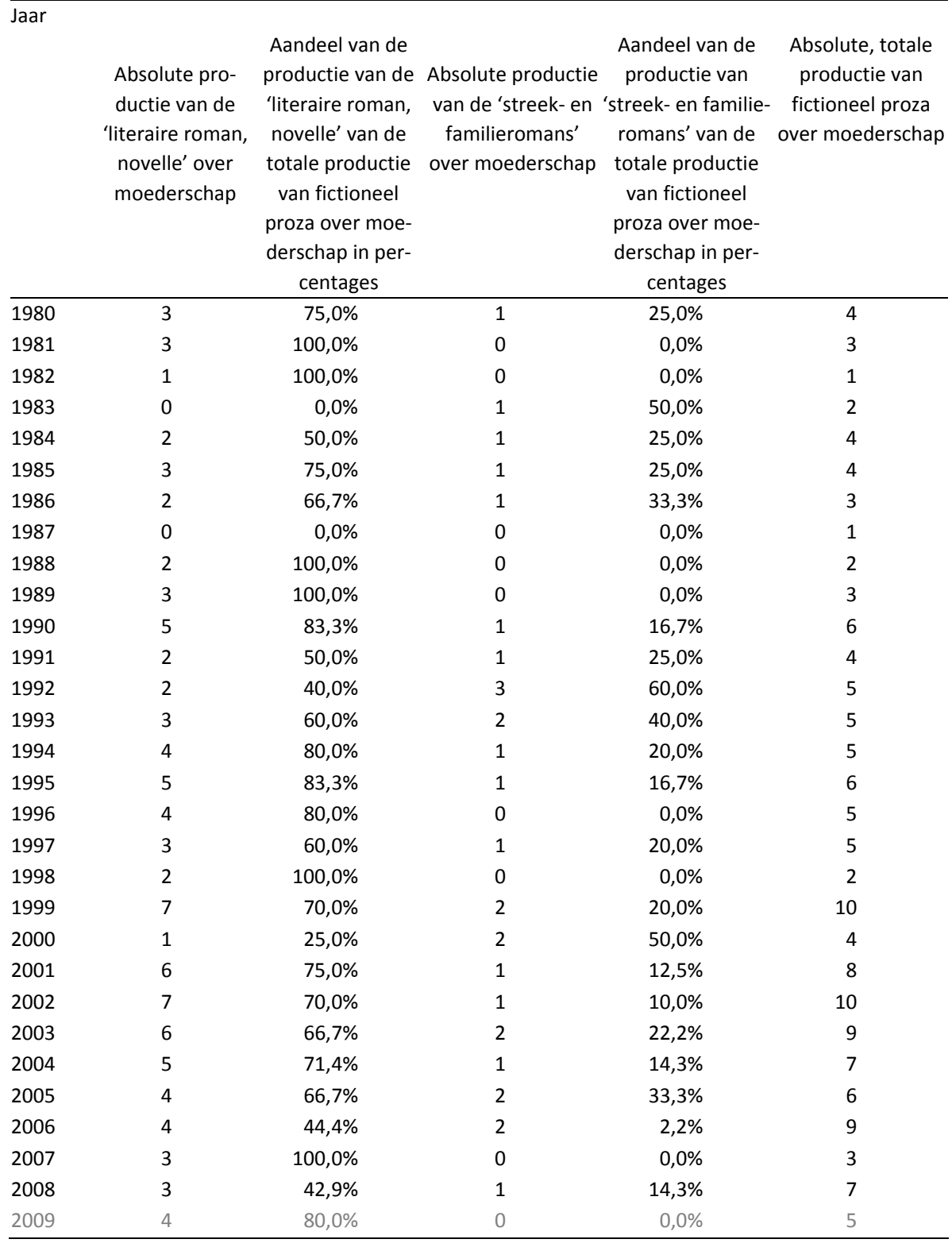




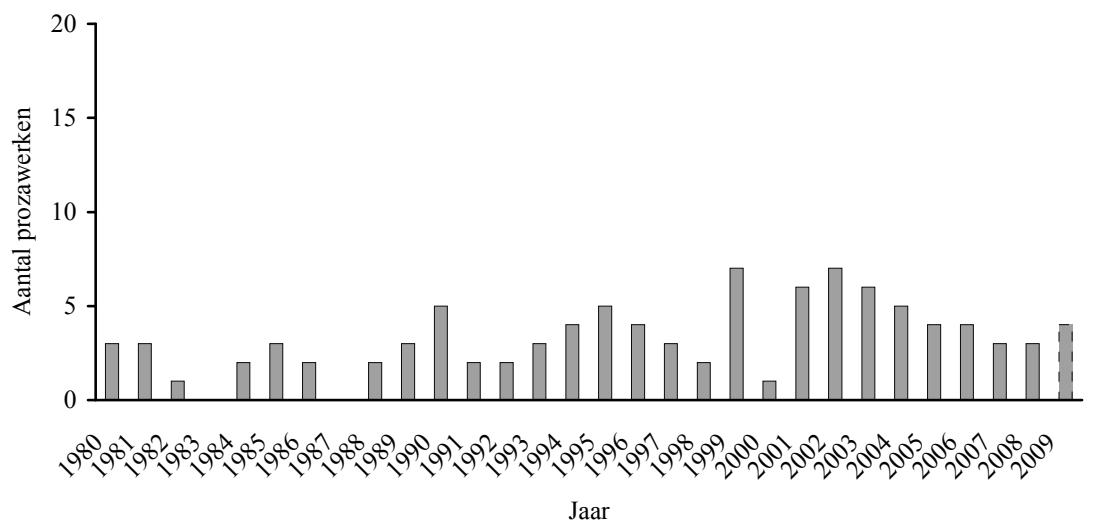

Figuur 15

Productie van de 'literaire roman, novelle' over moederschap (dataset 2)

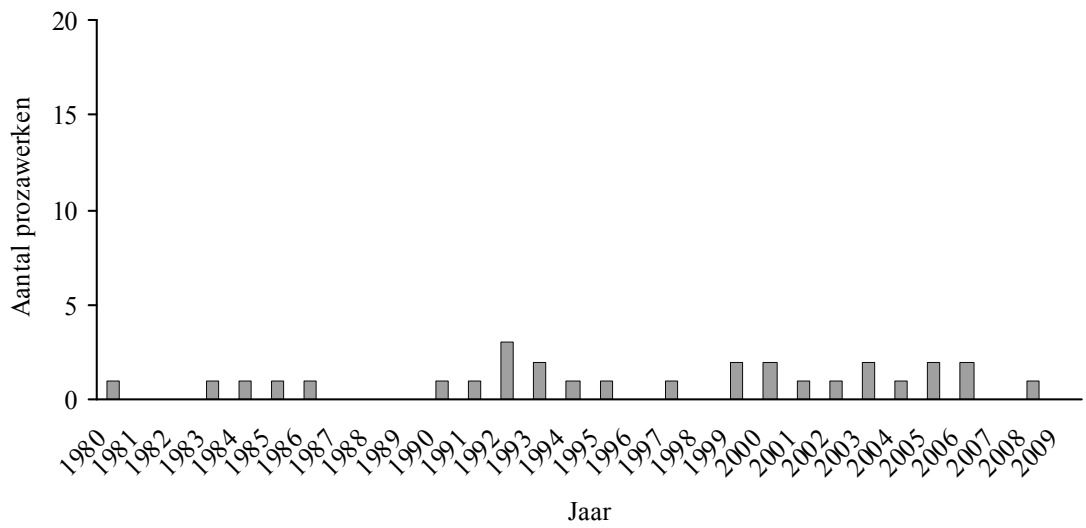

Figuur 16

Productie van 'streek- en familieromans' over moederschap (dataset 2)

In Figuur 15 lijkt er vanaf medio jaren negentig weliswaar sprake van een zeer lichte stijging van de productie van de 'literaire roman, novelle', maar het gaat hier om zeer kleine absolute verschillen. De productie van de 'streek- en familieromans' blijft zeer gelijkmatig, getuige Figuur 16. De zeer lichte stijging in de productie van de 'literaire roman, novelle' en de gelijkmatige productie van de 'streek- en familieromans' wijst, in het licht van de genoemde algemene toename van de productie van proza in die tijd en van de lossere omgang met NUR-code 301, op een daling van interesse in moederschap in deze genres.

Wanneer we ons over de verbeelding van moederschap in beide genres buigen, dan blijkt dat moederschap in de 'literaire roman, novelle' in $89,9 \%$ van de gevallen wordt geproblematiseerd. Bij $1,0 \%$ is er sprake van een eenzijdige idealisering van 
het moederschap en bij 9,1\% kan er hierover niets gezegd worden. Bij de 'streek- en familieromans' is het moederschap in $96,6 \%$ van de gevallen niet idyllisch. Van de overige $3,4 \%$ is het onduidelijk hoe moederschap in dit opzicht precies wordt verbeeld. In Tabel 14 en 15 is het aandeel van verschillende thema's in het genre 'literaire roman, novelle' en het genre 'streek- en familieromans' weergegeven.

\section{Tabel 14}

Aandeel van verschillende thema's in het genre 'literaire roman, novelle' (dataset 2)

\begin{tabular}{|c|c|c|}
\hline Thema & $\begin{array}{l}\text { Absolute } \\
\text { productie }\end{array}$ & $\begin{array}{l}\text { Aandeel van de totale } \\
\text { productie van de } \\
\text { 'literaire roman, } \\
\text { novelle' over moeder- } \\
\text { schap in percentages }\end{array}$ \\
\hline 1. Dood en/of ziekte van een moeder & 48 & $48,8 \%$ \\
\hline 2. Afwezigheid van een vader & 26 & $26,3 \%$ \\
\hline 3. Oorlog & 19 & $19,2 \%$ \\
\hline 4. Alleenstaande moeder & 18 & $18,2 \%$ \\
\hline 5. Dood en/of ziekte van een vader & 16 & $16,2 \%$ \\
\hline 6. Religie & 16 & $16,2 \%$ \\
\hline 7. Afwezigheid van een moeder & 15 & $15,2 \%$ \\
\hline 8. Migratie & 13 & $13,1 \%$ \\
\hline 9. Adoptie-, stief-, of pleegouderschap & 13 & $13,1 \%$ \\
\hline 10. Scheiding & 7 & $7,1 \%$ \\
\hline 11. Overspel & 6 & $6,1 \%$ \\
\hline 12. Buitenechtelijke zwangerschap en/of kind & 6 & $6,1 \%$ \\
\hline $\begin{array}{l}\text { 13. Mishandeling van een kind door iemand anders dan een } \\
\text { moeder of vader }\end{array}$ & 5 & $5,1 \%$ \\
\hline 14. Dood van een kind & 4 & $4,0 \%$ \\
\hline 15. Ziek, gehandicapt en/of gewond kind & 4 & $4,0 \%$ \\
\hline 16. Homoseksualiteit & 4 & $4,0 \%$ \\
\hline 17. Mishandeling of verwaarlozing van een kind door een moeder & 4 & $4,0 \%$ \\
\hline 18. Alleenstaande vader & 3 & $3,0 \%$ \\
\hline 19. Verdwijning van een kind & 2 & $2,0 \%$ \\
\hline 20. Crimineel kind & 2 & $2,0 \%$ \\
\hline 21. Tienerzwangerschap & 2 & $2,0 \%$ \\
\hline 22. Problemen met de combinatie van werk en moederschap & 2 & $2,0 \%$ \\
\hline 23. Drugsverslaafd kind & 2 & $2,0 \%$ \\
\hline 24. Armoede & 2 & $2,0 \%$ \\
\hline 25. Mishandeling of verwaarlozing van een kind door een vader & 1 & $1,0 \%$ \\
\hline 26. Een moeilijke zwangerschap, bevalling en/of kraamtijd & 1 & $1,0 \%$ \\
\hline 27. Ongewilde kinderloosheid & 1 & $1,0 \%$ \\
\hline
\end{tabular}


Tabel 15

Aandeel van verschillende thema's in het genre 'streek- en familieromans' (dataset 1)

\begin{tabular}{|c|c|c|}
\hline Thema & $\begin{array}{l}\text { Absolute } \\
\text { productie }\end{array}$ & $\begin{array}{l}\text { Aandeel van de totale } \\
\text { productie van 'streek- } \\
\text { en familieromans' } \\
\text { over moederschap in } \\
\text { percentages }\end{array}$ \\
\hline 1. Afwezigheid van een vader & 13 & $44,8 \%$ \\
\hline 2. Buitenechtelijke zwangerschap en/of kind & 12 & $41,4 \%$ \\
\hline 3. Religie & 10 & $34,5 \%$ \\
\hline 4. Adoptie-, stief-, of pleegouderschap & 9 & $31,0 \%$ \\
\hline 5. Afwezigheid van een moeder & 7 & $24,1 \%$ \\
\hline 6. Alleenstaande moeder & 6 & $20,7 \%$ \\
\hline 7. Dood en/of ziekte van een moeder & 5 & $17,2 \%$ \\
\hline 8. Dood en/of ziekte van een vader & 3 & $10,3 \%$ \\
\hline 9. Scheiding & 3 & $10,3 \%$ \\
\hline 10. Armoede & 3 & $10,3 \%$ \\
\hline 11. Tienerzwangerschap & 3 & $10,3 \%$ \\
\hline 12. Verdwijning van een kind & 2 & $6,9 \%$ \\
\hline 13. Oorlog & 2 & $6,9 \%$ \\
\hline 14. Mishandeling of verwaarlozing van een kind door een vader & 2 & $6,9 \%$ \\
\hline 15. Crimineel kind & 2 & $6,9 \%$ \\
\hline 16. Alleenstaande vader & 1 & $3,4 \%$ \\
\hline $\begin{array}{l}\text { 17. Mishandeling van een kind door iemand anders dan een } \\
\text { moeder of vader }\end{array}$ & 1 & $3,4 \%$ \\
\hline 18. Mishandeling of verwaarlozing van een kind door een moeder & 1 & $3,4 \%$ \\
\hline 19. Migratie & 1 & $3,4 \%$ \\
\hline 20. Dood van een kind & 1 & $3,4 \%$ \\
\hline 21. Een moeilijke zwangerschap, bevalling en/of kraamtijd & 1 & $3,4 \%$ \\
\hline 22. Problemen met de combinatie van werk en moederschap & 1 & $3,4 \%$ \\
\hline
\end{tabular}

Vergelijken we Tabel 14 met het algemene overzicht van thema's in fictioneel proza over moederschap (Tabel 4), dan blijkt het meest voorkomende onderwerp in het genre 'literaire roman/novelle' met de dood en/of ziekte van een moeder hetzelfde. Daarnaast zijn er enkele kleine verschillen. Zo staan religie en een buitenechtelijke zwangerschap en/of kind lager op de ranglijst van de 'literaire roman/novelle' en oorlog en migratie juist weer hoger. Wanneer we het overzicht van de thema's in 'familie- en streekromans' (Tabel 15) met het algemene overzicht (Tabel 4) vergelijken, dan blijkt dat er hier een ander thema aan de top prijkt: de afwezigheid van een vader. Daarnaast doen onderwerpen als een buitenechtelijke zwangerschap en/of kind en adoptie-, stief-, of pleegouderschap het verhoudingsgewijs goed in streek- en familieromans. 


\section{Discussie resultaten dataset 1 en 2}

De analyse van beide datasets wijst er op dat er vooral binnen de genres 'literaire roman, novelle' en 'streek- en familieromans' over ouderschap en moederschap wordt geschreven. Voor het laatste genre is dit geen verrassing. Johanna Maria van Buuren (2005) heeft er al op gewezen dat familierelaties in 'streek- en familieromans' een centraal thema zijn.

Uit de analyse van de tweede dataset blijkt dat vrouwelijke auteurs in beide genres in de meerderheid zijn. Voor de eerste dataset geldt dit alleen voor de 'streek- en familieromans'. In het genre 'literaire roman, novelle' vormen mannen een nipte meerderheid. Desondanks is het aandeel van de vrouwelijke auteurs ook in dit genre opvallend groot. Wanneer beschikbare gegevens er op wijzen dat, zoals eerder vermeld, de prozaproductie van vrouwelijke auteurs in het algemeen veel lager is, is $46,2 \%$ immers een behoorlijk aandeel (Van Rees, Janssen \& Verboord, 2006; Vos, 2008).

Overigens kan op basis van de gegevens over de productie van de 'literaire roman, novelle' in de eerste dataset, niet zomaar geconcludeerd worden dat vrouwen voornamelijk 'onliteraire' boeken over ouderschap en moederschap schrijven en mannen zich met 'literatuur' bezighouden. Dat zou geen recht doen aan het feit dat het toekennen van de NUR-codes een proces is waarbij symbolische waarde aan de boeken wordt toegekend en waarbij stereotypen over sekse een rol zouden kunnen spelen. In de categorisering van de prozawerken door uitgeverijen en het Centraal Boekhuis via de NUR-codes zouden soortgelijke opvattingen onbewust een rol kunnen spelen. Zij zouden aan het werk van vrouwelijke auteurs over ouderschap en moederschap wellicht sneller NUR-codes kunnen toekennen die niet 'literair' zijn, dan ze bij mannelijke auteurs over dit thema zouden doen.

Uit de afzonderlijke analyse van de verbeelding van ouderschap en moederschap in de 'literaire roman, novelle' en 'streek- en familieromans' blijkt dat ouderschap en moederschap in beide genres hoofdzakelijk wordt geproblematiseerd. Wanneer we naar de thematische uitwerking van de romans kijken, dan zijn er enkele nuanceverschillen aan te duiden in de onderwerpen die aan bod komen. Zo blijkt er in de 'literaire roman, novelle' zowel bij de eerste als de tweede dataset een lichte voorkeur voor onderwerpen als oorlog en migratie te bestaan en in 'streek- en familieromans' voor een buitenechtelijke zwangerschap en/of kind. Op basis van een analyse van het grootste literaire genre uit de tweede dataset kan de stelling dat meestal negatieve aspecten en ervaringen van moederschap in literaire boeken worden verbeeld, onderschreven worden. Ten aanzien van de relatie tussen de in deze literaire romans uitgewerkte thema's en de maatschappelijke idealisering van en probleemvertogen over moederschap, geldt hetzelfde als voor fictioneel proza over ouderschap. Zulke verbanden zijn op basis van de gemaakte analyse moeilijk te leggen. Dat moederschap in de 'literaire roman, novelle' vaak geen idylle is, hoeft in ieder geval niet per definitie te betekenen dat de dwingende maat- 
schappelijke idealisering ervan er door ter discussie wordt gesteld. De informatie in de NCC biedt onvoldoende aanknopingspunten om hier iets over te kunnen zeggen.

Tot slot, twee algemene observaties bij de analyses van de genres. Ten eerste valt op dat de 'literaire thriller' hier buiten beeld blijft, terwijl dit genre in Nederland vaak bij uitstek over vastgelopen gezinsverhoudingen gaat. Ten tweede, moet worden opgemerkt dat de NUR-codes geen recht doen aan de generische complexiteit van veel romans. Romans incorporeren vaak elementen uit verschillende genres en zijn daardoor niet zo eenvoudig in een hokje te plaatsen als de NUR-codes doen voorkomen. Zelfs niet als er twee of drie codes aan een boek zijn toegekend. Om die complexiteit voor het voetlicht te brengen zijn diepgaande interpretaties van de romans onontbeerlijk.

\section{Symbolische productie}

\section{Opzet van de analyse}

De culturele reikwijdte van romans kan worden afgelezen aan verschillende indicatoren. De representatie van een boek in de media is er een van (Janssen, 1994, 1997, 1998, 1999). Zo is het gegeven of een werk überhaupt wordt genoemd in de media en hoeveel aandacht er aan wordt besteed, van betekenis voor de culturele waarde en invloed van een roman. Daarbij spelen kranten nog altijd een belangrijke rol, ondanks de oprukkende aanwezigheid van digitale media (Janssen, 1999). Naast vermelding in de media is de inhoud van die vermelding van belang. Andere belangrijke indicatoren van de culturele reikwijdte zijn oplage, literaire prijzen, bestsellerlijsten, nevenactiviteiten van auteurs en de opname van een boek in het onderwijscurriculum (zie Van Rees, Janssen \& Verboord, 2006; Janssen, 1994; Janssen, 1998).

De analyse van het bereik van de in de NCC gevonden werken over ouderschap en moederschap beperkt zich tot een kwantitatieve exploratie van de vermeldingen van het via de NCC gelokaliseerde proza in vijf Nederlandse dagbladen die toegankelijk zijn via de database LexisNexis: Algemeen Dagblad, de Volkskrant, Het Parool, NRC Handelsblad en Trouw. Het doel van de kwantitatieve analyse van de recensies is om een eerste indruk te krijgen van het soort werken dat in de onderzochte kranten worden genoemd. Daarbij is er aandacht voor de rol die de sekse van de auteur van een boek hierbij mogelijk speelt. Wordt het werk van mannelijke auteurs vaker of minder vaak vermeld dan dat van vrouwelijke auteurs? En zo ja, duidt dit dan op een relatie tussen de vermelding in de dagbladen en de sekse van de auteur?

Volgens de cijfers van CEBUCO, de marketingorganisatie van De Nederlandse Dagbladpers, zijn Algemeen Dagblad, de Volkskrant, NRC Handelsblad en Trouw wat betreft oplage en bereik anno 2009 vier van de vijf grootste nationale kranten in Nederland (CEBUCO, 2009). Het Parool was tot 1997 ook een landelijk krant, maar 
werd daarna een krant voor de regio Amsterdam (Oudejans, 1997). Dat neemt echter niet weg dat de krant, die zich sterk op kunst en cultuur richt (De Persgroep Banen, 2011), tot op heden een landelijke uitstraling heeft. $\mathrm{Er}$ is daarom voor gekozen om ook deze krant in de analyse mee te nemen. In LexisNexis zijn de jaargangen die vanaf de jaren negentig van deze kranten zijn verschenen, digitaal toegankelijk. De precieze datum tot wanneer er artikelen kunnen worden opgezocht, is per krant verschillend. Van de geanalyseerde kranten kunnen we bij de Volkskrant het minst ver terug gaan. Alleen de artikelen die op of na 2 januari 1995 in deze krant zijn verschenen, zijn beschikbaar in LexisNexis (LexisNexis, 2010a). De analyse is zodoende beperkt tot de prozawerken in de datasets die vanaf 1995 zijn gepubliceerd. Bij de eerste dataset zijn dit er 343 en bij tweede dataset gaat het om 96 boeken. ${ }^{80}$

Het weglaten van een deel van het oorspronkelijke corpus van 459 boeken uit de eerste dataset heeft geen noemenswaardig effect gehad op de verdeling tussen de seksen. Het aandeel van de vrouwen was in het oorspronkelijk corpus van 459 boeken 59,9\% ( $n=549$ ) en bij de 343 boeken die hier worden onderzocht is dat $61,5 \%(n=343)$. Het aandeel van de mannelijke auteurs was $39,7 \%(n=549)$ en is nu $38,2 \%(n=343)$, en dat van de auteurskoppels was $0,4 \%(n=549)$ en is na selectie $0,3 \%(n=343)$. Ook bij de tweede dataset is de verdeling tussen de seksen vrijwel gelijk gebleven. Oorspronkelijk namen vrouwelijke auteurs $68,2 \%$ van de romans over moederschap voor hun rekening versus een aandeel van $31,8 \%$ van de hand van mannelijke auteurs $(n=148)$. In de hier overgebleven boeken zijn er $70,8 \%$ van vrouwen en $29,2 \%$ van mannen ( $n=96$ ).

Voor de prozawerken uit de twee datasets is in eerste instantie nagegaan of ze überhaupt in Algemeen Dagblad, de Volkskrant, Het Parool, NRC Handelsblad en Trouw worden genoemd. Er is daarna ook naar het aantal vermeldingen gekeken. $\mathrm{Er}$ is geen onderscheid gemaakt tussen verschillende soorten vermeldingen en tussen de kranten waarin een boek wordt genoemd. Vermeldingen konden uiteenlopen van korte aankondigingen van de publicatie van een boek, top tien lijsten van romans, tot uitgebreide besprekingen en interviews. ${ }^{81}$

\footnotetext{
${ }^{80}$ Een andere grote, nationale krant in Nederland die ik hier niet heb meegenomen is De Telegraaf. Deze krant is momenteel ook de grootste landelijke krant (CEBUCO, 2009). Uit De Telegraaf kunnen alleen de artikelen die na 1999 zijn gepubliceerd in LexisNexis worden opgezocht (LexisNexis, 2010b). Aangezien de tijdspanne en het aantal romans, novellen en verhalenbundels dat meegenomen zou kunnen worden erg klein zou worden, als alleen naar de vermeldingen van de boeken van na 1999 wordt gekeken, is De Telegraaf buiten beschouwing gelaten in deze analyse. Er zouden namelijk nog maar 255 romans van de oorspronkelijk 549 uit de eerste dataset en 78 van de oorspronkelijke 148 boeken uit de tweede dataset overblijven.

${ }^{81}$ In verder onderzoek naar de vermelding van deze prozawerken zou dit kunnen worden gespecificeerd om zo een genuanceerder beeld te krijgen van de receptie. Het gaat mij hier om het verkrijgen van een eerste indruk.
} 


\section{Vermelding in vijf dagbladen, sekse en genre}

\section{Resultaten dataset 1: ouderschap}

Van de 343 vanaf 1995 gepubliceerde boeken, blijkt minder dan de helft (148 stuks) te worden genoemd in de kranten. Figuur 17 geeft de relatieve verdeling weer.

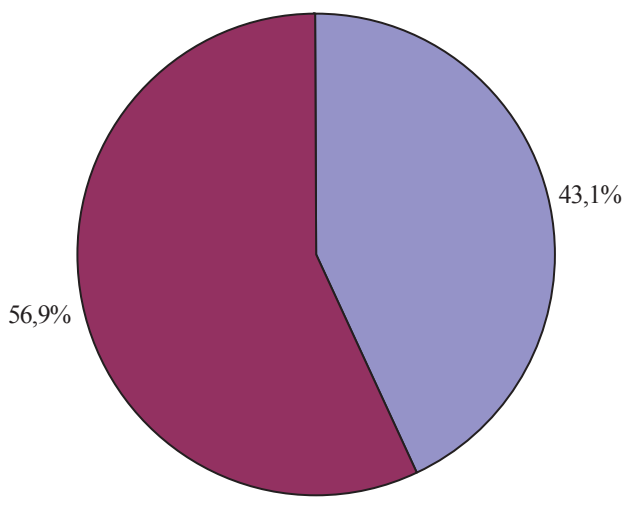

$\square$ Wel vermeld $\square$ Niet vermeld

\section{Figuur 17}

Vermelding van prozawerken over ouderschap vanaf 1995 in vijf dagbladen (dataset 1 )

$n=343$

Van het corpus van 343 werken dat hier is onderzocht, is zoals gezegd $61,5 \%$ van de productie van de hand van vrouwen, $38,2 \%$ van de hand van mannen en $0,3 \%$ van een auteurskoppel dat uit een man en een vrouw bestaat. Voor het proza dat in de dagbladen wordt vermeld, is de verdeling tussen vrouwelijke en mannelijke auteurs echter nagenoeg gelijk. De auteurskoppels worden niet genoemd. Figuur 18 laat de sekseverdeling zien voor de 148 werken die in de dagbladen worden genoemd. 


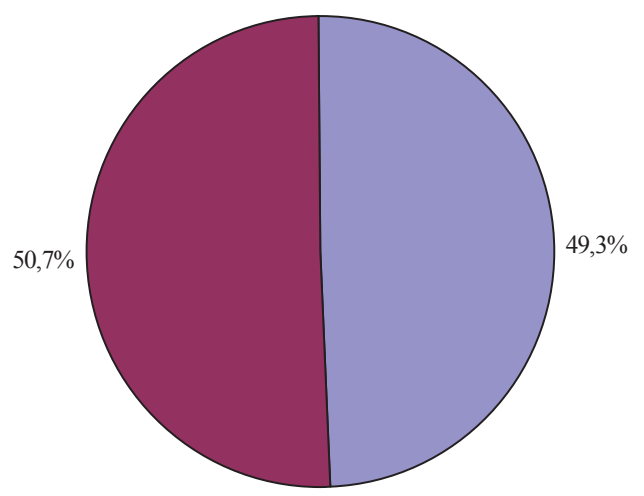

$\square$ Man $\square$ Vrouw

\section{Figuur 18}

Sekse van de auteur van de in vijf dagbladen vermelde fictionele prozawerken over ouderschap vanaf 1995 in percentages (dataset 1)

$n=148$

Hieruit blijkt dat 49,3\% van de werken die in de onderzochte media worden opgepikt door een man zijn geschreven of geredigeerd en dat terwijl mannen voor maar $38,2 \%$ van de productie verantwoordelijk zijn. Dat is een verschil van meer dan $10 \%$. In Tabel 16 is het aandeel van vrouwelijke en mannelijke auteurs niet alleen apart weergegeven ten opzichte van de totale productie, maar ook ten opzichte van de productie door de eigen sekse. 
Vermelding van fictioneel proza over ouderschap vanaf 1995 in vijf dagbladen uitgesplitst naar sekse van de auteurs (dataset 1 )

\begin{tabular}{|c|c|c|c|c|}
\hline & & Wel vermeld & Niet vermeld & $\begin{array}{c}\text { Totale } \\
\text { productie } \\
\text { vanaf } 1995\end{array}$ \\
\hline \multirow{3}{*}{$\frac{\sqrt{0}}{\sum^{\pi}}$} & -Absoluut aantal & 73 & 58 & 131 \\
\hline & $\begin{array}{l}\text {-Aandeel van de productie van mannelijke } \\
\text { auteurs van de totale productie van manne- } \\
\text { lijke auteurs in percentages }\end{array}$ & $55,7 \%$ & $44,3 \%$ & $100,0 \%$ \\
\hline & $\begin{array}{l}\text {-Aandeel van de productie van mannelijke } \\
\text { auteurs van de totale productie van fictio- } \\
\text { neel proza over ouderschap in percentages }\end{array}$ & $49,3 \%$ & $29,7 \%$ & $38,2 \%$ \\
\hline \multirow{3}{*}{$\frac{3}{3}$} & -Absoluut aantal & 75 & 136 & 211 \\
\hline & $\begin{array}{l}\text {-Aandeel van de productie van vrouwelijke } \\
\text { auteurs van de totale productie van vrouwe- } \\
\text { lijke auteurs in percentages }\end{array}$ & $35,5 \%$ & $64,5 \%$ & $100,0 \%$ \\
\hline & $\begin{array}{l}\text {-Aandeel van de productie van vrouwelijke } \\
\text { auteurs van de totale productie van fictio- } \\
\text { neel proza over ouderschap in percentages }\end{array}$ & $50,7 \%$ & $69,7 \%$ & $61,5 \%$ \\
\hline \multirow{3}{*}{ 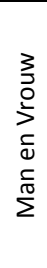 } & -Absoluut aantal & 0 & 1 & 1 \\
\hline & $\begin{array}{l}\text {-Aandeel van de productie van auteurskop- } \\
\text { pels van de totale productie van auteurs- } \\
\text { koppels in percentages }\end{array}$ & $0,0 \%$ & $100,0 \%$ & $100,0 \%$ \\
\hline & $\begin{array}{l}\text {-Aandeel van de productie van auteurskop- } \\
\text { pels van de totale productie van fictioneel } \\
\text { proza over ouderschap in percentages }\end{array}$ & $0,0 \%$ & $0,5 \%$ & $0,3 \%$ \\
\hline \multirow{2}{*}{$\begin{array}{l}\bar{\pi} \\
\substack{\pi \\
0} \\
\stackrel{0}{0}\end{array}$} & -Absoluut aantal & 148 & 195 & 343 \\
\hline & $\begin{array}{l}\text {-Aandeel van de totale productie van fictio- } \\
\text { neel proza over ouderschap in percentages }\end{array}$ & $43,1 \%$ & $56,9 \%$ & $100,0 \%$ \\
\hline
\end{tabular}

In Tabel 16 zien we dan dat het percentage vermelde boeken van vrouwelijke auteurs ten opzicht van hun bijdrage aan de totale productie met 35,5\% aanzienlijk lager is dan de $55,7 \%$ van de mannelijke auteurs.

Het feit dat mannelijke auteurs in verhouding tot hun aandeel in de productie vaker worden genoemd dan vrouwelijke auteurs, terwijl vrouwen de grootste producenten van proza over ouderschap zijn, impliceert dat de sekse van de auteur mogelijk verband houdt met de vermelding van een werk in een van de kranten. Om te controleren of dit inderdaad het geval is, zijn de vermeldingen in de dagbladen verder uitgesplitst naar genre (Tabel 17). Daarbij is er een onderscheid gemaakt tussen de twee grootste genres en zijn de andere, kleinere genres samengevoegd in een aparte categorie 'overige genres'. Het is belangrijk om de kleine genres niet uit te sluiten, gezien het beperkt totaal aantal boeken dat hier kan worden meegenomen in de analyses. Omdat de genres echter zo klein zijn, heeft het weinig zin om ze als aparte categorieën op te nemen. 


\section{Tabel 17}

Vermelding van fictioneel proza over ouderschap vanaf 1995 in vijf dagbladen uitgesplitst naar genre en sekse van de auteurs (dataset 1 )

\begin{tabular}{|c|c|c|c|c|c|}
\hline & & & Wel vermeld & Niet vermeld & $\begin{array}{c}\text { Totale } \\
\text { productie } \\
\text { vanaf } 1995\end{array}$ \\
\hline \multirow{11}{*}{$\begin{array}{l}\text { Literaire } \\
\text { roman, } \\
\text { novelle }\end{array}$} & \multirow{3}{*}{$\sum^{\frac{5}{\pi}}$} & -Absoluut aantal & 62 & 26 & 88 \\
\hline & & $\begin{array}{l}\text {-Aandeel van de productie van } \\
\text { mannelijke auteurs van de } \\
\text { totale productie van de 'literai- } \\
\text { re roman, novelle' over ouder- } \\
\text { schap door mannelijke auteurs } \\
\text { in percentages }\end{array}$ & $70,5 \%$ & $29,5 \%$ & $100,0 \%$ \\
\hline & & $\begin{array}{l}\text {-Aandeel van de productie van } \\
\text { mannelijke auteurs van de } \\
\text { totale productie van de 'literai- } \\
\text { re roman, novelle' over ouder- } \\
\text { schap in percentages }\end{array}$ & $35,0 \%$ & $14,7 \%$ & $49,7 \%$ \\
\hline & \multirow{3}{*}{$\begin{array}{l}3 \\
3 \\
0\end{array}$} & -Absoluut aantal & 60 & 28 & 88 \\
\hline & & $\begin{array}{l}\text {-Aandeel van de productie van } \\
\text { vrouwelijke auteurs van de } \\
\text { totale productie van de 'literai- } \\
\text { re roman, novelle' over ouder- } \\
\text { schap door vrouwelijke auteurs } \\
\text { in percentages }\end{array}$ & $68,2 \%$ & $31,8 \%$ & $100,0 \%$ \\
\hline & & $\begin{array}{l}\text {-Aandeel van de productie van } \\
\text { vrouwelijke auteurs van de } \\
\text { totale productie van de 'literai- } \\
\text { re roman, novelle' over ouder- } \\
\text { schap in percentages }\end{array}$ & $33,9 \%$ & $15,8 \%$ & $49,7 \%$ \\
\hline & \multirow{3}{*}{$\begin{array}{l}3 \\
3 \\
0 \\
\frac{3}{5} \\
\frac{1}{0} \\
\frac{1}{\pi} \\
\sum\end{array}$} & -Absoluut aantal & 0 & 1 & 1 \\
\hline & & $\begin{array}{l}\text {-Aandeel van de productie van } \\
\text { auteurskoppels van de totale } \\
\text { productie van de 'literaire } \\
\text { roman, novelle' over ouder- } \\
\text { schap door auteurskoppels in } \\
\text { percentages }\end{array}$ & $0,0 \%$ & $100,0 \%$ & $100,0 \%$ \\
\hline & & $\begin{array}{l}\text {-Aandeel van de productie van } \\
\text { auteurskoppels van de totale } \\
\text { productie van de 'literaire } \\
\text { roman, novelle' over ouder- } \\
\text { schap in percentages }\end{array}$ & $0 \%$ & $0,6 \%$ & $0,6 \%$ \\
\hline & \multirow[b]{2}{*}{$\begin{array}{l}\bar{\pi} \\
\mathbb{\mathbb { J }} \\
\text { 。ㅇ }\end{array}$} & -Absoluut aantal & 122 & 55 & 177 \\
\hline & & $\begin{array}{l}\text {-Aandeel van de totale produc- } \\
\text { tie van de 'literaire roman, } \\
\text { novelle' over ouderschap in } \\
\text { percentages }\end{array}$ & $68,9 \%$ & $31,1 \%$ & 100,0 \\
\hline
\end{tabular}




\section{Tabel 17 (vervolg)}

Vermelding van fictioneel proza over ouderschap vanaf 1995 in vijf dagbladen uitgesplitst naar genre en sekse van de auteurs (dataset 1 )

\begin{tabular}{|c|c|c|c|c|c|}
\hline & & & Wel vermeld & Niet vermeld & $\begin{array}{c}\text { Totale } \\
\text { productie } \\
\text { vanaf } 1995\end{array}$ \\
\hline \multirow{8}{*}{$\begin{array}{l}\text { Streek- } \\
\text { en } \\
\text { familie } \\
\text { romans }\end{array}$} & \multirow{3}{*}{$\sum^{\frac{5}{10}}$} & -Absoluut aantal & 0 & 13 & 13 \\
\hline & & $\begin{array}{l}\text {-Aandeel van de productie van } \\
\text { mannelijke auteurs van de } \\
\text { totale productie van 'streek- en } \\
\text { familieromans' over ouder- } \\
\text { schap door mannelijke auteurs } \\
\text { in percentages }\end{array}$ & $0,0 \%$ & $100,0 \%$ & $100,0 \%$ \\
\hline & & $\begin{array}{l}\text {-Aandeel van de productie van } \\
\text { mannelijke auteurs van de } \\
\text { totale productie van 'streek- en } \\
\text { familieromans' over ouder- } \\
\text { schap in percentages }\end{array}$ & $0,0 \%$ & $14,4 \%$ & $14,4 \%$ \\
\hline & \multirow{3}{*}{$\begin{array}{l}3 \\
3 \\
\frac{3}{3}\end{array}$} & -Absoluut aantal & 1 & 76 & 77 \\
\hline & & $\begin{array}{l}\text {-Aandeel van de productie van } \\
\text { vrouwelijke auteurs van de } \\
\text { totale productie van 'streek- en } \\
\text { familieromans' over ouder- } \\
\text { schap door vrouwelijke auteurs } \\
\text { in percentages }\end{array}$ & $1,3 \%$ & $98,7 \%$ & $100,0 \%$ \\
\hline & & $\begin{array}{l}\text {-Aandeel van de productie van } \\
\text { vrouwelijke auteurs van de } \\
\text { totale productie van 'streek- en } \\
\text { familieromans' over ouder- } \\
\text { schap in percentages }\end{array}$ & $1,1 \%$ & $84,4 \%$ & $85,6 \%$ \\
\hline & & -Absoluut aantal & 1 & 89 & 90 \\
\hline & \begin{tabular}{l}
$\bar{\pi}$ \\
\multirow{\pi}{0}{} \\
$\stackrel{1}{1}$
\end{tabular} & $\begin{array}{l}\text {-Aandeel van de totale produc- } \\
\text { tie van 'streek- en familiero- } \\
\text { mans' over ouderschap in } \\
\text { percentages }\end{array}$ & $1,1 \%$ & $98,9 \%$ & $100,0 \%$ \\
\hline
\end{tabular}


Vermelding van fictioneel proza over ouderschap vanaf 1995 in vijf dagbladen uitgesplitst naar genre en sekse van de auteurs (dataset 1 )

\begin{tabular}{|c|c|c|c|c|c|}
\hline & & & Wel vermeld & Niet vermeld & $\begin{array}{c}\text { Totale } \\
\text { productie } \\
\text { vanaf } 1995\end{array}$ \\
\hline Overige & \multirow{3}{*}{$\sum^{\frac{5}{10}}$} & -Absoluut aantal & 11 & 19 & 30 \\
\hline \multirow[t]{7}{*}{ genres } & & $\begin{array}{l}\text {-Aandeel van de productie van } \\
\text { mannelijke auteurs van de } \\
\text { totale productie van overige } \\
\text { genres over ouderschap door } \\
\text { mannelijke auteurs in percen- } \\
\text { tages }\end{array}$ & $36,7 \%$ & $63,3 \%$ & $100,0 \%$ \\
\hline & & $\begin{array}{l}\text {-Aandeel van de productie van } \\
\text { mannelijke auteurs van de } \\
\text { totale productie van overige } \\
\text { genres over ouderschap in } \\
\text { percentages }\end{array}$ & $14,5 \%$ & $25,0 \%$ & $39,5 \%$ \\
\hline & \multirow{3}{*}{$\begin{array}{l}3 \\
3 \\
0 \\
\vdots\end{array}$} & -Absoluut aantal & 14 & 32 & 46 \\
\hline & & $\begin{array}{l}\text {-Aandeel van de productie van } \\
\text { vrouwelijke auteurs van de } \\
\text { totale productie van overige } \\
\text { genres over ouderschap door } \\
\text { vrouwelijke auteurs in percen- } \\
\text { tages }\end{array}$ & $30,4 \%$ & $69,6 \%$ & $100,0 \%$ \\
\hline & & $\begin{array}{l}\text {-Aandeel van de productie van } \\
\text { vrouwelijke auteurs van de } \\
\text { totale productie van overige } \\
\text { genres over ouderschap in } \\
\text { percentages }\end{array}$ & $18,4 \%$ & $42,1 \%$ & $60,5 \%$ \\
\hline & \multirow[b]{2}{*}{ 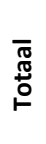 } & -Absoluut aantal & 25 & 51 & 76 \\
\hline & & $\begin{array}{l}\text {-Aandeel van de totale produc- } \\
\text { tie van overige genres over } \\
\text { ouderschap in percentages }\end{array}$ & $32,9 \%$ & $67,1 \%$ & $100,0 \%$ \\
\hline
\end{tabular}

Tabel 17 laat zien dat er binnen de drie genrecategorieën nauwelijks verschillen bestaan tussen de vermelding van mannelijke en vrouwelijke auteurs in de vijf dagbladen. Binnen het genre 'literaire roman, novelle' worden $68,9 \%$ van het totaal aantal boeken in de dagbladen genoemd. Hiervan is $35,0 \%$ van mannelijke auteurs en $33,9 \%$ van de hand van vrouwelijke auteurs. Wanneer we de vermelding van boeken van mannelijke auteurs afzetten tegen de totale productie van de 'literaire roman, novelle' door mannelijke auteurs, dan blijkt dat $70,5 \%$ van de boeken van mannen wordt vermeld. Bij vrouwen is dit afgezet ten opzichte van de productie door vrouwen $68,2 \%$. Er zijn dus nauwelijks verschillen tussen beide seksen binnen dit genre. Dit geldt ook voor het genre 'streek- en familieromans' en de categorie overige genres. Wanneer we de vermelding in de vijf onderzochte kranten dus verder uitsplitsen naar genre, dan blijkt dat er geen aanwijzingen zijn voor een relatie 
tussen sekse van de auteur en het feit of een boek in de onderzochte dagbladen wordt vermeld. Genre lijkt er echter wel toe te doen. Er is in de dagbladen duidelijk een voorkeur voor het vermelden van werken uit het genre 'literaire roman, novelle'. Van de totale productie van de 'literaire roman, novelle' over ouderschap duikt $68,9 \%$ in de kranten op. Van de 'streek- en familieromans' verschijnt te vergelijking slechts één boek in de dagbladen. Dat is $1,1 \%$ van de totale productie van 'streeken familieromans' over ouderschap.

We moeten wel voorzichtig zijn met het trekken van deze conclusies, omdat het aantal romans dat kon worden meegenomen in de verschillende genrecategorieën bij tijd en wijle klein is. Bovendien blijkt de celvulling in tabel 17 soms erg laag. Minimale verschuivingen in de data kunnen dan grote effecten hebben. Dit geldt met name voor de 'streek- en familieromans'. Met de categorie overige genres moeten we ook voorzichtig omspringen. Het is immers een vrij diffuse categorie die uit zeer veel verschillende, kleine genres bestaat. We kunnen de gevonden resultaten ook niet zomaar generaliseren naar de boeken die voor 1995 zijn gepubliceerd. Al was het maar, omdat de verdeling over verschillende genres van de 343 boeken die vanaf 1995 zijn gepubliceerd, verschilt ten opzichte van het oorspronkelijke corpus van 549 boeken. In Tabel 18 heb ik het aandeel van de verschillende genres met betrekking tot de 343 boeken die vanaf 1995 zijn gepubliceerd weergegeven. 
Productie fictioneel proza over ouderschap vanaf 1995 per NUR-genre (dataset 1)

\begin{tabular}{|c|c|c|}
\hline NUR-genre & $\begin{array}{l}\text { Absolute } \\
\text { productie }\end{array}$ & $\begin{array}{l}\text { Aandeel van de totale } \\
\text { productie van fictioneel } \\
\text { proza over ouderschap } \\
\text { in percentages }\end{array}$ \\
\hline -literaire fictie algemeen & 9 & $2,6 \%$ \\
\hline -literaire roman, novelle & 177 & $51,6 \%$ \\
\hline -verhalenbundels & 5 & $1,6 \%$ \\
\hline -pockets algemeen & 1 & $0,3 \%$ \\
\hline -pockets literaire fictie & 1 & $0,3 \%$ \\
\hline -pockets spanning & 1 & $0,3 \%$ \\
\hline -spannende boeken algemeen & 4 & $1,2 \%$ \\
\hline -detective & 2 & $0,6 \%$ \\
\hline -thriller & 2 & $0,6 \%$ \\
\hline -fantasy & 3 & $0,9 \%$ \\
\hline -griezel- en spookverhalen, horror & 2 & $0,6 \%$ \\
\hline -populaire fictie algemeen & 4 & $1,2 \%$ \\
\hline -historische roman (populair) & 3 & $0,9 \%$ \\
\hline -romantiek & 7 & $2,0 \%$ \\
\hline -streek- en familieromans & 90 & $26,2 \%$ \\
\hline -fictie overig algemeen & 1 & $0,3 \%$ \\
\hline -literaire fictie algemeen \& literaire roman, novelle & 2 & $0,6 \%$ \\
\hline -literaire roman, novelle \& verhalenbundels & 1 & $0,3 \%$ \\
\hline -literaire roman, novelle \& pockets literaire fictie & 11 & $3,2 \%$ \\
\hline -verhalenbundels \& pockets literaire fictie & 1 & $0,3 \%$ \\
\hline -verhalenbundels \& streek- en familieromans & 1 & $0,3 \%$ \\
\hline -pockets spanning \& spannende boeken algemeen & 1 & $0,3 \%$ \\
\hline -populaire fictie algemeen \& streek- en familieromans & 4 & $1,2 \%$ \\
\hline -romantiek \& streek- en familieromans & 10 & $2,9 \%$ \\
\hline
\end{tabular}

$n=343$

Wanneer we Tabel 18 vergelijken met Tabel 8, waarin de genreverdeling voor alle gevonden boeken over ouderschap van 1980 tot en met 2009 is weergegeven, dan blijkt dat de twee grootste categorieën en hun relatieve aandeel nog altijd hetzelfde zijn. Het aandeel 'literaire roman, novelle' is oorspronkelijk namelijk $52,1 \%(n=549)$ en nu $51,6 \%(n=343)$ en het aandeel van de 'streek- en familieromans' $26,6 \%$ ( $n=$ 549 ) en nu $26,2 \%$ ( $n=343$ ). Maar ondanks deze belangrijke overeenkomsten, zijn enkele kleinere genrecategorieën hier niet langer vertegenwoordigd.

Het aantal vermeldingen van de fictionele prozawerken over ouderschap vanaf 1995 is zoals gezegd ook onderzocht. Op basis van deze inventarisatie lijkt er een relatie te bestaan tussen het aantal vermeldingen in de kranten en de sekse van de auteur. Het gemiddeld aantal vermeldingen dat het werk van mannelijke auteurs mag genieten $(M=12,3 ; S D=28,9)$ is aanzienlijk hoger dan het gemiddeld aantal vermeldingen van het werk van vrouwen $(M=2,7 ; S D=7,2)$. Om te onderzoeken of er 
inderdaad een indicatie is voor een verband met sekse en het aantal vermeldingen bestaat is het aantal vermeldingen in Tabel 19 per sekse uitgesplitst naar genre.

Tabel 19

Gemiddeld aantal vermeldingen van fictioneel proza over ouderschap vanaf 1995 in vijf dagbladen, uitgesplitst naar genre en sekse van de auteurs (dataset 1)

\begin{tabular}{llcrr}
\hline Genre & Sekse & $\begin{array}{c}\text { Gemiddeld aantal } \\
\text { vermeldingen }\end{array}$ & Absolute productie & Std. Deviatie \\
\hline Literaire roman, & Man & 14,5 & 88 & 28,9 \\
novelle & Vrouw & 5,2 & 88 & 9,3 \\
& Man en vrouw & 0,0 & 1 & \\
& Totaal & 9,8 & 177 & 21,9 \\
\hline Streek- en fa- & Man & 0,0 & 13 & 0,0 \\
milieromans & Vrouw & 0,0 & 77 & 0,1 \\
& Totaal & 0,0 & 90 & 0,1 \\
\hline Overige genres & Man & 11,4 & 30 & 34,1 \\
& Vrouw & 2,5 & 46 & 6,9 \\
\hline Totale productie van & Man & 6,0 & 76 & 22,3 \\
fictioneel proza over & Vrouw & 12,3 & 131 & 28,9 \\
ouderschap & Man en vrouw & 2,7 & 211 & 7,2 \\
& Totaal & 0,0 & 1 & 19,3 \\
\hline
\end{tabular}

Over de 'streek- en familieromans' kunnen we hier niet veel zeggen, omdat boeken uit dit genre nauwelijks worden genoemd in de media. Binnen de 'literaire roman, novelle' en de categorie overige genres blijken er echter nog steeds opvallende verschillen te bestaan tussen mannelijke en vrouwelijke auteurs, waarbij mannelijke auteurs aanzienlijk in het voordeel blijken te zijn. Zo is het aantal vermeldingen dat een mannelijke auteur van een literaire roman, novelle ten deel valt $14,5(S D=28,9)$ tegenover de 5,3 (SD = 9,3) vermeldingen waar een vrouwelijke auteur van een boek binnen dit genre op mag rekenen. En binnen de overige genres is het gemiddeld aantal vermeldingen voor boeken van mannelijke auteurs 11,4 (SD $=34,1$ ) versus 2,5 van vrouwelijke auteurs (SD $=6,8)$.

De hogere standaarddeviaties bij het gemiddelde aantal vermeldingen van mannelijke auteurs in het algemeen en in het genre 'literaire roman, novelle' en de categorie overige genres in het bijzonder, wijzen er op dat er sprake is van een grotere spreiding van het aantal vermeldingen dan bij vrouwelijke auteurs. Dit komt doordat er enkele boeken van mannelijke auteurs zijn, die opmerkelijk veel aandacht hebben gekregen krijgen. Zo is er een uitschieter bij met maar liefst 186 vermeldingen. In Figuur 19 is de spreiding van het aantal vermeldingen van prozawerken visueel zichtbaar gemaakt met behulp van een boxplot, uitgesplitst naar sekse van de auteur. 


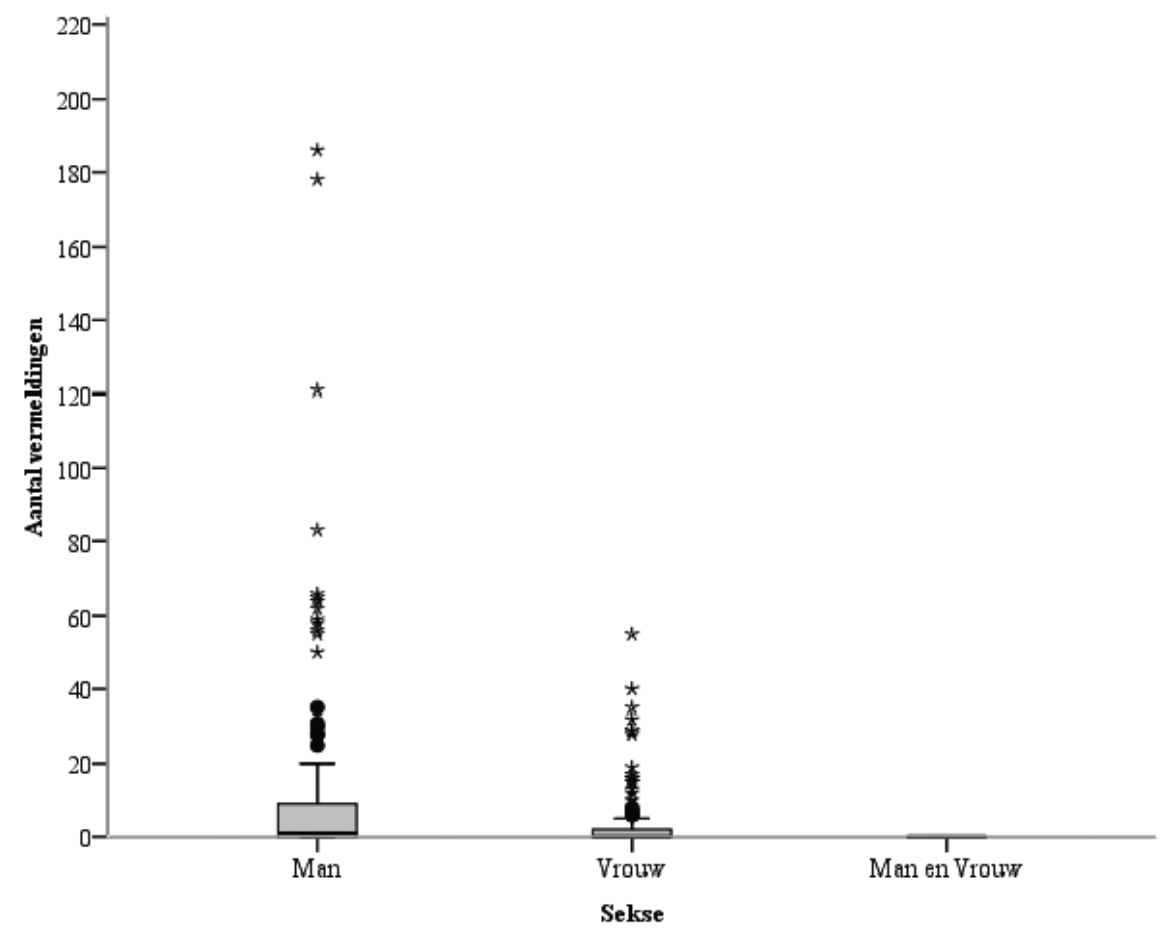

Figuur 19

Boxplot: spreiding van het aantal vermeldingen van fictionele prozawerken over ouderschap in vijf dagbladen uitgesplitst naar sekse (dataset 1 )

De gele rechthoeken (boxen) in de boxplot vertegenwoordigen de middelste vijftig procent van de waarnemingen. ${ }^{82}$ De bolletjes zijn de zogenaamde uitbijters en de sterretjes vertegenwoordigen extreme waarnemingen. ${ }^{83}$ De meest extreme waar-

\footnotetext{
${ }^{82}$ Zij vertegenwoordigen om het anders te zeggen de waarnemingen die zich tussen het eerste en derde kwartiel (Q1 en Q3) van de verdeling bevinden. Het eerste kwartiel wordt aangegeven door de onderste lijn van de box in de boxplot en het derde kwartiel door de bovenste lijn van de box.

${ }^{83}$ De horizontale lijn die de verticale lijn die vanuit de box vertrekt begrenst, geeft in de boxplot de grens aan voor het bepalen van de uitbijters en extreme waarden. Waarden die onder de horizontale lijn vallen, vallen binnen de 'normale' range. Waarden die daarbuiten vallen zijn 'extreem'. Die grens is hier, zoals gebruikelijk is, bepaald met behulp van het zogenaamde "1,5 x interquartile range criterium", waarvan de formule als volgt luidt: 1,5x(Q3-Q1) (Moor \& McCabe, 1998, p. 47-48). Het bepalen van de grens werkt als volgt. Bij de hoogste waarde van het derde kwartiel wordt de waarde opgeteld die wordt verkregen wanneer we het eerste kwartiel van het derde kwartiel aftrekken en vervolgens met 1,5 vermenigvuldigen. De grens wordt in de boxplot getrokken bij de laatste waarneming die nog binnen deze verkregen waarde valt. Waardes die buiten deze grens vallen, maar die kleiner zijn dan de waarde die wordt verkregen wanneer we bij het derde kwartiel 3 maal het interquartile range criterium optellen, Q3+3x(Q3-Q1), worden als uitbijters beschouwd. Waarnemingen die daar nog buiten vallen, worden als
} 
den blijken boeken van mannen te zijn. De waargenomen verschillen tussen mannen en vrouwen zouden louter gebaseerd kunnen zijn op zulke extreme waarden. Een of twee boeken van mannelijke auteurs zouden verantwoordelijk kunnen zijn voor de waargenomen verschillen. Om na te gaan of dit het geval is, is het gemiddeld aantal vermeldingen naar sekse en genre uitgesplitst voor de boeken met 75 of minder vermeldingen (Tabel 20). De meest extreme waarden bij de mannelijke auteurs zijn dus buiten beschouwing gelaten. Het heeft weinig zin om alle extreme waarden en uitbijters bij mannelijke en vrouwelijke uit te sluiten, omdat er dan te weinig gegevens voor analyse over blijven. Vandaar dat de grens bij 75 is getrokken.

Tabel 20

Gemiddeld aantal vermeldingen van fictioneel proza over ouderschap vanaf 1995 met 75 of minder vermeldingen in vijf dagbladen, uitgesplitst naar genre en sekse van de auteurs (dataset 1 )

\begin{tabular}{|c|c|c|c|c|}
\hline Genre & Sekse & $\begin{array}{l}\text { Gemiddeld aantal } \\
\text { vermeldingen }\end{array}$ & Absolute productie & Std. Deviatie \\
\hline \multirow{4}{*}{$\begin{array}{l}\text { Literaire roman, } \\
\text { novelle }\end{array}$} & Man & 10,4 & 85 & 17,5 \\
\hline & Vrouw & 5,2 & 88 & 9,3 \\
\hline & Man en vrouw & 0,0 & 1 & \\
\hline & Totaal & 7,7 & 174 & 14,1 \\
\hline \multirow{3}{*}{$\begin{array}{l}\text { Streek- en fa- } \\
\text { milieromans }\end{array}$} & Man & 0,0 & 13 & 0,0 \\
\hline & Vrouw & 0,0 & 77 & 0,1 \\
\hline & Totaal & 0,0 & 90 & 0,1 \\
\hline \multirow[t]{3}{*}{ Overige genres } & Man & 5,6 & 29 & 13,5 \\
\hline & Vrouw & 2,5 & 46 & 6,9 \\
\hline & Totaal & 3,7 & 75 & 10,0 \\
\hline \multirow[t]{4}{*}{ Totale productie } & Man & 8,3 & 127 & 16,0 \\
\hline & Vrouw & 2,7 & 211 & 7,2 \\
\hline & Man en vrouw & 0,0 & 1 & \\
\hline & Totaal & 4,8 & 339 & 11,6 \\
\hline
\end{tabular}

Wanneer we Tabel 20 bekijken, dan blijken er zelfs met het weglaten van romans met meer dan 75 recensies nog altijd grote verschillen tussen mannelijke en vrouwelijke auteurs te zijn, zowel in totaal als binnen het genre 'literaire roman, novelle' en de categorie overige genres. Na weglaten van de extreme waarden blijft het verschil tussen mannen en vrouwen dus overeind. Dit wijst er op dat de sekse van de auteur er toe doet wanneer het om het aantal vermeldingen in de dagbladen gaat. Mannen zijn daarbij in het voordeel. Zij worden vaker vermeld.

extreme waarden beschouwd. Zie bijvoorbeeld David Moor en George McCabe (1998) of Arie Buys (2008) voor een toegankelijke, uitgebreidere bespreking van de boxplot. 


\section{Resultaten dataset 2: moederschap}

Van de 96 boeken in de tweede dataset blijken er 49 in de dagbladen te zijn vermeld (51,0\%). Van de 96 romans zijn er zoals gezegd $70,8 \%$ geproduceerd door vrouwen en $29,2 \%$ door mannen. Van de romans die in de kranten worden genoemd, is het merendeel ook van vrouwelijke auteurs. Figuur 20 laat de sekseverdeling zien voor de werken uit de tweede dataset die in de dagbladen worden genoemd.

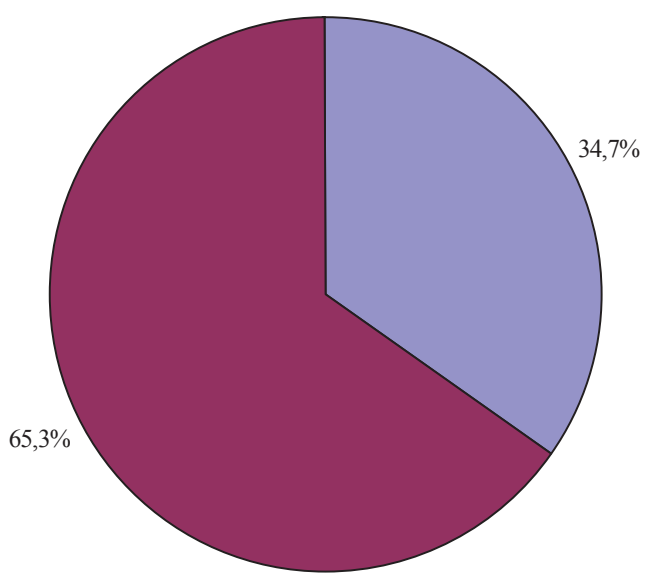

$\square$ Man $\square$ Vrouw

Figuur 20

Sekse van de auteur van de in vijf dagbladen vermelde fictionele prozawerken over moederschap vanaf 1995 in percentages (dataset 2)

$n=96$

Het percentage boeken van vrouwelijke auteurs dat in de onderzochte media wordt genoemd, benadert het relatieve aandeel van de oorspronkelijke productie dat vrouwen voor hun rekening nemen vrij dicht. Datzelfde geldt voor de mannelijke auteurs wanneer het om hun aandeel in de productie gaat. Er lijkt dus geen sprake te zijn van een relatie tussen de sekse van de auteur en de vermelding van een boek in een van de dagbladen. Het lijkt er met andere woorden niet toe te doen of een auteur man of vrouw is, wanneer het aankomt op de kans dat een boek over moederschap in de onderzochte kranten wordt genoemd. In Tabel 21 is de vermelding in de dagbladen verder uitgesplitst naar genre. 


\section{Tabel 21}

Vermelding van fictioneel proza over moederschap vanaf 1995 in vijf dagbladen uitgesplitst naar genre en sekse van de auteurs (dataset 2)

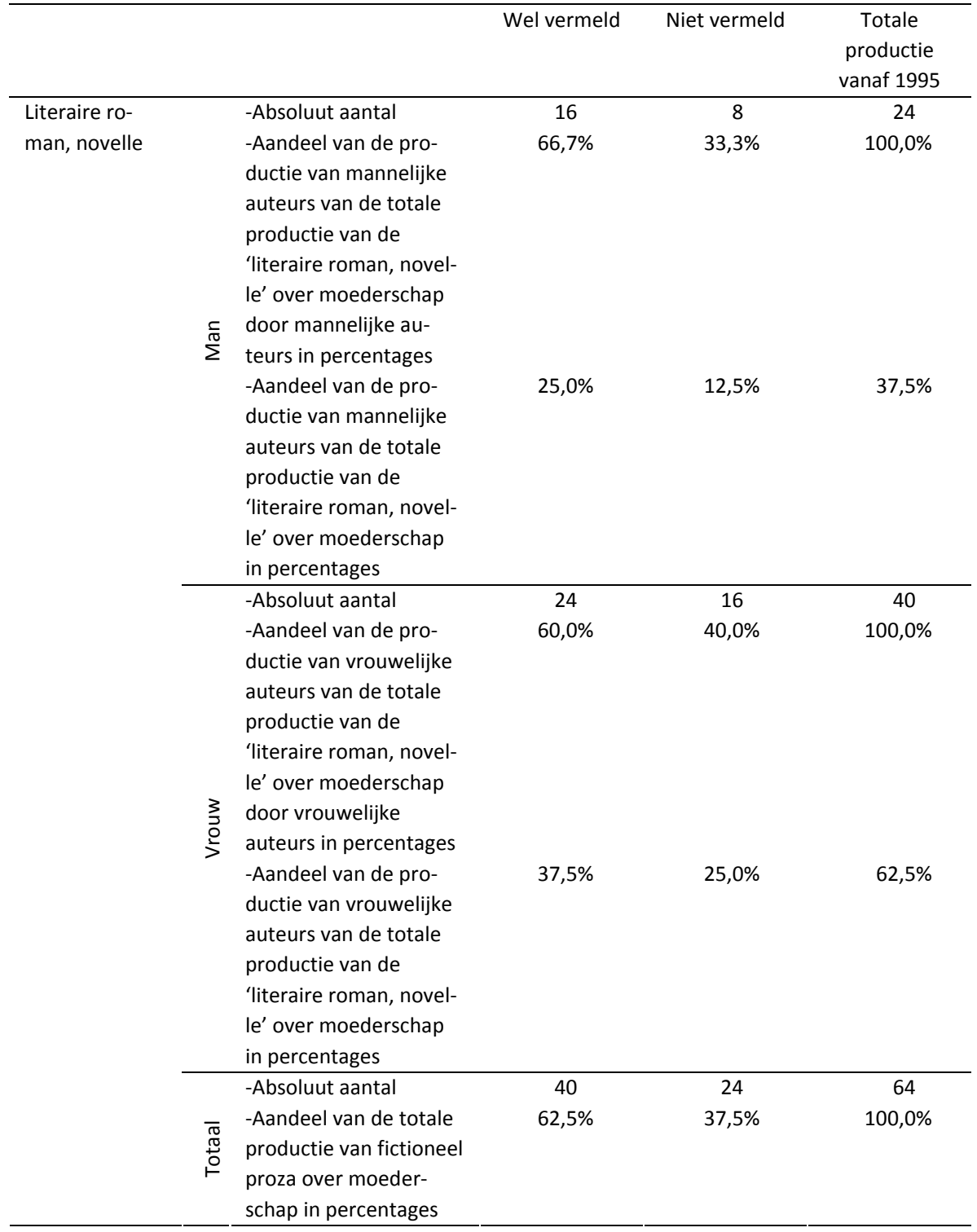




\section{Tabel 21 (vervolg)}

Vermelding van fictioneel proza over moederschap vanaf 1995 in vijf dagbladen uitgesplitst naar genre en sekse van de auteurs (dataset 2)

\begin{tabular}{|c|c|c|c|c|c|}
\hline & & & Wel vermeld & Niet vermeld & $\begin{array}{c}\text { Totale } \\
\text { productie } \\
\text { vanaf } 1995\end{array}$ \\
\hline Streek- en & \multirow{3}{*}{$\sum^{\frac{1}{\pi}}$} & -Absoluut aantal & 0 & 1 & 1 \\
\hline \multirow[t]{7}{*}{ familieromans } & & $\begin{array}{l}\text {-Aandeel van de pro- } \\
\text { ductie van mannelijke } \\
\text { auteurs van de totale } \\
\text { productie van 'streek- } \\
\text { en familieromans' over } \\
\text { moederschap door } \\
\text { mannelijke auteurs in } \\
\text { percentages }\end{array}$ & $0,0 \%$ & $100,0 \%$ & $100,0 \%$ \\
\hline & & $\begin{array}{l}\text {-Aandeel van de pro- } \\
\text { ductie van mannelijke } \\
\text { auteurs van de totale } \\
\text { productie van 'streek- } \\
\text { en familieromans', over } \\
\text { moederschap in per- } \\
\text { centages }\end{array}$ & $0,0 \%$ & $6,3 \%$ & $6,3 \%$ \\
\hline & \multirow{3}{*}{$\begin{array}{l}3 \\
3 \\
\frac{3}{5}\end{array}$} & -Absoluut aantal & 0 & 15 & 15 \\
\hline & & $\begin{array}{l}\text {-Aandeel van de pro- } \\
\text { ductie van vrouwelijke } \\
\text { auteurs van de totale } \\
\text { productie van 'streek- } \\
\text { en familieromans' over } \\
\text { moederschap door } \\
\text { vrouwelijke auteurs in } \\
\text { percentages }\end{array}$ & $0,0 \%$ & $100,0 \%$ & $100,0 \%$ \\
\hline & & $\begin{array}{l}\text {-Aandeel van de pro- } \\
\text { ductie van vrouwelijke } \\
\text { auteurs van de totale } \\
\text { productie van 'streek- } \\
\text { en familieromans' over } \\
\text { moederschap in per- } \\
\text { centages }\end{array}$ & $0,0 \%$ & $93,8 \%$ & $93,8 \%$ \\
\hline & & -Absoluut aantal & 0 & 16 & 16 \\
\hline & $\begin{array}{l}\bar{T} \\
\mathbb{T} \\
0 \\
\vdash\end{array}$ & $\begin{array}{l}\text {-Aandeel van de totale } \\
\text { productie van 'streek- } \\
\text { en familieromans' over } \\
\text { moederschap in per- } \\
\text { centages }\end{array}$ & $0,0 \%$ & $100,0 \%$ & $100,0 \%$ \\
\hline
\end{tabular}


Vermelding van fictioneel proza over moederschap vanaf 1995 in vijf dagbladen uitgesplitst naar genre en sekse van de auteurs (dataset 2)

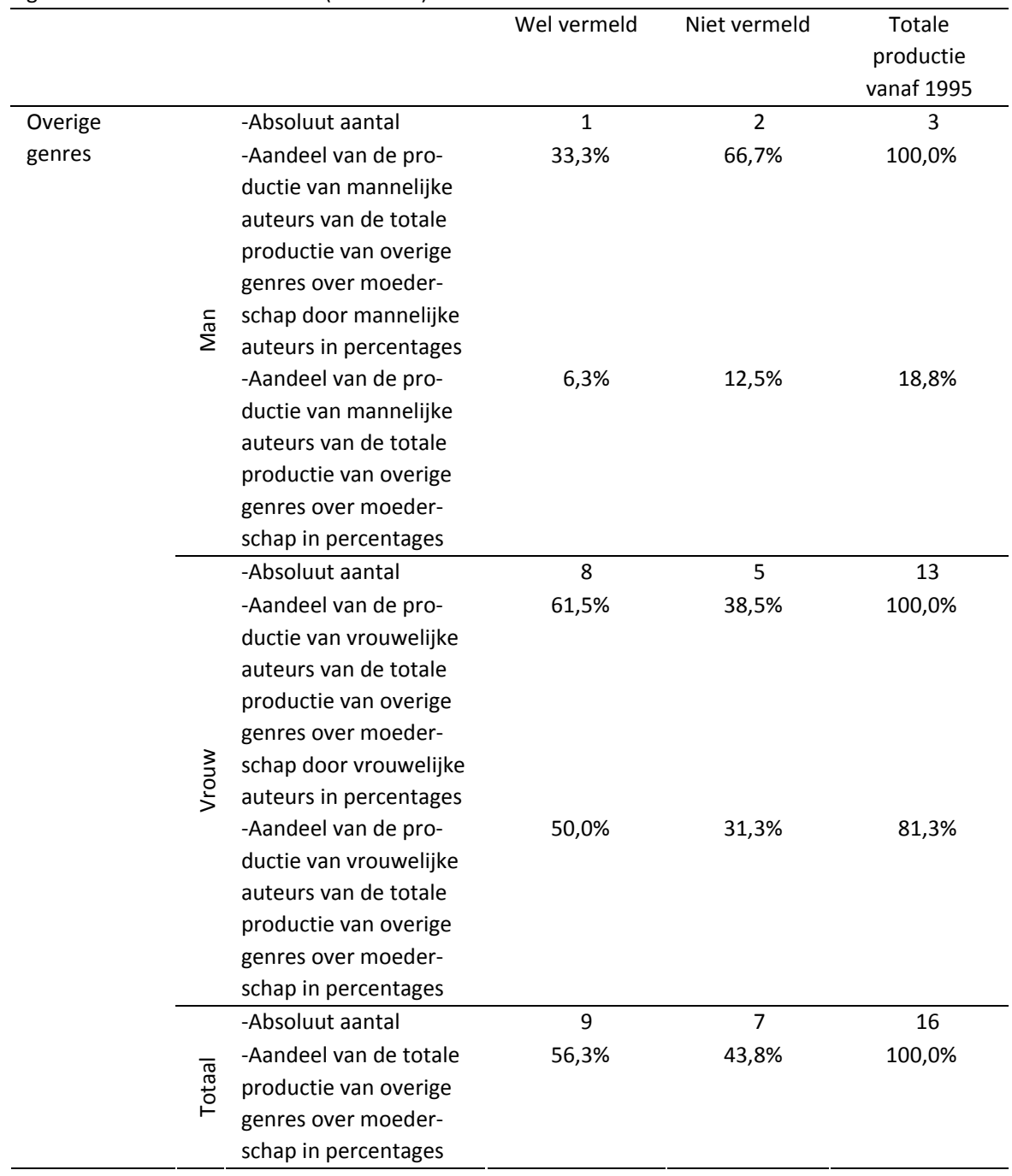

Bij de genres 'literaire roman, novelle' en 'streek- en familieromans' wijst niets in Tabel 21 in de richting van een relatie tussen de sekse van de auteurs en de vermelding van de boeken in de vijf dagbladen. Bij de categorie overige genres is er wel sprake van zo'n indicatie, die in het voordeel van vrouwelijke auteurs uitvalt. Bij vrouwen wordt immers maar liefst $61,5 \%$ van de door hun geproduceerde boeken in de kranten vermeld, terwijl dit bij de mannelijke auteurs maar 33,3\% is. Er zijn ook aanwijzingen voor een verband tussen het genre van het boek en de vermelding in de dagbladen. De 'streek- en familieromans' lijken niet geliefd. Ze worden hele- 
maal niet genoemd in de dagbladen, terwijl van de 'literaire roman, novelle' en de categorie overige genres respectievelijk maar liefst $62,5 \%$ en $56,3 \%$ van de geproduceerde boeken worden vermeld. Vanwege het lage aantal romans dat in de verschillende genres geanalyseerd kon worden, kunnen we echter niet zomaar concluderen dat er verbanden zijn. We kunnen op basis van onderzochte boeken geen harde conclusies trekken over de rol die sekse en genre bij de vermelding van een boek in de kranten mogelijk spelen. Bij de categorie overige genres moeten we hier nog voorzichtiger mee zijn, omdat dit immers zoals eerder gezegd een vrij diffuse categorie is die uit verschillende kleine genres bestaat.

Wanneer het om het aantal vermeldingen gaat, dan zien we direct duidelijk verschillen tussen de seksen. Het gemiddeld aantal vermeldingen dat het werk van mannelijke auteurs $(M=9,9 ; S D=17,9)$ is aanzienlijk hoger dan het gemiddeld aantal vermeldingen van het werk van vrouwen $(M=3,6 ; S D=7,8)$. Om te onderzoeken of er een verband met sekse bestaat, is het aantal vermeldingen ook verder uitgesplitst naar genre (Tabel 22).

Tabel 22

Gemiddeld aantal vermeldingen van fictioneel proza over moederschap vanaf 1995 in vijf dagbladen, uitgesplitst naar genre en sekse van de auteurs (dataset 2)

\begin{tabular}{|c|c|c|c|c|}
\hline Genre & Sekse & $\begin{array}{l}\text { Gemiddeld aantal } \\
\text { vermeldingen }\end{array}$ & Absolute productie & Std. Deviatie \\
\hline \multirow{3}{*}{$\begin{array}{l}\text { Literaire roman, } \\
\text { novelle }\end{array}$} & Man & 10,8 & 24 & 18,9 \\
\hline & Vrouw & 4,6 & 40 & 8,7 \\
\hline & Totaal & 6,9 & 64 & 13,7 \\
\hline \multirow{3}{*}{$\begin{array}{l}\text { Streek- en fa- } \\
\text { milieromans }\end{array}$} & Man & 0,0 & 1 & \\
\hline & Vrouw & 0,0 & 15 & 0,0 \\
\hline & Totaal & 0,0 & 16 & 0,0 \\
\hline \multirow[t]{3}{*}{ Overige genres } & Man & 6,3 & 3 & 11,0 \\
\hline & Vrouw & 4,9 & 13 & 8,5 \\
\hline & Totaal & 5,1 & 16 & 8,6 \\
\hline \multirow[t]{3}{*}{ Totale productie } & Man & 9,9 & 28 & 17,9 \\
\hline & Vrouw & 3,6 & 68 & 7,8 \\
\hline & Totaal & 5,5 & 96 & 11,9 \\
\hline
\end{tabular}

Over de 'streek- en familieromans' kunnen we vanwege de lage celvulling van sommige cellen opnieuw niet veel zeggen. Ook bij de 'literaire roman, novelle' en de overige genres moeten we, gezien het relatief kleine aantal romans dat in de analy- 
se konden worden meegenomen en vanwege het diffuse karakter van de categorie overige genres, voorzichtig zijn met het doen van harde uitspraken. Binnen de categorie overige genres zijn er nauwelijks verschillen tussen het gemiddeld aantal vermeldingen van mannelijke auteurs $(M=6,3, S D=11,0)$ en vrouwelijke auteurs ( $M=$ $4,9, \mathrm{SD}=8,5$ ). Binnen het genre 'literaire roman, novelle' bestaat er wel een duidelijk verschil tussen het gemiddeld aantal vermeldingen bij mannelijke ( $M=10,8, S D$ $=18,9)$ en vrouwelijke auteurs ( $M=4,6, S D=8,7)$, waarbij mannelijke auteurs duidelijk in het voordeel zijn.

De hoge standaarddeviatie bij het aantal vermeldingen van boeken van mannelijke auteurs in het algemeen wijst op een grote spreiding. Wanneer we figuur 21 bekijken, waarin de spreiding van het aantal vermeldingen voor beide seksen zichtbaar is gemaakt, dan lijkt het erop dat een aantal extreme waarden verantwoordelijk is voor deze grote spreiding bij het aantal vermeldingen bij mannelijke auteurs. Slechts enkele extreme waarden, drie boeken van mannelijke auteurs om precies te zijn, zouden de waargenomen verschillen tussen het gemiddeld aantal vermeldingen van boeken van mannelijke versus vrouwelijke auteurs kunnen veroorzaken.

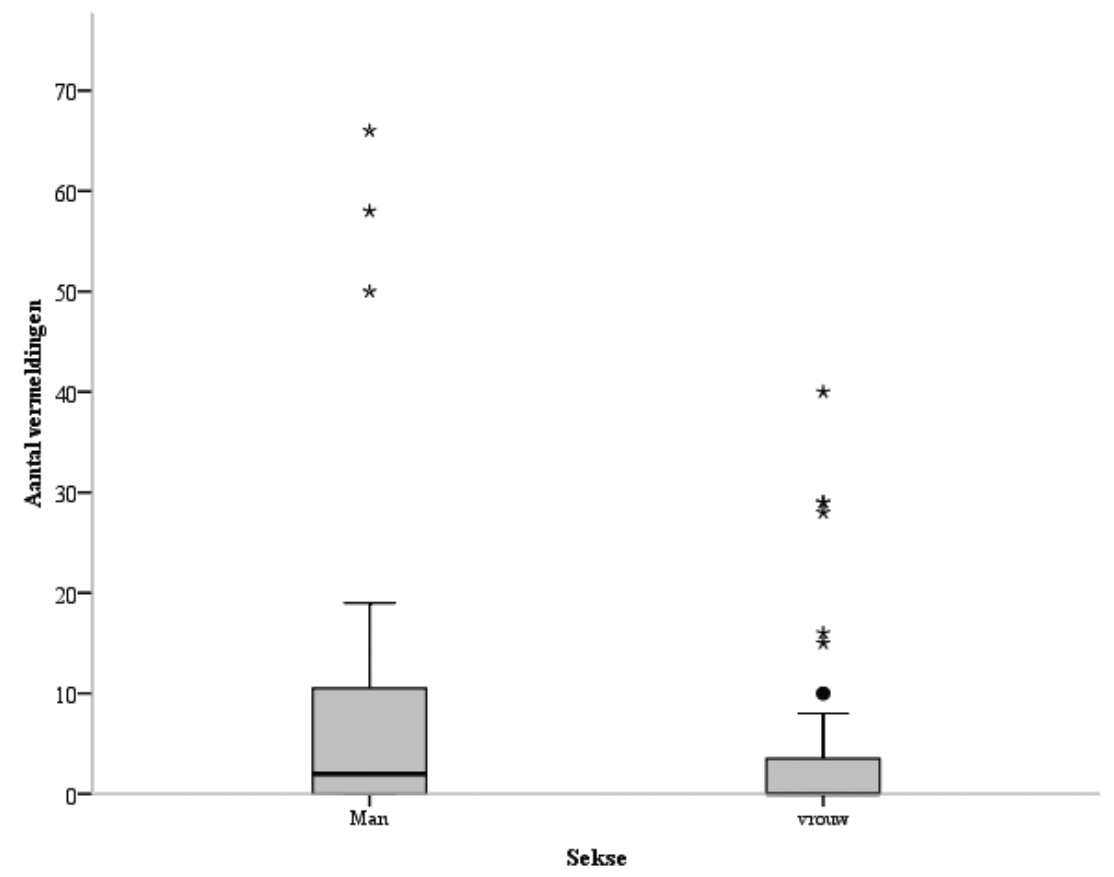

Figuur 21

Boxplot: Spreiding het aantal vermeldingen van fictionele prozawerken over moederschap in vijf dagbladen uitgesplitst naar sekse (dataset 2) 
Om te achterhalen in hoeverre deze extreme waarden het beeld van de verhoudingen tussen de seksen beïnvloeden, is het gemiddeld aantal vermeldingen opnieuw naar genre en sekse uitgesplitst, maar nu alleen voor boeken met veertig of minder vermeldingen (Tabel 23).

\section{Tabel 23}

Gemiddeld aantal vermeldingen van fictioneel proza over moederschap vanaf 1995 met veertig of minder vermeldingen in vijf dagbladen, uitgesplitst naar genre en sekse van de auteurs (dataset 2)

\begin{tabular}{llccc}
\hline Genre & Sekse & $\begin{array}{c}\text { Gemiddeld aantal } \\
\text { vermeldingen }\end{array}$ & Absolute productie & Std. Deviatie \\
\hline $\begin{array}{l}\text { Literaire roman, } \\
\text { novelle }\end{array}$ & Man & 4,1 & 21 & 4,9 \\
& Vrouw & 4,6 & 40 & 8,7 \\
& Totaal & 4,4 & 61 & 7,6 \\
\hline Streek- en fa- & Man & 0 & 1 & 0,0 \\
milieromans & Vrouw & 0 & 15 & 0,0 \\
& Totaal & 0 & 16 & 11,0 \\
\hline Overige genres & Man & 6,3 & 3 & 8,5 \\
& Vrouw & 4,9 & 13 & 8,6 \\
\hline Totale productie & Man & 5,1 & 16 & 7,6 \\
& Vrouw & 4,2 & 68 & 7,8 \\
& Totaal & 3,6 & 93 & 7,2 \\
\hline
\end{tabular}

Uit Tabel 23 blijkt dan dat er geen opvallende verschillen tussen het gemiddeld aantal vermeldingen voor mannelijke en vrouwelijke auteurs zijn waar te nemen, zowel in het algemeen als binnen de afzonderlijke genres, wanneer we de meest extreme waarden weglaten. De eerder waargenomen verschillen tussen de twee seksen zijn dus inderdaad te wijten aan enkele boeken van mannen die uitzonderlijk veel aandacht krijgen. De beschikbare data wijzen er zodoende niet op dat de sekse van de auteur een structurele rol van betekenis speelt, wanneer het om het aantal vermeldingen gaat waar boeken over moederschap op kunnen rekenen.

Net als bij de eerste dataset moeten we een slag om de arm houden bij het generaliseren van deze conclusies naar de oorspronkelijke populatie, omdat er sprake is van enige verschillen ten aanzien van de genreverdeling van de hier geanalyseerde 96 boeken ten opzichte van het oorspronkelijke corpus van 148 boeken. Wanneer we Tabel 24 met Tabel 12 vergelijken dan blijken de twee grootste genrecategorieen nog steeds de 'literaire roman, novelle' en de 'streek- en familieromans'. Het 
aandeel van de 'literaire roman, novelle' is nog steeds nagenoeg even groot. In het oorspronkelijke corpus is het aandeel $66,6 \%(n=148)$ en nu $66,7 \%(n=96)$. Maar het aandeel van de 'streek- en familieromans' is hier wel iets kleiner: $16,7 \%(n=96)$ ten opzichte van $19,6 \%$ ( $n=148$ ) eerst. Ook is het totaal aantal genres dat in de selectie van 96 is vertegenwoordigd, kleiner dan het aantal genres in het oorspronkelijke cohort van 148 boeken.

Tabel 24

Productie van fictioneel proza over moederschap vanaf 1995 per NUR-genre (dataset 2)

\begin{tabular}{lrc}
\hline NUR-genre & Absolute productie & $\begin{array}{c}\text { Aandeel van de totale productie van fictioneel } \\
\text { proza over moederschap in percentages }\end{array}$ \\
\hline literaire fictie algemeen & 4 & $4,2 \%$ \\
literaire roman, novelle & 64 & $66,7 \%$ \\
thriller & 1 & $1,0 \%$ \\
populaire fictie algemeen & 1 & $1,0 \%$ \\
historische roman (populair) & 1 & $1,0 \%$ \\
romantiek & 1 & $1,0 \%$ \\
streek- en familieromans & 16 & $16,7 \%$ \\
fictie overig algemeen & 1 & $1,0 \%$ \\
literaire fictie algemeen \& & 2 & $2,1 \%$ \\
literaire roman, novelle & & $4,2 \%$ \\
literaire roman, novelle \& & 4 & $1,0 \%$ \\
pockets literaire fictie & 1 & \\
romantiek \& streek- en fa- & & \\
milieromans & & \\
$n=96$ & &
\end{tabular}

\section{Discussie resultaten dataset 1 en 2}

Bij de eerste dataset lijkt er in eerste instantie sprake te zijn van een relatie tussen de vermelding van een boek over ouderschap in een van de dagbladen en de sekse van de auteurs. Wanneer we een en ander uitsplitsen naar het genre van de romans, dan blijkt dit niet het geval. Wel zijn er aanwijzigen voor een verband tussen het genre van een boek en de vermelding ervan in de onderzochte kranten. Er is daarnaast een sterke indicatie voor het bestaan van een relatie tussen het aantal vermeldingen van boeken over ouderschap en de sekse van de auteur, waarbij mannelijke auteurs in het voordeel zijn ten opzichte van vrouwelijke auteurs. Bij de tweede dataset zijn aanwijzingen voor verbanden tussen het feit of een boek over moederschap überhaupt vermeld wordt, het aantal vermeldingen en sekse niet aanwezig of ze zijn niet sterk genoeg. Genre lijkt wel een rol te spelen, maar gezien het kleine aantal romans over moederschap dat hier kon worden geanalyseerd, kunnen we hier geen harde uitspraken over doen.

Dat een directe relatie met de sekse van de auteur niet altijd kon worden aangetoond, wil overigens niet zeggen dat sekse indirect geen invloed heeft op de vermelding van fictioneel proza over ouderschap en moederschap in de media. "De 
crux van [...] ongelijke behandeling [van de seksen] is [namelijk] niet altijd op het eerste oog zichtbaar" (Meijer, 1993, p. 124). Ook zeggen de uitgevoerde analyses niets over de wijze waarop boeken van mannelijke auteurs mogelijk anders worden gewaardeerd dan die van vrouwelijke auteurs. Uit onderzoek van Marije Groos (2000) naar de receptie van veertig romans in dag - en weekbladen die door Nederlandstalige schrijfsters tussen 1994 en 2000, blijkt dat stereotiepe opvattingen een rol spelen in de waardering van vrouwelijke auteurs. Er zijn echter ook positieve geluiden te melden. Een verkennende studie naar de receptie van hedendaagse vrouwelijke auteurs door Erica van Boven (2006) wijst er op dat sekse in de afgelopen decennia een minder grote rol is gaan spelen in de waardering van auteurs. De romans van vrouwelijke auteurs worden aan het einde van twintigste eeuw en het begin van de eenentwintigste eeuw vaak op dezelfde wijze beoordeeld als die van mannen (Van Boven, 2000). Daarbij kan en moet ten eerste worden aangetekend dat Van Boven (2006) er niet op ingaat in hoeverre de meetlat waarlangs vrouwelijke en mannelijke auteurs nu worden gelegd zelf mogelijk door sekse is gekleurd. Worden bepaalde onderwerpen en schrijfstijlen die doorgaans als 'mannelijk' worden beschouwd bijvoorbeeld hoger aangeslagen? Tegen deze achtergrond dringt zich de vraag op of de toegenomen waardering voor het werk van vrouwelijke auteurs ook geldt voor boeken waarin moederschap een centraal thema is; een thema dat vaak nog als 'vrouwelijk' wordt beschouwd. Om die vraag te beantwoorden zou er verder onderzoek gedaan moeten worden naar de inhoud van de krantenartikelen.

Daarnaast wijst Van Boven (2006) er echter ook op dat er, ondanks de vooruitgang die er is geboekt, nog een wereld is te winnen. De neiging om seksestereotiepe uitspraken te doen over de 'literaire' waarde van romans, vaak ten nadele van vrouwelijke auteurs of lezers, behoort vandaag de dag niet volledig tot het verleden. In de hier onderzochte recensies in de NCC komen we ze ook tegen. Zo wordt van de streek- en familieroman De zoon van Sofie (2007) van Karin Peters gezegd dat het een "makkelijk leesbaar boek [is] voor een grote groep vooral vrouwelijke lezers" (Ohio College Library Center, geen datum b). Door op deze manier de toegankelijkheid van het boek te koppelen aan de sekse van het publiek, wordt er al dan niet bewust een verband tussen beide zaken gesuggereerd. De impliciete en wellicht onbedoelde boodschap lijkt hier te zijn dat gemakkelijke boeken er voor vrouwen zijn of dat vrouwen vooral in gemakkelijke boeken zijn geïnteresseerd. Dit is niet het enige voorbeeld van een recensie waarin er een relatie tussen de sekse van het lezerspubliek en de toegankelijkheidsgraad van een boek wordt gelegd. De literaire roman Het eiland van mijn vader (2003) van Albertine Sterk wordt bijvoorbeeld als volgt omschreven: "Het verhaal is sterk en leest makkelijk, maar de karakters zijn nogal zwart-wit en blijven oppervlakkig. Het zal vooral een vrouwelijk publiek trekken" (Ohio College Library Center, geen datum c). Over Renate Dorresteins literaire roman Mijn zoon heeft een seksleven en ik lees mijn moeder roodkapje voor (2006) 
wordt gezegd dat de stijl "toegankelijk [is] en het boek zal vooral een breed publiek van vrouwen in de middelbare leeftijd aanspreken" (Ohio College Library Center, geen datum d). Het hoofdpersonage in Dorresteins roman is zelf ook een vrouw van middelbare leeftijd. In de recensie wordt een verband gelegd tussen de eigenschappen van het hoofdpersonage en het soort lezer dat volgens de auteur van de recensie in het boek geïnteresseerd zal zijn. Dit type uitspraken wordt opmerkelijk genoeg vooral over romans van vrouwelijke auteurs gedaan. Slechts in één recensie over een prozawerk van een mannelijke auteur wordt er naar de sekse van het lezerspubliek verwezen. Deze betreft de literaire roman Verdoken vader (2007) van Frans Ouweland. Daarover valt het volgende te lezen:

\footnotetext{
Dit boek kan men een echt mannenboek noemen zowel qua inhoud als taalgebruik. Stoere mannelijke taal, mannelijke interesse-sferen [sic], mannelijke probleembenaderingen, mannelijke oplossingen. Het boek leest over het algemeen vlot, maar wanneer het bijvoorbeeld over politiek gaat, maken discussies dat de voortgang van het verhaal wat hapert. Een allereerst voor mannen, maar ook voor andere geïnteresseerden in de vader-zoonverhouding boeiend verhaal. (Ohio College Library Center, geen datum e)
}

Er wordt een verband gelegd tussen het mannelijke onderwerp, het mannelijke taalgebruik, wat die ook mogen zijn, en de mannelijke sekse van de potentieel geïnteresseerde lezers. Opmerkelijk genoeg wordt er in de laatste regel op gewezen dat de roman ook interessant is voor andere dan mannelijke lezers. Dat gebeurt niet bij de boeken die aan vrouwen worden aanbevolen.

\section{Conclusie}

In dit hoofdstuk heb ik vooral willen onderzoeken of moederschap in literaire fictie voornamelijk wordt geproblematiseerd. Op basis van een kwantitatieve analyse van de samenvattingen en recensies in de NCC van boeken uit het grootste fictionele literaire genre dat bij de analyse van de tweede dataset naar voren kwam - de 'literaire roman, novelle' - kan de conclusie worden getrokken dat moederschap vooral wordt verbeeld in relatie tot problemen. Die verbeelding van moederschap in literaire fictie maakt deel uit van een meer algemene tendens om niet alleen moederschap, maar ook ouderschap op een niet rooskleurige wijze voor te stellen. Deze trend beperkt zich niet alleen tot literaire genres, maar strekt zich ook uit naar een genre als 'streek- en familieromans'. Contemporain, Nederlands, fictioneel proza lijkt een domein waarin ouderschap en moederschap op systematische wijze met ongeluk worden verbonden.

Er zijn wel enkele nuanceverschillen aan te wijzen in de manieren waarop problemen van gezinnen gestalte krijgen. Dit blijkt uit de vergelijking van de twee grootste genres de 'literaire roman, novelle' en de 'streek- en familieromans'. Daaruit kwam bij beide datasets naar voren dat er in het hiergenoemde literaire genre 
bijvoorbeeld iets meer aandacht voor thema's als migratie en oorlog bestaat, terwijl in de 'streek- en familieromans' thema's als religie, een buitenechtelijke zwangerschap of adoptie-, stief-, of pleegouderschap het goed doen. De analyse van de twee datasets wijst er verder op dat vrouwelijke auteurs meer fictioneel proza over ouderschap en moederschap publiceren dan mannelijke auteurs. Kijken we alleen naar de 'literaire roman, novelle' dan vormen mannen een kleine meerderheid wanneer het om boeken over ouderschap gaat, maar afgezet tegen de beschikbare cijfers over de algemene productie van fictioneel proza en de literaire genres zijn vrouwen met $46,2 \%$ hier opvallend goed vertegenwoordigt. Bij boeken die alleen met de zoektermen met betrekking tot moederschap zijn gevonden (de tweede dataset), vormen vrouwen een meerderheid van $68,2 \%$.

Het laatste doel van dit hoofdstuk was om een indruk te krijgen van de culturele reikwijdte van fictioneel proza over ouderschap en moederschap, en literaire fictie in het bijzonder, via een analyse van de representatie van de boeken in vijf dagbladen. Van het proza uit de eerste dataset dat vanaf 1995 is gepubliceerd, wordt iets minder dan de helft in de dagbladen genoemd. Bij de tweede dataset is dit iets meer dan de helft. Een relatie tussen vermelding in de dagbladen en de sekse van de auteur is voor romans over ouderschap niet aan te tonen, maar genre lijkt een rol van betekenis te spelen. Er is wel een sterke indicatie voor een verband tussen het aantal vermeldingen en de sekse van de auteurs. Daarbij blijken mannen in het voordeel te zijn. Hun boeken worden aanzienlijk vaker genoemd in de kranten dan die van vrouwelijke auteurs. Over de boeken over moederschap kunnen we eigenlijk geen harde uitspraken doen over mogelijke verbanden tussen sekse, genre en (het aantal) vermelding(en) in de dagbladen, vanwege de lage celvullingen en het kleine aantal boeken dat kan worden geanalyseerd binnen de verschillende genres.

De kwantitatieve analyses in dit hoofdstuk hebben een aantal beperkingen. Ten eerste blijkt de analyse van de thema's een voor dit onderzoek incompleet beeld op te leveren. Infanticide, dat door recensenten en literatuurwetenschappers nochtans is aangeduid als een belangrijk thema in literaire fictie in het licht van het bestaan van een geïdealiseerd beeld van moederschap, kwam niet voor in de onderzochte samenvattingen en recensies. Bij de inventarisatie van de NUR-genres bleef de 'literaire thriller' buiten beeld, terwijl dit genre door critici wel in verband is gebracht met ouderschap en het gezinsleven. Daarbij doet de typering van een boek in de vorm van meestal één, hooguit drie genres geen recht aan de vaak generische complexiteit ervan. Een van de belangrijkste beperkingen bij het beantwoorden van de centrale vragen in dit onderzoek, is dat er op basis van de samenvattingen en recensies uit de NCC nauwelijks iets gezegd kan worden over de relatie van het onderzochte proza tot het vertoog van genieten. Hiervoor zijn interpretaties van de romans nodig die in de volgende hoofdstukken centraal zullen staan. 



\section{Hoofdstuk 3}

\section{Theoretische overwegingen}

\section{Een ontmoeting tussen romaninterpretaties en literatuursociologie}

Literatuursociologische analyses van de materiële en symbolische productie van literatuur zoals die in het vorige hoofdstuk aan bod zijn gekomen, treffen we niet vaak aan in onderzoeken waarin het maken van kwalitatieve interpretaties van romans centraal staat. Omgekeerd komen zulke interpretaties van romans nauwelijks voor in literatuursociologisch onderzoek naar de productie van Nederlandse literatuur. De combinatie van romaninterpretaties en literatuursociologie in dit boek vereist daarom enige uitleg.

Verschillende literatuursociologen vinden de praktijk van de tekstuele analyse van romans in de regel te interpretatief en daarmee te speculatief, te subjectief en onwetenschappelijk (zie hierover bijvoorbeeld Cees van Rees, Susanne Janssen en Marc Verboord (2006) en Cees van Rees en Gilles Dorleijn (2006)). Zo wordt het proces van de interpretatie van literatuur als volgt omschreven in de inleiding van de literatuursociologische bundel De productie van literatuur. Het Nederlandse literaire veld 1800-2000:

\footnotetext{
Via introspectie en vanuit een essentialistische visie op het kunstwerk plachten zij normatieve literatuuropvattingen als instrumenten bij de interpretatie en evaluatie van literaire werken in te zetten, in de overtuiging zo de intrinsieke eigenschappen er van bloot te leggen. (Van Rees \& Dorleijn, 2006, p. 17)
}

In de introductie lezen we weinig tot niets over verschillende tradities van kwalitatieve interpretatie van literaire werken die in de afgelopen dertig à veertig jaar zijn ontstaan na bijvoorbeeld feministische, poststructuralistische postkoloniale kritiek op de hier beschreven manier van interpretatie (zie bijvoorbeeld Meijer, 1996c). Sindsdien hebben verschillende literatuurwetenschappers waaronder New Historicists juist rekenschap van het interpretatieve gehalte van hun werk gegeven. Zij stellen zich niet tot doel om vaststaande, intrinsieke betekenissen van romans bloot te leggen en maken juist inzichtelijk en navolgbaar hoe hun interpretaties tot stand komen. Het in het bovenstaande citaat geschetste beeld geeft daarmee op zijn hoogst slechts één manier weer waarop romans worden geïnterpreteerd in de literatuurwetenschap. Daarbij komt dat er te snel voorbij lijkt te worden gegaan aan het feit dat literatuursociologische analyses van de productie van literatuur in zekere zin ook subjectief, d.w.z. interpretatief zijn, zelfs wanneer het om puur kwantita- 
tieve analyses van de materiële productie gaat. In analyses van de materiële productie van romans, zoals die in het vorige hoofdstuk aan bod zijn gekomen, wordt dit interpretatieve element zichtbaar. De kwantitatieve analyses zijn om te beginnen gebaseerd op interpretaties van de genres van de romans door medewerkers van uitgeverijen en het Centraal Boekhuis. Zij bepalen immers de NUR-code van een boek en dit vraagt om interpretatie. Ook in de verzameling van de data zit een interpretatief element. Er is immers besloten om de data op een bepaalde manier af te bakenen en daar komt in een bepaald opzicht ook interpretatie bij kijken. Welke auteurs bijvoorbeeld als Nederlands worden beschouwd, is een kwestie van interpretatie en staat open voor discussie. Ten slotte, is het duiden en verklaren van bepaalde stijgingen of dalingen in de cijfers ook interpretatief werk. Dit soort interpretatieve momenten zijn inherent aan elk kwantitatief, literatuursociologisch onderzoek naar de materiële productie van literatuur.

De kloof tussen kwantitatieve literatuursociologische analyses en romaninterpretaties is daarmee wellicht niet zo groot als die soms wordt verondersteld te zijn. Dit geldt al helemaal wanneer we naar literatuursociologische onderzoeken kijken, waarin kwalitatieve methodes worden gebruikt om de symbolische productie van romans te ontrafelen. Niet voor niets acht Gilles Dorleijn (2009) het nuttig en mogelijk om instrumenten die voor de tekstuele analyses van romans zijn ontwikkeld in te zetten in literatuursociologisch onderzoek naar de symbolische productie van literatuur. Hij laat zien hoe ze bijvoorbeeld behulpzaam kunnen zijn bij het duiden van de receptie van romans. Het belangrijkste verschil tussen literatuursociologisch onderzoek naar de productie van literatuur en onderzoek dat om de interpretatie van romans draait, ligt dan ook eerder in het soort vragen dat men beantwoord wil zien. Volgens Dorleijn (2009) is de literatuursocioloog geïnteresseerd in de institutionele context waarbinnen literatuur wordt geproduceerd en dus niet in het betekenispotentieel van de roman zelf. En juist daarom worden beiden typen onderzoek weinig gecombineerd: ze beogen iets anders te doen. Volledige integratie van beide perspectieven in een onderzoek is daarom haast onmogelijk, maar Dorleijn (2009) stelt dat het - naast het gebruik van instrumenten uit de romaninterpretatie in de literatuursociologie - mogelijk en van toegevoegde waarde kan zijn om literatuursociologische analyses in te zetten in een onderzoek dat op de interpretatie van romans is gericht.

In dit boek wordt duidelijk dat dit voorstel van Dorleijn (2009) inderdaad hout snijdt. De methodes vullen elkaar aan bij het beantwoorden van de centrale vragen die hier worden gesteld. De institutionele analyse van de productie heeft het mogelijk gemaakt om zicht te krijgen op bredere tendensen in het literaire veld. Zo kunnen we niet alleen de aanname die aan dit onderzoek ten grondslag ligt onderzoeken, maar wordt het mogelijk om de vier case studies en hun betekenissen in een bredere context te plaatsen. De interpretaties van de case studies maken het op hun beurt mogelijk om het betekenispotentieel van romans in relatie tot de maat- 
schappelijke context verder te bestuderen. De keuze voor de te interpreteren boeken kan in het verlengde van de uitkomsten van de kwantitatieve analyse van romans over moederschap (de tweede dataset) in de Nederlandse Centrale Catalogus [NCC] worden gezien en als een aanvulling op de beperkingen ervan. In wat volgt wordt deze keuze verder toegelicht. Daarna wordt de kwalitatieve methode die wordt gebuikt om de romans te interpreteren uiteengezet.

\section{De keuze voor de vier romans}

In de volgende vier hoofdstukken staan achtereenvolgens de kwalitatieve interpretaties van de romans De reis naar het kind (1989) van Vonne van der Meer, Nieuwe buren (2006) van Saskia Noort, Een hart van steen (1998) van Renate Dorrestein en Met onbekende bestemming (2000) van Maya Rasker centraal. Het centrale onderwerp van de romans is de eerste en belangrijkste factor geweest in hun selectie. Er is met deze vier romans expliciet gekozen voor werken waarin het juist om het type moederschap draait dat in maatschappelijke context vaak wordt geïdealiseerd: blank, middenklasse, bewust gekozen moederschap in de context van een heteroseksueel kerngezin. Twee van de vier romans gaan daarbij specifiek over vrouwen die ongewild kinderloos zijn: De reis naar het kind (Van der Meer, 1989) en Nieuwe buren (Noort, 2006). De andere twee romans draaien om een moeder die haar kind(eren) vermoordt: Een hart van steen (Dorrestein, 1998) en Met onbekende bestemming (Rasker, 2000). Ongewilde kinderloosheid kwam bij de kwantitatieve

analyse van de samenvattingen en recensies van de boeken over moederschap (de tweede dataset) in het vorige hoofdstuk als een van de kleinere thema's uit de bus. Romans over ongewilde kinderloosheid zijn in het kader van dit onderzoek interessant, omdat ze niet alleen over een verlangen naar moederschap gaan, maar ook over moederschap zelf. Als een kinderwens niet of moeilijk is te verwezenlijken, dringt de vraag wat het betekent om moeder te zijn en wat de personages nu eigenlijk mislopen, zich immers op. Bij de kwantitatieve analyse kwamen romans waarin moeders hun kinderen naar het leven staan niet aan de orde. Infanticide is door literatuurwetenschappers als Rosemarie Buikema en Elisabeth Wesseling (2000, 2006) echter expliciet in verband gebracht met een rooskleurig beeld van moederschap en zij gaan daarbij expliciet in op Een hart van steen (1998) van Dorrestein. In recensies van Raskers Met onbekende bestemming (2000) wordt er een zelfde verband gelegd. In het kader van dit onderzoek zijn deze romans uitermate interessante cases, vanwege hun gespannen relatie tot hedendaagse idyllische beelden van moederschap. Om deze reden, en als aanvulling op de kwantitatieve analyses uit het vorige hoofdstuk, is er voor Een hart van steen (Dorrestein, 1998) en Met onbekende bestemming (Rasker, 2000) gekozen. Dit geldt ook voor de twee geselecteerde romans over kinderloosheid. De reis naar het kind (Van der Meer, 1989) en Nieuwe buren (Noort, 2006) zijn door hun auteurs of critici eveneens in verband 
gebracht met elementen uit het vertoog van genieten over moederschap. Zo blijkt uit een interview met Vonne van der Meer (Schouten, 1989) dat ze haar roman De reis naar het kind (1989) onder andere ziet als een commentaar op het idee dat we simpelweg voor het krijgen van een kind kunnen kiezen. En Saskia Noort benadrukt in een interview in de Volkskrant naar aanleiding van haar dan net verschenen roman Nieuwe Buren (2006) dat ze over de beperkingen van het hedonisme schrijft, "over de verplichting van het NU genieten" (Van den Bergen, 2006). De interpretaties die critici, lezers en auteurs zelf van de romans hebben gegeven, worden als betekenissen beschouwd die al door de romans zijn geproduceerd. Deze vormen een uitgangspunt bij de keuze voor deze vier romans.

Ongewilde kinderloosheid vertegenwoordigt een kant van het krijgen en hebben van kinderen, die lastig valt te rijmen met het idee dat we simpelweg voor kinderen kunnen kiezen, zoals Van der Meer (Schouten, 1998) zelf al heeft aangegeven. Het lijkt moeilijk in te passen in de moderne, individualistische maakbaarheidsretoriek, in de 'psychology of choice' waarmee het rooskleurige beeld van moederschap zo sterk is verbonden. Er bestaat vandaag de dag binnen westerse, moderne samenlevingen, waaronder Nederland, een wijdverspreid geloof in het idee dat wij met behulp van anticonceptiemiddelen en vruchtbaarheidstechnologieën, zoals IVF, haast onbeperkte controle op dergelijke keuzes hebben. Dit ondanks de aanzwellende kritiek op het idee van maakbaarheid in het denken over mens en maatschappij. ${ }^{84}$ Het gros van de mensen dat besluit om aan kinderen te beginnen, is zich er dus niet bewust van dat die keuze voor kinderen niet gerealiseerd zou kunnen worden door onvruchtbaarheid of verminderde vruchtbaarheid (Dykstra en Hagestad, 2007). Ook beseffen mensen vaak niet dat hier niet altijd iets aan gedaan kan worden met behulp van vruchtbaarheidstechnologieën (Dykstra en Hagestad, 2007). De klap van ongewilde kinderloosheid komt hierdoor waarschijnlijk zelfs harder aan dan ongeveer vijftig jaar geleden en is voor vrouwen en mannen vaak een zeer emotionele en zelfs traumatische ervaring (Dykstra \& Hagestad, 2007). Dat het beeld van een moeder die haar kinderen vermoordt haaks op de hedonistische inkleding van het moederschap staat, hoeft geen betoog. Het is een zeer extreme, zo niet de meest extreme, confronterende voorstelling van het moederschap. Een lezing van dergelijke op het eerste oog van de norm afwijkende romans kan ons inzicht in de werking van het maatschappelijke vertoog van genieten over moederschap mijn inziens verdiepen. Juist wanneer onderwerpen en ervaringen niet gemakkelijk in een vertoog zijn in te passen, wanneer het wringt, wordt immers duidelijk wat de structurerende normen en regels zijn die dit vertoog vormen. Daarnaast verschaft interpretatie van deze romans hopelijk inzicht in manieren om aan dit vertoog te ontsnappen. Als literatuur normondermijnend kan zijn, dan hebben we

\footnotetext{
${ }^{84}$ Zie bijvoorbeeld Jan Willem Duyvendak en Ido de Haan (1997).
} 
mijns inziens de grootste kans om dit potentieel daar aan te treffen. Door aandacht te besteden aan potentieel alternatieve verbeeldingen van moederschap wordt er hier een poging gedaan om een tegenwicht aan de normatieve invloed van het vertoog van genieten te bieden. In dit opzicht sluit dit onderzoek aan bij gender studies, dat inzicht verschaft in de culturele constructies van de verhoudingen tussen vrouwen en mannen. Het doel is hierbij om kennis te genereren die het mogelijk maakt om ongelijkheden tussen de seksen effectief ter discussie te stellen en te transformeren (Ramazanoglu \& Holland, 2002). Hierbij dient Judith Butlers Gender trouble (1990) als inspiratiebron. ${ }^{85}$ Butler (1990) stelt dat alle manifestaties van sekseverschillen, ook lichamelijke verschillen, tot op zekere hoogte sociaal geconstrueerd zijn. Daarmee ontkent ze niet dat er biologische verschillen zijn, maar wel dat die er pas op bepaalde manieren toe gaan doen in relatie tot culturele praktijken. Daarom beperkt Butler (1990) zich tot het gebruik van één woord om naar allerlei verschillen tussen mannen en vrouwen te verwijzen: gender. Butlers visie op sekseverschillen wordt hier onderschreven. Vanwege de leesbaarheid is er in dit boek echter voor gekozen om het Nederlandse woord sekse in plaats van het Engelse woord gender te gebruiken. Deze term wordt echter met dezelfde intentie gebruikt als de manier waarop Butler het woord gender inzet.

$\mathrm{Er}$ is gekozen voor vier romans van als vrouwelijk gepercipieerde auteurs. Daarmee zijn deze werken, wat betreft sekse, representatief voor de grootste groep auteurs die over moederschap publiceren, zoals bij de kwantitatieve analyse van de tweede dataset naar voren kwam. Hoewel de waardering voor het werk van vrouwelijke auteurs de afgelopen jaren is toegenomen, is er nog steeds een wereld te winnen wanneer het gaat om vooroordelen ten opzichte van het werk van vrouwelijke auteurs (Van Boven, 2006). Uit de analyse van de recensies in de NCC in het vorige hoofdstuk blijkt dat seksestereotiepe opvattingen in negatieve zin nog een rol lijken te spelen bij de beoordeling van romans van vrouwelijke auteurs over ouderschap in het algemeen en moederschap in het bijzonder. Jane Tompkins (1985) heeft er op gewezen dat literatuurwetenschappelijke interpretaties van het werk van vrouwelijke auteurs waarbij men ze op hun eigen merites beoordeelt, aan dit soort ongelijkheid een tegenwicht kan bieden. Dit is ook de reden waarom zij uitsluitend vrouwelijke auteurs bespreekt. Daarmee sluit Tompkins (1985) aan bij een in gender studies veel gehoord geluid (zie onder meer Maaike Meijer (1993)). De keuze voor vier vrouwelijke auteurs hangt in eerste instantie samen met het feit dat ze op basis van de verzamelde kwantitatieve gegevens de grootste groep auteurs vertegenwoordigen. Daarnaast wil ik hier met de keuze voor vier vrouwelijke auteurs hetzelfde als Tompkins (1985) doen. Het gaat me er daarbij niet om een bepaalde literaire status voor deze werken te claimen, maar wel om te laten zien

\footnotetext{
${ }^{85}$ Zie Halsema (2000) en Salih (2004) voor een uitgebreidere introductie in Butlers werk.
} 
dat ze een specifieke culturele rol spelen in het maatschappelijke veld en dat het interessant en relevant is om hier bij stil te staan. Studies waarin vanuit een gender studies-perspectief voornamelijk of alleen vrouwelijke auteurs worden onderzocht, lopen een zeker risico dat ze (bestaande) ongelijkheden tussen de seksen juist (re)produceren. Dit is het geval wanneer het werk van vrouwen en vrouwelijke auteurs als uniforme categorieën worden behandeld (Van Boven, 1992). Zeker bij een onderwerp als moederschap dat nog wel eens met vrouwelijke auteurs wordt geassocieerd, ligt dit gevaar op de loer. Door echter juist in te gaan op de individuele eigenschappen van de romans, wordt dit risico hopelijk afdoende ingeperkt.

Dit proefschrift behandelt romans die volgens de Nederlandstalige Uniforme Rubrieksindeling [NUR] als literaire fictie voor volwassenen kunnen worden beschouwd. Drie van de romans worden beschouwd als een 'literaire roman, novelle' en behoren dus tot het grootste NUR-genre, dat naar voren kwam bij de kwantitatieve analyse van romans over moederschap in de NCC. Dit zijn De reis naar het kind (Van der Meer, 1989), Een hart van steen (Dorrestein, 1998) en Met onbekende bestemming (Rasker, 2000). Daarnaast vertegenwoordigt Nieuwe buren (Noort, 2006) het NUR-genre 'literaire thriller'. Dit genre bleef bij de kwantitatieve analyse buiten beeld. Nieuwe buren (Noort, 2006) kan als een aanvulling op deze beperking van de kwantitatieve analyse worden beschouwd. Een andere reden voor de keuze voor een 'literaire thriller' is dat er in de Nederlandse literatuurwetenschap relatief gezien nog maar weinig tekstuele analyses zijn gemaakt van dit bij het grote publiek zeer populaire genre (zie Jos van Cann en Henri-Floris Jespers (2008)).

Ten slotte hebben deze vier werken een grote culturele reikwijdte. Het zijn romans die zowel binnen als buiten Nederland veel zijn gelezen en besproken. De reis naar het kind (1989) van Vonne van der Meer is verscheidene malen herdrukt ${ }^{86}$ en in het Duits en het Frans vertaald. Daarnaast is de roman genomineerd voor de Minerva Award for the European Novel of the Year (Willems, 2009). Het boek, dat onder meer over adoptie gaat, is bovendien opgenomen in leeslijsten op websites voor en door (aspirant) adoptieouders. ${ }^{87}$ In 2009 is filmmaakster Heddy Honigman begonnen met een verfilming van het boek (Van de Graaf, 2008). Nieuwe buren (Noort, 2006) heeft in het jaar van uitgave wekenlang op de eerste plaats van de lijst met de zestig meest verkochte boeken van de stichting Collectieve Propaganda van het Nederlandse Boek gestaan (Collectieve Propaganda van het Nederlandse Boek, geen datum). In 2008 was de roman aan haar zeventiende druk toe en inmiddels is Nieuwe buren (Noort, 2006) in het Deens en Bulgaars vertaald (Ambo/Anthos uitgevers en Buro TEXT, geen datum). Een hart van steen (1998) van Renate Dorrestein is zowel nationaal en internationaal een groot succes geweest. In het jaar van de eer-

\footnotetext{
${ }^{86}$ In 2009 is de roman aan de achtste druk toe. Dit is een jubileumuitgave ter gelegenheid van 75-jarige bestaan van Uitgeverij Contact (Picarta, 2009).

${ }^{87}$ Zie bijvoorbeeld www.adoptietrefpunt.nl en www.adoptie.nl
} 
ste uitgave zijn er in Nederland meer dan 35.000 exemplaren van verkocht (Collectieve Propaganda van het Nederlandse Boek, 1998). De roman heeft in Nederland in 2008 zijn negentiende druk beleefd en is in 16 andere landen gepubliceerd (Uitgeverij Contact, geen datum a). Een hart van steen (Dorrestein, 1998) is genomineerd voor de Trouw-Publieksprijs ${ }^{88}$ en The International IMPAC Dublin Literary Award (Uitgeverij Contact, geen datum b). Met onbekende bestemming (2000) is als debuutroman van Rasker eveneens zeer succesvol en veel gelezen. Het boek is in het Engels, Duits, Spaans en Hongaars vertaald en Rasker heeft er de Gouden Ezelsoor voor het best verkochte literaire debuut en de Vrouw \& Kultuur DebuutPrijs voor gekregen. De roman is bovendien genomineerd voor de ECI-prijs Schrijvers van Nu, en heeft "op de longlist van de Gouden Uil 2001 en [...] de Dublin IMPAC Literary Award" (Met onbekende bestemming, geen datum) gestaan.

\section{Methode}

Zoals in de inleiding uiteen is gezet, is dit boek gericht op de studie van interferenties tussen literatuur en maatschappij. Daarvoor wordt er een leesmethode gebruikt waarin aandacht voor intertekstualiteit een belangrijke rol speelt. Meer bepaald is die methode gebaseerd op Maaike Meijers (1996a) notie van intertekstualiteit.

Volgens Meijer (1996a) zijn er drie vormen van intertekstualiteit. De verwijzingen in een roman naar een andere bron waarbij die bron expliciet wordt genoemd, is de eerste van deze drie vormen van intertekstualiteit. Via aandacht voor deze vorm van intertekstualiteit wordt de verhouding tot andere (niet-literaire) bronnen op de meest directe manier zichtbaar. Bij de andere twee vormen is dat in mindere mate het geval. Dit is ten eerste een vorm van intertekstualiteit waarbij het gaat om verwijzingen in een vertelling naar "meer omvattende 'cultuurteksten' (discoursen) waarvan de bron niet meer is te achterhalen" (Meijer, 1996a, p. 38). Daarnaast kunnen we de verwijzingen in een specifieke literaire tekst naar bepaalde genres als een derde vorm van intertekstualiteit beschouwen. Het gaat dan om het gebruik van een voor een bepaald genre typerende plotstructuur of thematiek in een roman. Aandacht voor genre is een belangrijk ingrediënt in mijn interpretatiemethode. Daarmee wordt er aangesloten bij de observatie van verschillende Amerikaanse New Historicists dat de opkomst en het gebruik van bepaalde literaire genres niet los kunnen worden gezien van de maatschappelijke context waarin dit gebeurt. Zoals in de inleiding van dit boek aan de orde kwam, laten New Historicists als Stephen Greenblatt $(1983)$ en Tompkins $(1985,1993)$ in hun werk zien dat genres bij hun ontstaan vaak antwoorden op nieuwe ontwikkelingen in de maatschappij zijn, die in of via bestaande genres niet of minder gemakkelijk kunnen worden verwoord. Ook

\footnotetext{
${ }^{88}$ In 2003 omgedoopt tot de NS-Publieksprijs.
} 
worden bestaande genres om die reden aangepast of worden genres die uit de mode zijn geraakt opnieuw tot leven gewekt. Hiermee is niet gezegd dat literatuur enkel en alleen als het resultaat van maatschappelijke ontwikkelingen mag worden beschouwd. Literatuur drukt zelf ook haar stempel op de maatschappij, zoals Tompkins (1993) uitstekend heeft laten zien. Voortbordurend op deze inzichten wordt het, voor het beantwoorden van vragen naar de sociale functie en betekenis van literatuur, hier van belang geacht om de genreaspecten van romans te onderzoeken. Dit kan ons inzicht in de wijze waarop een roman met die maatschappelijke context in dialoog gaat immers vergroten.

Het instrumentarium van de structuralistische narratologie wordt ingezet om genre-invloeden op de romans te achterhalen. Daarbij vormen de instrumenten die Mieke Bal $(2007,1980)$ heeft ontwikkeld de belangrijkste leidraad. De structuralistische narratologie is gericht op het systematisch blootleggen van de vorm van een vertelling, van de manier waarop een vertelling is opgebouwd, door onder andere plot, vertelinstanties en focalisaties te ontrafelen. Bal deelt een vertelling daartoe op in drie te analyseren lagen: de "geschiedenis", "het verhaal" en "de tekst". Met de term geschiedenis verwijst ze naar "de stof die tot een verhaal wordt bewerkt" (Bal, 1980, p. 15). De geschiedenis bestaat met andere woorden uit "een serie logisch en chronologisch aan elkaar verbonden gebeurtenissen, die worden veroorzaakt of ondergaan door 'acteurs'" (Bal, 1980, p. 13). Het gaat hier dus om de geschiedenis die in een vertelling uit de doeken wordt gedaan in haar 'oorspronkelijke' logische en chronologische vorm. Het gaat om de 'diepste' laag van een vertelling, die niet als zodanig aan lezers wordt gepresenteerd, maar die lezers zelf achteraf kunnen reconstrueren op basis van wat hen in een roman wordt voorgeschoteld. Op het niveau van het verhaal gaat het om de wijze waarop de elementen uit onderliggende geschiedenis zijn georganiseerd. Het gaat dan bijvoorbeeld om de ordening in tijd, de uitwerking van karakters tot personages en de focalisatie(s). Onder focalisatie verstaat Bal het perspectief van waaruit een vertelling of een deel daarvan wordt gerepresenteerd. De betekenissen die aan de locaties waar de gebeurtenissen zich afspelen worden toegekend door personages en vertellers behoren eveneens tot dit niveau. Bal spreekt van "ruimte" (1980, p. 101) om naar deze tekstueel geconcretiseerde locaties of plaatsen te verwijzen. De term tekst verwijst ten slotte naar het oppervlakteniveau van een vertelling, waarin het gaat om de wijze waarop het verhaal wordt geformuleerd. Op dit niveau spelen zaken als woordkeuze en vertelinstantie een rol. Deze termen worden in de volgende vier hoofdstukken gebruikt zoals Bal $(1980,2007)$ dit doet, met een uitzondering voor de termen verhaal. Deze wordt soms ook op conventionele wijze gebruikt om naar korte vertellingen te verwijzen.

De structuralistische narratologie wordt in dit proefschrift niet alleen benut om de generische invloeden beter te kunnen traceren, maar ook om de wijze waarop moederschap wordt verbeeld in de vier romans en de unieke wijze waarop dat in 
ieder van de romans gebeurt, beter te kunnen onderzoeken. Daarbij wordt er in samenhang met de verbeelding van moederschap ook aandacht besteed aan de wijze waarop vaderschap in de romans wordt gerepresenteerd, vanuit het idee dat beide categorieën elkaar vormen (zie Deborah Chambers, 2001). Zo kunnen zowel de overeenkomsten als de verschillen tussen de werken in detail worden onderzocht en kan er recht worden gedaan aan de diversiteit van de romans. 



\section{Hoofdstuk 4}

\section{Het sprookje van genieten} ondermijnd? De reis naar het kind (1989) van Vonne van der Meer

\section{Inleiding}

Het krijgen en hebben van kinderen is een terugkerend thema in de romans en verhalenbundels van Vonne van der Meer. Over de rol van kinderen in haar werk zei Van der Meer zelf, dat "[e]en boek zonder kind [...] als een stad zonder park" is (Van Soest, 2002). Vooral de relaties tussen vrouwen en hun (ongeboren) kinderen komen op verschillende manieren aan bod in Van der Meers oeuvre. Zo gaat het verhaal Take me to the Bullfight uit haar debuutbundel Het limonadegevoel en andere verhalen (Van der Meer, 1985) ${ }^{89}$ over een vrouw die doet alsof ze zwanger is en de buitenwereld hiervan overtuigt door een kussen voor haar buik te binden. Daarnaast bevat de bundel het autobiografisch getinte Afscheid van Phoebe over het baren van een tijdens de zwangerschap gestorven kind. ${ }^{90}$ In de trilogie Eilandgasten (1999), De avondboot (2001) en Het laatste seizoen (2002) waarmee Van der Meer bij het grote publiek bekend is geworden, komen onderwerpen als zwangerschap, ongewilde kinderloosheid en abortus aan bod. De thematiek wordt door Van der Meer echter in het bijzonder uitgewerkt in de in 1989 voor het eerst gepubliceerde roman De reis naar het kind (2002/1989) over de pogingen van een echtpaar om een kind te adopteren. Uit onderzoek naar Engelstalige adoptieromans blijkt dat heersende opvattingen over moederschap en vaderschap in dit soort romans vaak worden blootgelegd en kritisch onderzocht (Novy, 2008, 2007). De verwachting is dat dit ook voor De reis naar het kind (Van der Meer, 2002/1989) geldt en dat het juist ook daarom interessant is om deze roman hier aan een nader onderzoek te

\footnotetext{
${ }^{89}$ Waarvoor ze de Geertjan Lubberhuizen-prijs heeft ontvangen (Letterkundig Museum, 2009).

${ }^{90}$ Van der Meer gaat in verschillende interviews in op het autobiografische karakter van dit verhaal (Van Marle, 1988; Sas, 1986).
} 
onderwerpen. Hedendaagse Nederlandse adoptieromans zijn tot nog toe nauwelijks bestudeerd. Het meeste onderzoek richt zich op Engelse en Amerikaanse literatuur. ${ }^{91}$ De interpretatie van deze roman brengt daarin hopelijk verandering.

De reis naar het kind (Van der Meer, 2002/1989) gaat over de belevenissen van Julia, onderwijzeres klassieke talen, en Max, architect. Ze willen graag kinderen krijgen, maar ze slagen er niet in om een kind te verwekken. Daarop proberen zij eerst op legale wijze en daarna via het illegale circuit een kind te adopteren, waarvoor zij naar Lima in Peru reizen. De gebeurtenissen spelen zich grofweg af in de periode van 1983 tot 1987 en worden beschreven door wat Mieke Bal (1980) een externe, niet-personage gebonden verteller noemt. Deze beschrijft de geschiedenis vanuit Julia's perspectief en zij fungeert zodoende als de belangrijkste focalisator. Haar verlangen naar een kind, haar ideeën over het moederschap en haar ervaringen met adoptie staan centraal in de roman. De ontwikkelingen rondom de voorgenomen illegale adoptie nemen halverwege de vertelling een bijzondere wending. Een van de tussenpersonen die Julia en Max tegen betaling helpt bij het vinden van een kind, bedriegt hen. Julia is inmiddels alleen in Peru, omdat Max vanwege zijn werk terug naar Nederland is gereisd. De tussenpersoon brengt Julia naar een oud, donker huis en vertelt haar dat haar kind, een jongetje, zich in dit huis bevindt. Eenmaal binnen denkt Julia in eerste instantie inderdaad het haar beloofde jongetje in een rieten stoel te hebben aangetroffen. In de duisternis lijkt hij met zijn tandeloze glimlach en kale hoofd niet ouder dan een half jaar. Maar wanneer ze haar hand langs de wang van het jongetje laat glijden, voelt ze baardstoppels en zo komt ze tot de ontdekking dat er geen kind, maar een oude man van tachtig à negentig jaar in de stoel zit. De foto van deze man staat ook op het paspoort en de papieren die ze in verband met de adoptie heeft ontvangen, maar eerder geen blik waardig heeft gekeurd. Ze realiseert zich dat ze bedrogen is. De tussenpersoon is op dat moment al lang gevlogen. Wanneer ze achter het bedrog komt, besluit Julia om de oude man, die ze Pablo noemt, mee naar Nederland te nemen. Max denkt dat Julia met een kind zal arriveren en is geschokt wanneer hij in plaats daarvan de bejaarde man ontmoet. Hoewel hij aanvankelijk niets van Pablo wil weten, nemen Julia en Max hem in hun huis op. Dan blijkt Julia enige maanden later alsnog spontaan zwanger van Max te zijn. Kort na deze ontdekking sterft Pablo met zijn hand op Julia's zwangere buik.

De reacties van recensenten op De reis naar het kind (Van der Meer, 2002/1989) zijn wisselend. Literatuurcriticus Koos Hageraats (1989) is zeer teleurgesteld in de roman. Vooral het feit dat Julia een oude man in plaats van een kind aantreft en deze mee naar huis neemt, is hem een doorn in het oog. De wending

\footnotetext{
${ }^{91}$ Zie voor exemplarische voorbeelden de door Marianne Novy geredigeerde bundel Imagining adoption. Essays on literature and culture (2007).
} 
zou volgens hem de geloofwaardigheid van de roman aantasten. Van der Meer vertelt dat ook sommige lezers deze wending niet kunnen waarderen. In een interview in het NRC Handelsblad laat zij weten dat er lezers zijn, die haar hebben verteld dat ze "op het moment dat de vrouw in een stoel die oude man aantreft in plaats van een baby, het boek woedend hebben weggeslingerd" (Hellmann, 1996). Hageraats en deze lezers zetten de wending met andere woorden weg als een verkeerd element in de roman en beschouwen hem onder andere daarom als mislukt. Niet iedereen deelt deze mening. Diny Schouten (1989) is in Vrij Nederland bijvoorbeeld zeer te spreken over De reis naar het kind (Van der Meer, 2002/1989), evenals Jan Zandbergen (1989) in Intermagazine. Zij vinden de wending niet ongeloofwaardig, net zo min als Stefaan van Laere (1989) in zijn bespreking van het boek in het Vlaamse blad Dietsche Warande en Belfort. Hoewel hij kritisch is over de diepgang van de roman als geheel, noemt hij de wending juist "lovenswaardig" (Van Laere, 1989, p. 494). Van der Meer zelf is van mening dat de kritiek op de geloofwaardigheid van de wending ongefundeerd is. Ze suggereert dat die het gevolg is van het feit dat de roman als een realistische vertelling wordt benaderd. Zo moeten we de roman volgens haar echter niet lezen. Hoewel ze vindt dat haar werk tot op zekere hoogte van realistische signatuur is - er gebeurt niets in De reis naar het kind (Van der Meer, 2002/1989) dat in de werkelijkheid niet ook zou kunnen gebeuren - gaat het haar er om een op het eerste oog realistische vertelling te laten "ontsporen" (Hellman, 1996). ${ }^{92}$

Wanneer het om het keerpunt in de roman gaat, sluit deze interpretatie aan bij de lezingen van Schouten (1989), Zandbergen (1989), Van Laere (1989) en Van der Meer (Hellman, 1996) zelf. In wat volgt zal blijken dat de draai die er aan de gebeurtenissen wordt gegeven juist wel 'past' binnen de roman, omdat de roman ons er op verschillende manieren toe aanzet om de geschiedenis van Julia en Max als een fantastische, sprookjesachtige vertelling te benaderen. Wanneer we de roman op deze manier gaan lezen, dan blijkt De reis naar het kind (Van der Meer, 2002/1989) weg te voeren van het moderne vertoog van genieten over moederschap. Bovendien blijkt dan dat we de roman als een adoptiekritiek kunnen beschouwen. De aspecten van De reis naar het kind (Van der Meer, 2002/1989) die een zogenaamde fantastische leeshouding oproepen komen hier eerst aan bod. Daarna komt aan de orde hoe er aan elementen van het vertoog van genieten over moederschap in de roman worden gerefereerd. Vervolgens wordt besproken hoe deze bij een fantastische lezing, waarbij we de 'vreemde' wending in de roman niet als een misplaatst element aan de kant schuiven, op metaforische wijze op de korrel blijken te worden genomen. Omdat de geschiedenis vanuit Julia wordt verteld, richt deze interpretatie zich, net als de roman, voornamelijk op de wijze waarop haar onvervulde kinder-

\footnotetext{
${ }^{92}$ Zie hierover ook Schouten (1989).
} 
wens, haar ervaringen van het adoptieproces en haar ideeën over het moederschap worden verbeeld. Het vaderschap van Max komt echter ook aan bod.

\section{Een fantastische leeshouding}

De reis naar het kind (Van der Meer, 2002/1989) doet aanvankelijk realistisch aan. De term realisme wordt binnen de literatuurwetenschap doorgaans op twee manieren gebruikt. Ten eerste, om te verwijzen naar een Europese literaire stroming uit de negentiende eeuw. Ten tweede, om in meer algemene zin een stijl te beschrijven die als een waarheidsgetrouwe representatie van de werkelijkheid overkomt (Gorp, Delabastita \& Ghesquiere, 2007; Schipper, 1979; Van Dijk, 2001). Wanneer recensenten en Van der Meer het hebben over het realisme van De reis naar het kind (Van der Meer, 2002/1989), gebruiken zij de term op deze laatste manier. Met realistische romans worden dan boeken bedoeld die zo zijn geschreven, dat we ons kunnen voorstellen dat de vertelde gebeurtenissen in werkelijkheid hebben plaatsgevonden, hoewel ze fictioneel zijn. Realistische romans gaan dus niet over een waargebeurde geschiedenis, maar presenteren een fictieve geschiedenis op zo'n manier dat deze "waarschijnlijk" (Schipper, 1979, p. 5, p. 7) lijkt, terwijl we weten dat dit niet zo is. Wat we als een realistische stijl beschouwen, is afhankelijk van de literaire en maatschappelijke conventies in een bepaalde periode en verschuift daarom voortdurend. Hierdoor is het realisme van een roman per definitie beperkt houdbaar. Een roman kan enkel realistisch zijn voor een specifiek publiek in een bepaalde sociaalhistorische context.

Dat maakt het lastig zo niet onmogelijk om in algemene zin te bepalen wat een bepaalde stijl nu precies realistisch maakt. Literatuurwetenschapster Mineke Schipper (1979) doet in navolging van Phillipe Hamon (1973) echter een goede poging en formuleert algemene kenmerken van een realistische stijl, die mijns inziens ook vandaag de dag nog bruikbaar zijn. ${ }^{93}$ Een van die kenmerken is dat de personages in een realistische roman concreet en voorstelbaar zijn. In De reis naar het kind (Van der Meer, 2002/1989) zijn de personages Julia en Max concreet en dit maakt de stijl van de roman realistisch. Echter niet alle personages zijn op realistische wijze weergegeven. De contactpersonen die bij de illegale adoptie betrokken zijn, zijn ongrijpbaar. En ook Pablo's verleden en persoonlijkheid blijven mysterieus, tot grote frustratie van sommige recensenten (zie bijvoorbeeld Van Laere, 1989). Een tweede door Schipper (1979) genoemd kenmerk van een realistische vertelling is dat er vaak wordt verwezen naar de historische werkelijkheid. Zo ook in De reis naar het kind (Van der Meer, 2002/1989). Zo bevat de roman expliciete intertekstuele verwijzin-

\footnotetext{
${ }^{93}$ Of dit in de toekomst nog steeds het geval is, moet zich uitwijzen en is afhankelijk van veranderingen in onze opvattingen over de werkelijkheid en verschuivingen van literaire conventies.
} 
gen naar de adoptiewetgeving in Nederland uit de jaren tachtig. We kunnen lezen dat Julia en Max na hun veertigste wettelijk gezien geen kind meer mogen adopteren. In de periode dat de vertelling zich afspeelt, is het in Nederlands ook daadwerkelijk niet mogelijk om dan een kind te adopteren ('Regeling inzake de opneming in Nederland van buitenlandse kinderen met het oog op adoptie. Oorspronkelijke tekst van het voorstel van wet en van de memorie van toelichting zoals voorgelegd aan de raad van state en voor zover nadien gewijzigd. Vergaderjaar 1986-1987, Kamerstuk 20 046', 1987). ${ }^{94}$ Daarnaast bevat de roman een aantal verwijzingen naar bestaande plekken in Peru, zoals het vliegveld "Jorge Chavez" (Van der Meer, 2002/1989, p. 57), de wijk "Miraflores" (Van der Meer, 2002/1989, p. 60) en de straten, "Avenida Schell", "Plaza des Armes" en "Plaza St. Martin" (Van der Meer, 2002/1989, p. 58). Deze verwijzingen dragen bij aan een illusie van werkelijkheid.

Het is dan ook niet geheel verwonderlijk dat het boek als een realistisch werk is gelezen en dat lezers en recensenten verrast zijn door de wending die de roman neemt. Maar de gedeeltelijk realistisch aandoende stijl ten spijt, zijn er van meet af aan verscheidene aanwijzingen dat we hier met een vertelling te maken hebben, waarin de grenzen van de werkelijkheid flink worden opgerekt. Het gaat daarbij voornamelijk om intertekstuele verwijzingen naar andere, traceerbare bronnen en naar literaire genres. ${ }^{95}$ De roman stimuleert ons via deze verwijzingen om de geschiedenis van Julia en Max niet letterlijk te nemen. De reis naar het kind (Van der Meer, 2002/1989) roept met andere woorden een leeshouding op die we als fantastisch kunnen karakteriseren. Zo worden we voorbereid op de wending, die door recensenten bizar, absurd, fantastisch of grotesk is genoemd (Hageraats, 1989; Kossman, 1989; Van de Haar, 1998; Schouten, 1989; Bakker, 1993; Zandbergen, 1989).

\footnotetext{
${ }^{94}$ In principe mag de adoptieouder in deze periode niet ouder zijn dan veertig jaar. In uitzonderlijke gevallen mag de adoptieouder maximaal tweeënveertig jaar zijn. In het jaar dat De reis naar het kind (Van der Meer, 2002/1989) uitkomt, wordt de leeftijd iets opgerekt: bij interlandelijke adoptie mag de adoptieouder sinds 15 juli 1989 maximaal tweeënveertig jaar oud zijn en in uitzonderlijke gevallen niet ouder dan vierenveertig jaar (Beatrix, Korte-van Hemel, Korthals Altes, 1989;1 Korthals Altes1, 1988a). Het leeftijdsverschil tussen de aspirant adoptieouders en het te adopteren buitenlandse kind mag dan wel niet groter zijn dan veertig jaar (Korthals Altes1, 1988b). In 2000 zijn deze richtlijnen iets versoepeld en kan er in bijzondere gevallen een uitzondering worden gemaakt, wanneer een van de ouders ouder dan vierenveertig jaar is, maar niet ouder dan zesenveertig jaar (Cohen, 2000). Recent heeft de Commissie Kalsbeek een aanbeveling gedaan waardoor adoptieouders maximaal achtenveertig jaar zouden mogen zijn (Ministerie van Justitie, 2008). Momenteel is er geen leeftijdsgrens voor adoptie van Nederlandse kinderen door Nederlandse adoptieouder(s), maar de adoptieouder moet wel minimaal achttien jaar ouder zijn dan het te adopteren kind ('Burgerlijk wetboek, boek 1, artikel 228, eerste lid onder c', 2010). Voor 1998 mocht de adoptieouder bij adoptie in Nederland maximaal vijftig jaar zijn (Koens, 2006).

${ }^{95}$ Het gaat hier dus om de eerste vorm van intertekstualiteit die hier met Maaike Meijer (1996a) wordt gebruikt. Zie hoofdstuk 3 voor een nadere toelichting hierop.
} 
Nog voordat we de roman openslaan en deze intertekstuele verwijzingen tegenkomen, worden we echter al geconfronteerd met de eerste aanwijzing dat we hier niet met een 'eenvoudige' realistische roman te maken hebben. De titel van de roman, "de reis naar het kind" (Van der Meer, 2002/1989), moeten we bijvoorbeeld metaforisch opvatten. We maken een reis naar een land of een plek, maar de uitdrukking 'de reis naar het kind' is niet gangbaar. We zullen eerder geneigd zijn om de strekking van de titel als een metafoor te beschouwen, omdat zij anders weinig of zelfs niet betekenisvol zal zijn. De titel kan een puur realistische lezing van de roman zodoende al minder voor de hand liggend maken.

De eerste intertekstuele aanwijzing dat we de roman niet als een puur realistische vertelling moeten lezen, komen we tegen in het eerste hoofdstuk. Julia en Max brengen samen een weekendje op een van de Nederlandse Waddeneilanden door om hun relatie nieuw leven in te blazen en hun tiende huwelijksverjaardag te vieren. Ze hebben nog niet besloten om een kind te adopteren en zijn op dat moment twee à drie jaar bezig om zwanger te raken. Dat zij daarin niet slagen, heeft voor verwijdering tussen hen gezorgd. Wanneer Julia over hun moeizame relatie nadenkt, maakt zij een wandeling over het eiland. Die wandeling wordt door de verteller als volgt beschreven: "Eindelijk zette zij voet op het beter begaanbare gedeelte van het strand. De ribbels leken net bergen, haar laarzen de laarzen van Gulliver" (Van der Meer, 2002/1989, p. 15). Er wordt hier gerefereerd aan A voyage to Lilliput, de bekendste van de vier fantastische reisverhalen uit het boek dat bekend staat als Gulliver's travels (Swift, 1757/1726). ${ }^{96}$ In A voyage to Lilliput komt Gulliver in het land Lilliput terecht, waar alles aanzienlijk kleiner is dan in de wereld waar hij vandaan komt. Gulliver's travels (Swift, 1757/1726) wordt vanwege haar fantastische elementen als een satire beschouwd, waarin de achttiende-eeuwse Engelse samenleving op de hak wordt genomen (Gorp, Delabastita \& Ghesquiere, 2007). Daarnaast geldt het boek als een parodie van het reisverhaal. Kenmerkend voor het reisverhaal is dat "een reiservaring, gewoonlijk in een vreemd land, [er] een belangrijke rol [in] speelt, zonder dat ze echter een hoofdmotief van het werk moet zijn" (Gorp, Delabastita \& Ghesquiere, 2007, p. 399). Tot het genre worden ook vertellingen gerekend waarin de reis puur symbolisch of imaginair is. De reis naar het kind (Van der Meer, 2002/1989) is net als Gulliver's travels (Swift, 1757/1726) naar het genre van het reisverhaal gemodelleerd. In een groot deel van de roman staan immers Julia's reis naar Peru centraal en de (symbolische) reis naar het kind, waar de titel van de roman naar verwijst. Door deze genreovereenkomst met Gulliver's Travels (Swift, 1757/1726) wordt onze aandacht op de expliciete verwijzing naar Swifts werk gevestigd, waarvan we weten dat het een allesbehalve realistisch reisverhaal

\footnotetext{
${ }^{96}$ De oorspronkelijke, volledige titel van dit boek is Travels into several remote nations of the world, in four parts. By Lemuel Gulliver, first a surgeon, and then a captain of several ships (Swift, 1757/1726).
} 
is. Zo kan deze verwijzing vragen oproepen over het realistische gehalte van De reis naar het kind (Van der Meer, 2002/1989). De overeenkomst van de titel van Van der Meers roman met $A$ voyage to Lilliput wakkert mogelijke twijfels hierover aan. Hoewel de reis in De reis naar het kind (Van der Meer, 2002/1989) naar een in werkelijkheid bestaande plek voert, Lima in Peru, stuurt de in het oog springende verwijzing naar de fantastische reizen uit de vertellingen van Swift $(1757 / 1726)$ ons verder in de richting van een fantastische leeshouding.

Op zichzelf zijn deze aanwijzingen niet afdoende om De reis naar het kind (Van der Meer, 2002/1989) als een fantastische, sprookjesachtige vertelling te gaan lezen, maar er zijn andere en belangrijkere, intertekstuele verwijzingen die deze lezing bevorderen. Dit zijn verwijzingen naar het genre van het sprookje. ${ }^{97}$ Verscheidene literatuurcritici hebben op de invloed van dit genre gewezen in hun bespreking van De reis naar het kind (Van der Meer, 2002/1989) en sommigen categoriseren de roman zelfs als een modern, literair sprookje (Hageraats, 1989; Schouten; 1989; Dirksen, 1997; Van Laere, 1989). Om de invloed van het sprookje op de roman toe te lichten, eerst kort een bespreking van enkele centrale kenmerken van dit genre.

Het sprookje is een verhalend genre dat oorspronkelijk mondeling werd overgeleverd, maar dat sinds de zeventiende eeuw schriftelijke navolging heeft gekregen. ${ }^{98}$ In sprookjes voert het bovennatuurlijke en het magische de boventoon alsof het de normaalste zaak van de wereld is (Gorp, Delabastita \& Ghesquiere, 2007; Kardaun, 2009; Swann Jones, 2000). Het is een genre waarin er ruimte is voor excessen, doordat het vrij is van de beperkingen van realistische representaties, en waarin de wereld op zijn kop wordt gezet (Dekker, Van der Kooi \& Meder, 1997). Pratende spiegels, toverbonen, pompoenen die in koetsen veranderen, reuzen, dwergen, heksen en elfjes; in een sprookje worden ze met een bepaalde vanzelfsprekendheid opgevoerd. De kern van ieder sprookje is dan ook de verbeelding van de ons bekende wereld via stijlmiddelen als overdrijving, metonymie en metafoor (Swann Jones, 2002). Een ander kenmerk van het sprookje is dat de plotstructuur vaak berust op de zoektocht van het hoofdpersonage, waarvan het doel persoonlijk geluk is,"measured as a rule by domestic satisfaction and tranquility" (Swann Jones, 2002, p. 16). Niet voor niets eindigen veel sprookjes met een huwelijk tussen een prins en een door hem geredde prinses. Bij het bereiken van dat doel wordt het hoofdpersonage vaak gehinderd door allerlei obstakels, die meestal bovennatuurlijk van aard

\footnotetext{
${ }^{97}$ Het gaat dus bovenal om de derde vorm van intertekstuele verwijzingen die hier in navolging van Meijer (1996a) als een analytisch instrument worden benut. Zie hoofdstuk 3 voor een toelichting.

${ }^{98}$ Zie hierover onder andere Swann Jones (2002). De auteurs van de mondeling overgeleverde sprookjes zijn ons niet bekend. Dit in tegenstelling tot de auteurs van de schriftelijk sprookjes van latere datum. Er wordt mede daarom ook wel een onderscheid gemaakt tussen volkssprookjes enerzijds en cultuursprookjes of kunstsprookjes anderzijds. Met de volkssprookjes worden de mondelinge, anonieme sprookjes bedoeld en met de cultuur- of kunstsprookjes de geschreven sprookjes van ons bekende auteurs (Gorp, Delabastita \& Ghesquiere, 2007).
} 
zijn. Uiteindelijk slaagt hij of zij er in om zijn of haar doel te bereiken en de vertelling wordt dan doorgaans afgesloten met de frase 'en ze leefden nog lang en gelukkig'. Het hoofdpersonage kan in sprookjes bijna altijd op de (onbewuste) hulp rekenen van "helper" (Propp, 1997/1939, p. 105) personages ${ }^{99}$, vaak oude, wijze mannen of vrouwen. Dit zijn, zoals alle personages in sprookjes, per definitie platte personages, die enkel in de vertelling voorkomen zolang ze nodig zijn voor de ontwikkeling van het plot (Bal, 2007). ${ }^{100}$ Een derde kenmerk van sprookjes is daarmee al genoemd: de personages in sprookjes zijn plat en kennen geen diepgaande karakterontwikkeling (Kardaun, 2009). Dat de personages niet als individuen van vlees en bloed zijn bedoeld, komt vaak tot uitdrukking in hun namen. Het komt geregeld voor dat ze naar een eigenschap of een uiterlijk kenmerk zijn vernoemd of naar hun functie in de vertelling (Dekker, Van der Kooi \& Meder, 1997). Ten slotte is het in het kader van het onderwerp in dit boek belangrijk om op te merken dat het sprookje een genre is, waarin ongelukkige gezinnen figureren. Zo gaan veel sprookjes over (stief)ouders meestal stiefmoeders die hun kinderen naar het leven staan, zoals Sneeuwwitje, of over kinderen die door hun ouders worden verlaten, zoals Hans en Grietje.

De reis naar het kind (Van der Meer, 2002/1989) bevat een uitgebreide verwijzing naar het genre van het sprookje. Het tweede hoofdstuk van de roman bestaat namelijk in zijn geheel uit het begin van een door Julia verzonnen sprookje. Julia heeft dit sprookje in een schrift opgeschreven, nadat ze tot adoptie heeft besloten. Dat we met een sprookje te maken hebben, blijkt direct, omdat het hoofdstuk op een voor een sprookje typerende manier begint met de zinsnede "Er waren eens een man en een vrouw" (Van der Meer, 2002/1989, p. 21). De inhoud van dit sprookje vertoont sterke overeenkomsten met de geschiedenis in de roman zelf. Het gaat over een kinderloze man en vrouw, die net als Julia en Max wanhopig pro-

\footnotetext{
${ }^{99}$ In De morfologie van het toversprookje. Vormleer van een genre (1997/1939) probeert de Russische literatuurwetenschapper Vladimir Propp aan de hand van de functies die personages in sprookjes vervullen tot een universele classificatie van sprookjes te komen. Dit doet hij door een groot aantal varianten van Russische sprookjes met elkaar te vergelijken en op zoek te gaan naar overeenkomsten tussen die sprookjes. Op grond van deze exercitie komt hij tot een wetmatige formule van de basisvorm van alle sprookjes. Inmiddels is er terecht kritiek geformuleerd op verschillende aspecten van Propps structuralistische benadering van sprookjes. Voor een overzicht van deze kritiek verwijs ik naar Max Louwerse (1997). Een belangrijk punt van kritiek is dat de verschillen tussen individuele sprookjes in Propps werk uit het zicht raakt. Dat neemt echter niet weg dat helperpersonages inderdaad vaak een cruciale rol in sprookjes vervullen.

${ }^{100}$ Bal wijst er in dit verband terecht op dat het veelgemaakte onderscheid tussen platte en ronde personages nutteloos is voor de analyse van sprookjes, omdat alle personages in sprookjes plat zijn (Bal, 2007). Dit geldt ook voor andere genres waarin de personages per definitie meestal plat zijn, zoals de detective en de thriller. Omdat Bal (2007) een narratologisch model wil ontwikkelen dat toegepast kan worden op alle narratieve genres, maakt zij dan ook geen gebruik van dit onderscheid in haar analyses. Zo'n onderscheid voegt inderdaad weinig toe aan de analyse van conventionele sprookjes, het is wel nuttig voor de analyse van de invloed van dit genre op een roman als De reis naar het kind (Van der Meer, 2002/1989). Daarom wordt het onderscheid in dit hoofdstuk wel gebruikt.
} 
beren een kind te krijgen. Omdat de gewenste zwangerschap uitblijft, reist het koppel uit het sprookje stad en land af op zoek naar artsen die hen kunnen helpen. Maar niemand blijkt iets te kunnen doen, "want alles was in orde. Het lag niet aan haar en het lag niet aan hem, er hoefde niets weggehaald of ingeplant te worden, er viel niets te opereren, ze moesten geduld hebben" (Van der Meer, 2002/1989, p. 22). Maar hoeveel geduld ze ook hebben, een zwangerschap blijft uit. Het verlangen wordt er echter niet minder om, integendeel. Na drie jaar verzucht de vrouw zelfs dat ze bereid is om "alles, alles" te doen "in ruil voor een kind": "Als er een heks bestond ging ik ernaar toe. Ik zou de smerigste brouwsels drinken, in slangenpis baden, mijn haar laten groeien en het weer afknippen jaar in jaar uit als zij het me vroeg" (Van der Meer, 2002/1989, p. 23). Om hun kinderwens te vervullen, melden de man en vrouw zich bij een adoptiebureau. Het begin van het sprookje eindigt met de ontvangst van een brief van het adoptiebureau een jaar na hun inschrijving. In die brief staat dat ze "aan de beurt" (Van der Meer, 2002/1989, p. 24) zijn en dat er iemand langs zal komen om te bepalen of zij geschikte ouders zijn.

Het sprookje is overduidelijk een bewerking van de gebeurtenissen die Julia en Max tot op dat moment zijn overkomen. De manier waarop het sprookje in de roman is ingebed, wijst daar ook op. In het volgende hoofdstuk wordt de vertelling over Julia en Max voortgezet op het moment waarop het begin van het sprookje eindigt: iemand van het adoptiebureau komt op bezoek. Zo zet de roman ons er toe aan om niet alleen het tweede hoofdstuk, maar ook de rest van de roman als een sprookje te gaan lezen. Nu gaat het te ver om te zeggen dat De reis naar het kind (Van der Meer, 2002/1989) een conventioneel sprookje is. Een essentieel kenmerk van het sprookje ontbreekt immers. Hoe onwerkelijk de adoptie van de oude man misschien ook op ons overkomt, er wordt geen magische of bovennatuurlijke wereld in het leven geroepen. Bovendien is het hoofdpersonage Julia geen plat personage, want de nadruk ligt op de beschrijving van haar diepste zielenroerselen. lets wat in een sprookje niet zo sterk het geval zou zijn. Daarnaast is er geen sprake van een ongecompliceerd happy end, wat eveneens typerend is voor sprookjes. De roman eindigt wel optimistisch, Julia is immers zwanger, maar we kunnen er niet zeker van zijn of ze het kind daadwerkelijk gezond ter wereld zal brengen. Niettemin kan het ingebedde sprookje ervoor zorgen dat we de roman tot op zekere hoogte als een sprookje gaan benaderen. Een aantal andere intertekstuele verwijzingen naar het sprookje levert hier ook een bijdrage aan.

Ten eerste worden er een aantal sprookjesachtige dromen van Julia beschreven. In een van die dromen ontmoet Julia de biologische moeder van een net geboren kind dat zij wil adopteren. Zij smeekt Julia om haar kind niet mee te nemen en haar in plaats daarvan financieel te ondersteunen, zodat ze het kind zelf kan opvoeden. In haar droom is Julia onverbiddelijk, waarop de biologische moeder het kind in elkaar kneedt tot het niet groter is dan een kikker om het weer terug in haar baarmoeder te stoppen. Dat de beschrijvingen van Julia's dromen aan sprookjes doen 
denken, is niet verrassend. Niet voor niets hebben verscheidene literatuurwetenschappers op de nauwe verwantschap tussen de culturele functie van sprookjes en dromen gewezen. Ze zouden allebei uitdrukking geven aan onbewuste angsten en preoccupaties. Dromen doen dit op individueel niveau, terwijl in sprookjes onbewuste angsten en preoccupaties worden gerepresenteerd die in onze samenleving als geheel leven (Swann Jones, 2002).

Daarnaast put Van der Meer (2002/1989) bij de stilering van de roman tot op zekere hoogte uit het genre van het sprookje, wanneer het om de plotstructuur en de uitwerking van andere personages dan Julia en Max gaat. De reis naar het kind (Van der Meer, 2002/1989) is daarmee qua genre een vrij hybride werk en wordt niet alleen beïnvloed door het reisverhaal, maar ook door het sprookje. De invloed van het sprookje op het plot blijkt onder andere uit het feit dat het boek om een zoektocht naar persoonlijk, huiselijk geluk draait. Daarbij wordt Julia net als in sprookjes door allerlei obstakels belemmerd. Ze krijgt hierbij hulp van Pablo. Pablo is het voor sprookjes typerende helperpersonage. Hij is een plat personage dat omwille van de ontwikkeling van het plot wordt opgevoerd en zodra hij zijn functie heeft vervuld, verdwijnt door te sterven. De rol die Pablo vervult, komt later nog uitgebreider aan de orde. Pablo is overigens niet het enige platte personage. Buiten Julia en Max zijn haast alle personages plat en ze staan puur in dienst van de ontwikkeling van het plot. Die oppervlakkigheid van de personages hangt onder andere samen met de filmische, soms wat oppervlakkige, schetsende stijl die Van der Meer (2002/1989) hanteert. Daarnaast speelt het feit dat de focalisatie voornamelijk bij Julia ligt een rol. Hierdoor worden de meeste andere personages niet van binnenuit kenbaar. Het gebrek aan karakterontwikkeling van de personages wordt soms, net als in sprookjes, gemarkeerd door hun naam. Zo wordt de man die Julia in Peru helpt om een kind te vinden en die haar bedriegt, consequent en met een hoofdletter "Tussenpersoon" (Van der Meer, 2002/1989, p. 119) genoemd, naar de rol die hij in de vertelling vervult. Tot slot is het belangrijk om hier op te merken dat de roman een duidelijke moraal heeft en in dit opzicht zelfs tot allegorie neigt. Daarmee is De reis naar het kind (Van der Meer, 2002/1989) geen uitzondering in het oeuvre van Van der Meer. Ook andere romans en verhalen van haar hand zijn door literatuurcritici allegorisch genoemd (Chamuleau, 2004). Van der Meer wordt gezien als een auteur die, vanaf de publicatie van haar eerste boek, in ethische vragen geïnteresseerd is. Bij het smeden van een vertelling rondom deze morele kwesties, put Van der Meer onder andere uit sprookjes maar ook uit de Bijbel, de Griekse mythologie en legendes (Chamuleau, 2004). Allemaal premoderne bronnen waarin metaforen en symbolen van groot belang zijn. In De reis naar het kind (Van der Meer, 2002/1989) worden morele vragen rondom adoptie en moederschap, vooral met behulp van het sprookje op metaforische wijze verbeeld. Over de moraliserende aard van de roman straks meer. Voor nu volsta ik met de observatie dat de ge- 
noemde invloed van het sprookje op de plotstructuur en de vormgeving van de personages, een fantastische lezing van de roman kunnen bevorderen.

Wanneer we bereid zijn om De reis naar het kind (Van der Meer, 2002/1989) niet als een 'eenvoudige' realistische vertelling te benaderen, maar als een realistisch aandoende vertelling met een fantastische kant, dan doet de 'absurde' adoptie van de bejaarde man niet langer vreemd aan. In fantastische vertellingen en zeker in sprookjes gebeuren er immers voortdurend dingen die tegen de wetten van de realiteit ingaan en die we symbolisch kunnen duiden. Hoewel de ontmoeting met de oude man die wetten in wezen niet aantast, omdat deze in werkelijkheid zou kunnen plaats vinden, wordt deze ontmoeting wel geloofwaardiger wanneer we oog hebben voor de fantastische uitwerking van de geschiedenis van Julia en Max.

Wat betekent het nu voor onze interpretatie van de verbeelding van het verlangen naar een kind en van moederschap, wanneer we De reis naar het kind (Van der Meer, 2002/1989) als een soort van sprookje gaan lezen en we de wending in het boek hierdoor serieus gaan nemen? Deze vraag staat vanaf nu centraal bij de interpretatie an de roman. Daarbij is er zowel aandacht voor de realistische als de fantastische en sprookjesachtige onderdelen van die verbeelding en hun onderlinge verhouding. Het uitgangspunt bij de interpretatie is dat de roman in twee delen kan worden opgesplitst: het deel voor en het deel na de ontmoeting met Pablo. De ontmoeting met Pablo vormt een belangrijke waterscheiding in de roman, zowel op wat Bal (1980) het niveau van de geschiedenis als het niveau van het verhaal noemt. ${ }^{101}$ Op het niveau van de geschiedenis markeert de ontmoeting met Pablo een scheiding tussen twee fases uit het leven van Julia: de fase waarin zij haar kinderwens najaagt en de fase waarin zij deze wens loslaat. Deze onderverdeling wordt op het niveau van het verhaal gereproduceerd. De gebeurtenissen worden namelijk grotendeels gerepresenteerd, zoals ze 'oorspronkelijk' op het niveau van de geschiedenis zouden hebben plaatsgevonden, wanneer we die op basis van de gepresenteerde tekst reconstrueren. In de eerste hoofdstukken van de roman staat zodoende de zoektocht naar een kind van Julia centraal, die zich voor de ontmoeting met Pablo afspeelt. Pas nadat de ontmoeting met Pablo halverwege de roman wordt opgevoerd, komt hierin verandering en wordt de rest van het werk gewijd aan het loslaten van die kinderwens door Julia.

\section{Een kwestie van kiezen}

Wanneer we de verbeelding van het verlangen naar een kind in het eerste deel van De reis naar het kind (Van der Meer, 2002/1989) onder de loep nemen, dan valt op

\footnotetext{
${ }^{101}$ Voor een toelichting van deze begrippen zie hoofdstuk 3 in dit boek.
} 
dat Julia en aanvankelijk ook Max er rotsvast van overtuigd zijn, dat zij zelf kunnen bepalen of zij ouders worden. Zij zijn zich er in dit verband niet van bewust dat hun keuze voor een kind wel eens niet gerealiseerd zou kunnen worden. Dat dit het geval is, blijkt al in het tweede hoofdstuk van de roman dat uit het sprookje van Julia bestaat. Zoals gezegd kunnen we dit sprookje als een bewerking van de ervaringen van Max en Julia beschouwen. Uit het sprookje blijkt dat Max en Julia "niet [anders] verwachten dan dat het kind zich spoedig aan zou dienen", "[o]mdat ze het [kind] nu allebei wilden, zielsgraag" (Van der Meer, 2002/1989, p. 22). Julia en Max gaan er dus vanuit dat zij door de keuze voor een kind te maken, kunnen bepalen dat ze ouders worden. Na die keuze gemaakt te hebben, blijft een zwangerschap echter uit. Niettemin twijfelen de man en de vrouw uit het sprookje, ergo Julia en Max, er nog niet aan dat zij hun keuze zullen kunnen verwezenlijken. Met behulp van medische vruchtbaarheidstechnologieën denken zij dat er wel een mouw aan valt te passen. Die verwachting wordt niet ingelost. Afgaand op Julia's sprookje, begint Max er vanaf dat moment aan te twijfelen of een kind wel voor hen is weggelegd. Julia zelf volhardt echter in haar pogingen om haar kinderwens te vervullen en deze vormen het onderwerp van het laatste deel van het sprookje en de daaropvolgende hoofdstukken.

De eerste poging die Julia onderneemt, is adoptie via de legale weg. Zij overtuigt Max ervan om zich met haar bij een adoptiebureau in te schrijven, maar na enige tijd blijkt dat het legale adoptieproces evenmin soelaas biedt. Pas na een jaar komen Julia en Max eventueel in aanmerking voor adoptie. Maar dan is Max al bijna veertig jaar, een leeftijd waarna het voor Julia en Max, in de periode waarin de roman speelt, wettelijk niet meer is toegestaan in Nederland om een kind uit het buitenland te adopteren. De tijd dringt dus. Julia wendt zich daarom tot Roland Mafait, die ze heeft ontmoet op een voorlichtingsavond van het adoptiebureau en die haar met illegale adoptie zegt te kunnen helpen. Pas nadat Julia hem achtduizend gulden heeft betaald, vertelt ze Max over haar contact met Mafait. Hoewel Max heftig protesteert, vertrekken ze beiden naar Peru waar zij hun kind in ontvangst zullen kunnen nemen. Daar krijgen zij te horen dat het door hen te adopteren kind niet levensvatbaar is. Julia blijft desondanks vasthouden aan het idee dat ze haar wens zal kunnen vervullen. Ze gaat dan ook akkoord met de oplossing die door Manuel, hun belangrijkste contactpersoon in Lima, wordt aangedragen: ze kunnen een ander kind adopteren dat binnenkort geboren zal worden. Een andere vrouw die haar kind voor adoptie heeft opgegeven, blijkt namelijk onverwacht zwanger van een tweeling. Het echtpaar dat het kind van deze vrouw is beloofd, ziet het niet zitten om twee kinderen in hun gezin op te nemen. Daarom kan Manuel het tweede kind aan Max en Julia aanbieden. Opnieuw volgt er slecht nieuws voor Julia: bij de geboorte blijkt er geen sprake van een tweeling. Er wordt slechts één kind geboren en dit kind wordt aan het andere stel afgestaan. Julia, die inmiddels alleen in Peru is achtergebleven, is nog steeds niet bereid om haar kinderwens op te geven. Midden 
in de nacht klopt zij hysterisch op de deur van de hotelkamer van het andere echtpaar en biedt hen geld in ruil voor het kind. Manuel sleurt haar weg bij de deur en overtuigt haar ervan dat er nog andere mogelijkheden zijn. Hij kan iemand inschakelen om voor haar een kind op het platteland te gaan zoeken. Julia verkoopt haar sieraden en haar fotocamera om deze "Tussenpersoon" (Van der Meer, 2002/1989, p. 119) te betalen, die haar na enige tijd laat weten een jongetje voor haar te hebben gevonden. Dit blijkt de oude man Pablo te zijn. Op dat moment geeft Julia de zoektocht naar een kind eindelijk op. Daarvoor is Julia er echter rotsvast van overtuigd dat het krijgen van een kind een maakbare aangelegenheid is.

In het eerste hoofdstuk in dit boek is duidelijk geworden, dat het idee dat we zelf kunnen bepalen of we kinderen krijgen een hoofdingrediënt van het heersende moederschapsideaal. Dit idee heeft er, zoals gezegd, ook toe geleid dat het gros van de mensen dat vandaag de dag besluit om aan kinderen te beginnen, zich er niet van bewust is dat die wens wel eens averij kan lopen. Aan deze opvattingen wordt duidelijk gerefereerd in de beschrijvingen van Julia's zoektocht naar een kind. ${ }^{102}$ Dat Julia in eerste instantie haar heil zoekt bij medische technologieën en daarna voor adoptie kiest om haar wens te realiseren, wijst hier ook op. Het geloof dat we voor kinderen kunnen kiezen, is nauw verbonden met een diep vertrouwen in medische vruchtbaarheidstechnologieën als IVF. ${ }^{103}$ Ook de praktijk van adoptie zoals die in hedendaagse westerse, moderne samenlevingen vaak gestalte krijgt, is hiermee verknoopt. In maatschappelijke en sociaalwetenschappelijke discussies over adoptie wordt vaak gewezen op een verband tussen adoptie en het geloof dat we voor kinderen kunnen kiezen (Novy, 2008). Er wordt beweerd dat het idee dat het leven maakbaar is, vandaag de dag dikwijls ten grondslag ligt aan de keuze van westerse koppels voor adoptie. Daarbij is adoptie vaak een tweede keus. Het is de oplossing die voor de vervulling van een kinderwens wordt aangegrepen, nadat het krijgen van kinderen via een 'natuurlijke' weg niet mogelijk is gebleken. Volgens critici is deze vorm van adoptie gevaarlijk en schadelijk, omdat kinderen als producten worden gezien die eenvoudigweg tegen betaling kunnen worden aangeschaft en die inwisselbaar zijn (Novy, 2008). Dat Julia er in ieder geval zo tegenaan kijkt, blijkt bijvoorbeeld op het moment dat ze het andere koppel in het hotel geld aanbiedt in ruil voor het overgebleven kind. Julia belichaamt als romanpersonage bij uitstek de zogenaamde "psychology of choice" (Beck-Gernsheim, 1996). Ze gelooft rotsvast dat haar keuzes per definitie realiseerbaar (moeten) zijn.

\footnotetext{
${ }^{102}$ Het gaat hier dus om wat Meijer (1996a) intertekstuele verwijzingen naar bredere discoursen of cultuurteksten noemt. Zie hoofdstuk 3 voor een bespreking van deze vorm van intertekstualititeit.

${ }^{103}$ Zie hoofdstuk 1 voor een toelichting.
} 


\section{Hedonistisch moederschap}

Dat Julia het krijgen van een kind als een plooibare aangelegenheid beschouwt, staat buiten kijf. Julia en Max kiezen daarbij voor een kind, omdat zij hier zelf gelukkig van denken te worden. Vooral Julia is deze overtuiging toegedaan. Dat blijkt allereerst uit een aantal passages uit het eerste hoofdstuk. De titel van dit hoofdstuk is Kom terug vreugde, hier. In het hoofdstuk komen we een aantal variaties op deze titel tegen. De eerste variant staat in een stuk over een vrouw die haar hond Joy bij haar roept, op het moment dat Julia de hond wil aaien:

[Julia] trok haar want uit en strekte haar hand al naar hem uit, maar vóór de hond bij haar was werd hij teruggesnauwd: 'Kom terug, Joy, hier!' Julia trok haar want weer aan. Kom terug, vreugde, hier toepasselijker woorden voor haar stemming had ze zelf niet kunnen bedenken. (Van der Meer, 2002/1989, p. 14)

Een tweede adaptatie van de titel vinden we een passage, waarin wordt beschreven hoe Julia een gesprek met een vrouwelijke garnalenvisser probeert aan te knopen. Het gesprek komt tot verdriet van Julia niet op gang: " [Julia] wilde iets tegen haar zeggen maar wist niet wat. De enige zin die ze zich in gedachten over het geruis van de zee hoorde roepen was: kom terug, vreugde, kom hier" (Van der Meer, $2002 / 1989$, p. 18). In beide gevallen worden de gewijzigde versies van de hoofdstuktitel gebruikt om te verwijzen naar neerslachtige gevoelens van Julia over het mislukken van iets. De zinnen worden gebruikt op het moment waarop Julia naar iets verlangt en het object van haar verlangen buiten haar bereik blijkt te liggen: de hond en het contact met de visser. Nu lijken deze passages en de titel van het hoofdstuk niet direct iets met Julia's kinderwens van doen te hebben. In het eerste hoofdstuk weten we namelijk nog niet dat Julia ongelukkig is, omdat het niet lukt om zwanger te worden. Pas na het eerste hoofdstuk krijgen we deze informatie. Dan blijkt eveneens dat Julia ooit wel gelukkig was met een leven zonder kinderen. Zodra zij de keuze voor een kind heeft gemaakt, kan zij zonder een kind echter niet meer gelukkig zijn. Gaandeweg raken de titel van het eerste hoofdstuk en de variaties er op in retroperspectief verbonden met Julia's verdriet over haar onvervulde kinderwens. In dit verband is het interessant dat de hond en het contact met de visser, waar Julia naar verlangt, achteraf als symbolen kunnen worden beschouwd voor het kind dat Julia begeert. Uit dit alles blijkt dat het verwezenlijken van haar kinderwens, voor Julia een kwestie van persoonlijk geluk is. Ze kan niet gelukkig zijn zonder kind, nu ze eenmaal voor het moederschap heeft gekozen. Ze moet en zal daarom een kind krijgen.

Daarbij houdt Julia er een sterk geïdealiseerd beeld van het moederschap op na. Julia's besluit om een kind te krijgen wordt, volgens het ingebedde sprookje, ingegeven door een dagdroom, waarin ze zichzelf en haar toekomstige kind als volgt ziet: 
Op een goede dag, een maand of drie nadat haar man over kinderen begonnen was, zag de vrouw [ergo Julia] tijdens een wandeling een fiets staan, met aan het stuur een zitje. Plotseling stelde ze het zich heel duidelijk voor: ze zag zichzelf over een dijk rijden, langs het glinsterend wad, met voor op haar fiets in een zitje een kind. Zo nu en dan raakte haar kin zijn kruin, die naar zon rook. Vanaf die dag stond ze niet meer stil bij alles wat ze voor het moederschap zou moeten opgeven. (Van der Meer, 2002/1989, p. 21)

Dit idyllische, symbiotische beeld van een gelukkige moeder en haar jonge kind keert later in het boek terug, wanneer het gesprek met de vrouw van het adoptiebureau wordt beschreven. Een van de vragen die de vrouw aan Julia stelt, is waarom ze zo graag een kind wil. Volgens de niet-personage gebonden verteller heeft Julia zich op deze vraag voorbereid en een aantal redenen op een rijtje gezet. Op het moment dat de vrouw haar de vraag stelt, verdwijnen al deze vooraf bedachte redenen naar de achtergrond en kan Julia enkel over haar dagdroom van de fiets met het kinderzitje vertellen. ${ }^{104}$

Ook op een andere, minder expliciete manier lijkt de keuze voor een kind van Julia en Max een keuze voor hun persoonlijke geluk. Julia heeft Max enkele jaren geleden met Alain bedrogen, die zij tijdens een verblijf op een van de Waddeneilanden heeft ontmoet. Max verwijt Julia het overspel en Julia kan Alain niet uit haar hoofd zetten. Pas wanneer Max voorstelt om samen een kind te nemen en Julia dit ook wil, kan hij de affaire vergeten en slaagt Julia erin om haar verlangen naar Alain los te laten. Julia's verlangen naar een kind komt als het ware in de plaats van de wens om bij haar minnaar te zijn: "Pas toen Max over een kind begonnen was, in die maanden daarna, was ze Alain gaan vergeten. De laatste tijd dacht ze nog zelden aan hem, ook Max bracht hem nooit meer ter sprake" (Van der Meer, 2002/1989, p. 29). De keuze voor een kind lijkt dus het ideale lijmmiddel voor hun relatie en speelt onbewust of bewust mee bij hun keuze er voor. Door Julia's vasthoudende pogingen om haar kinderwens te verwezenlijken komt die relatie later overigens wel weer onder druk te staan.

Zo wordt de kinderwens van Julia (en Max) in het eerste deel van de roman als een keuze voor een manier van leven neergezet, waarin het om het persoonlijke geluk van de moeder (en de vader) draait. Door aan te sluiten bij heersende geïdealiseerde opvattingen over moederschap, voelt de roman juist ook tot op zekere hoogte realistisch aan. Deze opvattingen zijn immers onderdeel van de maatschappelijke context, waarin de lezers van de roman zich begeven. In wat volgt wordt duidelijk dat deze twee elementen van het vertoog van genieten uiteindelijk worden ondermijnd in de roman.

\footnotetext{
${ }^{104}$ Deze passage is dus een expliciete verwijzing naar de dagdroom uit het ingebedde sprookje en daarmee een bevestiging van het feit dat we het sprookje als een bewerking van Julia's en Max' leven kunnen lezen.
} 


\section{Maakbaarheidskritiek}

Uit onderzoek naar Engelstalige romans over adoptie blijkt dat het geloof in maakbaarheid dikwijls kritisch onder de loep wordt genomen in literaire fictie (Novy, 2008). Dit gebeurt ook in De reis naar het kind (Van der Meer, 2002/1989). We worden er op verschillende manieren toe aangezet om de roman als een kritisch commentaar te lezen op het geloof dat we simpelweg voor kinderen kunnen kiezen. Het moment waarop Julia Pablo ontmoet en de gebeurtenissen die daarna in het tweede deel van de roman worden beschreven, spelen daarin een doorslaggevende rol. Voordat dit moment zich echter aandient, worden we er al in het eerste deel van de roman op voorbereid om Julia's maakbaarheidsgeloof in twijfel te gaan trekken.

Die twijfel wordt ten eerste gezaaid doordat Julia nietsontziend en obsessief te werk gaat bij haar pogingen om haar wens te vervullen. Dat er sprake is van een obsessie, blijkt onder andere uit de titel van het deel van de roman waarin het legale en illegale adoptieproces worden beschreven: "Koorts" (Van der Meer, 2002/1989, p. 19). In dit deel van de roman wordt duidelijk dat Julia zich koortsachtig op haar kinderwens gaat richten, totdat zij aan niets anders meer kan denken. Haar blik wordt overal naar kinderen en gezinnen getrokken. En wanneer zij alleen in Peru op de geboorte van de veronderstelde tweeling wacht, blijkt zij gedreven door haar obsessieve verlangen zelfs onbewust kinderen op straat te achtervolgen:

[L]ater gebeurde het dat ze er zonder zelf erg in te hebben een kind bleek te zijn gevolgd - een paar maal zelfs tot in de bus. Toen het kind een huis binnen ging en Julia zich realiseerde wat ze gedaan had, wist ze niet eens waar ze was. In een volkomen onbekend gedeelte van de stad was ze beland. (Van der Meer, 2002/1989, p. 106)

Het feit dat alles voor haar wens moet wijken, blijkt ook uit de manier waarop zij zich in het illegale adoptiecircuit begeeft. Max zet er terecht ethische vraagtekens bij: “'lk wil graag een kind. Maar niet tegen iedere prijs, niet op deze manier'” (Van der Meer, 2002/1989, p. 51). Julia wordt daarbij voortdurend als een emotioneel, onberekenbaar persoon neergezet en Max als de meer rationele factor in hun relatie. Hij zal ethisch gezien sneller het juiste doen, omdat hij zich niet door zijn emoties laat leiden. Julia leidt hem van het juiste pad af. Er wordt in de verbeelding van beide personages zodoende teruggegrepen op een conservatieve manier van denken over emotionaliteit en rationaliteit. Daarbij wordt emotionaliteit als een vrouwelijke en negatieve eigenschap en rationaliteit als een mannelijke en positieve eigenschap beschouwd (Ahmed, 2004). Julia weet dat ze Max kan verliezen als ze toch met de illegale adoptie doorgaat en dat het eigenlijk niet in de haak is wat ze doet, maar gedreven door haar verlangens en emoties zet ze haast zonder aarzeling door. We gaan ons daardoor bijna onvermijdelijk ongemakkelijk voelen bij haar gedrag. Doordat de niet-personage gebonden verteller zich voortdurend op Julia's gedachten, uitspraken en ervaringen richt, wordt dit gevoel mogelijk versterkt. We 
worden daardoor constant met Julia's obsessie geconfronteerd. In de vorm van de roman wordt Julia's obsessieve verlangen naar een kind zo gespiegeld. ${ }^{105}$ Andere perspectieven komen nauwelijks aan bod in het boek en zo'n vernauwde blik op de wereld treffen we ook bij Julia aan.

Daarnaast wordt Julia's zoektocht tot twee keer toe expliciet als dwaas afgeschilderd. Om te beginnen noemt Julia haar kinderwens nota bene zelf een "amour fou" (Van der Meer, 2002/1989, p. 29), waarbij haar kinderwens a passant als een romantische liefde wordt gerepresenteerd. Wanneer Julia Max vertelt dat ze naar Lima gaat om op illegale wijze een kind te adopteren, herinnert Max haar bovendien aan een uitspraak van de Griekse filosoof Epicticus, die Julia zelf altijd gebruikte wanneer Max iets wilde dat niet mogelijk was: "Alleen een dwaas zoekt 's winters vijgen, en even dwaas is iemand die. . .." (Van der Meer, 2002/1989, p. 50). Julia onderbreekt Max op dit punt, zodat hij het citaat niet kan afmaken. De volledige uitspraak van Epicticus luidt, zoals we onder andere in een interview met Van der Meer kunnen lezen, als volgt: "Alleen een dwaas zoekt 's winters vijgen, en even dwaas is iemand die een kind verlangt, als het niet gegeven wordt" (Schouten, 1989). ${ }^{106}$

Het begin van het sprookje in de vertelling kan ook verontrusting te weeg brengen over Julia's vasthoudende geloof dat een kind iets is, waarvoor ze kan kiezen. In dit sprookje staat dat Julia bereid is om "alles, alles" (Van der Meer, 2002/1989, p. 23) voor een kind te doen, zelfs naar een heks te gaan. Daar komt in sprookjes meestal niet veel goeds van. Er is altijd een addertje onder het gras of er is een hoge prijs die er voor de hulp van een heks betaald zal moeten worden. De verwijzing naar de heks kan er zodoende bij voorbaat voor zorgen dat Julia's inspanningen om haar wens in vervulling te laten gaan, zoals die in de rest van de vertelling uit de doeken worden gedaan, een nare bijsmaak krijgen. Dat geldt zeker vanaf het moment dat zij zich tot Mafait wendt, die de onbetrouwbare figuur van de heks uit het sprookje spiegelt (zie ook Joop Dirksen, 1997). Net als een heks kan ook Mafait de werkelijkheid naar zijn hand zetten; weliswaar niet met toverkracht, maar door de wettelijke adoptieprocedures te omzeilen. Dat Mafait niet te vertrouwen is, blijkt onder meer uit wat er over zijn lichaamsgeur wordt gezegd. De reis naar het kind

\footnotetext{
${ }^{105}$ Uit de bespreking van Van der Meers oeuvre door Rody Chamuleau (2004) blijkt dat personages, gebeurtenissen, plaatsen en voorwerpen ook in andere romans en verhalen van Van der Meer vaak gespiegeld en zelfs verdubbeld worden. Agnes Andewegs $(2010,2011)$ analyse van Spookliefde. Een lers verhaal (1995) bevestigt dit.

${ }^{106}$ De intertekstuele verwijzing naar Gulliver's Travels (1757/1726) kan ook gelezen worden als een vingerwijzing naar de dwaasheid van Julia's geloof dat het leven maakbaar is. Gulliver's Travels $(1757 / 1726)$ is onder andere geïnterpreteerd als een boek met de boodschap dat "we should not too proudly aspire to perfection and happiness through reason and technology. That way lies madness, as Gulliver portrays but never learns" (Smedman, 1990, p. 95). In haar pogingen om de werkelijkheid naar haar hand te zetten lijkt Julia op Gulliver.
} 
(Van der Meer, 2002/1989) is doorspekt met beschrijvingen van geuren en is daarom ook wel met Das Parfum: die Geschichte eines Mörders (1985) van Patrick Süskind vergeleken (Van Uffelen, 1992). De geur van Mafait vindt Julia in eerste instantie prettig, maar hij roept bij nader inzien "een wee gevoel op. Alsof ze een hap van de verkeerde bonbon nam" (Van der Meer, 2002/1989, p. 42). Ze stopt dat gevoel echter snel weg, omdat ze koste wat kost een kind wil. Door deze karakterisering van de geur van Mafait en doordat zijn personage door de heks uit het sprookje wordt gespiegeld, zijn we er voor gewaarschuwd dat er niet veel goeds van Julia's zoektocht terecht kan komen zodra ze Mafait om hulp vraagt. Het raadplegen van een heks doet dat in sprookjes immers ook niet. Als we bereid zijn om De reis naar het kind (Van der Meer, 2002/1989) als een sprookje te lezen, dan weten we dat we van de 'heks' Mafait niet veel beter kunnen verwachten.

Ook andere passages uit het eerste deel van de roman wijzen vooruit naar het mislukken van Julia's voorgenomen adoptie. De beschreven sprookjesachtige droom, waarin een vrouw een kind tot de grootte van een kikker kneedt en terug in de baarmoeder stopt, is daar een voorbeeld van. In deze droom krijgt Julia het kind immers niet. Dat geldt ook voor de al genoemde passages over de hond die Julia probeert te aaien en het gesprek dat ze met de visser probeert aan te knopen. Ook dan krijgt ze niet wat ze verlangt. Wat veelzeggend is, omdat de hond en het gesprek symbool staan voor het gewenste kind.

De roman werkt zo op verschillende manieren toe naar een climax waarbij de keuzeretoriek die Julia in haar ban heeft, stukloopt op het moment waarop Julia de oude man in plaats van een kind aantreft. Dit moment en de gebeurtenissen die daarna in het tweede deel van de roman volgen, zorgen ervoor dat wij er niet langer aan kunnen ontkomen om Julia's maakbaarheidsgeloof kritisch te bekijken.

Die kritische houding wordt ten ten eerste opgeroepen doordat Julia zelf het idee dat zij kan bepalen of ze moeder wordt na de ontmoeting laat varen. Julia geeft haar zoektocht op als ze Pablo ontmoet, maar het verdriet over haar verlies laat zij dan nog niet toe. Dat doet zij pas later die dag, met hulp van Pablo die ze meeneemt naar haar hotelkamer.'s Avonds kijkt Julia uit het hotelraam naar een vrouw en haar baby in een appartement in een flatgebouw aan de overkant van het hotel, die zij tijdens haar verblijf al vaker heeft geobserveerd. Op dit moment spreekt Pablo haar aan en tikt "met een vingertop tegen de dunne huid onder zijn oog" en spreekt daarbij het Spaanse woord voor traan "lágrima" uit (Van der Meer, 2002/1989, p. 126). Terwijl Julia het woord herhaalt, breekt haar laatste restje verzet en laat ze zich door Pablo troosten. Met de onbewuste hulp van Pablo accepteert Julia dat ze haar kinderwens moet loslaten. Door de wending die de roman neemt, worden we er op een extreme wijze toe aangezet om net als Julia afscheid te nemen van het idee, dat het krijgen van kinderen een kwestie van individuele volharding in een keuze is. Dat Julia de belangrijkste focalisator is, draagt hier aan bij. Mieke Bal stelt 
samen met Jan van Luxemburg en Willem Weststeijn (Van Luxemburg, Bal \& Weststeijn, 1981) namelijk terecht dat we als lezers vlugger geneigd zijn, om ons te identificeren met personages die veel focaliseren, dan met personages die niet of nauwelijks focaliseren. Dit komt omdat hun gezichtspunt van binnenuit kenbaar wordt. Het lezen van deze roman kan daardoor voor lezers ook een pijnlijk proces zijn. Doordat Julia focaliseert, wordt onze aandacht immers op haar gevoelens van machteloosheid en verdriet gevestigd. Bovendien kunnen we door de opgeroepen identificatie met Julia hoop blijven koesteren met haar, ondanks verschillende aanwijzingen dat deze hoop ijdel is. Het is dan ook niet helemaal opzienbarend dat sommige lezers het boek juist op het moment dat de adoptie definitief mislukt, woedend hebben weggegooid. Een puur realistische lezing van de roman zou hier, zoals Van der Meer heeft geopperd, inderdaad een oorzaak van kunnen zijn (Hellmann, 1996). Maar er is wellicht meer aan de hand. Lezers kunnen als gevolg van de wijze waarop de focalisatie is georganiseerd intens met Julia mee gaan leven. En dit kan heftige emoties oproepen.

Het einde van de roman waarin Julia zwanger blijkt te zijn, bevestigt de interpretatie van De reis naar het kind (Van der Meer, 2002/1989) als een kritiek op het idee dat we het moederschap naar onze hand kunnen zetten en dat we het krijgen van kinderen kunnen beheersen. Julia's zwangerschap kan als een beloning worden gezien voor het feit dat zij dit idee juist heeft losgelaten. Pablo fungeert als een helperfiguur bij het tot stand komen van de zwangerschap. In dit opzicht doet De reis naar het kind (Van der Meer, 2002/1989) qua vorm duidelijk aan een sprookje denken, waarin voor wijze, oudere mannen of vrouwen vaak een belangrijke rol als helperfiguren is weggelegd. Een aantal passages aan het einde van de roman maakt deze interpretatie van Pablo's rol overtuigend. Zo overlijdt Pablo op het moment dat Julia zwanger blijkt te zijn met zijn hand op haar zwangere buik. Er wordt zo een relatie gesuggereerd tussen de aanwezigheid van Pablo en de zwangerschap. $\mathrm{Na}$ Pablo's dood legt Julia eveneens een verband tussen haar zwangerschap en de tijd die ze met Pablo heeft doorgebracht. In het schrift waarin ze ooit het sprookje heeft opgeschreven en waarin ze een reisverslag heeft bijgehouden voor het te adopteren kind, richt zij de volgende zinnen aan haar nog ongeboren kind:

\footnotetext{
Pablo is drie weken geleden gestorven, jij bent er nog niet. Een beter moment om over de afgelopen periode na te denken doet zich misschien niet meer voor: straks zul jij, als alles goed gaat, op jouw beurt mijn gedachten in beslag nemen. Wat er de laatste maanden gebeurd is, staat niet los van jou. Je zou kunnen zeggen dat die gebeurtenissen jou verwekt hebben. (Van der Meer, 2002/1989, p. 147)
}

Hier worden de ontmoeting met Pablo en de gebeurtenissen erna door Julia als de metaforische verwekkers van haar kind afgeschilderd. Sprookjes verbeelden de wereld, zoals besproken, bij uitstek door middel van extreme vergelijkingen en De reis naar het kind (Van der Meer, 2002/1989) sluit hier wat dit betreft bij aan. 
Dat de roman een kritiek is op het geloof dat het krijgen van kinderen een plooibare praktijk is, blijkt ook op een andere manier uit het slot. De reis naar het kind (Van der Meer, 2002/1989) heeft in zekere zin een open einde. We weten aan het einde weliswaar dat Julia zwanger is, maar we weten niet of zij het kind gezond ter wereld zal brengen. Door het ontbreken van een zekerheid over de uitkomst van de zwangerschap, overtuigt de roman als een kritische kanttekening bij het idee dat we als mensen de werkelijkheid naar onze hand kunnen zetten. Julia zelf is zich maar al te goed bewust van deze les. Wanneer Max zei

\footnotetext{
'Nog even...' of: 'Nog zes maanden en dan zijn we met z'n drieën.' En dan zei zij: 'Misschien.' Dit keer zei ze het niet om hem een plezier te doen of uit beleefdheid jegens het lot. Het lot was een zootje gangsters, het deed met je wat het wilde. (Van der Meer, 2002/1989, p. 164)
}

Zo benadrukt De reis naar het kind (Van der Meer, 2002/1989) dat we niet kunnen weten wat er in de toekomst in het verschiet ligt en dat enige nederigheid gepast is. Door ons enig werkelijk inzicht in de toekomst van Julia en Max te onthouden, wordt deze les ons als lezers goed ingepeperd.

\section{De zichzelf opofferende moeder}

We kunnen De reis naar het kind (Van der Meer, 2002/1989) tot op zekere hoogte ook als een kritisch commentaar lezen op een hedonistische visie op het moederschap. Het feit dat Julia, en in mindere mate ook Max, alleen voor haar eigen, persoonlijke geluk voor een kind kiest, wordt namelijk ter discussie gesteld. Wederom spelen de ontmoeting met Pablo en de gebeurtenissen daarna, hierin een beslissende rol. En ook nu worden we in het eerste deel van de roman al op het spoor van dit kritisch potentieel van de roman gezet. De eerste helft van de roman wordt vanuit deze gedachte hier eerst onder de loep genomen. Daarna volgt een uitgebreide exploratie van het tweede gedeelte.

Het feit dat Julia alleen maar een kind wil omdat het haar gelukkig zal maken, is een motief dat in het eerste stuk van de roman al met vraagtekens wordt omkleed. Van der Meer (2002/1989) belicht een kwalijke uitkomst van een puur hedonistische visie op het moederschap waarin alleen het eigen geluk van de moeder telt. De belangen van het kind en andere mensen kunnen er door uit het oog worden verloren. Julia geeft alleen om haar eigen geluk en daarvoor moet alles en iedereen wijken. Die houding is niet alleen het gevolg van haar vasthoudende geloof in de maakbaarheid van haar leven, maar ook door het geïdealiseerde beeld van moederschap dat ze erop nahoudt. Gezamenlijk maken zij Julia tot een rücksichtsloze vrouw die zich enkel richt op de realisatie van wat zij zelf wil. De belangen van Max doen er bijvoorbeeld niet toe. Ze schuift zijn bezwaren tegen illegale adoptie zonder nadenken aan de kant. Ook de noden van het te adopteren kind en die van de biologische moeder en vader zijn van ondergeschikt belang. Julia is zich in eerste instantie zelfs 
niet eens bewust van het bestaan van die behoeftes, zoals bijvoorbeeld blijkt uit een passage waarin wordt beschreven dat Julia enkel een kind dat niet ouder dan drie maanden is wil adopteren, zodat het als haar 'eigen' kind aanvoelt. Bij de keuze voor een jong kind gaat het haar om haar eigen verlangens en niet om het belang van het te adopteren kind, voor wiens hechting het wellicht ook beter is om zo jong mogelijk geadopteerd te worden. Tijdens haar verblijf in Peru gaat Julia uiteindelijk wel nadenken over de positie van het te adopteren kind en zijn biologische ouders en dan vooral die van de moeder. Zij begint er zelfs aan te twijfelen of het wel zo'n goed idee is om een kind bij zijn of haar biologische moeder weg te halen. Ook bedenkt ze dat het voor de biologische ouders erg moeilijk zou kunnen zijn om afstand van hun kind te doen en dat ze zich daartoe door armoede gedwongen voelen. Het lijkt er op dat ze onbewust heeft gedacht dat een moeder die haar kind opgeeft, dit doet omdat ze niet genoeg van haar kind houdt en dat zo'n kind daarom beter af is bij haar zelf. Dat vooral armoede een rol zou kunnen spelen, is opvallend genoeg niet eerder bij haar opgekomen. Julia onderdrukt al deze nieuwe gedachtes echter, om zich op het vervullen van haar eigen kinderwens te kunnen blijven richten.

Doordat Julia zowel de belangen van Max, het te adopteren kind en zijn of haar biologische ouders aan de kant schuift ten behoeve van haar eigen wensen, kunnen we verontrust raken over haar visie op het krijgen en hebben van kinderen. Deze beroering wordt verder opgevoerd door een expliciete intertekstuele verwijzing naar een bekende Bijbelpassage uit het Oude Testament: Salomo's wijsheid. ${ }^{107}$ Deze bestaat uit een droom van Julia in de nacht nadat ze te horen heeft gekregen dat de tweeling, waarvan haar een kind is beloofd, geen tweeling blijkt te zijn:

\footnotetext{
Ze had gedroomd dat ze Thea [de vrouw van het koppel dat het overgebleven kind mag adopteren] op de trap tegenkwam, Thea met in haar armen een Siamese tweeling. De kinderen hadden samen één lijf, één nek. Op die ene nek stonden twee hoofden. Toen zij het kind wilde overnemen riep Thea met schrille stem dat het haar kinderen waren - allebei. Tegelijk hadden ze een armpje van het kind gepakt, en waren daar aan gaan rukken tot ze ieder met een bloedende helft... (Van der Meer, 2002/1989, pp. 96-97)
}

De droom verwijst onmiskenbaar naar Salomo's wijsheid. Deze Bijbelpassage gaat over twee vrouwen die bij elkaar in huis wonen en beiden een kind hebben gebaard. ${ }^{108}$ Een van de kinderen overlijdt en beide vrouwen beweren daarna de moeder van het overgebleven, levende kind te zijn. Aan koning Salomo wordt gevraagd om te bepalen wie de echte moeder is. Salomo geeft vervolgens de opdracht om

\footnotetext{
${ }^{107}$ Van der Meer verwijst ook in veel van haar andere boeken naar passages uit de Bijbel. Zeker na haar bekering tot het katholicisme in 1994 staat ze daarom ook wel te boek als een auteur van boeken over geloofsvragen (Chamuleau, 2004).

${ }^{108}$ Ik ga hier uit van de passage over Salomo zoals we die aantreffen in De Nieuwe Bijbelvertaling van het Nederlands Bijbelgenootschap (NBG) en de Katholieke Bijbelstichting uit 2004.
} 
het kind met een zwaard in tweeën te klieven en iedere vrouw de helft te geven. Een van de vrouwen smeekt de koning daarop om het kind aan de andere vrouw te geven, zodat het in ieder geval in leven blijft. Op basis van deze smeekbede komt Salomo tot de conclusie dat de vrouw die het leven van het kind afsmeekt, de werkelijke moeder is en hij geeft haar het kind. De gelukkige afloop van de Bijbelpassage staat in schril contrast met het bloedige einde van Julia's droom. Julia kan het welzijn van het kind niet boven haar eigen geluk plaatsen en het kind wordt aan stukken gescheurd. De droom zorgt er echter niet voor dat Julia van koers verandert. Op de ochtend na de droom, betaalt zij Manuel een flink bedrag om op het platteland een kind te gaan zoeken.

Naast de verwijzing naar Salomo's wijsheid staan er in het eerste deel van de roman andere intertekstuele verwijzingen die Julia's queeste in een kwalijk daglicht stellen. Deze vestigen onze aandacht op de positie van het te adopteren kind en zijn of haar biologische moeder. Het gaat ten eerste om verwijzingen naar de Amerikaanse acteur, regisseur, schrijver en producer Orson Welles. Max en Julia leggen een aantal keer een verband tussen Orson Welles en het te adopteren kind. Wanneer Julia en Max zich bijvoorbeeld voorbereiden op het gesprek met het adoptiebureau om hun geschiktheid als ouders te bepalen, waarschuwt Julia Max dat hij geen rare dingen moet doen, zoals zeggen dat "[a]lle baby's op Orson Welles lijken" (Van der Meer, 2002/1989, pp. 96-97, p. 25). Deze vergelijking wordt later door Max zelf ook nog een keer gemaakt. Het is niet voor de hand liggend om een parallel tussen Orson Welles en baby's te trekken. Het is geen algemeen gebezigde uitdrukking of een zegswijze en daarom trekt het de aandacht. Er wordt hier op het eerste oog een simpele uiteerlijke overeenkomst tusesen Welles en baby's gesuggereerd, maar de vergelijking kan ook andere betekenissen oproepen. Orson Welles is vooral bekend van de film Citizen Kane (2003/1941) die hij heeft geregisseerd en geproduceerd. Citizen Kane (2003/1941) gaat over het leven van de krantenmagnaat Foster Kane, vertolkt door Orson Welles zelf. De film begint met de dood van Kane, die op zijn sterfbed de woorden "rose bud" (Welles, 2003/1941) uitspreekt. In de rest van de film zien we hoe een journalist op onderzoek uitgaat om de betekenis van deze laatste woorden te achterhalen. Kane blijkt in zijn jeugd door zijn moeder aan Mr. Tatcher te zijn afgestaan, de directeur van de bank die haar vermogen beheerste. De moeder zou dit hebben gedaan, om er voor te zorgen dat haar zoon een goede opleiding in de stad zou kunnen volgen en om te voorkomen dat hij door zijn vader mishandeld zou worden. Kane wordt door de scheiding van zijn moeder echter een egocentrische man, die niet weet wat liefde is en eenzaam sterft. Aan het einde van de film blijkt dat de woorden rose bud op de slee van de jonge Kane stonden. De slee waaraan hij in zijn jeugd, toen hij nog bij zijn moeder woonde, zo veel plezier heeft beleefd. De woorden die hij op zijn sterfbed uitspreekt, verwijzen naar de enige tijd waarin hij gelukkig was en moederliefde kende. De verwijzingen naar Orson Welles herinneren in een adoptieroman als De reis naar het kind (Van der 
Meer, 2002/1989) haast onvermijdelijk aan Citizen Kane (2003/1941). Zo worden de vaak moeilijke omstandigheden waardoor een moeder zich gedwongen kan voelen om een kind af te staan impliciet naar voren geschoven. Ook het traumatische effect dat adoptie op een kind kan hebben, wordt op deze manier onder de aandacht gebracht.

De genoemde verwijzingen naar het sprookje hebben hetzelfde effect. Een thema dat in veel bekende sprookjes naar voren komt, zijn kinderen die door hun moeder en vader worden verlaten of opgegeven vanwege armoede. Zo worden de kinderen in Hans en Grietje door hun ouders in het bos achtergelaten, omdat ze niet genoeg te eten hebben om hen in leven te houden. In een roman over interlandelijke adoptie waarbij armoede wordt opgevoerd als een reden waarom moeders en vaders hun kind afstaan, kunnen de meer algemene verwijzingen naar het genre deze specifieke sprookjes gemakkelijk in herinnering roepen.

Ten slotte mag de verwijzing naar het gedicht van de Spaanse dichter Miguel Hernández: Nanas de la Cebolla (1990a) hier niet ongenoemd blijven. Hernández werd vanwege zijn kritiek op het fascisme ten tijde van het Franco regime in 1940 ter dood veroordeeld. De straf werd omgezet in een levenslange gevangenisstraf (Honig, 1990; Asociación Amigos de Miguel Hernández, 2005). Slechts twee jaar later overleed hij in de gevangenis van Alicante (Honig, 1990; Asociación Amigos de Miguel Hernández, 2005). Nanas de la Cebolla betekent letterlijk vertaald het Wiegelied van de ui en is waarschijnlijk het bekendste gedicht dat Hernández heeft geschreven. Die bekendheid heeft het mede te danken aan het lied dat de in Spanje en Latijns Amerika geliefde zanger Joan Manuel Serrat (2006/1972) er van heeft gemaakt. Hernández schreef het gedicht in de gevangenis en het was een reactie op een brief van zijn vrouw, waarin ze hem vertelde dat zij en hun zoontje enkel brood en uien te eten hadden. Het is een complex en lang gedicht van maar liefst twaalf strofen. In De reis naar het kind (Van der Meer, 2002/1989) worden er drie regels uit geciteerd, vlak voordat Julia Pablo ontmoet: "Es tu risa en tus ojos, la luz del mundo...Tu risa me hace libe ..." (Van der Meer, 2002/1989, p. 109). Ze worden door de moeder uit het appartement aan de overkant van Julia's hotel voor haar kind gezongen. Het gaat waarschijnlijk om het genoemde lied van Serrat en Julia vangt er flarden van op, wanneer ze moeder en kind observeert. Het voert te ver om het hele gedicht in detail te analyseren, maar een van de voor de hand liggende betekenissen die het gedicht oproept, verdient gezien de aard van de roman aandacht. Het gedicht geeft onder andere uitdrukking aan de moeilijke omstandigheden waaronder Hernández en zijn vrouw hun zoontje moeten grootbrengen. In een aanzienlijk deel van het gedicht beschrijft Hernández de honger die zijn vrouw en vooral zijn zoontje moeten lijden, zoals in de volgende regels: 
En la Cuna del hambre

Mi niño estaba.

Con sangre de cebolla

Se amamantaba.

(Hernández, 1990a, p. 55)

De Engelse vertaling van deze dichtregels luidt als volgt:

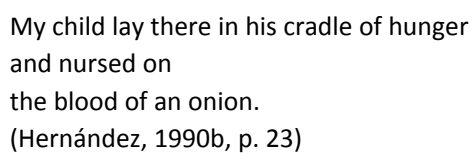

Ondanks de voortdurende nadruk op de honger van het kind, is het gedicht opvallend genoeg niet wanhopig van aard. Er spreekt juist hoop en liefde uit. De lach van dat kind wordt door Hernández (1990a, 1990b) als een lichtpunt in een moeilijk bestaan beschreven. De drie regels die in De reis naar het kind (Van der Meer, 2002/1989) zijn opgenomen, illustreren dit. De Engelse vertaling van deze regels luidt als volgt:

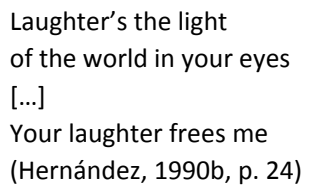

Net als de verwijzingen naar Orson Welles en het sprookje fungeert de opname van een deel van dit gedicht in de adoptieroman De reis naar het kind (Van der Meer, 2002/1989) als een manier om de moeilijke omstandigheden, waaronder ouders in ontwikkelingslanden hun kinderen moeten opvoeden, onder de aandacht te brengen. De opgenomen dichtregels worden namelijk door een arme Peruaanse moeder worden gezongen die de eindjes met veel moeite aan elkaar weet te knopen. Julia heeft gezien hoe deze moeder iedere avond samen met haar man na het werk zelfgebakken taarten op straat moet verkopen en dat ze pas naar huis kan gaan als alle taarten verkocht zijn. Desondanks ziet Julia, en het verrast haar dat de moeder zeer liefdevol met haar kind omgaat ondanks haar armoede. Door het gedicht van Hernández (1990a, 1990b) worden we nogmaals gewezen op een van de gedachtes die Julia probeert weg te stoppen, omdat ze niet in haar straatje passen: dat armoede en niet een gebrek aan moederliefde de motor van interlandelijke adoptie zijn en dat het daarom nog maar de vraag is of het ethisch gezien te rechtvaardigen valt om een kind bij zijn liefhebbende, biologische moeder weg te halen.

$\mathrm{Bij}$ het lezen van de roman worden we voortdurend aangemoedigd om over de positie van de biologische ouders en de belangen van het te adopteren kind na te denken, terwijl Julia bewust weigert om hier bij stil te staan. Deze tegenstelling 
noopt ons er als lezers bijna onvermijdelijk toe om adoptie zoals het in de roman wordt voorgesteld, als een product van onrechtvaardige welvaartsverschillen te zien. Daarbij lijkt het er in eerste instantie op dat biologisch moederschap en vaderschap hoger worden aangeslagen dan adoptieouderschap. In dit opzicht verschilt $D e$ reis naar het kind (Van der Meer, 2002/1989) niet van vele Engelstalige adoptieromans. De strekking van hedendaagse Engelstalige adoptieliteratuur is vaak dat biologisch ouderschap de beste en enige 'ware' vorm van ouderschap is. (Novy, 2008). Deze opvatting kan ook aan De reis naar het kind (Van der Meer, 2002/1989) worden toegeschreven. Ten eerste doordat er voortdurend vraagtekens bij het scheiden van biologische ouders en hun kinderen worden geplaatst. Daarnaast speelt het feit dat de voorgenomen adoptie 'mislukt' hierin mee. Ook het slot van de roman, waarin de geboorte van een biologisch 'eigen' kind in het verschiet ligt, lijkt de boodschap uit te dragen dat biologisch ouderschap te verkiezen is boven adoptie.

Een eenzijdige biologische definitie van moederschap is binnen gender studies terecht bekritiseerd. Verschillende onderzoekers uit dit interdisciplinaire vakgebied hebben op de patriarchale oorsprong van deze invulling van moederschap gewezen (Cuthbert, Murphy \& Quartly, 2009). Zij hebben adoptiemoederschap als een positieve, alternatieve vorm van moederschap naar voren geschoven om een eenzijdige, biologische definitie van moederschap te deconstrueren (Cuthbert, Murphy \& Quartly, 2009). In De reis naar het kind (Van der Meer, 2002/1989) lijkt juist het tegenovergestelde te worden betoogd. Daar moet bij worden opgemerkt, dat er binnen gender studies tot nog toe relatief weinig aandacht is besteed aan de positie van arme en achtergestelde vrouwen en meisjes, wiens kinderen geadopteerd worden (Cuthbert, Murphy \& Quartly, 2009). Juist vanuit een gender studies-perspectief is het belangrijk om de positie van deze vrouwen en meisjes niet uit het oog te verliezen. In dit opzicht kan Van der Meers roman juist waardevol zijn: vanwege de aandacht die er aan de mogelijk nijpende situatie van de biologische moeders en hun kinderen wordt besteed. Bovendien biedt de roman een sterk tegenwicht aan de interpretatie dat biologisch moederschap beter zou zijn dan adoptiemoederschap. De relatie tussen Julia, Max en Pablo wordt in het tweede deel van de roman namelijk op een positieve manier als een ouder-kindrelatie voorgesteld, terwijl deze niet op bloedverwantschap berust. In samenhang met dit metaforische beeld moeten we het mislukken van de adoptie en de uiteindelijke zwangerschap eerder in het licht van Julia's maakbaarheidsgeloof en haar hedonistische levenshouding zien. Het blijkt er dan niet zo zeer om te gaan dat biologisch moederschap de juiste vorm van moederschap is. De moraal is veeleer dat hedonisme en moederschap zich niet met elkaar verdragen, omdat moederschap tot zelfopoffering noopt. In wat volgt wordt duidelijk hoe deze interpretatie wordt ondersteund door de manier waarop de relatie tussen Julia, Max en Pablo wordt verbeeld. 
De relatie tussen Julia, Max en Pablo roept sterke associaties op met een relatie tussen een moeder, vader en een kind. Deze associaties worden ten eerste op impliciete wijze opgewekt, doordat de beschrijvingen van Pablo aan het kind doen denken dat Julia zo graag had willen adopteren. ${ }^{109}$ Zo is Julia er tijdens de eerste ontmoeting met Pablo een moment lang van overtuigd dat Pablo een kind is. Ook als lezers worden wij met haar even in die waan gelaten. Net als het kind dat Julia had willen adopteren, geeft Julia de oude man bovendien zijn naam. 'Pablo' vertelt haar zijn naam wel, maar Julia kan die niet goed verstaan noch uitspreken en daarom vraagt ze hem of ze hem Pablo mag noemen. Pablo maakt daarnaast gebruik van de spullen die voor de baby zijn bedoeld. Zo smeert hij zich na een bad in de hotelkamer in Lima te hebben genomen met talkpoeder in. De kinderkamer in het huis van Julia en Max in Nederland wordt zijn slaapkamer en de speelgoedkist, die Max voor de baby heeft gemaakt, wordt Pablo's lievelingsbezit. Ten slotte wordt er met de dood van Pablo een verband met het kind gelegd: met zijn overlijden kondigt zich nieuw leven aan. De roman biedt als zodanig overigens een cyclische visie op de vernieuwing van het leven. Dit idee wordt gespiegeld in de cyclische vorm van de roman: de vertelling begint en eindigt in een vakantiehuisje op de Waddeneilanden. $^{110}$

De relatie tussen Julia, Max en Pablo roept niet alleen op impliciete wijze gedachtes aan een ouder-kindrelatie op, maar wordt ook expliciet door Julia op die manier ervaren. Julia ziet de zorg voor Pablo als een vorm van moederschap. Een voorbeeld hiervan is een passage waarin ze geërgerd op Max reageert wanneer hij kritiek op haar besluit heeft om Pablo in huis te nemen: "[h]oe jong moet iemand zijn wil ik me over hem mogen ontfermen? Is dat aan een leeftijd gebonden? Moet iemand onder de zes zijn, onder de vier? Liefst onder de drie maanden natuurlijk?"

\footnotetext{
${ }^{109}$ Verschillende sociologen en cultuurwetenschappers die zich met age studies en aging studies bezighouden, hebben er op gewezen dat de representatie van oude mensen als kinderen vaak in een desubjectivisering van oude mensen resulteert (Hockey \& James, 1995; Woodward, 1999, Hockey \& James, 1995). Ze worden als passieve, afhankelijke en hulpeloze wezens voorgesteld die zelf geen beslissingen kunnen en mogen nemen. Dit komt omdat kinderen in onze cultuur vaak niet als volwaardige subjecten beschouwd. Het op deze manier marginaliseren van kinderen wordt binnen age studies en aging studies ook bekritiseerd. Omdat Pablo nauwelijks spreekt en focaliseert in De reis naar het kind (Van der Meer, 2002/1989), lijkt het er inderdaad op dat zijn subjectiviteit en die van het kind waar hij voor staat worden gemarginaliseerd. Daar staat tegenover dat Julia in haar omgang met Pablo juist tot de ontdekking komt dat hij een subject is: een persoon met zijn eigen behoeftes waaraan ze tegemoet moet komen en die zelf beslissingen kan nemen. Ze ontdekt dit door hem als een kind te benaderen. De subjectiviteit van de oude man en het kind waarvoor hij symbool staat, worden zo door Julia ontdekt.

${ }^{110}$ De Waddeneilanden zullen zich uiteindelijk tot een van de belangrijkste locaties in Van der Meers werk ontwikkelen, zoals blijkt uit de romans, novellen en verhalenbundels die na De reis van het kind (2002/1989) verschenen. Het gaat dan met name om de Eilandgasten (1999), De avondboot (2001) en Het laatste seizoen (2002). Deze boeken worden net als De reis naar het kind (2002/1989) gekenmerkt door een cyclische opbouw en dit geldt ook voor andere romans van haar hand (Chamuleau, 2004).
} 
(Van der Meer, 2002/1989, p. 143). Julia stelt Pablo hier onmiskenbaar gelijk aan het te adopteren kind. Ook de omgang tussen Max en Pablo wordt door haar als een verhouding tussen een vader en een kind geïnterpreteerd. Wanneer Max Pablo in bad doet, denkt Julia daar volgens de verteller bijvoorbeeld het volgende bij:

\footnotetext{
Ze zag Max een gebaar maken dat ze vrienden wel eens had zien maken als ze hun kind uit bad haalden. Een gebaar dat haar altijd had getroffen als allerzorgzaamst. Ze zag hoe hij eerst zijn handen door het warme badwater haalde voor hij ze naar Pablo uitstrekte. (Van der Meer, 2002/1989, p. 155)
}

Julia en Max sturen bovendien een geboortekaartje naar hun vrienden en familie om de 'adoptie' van Pablo bekend te maken, met daarop Pablo's vermoedelijke geboortedatum:

Wij verwelkomen Pablo

Geboren 1 mei 1897 te Lima, Peru

Bij ons sinds 3 augustus 1987 (p. 155)

We kunnen stellen dat Pablo symbool staat voor het kind dat Julia graag wilde krijgen. Het moederschap, en in mindere mate het vaderschap, krijgt zodoende op een onverwachte, onconventionele manier vorm. Wanneer we de roman als een sprookje benaderen, zal het metaforische karakter van de relatie tussen de drie volwassenen in De reis naar het kind (Van der Meer, 2002/1989) ons sneller opvallen. Dan wordt ook duidelijk dat de hedonistische visie op moederschap als niet reëel op de korrel wordt genomen. In plaats hiervan wordt het krijgen van een kind voorgesteld als iets dat om opofferingen vraagt. Dit is in ieder geval de les die Julia als 'moeder' van Pablo leert. Pablo tart elke verwachting die zij van haar baby had. Hij dwingt haar het gedroomde ideale kind waarvan ze de moeder wilde zijn, los te laten. Gaandeweg leert ze om 'het kind' Pablo te accepteren zoals hij is en ze komt er als zijn moeder ook achter dat zijn wensen niet altijd met haar verlangens overeenkomen. Zo weigert hij om de kleren aan te trekken die Julia voor hem klaar legt. Aanvankelijk ergert Julia zich hier aan, net zoals ze zich aan zijn traagheid tijdens hun strandwandelingen stoort. Uiteindelijk accepteert ze dat Pablo zich door haar niet in een gewenste mal laat drukken. Julia leert zodoende met hulp van Pablo dat zij haar eigen verwachtingen niet aan een kind kan en moet opleggen en dat zij haar eigen wensen soms ondergeschikt moet maken aan het welzijn van haar kind. Deze interpretatie wordt bevestigd door het einde van de roman. Vlak nadat Julia deze les over het moederschap heeft geleerd, ontdekt ze dat ze zwanger is. Het lijkt er op dat ze ook voor deze geleerde les beloond wordt. Van een moeder wordt hier dus verwacht dat zij zichzelf op zijn minst ten dele opoffert voor haar kind. Ook voor de vader geldt er zo'n verwachting, maar dit komt minder goed uit de verf, omdat het toch vooral Julia's ervaringen zijn waar het in het boek om draait. De roman neigt 
hierdoor naar de (re)productie van een conventionele, patriarchale vorm van moederschap waarbij zelfopoffering centraal staat. Het type moederschap dat gepaard wordt aan zelfopoffering is opvallend genoeg een vorm van moederschap die we vaak ook in traditionele sprookjes tegenkomen (Wiley, 2000). Binnen gender studies is deze visie op moederschap allesbehalve onbekritiseerde. Het zou een ongelijke taakverdeling tussen moeders en vaders in de hand werken en de eigen verlangens en zelfontplooiing van de moeders uitvlakken.

\section{Conclusie}

De reis naar het kind (Van der Meer, 2002/1989) blijkt een tegenwicht te bieden aan het idee dat we zelf kunnen bepalen of en wanneer we kinderen krijgen; aan de keuzemoraal waarmee het rooskleurige beeld van moederschap is omgeven. De roman bekritiseert ook de hedonistische visie op moederschap. Daarbij kan dit boek als een kritische exploratie van interlandelijke adoptie worden gelezen. Bovendien brengt de roman het verdriet, de pijn en de wanhoop van ongewilde kinderloosheid in beeld. De reis naar het kind (Van der Meer, 2002/1989) blijkt bovendien een pleidooi voor een vorm van moederschap, waarin zelfopoffering meer centraal komt te staan. Daarbij wordt er subtiel op gewezen dat de wensen en verlangens van moeders en kinderen niet dezelfde zijn.

Dit werkpotentieel van de roman wordt geactiveerd door een fantastische leeswijze, die door het samenspel van verschillende soorten intertekstuele verwijzingen in de roman wordt gelegitimeerd en mogelijk wordt gemaakt. Vooral verwijzingen naar het premoderne genre van het sprookje spelen hierin een cruciale rol. Zij maken het immers bij uitstek mogelijk om De reis naar het kind (Van der Meer, 2002/1989) als een onrealistische vertelling en meer specifiek als een sprookje te lezen, waarin moederschap en vaderschap op metaforische wijze wordt gerepresenteerd. 


\section{Hoofdstuk 5}

\section{Zwanger van herkenbare spanning. Nieuwe buren (2006) van Saskia Noort}

\section{Inleiding}

In een interview met Saskia Noort in het NRC Handelsblad wijst Hester Carvalho er op dat Noorts thrillers om in gevaar verkerende moeders en hun kinderen gaan (Carvalho, 2009). Noort beaamt dit en ziet onder meer "het idee dat een kind iets overkomt", wat voor een ouder "het meest bedreigende [is] dat je kunt bedenken" (Carvalho, 2009), als een belangrijk thrillerelement in haar romans. In Nieuwe buren (2006) beschrijft Noort het onvervulde verlangen van het echtpaar Peter en Eva naar een kind en hoe Eva's pogingen om dit verlangen in vervulling te laten gaan, uiteindelijk desastreuze en zelfs dodelijke gevolgen voor haar en haar ongeboren kind hebben.

De ontvangst van deze en andere romans van Noort in de literatuurkritiek is doorgaans niet positief. Vooral het literaire gehalte van Noorts werk wordt in recensies gehekeld. Nieuwe buren (Noort, 2006) zou bijvoorbeeld niet literair zijn, omdat de personages stereotiep zijn en het plot te formulematig (Schenke, 2006; Botman, 2006; 'Kip zonder kop', 2006). Ondanks deze kritiek verkopen Noorts boeken zeer goed. Van Nieuwe buren (Noort, 2006) zijn in twee maanden tijd maar liefst tweehonderdduizend exemplaren verkocht. Dit is een recordaantal wanneer het gaat om de verkoop van spannende boeken in Nederland ('Kort nieuws', 2006). De herkenbaarheid en toegankelijkheid van haar werk wordt dus door een grote groep lezers gewaardeerd. Niet voor niets is het boek ook voor de NS Publiekprijs 2006 genomineerd ('Genomineerden NS Publieksprijs.......... .', 2006). Ook binnen het thrillercircuit wordt haar werk positief ontvangen. Ze is verscheidene malen genomineerd voor de Gouden Strop (Gouden Strop, geen datum). Dit is een jaarlijkse prijs voor de beste Nederlandstalige misdaadroman en wordt uitgereikt door het Genootschap van Nederlandstalige misdaadauteurs (Gouden Strop, geen datum). Noort zelf ontkent overigens niet dat haar romans toegankelijk zijn en haar personages zeer herkenbaar. Ze meent bovendien dat die herkenbaarheid de kracht van haar werk is, ook al zijn de omstandigheden waarin die personages belanden extreem. Ze pro- 
beert naar eigen zeggen zodanig over mensen en hun problemen te schijven dat lezers zichzelf er in kunnen herkennen (Van den Bergen, 2006). Juist daarom hebben haar boeken volgens haar meer te bieden dan alleen amusement. In een interview over Nieuwe buren (Noort, 2006) in de Volkskrant zegt ze hierover:

\footnotetext{
'Natuurlijk wil ik de lezer meer meegeven dan een paar uurtjes light entertainment, en de goede verstaander maakt dit ook op uit mijn boeken. Ik schrijf over deze tijd. De goddeloze tijd, waarin we allemaal met onszelf bezig zijn, met de duizenden keuzes en mogelijkheden waarvoor we staan, en de verplichting van het NU genieten. Mijn personages worstelen hiermee en hebben niet de geestelijke bagage om om te gaan met pech, ongeluk, onvrede. Geen literaire helden, maar mensen die je overal tegen kunt komen, die je misschien wel kent, of bent. Het enige verschil tussen mijn personages en mijn lezers is dat de keuzes die mijn personages maken, fataal uitpakken. Ik wil daarmee niet moraliseren, maar misschien wel een spiegel voorhouden. (Van den Bergen, 2006)
}

Het doel is hier, zoals in inleiding van dit boek aan bod kwam, niet om te beweren dat Nieuwe buren (Noort, 2006) als literair kan worden beschouwd, omdat de roman verrassend, vernieuwend of uniek is. Het gaat er om de betekenissen die de roman kan genereren te onderzoeken in het licht van de moderne hedonistische benadering van het moederschap. In dit hoofdstuk wordt zichtbaar dat we twee kanten op kunnen met de roman. We kunnen het boek als een kritiek op, maar ook als een bevestiging van het vertoog van genieten over moederschap lezen. Het culturele werkpotentieel van de roman wordt blootgelegd via een analyse van de wijze waarop Nieuwe buren (Noort, 2006) bij de genres van de thriller, de a-heroïsche misdaadroman en de gothic novel aansluit. Daarbij zal duidelijk worden dat Noort (2006) het herkenbare inderdaad allerminst schuwt. Eerst echter een korte bespreking van de algemene inhoud en opbouw van de roman.

\section{Seks, drugs en rock' $n$ roll in een Vinexwijk}

Nieuwe buren (Noort, 2006) is een roman over intriges en moord. De schuin gedrukte proloog van vijf pagina's zet duidelijk de toon. In het Center Parcs vakantiebungalowpark De Kempervennen treft een medewerker in de gang van een van de bungalows een sterk ondervoede, ongewassen en uitgedroogde, maar nog levende peuter aan. De hulpdiensten worden gealarmeerd en deze vinden in de woonkamer vervolgens de levenloze lichamen van drie volwassenen, twee vrouwen en een man, en een vierde zwaar gewond persoon wiens sekse niet wordt genoemd. De drie zijn duidelijk geen natuurlijke dood gestorven, want het tapijt heeft zich "volgezogen [...] met bloed" (Noort, 2006, p. 12) en bij het levenloze lichaam van de man ligt een vuurwapen. Deze gruwelijke ontdekking betreft op het geschiedenisniveau chronologisch gezien het einde van de gebeurtenissen die in de rest van de roman uit de doeken worden gedaan. We hebben op dit niveau dus eigenlijk te maken met een epiloog in plaats van een proloog. Als lezer begin je het boek zodoende met kennis van het einde en word je opgezadeld met een aantal prangende vragen: Hoe heeft 
dit kunnen gebeuren? Wie zijn deze slachtoffers? En wie heeft dit op zijn geweten? Het zijn deze vragen die in loop van de roman zullen worden beantwoord. Daarbij probeert Noort (2006) de antwoorden zo lang mogelijk te verbergen en zo de spanning vast te houden.

$\mathrm{Na}$ de proloog wordt de eigenlijke geschiedenis achteraf, maar in tegenwoordige tijd verteld, afwisselend vanuit het perspectief van de hoofdpersonages Peter en Eva. We leren het echtpaar kennen, als ze met tegenzin hun nieuwe twee-onderéén-kap-woning betrekken in de Vinexwijk De Zonnepolder. Al snel wordt duidelijk dat ze de betonnen, grijze nieuwbouwwoning in deze kindvriendelijke buurt hebben gekocht om er als gezin te gaan wonen. Toen ze een bod deden op het destijds nog te bouwen huis, was Eva namelijk zwanger. Voordat ze het huis konden betrekken, verloren ze het kind echter. Eva bracht hun dochtertje Lieve na acht maanden zwangerschap dood ter wereld. Deze zwangerschap blijkt niet vanzelfsprekend te zijn geweest, omdat Peter praktisch onvruchtbaar is. Hij heeft lui zaad en produceert ook nog eens zeer weinig zaadcellen. Eva en Peter hebben zodoende een lange tocht door de medische wereld achter de rug: "negen IUI-pogingen, vier ICSIbehandelingen, en vijf keer KID" (Noort, 2006, p. 44). ${ }^{111}$ Lieve is het resultaat van de laatste kunstmatige inseminatie met donorsperma (KID) en is biologisch gezien niet de dochter van Peter. Nog midden in het rouwverwerkingsproces en totaal vervreemd van elkaar door de beproevingen die ze hebben moeten doorstaan, komen Eva en Peter in hun nieuwe huis terecht. Hoewel ze in principe met hulp van psychotherapeute en ervaringsdeskundige Hetty hebben besloten de medische molen stop te zetten en ze proberen een leven zonder kinderen te accepteren, blijkt dit een moeilijke zaak.

Hun leven is dus allesbehalve rooskleurig en hun relatie staat op springen. lets dat Peter enorme angst inboezemt, want meer nog dan naar een kind verlangt hij naar Eva. Hij wil haar hoe dan ook niet verliezen. Op dit moment sluiten ze vriendschap met de zongebruinde thuiskapster Rebecca en motoragent en voormalig Dutchbatter Steef, die samen met hun jonge zoontje Sem in een huurhuis tegenover

\footnotetext{
${ }^{111}$ IUI, ICSI en KID zijn vruchtbaarheidsbehandelingen. De afkorting IUI staat voor intra-uteriene inseminatie (Evers \& Heineman, 1999). Bij deze behandeling worden met behulp van een flexibel katheter "na bewerking verkregen mobiele spermatozoa (...) rond het tijdstip van de ovulatie, hoog in de [baarmoeder] (...) [in]gebracht" (Evers \& Heineman, 1999, p. 121). ICSI is de afkorting van intracytoplasmatische sperma injectie en is een laboratoriumprocedure, die wordt gebruikt bij in-vitro fertilisatie (IVF) (Evers \& Heineman, 1999). Het is een procedure waarbij met behulp van een pipet een enkele zaadcel direct wordt ingebracht in het cytoplasma van een eicel. ICSI en IUI worden vooral toegepast in geval van verminderde vruchtbaarheid van de mannelijke partner (American Society for Reproductive Medicine, 2001). Een KID-behandeling betreft kunstmatige inseminatie met sperma van een donor (De Bruyn, 2001; Evers \& Heineman, 1999). In tegenstelling tot de IUI- en ICSI-behandelingen wordt hierbij dus niet het sperma van de mannelijke partner gebruikt. Voor een verdere uiteenzetting over IUI, KID, ICSI en IVF zie Johannes Evers en Maas Heineman (1999).
} 
hen wonen. De verhuizing van Peter en Eva naar de Vinexwijk en de gebeurtenissen die er na volgen, spelen zich waarschijnlijk af in het jaar 2005. Dit blijkt uit een aantal intertekstuele verwijzingen naar de Vertigo-tour van de rockband U2, waarvan Steef en Peter samen een concert in de Amsterdam ArenA bezoeken. ${ }^{112}$ Onder invloed van de seksueel vrije en ongeremde Steef en Rebecca, die regelmatig parenclubs bezoeken, aan partnerruil doen (swingen) en hard drugs gebruiken, lijken Eva en Peter de draad van hun leven op te pakken. Maar dit is slechts schijn. In het bijzonder Eva blijkt haar kinderwens niet los te kunnen laten en zij vertrouwt dit haar nieuwe vriendin Rebecca toe. Rebecca kan zich zeer goed verplaatsen in de behoefte van Eva. Ook zij had ooit een onvervulde kinderwens, want haar echtgenoot Steef zag het vaderschap absoluut niet zitten. Dat heeft haar er echter niet van weerhouden om een kind van Steef te krijgen; ze is opzettelijk de pil 'vergeten'. Rebecca meent dat ook Eva zich niet moet laten tegenhouden bij het verwezenlijken van haar wens. Samen smeden Eva en Rebecca het plan om een swingavondje tussen de twee stellen te organiseren, in de hoop dat Eva dan 'per ongeluk' zwanger wordt van Steef. Ze slagen in hun opzet en Eva wordt zwanger. Hierop ontvlucht zij de Vinexwijk, uit angst dat ze door Steef gedwongen wordt het kind weg te laten halen en omdat ze niemand anders nodig denkt te hebben behalve haar toekomstige kind. Eva maakt echter een fatale tussenstop in het van de proloog al bekende bungalowpark De Kempervennen. Daar weten Rebecca, Steef en later ook Peter haar te vinden. Peter wordt, na het swingavondje en nadat Eva hem heeft verlaten, in toenemende mate geplaagd door waanideeën. Zo is Steef volgens hem de duivel. Om zichzelf en zijn vrouw te beschermen tegen hun buren heeft hij een vuurwapen gekocht, waarmee hij Eva, Steef en Rebecca in de bungalow bedreigt. Uiteindelijk is het echter Rebecca die het eerste schot lost met het dienstwapen van Steef en Peter verwondt, waarna Peter hen alle drie neerschiet. Alleen Sem, het zoontje van Steef en Rebecca, blijft als een baken van onschuld relatief ongeschonden overeind aan het eind van de roman.

Hoe kunnen we Nieuwe buren (Noort, 2006) nu lezen in het licht van het idee dat bewust gekozen moederschap genieten behoort te zijn? Hoe wordt moederschap, en in het bijzonder de (frustratie van de) wens om moeder te worden, hier precies verbeeld? Omdat Peter net zo'n belangrijke focalisator is als Eva, zal de verbeelding van zijn verlangen om vader te worden ook worden besproken.

\footnotetext{
${ }^{112}$ Dat het om deze tour gaat blijkt onder andere uit citaten uit het nummer Vertigo van het album How to dismantle an atomic bomb (2004), naar aanleiding waarvan de Vertigo-tour van start ging.
} 


\section{I want it all, and I want it now...?}

Het moederschap, en in mindere mate het vaderschap, wordt door de meeste personages in Nieuwe Buren (Noort, 2006) geïdealiseerd op een manier die sterke overeenkomsten vertoont met de manier waarop dit in het maatschappelijke vertoog van genieten gebeurt. Zowel Eva als Peter en Rebecca stellen het hebben en krijgen van een kind, nadat ze er voor hebben gekozen om ouders te worden, herhaaldelijk gelijk aan ultiem geluk en genieten. Dat dit voor Eva het geval is, blijkt onder andere wanneer ze terugblikt op haar gedrag en gevoelens na de eerste mislukte pogingen om zwanger te worden van Peter. Ze voelt zich dan beroerd en om zich beter te voelen gaat ze naar het babywarenhuis Prénatal. Bij uitstek een plek waar het moederschap wordt geromantiseerd. Daar beeldt ze zich in dat ze net als de andere vrouwen in de winkel ook zwanger is.

[Ik] [I]iet me uitgebreid adviseren over kolfapparaten en voedingsbeha's, kocht rompertjes en speentjes met I $\vee$ MAMA erop. Ik genoot ervan aangesproken te worden als een van hen, ik wilde zelf geloven dat er een kind in mijn buik groeide, totdat ik de winkel weer verliet met een tas vol spullen en een hol hart. (Noort, 2006, p. 113)

Wanneer ze zich door Rebecca ervan laat overtuigen om zwanger te worden van Steef, breit ze haar bedrog voor zichzelf bovendien recht door te bedenken dat "[e]en kind alles" (Noort, 2006, p. 118) goed maakt. De (re)productie van een rooskleurig beeld van moederschap wordt versterkt door de wijze waarop het zoontje Sem van Rebecca en Steef wordt verbeeld. Sem fungeert niet zo zeer als een personage, maar als een symbool dat het belangrijkste verschil tussen de twee stellen markeert: het ene koppel heeft wel een kind en het andere kan geen kinderen krijgen. Doordat Sem als personage niet wordt uitgewerkt, kan er een eenzijdig idyllisch beeld van hem en daarmee van het moederschap van Rebecca worden geschetst. $\mathrm{Hij}$ is immers geen kind van vlees en bloed met zijn onvermijdelijke nukken en grillen. Eva ziet hem bijvoorbeeld als volgt: "Zo zoet, zo onschuldig, zo tevreden" (Noort, 2006, p. 82). Het is interessant dat het vaderschap dat Peter voor ogen heeft op een soortgelijke wijze wordt geïdealiseerd als het moederschap van Eva: als een middel tot persoonlijk geluk. Zo stelt Peter dat wanneer mensen horen dat je geen kinderen kunt krijgen, ze je vaak "gaan [...] vertellen dat het hebben van kinderen ook niet alles is. Terwijl het dat natuurlijk wel is" (Noort, 2006, p. 46) en "Ik heb jarenlang gedacht: straks, als ons kind er is, gaan we genieten” (Noort, 2006, p. 98). Daarmee sluit de roman aan bij de recente voorzichtige uitbreiding van het vertoog van genieten naar vaderschap.

Daarbij moet worden opgemerkt dat Steef allesbehalve lyrisch over zijn vaderschap is. Steef heeft echter niet bewust voor een kind kunnen kiezen en de ondermijnende kracht van zijn visie op de hedonistische inkleding van het vaderschap is daarmee beperkt. Het moderne geïdealiseerde discours van het moederschap en 
vaderschap wordt ook op andere meer of minder dubbelzinnige manieren ondergraven door de verschillende personages. Om te beginnen besluit Eva om buiten de context van het kerngezin van haar moederschap te gaan genieten. Uit de beschrijvingen van haar gedachten over haar vertrek kunnen we opmerken, dat ze van mening is dat het heteroseksuele kerngezin haar als vrouw en moeder weinig geluk heeft te bieden. Wanneer ze zwanger is van Steef en besluit haard, huis en man te verlaten, stelt ze dat ze "lang genoeg ongelukkig [is] geweest. Ik wil niet meer. Mijn huis, mijn huwelijk verpletteren me. En nu heb ik eindelijk een reden om weg te gaan. Om voor mezelf te kiezen" (Noort, 2006, p. 229). Het moederschap is voor haar zodoende ook een middel om met de norm het heteroseksuele kerngezin te breken. Daarnaast zetten alle personages op zijn minst één keer vraagtekens bij het idee dat het leven maakbaar is. Daarbij zijn zij sceptisch over de schijnbaar eindeloze zoektocht naar middelen om de zelfgemaakte keuze voor een kind te realiseren; een zoektocht die Eva en Peter meestal op een hedonistische wijze legitimeren door te stellen dat een kind hen gelukkig zal maken. Rebecca zegt bijvoorbeeld tegen Eva, voordat ze het idee krijgt om Eva door Steef te laten bevruchten, dat "[e]en kind (...) niet zaligmakend [is]. Je kunt je liefde ook in andere dingen kwijt" (Noort, 2006 p. 72). En Peter laat na de uit de hand gelopen partnerruil zijn gedachten als volgt gaan:

\footnotetext{
We zullen allemaal kapot gaan, we hebben er geen enkele invloed op, we zijn niets en blijven ons maar druk maken om onszelf, ons eigen benauwde bestaan. We zetten maar kinderen op de wereld, hoeveel moeite het ons ook kost, alles hebben we er voor over, om straks met zoveel mogelijk mensen tegelijk ten onder te gaan. Het maakt ons niet uit of onze kinderen verzuipen, als ze ons eerst maar gelukkig hebben gemaakt, ons hebben laten voelen dat we compleet zijn. (Noort, 2006, p. 184)
}

Tijdens een therapiesessie met Hetty bekent Peter, dat hij gelooft "dat we moeten zoeken naar een andere manier om gelukkig te worden. Of gelukkig....Tevreden is misschien een beter woord. Het gaat zoals het gaat, zei mijn vader altijd. En zo is het volgens mij" (Noort 2006, p. 114). Eva zegt later iets soortgelijks:

Waarom junks met hiv wel gezonde baby's krijgen en ik niet. Kennelijk heeft het helemaal geen zin om je best te doen. Het gaat zoals het gaat. Soms heb je geluk, soms pech. Sommigen hebben alle geluk, anderen alle pech. (Noort, 2006, p. 11)

Toch kunnen Peter en Eva de overtuiging dat ze hun leven naar hun eigen inzicht en wensen kunnen inrichten en een daarmee samenhangende hedonistische levenshouding uiteindelijk niet loslaten. Zo blijft Eva haar droom om moeder te worden najagen en kan Peter uiteindelijk niet accepteren dat Eva hem verlaat. Ook Rebecca en Steef hebben het idee dat het leven maakbaar is en het vervullen van hun persoonlijke verlangens hoog in het vaandel staan. Genieten en instant bevrediging zijn Steefs motto: "Geniet. Haal uit het leven wat er in zit" (Noort, 2006, p. 81). Rebecca 
stelt haar eigen behoeftes eveneens boven alles en iedereen. Dit blijkt bijvoorbeeld wanneer duidelijk wordt dat ze Eva vooral helpt, omdat ze graag een broertje of zusje voor Sem wil. Zelf kan zij geen kinderen meer krijgen, omdat ze zich op aandringen van Steef heeft laten steriliseren. Daar legt zij zich niet zomaar bij neer. Door Eva zwanger te laten maken door Steef, hoopt ze alsnog het gedroomde zusje of broertje voor Sem te krijgen. Dit vertelt ze Eva pas als de partnerruil al heeft plaats gevonden. Rebecca's aanbod om Eva te helpen een kind te krijgen is dus niet onbaatzuchtig.

Op basis hiervan kunnen we voorzichtig concluderen dat Nieuwe buren (Noort, 2006) zich ambigue verhoudt ten aanzien van het vertoog van genieten over moederschap en de recente uitbreiding ervan naar het vaderschap. Dit blijkt ook uit een analyse van de verschillende (sub)genres waar Noort (2006), al dan niet bewust, bij aanhaakt.

\section{Een thrilleresque a-heroïsche misdaadroman}

Nieuwe Buren (Noort, 2006) wordt door uitgeverij Anthos verkocht als een literaire thriller. De meest voor de hand liggende manier om de roman generisch te categoriseren, als een thriller, lijkt daarmee gegeven. De term thriller is als verwijzing naar een bepaald genre echter diffuus en verdient daarom een toelichting.

Filmwetenschapper Martin Rubin (1999) wijst er terecht op dat het etiket thriller weliswaar veel wordt gebruikt in de literatuur- en filmwetenschap en daarbuiten, maar dat de term veel breder wordt gehanteerd dan conventionele genrecategorieën, die naar een "conventionalized category of story" (p. 4) verwijzen. Volgens Rubin (1999) kunnen we de thriller niet als zo'n soort genre beschouwen. Daarvoor is het spectrum aan romans en films dat thriller is genoemd te divers en omvangrijk (Rubin, 1999, p. 4). Romans die onder de uiteenlopende genres van bijvoorbeeld de misdaadroman, horrorroman, spionageroman, detectiveroman, science fictionroman en de gotieke roman kunnen worden geschaard, staan als thriller te boek. Er bestaat volgens Rubin (1999) niet zoiets als de thriller pur sang, wat hij een "thriller, thriller" (p. 4) noemt. Hij beschouwt de thriller daarom niet als een conventioneel genre, maar als een 'metagenre' waaronder verschillende andere genres geschaard kunnen worden. Onder de thriller verstaat hij veeleer bepaalde "thrilleresque" (Rubin, 1999, p. 4) kwaliteiten die we in boeken uit verschillende genres kunnen tegenkomen. Niet alle thrillers hoeven deze eigenschappen te bezitten en het blijft volgens Rubin (1999) lastig om er precies de vinger op te leggen wat een boek of film nu precies tot een thriller maakt. Niettemin kunnen we op basis van zijn werk een aantal van deze thrilleresque kwaliteiten aanwijzen.

De thriller is volgens Rubin (1999) bij uitstek een modern genre en komt aan het begin van de twintigste eeuw op in Amerika. Op basis van het werk van verschillende literatuurwetenschappers over genres en romans die onder de thriller worden 
geschaard, wijst hij onder meer de volgende kenmerken aan die een boek of een film tot een thriller maken of, beter gezegd, die wijzen op thrilleresque kwaliteiten. Om te beginnen kennen boeken en films die onder dit metagenre vallen doorgaans veel suspense en actie en is er sprake van een "sense of departure from the routine world into a realm that is more marvelous and exciting" (Rubin, 1999, p.5). Onder suspense wordt meestal het geheel "van factoren" in een roman verstaan "waardoor de betrokkenheid van de lezer (...) gestimuleerd wordt en zijn aandacht (...) op de ontknoping der gebeurtenissen" (Gorp, Delabastita \& Ghesquiere, 2007, p. 439) wordt gericht. Het gaat met andere woorden om het creëren van spanning. Dit gebeurt onder andere door bepaalde zaken voor de lezers verborgen te houden en de onthulling hiervan zo lang mogelijk uit te stellen (Gorp, Delabastita \& Ghesquiere, 2007; Rubin, 1999). Daarnaast grossieren de meeste thrillers volgens Rubin (1999) in overdrijving. Bepaalde aspecten van de vertelling worden meer dan nodig zou zijn voor het strikt vertellen van de geschiedenis breed uitgemeten. Het gaat dan vooral om het overdrijven van gevoelens van "suspense, fright, mystery, exhilaration, excitement, speed, movement" (Rubin, 1999, p. 6). Daarbij wordt de thriller gekenmerkt door een ambiguïteit bij het weergeven en oproepen van bepaalde gevoelens bij de lezers. De lezers worden in verschillende richtingen getrokken. Het belangrijkste voorbeeld hiervan is dat we bij het lezen van een thriller plezier aan de lijdensweg van de hoofdpersonages beleven, maar dat we zelf ook lijden door onze identificatie met die hoofdpersonages. Deze personages zijn overigens meestal vrij hulpeloos:

They are swept up in a rush of events over which they have little control. The thriller creates, in both hero and spectator, a strong sense of being carried away, of surrendering oneself. Controlvulnerability is a central dialectic of the thriller. (Rubin, 1999, p. 7)

De setting waarin een thriller zich afspeelt, is de moderne wereld, meestal een stad. Deze omgeving wordt in de thriller voorzien van een "archaic and even primitive sense of the marvelous, the wild and the adventurous" (Rubin, 1999, p. 14). De setting en ook de personages zijn op het eerste oog vaak heel herkenbaar en alledaags in de optiek van de lezers die deel uitmaken van de sociaalhistorische context waarin de roman of film wordt gepubliceerd. Dit beeld wordt echter verstoord door buitengewone zaken zoals een moord. Op deze en andere manieren wordt er in de thriller gespeeld met het contrast tussen het gewone en het uitzonderlijke. Er wordt gespeeld met de angst voor de terugkeer van het door de modernisering verdrongen verleden, voor anarchie en het appelleert tegelijkertijd aan ons verlangen om aan de heersende orde te ontsnappen. De aantrekkingskracht van de thriller ligt in "its grip on our ambivalent desires both to escape from and to remain within the uneasy security of our increasingly downsized world" (Rubin, 1999, p. 268).

De misdaadroman is volgens Rubin (1999) een van de genres waarbinnen we veel romans tegenkomen die thrilleresque kwaliteiten hebben. Met de term mis- 
daadroman wordt doorgaans verwezen naar vertellingen "over een of meer misdadigers of een misdaad” (Gorp, Delabastita \& Ghesquiere, 2007, p. 298). De misdaadroman is in de negentiende eeuw ontstaan, maar heeft enkele voorlopers in de achttiende eeuw. Het is in de twintigste en een eenentwintigste eeuw nog steeds een bloeiend genre, dat meestal tot de lectuur en niet tot de literatuur wordt gerekend. De bekendste vorm van de misdaadroman is de detective, ook wel whodunit genoemd, waarin een heroïsche detective een moord oplost en de verstoorde orde zo herstelt (Gorp, Delabastita \& Ghesquiere, 2007). Literatuurwetenschappers Katharine Horsley en Lee Horsley (1999) wijzen er op dat er binnen de misdaadroman in de jaren dertig van de twintigste eeuw een subgenre opkomt dat zij de "noir aheroic crime novel" noemen. Anders dan in de klassieke misdaadroman handelen de hoofdpersonages in deze a-heroïsche misdaadromans niet met het oog op het herstellen van de orde, maar zijn zij zelf moordenaars of de (beoogde) slachtoffers van een moordenaar (Horseley \&Horseley, 1999). Dit subgenre heeft, aldus Horsley en Horsley (1999), verder de volgende kenmerken:

The normal world is shown to be vulnerable and easily disrupted; there are no clear distinctions between guilt and innocence; love ends in crime and death; the resolution is ambiguous and irony is pervasive; there is no heroic detective figure in the ascendancy; instead, obsessed, alienated, schizoid characters struggle to make sense of chaotic reality, haunted by dark secrets, their lives possessed by the past, their identities destabilized. (Horsley \& Horsley, 1999, p. 371)

In de eerste a-heroïsche misdaadromans staat doorgaans een mannelijk personage centraal. Het gaat in deze romans om een crisis van de mannelijke identiteit van het hoofdpersonage (Horsley \& Horsley, 1999). Het mannelijke hoofdpersonage in een a-heroïsche misdaadroman wordt gekenmerkt door

\footnotetext{
impotence or impaired masculinity, submitting passively to his fate or driven to an act of violence from the consequences of which there is no escape; polarized judgments are broken down by the creation of a central figure who is not heroically pitted against the forces of evil, but who instead struggles against his own self-division--against the 'schisms [...] within the male psyche' (Krutnik 129). The 'crisis of masculinity' portrayed is most obviously a crisis of agency. That is, the narrative centers on a testing of the protagonist's masculine competence and his capacity for selfdetermination. He engages in a quest to consolidate his masculine identity. (Horsley \& Horsley, 1999, p. 371)
}

De nadruk op onbeheersbare, onbewuste, verdrongen driften is een veelvoorkomend motief in het subgenre en lijkt psychoanalytisch geïnspireerd. In dit opzicht staan de a-heroïsche misdaadromans op gespannen voet met het moderne mensbeeld waarbij het draait om rationaliteit, autonomie, keuzevrijheid en controle. Afgaand op de beschrijving van Horseley en Horseley (1999) heeft het mannelijke hoofdpersonage in de a-heroïsche misdaadroman zichzelf juist vaak niet in bedwang en is hij allesbehalve rationeel. Er wordt gespeeld met angst voor het verlies aan controle en voor onderbewuste driften. 
Vanaf de tweede feministische golf verschijnen er volgens Horsley en Horsley (1999) steeds meer Engelstalige a-heroïsche misdaadromans waarin het gaat om de vrouwelijke identiteit in crisis. Deze zijn van de hand van vrouwelijke auteurs, zoals Barbara Vine en Patricia Highsmith. Ze noemen deze romans vanwege de centrale aandacht voor vrouwelijke identiteit en omdat ze meestal door vrouwen zijn geschreven, ook wel "women's noir" (Horsley \& Horsley, 1999, p. 376). 'Vrouwelijke' a-heroïsche misdaadromans zijn vaak boeken waarin de drang om te 'moederen' van het vrouwelijke hoofdpersonage desastreuze gevolgen heeft (Horsley \& Horsley, 1999). In de conventionele 'mannelijke' a-heroïsche misdaadromans komt de figuur van de moeder ook wel voor, maar daarin gaat het niet zo zeer om haar beleving van het moederschap. De moeder fungeert dan niet als een subject, maar als een objectfiguur in een vertelling waarin haar volwassen zoon centraal staat. Daarbij wordt een verkeerde binding tussen moeder en zoon vaak als de oorzaak van misdadig, meestal moorddadig gedrag van haar zoon aangewezen. ${ }^{113}$ In de 'vrouwelijke' a-heroïsche misdaadromans staat de moeder als subject juist centraal. Daarbij worden heersende, geïdealiseerde opvattingen over vrouwelijke identiteit blootgelegd en wordt de handelingsruimte van het vrouwelijke subject onderzocht. Vooral geïdealiseerde beelden van het moederschap worden op een kritische manier onder een vergrootglas gelegd. Daarbij eindigen de romans dikwijls niet optimistisch en ze ontsnappen niet aan een vorm van motherblaming. De moeders blijven "guilty as charged"--inflicting psychological damage, erring in their judgments, or themselves committing crimes of violence" (Horsley \& Horsley, 1999, p. 374). De betekenissen die deze boeken oproepen zijn daarmee vaak tegenstrijdig.

De term 'vrouwelijke' en 'mannelijke' a-heroïsche misdaadromans wordt hier verder ook gebruikt, maar alleen om te verwijzen naar het feit dat het in deze misdaadromans om de identiteitscrisis van respectievelijk een vrouwelijk of mannelijk hoofdpersonage gaat. Het gaat bij het gebruik van deze termen in dit hoofdstuk dus niet om een verband tussen de sekse van de auteurs en een bepaald genre. ${ }^{114}$

Nieuwe buren (Noort, 2006) heeft onmiskenbaar een thrilleresque kwaliteit. Het boek kent een snel actieverloop en het creëren van suspense staat voorop. Die suspense wordt onder andere opgeroepen doordat we als lezers niet op de hoogte zijn van de toedracht van de moord. Doordat wij wel van de naderende moord afweten

\footnotetext{
${ }^{113}$ Zie bijvoorbeeld Roel van den Oever (forthcoming) voor een uitgebreidere analyse van deze vorm van motherblaming zoals die onder meer in Amerikaanse thrillers na de Tweede Wereldoorlog gestalte krijgt. ${ }^{114}$ Wanneer soortgelijke termen als vrouwenromans of chicklit in het verleden wel op deze manier werden gebruikt, heeft dit meer dan eens geleid tot stereotiepe karakteriseringen van het werk van bepaalde auteurs op basis van hun sekse. Daarbij zijn vrouwelijke auteurs vaak nogal gemakkelijk en onterecht op een hoop gegooid. Er is geen aandacht aan de verschillen tussen hun romans besteed (zie bijvoorbeeld Erica van Boven, 1992). Daarom worden de termen 'vrouwelijke' en 'mannelijke' aheroïsche misdaadromans in dit hoofdstuk niet op deze manier ingezet.
} 
en de personages niet, kan er bovendien een gevoel van dreiging en spanning ontstaan en wellicht de behoefte om de personages te waarschuwen. De roman wordt daarnaast gekenmerkt door een uiterst beklemmende sfeer. Daarvoor put Noort (2006) onder andere uit het repertoire van de gothic novel en meer specifiek de homely gothic novel. Daarover later meer. De personages kunnen bovendien ambivalente gevoelens bij ons als lezers te weeg brengen. Eva en Peter focaliseren en we zijn daardoor geneigd om ons met hen te identificeren, maar het feit dat ze lijden levert ook een vermakelijke geschiedenis op. Zij lijken, en dit geldt vooral voor Peter, bovendien vrij hulpeloos en hebben de controle over de gebeurtenissen of zichzelf verloren. De setting is ten slotte modern, weliswaar geen stad maar een buitenwijk en is net als de personages op het eerste oog heel herkenbaar en alledaags. Het gewone wordt echter verstoord door intriges en geweld.

Daarbij kunnen we stellen dat de roman overduidelijk een a-heroïsche misdaadroman is. De hoofdpersonages zijn immers de dader (Peter) en een slachtoffer (Eva) en bijvoorbeeld niet een heroïsche detective die een moord komt oplossen. Het is geen klassieke detective. Het adjectief 'literair' dat door uitgeverij Anthos aan Noorts thriller wordt verbonden, verwijst hiernaar, aldus Noort zelf. In het tvprogramma De Wereld Draait Door stelt Noort dat zij en haar uitgever met het woord 'literair' op haar boeken het signaal willen afgeven dat het niet om klassieke "whodunit[s]" gaat (VARA, 2006). In de uitwerking van de geschiedenis van Peter en Eva sluit Noort (2006) in bepaalde opzichten aan bij het subgenre van de 'vrouwelijke' a-heroïsche misdaadroman. Eva is in strikte zin weliswaar geen moeder, maar daar valt iets op af te dingen. Zij heeft immers een dood kind gebaard en voelt zich daardoor in zekere zin toch een moeder. "Ik ben moeder. Weliswaar van een dood kind, maar ik ben en blijf een moeder die zielsveel van haar kind houdt, al is het dood. Al heb ik haar nooit echt gekend" (Noort, 2006, p. 74). We kunnen bovendien zeker stellen, dat het verlangen om te moederen in deze roman, net als in de 'vrouwelijke' a-heroïsche misdaadromans, debet is aan de verstoring van de 'normale' orde. Bovendien gaat de roman over de identiteitscrisis van het vrouwelijke én het mannelijke hoofdpersonage. In het laatste opzicht heeft Nieuwe buren (Noort, 2006) ook veel weg van de 'mannelijke' a-heroïsche misdaadromans. In feite hebben we hier dus met een mengvorm van de 'vrouwelijke' en 'mannelijke' variant van de a-heroïsche misdaadroman van doen.

De verbeelding van de vrouwelijke en mannelijke identiteit in crisis komt hierna als eerste aan de orde. Daarmee wordt meteen een belangrijk thrilleresque element van de roman ontrafeld: personages die geen vat meer hebben op zichzelf en hun omgeving. Daarna wordt de beklemmende sfeer en suspense ontleed. De verbeelding van de locaties waar de gebeurtenissen zich afspelen dragen, in relatie tot de worsteling van personages met (verdrongen) verledens en verlangens, bij aan die beklemming en suspense. Hierbij kunnen we intertekstuele verwijzingen naar de homely gothic novel ontwaren, een aan het thriller verwant genre. Ook deze verwij- 
zingen geven de roman een thrilleresque kwaliteit. Vanuit de vraag hoe het fatale verlangen naar moederschap in relatie tot de norm van genieten rondom bewust gekozen moederschap kan worden gelezen, is het de moeite waard om deze elementen achtereenvolgens te bespreken.

\section{Vrouwelijke en mannelijke identiteit in crisis}

Nieuwe buren (Noort, 2006) drijft op het verlangen van Eva naar een kind. Haar zelfbeeld komt in het gedrang, omdat het haar niet lukt om moeder te worden. Haar inspanningen om koste wat kost zwanger te worden, zorgen ervoor dat de orde in de levens van Eva en Peter gruwelijk wordt verstoord. In dit opzicht is Eva niet zomaar een onschuldig slachtoffer. De roman draait voor groot deel om haar maternal guilt, ook al is het Peter die de trekker overhaalt. Voor Eva is het moederschap het grootste begeerde goed. Het kan dan ook haast niet toevallig zijn, dat ze Eva heet. Wat een overduidelijke intertekstuele verwijzing naar de Bijbelse Eva is, die binnen het christendom als de oermoeder wordt beschouwd. Eva's verlangen naar een kind resulteert in een seksuele uitspatting waarbij zij en Peter hun belofte van huwelijkse trouw doorbreken.

Op aandringen van Eva laat Peter zich er van overtuigen dat partnerruil een goed idee is. Die partnerruil worden erg expliciet beschreven en de seksscènes in de roman zijn bijna pornografisch. lets waar sommige recensenten ook aanstoot aan hebben genomen (zie bijvoorbeeld Bertram Mourits (2007)), maar wat wel past bij het 'overdreven' karakter van thrillers. Uiteindelijk heeft de partnerruil gruwelijke gevolgen voor Eva en de andere personages. Peter wordt er immers waanzinnig door. Hij slaat echter pas volledig door wanneer Eva besluit er van door te gaan en het kind alleen op te voeden. Daarvoor benadert ze eerst Rebecca, met het voorstel om met hun kinderen samen te vertrekken: "Volgens mij moeten we weggegaan, Rebecca. Samen, naar Frankrijk, of Spanje, of nog verder. In alle rust en veiligheid Sem opvoeden en dit kind krijgen" (Noort, 2006, p. 228). Maar Rebecca weigert uit angst voor wat Steef dan zou kunnen doen en Eva gaat alleen. Eva wordt zo als een onafhankelijke, geëmancipeerde vrouw afgebeeld. Ze weet wat ze wil en zal er alles voor doen om het te krijgen. Daarbij tart ze de mannelijke autoriteit van Peter en Steef op twee manieren. Ten eerste door zwanger te worden van Steef, terwijl Steef en ook Peter dit absoluut niet willen. Ten tweede, door er vandoor te gaan met de intentie om haar kind zonder mannen op te voeden. Daarbij knaagt ze aan patriarchale normen van huwelijkstrouw en het heteroseksuele kerngezin. Tegelijkertijd lijkt ze vast te houden aan een vrij conservatief beeld van de invulling van haar identiteit en haar leven als vrouw: alleen het moederschap voldoet.

We kunnen de dodelijke ontknoping op twee manieren interpreteren. Enerzijds kunnen we het slot als een kritisch commentaar beschouwen op het idee dat een waardevolle invulling van de vrouwelijke identiteit enkel in het moederschap is 
gelegen, zoals Eva lijkt te denken. Als Eva er in was geslaagd dit idee los te laten, had ze waarschijnlijk nog geleefd. Dat ze dit niet kan, hangt samen met het feit dat ze denkt dat het leven maakbaar is en dat ze er op hedonistische wijze van overtuigd is, dat ze recht heeft op datgene waarvoor ze kiest. We kunnen de roman dus ook als een kritische kanttekening bij deze ideeën lezen; ideeën die onderdeel zijn van het beschreven moderne moederschapsideaal. Anderzijds kunnen we het einde net zo gemakkelijk als een afstraffing voor de emancipatoire strevingen van Eva beschouwen, net zoals de Bijbelse Eva voor het plukken van verboden vruchten is gestraft. Juist omdat Eva de mannelijke autoriteit trotseert, moet ze sterven. Het moederschap dat zich buiten de context van het heteroseksuele kerngezin afspeelt, wordt in de kiem gesmoord. Vanuit dit perspectief bezien (re)produceert de roman het geïdealiseerde beeld van moederschap dat binnen het vertoog van genieten centraal staat en dat juist uitgaat van dit heteroseksuele kerngezin. Buiten de patriarchale orde waarin mannen het voor het zeggen hebben, blijkt er geen ruimte voor het moederschap. Daar loert enkel de dood. Er zit dan ook zeker een kern van waarheid in de opmerking van een criticus als Arie Storm dat het werk van Noort "vrouwonvriendelijk" is ('Kip zonder kop', 2006).

Uit de wijze waarop de mannelijke identiteit van Peter wordt verbeeld, blijkt ook dat de roman meerduidige betekenissen oproept. Peter lijkt op het eerste gezicht een geëmancipeerde, zorgzame man die op gelijke voet met zijn vrouw staat. Al snel wordt duidelijk dat hij eigenlijk helemaal niet zo geëmancipeerd is. Zijn zelfbeeld komt in het geding, wanneer hij merkt dat hij onvruchtbaar is en dat zijn vrouw daardoor niet langer afhankelijk van hem is. In een tijd waarin vrouwen in principe hun eigen brood op de plank kunnen brengen, hebben ze mannen in de beleving van Peter enkel nog nodig vanwege hun zaad. Dat Peter niet in staat is om een kind te verwekken, brengt het beeld dat hij van zichzelf als man heeft aan het wankelen. Peter kan zijn opvattingen over wat een man behoort te zijn, niet verenigen met zijn onvruchtbaarheid. Voor hem hangt zijn mannelijkheid onlosmakelijk samen met zijn vruchtbaarheid. Daarmee onderschrijft hij conventionele, patriarchale opvattingen over mannelijkheid. Hierin wordt mannelijkheid gekoppeld aan vruchtbaarheid en ook aan viriliteit en geweld, en daarnaast aan zaken als rationaliteit, controle, autonomie, daadkracht; met andere woorden aan de moderne notie van het subject (Throsby \& Gill, 2004; Connell, 1995). Een 'echte' man is binnen dit vertoog bovendien heteroseksueel en zijn vrouw is afhankelijk en ondergeschikt aan hem. Vruchtbaarheid en viriliteit worden binnen de parameters van dit discours vaak als inwisselbaar beschouwd en verminderde vruchtbaarheid wordt hierdoor dikwijls geasso- 
cieerd met impotentie (Throsby \& Gill, 2004). ${ }^{115}$ Dit stereotype wordt gereproduceerd in de roman. Peter wordt door zijn verminderde vruchtbaarheid seksueel minder viriel. Hoewel hij niet impotent is, kan hij zijn vrouw niet meer tot seks verleiden. Laat staan dat hij haar tot seksuele hoogtepunten kan brengen. Hierdoor voelt Peter zich minder mannelijk.

Peters negatieve zelfbeeld wordt gevoed door zijn ontmoeting met Steef. Steef is op het eerste oog een 'echte' man. Zijn vrouw stelt zich afhankelijk van hem op, hij is uiterst vruchtbaar, kan Eva tijdens de partnerruil tot grote seksuele hoogten brengen en deinst er niet voor terug om geweld te gebruiken. De beroepen die hij uitoefent en heeft uitgeoefend, respectievelijk politieagent en militair, worden in veel westerse samenlevingen als zeer mannelijk beschouwd. In het bijzonder het leger geldt als een organisatie die in verband wordt gebracht met het hierboven beschreven conservatieve ideeën over mannelijkheid. Het leger wordt, ook in Nederland, gezien als een "bastion of male identity and the place where 'boys' are turned into 'men'” (Sion, 2007, p. 96). Door zijn vriendschap met Steef wordt Peter gesterkt in zijn overtuiging dat hij als man te kort schiet en dat hij Eva daardoor aan Steef verliest. Steef, die symbool staat voor een vorm van mannelijkheid waaraan hij niet kan voldoen, wordt opvallend genoeg in eerste instantie een object van seksueel verlangen voor Peter. Peter is gefascineerd door hem en deze fascinatie wordt door Noort (2006) in zeer seksueel beladen termen beschreven. Een voorbeeld hiervan is de passage die volgt nadat Steef en Peter XTC-pillen hebben geslikt op het U2-concert:

Ik zie Steef. Het is een wonder en tegelijkertijd niet meer dan logisch. We horen bij elkaar. Steef is mijn man. Mijn vriend. We zijn niet voor niets tegenover elkaar komen wonen. We hebben een magische band. Soulmates. We tillen elkaar op. [...] Steef is de enige man met wie ik het zou kunnen doen. Ik houd van hem. En wat is daar eigenlijk gek aan. (Noort, 2006, p. 133)

Tijdens de partnerruil kust Steef Peter bovendien op de mond en kunnen we het volgende lezen: "Steef knuffelt me [Peter] en ik voel zijn zachte lul langs mijn onderbuik gaan. Hij gloeit" (Noort, 2006, p. 155). Steef is wellicht dus niet zo heteroseksueel, als hij in eerste instantie lijkt te zijn. Peters angst om Eva kwijt te raken en naar we mogen veronderstellen hoogst waarschijnlijk ook een onbewuste homofobische angst voor zijn gevoelens voor Steef, ook al wordt daar niet expliciet naar verwezen - zijn in feite angstgevoelens om het restje van wat hij als zijn mannelijkheid beschouwt te verliezen. Daarom gaat hij Steef haten en wordt hij waanzinnig. Hij denkt op een gegeven moment zelfs dat de songteksten van de nummers van

\footnotetext{
${ }^{115}$ Dit vertoog over heteroseksuele mannelijkheid is sterk normatief en heeft er in Nederland onder andere toe geleid dat er een taboe op onvruchtbaarheid bij mannen rust. Dit taboe is sinds het midden van de jaren zeventig wel enigszins doorbroken (De Bruyn, 2001).
} 
zijn favoriete bands en zangers verborgen boodschappen voor hem bevatten en verschanst zich nachtenlang in de huiskamer om die te ontcijferen. Zijn waanzin resulteert uiteindelijk in moord.

We kunnen de verbeelding van Peters identiteitscrisis enerzijds als een kritiek op het mannelijkheidsideaal dat hij heeft omarmd beschouwen en daarmee ook op de notie van het moderne subject dat als autonoom, rationeel en beheerst geldt. Juist omdat Peters identiteit niet met dit ideaal strookt, pleegt hij immers uiteindelijk een moord. Daarbij wordt het idee van een subject dat zichzelf volledig in de hand heeft als onhoudbaar gerepresenteerd. Het ideaal van het moderne subject wordt verruild voor een meer psychoanalytisch idee van de mens die ten prooi valt aan onbewuste driften. Dat de door Peter omarmde mannelijke, moderne notie van de mens als onhoudbaar wordt voorgesteld, blijkt ook uit de wijze waarop het beeld van de daadkrachtige en autonome Steef gaandeweg wordt ondergraven. Zijn vrouw blijkt helemaal niet zo afhankelijk en onderdanig, maar gaat op slinkse wijze tegen zijn wensen in. Hij blijkt bovendien aan zijn tijd in het leger, een posttraumatische stressstoornis te hebben overgehouden. Daardoor is hij een emotioneel ongeleid projectiel geworden en wordt hij geplaagd door gewelddadige uitbarstingen. Zo wordt er lange tijd gesuggereerd dat hij wel eens de moorden gepleegd zou kunnen hebben. Een zijspoor dat de suspense van de roman opvoert. Tegelijkertijd kunnen we de verbeelding van Peters identiteitscrisis in Nieuwe buren (Noort, 2006) als een waarschuwing voor het overschrijden van een heteroseksuele huwelijksnorm lezen. Peter lijkt zijn verstand immers juist ook te verliezen, omdat hij het zijn vrouw heeft toegestaan met een andere man te vrijen en omdat hij homo-erotische gevoelens voor Steef is gaan koesteren. Had Peter zich netjes aan de heersende heteroseksuele culturele regels gehouden, dan was het waarschijnlijk niet zo uit de hand gelopen. De roman kan als zodanig zelfs homofobe betekenissen genereren.

In Nieuwe buren (Noort, 2006) wordt de ruimte voor de beleving van vrouwelijke en mannelijke identiteiten onderzocht in een context waarin patriarchale, heteroseksuele normen over de relatie tussen de seksen en het gezinsleven aan erosie onderhevig zijn. Daarbij kunnen we de verhouding van de roman tot moderne ideeen over de rationele, autonome, zelfkiezende mens en de norm van het heteroseksuele kerngezin, die ook onderdeel zijn van het vertoog van genieten over moederschap, als tweeslachtig beschouwen.

\section{De suspense van de Vinexwijk}

De verbeelding van locaties en vooral het nieuwbouwhuis en de Vinexwijk speelt in Nieuwe buren (Noort, 2006) een belangrijke rol bij het oproepen van een beklemmende atmosfeer en de creatie van suspense. De roman sluit in dit opzicht aan bij het genre van de gothic novel en meer specifiek de homely gothic novel. Rubin (1999) beschouwt de gothic novel als de historische voorloper van de hedendaagse 
thriller en schaart verschillende hedendaagse films die als gotiek kunnen worden beschouwd onder het metagenre van de thriller. Ook door anderen wordt er op de invloed van de gothic novel op de thriller gewezen (Gorp, Delabastita \& Ghesquiere, 2007). De gothic novel ontstaat in Engeland in de achttiende eeuw en krijgt in de negentiende eeuw navolging in Amerika (Andeweg, 2010, 2011). Er is in dit griezelgenre sprake van een sfeer van suspense en raadselachtigheid. Het bovennatuurlijke speelt er vaak een rol in en de grenzen tussen de levenden en de doden zijn vaag. Gotieke vertellingen kunnen als "tales of darkness, desire and power" (Botting, 1996, p. 2) gekarakteriseerd worden, waarin de schaduwkant van de modernisering van de westerse samenleving wordt verbeeld en er onder andere wordt geappelleerd aan de angst voor een terugkeer van het ongetemde verleden. Het overschrijden van grenzen en mogelijke bedreigingen ten aanzien van de heersende normen en waarden staan centraal. De gotieke roman wordt met andere woorden gekenmerkt door een "fascination with transgression and anxiety over cultural limits and boundaries" (Botting, 1996, p. 2). Daarbij is er een belangrijke rol weggelegd voor de terugkeer van het verdrongene: "[d]e gotieke vertelling geeft met name uitdrukking aan het ongemakkelijke gevoel dat het verleden nooit echt afgesloten kan worden" (Buikema \& Wesseling, 2006, p. 10-11).

De wijze waarop het spel van grensoverschrijdingen vorm krijgt, heeft sinds de opkomst van het genre, uiteenlopende vormen aangenomen (Botting, 1996). ${ }^{116}$ In de achttiende-eeuwse gotieke vertellingen draait het plot veelal om een jong, onschuldig, uit de middenklasse afkomstig meisje, dat onder de hoede komt te staan van een adellijke, oudere man met oneerbare bedoelingen of bedreigd wordt door een monster, een spook of een demon. Er voltrekt zich een strijd tussen deze twee personages. Deze speelt zich veelal af in een ver afgelegen landhuis. Een plek die zowel qua tijd als afstand ver afstaat van de plek waar de lezers zich bevinden (Botting, 1996). In de loop van de negentiende eeuw raakt het conflict tussen goed en kwaad geïnternaliseerd en worden de romans minder fantastisch. Onder invloed van de opkomst van de psychoanalyse en de toenemende psychologisering van de samenleving, komen de onpeilbare, duistere dieptes van de menselijke psyche en interne psychische conflicten centraal te staan. Het genre draait dan in toenemende mate om de angst van de terugkeer van het psychisch verdrongene en is daarmee nauw verbonden met de psychoanalyse van Freud (Botting, 1996). Met name de moderne notie van de mens wordt daarbij, net als de twintigste-eeuwse a-heroïsche misdaadromans, ter discussie gesteld. Ook de plek van handeling verandert. In plaats van een afgelegen landhuis of kasteel, is de locatie nu realistischer en krijgt meestal de vorm van een onheilspellend, unheimlich burgerhuis (Botting, 1996). De

\footnotetext{
${ }^{116}$ Voor een uitgebreidere bespreking van die ontwikkelingen zie Fred Botting (1996) en David Punter en Glennis Byron (2004).
} 
gestalte die de gotieke roman aanneemt in de negentiende eeuw wordt daarom ook wel het subgenre van de homely gothic genoemd (Botting, 1996). Het betreft een genre waarin "gruwel en verschrikking middenin het burgerlijke gezin" (Buikema \& Wesseling, 2006, p. 38) worden gesitueerd. De dreiging komt nu dus van binnenuit. Er wordt met andere woorden gespeeld met het idee van het gezinshuis als een haven in a heartless world, wat het in deze boeken helemaal niet blijkt te zijn. ${ }^{117}$

De verbeelding van vrouwelijke en mannelijke identiteit in de roman, zouden we met enige goede wil ook een element uit de homely gothic novel kunnen noemen. Maar het is vooral de representatie van de plek van handeling in relatie tot de verlangens en de verledens van de personages, die in Nieuwe buren (Noort, 2006) een gotiek karakter heeft. Het is net als in homely gothic novels een unheimlich middenklasse gezinshuis in een kindvriendelijke wijk. Op het eerste oog zijn het een heel gewone woning en wijk. Anders dan in de conventionele homely gothic novels is het huis niet oud, maar splinternieuw. Het is een woning zonder geschiedenis, maar dat maakt het er niet minder onheilspellend op. Hoewel het gezinshuis geen verleden heeft, sijpelt de moeilijke geschiedenis dat Eva en Peter proberen te ontvluchten onvermijdelijk door de betonmuren van hun huis. Dat de Vinexwijk geen kindvriendelijke, veilige thuishaven is, wordt eigenlijk al vroeg in de roman duidelijk wanneer de wijk door Peter wordt beschreven.

'In de planetenvilla's ontworpen door Bakker en Van Haasdracht waant men zich permanent op vakantie vanwege de Russische, Etruskische, Italiaanse en Egyptische gevels.'

Zo beloofde de brochure van de makelaar over deelplan 10, Vinexwijk De Zonnepolder twee jaar geleden. Deze week worden de huizen aan het Mercuriusplein opgeleverd. Met de beste wil van de wereld heb ik tot nu toe geen Italiaanse en Egyptische gevels kunnen ontdekken. Alle woningen lijken uit de lucht gevallen blokken beton in een zanderige woestenij (Noort, 2006, p. 25).

Wat deze beschrijving vooral zo beklemmend maakt, is de verwijzing naar de Vinexwijk als vakantieoord. Dat doet denken aan vakantiepark De Kempervennen waar de drie bloederige lijken, de verwaarloosde peuter en gewonde persoon worden aangetroffen. We worden daarbij herhaaldelijk getrakteerd op griezelige verwijzingen naar de kinderrijke wijk De Zonnepolder. Daarbij wordt er onder andere verwezen naar de aanwezigheid van bovennatuurlijke krachten. Dat is typerend

\footnotetext{
${ }^{117}$ Tot voor kort werd de term gotiek nauwelijks in verband gebracht met de Nederlandse romans. Dit komt onder andere doordat het gotieke genre in tegenstelling tot bijvoorbeeld Groot Brittannië, Duitsland en de Verenigde Staten tot en met de Tweede Wereldoorlog in Nederland weinig beoefend werd. $\mathrm{Na}$ de Tweede Wereldoorlog veranderde dit echter. Buikema en Wesseling (2006) en Agnes Andeweg $(2005 ; 2010,2011)$ munten als een van de eersten de term gotiek binnen de Nederlandse letterkunde en wijzen op het gebruik van gotieke genre-elementen in het werk van onder andere Renate Dorrestein, W.F. Hermans, Frans Kellendonk, Gerard Reve, Thomas Rosenboom, Helga Ruebsamen en Vonne van der Meer. Vooral het subgenre van de homely gothic heeft volgens Buikema en Wesseling (2006) navolging gekregen in Nederland.
} 
voor de klassieke gothic novel. Peter is er op een gegeven moment van overtuigd dat het huis een plek van het kwaad is. Het is een "satanskerk" (Noort, 2006, p. 215). Volgens hem heeft de doodgeboren Lieve er daarom voor gekozen niet op deze plek geboren te worden en de kwade krachten die er heersen, zijn tevens de reden waarom hij zijn vrouw Eva dreigt kwijt te raken. Ook Eva ervaart het huis als verpletterend (Noort, 2006). Daarnaast lezen we dat het een "nieuwbouwgribus" is met "gemanicuurde tuintjes" (Noort, 2006, p. 48). Ook wordt de wijk vergeleken met een "kerkhof" met het enige verschil dat "de kisten boven de grond" (Noort, 2006, p. 48) staan. Op deze manier worden de moderne locaties voorzien van wat Rubin (1999) "een archaic and even primitive sense of the marvelous, the wild and the adventurous" (p. 14) noemt. De op het eerste oog alledaagse woning en wijk blijkt in de ogen van de personages, en dan met name Peter, helemaal niet zo gewoon en dat maakt de roman thrilleresque.

De Vinexwijk en de eengezinswoning zijn echter meer dan een griezelige achtergrond voor de te vertellen geschiedenis, ze brengen de noodlottige ontwikkeling van de gebeurtenissen mede op gang en dragen daarmee bij aan de creatie van suspense. Een uitgebreidere analyse van de betekenissen die zich aan deze locaties via de verbeelding van vertellers en personages hechten - hoe zij op het niveau van het verhaal van de roman in de woorden van Mieke Bal (1980) "ruimte[s]" (p. 101) worden $^{118}$ - maakt dit duidelijk.

Nieuwe buren (Noort, 2006) sluit aan bij stereotiepe beelden over Vinexwijken die in Nederland de ronde doen. Vinexwijken zijn vanaf de jaren negentig op verschillende plaatsen in Nederland uit de grond gestampt en zijn het resultaat van gericht overheidsbeleid met betrekking tot ruimtelijk ordening, meer specifiek van de Vierde Nota Ruimtelijke Ordening Extra (VINEX) uit 1990 (Ministerie van VROM, 1990). Het doel van de nota is om wijken buiten de grenzen van de stad te realiseren, maar met het centrum van de stad binnen handbereik. In deze wijken moet een mix van wonen en werken ontstaan, en een hoog voorzieningenniveau om zo het woon-werkverkeer in Nederland te verminderen (Snellen, 2003; Boomkens, 2003). Vinexwijken vertegenwoordigen in de ogen van beleidsmakers het beste van twee werelden: de verbondenheid van een kleine gemeenschap van een dorp en de voorzieningen van een stad. Ze worden door hen gezien als de ideale oorden voor jonge gezinnen. Zij hebben echter bij de Nederlandse bevolking al snel een negatieve reputatie (Snellen, 2003; Boomkens, 2003; Hamers, 2003, Atzema \& Hooimeijer, 2006). Het zouden plekken zijn waar enkel gewoond zou kunnen worden en waar niets te beleven valt. De Vinexwijk wordt een "aura van cultuurloosheid, van niksig-

\footnotetext{
${ }^{118}$ Zie hoofdstuk 3 in dit boek voor een toelichting van het gebruik van de termen locatie en ruimte door Bal (1980).
} 
heid toegeschreven. (...) Hier woonde de aanhang van RTL4, met drie boeken in de boekenkast, en met Queens 'Bohemian Rhapsody' als favoriete muziek” (Boomkens, 2003, p. 85). De bevolking in de Vinexwijken zou bovendien (te) homogeen zijn. Men treft er hoofdzakelijk het klassieke middenklasse, heteroseksuele kerngezin aan, bestaande uit twee kinderen, de kostwinnende vader en de thuisblijfmoeder (Nio, 2006; Atzema \& Hooimeijer, 2006). Deze thuisblijfmoeders zouden in de buitenwijk wegkwijnen, want er zou nauwelijks contact tussen de bewoners van de wijken zijn. Het leven in een Vinexwijk wordt als monotoon beschouwd. Het mist het avontuurlijke aspect van leven in de stad en de sociale cohesie die het leven in een dorp kenmerkt. ${ }^{119}$

Noort volgt in Nieuwe buren (2006) dat negatieve beeld van de Vinexwijk. Ook Eva en Peter kochten het huis met de verwachtingen er een gezin te gaan vormen. Doordat hun verwachtingen niet worden ingelost, ontstaat er een spanning tussen wat de wijk en het huis aanvankelijk voorstaan en hun leven zonder kinderen. De Vinexwijk blijkt al snel geen toevluchtsoord voor een koppel dat geen kinderen kan krijgen, maar wel een diepe kinderwens koestert. Voor de ongewild kinderloze Peter en vooral voor Eva wordt de Vinexwijk een onheilspellende en onprettige plek. Omringd door blanke, middenklasse, heteroseksuele gezinnen worden zij voortdurend aan hun kinderloosheid en het doodgeboren kind herinnerd. Daarbij moet worden aangetekend dat er in de verbeelding van de middenklasse bevolking in de Vinexwijk sprake is van enige diversiteit. Rebecca en Steef behoren namelijk tot een andere middenklasse dan Eva en Peter. Rebecca en Steef oefenen beroepen uit die minder opleiding vereisen dan het werk van Eva en Peter. Eva en Peter zitten waarschijnlijk ook ruimer in de slappe was. Ze hebben immers een koophuis, terwijl Rebecca en Steef in een huurhuis wonen. Rebecca en Steef lijken daarmee tot de zogenaamde lagere middenklasse te behoren en Eva en Peter tot de hogere middenklasse. ${ }^{120}$ Dit neemt echter niet weg dat de bevolking van de wijk in zijn geheel, Steef en Rebecca incluis, homogeen is. Het zijn allemaal blanke gezinnen die een middenklasse bestaan leiden. In het bijzonder bij Eva lijkt de wijk daardoor bij te dragen aan een hernieuwde oriëntatie op het verloren kind en het moederschap. Wanneer ze met Rebecca heeft besloten om zich zwanger te laten maken door Steef wordt dit duidelijk zichtbaar:

\footnotetext{
${ }^{119}$ Dit sterk clichématige beeld van de Vinexwijk is de afgelopen jaren iets genuanceerd (Nio, 2006). Verschillende onderzoekers en kunstenaars hebben geprobeerd om dit beeld bij te stellen door de architectonische variatie en de diversiteit van de middenklasse bewoners van de wijken in kaart te brengen, waaronder Arnold Reijndorp, Vincent Kompier, Stefan Metaal, Bianca Pilet \& Lucas Verwij (1998), Daniëlle Snellen (2003) en Piet Hein Stulemeijer (2003). Desondanks blijft het stereotype van de Vinexwijk in de media overeind (Atzema \& Hooimeijer, 2006; Nio, 2006).

${ }^{120}$ Zie hoofdstuk 1 voor de in dit proefschrift gehanteerde definities van deze middenklassen.
} 
Over haar [Rebecca's] schouder kijk ik naar onze wijk, die achter de eendenvijver ligt te zinderen in de zon en ineens zie ik die kale berg stenen als een paradijs vol beloftes. Ooit zal ik daar achter een eigen buggy lopen. Met een kar vol pampers door de supermarkt schrijden. Net zo uniek als alle anderen. (Noort, 2006, p. 119)

Daarbij valt het op dat niemand Peter en Eva terugfluit wanneer ze duidelijk te ver gaan bij het verwezenlijken van hun wensen: voor Peter het bij zich houden van Eva en voor Eva het verwekken van een kind. Buiten hun contact met Steef en Rebecca en een sporadische afspraak met hun psychotherapeute, lijken ze een volledig geïsoleerd leven te leiden. Eva en Peter lijken amper contact met collega's, vrienden en familie van buiten de wijk te hebben. Ze worden slechts vluchtig genoemd. Pas wanneer Eva al is weggevlucht, worden familieleden, waaronder Eva's zus, iets uitgebreider geïntroduceerd. Daar komt bij dat er binnen de wijk zelf sprake is van weinig sociale cohesie. De relaties met de andere buurtbewoners, buiten Steef en Rebecca, zijn zeer oppervlakkig. Maar zelfs de betrekkingen tussen de vier hoofdpersonages zijn in wezen niet zo nauw. Eva en Peter praten bijvoorbeeld nauwelijks meer met elkaar. Rebecca verzwijgt ten opzichte van Eva dat ze er zelf ook baat bij heeft als Eva zwanger wordt. Zij en Eva delen hun plannen bovendien niet met Peter en Steef. Juist doordat er niet met elkaar gecommuniceerd wordt, kan de geschiedenis zich zo dramatisch ontknopen. Door het openbare leven en de privésfeer te scheiden en de gemeenschap in de buitenwijk als een groep in zichzelf gekeerde mensen neer te zetten, wordt er een clichématig beeld van de Vinexwijken opgeroepen. Via dit beeld wordt de beklemmende functie van de wijk verder uitgebreid.

De identiteiten van de personages met hun verlangens en verledens raken zo verknoopt met de verbeelding van de Vinexwijk. Op een manier die een indringend gevoel van onbehagen oproept; een gevoel van een onvermijdbaar naderend noodlot. Daarmee kunnen wij als lezers het gevoel krijgen dat we in een op hol geslagen trein zitten. Door het noodlot zo een centrale rol toe te bedelen in de roman, worden de moderne ideeën dat het leven maakbaar is en de mens autonoom, rationeel en beheerst, ondergraven. En dit zijn ook ingrediënten van het hedonistische vertoog over moederschap.

\section{Coda}

Het idee van onvermijdelijkheid en de teloorgang van controle worden ook op andere manieren verbeeld. Ik wil er hier enkele noemen. Ten eerste is de plotstructuur op een cyclische manier opgezet. Het einde en het begin van de roman zijn haast eender: de gepleegde moord staat centraal. Dat kan verder bijdragen aan het oproepen van een gevoel van onvermijdelijkheid, samen met het feit dat de uitkomst van begin af aan al gegeven is. Dit effect krijgt bijval vanuit de hoofdstukken waarin Peter focaliseert, die doorspekt zijn met citaten uit populaire rock- en popnummers, die soms vooruitwijzen naar de gruwelijke afloop. De meest duidelijk verwijzing 
naar het einde is een fragment uit het nummer Hey Joe in de versie van Jimi Hendrix (1967) dat Peter samen met Steef zingt:

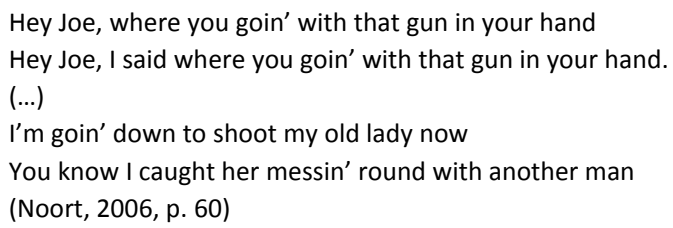

Deze expliciete intertekstuele verwijzing is overduidelijk een spiegeltekst, die het verloop van de roman als geheel herbergt. Peter zal uiteindelijk immers ook zijn eigen vrouw neerschieten, nadat zij met een andere man, Steef, het bed heeft gedeeld. De citaten uit de nummers worden bovendien frequenter naarmate Peter zijn realiteitszin verliest en kunnen worden opgevat als tekenen van zijn toenemende ontoerekeningsvatbaarheid. Verwijzingen naar nummers als Hey Joe (Hendrix, 1967) kunnen overigens wel afbreuk doen aan de suspense van de roman, omdat we er als lezers immers wel erg expliciet op worden gewezen hoe een en ander zal aflopen. Dat Menno Schenke (2006) in zijn bespreking van het boek in het Algemeen Dagblad over het gebrek aan spanning heeft geklaagd, zou hier wel eens mee kunnen samenhangen.

Daarnaast staan er in de roman een aantal intertekstuele verwijzingen naar de aanwezigheid van Nederlandse soldaten in Srebrenica. Steef blijkt hier gestationeerd te zijn geweest en heeft er zijn posttraumatisch stress syndroom opgelopen. Met de verwijzing naar Srebrenica wordt een herinnering aan een nationaal trauma gemobiliseerd; aan de massamoord die daar in 1995 heeft plaats gevonden in het bijzijn van het Nederlandse leger. In dat jaar zijn er vierhonderd gewapende Nederlandse blauwhelmen in dit gebied in Bosnië-Herzegovina gesitueerd, maar zij mogen van de Verenigde Naties niet ingrijpen als duizenden Bosnische mannen systematisch worden afgeslacht door Servische militanten onder opperbevel van generaal Ratko Mladić (Runia, 2004; NIOD, 2002). Zij moeten machteloos toekijken. Dit dramatische voorval heeft tot veel ophef in Nederland geleid, zowel in de politiek als in de pers. Naar aanleiding van deze gebeurtenissen is er, op verzoek van de Nederlandse overheid, een onderzoek door het Nederlandse Instituut voor Oorlogsdocumentatie (NIOD) en een parlementaire enquête gekomen. Het uiteindelijke rapport van het NIOD (2002) bevat zeer kritische uitspraken over de beslissing van de $\mathrm{Ne}$ derlandse overheid om troepen naar Srebrenica te sturen, die voor het toenmalige kabinet een reden zijn geweest om af te treden (Runia, 2004). Srebrenica kan in de context van deze roman zodoende als symbolisch voor het ontbreken aan zeggenschap over een situatie worden beschouwd, wat zoals besproken, een voor thrillers typerend onderwerp is. 


\section{Conclusie}

Nieuwe buren (Noort, 2006) is een dubbelzinnig commentaar op het bewustgekozen-moederschap-is-genieten-vertoog. Het moderne geïdealiseerde beeld van het gezinsleven en het moederschap wordt op thrilleresque wijze ter discussie gesteld. De roman nodigt op sommige punten echter ook uit tot een lezing waarbij dit beeld in bepaalde opzichten overeind blijft. Deze dubbelzinnigheid is onder andere het gevolg van de wijze waarop Nieuwe buren (Noort, 2006) aansluit bij de 'mannelijke' en 'vrouwelijke' variant van de a-heroïsche misdaadroman en de homely gothic novel. Hoewel het boek daardoor beklemt, beklijft de kritiek op het moderne gezinsleven uiteindelijk niet op een wezenlijke manier. Wellicht komt dit doordat er niet echt op premoderne literaire genres wordt teruggegrepen, hoewel het moderne genre van de thriller de deur naar archaïsche elementen wel kan open zetten. Dat de kritiek oppervlakkig aanvoelt, zou dan wellicht eerder iets van doen kunnen hebben met eigenschappen als het snelle actieverloop, de nadruk op suspense en de vaak platte personages van het genre van de thriller. De verbeelding van moederschap komt dan al snel in dienst te staan van het oproepen van een spannende leeservaring, van een thrilling experience. De kritiek die de roman van Noort (2006) kan oproepen, verliest hierdoor mogelijk aan diepgang. 


\section{Hoofdstuk 6}

\section{Een hormonale tragedie. Een hart van steen (1998) van Renate Dorrestein}

\section{Inleiding}

In januari 1997 wordt Nederland opgeschrikt door een gruwelijke moord. Een 36jarige man en zijn echtgenote hebben hun drie kinderen van negen, acht en zeven jaar gedood. De ouders hebben de kinderen eerst slaap- en kalmeringsmiddelen toegediend en vervolgens met een kussen verstikt. Daarna hebben ze een zelfmoordpoging gedaan. Tijdens de rechtszaak die volgt, wordt duidelijk dat het echtpaar het overlijden van hun oudste zoon aan leukemie niet had verwerkt. De ouders hadden zich met hun drie overgebleven kinderen bij hun overleden zoon willen voegen. Het koppel wordt uiteindelijk veroordeeld tot drie jaar cel en tbs met dwangverpleging ('Kindermoord: 3 jaar en TBS' (1997)).

De aandacht in de dagbladen voor de Hoofddorpse moordzaak is in 1997 groot. Uit de berichtgeving in 1997 over de moordzaak in bijvoorbeeld de Volkskrant, NRC Handelsblad, Trouw en Algemeen Dagblad ${ }^{121}$ blijkt dat de moord geregeld als de zoveelste zaak in een infanticidegolf ${ }^{122}$ wordt beschouwd, die in 1996 zou zijn begonnen. Er wordt gesproken van een serie die zich nog nooit ergens anders ter wereld heeft voorgedaan. Veel journalisten vragen zich af hoe ouders tot zulke daden

\footnotetext{
${ }^{121} \mathrm{lk}$ heb om precies te zijn de volgende artikelen kunnen traceren en geanalyseerd: 'Aandacht volgens traumatoloog impuls voor ouders; 'Media moeten zwijgen over kindermoorden" (1997), Harmen Bockma (1997), Afra Botman (1997), 'Drie kinderen in huis omgebracht' (1997), Vasco Groeneveld (1997), Bas den Hond (1997a), Bas den Hond (1997b), 'Hoogleraar wil nieuwe gevallen voorkomen' (1997), 'Hulp voor wanhopige ouders; Kinderbescherming zet teams in na golf van verontruste telefoontjes' (1997), Maarten Huygen (1997), 'Journalisten wijzen mediastilte van de hand' (1997), 'Justitie roept op tot terughoudendheid' (1997), 'Kindermoord' (1997), 'Kindermoord: 3 jaar en TBS' (1997), Bas Mesters (1997a), Bas Mesters (1997b), Fokke Obema en Ronald Ockhuysen (1997), 'Ouders kindermoord Hoofddorp volledig ontoerekeningsvatbaar' (1997), Margot Pol (1997), Frank Poorthuis (1997), Mirjam Schottelndreier (1997), 'Sorgdrager: Zuinig met informatie bij kindermoorden' (1997), Wil Thijssen (1997), 'Treurnis over dood broertjes' (1997), 'Vader verdacht van vermoorden twee kinderen'(1997), Rob Vreeken (1997).

122 In navolging van Barbara Barnett (2005) wordt met de term infanticide naar moord op kinderen tot achttien jaar door hun eigen ouder(s) bedoeld.
} 
kunnen komen en waarom er, in hun beleving althans, opeens zo veel van deze delicten worden gepleegd. ${ }^{123}$ Daarbij richt de discussie zich vooral op de mogelijke invloed van de media zelf. ${ }^{124}$ Berichtgeving over kindermoorden zou tot imitatiegedrag kunnen leiden bij andere ouders. Ondanks dat er voor de veronderstelde infanticidegolf verklaringen worden gezocht in bredere maatschappelijke ontwikkelingen, worden de ouders die hun kinderen hebben vermoord tegelijkertijd vaak als uniek beschouwd. Ouders die iets dergelijks doen zijn gek, wanhopig of ziek. Ze worden daarmee, al dan niet expliciet, als een uitzondering op de regel verbeeld. Daarbij wordt onder andere geput uit psychologische en medische vertogen over persoonlijkheidsstoornissen. ${ }^{125}$

De nadruk op het abnormale karakter van infanticide plegende ouders kunnen we onder andere herleiden tot de in dit boek besproken wijdverbreide idealiserende opvattingen over moederschap, vaderschap en het gezin. Met name van moeders verwachten we dat ze met een zekere vanzelfsprekendheid onvoorwaardelijk van hun kinderen houden, dat ze plezier beleven aan het moederschap, dat ze zachtaardig en geweldloos zijn en dat ze hun kinderen beschermen. Moeders die hun kinderen vermoorden, brengen deze ideeën aan het wankelen. ${ }^{126}$ Door zulke moeders als uitzonderingen op de regel te beschouwen, worden heersende opvattingen over moederschap echter in stand gehouden. Communicatiewetenschapster Barbara Barnett $(2005,2006)$ wijst er in haar interpretatie van media-aandacht voor moordende moeders in de Verenigde Staten op, dat deze verbeeldingsstrategie helpt om de maatschappelijke consternatie die zulke moeders kunnen oproepen te beperken. Wanneer we denken dat we met unieke, individuele voorvallen te maken

\footnotetext{
${ }^{123}$ In een analyse van de berichtgeving in Nederlandse landelijke dagbladen over twaalf kindermoorden in 1996 en 1997 stellen juriste Chrisje Brants en forensisch psychiater Frans Koenraadt (1998) dat er onterecht van een trend wordt gesproken. De moorden die zijn gepleegd, waaronder de Hoofddorpse moordzaak, verschillen daarvoor te veel van elkaar. Bovendien is het onmogelijk om vast te stellen of er sprake is van een toename van het aantal kindermoorden, omdat er op dat moment geen centrale, openbare registratie van het aantal kindermoorden door ouders bestaat.

${ }^{124}$ Zie de artikelen 'Aandacht volgens traumatoloog impuls voor ouders; 'Media moeten zwijgen over kindermoorden”' (1997), Bockma (1997), 'Hoogleraar wil nieuwe gevallen voorkomen' (1997), 'Journalisten wijzen mediastilte van de hand' (1997), 'Justitie roept op tot terughoudendheid' (1997) en 'Sorgdrager: Zuinig met informatie bij kindermoorden' (1997).

${ }^{125}$ Dit is het geval in de volgende artikelen: Bockma (1997), Botman (1997), 'Dan kunnen we maar beter samen gaan' (1997), Groeneveld (1997), Den Hond (1997b), Huygen (1997), 'Kindermoord: 3 jaar en TBS' (1997), Mesters (1997a), Mesters (1997b), ‘Ouders kindermoord Hoofddorp volledig ontoerekeningsvatbaar' (1997), Pol (1997) en Poorthuis (1997).

${ }^{126}$ Josephine Hendin (2004) wijst op dit culturele effect van gewelddadige vrouwen, waaronder moeders, in haar analyse van de verbeelding van deze vrouwen in Amerikaanse fictionele en niet-fictionele culturele bronnen.
} 
hebben, kunnen we immers weer relatief snel overgaan tot de orde van alle dag. ${ }^{127}$ Onze ideeën over hoe moeders 'normaliter' zijn, blijven intact.

Renate Dorrestein heeft de roman Een hart van steen (2003/1998) naar aanleiding van de Hoofddorpse moordzaak geschreven (zie bijvoorbeeld Margriet de Groot, 2010). Dorrestein wil met haar boeken naar eigen zeggen maatschappelijke opschudding te weeg brengen. Zij wil aan taboes raken en op die manier onrust zaaien (Pronk, 2007; Steenhuis, 2001). De schrijfster stelt dat haar "[I]iteratuur over (...) de menselijke configuratie [gaat], die een onuitputtelijke bron van wreedheid, verraad en conflict is, en dus onherroepelijk voor leed zorgt" (Pronk, 2007) ${ }^{128}$ Afgaand op enkele, opvallend felle reacties van lezers lijkt het er op dat Dorrestein er met Een hart van steen (2003/1998) in is geslaagd om beroering te veroorzaken. In een interview in Trouw vertelt ze over de "boze brieven" (Pronk, 2007) van lezers, die ze over Een hart van steen (2003/1998) heeft ontvangen. Een lezeres schreef haar het volgende: "Nu bent u te ver gegaan. [...] Het is beslist niet zo dat ik niks gewend ben, maar ik ben toch voor alles een moeder, en voor een moeder is het verminken van je eigen kind gewoon walgelijk" (Pronk, 2007). Deze lezeres gaat er, getuige het woord 'gewoon', vanuit dat een moeder haar kinderen geen kwaad zal berokkenen, omdat het tegen haar 'natuur' indruist.

De uitspraken van Dorrestein en dit soort reacties maken nieuwsgierig naar het culturele werkpotentieel van Een hart van steen (2003/1998). In de rest van dit hoofdstuk komt de vraag aan de orde in hoeverre en waarom de roman consternatie te weeg zou kunnen brengen, wanneer het om de beschreven moderne, geïdealiseerde representatie van moederschap gaat. In wat volgt wordt duidelijk dat Dorresteins roman een alarmerende uitwerking kan hebben, door de manier waarop er wordt verwezen naar het genre van de gothic novel en de Griekse tragedie en door intertekstuele verwijzingen naar het christendom. Via deze verwijzingen worden er anti- en premoderne ideeën over het menselijk subject en de omgang met het noodlot geïntroduceerd. Tegelijkertijd zal blijken, dat deze uitwerking van de roman onder andere wordt getemperd door de aanwezigheid van dezelfde individualiserende representatiestrategie die in de mediaberichtgeving over de Hoofddorpse zaak wordt gebruikt.

\footnotetext{
${ }^{127}$ Ik wil hiermee absoluut niets afdoen aan de mogelijke relevantie van psychologische en medische hulp voor ouders die hun kinderen hebben gedood of willen doden. Evenmin wil ik beweren dat we kindermoord 'normaal' moeten vinden in de ethische zin van het woord. Bescherming van kinderen tegen elke vorm van geweld en misbruik moet hoe dan ook altijd voorop staan. Het gaat mij hier om het aanwijzen van een mogelijke, bredere culturele functie van een verbeeldingstrategie.

${ }^{128}$ Deze uitspraak doet Dorrestein voor het eerst in het boek Het geheim van de schrijver (2010/2000), een handleiding voor het schrijven van proza.
} 


\section{Een gotiek gebrek aan controle}

In Een hart van steen (2003/1998) voert Dorrestein het personage Margje van Bemmel op. Margje, die zichzelf op een gegeven moment Betty noemt, is getrouwd met Frits en moeder van vijf kinderen: de vijftienjarige Sybille die ook wel Billie wordt genoemd, Kester of kortweg Kes die waarschijnlijk dertien of veertien jaar is, de twaalfjarige Ellen, de drie jaar oude kleuter Michiel die ook naar de naam Carlos luistert, en de pasgeboren baby Ida die later de naam Sofie krijgt. Samen met haar man onderhoudt Margje een knipselarchief, waarin mediaberichten over de Verenigde Staten worden opgeslagen en die tegen betaling kunnen worden ingezien. Zo kunnen zij en Frits van huis uit in hun levensonderhoud voorzien. Na de geboorte van haar dochtertje Ida in 1972 probeert Margje haar gezin te vermoorden. Ze drogeert Sybille, Kester, Michiel en Ida en bindt plastic zakken over hun hoofden. Ellen is op het moment van de moord net even de hond aan het uitlaten en wordt door haar moeder in het heetst van de strijd vergeten. Als ze thuiskomt, treft zij Sybille, Kester, Michiel en Ida met de plastic zakken over hun hoofden aan de keukentafel aan. Haar vader en moeder zitten, zo te zien slapend, op de bank in de woonkamer. Zij blijken later dood. Margje heeft zelfmoord gepleegd en Frits waarschijnlijk ook. Dit laatste wordt niet volledig duidelijk; hij zou ook door Margje kunnen zijn vermoord. Ellen vlucht na haar ontdekking naar de kelder van het huis. Ze sleept Michiel mee, trekt de zak van zijn hoofd en verstopt zich angstig voor haar ouders. Ellen weet Michiel zo te redden, maar Kester, Sybille en Ida sterven.

Deze geschiedenis wordt in Een hart van steen (Dorrestein, 2003/1998) vijfentwintig jaar na dato in retrospectief uit de doeken gedaan door de inmiddels volwassen, alleenstaande en zwangere Ellen. Er is dus sprake van een raamvertelling, waarin Ellen zojuist het huis van haar ouders heeft gekocht, de gewraakte plaats van het misdrijf. Daar is zij vanwege een dreigende miskraam aan het bed gekluisterd. Ellen heeft haar gruwelijke familieverleden allerminst verwerkt. Ze tast nog steeds in het duister over de oorzaak van de moord. Ze hoort de stemmen van haar overleden zus Sybille en broer Kester. Zij leven via haar voort en bepalen welke loop haar leven krijgt. Ellen durft geen levende mensen in haar hart toe te laten, omdat zij dit als verraad ervaart ten opzichte van haar broer en zus. Zij is niet voor niets patholoog-anatoom geworden. Ze leeft in het verleden. Daarom heeft zij ook haar ouderlijk huis gekocht: om het in oude glorie te herstellen, zodat zij hier samen met Sybille en Kester, net zoals voor de moord, kan wonen. Op verzoek van haar ongeboren dochter - die ze Ida-Sofie noemt en die ze als een reïncarnatie van haar vermoorde zusje Ida beschouwt - probeert zij de moord aan de hand van het familiefotoalbum te reconstrueren. Ze komt op een bepaald moment tot de conclusie dat de oorzaak een niet onderkende postpartum depressie is, die haar moeder psychotisch heeft gemaakt. 
Het ontrafelen van de toedracht van de moord staat dus centraal in Een hart van steen (Dorrestein, 2003/1998). Ellen vraagt zich af wat haar moeder bezield heeft, waarom haar vader niet heeft ingegrepen. Een hart van steen (Dorrestein, 2003/1998) is daarmee een roman over ontaard moederschap en, in mindere mate, over ontaard vaderschap. Het is echter ook een boek over de last van een overlevingsschuld. Hoewel Ellen haar broertje Michiel van een wisse dood heeft weten te redden, knaagt haar geweten. Had zij de anderen niet ook moeten en kunnen redden? Had het drama met andere woorden voorkomen kunnen worden? Ook wordt Ellen geplaagd door de vraag waarom zij wel aan de moordende hand van haar moeder is ontsnapt, maar haar broer en zussen niet. De roman gaat uiteindelijk ook om de wijze waarop Ellen door het verleden getekend is; om het feit dat ze zich in het heden niet geborgen en gelukkig kan voelen door de moord. Dat de voortdurende invloed van het verschikkelijke familieverleden op Ellen en belangrijke kwestie is in het boek, blijkt uit het motto dat Dorrestein (2003/1998) haar roman heeft meegegeven. Dit zijn twee regels uit het gedicht Mijn moeder is mijn naam vergeten (1966) van Neeltje Maria Min: “Noem mij, noem mij, spreek mij aan, o, noem mij bij mijn diepste naam" (Dorrestein, 2003/1998 p. 6). Het hele gedicht waaruit Dorrestein citeert, luidt als volgt:

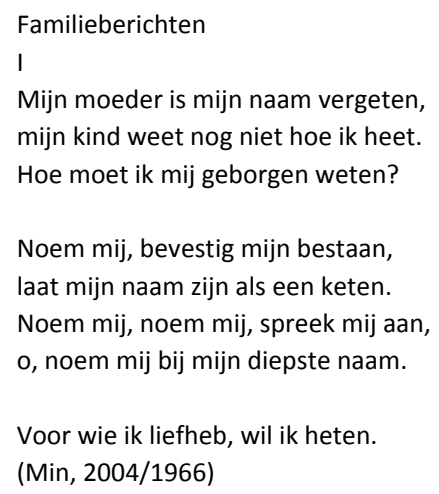

Als motto van de roman wordt het gedicht representatief voor de situatie waarin Ellen zich bevindt. ${ }^{129}$ Uiteindelijk slaagt Ellen er in met haar verleden af te rekenen. Die afrekening wordt onder meer gemarkeerd doordat zij het ouderlijk huis verkoopt, op zoek gaat naar een andere naam voor het kind in haar buik en doordat ze een relatie aanknoopt met een levend persoon: Bas. Aan het einde van de roman lijkt Ellen aan het begin van een gelukkig leven met haar nog ongeboren dochter en haar nieuwe partner te staan.

\footnotetext{
${ }^{129}$ Voor een uitgebreidere interpretatie van Mins poëzie zie onder andere Maaike Meijer (1988).
} 
Het is belangrijk om, voorafgaand aan de verdere interpretatie van de roman, expliciet te wijzen op het betekeniseffect van de historische context waarin de geschiedenis van de Van Bemmels wordt gesitueerd. Sybille, het eerste kind van Margje en Frits, wordt in 1957 of 1958 geboren en Ida, het laatste kind, in 1972. Het gezin wordt dus gesticht en vermoord in een tijd waarin het krijgen van kinderen in $\mathrm{Ne}$ derland nog niet vanzelfsprekend als een keuze wordt gezien. Margje en Frits hebben er in ieder geval niet bewust voor gekozen om een gezin te beginnen. Margje raakt onverwacht en onbedoeld zwanger van haar eerste kind als zij en Frits elkaar nog niet zo lang kennen en zij moeten daarom met elkaar trouwen. Dorrestein (2003/1998) heeft wellicht voor deze historische situering gekozen, omdat er zo ruimte ontstaat voor het vertellen van een negatieve geschiedenis over moederschap. Er is daarbinnen immers niet voor een kind gekozen en daarmee komt het moderne door keuzeretoriek gekleurde kader waarbinnen moederschap vandaag wordt geromantiseerd te vervallen, wat het cultureel gezien mogelijk maakt om een ander verhaal over moederschap te vertellen. Het is een strategie die we ook aantroffen in de artikelen over ongelukkige moeders in vrouwentijdschriften, zoals die in de inleiding van dit boek aan bod kwamen. Hierdoor wordt elke potentiële cultuurkritiek die van de roman kan uitgaan op de hedendaagse hedonistische moederschapsmoraal echter bij voorbaat minder sterk, dan wanneer de moord zich in een meer contemporaine context had voltrokken en de ouders bewust voor een gezin hadden gekozen. Het idee dat het krijgen van een kind een keuze is, is immers de voedingsbodem van deze moraal. Daar staat tegenover dat Margje wel bewust voor de andere kinderen heeft gekozen. We kunnen lezen dat Margje na de geboorte van Sybille heeft besloten dat ze zes kinderen wil, juist omdat een groot gezin haar zo leuk lijkt: "Ze heeft gelukkige visioenen van een huis vol gelach en kabaal. Een ronde tafel met acht stoelen eromheen. Bolle wangen waarmee verjaardagskaarsjes worden uitgeblazen" (Dorrestein, 2003/1998, p. 73). De geboorte van haar vijfde kind, waarna haar moederschap ontspoort, is dus wel het resultaat van een bewuste keuze geweest.

Het rondwaren van de geesten van de overleden Sybille en Kester, maakt de invloed van de gotieke roman op Een hart van steen (Dorrestein, 2003/1998) onmiskenbaar zichtbaar. Zoals in het vorige hoofdstuk aan bod kwam, zijn de grenzen tussen doden en levenden in gotieke romans vaak vaag en is er veel aandacht voor het bovennatuurlijke. ${ }^{130} \mathrm{Er}$ is door anderen al gewezen op de invloed van de gothic novel op deze roman van Dorrestein (2003/1998). Volgens literatuurwetenschapsters Rosemarie Buikema en Elisabeth Wesseling $(2000,2006)$ past de roman in de tradi-

\footnotetext{
${ }^{130}$ Zie hoofdstuk 5 voor een uitgebreide bespreking van de kenmerken van het genre van de gothic novel en de homely gothic novel.
} 
tie van homely gothic novels, waarin het idee van het gezin als een gelukkige, veilige thuishaven voor kinderen wordt gereproduceerd om het vervolgens uit te hollen. ${ }^{131}$ Op het geschiedenisniveau van de roman hebben we aanvankelijk inderdaad te maken met een op het eerste oog zeer normaal en gelukkig gezin. De 37-jarige Ellen heeft goede herinneringen aan haar jeugd. Dit blijkt onder andere, wanneer ze door de makelaar wordt rondgeleid door haar voormalige familiehuis:

En bij alles wat hij zei, kreeg ik kleine, felle schokken van pijnlijke vreugde, want het huis bracht me, onthutsend en onomwonden, bij elke mededeling weer in herinnering hoe gelukkig mijn jeugd op de keper beschouwd was geweest. Gek: geen mens heeft ooit de mogelijkheid geopperd dat ik ook nog een heleboel goeds zou kunnen hebben om op terug te zien. (Dorrestein, 2003/1998, p. 35)

Margje wil zelf ook juist graag van haar kinderen genieten en het is haar doel om ze een gelukkige jeugd te bezorgen, aldus Ellen. Pas nadat Margje zwanger is van Ida, loopt het volgens Ellen mis. Uit Ellens reconstructie van de gebeurtenissen krijgen we het idee dat de onvoorwaardelijke liefde van Margje voor haar kind(eren) juist de kiem van de infanticide bevat. Zo kunnen we lezen dat Margje haar daden begaat, omdat zij in haar waanzin gelooft haar kinderen op die manier te beschermen tegen het kwaad op de wereld. Margje denkt dat haar gezin door de duivel is uitverkozen als de broedplaats voor zonde. Ze geloof dat ze haar kinderen alleen van de duivel kan redden, door ze van het leven te beroven. Margje worstelt met de keuze waarvoor ze zich gesteld ziet. De kinderen laten leven, wat betekent dat ze door het kwade zullen worden ingepalmd, of ze doden en zo van de duivel redden. Daarbij wordt ze verscheurd door de liefde voor haar zoons en dochters:

Opstandig dacht ze: maar dan zal ik Michieltje nooit zijn tanden zien wisselen. Kester heeft voor niets voor zijn brommer gespaard. Sybille zal niet trouwen, Ellen niet naar de universiteit gaan. Toen week haar verzet, want waren dit op de keper beschouwd geen futiliteiten? En sprak hier niet louter haar egoïstische moederhart? $\mathrm{O}$, wat was de liefde oneindig bezitterig. Wat was het offer van hun aardse levens in vergelijking met de stralende eeuwigheid die hun daarna wachtte? Als ze nu twijfelde, bleven zij voor altijd de hulploze speelbal van het kwaad. Nu moest zij besluiten, nu, op dit moment van de geopenbaarde waarheid. (Dorrestein, 2003/1998, p. 226)

Rooskleurige beelden van het moederschap en het gezinsleven vormen zo een vertrekpunt voor allesbehalve idyllische beschrijvingen van moederschap.

Buikema en Wesseling $(2000,2006)$ stellen dat er op deze manier kritiek wordt geleverd op de hedonistische opvoedingsmoraal, zoals we die onder andere in het in 1946 gepubliceerde werk van opvoedexpert Benjamin Spock tegenkomen. Zoals in hoofdstuk 1 aan de orde is gekomen, claimt Spock (1955/1946) daarin dat wat leuk is voor de moeder ook leuk is voor het kind en omgekeerd. Een dergelijke invul-

\footnotetext{
${ }^{131}$ Het gaat hier om de derde vorm van intertekstuele verwijzingen, zoals die in hoofdstuk 3 is besproken. Het gaat dan om het gebruik van een voor een bepaald genre typerende elementen in een roman.
} 
ling van het moederschap wordt door hem niet als belastend beschouwd, omdat de behoeftes en verlangens van moeder en kind zouden samen vallen en de moeder van nature weet wat goed is voor het kind. In Een hart van steen (Dorrestein, 2003/1998) blijkt er juist helemaal niets goeds van te komen, wanneer de moeder op haar eigen ingevingen vertrouwt. Zo zou Dorrestein (2003/1998) invoelbaar maken dat we er helemaal niet vanuit mogen gaan dat een moeder instinctief doet wat goed is voor het kind; zelfs als ze veel van hem houdt. Daarbij wordt Margje als een allesbehalve rationeel, autonoom persoon gerepresenteerd. Ze is iemand die geen grip op haar onbewuste driften heeft (Buikema \& Wesseling, 2000, 2006). Dit is een in homely gothic romans vaak terugkerend motief.

In de beschrijvingen van de waanzinnige Margje vinden we veel verwijzingen naar hekserij en magie terug. Dit zijn eveneens onderwerpen die in gotieke romans vaak voorkomen. Margje raakt er, volgens Ellen, bijvoorbeeld van overtuigd dat zij ongewild grote natuurrampen en ander onheil veroorzaakt:

\footnotetext{
Terwijl ze kookte, terwijl ze Sybille haar huiswerk overhoorde of Michiel inwreef met zijn zalf, veroorzaakte ze aan de andere kant van de wereld overstromingen waardoor complete dorpen in de modder verdronken; ze veroorzaakte dat vulkanen hete lava braakten, dat kinderen op kale vlaktes omkwamen van de honger, dat corrupte kolonels naar de macht grepen, dat de oerang-oetan bijna uitstierf, dat er in iedere steeg ter wereld werd verkracht, geroofd en doodgeschopt, dat er op Cape Canaveral een lancering mislukte, dat er in Calcutta een lepra-uitbarsting plaatsvond en dat Elvis Presley zich op Graceland doodvrat van verdriet. (Dorrestein, 2003/1998, p. 221)
}

Daarnaast wordt er herhaaldelijk gerefereerd aan de magische, performatieve kracht die taal volgens Margje en de twaalfjarige Ellen hebben. Verkeerde naamgeving kan volgens hen noodlottige gevolgen hebben. Ellen heeft bijvoorbeeld de naam Ida voor het door haar ongewenste babyzusje verzonnen. Ze heeft voor deze naam gekozen, omdat het de lelijkste naam is die ze kon bedenken. "Ida rijmde op malaria, en als je er een paar letters bijgooide dan kreeg je diarree. Wat zou ze later op school gepest worden. Haar verdiende loon" (Dorrestein, 2003/1998, p. 16). Ellen is bang dat de naam Ida ongeluk over het gezin zal afroepen. In een poging het leed te herstellen, overtuigt ze haar moeder ervan Ida ritueel om te dopen tot Sofie. Ook vreest Ellen dat haar moeder zelf het noodlot tart, omdat ze haar eigen naam op een dag in Betty besluit te veranderen. Dit doet Margje, omdat deze naam gemakkelijker uit te spreken is voor de Amerikaanse klanten van het knipselbureau dat ze met Frits leidt.

Niet alleen Margje heeft gotieke trekken. Ook de vader van Ellen, Frits, heeft zichzelf bijvoorbeeld niet in de hand. Hoewel hij in principe een zachtaardige, moderne, geëmancipeerde man en vader is, die samen met zijn vrouw een gezin en een bedrijf leidt, steken oncontroleerbare seksuele driften onverwacht de kop op. Van het voordien zo bloeiende seksleven van Margje en Frits is na de geboorte van Ida niet veel over. Frits heeft hier moeite mee en hij verdenkt Margje ervan, overi- 
gens onterecht, een affaire te hebben. Ook raakt hij bezeten door het idee dat Ida mogelijk niet zijn dochter is. Woedend dwingt hij Margje tot seks met hem. Frits heeft hier onmiddellijk spijt van en gaat zijn vrouw uit schuldgevoel uit de weg. Het gezinsleven ontspoort hierdoor verder. De 37-jarige Ellen is evenmin de baas over haar eigen gedachten en daden. Zo leven de overleden Sybille en Kester in haar voort. Daarnaast is er iets vreemds aan de hand met de manier waarop Ellen het verleden van het gezin reconstrueert. Ze beschikt over informatie over voorvallen, waar zij helemaal niets van af kan weten. Zo herinnert ze zich de manier waarop Margje Ida mishandelt, terwijl niemand hier getuige van is geweest. Ellen begint zich af te vragen waar

\begin{abstract}
die verhalen vandaan [komen]? Heb ik ze waarheidsgetrouw gereconstrueerd uit gebeurtenissen uit die tijd, uit dingen die ik toen half bewust moet hebben opgepikt, en heb ik ze verder nauwgezet ingekleurd met mijn latere kennis over mijn moeders toestand? Of heb ik, om de toedracht kloppend te maken, aan mijn ouders handelingen, gedachten en motieven toegeschreven die mijn eigen verzinsels zijn? Maar voor verzinsels moet je moeite doen. Je fantasie kan stokken, terwijl deze verhalen gaaf, compleet en zonder aarzeling in me opwellen. Omdat Ida-Sofie ze me voorzegt? Is zij de vertelster, en niet ik? Ik klop zachtjes op mijn buik. Natuurlijk. Jij bent het. Jij weet oneindig veel meer dan ik: jij was er immers altijd bij, onafgebroken, terwijl ik naar school ging of in de tuin speelde met mijn hond. (Dorrestein, 2003/1998, p. 219)
\end{abstract}

Ellen komt tot de conclusie dat niet zij de verteller is, maar Ida-Sofie: haar ongeboren kind en de reïncarnatie van de vermoorde Ida.

Veel van de personages in Een hart van steen (Dorrestein, 2003/1998) hebben dus geen controle over zichzelf, net als in gotieke romans. Er is sprake van onduidelijkheid over wie ze zijn, wat hun aard is. De dubbele namen die zij bijna allemaal hebben, onderstrepen dit. Deze geven ook uitdrukking aan een gevoel van ontheemdheid dat Ellen ten opzichte van haar gezin van herkomst ervaart. Deze interpretatie van de naamgeving van de personages is des te waarschijnlijker in het licht van het motto van het boek: het gedicht van Min (2004/1966). Antropoloog Sjaak van der Geest (2003) heeft er al opgewezen dat het gebrek van een naam in dit gedicht geïnterpreteerd kan worden als een metafoor voor het ontbreken van een gevoel van geborgenheid. Vanwege het onderwerp van de roman, waarvan het gedicht een motto is, kan de betekenis die Van der Geest (2003) aan het gedicht van Min (2004/1966) toekent, hier gemakkelijk worden opgeroepen. ${ }^{132}$ Het gebrek aan controle van de personages wordt ook uitvergroot doordat het voor ons als lezers niet altijd even duidelijk is wie er nu precies vertelt. De belangrijkste verteller lijkt Ellen en via haar Ida te zijn. Maar zelfs Ida kan niet alles weten wat er over de

\footnotetext{
${ }^{132}$ De poëzie van Min is overigens bij nadere beschouwing vaak niet zo eenvoudig als hij op het eerste oog lijkt, zoals Meijer (1988) laat zien. Het voert hier te ver om allerlei mogelijke betekenissen van dit gedicht van Min (2004/1966) te analyseren, het gaat er hier om betekenissen aan te wijzen die het gedicht in de context van de roman oproept.
} 
moord wordt meegedeeld, omdat ze bij bepaalde voorvallen ook niet aanwezig is geweest. Dat Ida niet over alle informatie die ons wordt meegedeeld kan beschikken, zou kunnen betekenen dat er nog een andere, derde niet-personage gebonden verteller is, maar deze manifesteert zich niet als zodanig. Het zou ook kunnen dat Ellen het maken van "verzinsels" (Dorrestein, 2003/1998, p. 219) beter afgaat dan ze zelf denkt. Ten slotte wordt het verlies van beheersing dat de personages ervaren, gespiegeld door de verbeelding van het huis. Het staat vol met archiefkasten van het in Amerikaanse berichtgeving gespecialiseerde knipselbedrijfje. Wanneer het gezin steeds verder uit elkaar valt en Margje en Frits de controle over zichzelf verliezen, wordt het knipselarchief steeds moeilijker te bedwingen: overal liggen knipsels, vaak van nieuwsberichten over geweld (zie hierover ook Buikema en Wesseling, 2006).

Door bij het gotieke aan te haken zou het moderne, dwingende imperatief van genieten rondom moederschap ter discussie kunnen komen te staan. Dit imperatief wordt immers ten dele ontleend aan het idee dat een mens via het maken van bewuste keuzes grip op zijn/haar leven en omgeving heeft. In het gotieke genre komt dit idee juist op losse schroeven te staan. In de roman blijkt daarbij juist de liefde van Frits voor Margje en van Margje voor haar kinderen voor problemen te zorgen. Niet voor niets is Ellens hart na de moord net zo versteend als het stenen hart op de zerk van het familiegraf, waarnaar de titel van het boek verwijst. Ze is de liefde gaan wantrouwen en beschouwt het als "een breekbaar, onbetrouwbaar, trouweloos ding" dat "onnavolgbare gulzige en egoïstische" (Dorrestein, 2003/1998, p. 50) trekken heeft. Daarmee tast de roman het gangbare idee dat moederliefde beschermt aan.

De manier waarop het gotieke gestalte krijgt in deze roman kan echter net zo gemakkelijk, en wellicht zelfs gemakkelijker, tegenovergestelde betekenissen mobiliseren. Het kan om te beginnen de gedachte oproepen dat het leven uiteindelijk toch maakbaar is en dat het moderne zelfkiezende individu van desintegratie kan worden gered. Ten eerste doordat Ellen met het verleden dat haar achtervolgt, weet af te rekenen. Ze bant de geesten van haar overleden broer en zussen uit en schudt de schuldgevoelens van zich af. Ze herneemt de controle op haar eigen leven en een gelukkig gezinsleven met Bas en haar toekomstige kind ligt in het verschiet. Ten tweede, kunnen de norm van het autonome subject en de beschreven geïdealiseerde beelden van moederschap intact blijven, omdat Margje en haar gezin als een individuele afwijking op de norm kunnen worden beschouwd. Vooral Margje kunnen we als zodanig benaderen. Zij wordt immers door haar vertellende volwassen dochter Ellen bij uitstek als waanzinnig afgeschilderd. Margje houdt er een volgens hedendaagse moderne westerse maatstaven onwerkelijk wereldbeeld op na - ze gelooft dat ze magische krachten bezit - wat de identificatie met haar niet zal bevorderen. Het wordt daardoor gemakkelijk om Margje als abnormaal of ziek te be- 
schouwen. De hyperbolische, griezelige stijl die Dorrestein (2003/1998) hanteert draagt er ook aan bij dat we veeleer mentaal afstand van Margje nemen, dan dat we ons in haar zullen verplaatsen. We komen in de roman groteske scènes tegen, waarin bijvoorbeeld op grafische wijze wordt beschreven hoe Margje een appelboor in de vagina van haar dochtertje Ida steekt.

Deze mogelijke uitwerking van de roman wordt geïntensifieerd doordat de 37jarige Ellen de moord op een bepaald moment toeschrijft aan een niet onderkende postpartum depressie. Ze beschrijft hoe zij jaren geleden, tijdens een college gynaecologie, als student voor het eerst van het verschijnsel hoort en hoe verscheidene puzzelstukjes dan op hun plaats vallen:

\begin{abstract}
Maar tot op de dag van vandaag kan ik de plotselinge, opwaartse ruk van mijn hoofd voelen, de slagen die mijn hart miste, de tellen die mijn verstand stilstond, toen onze vooruitstrevende docente de zogeheten postpartum depressie met ons behandelde, in haar ergste vorm ook bekend als kraamvrouwenpsychose. 'Heftige stemmingswisselingen, verlies van het contact met de werkelijkheid, hallucinaties, wanen, irreële angsten en overbezorgdheid, verandering van persoonlijkheid en gedrag, gewelddadige neigingen jegens jezelf en anderen,' somde ze de symptomen op. Ze keek in haar papieren. 'De oorzaak ervan is een hormonale stoornis tengevolge van zwangerschap en bevalling. Dat betekent dat de patiënte haar eigen gedrag op geen enkele manier kan beïnvloeden of beteugelen: zij is ten prooi aan een endocrinologische ontregeling. Het ongeduldige advies van de omgeving dat zij zich eindelijk eens moet vermannen, helpt dus ook niet. Het enige dat helpt, snel en gegarandeerd, is een progesteronbehandeling.' (...) Ik stond op en werkte me door de volle collegezaal naar buiten. Nu kende ik de ware naam van het mysterie dat ons gezin had verwoest. Kraamvrouwenpsychose. (Dorrestein, 2003/1998, pp. 172-173)
\end{abstract}

Ellen vindt deze verklaring later overigens niet volledig bevredigend, omdat het de rol van haar vader niet verklaart. Dat neemt echter niet weg dat de introductie van de postpartum depressie in de roman een psychologiserende en individualiserende uitwerking kan hebben (zie ook Buikema en Wesseling $(2000,2006))$. Hierdoor zou het gemakkelijker worden om de moederfiguur als een 'abnormale' moeder weg te zetten. Bovendien wordt de introductie van de postpartum depressie gepaard aan een modern geloof in de beheersbaarheid ervan. Ellen stelt namelijk dat er "nooit een tragedie [had] hoeven plaatsvinden als mijn moeders toestand tijdig was herkend en men haar simpelweg de juiste medicijnen had voorgeschreven" (Dorrestein, 2003/1998, pp. 172-173). De integratie van het medisch-psychologische vertoog over postpartum depressie kan hierdoor het effect sorteren, dat de vertelling over Margje minder ondermijnend is voor geïdealiseerde opvattingen over moederschap.

Daarbij moeten we een slag om de arm houden. De relatie tussen het contemporaine, dwingende, idyllische beeld van het moederschap en het medischpsychologische vertoog over postpartum depressie is namelijk ambigue, zoals in hoofdstuk 1 is besproken. Die dubbelzinnigheid wordt ook in de roman zichtbaar. De postpartum depressie wordt namelijk ook expliciet ingezet om een normatief, 
rooskleurig beeld van pril moederschap te bekritiseren. Ellen herinnert zich hoe na de uitleg van haar docent in de collegezaal de volgende discussie losbarst:

Er werd met verontwaardiging vastgesteld dat artsen blijkbaar de grootste moeite hadden vrouwen als natuurlijke wezens te beschouwen, als mensen met een organisme dat nu eenmaal ontregeld kon raken: ze deden biochemische stoornissen na een bevalling af als aanstellerij. Zodra je baby er was, werd je geacht gelukkig te zijn, en als je dat niet was, was je een hysterica of een hypochonder. (Dorrestein, 2003/1998, p. 173)

De postpartum depressie fungeert hier als een verklaringsmodel dat door de studenten in de collegezaal juist wordt gebruikt om ervaringen van het krijgen van een kind die niet rooskleurig zijn bespreekbaar te maken.

\section{Vergissingen en keuzes met tragische gevolgen}

Naast de gotieke roman wordt er in Een hart van steen (Dorrestein, 2003/1998) ook verwezen naar het genre van de Griekse tragedie. ${ }^{133} \mathrm{Er}$ zijn verschillende expliciete intertekstuele verwijzingen ${ }^{134}$ naar de antieke Griekse cultuur en haar tragedies. Om te beginnen heet Ellens oudere zus Sybille; een impliciete verwijzing naar de vrouwelijke orakels uit de Griekse oudheid, die ook wel Sibillen werden genoemd (Baumgarten, 1998). Ellen zit in het jaar dat de moord wordt gepleegd bovendien in de eerste klas van het gymnasium, waar zij in contact komt met tragedies, figuren en gebeurtenissen uit de Griekse oudheid. Zodoende passeren verwijzingen naar Helena van Troje, Jason en de Argonauten, Orpheus, Homerus en Pallas Athene de revue. Ellen maakt zelfs een vergelijking tussen haar thuissituatie en Griekse tragedies in een passage die volgt nadat Ellen haar lerares Grieks in vertrouwen heeft genomen over het vreemde gedrag van haar moeder en vader. Die neemt Ellens klachten niet serieus en geeft haar te verstaan dat ze zulke privézaken voor zich moet houden. Ellen voelt zich in eerste instantie gerustgesteld, maar gaat dan aan het oordeel van haar lerares twijfelen:

Als je, zoals mijn lerares, de hele dag tot over je oren in de Griekse tragedies zat waarin complete koningshuizen elkaar uitmoordden zonder een traan te laten, dan vond je bepaalde dingen misschien wel gewoner dan andere mensen. Wee, wee, becommentarieerde het koor altijd droog, en dat was dan weer dat. Maar dat ik de vuile was niet buiten mocht hangen, had ik stevig in mijn oren

\footnotetext{
${ }^{133}$ Dit ligt tot op zekere hoogte voor de hand, want de genres zijn verwant aan elkaar. De ondertitel van een van de bekendste gotieke werken, Mary Shelley's Frankenstein (2003) is niet voor niets The Modern Prometheus (zie hierover Jos de Mul, 2006). Zowel in tragedies als in gotieke werken staan grensoverschrijdingen en ambiguïteiten centraal en wat filosoof De Mul een "onheilspellende houding tegenover het noodlot" (2006, p. 21) noemt.

${ }^{134}$ Het gaat hier om de eerste vorm van intertekstuele verwijzingen, zoals die in hoofdstuk 3 is besproken.
} 
geknoopt. Bezield met de beste voornemens reed ik door de stromende regen naar huis. (Dorrestein, 2003/1998, p. 167)

Later wordt het drama door de 37-jarige Ellen zelfs expliciet "een tragedie" (Dorrestein, 2003/1998, p. 230) genoemd. Als lezers worden we al daarvoor op dit spoor gezet, door de aanwezigheid van een passage als de volgende:

\footnotetext{
'In het oude Griekenland waren gezinnen gerechtigd hun ongewenste nakroost op de vuilnisbelt achter te laten. In Sparta werden baby's die niet aan de verwachtingen voldeden, zelfs van de rotsen geworpen of naar de Taygetos gebracht.' Dat stond in het verfomfaaide geschiedenisboek over antieke geschiedenis dat mijn vader en ik in de aula van mijn toekomstige school hadden weten te bemachtigen bij de verkoop van tweedehands boeken. (Dorrestein, 2003/1998, p. 26)
}

Slechts enkele pagina's later komen we te weten dat het de kinderen in het gezin Van Bemmel niet veel beter afgaat dan de hier genoemde kinderen uit het oude Griekenland. Een parallel is dan snel getrokken. Het is bovendien bijna onvermijdelijk om bij een roman over een moeder die haar kinderen vermoordt met zulke verwijzingen naar de Griekse oudheid en tragedies, niet aan de tragedie over Medea van Euripides (2008/431 v.Chr.) te denken. Zeker gezien de genoemde verwijzing naar Jason en de Argonauten, de mythe waarop Medea (Euripides, 2008/431 v.Chr.) is gebaseerd. Euripides' Medea (2008/431 v.Chr.) geniet nog altijd grote bekendheid en heeft Medea haar "canonical identity" (Boedeker, 1997, p. 127) gegeven. In de tragedie wordt Medea door haar man Jason, met wie ze twee zoons heeft, verlaten voor een politiek meer opportuun huwelijk met de dochter van Creon, koning van de Corintiërs. Medea vermoordt uit wraak de nieuwe bruid van haar ex-man en slaat de hand aan haar kinderen. ${ }^{135}$ Het is in dit opzicht een heel andere geschiedenis dan die van Margje, maar er is eveneens een raakpunt. Ook in de tragedie Medea lijkt het er op dat liefde de voedingsbodem van de moorden is. ${ }^{136}$ Anders dan in Een hart van steen (Dorrestein, 2003/1998) lijkt het hier niet zo zeer om moederliefde, maar vooral om romantische liefde te gaan.

Deze verwijzingen naar de Griekse tragedies kunnen een aantal interessante betekeniseffecten hebben, wanneer het om de verbeelding van de moord en het moederschap van Margje gaat. Ten eerste, wordt de moord die Margje begaat in een langere geschiedenis van infanticide geplaatst. De daad staat daardoor minder op zichzelf. De beschrijvingen van hedendaagse voorvallen waarin onder andere kinderen het slachtoffer van geweld zijn, die de jonge Ellen in de artikelen in de mappen van het knipselarchief aantreft, versterken dit effect:

\footnotetext{
${ }^{135}$ Medea vermoordt niet in alle overgeleverde of bewerkte versies van de mythe haar kinderen, maar wel in die van Euripides (Graf, 1997; Johnston, 1997).

${ }^{136} \mathrm{Er}$ is veel discussie over de betekenis van Euripides' Medea (2008/431 v. Chr.). De hier gegeven interpretatie is slechts een van de vele lezingen (Svarlien \& Mitchell-Boyask, 2008).
} 
Als je een map opende, ontblootten de ratten die in de Bronx een baby hadden doodgebeten, hun spitse tanden, maffiosi klikten hun stiletto's uit; oude shoppingbag-ladies staarden je aan met hun door alcohol verwoeste gezichten, studenten scandeerden 'Johnson moordenaar'; Timothy Leary zei dat LSD geen kwaad kon; lijken waarvan de geslachtsdelen waren verminkt, werden in plastic zakken geschoven. (Dorrestein, 2003/1998, p. 30)

Daar komt bij dat de volwassen, zwangere Ellen een tijdje onderdak verleent aan een moeder, die met haar dochters op de vlucht is voor haar gewelddadige man. In ruil hiervoor verzorgt deze vrouw, Lucia genaamd, Ellen die niet uit bed mag vanwege de dreigende miskraam. Ook hierdoor komt het geweld binnen het gezin van Van Bemmel minder op zichzelf te staan. Lucia en haar dochters worden immers ook door geweld binnen het gezin bedreigd. Zij verhuizen veelzeggend genoeg na een tijdje naar "een flat in Hoofddorp" (Dorrestein, 2003/1998, p. 206), een verdekte verwijzing naar de Hoofddorpse moordzaak. Door de moord op deze manier in te bedden, kan het idee dat het gezin in het algemeen - en dus niet alleen dat van de Van Bemmels - een warm en veilig nest is, onhoudbaar worden.

Een ander en wellicht belangrijker betekeniseffect van de expliciete intertekstuele verwijzingen naar Griekse tragedies, is dat het de mogelijkheid opent om de roman door de lens van de Griekse tragedie te gaan bekijken. En dan blijken er meer raakpunten tussen de roman en dit eeuwenoude genre te zijn dan de al genoemde verwijzingen. Er komen met andere woorden intertekstuele verwijzingen aan het licht die we onder de derde vorm van intertekstualiteit kunnen scharen die in hoofdstuk 3 aan de orde kwam, waarbij het gaat om de integratie van een voor bepaald genre kenmerkende eigenschappen in een roman. Met het oog hierop, eerst een korte toelichting op de kenmerken van dit genre. Er bestaat een levendig debat over de eigenschappen van de Griekse tragedie, waaraan vanuit verschillende disciplines, zoals de filologie, filosofie en literatuurwetenschap, een bijdrage wordt geleverd (zie bijvoorbeeld Rebecca Bushnell (2005) en Michael Silk (1996)). De Griekse tragedie wordt hier als een dramatisch genre beschouwd dat in de vijfde eeuw voor Christus hoogtij viert (Bushnell, 2008). Daarnaast is het uitgangspunt dat de Griekse tragedie doorgaans over "aangrijpende gebeurtenissen" gaat, met "een morele of mentale zelfondervraging van de toeschouwer als beoogd resultaat (catharsis)" (Van Gorp, Dirk Ghesquiere \& Delabastita, 1998, p. 446). In het genre is er bovendien sprake van een plotontwikkeling waarbij het vaak zo is dat

de held-protagonist (...) de natuurlijke orde [fataal verstoort]. Hij wordt daartoe gedreven door een tragische vergissing of door een psychologisch motief, zoals haat of overmoed (hybris). Deze fout (hamartia), nl. de miskenning van zijn eigen situatie als mens tegenover de godheid, maakt hem tot speelbal van het oppermachtige Noodlot. De held, die de verantwoordelijkheid voor zijn ordeverstoring op zich neemt, wordt opgenomen in een proces van heroïsch lijden dat hem tot waanzin of zelfmoord brengt, of tot louterend inzicht en verzoening. (Van Gorp, Ghesquiere \& Delabastita, 1998, p. 447) 
Filosoof Jos de Mul (2006) wijst er verder op dat Griekse tragedies niet alleen over vergissingen met een tragische uitkomst gaan, maar vaak ook over een keuze tussen twee kwaden. Personages in tragedies moeten vaak beslissingen nemen die hoe dan ook een noodlottige afloop impliceren. Noodlot en keuzevrijheid vallen dan onvermijdelijk met elkaar samen. Als zodanig kan de tragedie als een genre worden beschouwd, waarin er wordt gereflecteerd op de grenzen van menselijke keuzevrijheid en de spanning tussen vrijheid en het noodlot. Literatuurwetenschapster Bushnell (2005) claimt iets soortgelijks, wanneer ze benadrukt dat de blijvende relevantie van de tragedie ligt besloten in het feit dat het tragische moderne ideeën over keuzevrijheid en zelfbeschikking te discussie stelt. Dat een personage tussen twee kwaden moet kiezen, betekent in tragedies bovendien meestal niet dat hij/zij wordt vrijgepleit van de uitkomst van zijn/haar keuze (De Mul, 2006). Een kenmerk van de Griekse tragedie is dat het hoofdpersonage de verantwoordelijkheid voor de gevolgen van een keuze op zich neemt, ook als ze niet voorkomen hadden kunnen worden (De Mul, 2006). Wat tragedies zodoende kenmerkt, is een bepaalde houding ten opzichte van het noodlot, waarbij het noodlot gedefinieerd kan worden als "een onafwendbaar gebeuren (...) dat we niet, of slechts zeer ten dele, kunnen ontlopen" (De Mul, 2006, p. 15). Het gaat er om te accepteren dat het noodlot niet overwonnen kan worden, zonder daarbij het bestaan van keuzevrijheid te ontkennen en verantwoordelijkheid te ontlopen (zie ook Rebecca Bushnell, 2008). Cultuurwetenschapster Maria Kardaun (2009) beschrijft deze houding treffend:

\footnotetext{
[t]o the Greeks it was important to find one's humble place in a cosmos filled, not just with other human beings, but also with very tricky, often unpredictable and incomprehensible divine schemes and schedules. However, contrary to popular belief, the ancient Greeks were not particularly inclined to surrender to fate - after all, human beings have free will, and they will use it. Nor were they striving to overcome fate - which would be a dangerous presumption or hybris as they would call it. No, the idea in Pre-Socratic Antiquity was that we should attempt something in between, namely to come to terms with fate somehow. (Kardaun, 2009)
}

Tot slot, wordt de observatie onderschreven dat de vorm van de Griekse tragedie doorgaans eenzelfde stramien volgt. De tragedie begint met een proloog, waarna het koor zijn intrede doet met een lied, ook wel de parodos genoemd. Hierna wisselen een aantal dialogen tussen acteurs (episodes) en liederen van het koor zich met elkaar af (stasima). Het einde bestaat uit een slotlied van het koor terwijl die het toneel verlaat (exodos) (Bushnell, 2008).

Afgezet tegen de bovenstaande definitie hebben we met Een hart van steen (Dorrestein, 2003/1998) geen tragedie in strikte zin in handen. Het volgt als roman het beschreven vormstramien niet. Op thematisch niveau zijn er echter toch enkele overeenkomsten aan te wijzen. Ook in deze roman, over een moeder die haar gezin uitmoordt, is er sprake van "aangrijpende gebeurtenissen (...) met een psychologisch morele of sociale conflictstof" (Gorp, Ghesquiere \& Delabastita, 1998, p. 446). 
Daarnaast, en wellicht belangrijker, ontspint de geschiedenis van de moord zich rondom een aantal vergissingen van de hoofdpersonages met een onbedoelde, tragische uitkomst. Een vergissing die de twaalfjarige Ellen bijvoorbeeld maakt, is haar besluit om over de problemen in haar gezin te zwijgen op aanraden van haar lerares Grieks. Frits vergist zich eveneens jammerlijk. Hij maakt zich namelijk wel zorgen over de toestand van zijn vrouw, maar spreekt haar er niet op aan uit angst haar te verliezen. Omdat hij zijn vrouw ontloopt, komt hij er ook niet achter dat zij Ida mishandelt. Ook de artsen waar de zwaar mishandelde Ida herhaaldelijk naar toe wordt gebracht, vergissen zich. Zij stellen steeds opnieuw de verkeerde diagnose. Er wordt op een bepaald moment zelfs gedacht dat de oorzaak van de vele blauwe plekken op het lichaam van de baby wellicht leukemie is; een impliciete verwijzing naar de Hoofddorpse moordzaak. ${ }^{137}$ Dat de artsen het misbruik niet herkennen, komt onder andere omdat Ida vlak na haar geboorte een ernstige afwijking heeft, waardoor ze veel huilde. Ze had "een maagvernauwing" (Dorrestein, 2003/1998. p. 56) waaraan ze geopereerd moest worden, waarna ze enkele weken in het ziekenhuis moest blijven. Pas na haar thuiskomst beginnen de mishandelingen. Gezien de voorgeschiedenis ligt het voor de hand de artsen en ook Frits aan een medische oorzaak denken. Naast Frits en de artsen vergist ook de lerares Grieks zich door Ellen op te dragen haar mond te houden. Deze opstapeling van vergissingen maakt het uiteindelijk mogelijk dat de moord ongehinderd kan plaats vinden. Op deze manier wordt bovendien benadrukt dat het drama wellicht voorkomen had kunnen worden, wat Een hart van steen (Dorrestein, 2003/1998) juist ook zo aangrijpend maakt.

We treffen niet alleen vergissingen aan die een tragische uitkomst hebben, maar er doen zich ook keuzes tussen twee kwaden voor. We zagen al dat Margje het waanidee heeft dat ze tussen twee kwaden moet kiezen: haar kinderen laten leven, waardoor ze ten prooi zullen vallen aan de duivel of ze doden, waarna ze ten hemel zullen opstijgen. Het is echter de twaalfjarige Ellen die zich daadwerkelijk voor een keuze tussen twee kwaden gesteld ziet. Zij is vanwege de angst zelf vermoord te worden, niet in staat om al haar familieleden te redden en moet dus - al is ze zich daarvan op het moment zelf wellicht niet bewust - kiezen tussen haar broers en zussen. Ze ziet zich voor een situatie gesteld, waarin haar keuze hoe dan ook catastrofaal uit zal vallen. Keuzevrijheid en het noodlot vallen hier samen. Ellen neemt de verantwoordelijkheid voor de uitkomst van haar keuze jarenlang op zich, zoals personages uit de Griekse tragedies dit zouden doen. Haar overleden broer Kester en zus Sybille onderstrepen dit aspect van de roman, door haar als een soort van wraakgodinnen te achtervolgen. Zulke wraakgodinnen, die in de vijfde eeuw

\footnotetext{
${ }^{137}$ Deze verwijzing is ook opgepikt door Aleid Truijens (1998) in haar recensie van de roman in de Volkskrant.
} 
voor Christus in Griekenland ook wel bekend stonden als Erinyen of Furiën, komen we in verschillende Griekse tragedies tegen (Fainlight \& Littman, 2009). Een goed voorbeeld hiervan is de laatste tragedie over Oedipus van Sophocles, die in het Engels is verschenen als Oedipus at Colonus (2009/406 v.Chr.). ${ }^{138}$ Oedipus wordt na het (onbedoeld) begaan van misdaden - het doden van zijn vader en seks met zijn moeder - door wraakgodinnen achtervolgd. Wraakgodinnen verdedigen de belangen van de doden en wraken de misdaden die tegen ze zijn gepleegd (Fainlight \& Littman, 2009). Ze achtervolgen degene die schuldig is aan misdaden tegenover de doden en rusten pas wanneer er recht is gedaan. ${ }^{139}$ Ellens bevrijding van haar verleden zouden we in het verlengde hiervan als de loutering kunnen beschouwing die na voldoende lijden en inzicht in de gemaakte fouten in Griekse tragedies vaak volgt.

Frits, de artsen en de lerares Grieks kunnen we concluderend als personages beschouwen, die ondanks hun goede bedoelingen een schuld op zich laden door het begaan van vergissingen met tragische gevolgen. Margje komt daardoor minder geïsoleerd te staan. Niet alleen zij, maar de samenleving om haar heen krijgt zo een deel van de schuld te dragen. Ellen moet daarbij ook nog eens een keuze maken die hoe dan ook nadelig uitpakt. Noodlot, keuzevrijheid en verantwoordelijkheid komen hierbij op ambigue wijze samen en sluiten elkaar niet uit. Daarmee is de roman thematisch verwant aan het genre van de Griekse tragedie. Het idee van maakbaarheid - een essentieel ingrediënt van de hedendaagse hedonistische benadering van moederschap - lijkt daardoor het onderspit te delven in deze roman. Het contemporaine idee van maakbaarheid impliceert namelijk een ontkenning van het bestaan van het noodlot en van de mogelijkheid dat noodlot, individuele keuze, schuld en verantwoordelijkheid samenvallen (De Mul, 2006). ${ }^{140}$ Dit lijkt niet aan de orde, wanneer we kijken naar de wijze waarop Een hart van steen (Dorrestein, 2003/1998) bij de tragedie aansluit. Daar staat tegenover dat deze aan de tragedie ontleende visie op het noodlot niet volledig wordt doorgevoerd in deze roman. Dit komt onder andere doordat Dorrestein (2003/1998) uit het al genoemde medisch-psychologisch

\footnotetext{
${ }^{138}$ Er bestaat onzekerheid over wanneer deze tragedie van Sophocles precies is verschenen (Grene, 2010). Ruth Fainlight en Robert Littman (2009) houden het op 406 voor Christus en David Grene (2010) denkt dat het stuk een jaar later, in 405 voor Christus, verscheen.

${ }^{139}$ De tot rust gekomen wraakgodinnen worden ook wel Eumeniden genoemd (Fainlight \& Littman, 2009).

${ }^{140}$ Volgens De Mul (2006) is deze moderne houding onhoudbaar aan het worden. Het maakbaarheidsdenken is namelijk gebaseerd op een sterk geloof in de vooruitgang van technologische ontwikkelingen. Deze stellen ons in staat om grip te krijgen op de wereld om ons heen en in te grijpen, maar het is echter ook diezelfde technologie die, aldus De Mul (2006), steeds meer aan onze invloed dreigt te ontsnappen en vaak een noodlottige impact op ons leven kan hebben. Hij pleit daarom voor een andere houding ten opzichte van het noodlot. Deze zou op de Griekse tragedies geënt moeten zijn en de ambiguïteit van onze technologische cultuur moeten erkennen.
} 
vertoog over postpartum depressie put. Dit is een vertoog waarin de gedachte dat het noodlot overwonnen kan worden, juist vaak hoogtij viert. Het uit de tragedie afkomstige perspectief krijgt, wanneer het om de ondermijning van het moderne geloof in de controleerbaarheid van het leven gaat, echter versterking uit onverwachte hoek: het christendom.

\section{Een straf van God?}

In Een hart van steen (Dorrestein, 2003/1998) wordt meer dan eens expliciet verwezen naar het christendom, vooral in relatie tot de waanzinnige gedachten van Margje. Margje raakt er van overtuigd dat haar dochtertje Ida de Messias is, dat haar gezin doordrongen is van zonde en dat God haar opdraagt haar gezin te offeren, omdat dit de enige manier is om het kwaad uit te roeien. Volgens De Mul (2006) impliceert het christendom een mens- en wereldbeeld waarin de mens nauwelijks invloed heeft op zijn leven, noch op de wereld om hem heen. De mens wikt met andere woorden, maar God beschikt. De christelijke houding ten aanzien van het noodlot draait volgens hem zodoende om passiviteit en deemoedige berusting. Het idee van individuele keuzevrijheid en de schuldvraag, die binnen de tragedie zo'n grote rol spelen, verdwijnen daarbij sterk naar de achtergrond. De verwijzingen naar het christendom in de roman worden onder meer aan zo'n berustende houding gepaard, wat onder andere blijkt uit de wijze waarop de gewetensstrijd van Margje over de moord die ze denkt te moeten plegen, wordt beschreven:

\footnotetext{
Nu viel alles eindelijk op zijn plaats. Ida moest met dezelfde opdracht naar dit gezin zijn gezonden als waarmee een schuldeloze jongen tweeduizend jaar geleden in een kribbe was geboren, namelijk om de wereld te herinneren aan het bestaan van het kwaad en om dat via zijn kwetsbare, menselijke lichaam te bevechten. Het lijden van haar dochtertje had dus weldegelijk zin gehad, het moest alleen nog met de dood worden bekroond om haar onsterfelijk te maken. Ida zou de steen van haar graf wentelen en voor altijd rein en puur zijn, verlost en verlosser tegelijk. Boven elke Wet verheven, onaantastbaar, soeverein. Oppermachtig. 'Maar heb ik je dan voor de dood gebaard?' vroeg ze hardop, haar opdracht nog maar half bevattend, net zoals die vrouw in Galilea. Ze sloot haar ogen. Het eeuwige leven voor haar gepijnigde kind. Langzaam maakte haar verbijstering plaats voor dankbaarheid en overgave. (Dorrestein, 2003/1998, p. 224)
}

Margje is er dus van overtuigd dat God haar vraagt om haar dochtertje en de rest van haar gezin op te offeren en geeft zich hier berustend aan over. De schuldvraag en de vraag naar haar individuele verantwoordelijkheid verdwijnen uit beeld, wat een fatale houding voor het lot van het gezin blijkt te zijn. De roman kan zodoende kritische vragen oproepen over een berustende, christelijk geïnspireerde houding. Het gaat immers mis op het moment dat Margje geen individuele verantwoordelijkheid meer voor haar daden neemt.

De verwijzingen naar het christendom in de roman kunnen echter ook andere betekenissen oproepen, wat duidelijk wordt indien we onze definitie van de christe- 
lijke houding ten opzichte van het noodlot nuanceren en de relatie tussen het christendom en infanticide onder de loep nemen. Het beeld dat De Mul (2006) van het christendom schetst, is vooral gebaseerd op een Calvinistische invulling van het christelijk geloof, waaronder de Predestinatieleer valt. Daardoor is er weinig aandacht voor het idee van de vrije wil, dat als een van de belangrijke ingrediënten van de christelijke leer kan worden beschouwd (Borg, 1995). Volgens godsdienstsocioloog en filosoof Meerten ter Borg (1995) worden we juist op de wijze waarop we ons onder moeilijke omstandigheden gedragen, volgens de christelijke leer in het hiernamaals afgerekend. Zelfs het ongeluk dat ons tijdens ons leven overkomt, wordt volgens hem binnen het christendom lang niet altijd los gekoppeld van menselijk gedrag. Er gelden binnen het christendom duidelijke geboden en verboden voor de manier waarop mensen moeten leven. Zo wordt seks buiten het huwelijk als een zonde beschouwd (Borg, 1995). Zelfs binnen het huwelijk is seks niet ongecompliceerd. Seks geldt als een middel tot voortplanting, maar het is zeker niet de bedoeling dat men er plezier aan beleeft. Met name binnen het katholicisme heeft seks altijd connotaties van zonde en verleiding (Sardar, 1999). Wie van deze en andere voorschriften afwijkt, zal hiervoor in dit leven of in het hiernamaals een prijs moeten betalen. Zeker als men geen berouw toont en boete doet. Daarbij lijken protestanten overigens vaak zwaarder aan zonde te tillen dan katholieken. Bij katholieken kan de zonde immers via de biecht worden kwijtgescholden, wat bij protestanten niet het geval is. Deze christelijke visie lijkt meer verwantschap te hebben met de levenshouding zoals we die in tragedies tegenkomen. Het gaat er immers onder andere om hoe mensen zich gedragen in moeilijke omstandigheden. Daarbij worden keuzevrijheid en verantwoordelijkheid niet uitgevlakt. Tegelijkertijd heeft deze christelijke houding ook iets weg van het moderne maakbaarheidsdenken. De mens lijkt de loop van zijn leven te kunnen bepalen. Dit is echter maar tot op zekere hoogte het geval en het is al helemaal geen vrijbrief voor een hedonistische levensinstelling, waarbij de mens zijn leven mag inrichten zoals hem dat zelf goeddunkt.

Een aantal verwijzingen naar het christelijke geloof in Een hart van steen (Dorrestein, 2003/1998) lijkt op subtiele wijze bij de door Ter Borg (1995) beschreven houding ten opzichte van zonde aan te sluiten. Er wordt expliciet verwezen naar de christelijke en in het bijzonder de katholieke houding ten opzichte van seksuele zonde, wanneer wordt beschreven hoe de hoogzwangere Margje en Frits voor het altaar staan.

Achter zich hoorde hij [Frits] het kuchen en ritselen van de kerkgangers. Een golf van onrust leek zich door de ruimte te plaatsen, bank na harde bank, alsof iedereen op hetzelfde moment hetzelfde beeld voor zijn geestesoog zag oprijzen: Margje en Frits, loom van verzadiging, tussen de omgewoelde lakens. Onder kuise hoedjes en zedige voiles ontsprongen plotseling frivole gedachten, de atmosfeer knetterde ervan, en menige mannenhand verdween als vanzelf diep in de broekzak om wat in het kruis rond te rommelen. De bleke Maagd Maria in de zijbeuk sloeg hongerig haar enorme oogleden op, in de gebrandschilderde ramen bogen stramme heiligen zich wellustig over elkaars gemartelde lichaam en de houten duiven aan de voet van de kansel sloegen koerend aan het torte- 
len. Frits knipperde met zijn ogen en schoof de ring aan Margjes vinger. Het deed hem geweldig veel plezier dat zij daar geen spat respectabeler door werd. (Dorrestein, 2003/1998, p. 41)

Frits heeft duidelijk geen berouw over zijn in de ogen van de katholieke kerk zondige seksuele escapades. Ook in de rest van hun huwelijk genieten Frits en Margje van een levendig seksueel leven met elkaar, waarbij voorplanting lang niet altijd het doel is.

$\mathrm{Nu}$ wordt er bij herhaling gesuggereerd dat Margje en Frits de ondergang van hun gezin zelf hebben veroorzaakt door hun ongeremde seksuele activiteiten en hun gebrek aan berouw hierover. Die suggestie bestaat uit het feit dat hun seksuele daden met de moord in verband worden gebracht. Margje denkt om te beginnen dat zij en Frits onheil over hun gezin hebben afgeroepen, door de seks die ze met elkaar hebben gehad. Ze besluit daarom geen seks meer met hem te hebben. Zoals besproken draagt de daarop volgende verkrachting van Margje door Frits bij aan de noodlottige ontwikkeling van de gebeurtenissen. Had hij zijn lust kunnen bedwingen, dan was het wellicht anders gelopen. Daarnaast wordt er een verband gesuggereerd tussen Margjes daden en haar beleving van haar seksualiteit. Margje verricht namelijk seksuele handelingen op het moment dat zij bedenkt dat zij Ida van God moet doden:

Toen schortte ze haar rok op en raakte ze zichzelf aan. Haar kruis gloeide en klopte. Uit deze zinderende hitte en uit dit lichaam was Ida geboren. Hiervoor moest zij zelf, in al haar onwetendheid, haar leven lang zijn voorbestemd. (Dorrestein, 2003/1998, pp. 224-225)

Door seksuele lust op deze manier aan de moord te koppelen, wordt de suggestie gewekt dat Margje en Frits schuldig zijn aan de ontwrichting van hun gezin, door seksuele daden te verrichten die binnen het christendom als zondig gelden en daar geen berouw over te tonen. Een betekenis die hieraan kan worden toegekend, is dat een goede moeder, en wellicht ook vader, geen seksueel subject is. In dit opzicht zou de roman dan aansluiten bij een patriarchaal beeld van goede moeders als passief en "non-sexual" (O'Reilly, 2006, p. 12), dat we ook binnen het christendom aantreffen.

Tegelijkertijd kan de manier waarop de verwijzingen naar het christendom in de roman zijn geïntegreerd ons er ook toe aanzetten om ons juist kritisch op het christendom en de christelijke visie op seksualiteit te bezinnen. De christelijke religie staat van oudsher in wezen zeer afwijzend ten opzichte van het doden van kinderen door hun eigen ouders. In de eerste eeuwen na Christus ontstond er vanuit het christendom verzet tegen praktijken van infanticide die tot dan toe meer gangbaar waren. Er kwam een verbod op het doden van kinderen in de vierde eeuw na Christus (Isarin, 2002). Dit neemt echter niet weg dat de kerk waarschijnlijk zelf ook juist heeft bijgedragen aan het voortbestaan van infanticide, door buitenechtelijke seks 
als zondig te bestempelen. De volgende observatie van feministe Adrienne Rich (1976) klinkt in dit verband waarschijnlijk:

\footnotetext{
The Church had much to do with creating the crime of individual maternal infanticide, by pronouncing all children born out of wedlock "illegitimate." Until the eighteenth century or later bastards were largely excluded from participation in trades and guilds, could not inherit property, and were especially without the law. Since the "sin" of the child's father was more difficult to prove, it was on the unmarried mother that the full penalty fell; as the eternally guilty party, she was considered by the Church to be "the root of the whole sex problem". (pp. 263-264)
}

Doordat het juist de christelijke leer is, die in Een hart van steen (Dorrestein, 2003/1998) de waanzinnige Margje het laatste zetje geeft om haar kinderen te vermoorden, kan een soortgelijke kritische invalshoek zoals die van Rich (1976) in de roman ge(re)produceerd worden.

We kunnen zodoende twee kanten op met deze verbeelding van de moordende moeder in Een hart van steen (Dorrestein, 2003/1998). Enerzijds kunnen we de wijze waarop Margje wordt gerepresenteerd nog steeds als een bevestiging van het christelijke beeld van zondige (vrouwelijke) seksualiteit lezen. Door het gebruik van christelijke symboliek lijkt er in de roman zodoende een aantal kanttekeningen bij een berustende houding ten aanzien van het noodlot te worden geplaatst. Er wordt in plaats hiervan echter geen wereldbeeld naar voren wordt geschoven waarin alles mag en kan en waarin absolute maakbaarheid en hedonisme hoogtij vieren. Integendeel, er blijken duidelijk regels, vooral over seksualiteit, waaraan een moeder en ook een vader zich heeft te houden. In dit opzicht wordt het moderne hedonistische maakbaarheidsdenken via de verwijzingen naar het christendom net zo min gereproduceerd als door de verwijzingen naar de tragedie. Een hedonistische levensinstelling waarbij men bijvoorbeeld van seks geniet, is vanuit deze optiek zelfs uitgesloten. Anderzijds kan de roman ook als een impliciete kritiek op diezelfde christelijke visie op seksualiteit worden beschouwd, omdat juist deze tot de moord leidt.

\section{Conclusie}

De geschiedenis van de door Margje gepleegde moord krijgt onder meer vorm en kleur via intertekstuele verwijzingen naar de homely gothic novel, de Griekse tragedie en het christendom. Het gebruik van gotieke elementen brengt het beeld van de moderne, zelfkiezende, rationele, beheerste mens aan het wankelen. De verwijzingen naar de tragedie zorgen voor de introductie van een visie op het noodlot die afwijkt van het moderne maakbaarheidsdenken. Dit geldt ook voor de verwijzingen naar het christendom. De roman lijkt zo een scala aan betekenissen te kunnen genereren die de moderne idealiserende norm over moederschap uithollen. Deze is immers gebaseerd op het idee dat de mens zelf kiest en zijn leven bepaalt en beschouwt het krijgen en hebben van kinderen als een plooibare praktijk. 
Dit potentieel wordt echter op verschillende manieren begrensd. Ten eerste, doordat de geschiedenis van de Van Bemmels zich afspeelt in een tijd waarin het idee dat het krijgen van kinderen een bewuste keuze is, nog niet wijdverbreid geaccepteerd is. Echter, daar staat tegenover dat de geboorte Ida wel het resultaat van een bewuste keuze van haar moeder om zwanger te worden. Daarnaast zorgt de manier waarop het gotieke in de roman is ingebed er uiteindelijk voor dat het moderne, autonome subject op het niveau van de raamvertelling uiteindelijk herrijst. Ook kan de reproductie van het medisch-psychologische vertoog over postpartum depressie de verbeelding van Margjes moederschap onschadelijk maken. Hierdoor kan haar geval gemakkelijker gepathologiseerd en daarmee geïndividualiseerd worden. In dit opzicht heeft de roman iets gemeen met de manier van berichtgeving over de Hoofddorpse moordzaak in de landelijke dagbladen. De verwijzingen naar het christendom nopen evenmin tot een eenduidige interpretatie van de roman. Niettemin kunnen we stellen dat Een hart van steen (Dorrestein, 2003/1998) commotie kan veroorzaken. Deze ontspruit aan de introductie van anti- en premoderne genres en vertogen. Daarbij lijkt vooral de aanwezigheid van elementen uit de Griekse tragedie een niet te onderschatten rol te spelen. 


\section{Hoofdstuk 7}

\section{Een poëtische (de)constructie van kindermoord. Met}

onbekende bestemming (2000) van Maya Rasker

\section{Inleiding}

De debuutroman Met onbekende bestemming (2003/2000) van Maya Rasker gaat over het raadselachtige vertrek van Raya Mira Salomon, schrijfster van beroep. Zij verdwijnt precies een jaar na de dood van haar vijfjarige dochter, Lizzy Salomon, in de nacht van 31 augustus 1997. De geschiedenis van de verdwijning wordt een jaar na Raya's vertrek in retroperspectief verteld door fotograaf Gideon Salomon, Raya's echtgenoot en de vader van Lizzy. Gideon is tevens de belangrijkste focalisator. Hij probeert te achterhalen waarom Raya hem heeft verlaten. Daarvoor trekt hij zich terug op de zolder van hun huis. Daar buigt hij zich over de inhoud van een koffer die Raya bij vertrek heeft achtergelaten. In de koffer zitten fotoalbums, door Raya geschreven ansichtkaarten, kattebelletjes, verhalen, een brief die Raya ooit aan haar dochter heeft gestuurd en een nog ongeopende brief van Raya aan Gideon. Gideon leest ze allemaal, in de hoop een antwoord op zijn vraag te vinden en het verleden zo te kunnen afsluiten.

Het blijkt nog niet zo gemakkelijk om er achter te komen wat Raya's beweegredenen zijn geweest. Raya is een verhalenvertelster met een voorkeur voor fictie, ook als het om haar eigen leven gaat. Aan de vooravond van hun huwelijk heeft Gideon daarom aan Raya gevraagd om het hem altijd te vertellen als ze liegt. Raya heeft vanaf dat moment aan deze huwelijkse voorwaarde geprobeerd te voldoen door haar uitspraken van geschreven annotaties voor Gideon te voorzien. Deze blijkt ze te hebben bewaard in de koffer. Zelfs met deze annotaties in de hand kan Gideon zijn vrouw niet volledig doorgronden. Waarheid en leugen blijken dicht bij elkaar te liggen in het leven van Raya. Het lijkt er op dat Raya's worsteling met haar moederschap een belangrijke reden voor haar vertrek is geweest. Aan het einde van de roman blijkt uit de brief van Raya aan Gideon, dat Raya zelfs zoveel moeite met het moederschap heeft gehad dat ze Lizzy op de ochtend van haar vijfde verjaardag 
heeft vermoord. Ze heeft haar met een kussen verstikt. Tot dan toe verkeert Gideon - en wij, als lezers, met hem - in de veronderstelling dat Lizzy een natuurlijke dood is gestorven. In de brief staat verder dat Raya Gideon heeft verlaten, omdat de moord volgens haar hoe dan ook tussen hen in zou komen te staan. Als ze Gideon over de moord zou hebben verteld, dan zou die bekentenis tot verwijdering tussen hen hebben geleid. Als ze de moord zou hebben verzwegen, zou het effect hetzelfde zijn geweest, omdat ze dan haar huwelijksbelofte van eerlijkheid zou hebben verbroken. Raya schrijft dat er maar één manier was om haar belofte na te komen en tegelijkertijd met Gideon verbonden te blijven: verdwijnen en via een brief de waarheid vertellen "in de hoop voor altijd te mogen heten: vrouw van Gideon. Moeder van Lizzy" (Rasker, 2003/2000, p. 217). Het blijkt het gewenste effect te hebben. Na het lezen van de brief voelt Gideon zich opnieuw en voor eeuwig verbonden met de afwezige “mooie, ondoorgrondelijke Raya Mira Salomon" (Rasker, 2003/2000, p. 9).

Critici in binnen- en buitenland hebben Met onbekende bestemming (2003/2000) in relatie tot geïdealiseerde beelden van moederschap gelezen. Zo schrijft Agnes Andeweg (2000) in haar bespreking van de roman in Vrij Nederland, dat Rasker "over de ervaring van het moederschap met liefde maar zonder roze wolk" schrijft. In het juryrapport van de Nederlandse Vrouw \& Kultuur debuutprijs 2002 waarmee de roman is gelauwerd, kunnen we lezen dat Rasker de prijs ten deel is gevallen, omdat zij erin is geslaagd het "heilige moederschap kritisch te benaderen" (Jury Vrouw \& Kultuur debuutprijs, 2002, p. 2). In de Vlaamse krant De Morgen wordt de roman als een tegengeluid gezien voor "het cliché dat kinderen een levensvervulling zijn, een geschenk voor de ouders, een bron van geluk" (Gerrits, 2000). In de bespreking van de Duitse vertaling van het boek in Der Spiegel wordt de roman "ein rabiater Gegenentwurf zu dem derzeit auf alle Kanälen herausgetrompeteten neuen Mutterglück" (Wellershoff, 2001) genoemd.

Net als bij de vorige drie romans draait het hier om het bestuderen van de relatie van Met onbekende bestemming (Rasker, 2003/2000) tot de moderne, rooskleurige moederschapsmoraal in Nederland. Daarbij is er eveneens aandacht voor de verbeelding van Gideons vaderschap, dat uitgebreid aan bod komt in de roman. In dit hoofdstuk zal blijken dat moederschap en vaderschap in relatie tot elkaar worden verbeeld met behulp van intertekstuele verwijzingen naar evolutionairbiologische argumenten over moederschap en vaderschap, naar een probleemvertoog over de combinatie van werk en moederschap en naar een optimistisch discours over de combinatie van werk en vaderschap. Door het samenspel van deze vertogen kan de roman uiteenlopende en zelfs tegenstrijdige betekenissen genereren. Verder wordt duidelijk dat het contradictoire karakter van dit boek wordt versterkt door de overvloedige, intertekstuele verwijzingen naar het genre van de poëzie. Het gaat hier zowel om expliciete verwijzingen naar en citaten uit gedichten, als om de manier waarop prozataal op poëtische wijze wordt ingezet. Deze verwijzin- 
gen blijken een lezing te legitimeren, waarbij een poststructuralistische visie op werkelijkheid en taal in stelling kan worden gebracht tegen de moderne idealisering van moederschap.

\section{Biologische bestemmingen van moeders en vaders}

Uitgeverij Prometheus prijst Met onbekende bestemming (Rasker, 2003/2000) aan als "[e]en pijnlijke ontleding van het moederschap" (cover). In het licht van deze aanbeveling is het opvallend dat Raya, zowel op het geschiedenisniveau als verhaalniveau van de roman, als moeder in eerste instantie zeer gelukkig is. Doordat Gideon uitgebreid citeert uit de gesprekken die hij ooit met Raya heeft gevoerd en uit de brieven en schrijfsels die ze heeft achtergelaten, krijgt Raya veel ruimte als 'ingebedde' focalisator en verteller. ${ }^{141}$ Hieruit blijkt dat Raya zich aanvankelijk zonder problemen naar de rol van nagenoeg fulltime moeder voegt en er volledig in op gaat. Dit is ook hoe Gideon zich de eerste maanden van Raya's moederschap herinnert. Hoe anders is het voor hem. Hij ervaart het prille vaderschap als een worsteling. Hij voelt zich buitengesloten, is bang als vader nutteloos en overbodig te zijn, en heeft er geen idee van hoe hij aan zijn vaderschap inhoud kan geven. In het begin is de roman dan ook veeleer een pijnlijke ontleding van het vaderschap dan van het moederschap. Gideon benijdt Raya om de vanzelfsprekendheid waarmee zij "gelukzalig" met haar dochtertje op de grond kan liggen spelen. Hij voelt zich echter "een volslagen imbeciel [...] als [hij] langer dan een paar minuten ligt te frummelen met Lizzy" (Rasker, 2003/2000, p. 100).

Om deze verschillen tussen hem en Raya te verklaren grijpt Gideon terug op gepopulariseerde evolutionair-biologische ideeën over verschillen tussen de vrouwelijke en mannelijke sekse. Gideon denkt dat Raya minder problemen ondervindt dan hij, omdat "de natuur" (Rasker, 2003/2000, p. 14) vrouwen op het moederschap voorbereidt. Vrouwen dragen het kind tijdens de zwangerschap negen maanden bij zich en zijn daardoor al verbonden met het kind voordat het ter wereld komt. In tegenstelling tot mannen bekommeren vrouwen zich bovendien instinctief om het lot van kinderen. Er is in dit opzicht sprake van een "ongekende oerdrift" (Rasker, 2003/2000, p. 13), aldus Gideon. Voor mannen ligt het volgens hem anders:

De natuur heeft ons, de vaders, iedere houvast ontzegd om de meteoriet [het kind] op te vangen zonder erdoor verpletterd te worden: van de ene op de andere dag heb je een Kind, ben je Vader, en moet je er naar de maatstaven van de huidige tijd nog een Leuke Invulling aan geven ook.

Tijd voor vergroeiing is er niet - dus is het vluchten, of gelaten wachten op het moment van verzoening. (Rasker, 2003/2000, p. 124)

\footnotetext{
${ }^{141}$ Dit maakt Raya om met Mieke Bal (1980) te spreken een personagegebonden focalisator op het tweede, 'lagere' niveau van het verhaal en een personagegebonden verteller op het tweede niveau van de tekst.
} 
Gideon denkt achteraf dat het vaderschap hem in eerste instantie zo zwaar is gevallen, omdat hij, anders dan zijn vrouw, overvallen wordt door de komst van zijn kind. De titel van de roman - die op meerdere manieren geïnterpreteerd kan worden, zoals in de loop van dit hoofdstuk zal blijken - kunnen we onder andere als een verwijzing naar deze ervaring van Gideon lezen. Het vaderschap is voor hem immers een onbekende bestemming. Gideon zet zich daarbij af tegen het idee dat het vaderschap volgens de "maatstaven van de huidige tijd [...] een Leuke Invulling" (Rasker, 2003/2000, p. 124) behoort te krijgen. In dit opzicht, maakt de roman de in hoofdstuk 1 besproken uitbreiding van de dwingende norm van genieten van het vaderschap zichtbaar. Door het gebruik van hoofdletters bij de woorden "Leuke Invulling" (Rasker, 2003/2000, p. 124) wordt het normatieve karakter van dit dictaat in de roman op typografische wijze onderstreept. Gideon stelt deze norm ter discussie, door te beargumenteren dat het pas verworven vaderschap niet plezierig kan zijn vanwege biologische factoren. Daarmee zegt hij in feite dat mannen er niet vrijelijk voor kunnen kiezen om bij de geboorte van hun kind direct gelukkige vaders te zijn. En moeders kunnen er niets aan doen dat ze dit wel zijn. Hoewel Gideon benadrukt dat Raya bewust voor een kind en het voltijdse moederschap heeft gekozen, denkt hij dat de keuze voor een kind niet volledig vrij gemaakt kan worden. Die beperking geldt zowel voor mannen als voor vrouwen. Er is volgens hem sprake van "een biologische aandrift tot voortplanten" (Rasker, 2003/2000, p. 131) die in het teken staat van het evolutionaire belang van het voortbestaan van de menselijke soort. Het is een drift die we als mens maar moeilijk kunnen negeren, al is het niet volledig onmogelijk. Het idee dat het ouderschap geen volledig vrije keuze is, kunnen we ook gespiegeld zien in de titel van de roman. Daarin wordt er immers gesproken van een bestemming en dit heeft iets onontkoombaars.

Het evolutionair-biologisch discours staat haaks op het idee van vrije keuze, al laat Gideon de notie van keuzevrijgheid nooit helemaal los. Met behulp van dit vertoog wordt er een ander beeld van moederschap en vaderschap geschetst dan het moderne, hedonistische beeld. Via evolutionair-biologische argumenten kan Gideon de problemen die hij ervaart legitimeren zonder dat hij zich er schuldig over hoeft te voelen. Hij heeft er immers niet voor gekozen om ongelukkig te zijn. Moeders kiezen volgens Gideon ook niet volledig vrij, maar die zijn daarentegen juist wel gelukkig, omdat de natuur dat nu eenmaal zo heeft voorzien. Wanneer Gideon keuzevrijheid opschort voor een idee van biologische determinatie, wordt de idealisering van het moederschap dus niet verlaten. Om te beginnen treffen we ook bij moderne verheerlijkingen van het bewust gekozen moederschap nog vaak het idee aan dat het moederschap, als er eenmaal voor gekozen is, als 'van nature' vanzelf verloopt. Pas wanneer Gideon de aanname dat mannen en vrouwen vrijelijk voor kinderen kiezen ter discussie stelt, dwaalt hij daadwerkelijk af van dit vertoog. Daarbij stelt hij moederschap echter wel nog altijd voor als een alomvattende identiteit, als een symbiotische relatie die tot het geluk van de moeder strekt. Gideon 
sluit met zijn generaliserende, evolutionair-biologische opvattingen bovendien zelfs naadloos aan bij het negentiende-eeuwse, blanke, middenklasse vertoog over moederschap. ${ }^{142}$ Dit vertoog is verstoken van keuzeretoriek, maar een voorloper van de moderne, hedonistische benadering van het moederschap. Het moederschap wordt daarbij beschouwd als een natuurlijke, allesbepalende, gelukzalige bestemming voor alle vrouwen en niet alleen voor de vrouwen die er bewust voor kiezen om kinderen te krijgen. Het geïdealiseerde beeld van het moederschap dat Gideon naar voren schuift als hij aanleunt tegen evolutionair-biologische ideeën, is daarmee eigenlijk nog dwingender dan haar moderne variant. Een variant die binnen gender studies bovendien niet onbesproken is. Er wordt hier immers op een zeer generaliserende manier over vrouwen en mannen gepraat, waarbij verschillen tussen beide seksen worden gelegitimeerd door ze vast te pinnen op en te reduceren tot lichamelijke, biologische verschillen. Daarbij wordt er een universele, vrouwelijke identiteit geproduceerd: die van moeder. $\mathrm{Er}$ is binnen de parameters van het vertoog waar Gideon bij aansluit haast geen ruimte voor andersoortige ervaringen en keuzes van vrouwen en mannen. Er is evenmin aandacht voor eventuele sociale oorzaken van verschillen tussen mannen en vrouwen, zoals die door Gideon zijn waargenomen.

In de loop van de roman lijkt dit biologische verklaringsmodel echter ook bij tijd en wijle verlaten te worden, wanneer de beelden van het moederschap en vaderschap kantelen. Het moederschap wordt voor Raya een kwelling, terwijl het vaderschap Gideon juist gelukkig maakt. In de volgende twee paragrafen wordt zichtbaar dat de evolutionair-biologische ideeën onderuit gehaald kunnen worden door deze verschuiving in de verbeelding van moederschap en vaderschap. De mogelijkheid om deze verschuiving als een verdere reproductie van die ideeën op te vatten is paradoxaal genoeg echter ook reëel. Daarbij blijkt de verhouding tot het moderne genotsvertoog over moederschap, en vaderschap, eveneens ambigue.

\section{Schrijven en moederschap: een moeizame combinatie}

Met uitzondering van de beschrijvingen van Gideons en Raya's herinneringen aan het prilste moederschap, wordt er een negatief beeld van Raya's moederschap geschetst. In de brief van Raya aan Gideon die aan het eind van de roman wordt geïntroduceerd, kunnen we lezen dat het aanvankelijk Raya's bedoeling is om van het moederschap "een kunstwerk" (Rasker, 2003/2000, p. 214) te maken. Raya lijkt er zodoende bewust voor gekozen te hebben om moeder te worden en om zich hier vol overgave in te storten, ten behoeve van haar kunst. Zij heeft zich voorgenomen datgene te gaan beschrijven waarvan niemand haar had kunnen vertellen hoe het

\footnotetext{
${ }^{142}$ Zie hoofdstuk 1 voor een toelichting op dit discours.
} 
is: "Ze [Lizzy] was de klei in mijn handen, waarmee ik vorm zou geven aan dat onbekende, onzegbare dat een vrouw transformeert tot moeder" (Rasker, 2003/2000, p. 214).

Dat project blijkt onmogelijk te volbrengen. Raya denkt uiteindelijk dat ze er niet in slaagt om het moederschap te beschrijven, omdat het zich per definitie niet verdraagt met kunstenaarschap, met verbeelding. "Belangrijke kunstenaressen met kinderen" (Rasker, 2003/2000, p. 213) kunnen dan ook niet bestaan, aldus Raya, die met deze uitspraak een "beroemd schrijfster" (Rasker, 2003/2000, p. 213) citeert. De schrijfster die hier wordt bedoeld, blijkt uit een korte verantwoording achter in het boek van Rasker (2003/2000) de Oostenrijkse Elfriede Jelinek. Een interview met haar in het NRC Handelsblad (De Jong, 1998) blijkt Rasker te hebben geïnspireerd. In dat interview staat dat Jelinek, zelf kinderloos, romans schrijft waarin "kunstenaarschap en moederschap" met elkaar "vloeken" (De Jong, 1998). Verder kunnen we de provocerende uitspraak van de schrijfster lezen dat ze "geen belangrijke kunstenaressen met kinderen" kent (De Jong, 1998). Ook in de roman van Rasker kunnen moederschap en kunstenaarschap elkaar niet verdragen. Hoewel Raya nog schrijft ze publiceert sporadisch een journalistiek stuk in het blad Visserij Belangen, waar ze voor de geboorte van Lizzy vast in dienst was - lukt het haar niet om te schrijven wat zij wil. Volgens Raya komt dit omdat "[d]e essentie van het scheppen is dat de gehele creatie voortspruit uit je eigen brein, dat je heer en meester bent over ontstaan, wordingsproces en eindresultaat" (Rasker, 2003/2000, p. 213). Dit is voor een schrijfster die het moederschap tot haar kunstwerk maakt onmogelijk, omdat zij nooit het eindresultaat van haar schepping zal kunnen aanschouwen. Aldus Raya: "Ze kan wel zeggen: zo moet het zijn, nu ben je af - maar een kind gaat zijn eigen weg en leidt zijn eigen leven. Die laat zich niet op een sokkel schroeven" (Rasker, 2003/2000, p. 213). Bovendien verliest een vrouw volgens Raya zodra ze moeder wordt haar "soevereiniteit" (Rasker, 2003/2000, p. 214), terwijl die soevereiniteit voor een kunstenaar juist onontbeerlijk is. Door een alles overweldigende liefde en verantwoordelijkheid voor je kind, heers je als moeder, aldus Raya, "niet meer over je eigen leven - en iedereen vindt dat normaal" (Rasker, 2003/2000, p. 214).

Het verlies van Raya's soevereiniteit ligt aanvankelijk aan de basis van haar moedergeluk. Haar relatie met Lizzy is symbiotisch van aard en ze beleeft daaraan in eerste instantie juist veel plezier. Maar die symbiose gaat haar uiteindelijk opbreken. De eerste barsten in het moedergeluk worden - zowel op geschiedenisniveau als op verhaalniveau - niet voor niets zichtbaar in passages waarin Raya zich begint te realiseren dat zij zich in het moederschap dreigt te verliezen. De volgende is daar een goed voorbeeld van:

Het had me [Gideon] toegeschenen dat Raya in grote harmonie leefde met de keuzes die ze had gemaakt; dat ze vervulling vond in haar leven met Lizzy, in de kleine observaties van dat leven dat onder haar handen groeide; dat ze niet bang was voor de ontstellende liefde die ze voelde voor haar kind. 
'Zal er dan nooit meer een dag zijn,' stond er op het briefje dat ik toegeschoven kreeg toen ze naar bed ging, 'dat ik mijn eigen gedachten kan denken, mijn eigen gevoelens kan koesteren, mijn eigen dromen kan najagen, mijn eigen lichaam kan bestieren zonder een tweede stem in mij? Zou er dan nooit meer een dag zijn dat ik samenval met mezelf, zonder dat daar een ander tussen staat?' (Rasker, 2003/2000, pp. 108-109)

Heel expliciet wordt het verlies van de eigen identiteit verbeeld in een alinea, waarin Gideon het moment waarop Raya moeder wordt, beschrijft als het ogenblik waarop Raya sterft:

\footnotetext{
Toen ze opkeek van haar schrift zag ik een verandering in haar gezicht, subtiel maar onmiskenbaar. Eerst was ik opgetogen: onder mijn ogen voltrok zich een wonder, ik zie een moeder geboren worden! Maar ik hernam mezelf, het was iets anders: ik zag mijn Raya Mira verglijden naar een universum dat mij vreemd was. Zo zou iemand eruit kunnen zien die stervende is, schoot het door me heen. Achteraf was die gedachte misschien waarachtiger dan ik op dat moment durfde te bekennen: mijn vrouw was stervende, in haar werd een mens geboren met een wanhopige verantwoordelijkheid waarvan ik geen weet kon hebben. (Rasker, 2003/2000, p. 86)
}

In haar brief aan Gideon stelt Raya dat zij zich van het bestaan van dit identiteitsverlies niet bewust was, voordat zij aan het moederschap begon. Dat kon zij ook niet zijn, denkt ze, omdat verbeelding en moederschap elkaar immers juist uit blijken te sluiten. Daardoor heeft zelfs haar eigen moeder haar niet kunnen vertellen wat het precies is om moeder te zijn. Er is sprake van een verbeeldingstekort, waardoor niemand haar er voor heeft kunnen waarschuwen hoe beklemmend, die overigens wel "rijke bestemming" is waaronder "het verval" (Rasker, 2003/2000, p. 212) van de eigen identiteit, de eigen verlangens heerst. De titel van de roman kunnen we zodoende ook opvatten als een verwijzing naar de onbekende bestemming van het moederschap. Het is vanuit dit perspectief opvallend dat Raya niet de belangrijkste verteller is, maar haar echtgenoot. Het idee dat moederschap en verbeelding elkaar niet verdragen, wordt zo in de vorm op het tekstniveau van de roman gespiegeld.

Raya weigert zich neer te leggen bij het verlies van haar soevereiniteit; van haar eigen, van haar kind onafhankelijke, identiteit. Zij probeert het tij te keren door weer te gaan varen. Dat heeft zij voordat zij moeder werd vaker gedaan, in het kader van een journalistieke functie. Door afstand te scheppen tussen haar en haar kind hoopt Raya zichzelf te hervinden. Na maanden van afwezigheid ziet zij zich echter gedwongen om haar reis af te breken, wanneer Lizzy tijdens het voeren van de eendjes in een moment van onoplettendheid van Gideon door het ijs van een vijver zakt en bijna verdrinkt. Raya realiseert zich door dit voorval dat zij zich, zo lang Lizzy leeft, nooit van het moederschap zal kunnen losmaken. Wil ze haar eigen leven weer hernemen, dan kan dat in haar beleving enkel door Lizzy te doden: "Het kind en de schrijver verkeren [namelijk] voortdurend op voet van oorlog - en die oorlog is op leven en dood. (...) Het moederschap doodt de verbeelding. De verbeelding doodt het kind" (Rasker, 2003/2000, p. 213). Raya kan het moederschap 
uiteindelijk niet meer aan, doordat zij het als alomvattend ervaart. Daardoor is er geen ruimte meer voor het hebben van een eigen identiteit en het verwezenlijken van eigen verlangens. De moeder pleegt de moord in deze roman, net als in Een hart van steen (2003/1998) van Renate Dorrestein, dus niet omdat ze niet genoeg van haar kind houdt. Integendeel, Raya houdt juist ondraaglijk veel van Lizzy en dat is precies het probleem. Met de dood van Lizzy slaagt Raya erin om aan die liefde te ontsnappen, hoewel ze de liefde voor haar kind nooit helemaal te boven denkt te komen. Eindelijk kan zij voldoende afstand nemen van haar moederschap om er over te schrijven, wat ze onder meer doet in de brief die ze Gideon heeft nagelaten.

Daarmee kunnen we de roman opvatten als een kanttekening bij het door Gideon opgeroepen idee dat moederschap een tot op zekere hoogte natuurlijke bestemming voor vrouwen is, die een symbiotische relatie met het kind impliceert die gelukkig stemt. Raya blijkt er om te beginnen min of meer bewust voor te hebben gekozen om een kind te krijgen en om alles op te geven om bij dat kind te zijn. Ze is echter niet voorbereid op het symbiotische karakter van dat moederschap, dat zich min of meer van nature aan haar lijkt op te dringen en ze wordt er bovendien helemaal niet gelukkig van. Het verzwelgt haar en betekent daarom uiteindelijk de dood van Lizzy. Zo kan de roman vraagtekens oproepen over het rooskleurige beeld van een symbiotische moeder-kindrelatie dat ons in hedendaagse opvoedkundige handboeken, tijdschriften en reclames wordt voorgehouden.

Dit potentieel wordt versterkt door de wijze waarop de roman ons er toe aanzet om ons met Raya te gaan identificeren. In het vorige hoofdstuk kwam aan de orde dat we ons met de moeder uit Een hart steen (Dorrestein, 2003/1998) minder snel zullen vereenzelvigen, omdat we haar om verscheidene redenen als 'anders' en 'abnormaal' kunnen gaan beschouwen. In dit geval zullen we moderne moederschapsideaal niet zo gauw aan een kritisch onderzoek onderwerpen. Immers, wanneer we de moeder niet als één van ons beschouwen en we ons niet in haar kunnen herkennen, verwordt zij met haar moederschap tot een individuele uitzondering op de norm. Doordat de moeder expliciet valt buiten wat we als 'normaal' beschouwen, zou de verbeelding van haar moederschap de hedonistische benadering ervan kunnen reproduceren. In tegenstelling tot de moordende moeder in Een hart van steen (Dorrestein, 2003/1998) kan Raya ons dicht op de huid naderen. De moordende moeder in deze roman is een ondoorgrondelijke vrouw, maar zij weerstaat geen identificatie en kan binnen de parameters van de vertelling niet eenvoudig als 'abnormaal' worden afgevoerd.

Dat Raya niet gemakkelijk als 'afwijkend' kan worden weggezet, komt onder andere doordat zij niet als zodanig wordt beschreven door de belangrijkste verteller en focalisator: haar man. Doordat Gideon uitgebreid uit de schrijfsels van Raya citeert, krijgt Raya bovendien veel ruimte als 'ingebedde' focalisator en verteller. Daardoor zullen we er sneller toe overgaan om ons met haar te identificeren. De belangrijkste reden dat Raya niet eenvoudig als een 'ontaarde' moeder kan worden 
beschouwd, is echter dat wij pas aan het eind van de roman op de hoogte worden gesteld van de moord; in tegenstelling tot de chronologische volgorde van gebeurtenissen op het geschiedenisniveau van de roman. De relatief late introductie van de moord in de vertelling zorgt ervoor dat de lezing van de roman in eerste instantie niet beïnvloed wordt door de wetenschap van Raya's daad. In dit opzicht spiegelt de zoektocht van Gideon onze ervaring als lezers. Net als wij verkeert hij lange tijd in de veronderstelling dat zijn dochter een natuurlijke dood is gestorven. Pas een jaar na haar verdwijning ontdekt hij dat zijn vrouw hierin een rol heeft gespeeld wanneer hij Raya's brief vindt, die aan het eind van de roman in zijn geheel wordt geciteerd. Deze ontdekking resulteert niet in verregaande verontwaardiging bij Gideon, maar gaat gepaard met acceptatie. Die acceptatie komt voort uit zijn eerdere bereidheid om zich in Raya's leven te verdiepen - een verdieping die, en dat is cruciaal, voorafgaat aan de ontdekking van de moord. Door de spiegeling van onze leeservaring kunnen we ons verbonden gaan voelen met de ervaringen van Gideon en zo, net als Gideon, met Raya gaan sympathiseren.

Ten slotte is het van belang dat uit de brief waarin Raya de moord bekent, blijkt dat het besluit om haar dochter te doden weloverwogen was en niet de uitkomst van een vlaag van waanzin. Eerder in de roman wordt bovendien duidelijk dat Raya weinig op heeft met het idee dat een moeder haar kinderen vermoordt, omdat ze ontoerekeningsvatbaar is. Gideon vertelt hoe hij hierover ooit met Raya een verhit gesprek voert met een echtpaar dat ze tijdens een werkreis in Spanje zijn tegengekomen: Sonja en Sjef. Het gesprek gaat over de Amerikaanse vrouw Susan Smith, die in werkelijkheid heeft bestaan en die haar twee zoons van drie jaar en veertien maanden oud in 1994 bij de politie als vermist heeft opgegeven (Barnett, 2006). Later blijkt dat Smith heeft gelogen en dat ze haar kinderen heeft vermoord door haar auto in een nabijgelegen meer te rijden met de kinderen op de achterbank. ${ }^{143}$ Gideon, Raya en het echtpaar buigen zich over de vraag wat Smith en andere vrouwen die hun kinderen vermoorden zou kunnen bewegen. Sonja oppert voorzichtig dat het schizofrenie zou kunnen zijn. Raya veegt deze verklaring onmiddellijk en woedend van de hand en suggereert daarentegen dat deze daad voortvloeit uit de beklemmende symbiotische band tussen kind en moeder. Dat doet zij op metaforische wijze door een natuurkundig experiment te beschrijven "waarbij halve bollen op elkaar worden geplaatst en de ruimte ertussen vacuüm wordt getrokken" (Rasker, 2003/2000, p. 193). Tijdens de discussie blijkt dat Raya Susan Smith bovendien niet als afwijkend beschouwt. Wanneer Gideon opmerkt dat de meest verbolgen reacties in de USA-today op de zaak vooral van moeders afkomstig zijn, stelt Raya

\footnotetext{
${ }^{143}$ De rechtszaak die hierop in 1995 volgde en waarin Smith tot levenslang werd veroordeeld, bracht wereldwijd beroering en verontwaardiging te weeg (Rekers, 1995).
} 
dat dit "[a]llemaal projectie" (Rasker, 2003/2000, p. 192) is. Ze suggereert zo dat het idee om je eigen kind te doden moeders per definitie niet vreemd is.

In het licht van de interpretatie van Een hart van steen (Dorrestein, 2003/1998) is het overigens interessant dat Raya in dit gesprek ook naar het genre van de Griekse tragedie verwijst en meer in het bijzonder naar Medea. De introductie van de Griekse tragedie heeft hier echter niet precies hetzelfde effect als in Een hart van steen (Dorrestein, 2003/1998). In deze roman heeft het er veel van weg dat Medea wordt opgevoerd om infanticide nogmaals in verband te brengen met verlies van identiteit. Volgens Raya moeten we de door Medea gepleegde moorden niet alleen zien als een manier om wraak op Jason te nemen, maar als het gevolg van het verlies van Medea's waardigheid. Raya: “Op het moment dat een vrouw haar waardigheid dreigt te verliezen, Gideon, is ze tot alles in staat. Dat ontstijgt het niveau van goed en kwaad. Dat ontstijgt zelfs de schuldvraag" (Rasker, 2003/2000, p. 194). Gezien Raya's eerdere opmerkingen over het verlies van haar eigen identiteit, kunnen we het verlies van waardigheid waar ze hier over spreekt, interpreteren als een verwijzing naar het verlies van een identiteit, in dit geval die van echtgenote van Jason. De introductie van de Griekse tragedie roept hier dus niet zo zeer een specifieke visie op het noodlot op, zoals in Een hart van steen (Dorrestein, 2003/1998), maar het plaatst de daden van Raya wel net als in de roman van Dorrestein in een breder perspectief. Raya is niet de enige noch de eerste moeder die haar kind vermoordt en kan daarmee niet zomaar worden afgedaan als een uitzondering op de regel. De moord die Raya pleegt kan hierdoor een zeer verontrustende uitwerking hebben. Raya kan het heersende geïdealiseerde beeld van moederschap aan het wankelen brengen, omdat ze niet wordt gepathologiseerd en we ons met haar kunnen gaan identificeren. Ze is daarmee immers geen uitzondering op de norm; ze lijkt in eerste instantie een moeder als ieder ander. Als een 'normale' moeder een daad kan begaan die als 'abnormaal' geldt, dan worden er vragen over die norm opgeroepen. Hierdoor zullen we ons er ook gemakkelijker toe aangezet voelen om de alomvattende moederschapsideologie, waarin Raya verstrikt is geraakt, aan een kritisch onderzoek te onderwerpen.

De nadruk op de onmogelijkheid van de combinatie van schrijverschap en het moederschap kan echter ook een andere betekenis genereren. In hoofdstuk 1 bleek dat de combinatie van moederschap en een carrière vaak als een probleem wordt beschouwd. Dit vertoog over de moeizame combinatie van moederschap en een carrière vloeit voort uit het idee dat moederschap alomvattend behoort te zijn. Met onbekende bestemming (Rasker, 2003/2000, p. 213) (re)produceert het beeld dat moederschap en een ambitieuze baan, in dit geval een met creatieve aspiraties, niet gemakkelijk kunnen samengaan. 


\section{Fotografie en vaderschap: een plezierige verrijking}

Terwijl het moederschap Raya tot een last wordt, staat Gideon in de loop van de roman steeds positiever tegenover zijn vaderschap. Gideon slaagt er juist wel in om een leuke invulling aan zijn vaderschap te geven en zijn eerdere, biologisch geënte kritiek hierop lijkt daarmee in zekere zin weer onschadelijk gemaakt. Vanaf het moment dat de taakverdeling tussen Raya en Gideon - die vanaf het begin vrij traditioneel is georganiseerd - op de kop wordt gezet, is er sprake van een ommekeer in de manier waarop Gideon het vaderschap ervaart. Door het besluit van Raya om weer te gaan varen, wordt Gideon gedwongen om de zorg voor en opvoeding van Lizzy volledig op zich te nemen. En "[di]e onversneden verantwoordelijkheid voor het welzijn van mijn dochter zette de deur open naar mijn vaderschap. Ik had mijn houvast gevonden" (Rasker, 2003/2000, p. 124). Gideon verzoent zich vanaf dat moment met de volgens hem onlosmakelijke band van een ouder met een kind, die een nooit aflatende verantwoordelijkheid met zich meebrengt. Hij ervaart die verbondenheid met zijn dochter als een verrijking. Gideon verliest zich er in tegenstelling tot Raya niet in, maar ook bij hem heeft het verlies van soevereiniteit mogelijk op de loer gelegen. Een passage waarin Gideon zijn gedachten over het vaderschap als volgt laat gaan, getuigt hiervan:

\footnotetext{
Je moet die eerste versie van jezelf zien kwijt te raken - de versie waartegen je moeder 'ach, mijn jongen' zucht, en waaraan je vader zijn onvervulde dromen toont - om ruimte te maken voor die andere variant van jezelf: die waartegen iemand ooit papa zal zeggen. Doe je dat niet, dan loop je gedurig met drie exemplaren van jezelf te jongleren: het kind, de ouder, en nog een wezen waarvan je hoopt dat dat je autonome ' $i k^{\prime}$ ' is. Dat kan niet anders dan dringen worden, totdat er één je ontglipt en met een smak op de grond valt. (Rasker, 2003/2000, p. 143)
}

Gideon slaagt er klaarblijkelijk in om zijn identiteit als vader met zijn "autonome 'ik'” (Rasker, 2003/2000, p. 143) te verenigen. Het is in dit verband opvallend dat hij geen grote problemen ervaart bij de combinatie van zijn verbeeldende werk als fotograaf en de zorg voor Lizzy. Hij moet weliswaar soms een opdacht laten schieten of afzeggen om bij Lizzy te kunnen zijn, maar het werk van de verbeelding en vaderschap staan elkaar niet fundamenteel in de weg. Ze vallen zelfs soms samen: Gideon maakt voortdurend foto's van zijn dochtertje.

Daarmee lijkt de roman alsnog aan te sluiten bij de maatschappelijke uitbreiding van de hedonistische benadering naar het vaderschap of beter gezegd bij de idealisering van de combinatie van werk en vaderschap. Het combineren van een carrière en zorg wordt, zo bleek in hoofdstuk 1, vandaag de dag eerder als een obstakel wordt gezien wanneer het om moeders gaat, dan om vaders. Sinds de jaren negentig is er sprake van een tendens om die combinatie als een verrijking in het leven van mannen te beschouwen. Dat dit bij vaders wel en bij moeders niet gebeurt, komt onder andere omdat het vaderschap niet als een alomvattende aangelegenheid en identiteit wordt beschouwd en het moederschap wel. Het boek biedt 
een optimistisch beeld van de combinatie van fulltime vaderschap en werk. Het is immers een verrijking voor Gideon. Gideon lijkt via die combinatie ook aan zijn biologische bestemming te kunnen ontsnappen: het is mogelijk om een band met zijn kind op te bouwen. Voor het moederschap verandert er echter niets. Vrouwen lijken nog steeds door hun 'natuur' gedoemd, om door het moederschap verzwolgen te worden. Er lijkt geen ontsnappen aan. De roman blijft cirkelen binnen de parameters van een vorm van moederschap die weliswaar niet plezierig is, maar die nog altijd allesomvattend wordt verondersteld te zijn.

\section{Poëtische meerduidigheid}

Opvallend aan Met onbekende bestemming (2003/2000) is dat er rijkelijk wordt geciteerd uit gedichten. In enkele van de andere besproken romans kwamen we ook gedichten tegen, maar hier valt de poëzie door haar haast voortdurende aanwezigheid meer op. De loop van de tekst wordt herhaaldelijk onderbroken door poëzie. Gideon en Raya verwijzen uitgebreid naar gedichten van onder andere Rutger Kopland, Rainer Maria Rilke, Anna Achmatova, Frederico García Lorca en Salvatore Quasimodo.

Deze opeenstapeling van poëzie kan effect hebben op onze leeshouding. Poëzie roept doorgaans een andere leeshouding op dan proza. Er wordt volgens Maaike Meijer (1988) een zogenaamde "poëtische leeshouding" (p. 31) door geactiveerd. Meijer (1988) ontleent dit idee van een poëtische leeshouding aan het literatuurtheoretische werk van Jonathan Culler $(1975,1981)$ en Michael Riffaterre (1978, 1984). ${ }^{144}$ Het innemen van een poëtische leeshouding betekent volgens haar onder andere dat we meer aandacht aan zaken als metrum en rijm gaan besteden. Ook zullen we geneigd zijn om de gedichten op niet-referentiële wijze te lezen. Dat geldt zeker wanneer we in een gedicht ongrammaticaliteiten aantreffen die een referentiële lezing niet mogelijk maken. Het gaat dan bijvoorbeeld om woorden die niet direct op de werkelijkheid betrokken kunnen worden. Ook zaken als metrum en klank die binnen een gedicht extra betekenissen kunnen genereren, kunnen hiertoe gerekend worden. Gedichten kunnen door de aanwezigheid van deze ongrammaticaliteiten vanuit een niet-referentieel kader op indirecte wijze betekenissen gaan genereren en worden daardoor dikwijls ook meerduidig en dubbelzinnig. Doordat we bereid zijn om een gedicht op een poëtische manier te lezen kan er met andere woorden op omtrekkende wijze iets tot uitdrukking worden gebracht. Op basis van het werk van Culler $(1975,1981)$ stelt Meijer (1988) dat iedere tekstuele bron in wezen op een poëtische manier benaderd kan worden. Teksteigenschappen die we

\footnotetext{
${ }^{144}$ Zie voor een toegankelijke uiteenzetting over de hier genoemde poëtische leeshouding ook Ernst van Alphen, Lizet Duyvendak, Maaike Meijer en Ben Peperkamp (1996).
} 
als poëtisch beschouwen, zoals "equivalenties, paradoxen, ambiguïteit, of ongrammaticaliteiten [...] zitten in elke tekst" (Meijer, 1988, p. 49). De poëtische leeshouding wordt echter meestal geactiveerd door "de typografische presentatie van een tekst als gedicht" (Meijer, 1988, p. 31). De culturele afspraak is dat we deze bronnen op poëtische wijze lezen, terwijl we anders gepresenteerde bronnen in eerste instantie op een meer referentiële manier benaderen.

De gedichten in Met onbekende bestemming (Rasker, 2003/2000) roepen vooral door hun typografische presentatie een poëtische leeshouding op. We zullen vooral geneigd zijn om op zoek te gaan naar diepere, indirecte betekenissen van de gedichten in relatie tot de rest van de roman. ${ }^{145}$ De poëzie lijkt dan op indirecte wijze iets te zeggen over de ervaringen en gevoelens van Gideon en Raya. Goede voorbeelden hiervan zijn de veelvuldige citaten uit volgende twee gedichten: Terugkeer (1971/1930) van de Italiaanse dichter Salvatore Quasimodo en Epische motieven III (Achmatova, 1981/1914-1916) van de Russische dichteres Anna Achmatova. Deze gedichten maken deel uit van een fotografisch project waaraan Gideon voor en na de verdwijning van Raya heeft gewerkt. Het betreft het maken van een serie fotografische interpretaties van gedichten.

De geciteerde passages uit het gedicht Terugkeer (1971/1930) van Quasimodo wijzen bijvoorbeeld onder andere vooruit naar beschrijvingen van Gideons ervaringen van zijn relatie met zijn moeder. Uit het gedicht worden de volgende twee passages geciteerd:

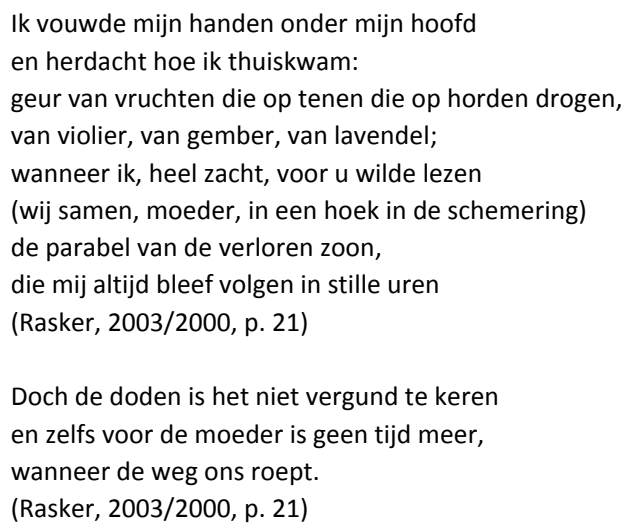

Deze passages lijken op het eerste oog over een relatie tussen een moeder en een zoon te gaan, beschreven vanuit het perspectief van de zoon. Er is sprake van een verwijzing naar de Bijbelse parabel van de verloren zoon die zijn ouders ooit heeft

\footnotetext{
${ }^{145}$ Het gaat hier dus om betekenissen die de citaten uit de gedichten in de roman oproepen en niet om het geven van een interpretatie van de gehele gedichten op zichzelf.
} 
verlaten, maar uiteindelijk weer terugkeert in hun armen. De thuiskomst lijkt hier uiteindelijk niet plaats te vinden. We kunnen het gedicht zodoende onder andere opvatten als een uitdrukking van het onmogelijke verlangen van een zoon om naar zijn moeder terug te keren. Later blijkt dat Gideon op een soortgelijke manier naar zijn eigen inmiddels overleden moeder verlangt. Gideon vertelt hoe hij als jongvolwassene herhaaldelijk op de stoep van zijn ouderlijk huis stond, nadat een van zijn relaties weer averij had gelopen. Gideon: “Mijn moeder zuchtte telkens: 'ach jongen, daar ben je weer!' nam blijmoedig de waszak aan en dirigeerde mijn vader naar boven met mijn koffers, waar onze jongenskamer was" (Rasker, 2003/2000, p. 36). Vanwege de innige band met zijn moeder kan Gideon haar dood moeilijk accepteren.

In relatie tot het gedicht is het interessant dat het de dode moeder van Gideon wel nog een keer is gegund om terug te keren. Ze verschijnt namelijk als geest voor Gideon, op het strand van het Duitse Waddeneiland Sylt, waar hij direct na de dood van Lizzy samen met Raya naartoe is gereisd om de dood van hun dochtertje te verwerken. In dit opzicht vertoont de roman ook enige verwantschap met de gotieke roman, waarin geestverschijningen een bekend motief vormen. Naast deze geestverschijning zijn er nog andere bovennatuurlijk aandoende elementen die we onder de noemer gotiek zouden kunnen scharen. Zo is er de albino vriendin van Raya, Brechje, die vanwege haar spookachtige, witte verschijning herhaaldelijk wordt vergeleken met een heks of een van de "witte wieven" (Rasker, 2003/2000, p. 95). En wanneer Gideon en Raya na de dood van hun dochtertje op een begraafplaats picknicken, beschrijft Gideon de reactie van zijn vrouw op de dood van Lizzy op een wijze die sterk doet denken aan de gotieke, culturele figuur van de weerwolf:

\footnotetext{
In het licht van de opkomende maan zag ik een eens vertrouwd gezicht veranderen in het masker van een beest: haar ogen sperden zich als knikkers, haar iris draaide weg, haar mond ging open, haar lippen barstten tot bloedens toe. Vanuit haar borst zag ik een schreeuw omhoogkomen; eerst was er nog niets, een zucht, een laatste adem - daarna weerklonk door de nacht op het kerkhof de verscheurende kreet van een stervende wolvin. (Rasker, 2003/2000, p. 170)
}

Deze gotieke elementen kunnen net als in de besproken romans Nieuwe buren (Noort, 2006) en Een hart van steen (Dorrestein, 2003/1998) een unheimlich gevoel over het gezin Salomon opwekken. Het gotieke lijkt hier echter ook een andere functie te vervullen. Het geeft uitdrukking aan de onwerkelijke pijn en het verdriet dat Gideon en met name Raya ervaren over het verlies van hun kind. Maar dit terzijde.

De passages uit het gedicht van Quasimodo (1971/1930) kunnen ook andere betekenissen oproepen, doordat de laatste twee regels van het gedicht van Quasimodo (1971/1930) een pagina later worden herhaald: "en zelfs voor de moeder is geen tijd meer, wanneer de weg ons roept" (Rasker, 2003/2000, p. 22). Deze dicht- 
regels krijgen daardoor meer nadruk en komen een moment op zichzelf te staan, waardoor ze los van de rest van de passage uit het gedicht gelezen kunnen worden. Het wordt dan mogelijk om dit deel van het gedicht als een vooruitwijzing naar Raya's keuze voor de weg van de verbeelding boven het moederschap te lezen en wellicht zelfs in verband met haar verdwijning.

Uit het gedicht Epische motieven III. De avond valt, en waar zo kort geleden (1981/1914-1916) van Achmatova wordt onder andere de volgende passage herhaaldelijk geciteerd:

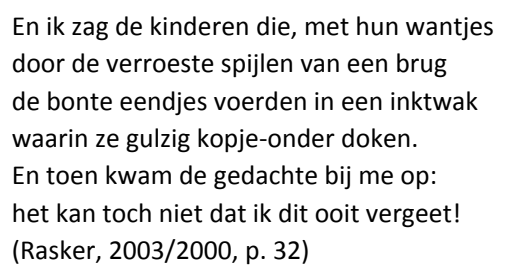

Het poëtisch oeuvre van Achmatova, en dan vooral haar latere werk, wordt vaak in verband gebracht met het Sovjetregime van Stalin (zie bijvoorbeeld Alexandra Harrington, 2006). Het gedicht waaruit in de roman van Rasker wordt geciteerd is echter voorafgaand aan de heerschappij van Stalin is verschenen. De cyclus waar Epische motieven III. De avond valt, en waar zo kort geleden (Achmatova, 1981/19141916) deel vanuit maakt, wordt onder meer beschouwd als een poging van de dichteres om zichzelf te construeren door middel van beschrijvingen van haar jeugd (Harrington, 2006). Daarbij schetst Achmatova (1981/1914-1916) een vrij positief en warm beeld van haar kindertijd (Harrington, 2006). In de context van de roman gaat het gedicht echter vooral fungeren als een aankondiging van de bijnaverdrinkingsdood van Lizzy, als ze bij het voeren van de eendjes door het ijs zakt. Het gedicht heeft ook iets triests en melancholisch en kan worden gelezen in relatie tot Gideons worsteling met het verleden en de verliezen die hij heeft geleden.

Omdat de gedichten zo talrijk zijn, worden we mogelijk ook gevoeliger voor de poëtische aspecten van het proza waarin ze zijn ingebed. Het poëtische blijkt dan in overvloed aanwezig in de roman. Neem bijvoorbeeld het volgende fragment, waarin Gideon beschrijft hoe hij als fotograaf aan de slag gaat wanneer hij probeert om de gedichten in foto's om te zetten. Voordat hij foto's neemt, maakt hij eerst schetsen van hoe hij denkt dat de gedichten er in beeld zouden uitzien:

Ik zet me aan de tafel voor de volgende serie schetsen. Het moet ergens beginnen. Het maakt je hersens lenig. Achmatova, Sint-Petersburg. Het houdt je bezig. Het leidt nergens toe, maar het houdt je lenig.

En als een zware weg mij wacht is dit

de lichte last, waarvan ik niet zal scheiden 
Het leidt nergens toe. Het maakt je lijden lenig. Het maakt je leden nijdig.

(Rasker, 2003/2000, p. 24)

De prozatekst die aan de dichtregels voorafgaat en er op volgt, lijkt bij nadere beschouwing opeens zeer poëtisch. Dit komt door de vele ongrammaticaliteiten die we hier aantreffen. De laatste twee zinnen uit de passage zijn hierdoor zelfs met geen mogelijkheid op een referentiële manier te lezen. Ook zijn de regels opvallend ritmisch. Er is sprake van "een regelmatige herhaling van beklemtoonde lettergrepen waartussen het aantal dalingen constant is" (Van Alphen, Duyvendak, Meijer \& Peperkamp, 1996, p. 45) oftewel van een metrum: Het máákt je líjden lénig. Het máákt je léden níjdig. Interessant genoeg komen we in het prozadeel van de passage vele herhalingen tegen. Bijna iedere zin begint op dezelfde wijze met het woord 'het'. Een dergelijke herhaling wordt binnen de poëzietheorie een "anafoor" (Van Alphen, Duyvendak, Meijer \& Peperkamp, 1996, p. 60) genoemd. Al deze ritmische en poëtische herhalingen lijken net als de gedichten zelf op een onrechtstreekse manier uitdrukking te geven aan het verdriet en de woede die Gideon voelt over de verdwijning van zijn vrouw en de dood van zijn kind.

Niet alleen afzonderlijke passages maar ook de roman als geheel wordt gekenmerkt door zo'n omtrekkende, poëtische beweging. De roman draait immers voortdurend heen om datgene wat cultureel gezien zeer gevoelig ligt heen: de moord op een kind door haar moeder. Pas aan het einde van de roman wordt de moord onthuld. Infanticide is niet gemakkelijk te verbeelden zonder daarbij de moordende moeder als abnormaal neer te zetten. Met behulp van de omtrekkende beweging van de poëzie lijkt deze roman hier echter aan voorbij te gaan en het voor ons als lezers mogelijk te maken om Raya als een redelijk 'normale' moeder te gaan beschouwen. Onze lezing van de roman wordt immers niet beïnvloed door kennis van de gepleegde moord.

Het gebruik van diezelfde poëzie maakt de ontknoping van de roman en de roman als geheel bovendien meerduidig. Om te beginnen omdat een poëtische leeshouding gepaard gaat met de bereidheid om meerduidigheid te accepteren en er zelfs naar op zoek te gaan. Uit de analyse van de betekenissen die de gedichten van Quasimodo (1971/1930) en Achmatova (1981/1914-1916) in de roman kunnen oproepen, bleek al dat meerdere interpretaties van de betekenis van de gedichten in het licht van de roman mogelijk zijn. De roman komt daardoor niet tot verstilling. Daarnaast vestigt het gebruik van poëtische taal expliciet de aandacht op het geconstrueerde, fictieve karakter van de vertelling. De fragmentarische manier waarop de geschiedenis wordt verteld, versterkt dit effect. Kenmerkend voor het boek zijn bijvoorbeeld de vele flashbacks en flashforwards. In relatie tot de inhoud van de vertelde geschiedenis worden we er zo toe aangezet om het 'waarheidsgehalte' van de vertelde geschiedenis te gaan betwijfelen. Het tekortschieten van referentiële taal, de onbetrouwbaarheid van de menselijke herinnering en de kracht van de 
verbeelding vormen namelijk een belangrijke en zelfs centrale thematiek in de roman. ${ }^{146}$ Gideon en Raya voeren voortdurend discussies over de relatie tussen beeld en werkelijkheid. Terwijl Gideon probeert om de werkelijkheid en herinneringen waarheidsgetrouw in zijn foto's te vangen, wijst Raya hem er steeds op dat dit onmogelijk is. Ook veel van de poëzie in de roman kan in relatie tot deze thematiek gelezen worden. Dit geldt bijvoorbeeld voor het titelgedicht van de roman Water $(1989){ }^{147}$ van Rutger Kopland:

\footnotetext{
Als met water zelf, met de gedachte

spelen dat je ooit en eindelijk

zult weten wat het is

Het is regen geweest, een rivier, een zee,

Hier was het, hier heb ik het gezien

En zie ik water en weet niet wat het is.

(Rasker, 2000, p. 5)
}

Het gedicht gaat in relatie tot de rest van de roman verwijzen naar het idee dat wij als mensen niet in staat zijn om de werkelijkheid in woord of beeld te vatten: "En zie ik water en weet niet wat het is" (Rasker, 2000, p. 5). Door dit alles kunnen we ook gaan twijfelen aan het waarheidsgehalte van de geschiedenis over Raya die Gideon ons voorschotelt. Gideon wordt hierover zelf uiteindelijk ook onzeker. Hij komt na het lezen van alle kattebelletjes en Raya's brief aan hem tot de conclusie dat de werkelijkheid zich niet laat vangen: "Nog weet ik niet, van alles wat hiervoor is geschreven, of het wel zo is gegaan. Het doet er niet meer toe. Het is de waarheid, het is een waarheid: het is een verhaal" (Rasker, 2003/2000, p. 219).

De roman weerstaat daarmee in laatste instantie elke eenduidige interpretatie. We kunnen er zelfs aan gaan twijfelen of Raya haar dochter wel echt heeft vermoord. Het doet in dit verband dan ook op zijn minst vreemd aan dat de huisarts die de dood van Lizzy heeft vastgesteld, de mogelijkheid van een onnatuurlijke doodsoorzaak blijkbaar niet heeft onderzocht. Het gevoel dat we met de bekentenis van Raya een sterk staaltje van verbeeldingskunst in handen hebben, kan hierdoor versterkt worden. De roman kan daarbij een poststructuralistisch perspectief op de relatie tussen werkelijkheid en taal mobiliseren. Het poststructuralisme is een term die op verschillende manieren wordt gebruikt en waaronder het werk van uiteenlopende auteurs als bijvoorbeeld Michel Foucault, Jean- Francois Lyotard en Jacques

\footnotetext{
${ }^{146}$ Uit de verantwoording achter in het boek blijkt dat Rasker (2003/2000) zich bij de uitwerking van dit thema onder andere heeft laten inspireren door het boek Vertrouwd en o zo vreemd - over geheugen en bewustzijn (1995) van Wim Kayzer en het artikel Een mens ziet wat hij weet (1992) van Reinjan Mulder. ${ }^{147}$ Dit gedicht wordt ook zo gelezen door Joris Gerrits (2000) in zijn recensie van het boek in de Vlaamse krant De morgen.
} 
Derrida wordt geschaard. De term poststructuralisme wordt hier in navolging van Stuart Hall (2002b) in brede zin gebruikt om te verwijzen naar een manier van denken die wordt gekenmerkt door een afwijzende houding ten opzichte van het idee dat we als mensen direct toegang hebben tot de werkelijkheid en dat we deze vervolgens op objectieve wijze kunnen beschrijven. $\mathrm{Er}$ is bovendien sprake van scepsis tegenover het idee dat taal een transparant middel is waarmee we de werkelijkheid kunnen doorgronden. Taal wordt als een gesloten systeem beschouwd, dat naar zichzelf verwijst en niet naar de werkelijkheid. De manier waarop mensen iets waarnemen, wordt vanuit dit perspectief mede bepaald door de beschikbare tekensystemen en deze zijn sociaal bepaald en veranderlijk. Gefixeerde, universeel ware kennis is volgens deze opvatting niet mogelijk, omdat kennis altijd contextueel is; ingebed in sociale praktijken. De notie van de moderne, zelfkiezende mens wordt daarbij ook verlaten. Doordat het geconstrueerde en talige karakter van de geschiedenis die in de roman van Rasker (2003/2000) wordt verteld voortdurend wordt benadrukt, kan de roman deze opvattingen over werkelijkheid en taal mobiliseren. Dat is zeker zo in combinatie met het tekortschieten van Gideons pogingen om de werkelijkheid te achterhalen. Dé werkelijkheid over Raya, en wellicht zelfs dé werkelijkheid in het algemeen, krijgt hierdoor een ontoegankelijk aura. Taal blijkt een voortdurend tekortschietend medium waarin dé werkelijkheid niet gevat kan worden. Er is om met Gideon te spreken slechts sprake van "een verhaal" (Rasker, 2003/2000, p. 219). De roman kan hierdoor bij de lezers het idee oproepen is dat dé waarheid over Raya's moederschap en zelfs wellicht over moederschap in het algemeen niet achterhaald kan worden, omdat de mens hier simpelweg niet toe in staat is. Normerende en generaliserende opvattingen over het moederschap kunnen vanuit dit perspectief kritisch bekeken gaan worden, te beginnen met de uitlatingen van Gideon en Raya.

\section{Conclusie}

In Met onbekende bestemming (Rasker, 2003/2000) worden moeilijkheden die een vader en een moeder beleven tegen het licht gehouden. Er vindt daarbij een frappante verschuiving plaats van de problematisering van vaderschap naar moederschap. We blijken ons te kunnen gaan identificeren met de moordende moeder uit deze roman, onder andere doordat zij niet wordt gepathologiseerd en door de chronologische volgorde waarin de geschiedenis wordt gepresenteerd. Verwijzingen naar de Griekse tragedie over Medea spelen daarbij een prominente rol. De manier waarop er bij het genre van de poëzie wordt aangesloten, maakt het vervolgens mogelijk om de roman zelfs als een soort van gedicht te beschouwen waarin op een omtrekkende manier over moederschap, vaderschap, infanticide, verlies en dood wordt geschreven. De roman weerstaat daardoor een eenduidige interpretatie. 
Hierdoor kunnen normerende, generaliserende beelden van het moederschap van een kritische afstand worden bekeken.

Opvallend genoeg lijkt Rasker de betekenissen die haar roman kan genereren te willen temperen. In interviews zegt ze bijvoorbeeld dat ze het persoonlijk niet eens is met de uitspraken van haar hoofdpersonage, over bijvoorbeeld de combinatie van kunstenaarschap en moederschap (zie bijvoorbeeld Jacob Moerman, 2000). Wellicht dat Rasker zich geroepen voelt om tegenover haar personage stelling te nemen, omdat ze veel biografische elementen in de roman heeft verwerkt. Net als Raya Salomon heeft Maya Rasker een deel van haar jeugd in Spanje doorgebracht, is zij later naar Groningen verhuisd en heeft zij in Scheveningen gewoond. Bovendien is ook Rasker moeder en schrijfster en heeft zij lange tijd reisverhalen geschreven. Het boek kan vanwege de sterke overeenkomsten tussen de biografie van de schrijfster en het hoofdpersonage gelezen worden als een roman waarin Raya onder andere over haar eigen ervaringen met het moederschap schrijft. Deze lezing wordt in de hand gewerkt door de opvallende overeenkomst tussen de voornaam van het hoofdpersonage en de naam van de auteur. Het feit dat Rasker zich echter publiekelijk distantieert van haar personage, zou kunnen betekenen dat zij, al dan niet bewust, niet in verband wil worden gebracht met een moeder die haar kinderen vermoord. In ieder geval maakt dit het culturele taboe op infanticide zichtbaar: de roman lijkt zelfs de auteur te gortig. 



\section{Conclusies}

In Nederlands fictioneel, literair proza van na 1980 is het moederschap geen idylle. Het moederschap in het niet-fictionele, maatschappelijke domein wordt in diezelfde periode daarentegen op een dwingende manier geïdealiseerd. Deze opmerkelijke tegenstelling vormde de aanleiding voor dit boek. Het doel was ten eerste om te achterhalen of moederschap in literatuur inderdaad een vooral moeizame aangelegenheid is. Ten tweede, ging het om het doorgronden van de betekenissen die romans over problematisch moederschap kunnen oproepen, gelezen tegen de achtergrond van het moderne maatschappelijke moederschapsideaal. Daarbij zijn niet alleen de relatie van literatuur tot de maatschappelijke verheerlijking van het moederschap in ogenschouw genomen - de centrale kwestie in dit boek - maar ook de verhouding tot beschikbare, niet-fictionele probleemvertogen over moederschap.

Aan de hand van opvoedkundige adviesboeken voor (aanstaande) ouders, opvoedkundige tijdschriften voor (aanstaande) ouders, vrouwentijdschriften en reclame voor babyproducten heb ik laten zien dat de hedonistische inkleding van het moederschap in de jaren zeventig terrein wint. Vanaf het begin van de jaren tachtig is dit perspectief een dominante voorstelling van het moederschap geworden. Dit vertoog bleek uit de aanname te bestaan dat de ideale moeder blank is, bij voorkeur niet of weinig werkt en tot de middenklasse behoort. Ze maakt voorts deel uit van een heteroseksueel kerngezin met jonge, gezonde kinderen. Moeders die aan die criteria voldoen, worden binnen dit vertoog op dwingende wijze verondersteld de opvoeding plezierig te vinden. Daarbij werd duidelijk dat de belangen en behoeftes van moeder en kind vaak aan elkaar gelijk worden gesteld. Het adagium is dat wat leuk is voor de moeder, leuk is voor het kind en omgekeerd. Het krijgen van kinderen wordt daarbij als het resultaat van een bewust gemaakte keuze beschouwd en ook de praktijk van het moederschap geldt als maakbaar.

De dominantie van een hedonistische visie in de niet-fictionele bronnen impliceert niet dat de representatie van moederschap volledig uniform is. Problemen die zich bij het krijgen, hebben en opvoeden van kinderen voor kunnen doen, worden ook zichtbaar gemaakt. Beschikbare probleemvertogen lijken echter vaak begrensd en gereguleerd te worden door de wijze waarop moederschap wordt geïdealiseerd. Zo worden problemen veelal als relatief gemakkelijk oplosbaar voorgesteld. Daarnaast wordt vaak juist het moederschap van vrouwen die bijvoorbeeld niet-blank zijn en die niet tot de middenklasse en een heteroseksueel kerngezin behoren in een negatief licht gesteld. Het rooskleurige middenklasse, blanke, heteroseksuele plaatje van het moederschap blijft daardoor uiteindelijk toch meestal intact en kan 
zelfs ge(re)produceerd worden door circulerende, niet-fictionele beelden van moeilijkheden rondom moederschap. De hedonistische visie op het krijgen van kinderen bleek zich overigens niet tot het moederschap te beperken, maar zich zeker de laatste jaren soms ook voorzichtig naar vaderschap uit te breiden.

De belangrijkste bevinding uit de kwantitatieve analyse van de productie van literatuur is dat moederschap er inderdaad als allesbehalve plezierig wordt gerepresenteerd. Er is mogelijk een verteltechnische noodzaak voor deze focus op problemen: alleen problemen of tekorten kunnen een narratieve tekst op gang brengen. Daarnaast werd onder andere duidelijk dat vrouwelijke auteurs het grootste deel van de literaire romans over moederschap schrijven. De kwantitatieve analyse bood de mogelijkheid om een eerste indruk te krijgen van het soort proza over moederschap. Zo'n eerste indruk zouden we op basis van kwalitatieve interpretaties van een beperkt aantal case studies nooit hebben kunnen verkrijgen. De kwantitatieve analyse kende niettemin beperkingen. Bepaalde genres en thema's worden in de literatuurkritiek juist als reacties op een idyllisch vertoog over moederschap beschouwd, zoals de literaire thriller en het onderwerp infanticide. Dit genre en thema bleven opvallend genoeg buiten beeld bij de analyse van de productie van romans. Bovendien bleek het onmogelijk om het culturele werkpotentieel van romans op basis van de summiere beschrijvingen in de NCC in kaart te brengen.

Via diepgaande interpretaties van een beperkt aantal romans bleek het wel mogelijk om hier meer inzicht in te krijgen. Uit deze interpretaties, waarbij de NURindelingen werden losgelaten voor een meer gedetailleerde onderzoek naar intertekstuele verwijzingen naar genres, bleek al hoe zeer deze romans van elkaar verschillen wanneer het om de wijze gaat waarop moederschap wordt verbeeld. In deze conclusie wil ik stil staan bij enkele opvallende overeenkomsten, zonder daarmee de diversiteit van de romans te niet te willen doen. Wanneer we de boeken na elkaar lezen, dan vallen er een aantal gemeenschappelijkheden op. Het moderne ideaal van genieten rondom moederschap wordt in alle romans op een kritische manier gethematiseerd. Daarbij wordt de dwingende werking die van dit ideaal kan uitgaan vaak zichtbaar. De romans vergroten zo ons inzicht in de aanwezigheid en de werking van het hedonistische perspectief. Het moderne moederschapsideaal wordt ter discussie gesteld door zichtbaar te maken dat de belangen van moeder en kind niet dezelfde zijn. In alle onderzochte romans blijkt het juist een probleem of zelfs ronduit gevaarlijk, wanneer een (aanstaande) moeder zich richt op het vervullen van haar eigen behoeftes. In drie van de vier van de romans delven kinderen daardoor het onderspit. In Nieuwe buren (Noort, 2006) wordt er een ongeboren kind door vermoord en verliest een peuter zijn ouders. In Een hart van steen (Dorrestein, 1998) en Met onbekende bestemming (Rasker, 2000) betekent het ook de dood van kinderen. De romans trekken de hedonistische benadering van de belangen van moeder en kind in twijfel. Ze kunnen daarbij andere normen over moederschap (re)produceren. De reis naar het kind (Van der Meer, 1989) kan bijvoorbeeld 
worden gelezen als een pleidooi voor een vorm van moederschap, waarbij een moeder wordt geacht om haar eigen belangen ondergeschikt aan die van het kind te maken.

Het belangrijkste resultaat van dit onderzoek is dat de introductie van premoderne of antimoderne perspectieven een belangrijke rol blijkt te spelen in de ondermijnende werking die de romans hebben. De boeken bevatten zonder uitzondering intertekstuele verwijzingen naar genres, die de deur naar premoderne of antimoderne verbeeldingen van het moederschap open zetten. Daarvoor hoeven die genres zelf overigens niet per definitie premodern te zijn. Voorbeelden van de ingezette genres zijn het sprookje in de roman van Van der Meer (1989), de a-heroïsche thriller in de roman van Noort (2006), de (homely) gothic novel in de boeken van Noort (2006), Dorrestein (1998) en Rasker (2000), de Griekse tragedie in het werk van Dorrestein (1998) en Rasker (2000) en de poëzie in Met onbekende bestemming (2000) van Rasker. De romans blijken het moederschap daarmee op een geheel andere wijze te verbeelden, dan de onderzochte maatschappelijke bronnen. Daarbij kunnen de romans soms zeer verrassende beelden van moederschap genereren. Zo wordt de relatie tussen een kinderloze vrouw en een oude man in De reis naar het kind (Van der Meer, 1998) via het genre van het sprookje op metaforische wijze omgesmeed tot een moeder-kindrelatie. De verwijzingen naar de genoemde genres ontsluiten bovendien vaak betekenissen, die het mogelijk maken om de romans als een kritiek op de contemporaine, hedonistische verbeelding van het moederschap te lezen. Vooral het maakbaarheidsgeloof en het moderne idee van de zelfkiezende, autonome mens moeten het daarbij ontgelden. Overigens werd ook duidelijk dat de introductie van dezelfde genres in verschillende romans niet per definitie hetzelfde werkpotentieel oplevert. Zo zullen de verwijzingen naar de tragedie in Met onbekende bestemming (Rasker, 2000) niet zo snel een aan de tragedie ontleend perspectief op noodlot en keuze oproepen als in Een hart van steen (Dorrestein, 1998). Ook vervult het gotieke een andere rol in Met onbekende bestemming (Rasker, 2000) dan in Nieuwe buren (Noort, 2006) en Een hart van steen (Dorrestein, 1998). In de eerste roman dient het onder andere als een middel om uitdrukking te geven aan de onmetelijke dieptes van het verdriet om het verlies van een kind, wat bij de andere twee romans niet het geval is.

Ondanks de ondermijnende betekenissen die de romans kunnen genereren, blijkt vooral de verhouding van de boeken van Noort (2006), Dorrestein (1998) en Rasker (2000) ten opzichte van het vertoog van genieten ambigue. $\mathrm{Er}$ is in deze romans geen sprake van een simpele bevestiging of ondermijning van het dictaat van genieten rondom moederschap. Die dubbelzinnigheid wordt onder andere veroorzaakt doordat verwijzingen naar bepaalde genres ook tegengestelde betekenisseneffecten kunnen sorteren. De gothic novel waarnaar in deze drie romans wordt verwezen is bijvoorbeeld een genre dat gekenmerkt wordt door haar ambigue verhouding tot de moderniteit. Agnes Andeweg $(2010,2011)$ heeft in haar 
proefschrift al gewezen op de dubbelzinnige uitwerking die het gotieke in de Nederlandse romans kan hebben. Mijn onderzoek bevestigt deze observatie. Ook in Nieuwe buren (Noort, 2006) en Een hart van steen (Dorrestein, 1998) bleken gotieke elementen tegengestelde betekenissen over moederschap te kunnen oproepen. Een hart van steen (Dorrestein, 1998) is bovendien contradictoir door intertekstuele verwijzingen naar een niet-fictioneel probleemvertoog, dat van zichzelf ambigue is wanneer het om geïdealiseerde opvattingen over moederschap gaat. Dit is het medisch-psychologische vertoog over postpartum depressie. De dubbelzinnigheid van dit vertoog wordt in de roman zelf expliciet ge(re)produceerd. In Met onbekende bestemming (Rasker, 2000) is er ook sprake van meerduidigheid. Deze wordt vooral opgeroepen door de wijze waarop er uit het genre van de poëzie wordt geput.

Dit alles roept de vraag op of het gebruik van bepaalde genres wellicht kenmerkend is voor hedendaagse literaire fictie waarin moeilijke aspecten en ervaringen van het moederschap aan bod komen. Op basis van de vier romans kunnen hier geen algemene uitspraken over worden gedaan. Ook de kwantitatieve analyse biedt hiervoor geen aanknopingspunten. Er zijn wel aanwijzingen dat de waargenomen tendensen zich niet tot deze vier romans beperkt. In de inleiding werd al De speeltuin van Teiresias (1994) van Hannes Meinkema genoemd, waarin verwijzingen naar de tragedie ook een belangrijke rol spelen. Vervolgstudies naar het oeuvre van deze en andere auteurs over moederschap zouden licht kunnen werpen op de vraag of bepaalde genres vaker worden ingezet om het idyllische beeld van moederschap ter discussie te stellen en welke (mogelijke) betekenissen het gebruik van deze genres oproept.

Dit proefschrift bevat ook andere aanzetten voor vervolgonderzoek. Met het bestuderen van het boek van Noort (2006) is het interpreterend onderzoek naar het Nederlandse thrillergenre hopelijk in de verf gezet. Het New Historicism blijkt een goed uitgangspunt voor onderzoek naar de betekenissen van Nederlandse thrillers te bieden. Bij de interpretatie van deze roman waren er sterke aanwijzingen dat aspecten van de thriller het kritische vermogen van Nieuwe buren (Noort, 2006) tegenwerken. Daarnaast kan het onderzoek naar de recente literaire verbeelding van adoptie, ongewilde kinderloosheid en kindermoord in Nederland op basis van dit proefschrift verder worden uitgebreid. Daarbij zouden verbeeldingen van vaderschap en romans over moederschap en vaderschap van mannelijke auteurs ook kunnen worden onderzocht. Zo kunnen romans over vaders die hun kinderen vermoorden naast de werken over moeders die dit doen worden gelegd. Tirza (2006) van Arnon Grunberg en Datumloze Dagen (2007) van Jeroen Brouwers zouden bijvoorbeeld interessante studieobjecten zijn, al gaat het hierbij wel om het doden van volwassen kinderen. Tot slot kan het interessant zijn om verder te onderzoeken of moederschap en vaderschap anders worden verbeeld in boeken uit verschillende NUR-genres. Het lijkt er op dat er in 'streek- en familieromans' bijvoorbeeld andere dingen gebeuren dan in de 'literaire roman, novelle'. Afgaand op de NCC- 
beschrijvingen en -recensies, wordt er in 'streek- en familieromans' opvallend vaak gekozen voor een christelijk perspectief op het moederschap en het gezinsleven en is er doorgaans ook sprake van een gelukkig einde. Wat betekenen deze kenmerken voor de verhouding van dit genre tot het moderne moederschapsideaal?

Tot slot kan dit proefschrift worden opgevat als een pleidooi voor de meerwaarde van de introductie van literatuursociologische, kwantitatieve methodes in onderzoek in de lijn van het New Historicism, gericht op het blootleggen van het culturele werkpotentieel van romans. Ik heb willen laten zien dat de combinatie van literatuursociologisch onderzoeksmethodes en de interpretatie van romans mogelijk en vruchtbaar is. Het kwantitatieve instrumentarium stelde ons in staat om tendensen in kaart te brengen en de aanname dat moederschap in literatuur allesbehalve rooskleurig is te toetsen. Het hielp ook bij het situeren van individuele werken in het literaire landschap. De intertekstuele, structuralistische analsye van de individuele romans maakte het mogelijk om de werking van de vier boeken en de betekenissen die ze produceren preciezer te duiden en verbanden tussen literatuur en maatschappij in detail te doordenken. Met dit proefschrift heb ik aandacht willen vragen voor de onvermijdelijke rol die interpretatie zowel in kwantitatieve literatuursociologische analyses en kwalitatieve interpretaties van individuele romans speelt. Die analyses en interpretaties maakten bovendien duidelijk dat het literaire domein, net als maatschappelijke, niet monolithisch noch eenduidig is als het om de verbeelding van moederschap gaat. Via structuralistische, intertekstuele interpretatie van de romans bleek het ten slotte onder andere mogelijk om de romans in bepaalde opzichten aan het werk te zetten als een breekijzer voor het ontmantelen van een modern, dwingend, idealiserend vertoog over moederschap. 



\section{Bibliografie}

Aandacht volgens traumatoloog impuls voor ouders; 'Media moeten zwijgen over kindermoorden' (1997, 28 januari). De Volkskrant, Binnenland, p. 6. Geraadpleegd op 10 september, 2007, via LexisNexis.

Achmatova, A. (1983/1914-1916). Epische motieven III. De avond valt, en waar zo kort geleden. In A. Achmatova, In andermans handen: gedichten (H. Boland, vert.) (p. 37). Amsterdam: Meulenhoff.

Ahmed, S (2004). The cultural politics of emotion. New York: Routledge.

Alphen, E. van, Duyvendak, L., Meijer, M., \& Peperkamp, B. (1996). Op poëtische wijze. Handleiding voor het lezen van poëzie. Bussum/Heerlen: Coutinho/Open Universiteit.

Ambo/Anthos uitgevers en Buro TEXT (geen datum). Vertalingen. Geraadpleegd op 29 november, 2010, via www. saskianoort.nl/\#/Boeken/Vertalingen/

American Society for Reproductive Medicine. (2001). Patient's fact sheet. Intracytoplasmic sperm injection (ICSI). Geraadpleegd op 26 februari, 2007, via www.asrm.org

Amsterdam RAI (2010). Exposeren. Het grootste consumentenevenement over zwangerschap en baby's. Geraadpleegd op 5 oktober, 2010, via www.negenmaandenbeurs.nl/nl/nl/Exhibit/Pages/default.aspx

Andel, R. van, \& Pol, P. van der (2010). Inleiding. In B. Spock \& S. Parker, Baby- en kinderverzorging en opvoeding (pp. 13-14) (W. van Andel, vert.). Utrecht: Kosmos Uitgevers. (Oorspronkelijke uitgave 1946)

Andeweg, A. (2000, 25 november). Een kind als een meteoriet: een overtuigend debuut. Vrij Nederland. Geraadpleegd op 27 september, 2008, via Literom [Cd-rom].

Andeweg, A. (2005). Bij hoog en bij laag. Het gotieke in Thomas Rosenbooms Vriend van verdienste. Nederlandse Letterkunde, 10(1), 18-33.

Andeweg, A. (2010). Griezelig gewoon. Gotieke verschijningen in Nederlandse romans, 1980-1995. Maastricht: Datawyse/Universitaire Pers Maastricht.

Andeweg, A (2011). Griezelig gewoon. Gotieke verschijningen in Nederlandse romans, 1980-1995. Amsterdam: Amsterdam University Press.

Asociación Amigos de Miguel Hernández (2005). Biografia. Geraadpleegd op 25 februari, 2009, via www.amigosmiguelHernández.org/biografia.htm

Atzema, O., \& Hooimeijer, P. (2006). Wonen in de Vinex. In C.H. Mulder \& F.M. Pinkster (red.), Onderscheid in wonen: het sociale van binnen en buiten (pp. 79-98). Amsterdam: Amsterdam University Press.

Autrique, A., Baggerman, J.E., Boer, F., Cuijpers, P., \& Knorth, E.J. et al. (2010). Gezin. Reeks Kinderen en adolescenten: problemen en risicosituaties. Houten: Bohn Stafleu van Loghum.

Bakker, J.H. (1993, 1 oktober). Nachtgoed: verhalen. Haagsche Courant. Geraadpleegd op 8 juni, 2008, via Literom [CD-ROM].

Bakker, N., Noordman, J., \& Rietveld-Van Wingerden, M. (2010). Vijf eeuwen opvoeden in Nederland. Idee en praktijk 1500-2000 ( $2^{\mathrm{e}}$ herz. dr.). Assen: Uitgeverij Van Gorcum.

Bal, M. (1980). De theorie van vertellen en verhalen. Inleiding in de narratologie. Muiderberg: Coutinho.

Bal, M. (2007). Narratology. Introduction to the theory of narrative (3e druk). Toronto, Buffalo/London: University of Toronto Press.

Barclay, L., \& Kent, D. (1998). Recent migration and the misery of motherhood: a discussion of pertinent issues (Elektronische versie). Midwifery, 14(1), 4-9.

Barcley, L., \& Loyd, B. (1996). The misery of motherhood: alternative approaches to maternal distress (Elektronische versie). Midwifery, 12(3), 136-139.

Barnett, B. (2005). Perfect mother or artist of obscenity? Narrative and myth in a qualitative analysis of press coverage of the Andrea Yates murders. Journal of Communication Inquiry, 29(1), 9-29. 
Barnett, B. (2006). Medea in the media: narrative and myth in newspaper coverage of women who kill their children. Journalism, 7(4), 411-432.

Baumgarten, R. von (1998). Heiliges Wort und Heilige Schrift bei den Griechen. Hieroi Logoi und erwandte Erscheinungen. Göttingen: Hubert \& Co.

Beatrix, Korte-van Hemel, V.N.M., \& Korthals Altes, F. (1989, 11 juli). Besluit opneming buitenlandse kinderen ter adoptie. Geraadpleegd op 31 November, 2010, via www.stab.nl/wettennr06/0739002 _Besluit_opneming_buitenlandse_kinder en_ter_adoptie.htm

Beck, U., \& Beck-Gernsheim, E. (1995). The normal chaos of love (M. Ritter \& J. Wiebel, vert.). Cambridge: Polity Press in association with Blackwell Publishers Ltd. (Orginele werk gepubliceerd in 1990)

Beck-Gernsheim, E. (1996). Life as a planning project. In S. Lash \& B.W. Szerszynski, B. (Eds.), Risk, environment and modernity: towards a new ecology (pp. 139-153). London: Sage.

Beer, P. de (2008). De middenklasse onder druk? (Elektronische versie). In Wetenschappelijke Raad voor het Regeringsbeleid/Strategieberaad Rijksbreed (red.), De kwetsbare middenklasse (pp. 15-42). Den Haag: Wetenschappelijke Raad voor het Regeringsbeleid/Strategieberaad Rijksbreed.

Bekker, M. (2007). Vrouwen, arbeid en gezondheid (Elektronische versie). In Shaufeli, W. \& Bakker, A. (red.), De psychologie van arbeid en gezondheid deel V (pp. 409-421). Houten: Bohn Stafleu van Loghum.

Bel, E.J. van, Sander, E., \& Verduin, R. (2007). Event driven marketing. Op het juiste moment, met het juiste aanbod, bij de juiste klant (2e druk). Amsterdam: Kluwer.

Belle, H. van (1997). Zichzelf kan hij niet zien. Een lectuur van de roman Rituelen van Cees Nooteboom. Leuven: Universitaire Pers Leuven.

Benali, A. (2009). De stem van mijn moeder. Amsterdam: De Arbeiderspers

Bergen, I. van den (2006, 2 juni). Goede misdaadromans bieden entertainment plus. De Volkskrant, Cicero, pp. 26-27. Geraadpleegd op 15 november, 2007, via LexisNexis.

Beurskens, H. (2007). Kid. Amsterdam: Meulenhoff.

Bigner, J.J. (1972). Parent education in popular literature 1950-1970 (Elektronische versie). The Family Coordinator, 21(3), 313-319.

Bijl, R., Boelhouwer, J., Pommer, E., \& Schijns, P. (red.). (2009). De sociale staat van Nederland 2009 (Elektronische versie). Den Haag: Sociaal Cultureel Planbureau.

Bijl, R.V., Zorlu, A., Rijn, A.S. van, Jennissen, R.P.W. \& Blom, M. (2005). Integratiekaart Nederland. De maatschappelijke integratie van migranten in de tijd gevolgd: trend- en cohortanalyses (Elektronische versie). Den Haag/Heerlen: Centraal Bureau voor de Statistiek/Wetenschappelijk Onderzoek- en Documentatiecentrum van het Ministerie van Justitie.

Bockma, H. (1997, 13 februari). Mediastilte? De Volkskrant. Geraadpleegd op 10 september, 2007, via LexisNexis.

Boedekker, D. (1997). Becoming Medea: assimilations in Euripides. In James J. Clauss \& Sarah Iles Johnston (Eds.), Medea. Essays on Medea in myth, literature, philosophy and art (pp. 127-148). Princeton, New Jersey: Princeton University Press.

Boomkens, R. (2003). Vinexfantasieën. In P.H. Stulemeijer (red.), Bespiegelingen over honderd seizoenen, van land tot stand. Breda: Uitgeverij De Geus.

Boost, E. (2006). Opvoeden...geniet ervan! Van baby tot en met puber. De meest gestelde vragen aan de Opvoeddesk. Utrecht: Kosmos Uitgevers.

Borg, M. te (1995). Kerk, macht en civilisatie. Enkele mechanismen. Amsterdams Sociologisch Tijdschrift, 21(4), 102-115.

Bos, W. (2009). Omvang en risicogroepen (Elektronische versie). In Centraal Bureau voor de Statistiek (red.), Lage inkomens, kans op armoede en uitsluiting 2009 (pp. 14-29). Den Haag/Heerlen: Centraal Bureau voor de Statistiek.

Bossink, R. (1989). Dromen van kinderen. Utrecht: Het Spectrum.

Botman, A. (1997, 1 februari). Bloed in een film is enger. Trouw, p. 1. Geraadpleegd op 10 september, 2007, via LexisNexis. 
Botman, A. (2006, 3 juni). Veel chardonnay, weinig inhoud. Trouw, Boeken, p. 13. Geraadpleegd op 15 november, 2007, via LexisNexis.

Botting, F. (1996). Gothic. London: Routledge.

Bourdieu, P. (1994). Regels van de kunst. Amsterdam: Van Gennep.

Boven, E. van (1992). Een hoofdstuk apart. Vrouwenromans in de literaire kritiek 1989-1930. Amsterdam: Sara/Van Gennep.

Boven, E. van (2006). Women authors and women's writing in the declining years of modernism. In G.J. Dorleijn (red.), New trends in modern Dutch literature (pp. 77-88). Leuven: Peeters.

Brannigan, John (1998). New historicism and cultural materialism. London: Macmillian Press LTD.

Brants, C. H., \& Koenraadt, F. (1998). Criminaliteit en media-hype. Een terugblik op de publieke beeldvorming rond kindermoord. Delikt en delikwent, 28(6), 542-564.

Breedveld, K., \& Broek, A. van de (2003). De meerkeuzemaatschappij. Facetten van de temporele organisatie van verplichtingen en voorzieningen (Elektronische versie). Den Haag: Sociaal Cultureel Planbureau.

Breeuwsma, G. (1999). Het neefje van de onderzoeker. Ambivalenties in het denken van de ontwikkelingspsycholoog (Elektronische versie). De Psycholoog, 34, 190-196.

Brinkgreve, C., \& Velde, E. te (2006). Wie wil er nog moeder worden? Amsterdam/ Antwerpen: Uitgeverij Augustus.

Brooks, P. (1992). Reading for the plot: design and intention in narrative. Cambridge: Harvard University Press

Brouwers, J. (1981). Bezonken rood. Amsterdam: De Arbeiderspers.

Brouwers, J. (2007). Datumloze dagen. Amsterdam: Atlas.

Brummelen, P. van (1994, 16 juli). Op de klapstoel - Ron Brandsteder intrigeert mij. Het Parool. Geraadpleegd op 15 november, 2009, via LexisNexis.

Bruyn, J.K. de (2001). Maatschappelijke ontwikkelingen rond KID. Tijdschrift Klinische Chemie, 26(5), 309313.

Büch, B. (1985). De kleine blonde dood. Amsterdam: De Arbeiderspers.

Buikema, R. \& Wesseling, E. (2000). De representatie van het moederschap in verlichte opvoedkunde en duistere gotiek. Een confrontatie tussen Benjamin Spock en Renate Dorrestein. Spiegel der Letteren, 42(2), 156-174.

Buikema, R., \& Wesseling, E. (2006). Het heilige huis. De gotieke vertelling in de Nederlandse literatuur. Amsterdam: Amsterdam University Press.

Burgerlijk wetboek, boek 1, artikel 228, eerste lid onder c (2010). In Wetteksten. Burgerlijk wetboek/wetboek van burgerlijke rechtsvordering. Inclusief overgangsrecht en transponeringstabellen. Editie 2010-2011 (p. 47). Deventer: Kluwer.

Bushnell, R. (2005). A companion to tragedy. Oxford: Blackwell Publishing.

Bushnell, R. (2008). Tragedy. A short introduction. Oxford: Blackwell Publishing.

Butler, J. (1990). Gender trouble: feminism and the subversion of identity. New York: Routledge.

Buuren, J.M.A. van (2005). De taal van het hart. Retorica en receptie van de Hedendaagse streekroman. Groningen: Rijksuniversiteit Groningen. Geraadpleegd op 18 november, 2009, via http://dissertations.ub.rug.nl.

Buys, A. (2008). Een bijzondere grafische voorstelling: de boxplot. In A. Buys, Statistiek om mee te werken (8ste dr.) (pp.79-81). Houten. Noordhoff Uitgevers B.V.

Cann, J. van, \& Jespers, H.F. (2008). Echte literatuur? In J. van Cann \& H.F. Jespers (red.), Thriller versus roman. Antwerpen/Apeldoorn: Garant.

Carvalho, H. (2009, 23 mei). 'Met schrijven ga ik mijn angsten te lijf'; Saskia Noort over haar thrillers vol bange mensen en moeders met kinderen. NRC Handelsblad, Kunst, p. 6.

Castelein, M. (2009). De mooiste tijd van je leven. De schaduwzijde van het moederschap. Amsterdam: Uitgeverij Augustus.

CEBUCO (2009). Dagbladen. Oplage- en bereikcijfers. Geraadpleegd op 29 april, 2010, via www.cebuco. nl/dagbladen/oplage_en_bereikcijfers 
Centraal Bureau voor de Statistiek (2009a). Relatie en gezin aan het begin van de $21^{\text {ste }}$ eeuw (Elektronische versie). Den Haag: Centraal Bureau voor de Statistiek.

Centraal Bureau voor de Statistiek (2009b). Religie aan het begin van de $21^{\text {ste }}$ eeuw (Elektronische versie). Den Haag: Centraal Bureau voor de Statistiek.

Chambers, D. (2001). Representing the family. London: Sage Publications.

Chamuleau, R. (2004). Vonne van der Meer. In Christelijk Lektuur Centrum (red.), Uitgelezen 20: reacties op boeken (pp. 91-104). Leidschendam: NBD Biblion Publishers.

Claes, C. (1996). Het bruidsboeket. Hoorn: Westfriesland.

Cloïn, M., Broek, A. van den, De Haan, J., \& Klis, M. van der (2009). Het dagelijkse leven: goed gevuld of te vol (Elektronische versie). In R. Bijl, J. Boelhouwer, E. Pommer \& P. Schijns (red.), De sociale staat van Nederland 2009 (pp. 99-124). Den Haag: Sociaal Cultureel Planbureau.

Cloïn, M., \& Souren, M. (2009). Onbetaalde arbeid en de combinatie van werk en zorg (Elektronische versie). In A. Merens \& B. Hermans (red.), Emancipatiemonitor 2008 (pp. 115-158). Den Haag: Sociaal en Cultureel Planbureau.

Cohen, M.J. (2000, 10 november). Richtlijnen opneming buitenlandse kinderen ter adoptie. Geraadpleegd op 31 november, 2010, via www.stab.nl/wettennr06/0739005_Richtlijnen_opneming_buitenlandse_ kinderen_ter_adoptie_2000.htm

Collectieve Propaganda van het Nederlandse Boek (1998). CPNB top 100 1998. Geraadpleegd op 29 november, 2010, via http://alias.cpnb.nl/top100/lijsten/CPNB_Top-100_1998.pdf

Collectieve Propaganda van het Nederlandse Boek (geen datum). Saskia Noort, Nieuwe buren, De bestseller 60. Geraadpleegd op 29 november, 2010, via http://alias.cpnb.nl/bs/popupZoekresultaat.asp?isbn $=9789041413499$

Connell, R. W. (1995). Masculinities. Cambridge: Polity Press.

Corti, L. (1998). The Myth of Medea and the murder of children (Vol. 89). Westport, Connecticut, London: Greenwood Press.

Cuisinier, M., \& Smit-Wiersinga, J. (1998). Hoezo roze wolk? Over depressief-zijn na de bevalling. Houten: Uitgeverij Van Holkema \& Warendorf.

Culler, J. (1975). Structuralist poetics: structuralism, linguistics, and the study of literature. London [etc]: Routledge \& Kegan Paul.

Culler, J. (1981). The pursuit of signs. Semiotics, literature, deconstruction. London [etc]: Routledge \& Kegan Paul.

Cuthbert, D., Murphy, K. \& Quartly, M. (2009). Adoption and feminism. Australian Feminist Studies, 24 (62), 395-419.

Dagevos, J. (2005). Minderheden, armoede en sociaal-culturele integratie (Elektronische versie). Migrantenstudies, 21(3), 135-154.

Dagevos, J., Hoff, S., \& Soede, A. (2006). Minderheden in de middenklasse (Elektronische versie). In Investeren in vermogen. Sociaal en cultureel rapport 2006 (p. 119-152). Den Haag: Sociaal en Cultureel Planbureau.

Dalen, R. van (2005). De kinderbijslag in de politiek (Elektronische versie). In Berghman, J. (red.), Kind en sociale zekerheid. Verwend of verdrukt? Amstelveen: SVB/Corporate Communication.

Dehue, T. (2006). De plicht het lot in eigen handen te nemen. Over de biomedische verbeelding van depressie (Elektronische versie). In B. Broekhans, A. Dijkstra, P. Groenewegen \& C. Koolstra (red.), Verbeelding van kennis - Jaarboek KennisSamenleving 2006 (pp. 152-172). Amsterdam: Uitgeverij Aksant.

Dekker, T., Van der Kooi, J., \& Meder, T. (1997). Van Aladdin tot Zwaan kleef aan. Lexion van sprookjes: ontstaan, ontwikkeling, variaties. Nijmegen: SUN.

De Opvoeddesk (2010a). Opvoeden en genieten. Geraadpleegd op 25 oktober, 2010, via www.opvoeddesk.nl

De Opvoeddesk (2010b). Bekend van. Geraadpleegd op 25 oktober, 2010, via www.opvoeddesk.nl

De Persgroep Banen (2011). Het Parool. Geraadpleegd op 29 mei, 2011, via www.persgroepbanen.nl/ merken/het-parool.html 
Dijk, H. van (2001). In het liefdeleven ligt gansch het leven: het beeld van de vrouw in het Nederlands realistisch proza, 1885-1930. Assen: Van Gorcum.

Dijk, Y. van (2010, 5 maart). Bezield door het prille leven. De baby is in de literatuur te vaak een clichématige wolk moraal. NRC Handelsblad, Boeken, p. 2.

Dijken, S. van \& Tavecchio, L.W.C. (1998). De pedagogische betekenis van vaders. Kind en Adolescent, 19(1), 68-77.

Dirksen, J. (1997). Sprookjesfiguren uit de jaren negentig: losse gedachten bij zeer uiteenlopende boeken. Tsjip/Letteren, 7(1), 10-12.

Doest, C. (2001). Anthon \& Anissa. Amsterdam: Vassallucci.

Dorleijn, G.J. (2009). De plaats van tekstanalyse in een institutioneel-poëticale benadering. Nederlandse Letterkunde, 14(1), 1-19.

Dorrestein, R. (1992). Ontaarde moeders. Amsterdam: Uitgeverij Contact.

Dorrestein, R. (1998). Een hart van steen. Amsterdam: Uitgeverij Contact.

Dorrestein, R. (2003/1998). Een hart van steen (16 ${ }^{\mathrm{e}} \mathrm{dr}$.). Amsterdam: Pandora Pockets, Uitgeverij Contact.

Dorrestein, R. (2003). Het duister dat ons scheidt. Amsterdam: Uitgeverij Contact.

Dorrestein, R. (2006). Mijn zoon heeft een seksleven en ik lees mijn moeder roodkapje voor. Amsterdam: Contact.

Dorrestein, R. (2008). Zolang er leven is. Amsterdam: Uitgeverij Contact.

Dorrestein, R. (2009). Is er hoop. Amsterdam: Uitgeverij Contact.

Dorrestein, R. (2010/2000). Het geheim van de schrijver. Amsterdam: Uitgeverij Contact.

Douglas, S. J., \& Michaels, M.W. (2005). The mommy myth. The idealization of motherhood and how it has undermined all women. New York, London, Toronto \& Sydney: Free Press.

Drayer, E. (2010). Verwende prinsesjes. Portret van de Nederlandse vrouw. Amsterdam: de Bezige Bij.

Drie kinderen in huis omgebracht (1997, 16 januari). NRC Handelsblad. Geraadpleegd op 10 september, 2007, via LexisNexis.

Driessen, H. (2004). Eva's last. Medische Antropologie, 16(1), 147-155.

Duijvelaar, L., \& Geluk, A. (1988). Het tweelingenboek, II, kraamtijd, verzorging en opvoeding. Amsterdam: Meulenhof Informatie.

Duyvendak, J.W. (1999). De planning van ontplooiing. Wetenschap, politiek en de maakbare samenleving. Den Haag: Sdu Uitgevers.

Duyvendak, J.W. (2004). Een eensgezinde, vooruitstrevende natie. Over de mythe van dé individualisering en de toekomst van de sociologie. Amsterdam: Vossius pers.

Duyvendak, J. W., \& Haan, I. de (1997). Liberale wortels en hedendaagse kritiek van de maakbare samenleving. Amsterdam: Amsterdam University Press.

Duyvendak, J.W., \& Hurenkamp, M. (red.). (2004). Kiezen voor de kudde. Lichte gemeenschappen en de nieuwe meerderheid. Amsterdam: TSS/Van Gennep.

Duyvendak, J.W., \& Stavenuiter, M.M.J. (red.). (2004). Working fathers, caring men: reconciliation of working life and family life. The Hague: Ministry of Social Affairs/Verwey Jonker Instituut.

Dykstra, P.A., \& Hagestad, G.O. (2007). Childlessness and parenthood in two centuries: different roads, different maps? Journal of Family Issues, 28(11), 1518-1532.

Euripides (2008/431v.Chr.). Medea. (D. Arnson Svarlien \& R. Mitchell-Boyask, vert.). Indianapolis: Hacket Publishing Company.

Evers, J.L.H., \& Heineman, M.J. (red.). (1999). Fertiliteitstoornissen. Maarssen: Elsevier/Bunge.

Fainlight, R., \& Littman, R.J. (2009). Introduction. In Sophocles (2009). The Theban plays: Oedipus the king, Oedipus at Colonus, Antigone (pp.xi-Ix) (R. Fainlight \& R.J. Littman, vert.). Baltimore, MD: Johns Hopkins University Press.

Felling, A.J.A. (2004). Het proces van individualisering in Nederland: een kwarteeuw sociaal-culturele ontwikkeling (Elektronische versie). Nijmegen: Katholieke Universiteit Nijmegen.

Fontana, D. (1991). Kinderen grootbrengen: een praktische hulp voor alle ouders van nu (K. Noë-Kuiter, vert.). Houten: Van Holkema \& Warenhof. (Oorspronkelijke uitgave 1990). 
FORUM (2010). Allochtonen op de arbeidsmarkt. $5^{e}$ monitor: effecten van de economische crisis. Geraadpleegd op 18 oktober, 2010, via www.forum.nl/Portals/0/pdf/FORUM-5e-monitor-Allochtonen-opde-Arbeidsmarkt.pdf

Foucault, M. (2002/1972). The archaeology of knowledge (A.M. Sheridan Smith, vert.). London: Routledge. (Originele werk gepubliceerd in 1969).

Garssen, J. (2006). Minder allochtone tienermoeders. CBS Webmagazine. Geraadpleegd op 20 januari, 2010, via www.cbs.nl/nINL/menu/themas/bevolking/publicaties/artikelen/archief/206/20062022 wm.htm

Garssen, J., Beer, J. de, Cuyvers, P., \& Jong, A. de (2001). Samenleven: nieuwe feiten over relaties en gezinnen (Elektronische versie). Voorburg/Heerlen: Centraal Bureau voor de Statistiek.

Garssen, J., Lalta, V., \& Portegijs, W. (2009). Bevolking (Elektronische versie). In A. Merens \& B. Hermans (red.), Emancipatiemonitor 2008 (pp. 23-45). Den Haag: Sociaal en Cultureel Planbureau.

Geest, S. van der (2003). Repelsteeltje. De magie van het juiste woord. In A. Oderwalt, F. Meulenberg, \& W. van Tilburg (red.), De taal van het gevoel (pp. 62-72). Amsterdam/Antwerpen: Uitgeverij Atlas.

Genomineerden NS Publieksprijs. (2006, 5 september). Het Parool, Kunst, p. 22. Geraadpleegd op 15 november, 2007, via LexisNexis.

Gerrits, J. (2000, 8 november). Een illusie die moet blijven bestaan: een beloftevolle debuutroman over de ondraaglijke zwaarte van het moederschap. De Morgen. Geraadpleegd op 6 april, 2009, via Literom [CD-rom].

Gils, M. van (2010). E-mail "Re: vragen onderzoek beeldvorming ouderschap" van de redactie van Ouders van Nu verstuurd aan Josje Weusten op 9 september 2010. (Verwijzing met toestemming van Ouders $\operatorname{van} \mathrm{Nu}$ ).

Goedegebuure, J. (2004). Inbrekers in de kersstal. De geboorte van Jezus in de Nederlandse literatuur van de twintigste eeuw. In S.J. Noorda (red.), Er is een kindeke - : de geboorte van Jezus in de Nederlandse en Vlaamse cultuur (pp. 147-158). Amsterdam: Amsterdam University Press.

Gorp, van H., Delabastita, D. \& Ghesquiere, R. (2007). Lexicon van literaire termen (8e herz. dr.). Groningen/Houten: Wolters Plantyn.

Gouden Strop (geen datum). Geraadpleegd op 11 Januari, 2011, via www.crime.nl/prijzen/goudenstrop.html

Graaf, B. van de (2008, 27 september). De film is zoiets als een oorvijg. Trouw. Geraadpleegd op 28 september, 2008, via www.trouw.nl.

Graaf, A. de (1980). Mijn dochter Linda. Haarlem: Gottmer.

Graaf, A. de (1994). De roep van een kind. Amsterdam: Zomer \& Keuning familieromans.

Graf, F. (1997). Medea, the enchantress via afar: remarks on a well-known myth. In J.J. Clauss \& S. Iles Johnston (red.), Medea. Essays on medea in myth, literature, philosophy and art (pp. 21-43). Princeton, New Jersey: Princeton University Press.

Greenblatt, S. (1981). Invisible bullets. In J. Rivkin \& M. Ryan (1998), Literary theory: an anthology (pp. 786-803). Malden, Oxford, Carlton: Blackwell Publishing. Geraadpleegd op 7 december, 2010, via www.colorado.edu/English/courses/engl5019/Readings/GrnInv.pdf

Greenblatt, S. (1983). Murdering peasants: status, genre and the representation of rebellion (Elektronische versie). Representations, 1, 1-29.

Grene, D. (2010). Introduction. In Sophocles (2010). Oedipus the King (pp. 1-8) (D. Grene, vert.). Chicago/London: The University of Chicago Press.

Groeneveld, V. (1997, 31 januari). Strafrecht schiet tekort in Hoofddorp. De Volkskrant, Economie, p. 15. Geraadpleegd op 10 september, 2007, via LexisNexis.

Groos, M. (2000). Wie schrijft, die blijft? Schrijfsters in de literaire kritiek van nu. Tijdschrift voor Genderstudies, 3(3), 31-36.

Groot, M. de (2010). Interview Renate Dorrestein. Libelle, 43, p. 66. Geraadpleegd op 7 februari, 2011 via www.libelle.nl/2010/10/interview-renate-orresteinlibellemagazinebladboekenclub-2/

Grunberg, A. (2006). Tirza. Amsterdam: Nijgh \& Van Ditmar

Guensberg, M. (2001). Saternacht. Amsterdam: Veen. 
Haar, G. van de (1998). Een overzicht ten behoeve van de vakantie. Wapenveld. Christelijk perspectief op geloof en cultuur, 48, 113-114.

Hageraats, K. (1989, 24 november). Doorsudderende moedergevoelens. In Vonne van der Meers jongste roman staat het thema van de kinderadoptie centraal, maar geloofwaardig is anders. De Tijd, 31.

Hall, S. (2002a). The spectacle of the 'other'. In S. Hall (red.), Representation. Cultural representations and signifying practices (pp. 223-290). London: Sage Publications.

Hall, S. (2002b). The work of representation. In S. Hall (red.), Representation. Cultural representations and signifying practices (pp. 1-30). London: Sage Publications.

Halsema, A. (2000). Judith Butler: turbulentie op het gebied van gender en seksualiteit. In J. Butler, A. Halsema \& M. Wilmink, Gender turbulentie/Judith Butler (pp. 7 29). Amsterdam: Boom/Parrèsia.

Hamers, D. (2003). Tijd voor suburbia. De Amerikaanse buitenwijk in wetenschap en literatuur. Amsterdam: Uitgeverij Van Gennep.

Hamon, P. (1973). Un discours contraint. Poétique, 16, 411-445.

Hanssen, L. (2006a). Het kind vrijlaten. Poëzie en de vloek van het authentieke. In L. Hanssen, Een misverstand om in te geloven. De poëzie van M. Vasalis (pp. 168 177). Amsterdam: Atheneum-Polak \& Van Gennep.

Hanssen, L. (2006b). Familiegeslijm? Moederschap en dochterschap. In L. Hanssen, Een misverstand om in te geloven. De poëzie van M. Vasalis (pp. 206-222). Amsterdam: Atheneum-Polak \& Van Gennep.

Harrington, A. (2006). The poetry of Anna Akhmatova. Living in different mirrors. London/New York: Anthem Press.

Hart, J. de (2005). Pretpark Hollandia. Over enkele veranderingen in het burgerlijk waardepatroon (Elektronische versie). In P. Dekker \& J. de Hart (red.), De goede burger. Tien beschouwingen over een morele categorie (pp. 43-58). Den Haag: Sociaal Cultureel Planbureau.

Hart, J. de (2007). Hier en hiernamaals gelukkig (Elektronische versie). In Sociaal Cultureel Planbureau (2006), Veel geluk in 2007 (pp. 61-65). Den Haag: Sociaal en Cultureel Planbureau.

Hays, S. (1996). The cultural contradictions of motherhood. New Haven: Yale University Press.

Heijden, A.F.Th. van der (2003). Uitdorsten. Amsterdam: Querido.

Heijst, A. van (1993). Leesbaar lichaam. Verhalen van lijden bij Blaman en Dorrestein. Kampen: Kok/Agora.

Hellman, N. (1996, 22 maart). Liefde voor de stilte, voor 't zwijgen. NRC Handelsblad. Geraadpleegd op 8 juni, 2008, via Literom [CD-ROM].

Hendin, J. G. (2004). Heartbreakers: women and violence in contemporary culture and literature. New York: Palgrave Macmillan.

Hendrix, Jimi (1967). Hey Joe [single].

Hermans, P. (2004). Contra-narratieven van Marokkaanse ouders: een weerwoord op discriminatie, paternalisme en stigmatisering (Elektronische versie). Migrantenstudies, 20(1), 36-53.

Hernández, M. (1990a). Nanas de la Cebolla. In E. Honig (red.), The unending lightning. The selected poems of Miguel Hernández (E. Honig, vert.) (p. 55). New York: The Sheep Meadow Press.

Hernández, M. (1990b). Lullaby of the Onion. In E. Honig (red.), The unending lightning. The Selected poems of Miguel Hernández (E. Honig, vert.) (p. 23). New York: The Sheep Meadow Press.

Hilhorst, M. (1999). De vader, de moeder en de tijd. Amsterdam: Meulenhoff.

Hockey, J., \& James, A. (1995). Back to Our Futures. Imaging Second Childhood. In M. Featherstone \& A. Wernick (red.), Images of aging. Cultural representations of later life (pp. 135-148). London \& New York: Routledge.

Hochschild, A.R. (2004). The commodity frontier. In J. Alexander, G. Marx, J. Williams (Red.), Self, structure and belief: essays in sociology (pp. 38-56). Berkeley and Los Angeles: University of California Press.

Hond, B. den (1997a, 20 januari). Kinderdoding: nabijheid ouders is grootste risico. Trouw, p. 1. Geraadpleegd op 10 september, 2007, via LexisNexis

Hond, B. den (1997b, 31 januari). Kinderdoding is meestal uit de hand gelopen afstraffing. Trouw, p. 9. Geraadpleegd op 10 september, 2007, via LexisNexis. 
Hoogleraar wil nieuwe gevallen voorkomen (1997, 28 januari). Trouw, p. 9. Geraadpleegd op 10 september, 2007, via LexisNexis.

Horsley, K., \& Hosley, L. (1999). Meres fatales: maternal guilt in the noir crime novel. Modern Fiction Studies, 45(2), 369-402.

Hulp voor wanhopige ouders; Kinderbescherming zet teams in na golf van verontruste telefoontjes (1997, 12 februari). Algemeen Dagblad, Binnenland, p. 3. Geraadpleegd op 10 september, 2007, via LexisNexis.

Huygen, M. (1997, 15 februari). Van kindermoord tot 'kinderdoding'. NRC Handelsblad, p. 3. Geraadpleegd op 10 september, 2007, via LexisNexis.

Isarin, J. (2002). Als het maar gezond is. Over ongelukkige kinderen, ongelukkige ouders en ongelukkige beslissingen(Elektronische versie). Filosofie \& Praktijk, 23(2).

Janssen, S. (1994). In het licht van de kritiek. Variaties en patronen in de aandacht van de literatuurkritiek voor auteurs en hun prozawerken. Hilversum: Uitgeverij Verloren.

Janssen, S. (1997). Reviewing as social practice: institutional constraints on critics' attention for contemporary fiction (Elektronische versie). Poetics, 24, 275-297.

Janssen, S (1998). Side-roads to success: the effect of sideline activities on the status of writers (Elektronische versie). Poetics, 25, 265-280.

Janssen, S. (1999). Art journalism and cultural change. The coverage of the arts in Dutch newspapers 1965-1990 (Elektronische versie). Poetics, 26, 329-348.

Jensen, L. (2007). Het New Historicism: de reddende engel? Bilderdijk als casus. Neerlandistiek.nl, artikel 07.06c, 1-6. Geraadpleegd op 7 december, 2010, via www.neerlandistiek.nl

Jensen, S. (2002). Waarom vrouwen van apen houden. Een liefdesgeschiedenis in literatuur en wetenschap. Amsterdam: Prometheus.

Jensen, S. (2009, 28 maart). Literaire sellerchicks leggen ontwrichting samenleving bloot. NRC Handelsblad. Geraadpleegd op 20 Januari, 2010, via www.stinejensen.nl/columns.php?clm_id=29

Johnston, D., \& Swatson, D. (2003). Invisible mothers: a content analysis of motherhood ideologies and myths in magazines (Elektronische versie). Sex Roles, 49(1/2), 21-33.

Jong, A. de (1998, 25 september). Ik ken geen belangrijke kunstenaressen met kinderen; gesprek met Elfriede Jelinek. NRC Handelsblad. Geraadpleegd op 16 Februari, 2011, via www.nrcboeken.nl/recensie/ik-ken-geen-belangrijke-kunstenaressen-met-kinderen-gesprek-met-elf riede-jelinek

Jonge Gezinnen BV (2010). Jonge gezinnen beurs. Zakelijk. Geraadpleegd op 14 oktober, 2010, via www.jongegezinnenbeurs.nl/Zakelijk.htm

Journalisten wijzen mediastilte van de hand (1997, 14 februari). Algemeen Dagblad, Binnenland, p. 4. Geraadpleegd op 10 september, 2007, via LexisNexis.

Jury Vrouw \& Kultuur debuutprijs (2002). Juryrapport Vrouw \& Kultuur debuutprijs 2002.

Justitie roept op tot terughoudendheid (1997, 13 februari). Trouw, p. 9. Geraadpleegd op 10 september, 2007, via LexisNexis.

Kabinet Rutte (2010). Regeerakkoord. Geraadpleegd op 19 oktober, 2010, via www.rijksoverheid.nl/regering/het-kabinet/regeerakkoord/

Kardaun, M. (2009, December 15). Jung and the fairy tale, or nosce te opsum (Elektronische versie). PSYART: A Hyperlink Journal for the Psychological Study of the Arts. Geraadpleegd op 7 februari, 2011, via www.psyartjournal.com/article/show/kardaun-jung_and_the_fairy_tale_or nosce te_ipsu.

Karsten, L., Kuiper, E., \& Reubsaet, H. (2001). Van de straat. De relatie jeugd en openbare ruimte verkend. Jeugd informatie onderzoek. Assen: Koninklijke van Gorcum.

Kayzer, W. (1995). Vertrouwd en o zo vreemd - over geheugen en bewustzijn. Amsterdam: Contact.

Kennedy, J.C. (1995). Nieuw Babylon in aanbouw. Nederland in de jaren zestig (S. Kennedy Doornbos, vert.) (Elektronische versie). Amsterdam: Boom. (Originele werk gepubliceerd in 1995)

Keuzenkamp, S. (2009). Focus op kleine deeltijdbaan (Elektronische versie). In S. Keuzenkamp, C. Hillebrink, W. Portegijs \& B. Pouwels (red.), Deeltijd (g)een probleem. Mogelijkheden om de arbeidsduur van vrouwen met een kleine deeltijdbaan te vergroten (pp. 17-27). Den Haag: Sociaal en Cultureel Planbureau. 
Keuzenkamp, S., Hillebrink, C., Portegijs, W., \& Pouwels, B. (red.). (2009). Deeltijd (g)een probleem. Mogelijkheden om de arbeidsduur van vrouwen met een kleine deeltijdbaan te vergroten (Elektronische versie). Den Haag: Sociaal en Cultureel Planbureau.

Kilbourne, J. (1999). Deadly persuasion: why women and girls must fight the addictive power of advertising. New York: Free Press.

Kindermoord (1997, 8 februari). De Volkskrant. Geraadpleegd op 10 september, 2007, via LexisNexis.

Kindermoord: 3 jaar en TBS (1997, 1 juli). Trouw, p. 3. Geraadpleegd 10 september, 2007, via LexisNexis.

Kip zonder kop (2006, 3 juni). De Volkskrant, Magazine, p. 47. Geraadpleegd op 15 november, 2007, via LexisNexis.

Knijn, T., \& Nievers, E. (1996). Combineren en organiseren: de moeder als manager. Psychologie en Maatschappij, 75, 149-162.

Knijn, T., \& Verheijen, C. (1991). Kiezen of delen: veranderingen in de beleving van het moederschap. Amsterdam: Uitgeverij An Dekker.

Koens, M.J.C. (2006). Titel 12. Adoptie, aantekening 5. Leeftijdsverschil (lid 1, sub c), bij t/m 01-04-2008. In Losbladige personen- en familierecht (Groene Serie). Deventer: Kluwer.

Koninklijke Bibliotheek (geen datum). Catalogi. Geraadpleegd op 8 november, 2010, via www.kb.nl/menu/catalogi.html

Kopland, R. (1989). Water. In Dankzij de dingen (p. 17). Amsterdam: Uitgeverij G.A. van Oorschot.

Korthals Altes, F. (1988a, 20 december). Wet opneming buitenlandse kinderen ter adoptie, artikel vijf, vijfde lid onder b. Geraadpleegd op 31 november, 2010, via www.stab.nl/wetten/0739 _Wet_opneming_buitenlandse_kinderen_ter_adoptie.htm

Korthals Altes, F. (1988b, 20 december). Wet opneming buitenlandse kinderen ter adoptie, artikel vijf, zevende lid. Geraadpleegd op 31 november, 2010, via www.stab.nl/wetten/0739_Wet_opneming_buiten-landse_kinderen_ter_adoptie.htm

Kort nieuws (2006, 28 juli). Algemeen Dagblad, p. 17. Geraadpleegd op 15 november, 2008, via LexisNexis.

Kossman, A. (1989, 18 november 1989). De bizarre reis naar een kind. Provinciale Zeeuwse Courant. Geraadpleegd op 8 juni, 2008 via Literom [CD-ROM].

Krielaars, M. (1998). En het dansen gaat door. Amsterdam: Contact.

Krielaars, M. (2002). Afkomst. Amsterdam: Contact.

Kuik, H. (1986). Aards bezit. Amsterdam: Meulenhoff.

Laere, S. v. (1991). Een flets sprookje van Vonne van der Meer. Dietsche Warande \& Belfort: Tijdschrift voor letterkunde en geestesleven, 136, 493-494.

Latten, J. (2005). Zwanger van segregatie. Een toekomst van sociale en ruimtelijke segregatie? (Elektronische versie). Amsterdam: Vossiuspers UvA.

Laura (2006, december). Lief kind? 'Je mag mijn dochtertje zó meenemen'. Jan, 60-66.

Layne, L.L. (2004). Making memories after pregnancy loss. In J. S. Taylor, L. L. Layne \& D. F. Wozniak (red.), Consuming motherhood. New Brunswick, New Jersey and London: Rutgers University Press.

Leach, P. (1979). Baby en kind: het volledige en praktische handboek voor de verzorging van kinderen (I. Verhagen, vert.). Utrecht: Uitgeverij Kosmos. (Oorspronkelijke uitgave 1977).

Leach, P. (1998). Baby en kind: het complete praktische handboek voor de verzorging van uw kind (J. Bakker, C. Bennink, J. Meerman \& J. Nelissen, vert.). (10e druk). Utrecht: Uitgeverij Kosmos. (Oorspronkelijke uitgave 1977).

Leach, P. (2003). Baby en kind: het complete praktische en handzame handboek voor de verzorging van uw kind. (J. Bakker, C. Bennink, J. Meerman \& J. Nelissen, vert.). (12e druk). Utrecht: Uitgeverij Kosmos. (Oorspronkelijke uitgave 1977).

Leach, P. (2008). Baby en kind: het complete praktische en handzame handboek voor de verzorging van uw kind. (J. Bakker, C. Bennink, J. Meerman \& J. Nelissen, vert.). (14e druk). Utrecht: Uitgeverij Kosmos. (Oorspronkelijke uitgave 1977).

Letterkundig Museum (2009). Literaire prijzen database. Geraadpleegd op 25 februari, 2009, via www.literaireprijzen.nl 
LexisNexis (2010a). De Volkskrant. Geraadpleegd op 8 november, 2010, via www.lexisnexis.nl/dutch/ bronnen/nederlandstalige-bronnen/national news/devolkskrant.aspx

LexisNexis (2010b). De Telegraaf. Geraadpleegd op 8 november, 2010, via www.lexisnexis.nl/dutch/bronnen/nederlandstalige-bronnen/national news/detelegraaf.aspx

Lieshout, I.J.Y. van (1993). Binding in een probleemcultuur. Deskundigen en ouders van nu. Utrecht: Universiteit Utrecht.

Lievens, S. (2007). Onbestaand, onbekend of onbemind? Schrijfsters in Vlaanderen. In Müller, Heidy M. \& Arteel, Inge (red.), Een vrouw die schrijft. Literatuur en literatoren feministisch bekeken (pp. 39-56). Brussel: Vubpress.

Lievens, S., Demoor, M., \& Saeys, F. (2004). Cherchez la femme: vrouwen en schrijverschap in Vlaanderen. Gent: Centrum voor Seksestudies UGent/Academia Press.

Loo, V. van de (2005). De vrouw beslist. De tweede feministische golf in Nederland. Utrecht: Uitgeverij Inmerc/IIAV.

Lourens, J. (1995). Kind ontvoerd. Utrecht: Bruna.

Louwerse, M. (1997). Inleiding. In V. Propp, Morfologie van het toversprookje. Vormleer van een genre (M. Louwerse, Vert.) (pp. 8-22). Utrecht: Uitgeverij Het Spectrum B.V.

Luxemburg, J. van, Bal, M., \& Weststeijn, W.G. (1981). Inleiding in de literatuurwetenschap. Muiderberg: Couthino.

Maarssen, M. \& Oosterwijk, F. (2006). Taboe. 100 gevoelens waar Nederlanders zich voor schamen. Amsterdam: Uitgeverij Balans.

Marchand, R. (1986). Advertising the American dream. Making way for modernity 1920-1940. Berkeley/Los Angeles: University of California Press.

Marle, M. van (1988). Een persoonlijke ontmoeting met schrijfster Vonne van der Meer: als je me vraagt wat doe je het liefst, dan is dat op een terras zitten en naar mensen kijken. Libelle. Geraadpleegd op 8 juni 8, 2008 via Literom [CD-ROM].

Mathijsen, M. (2000). De mythe terug: negentiende-eeuwse literatuur als travestie van maatschappelijke conflicten (Electronische versie). Amsterdam: Vossiuspers AUP.

Mathijsen, M. (2007). Over de historische letterkunde, over historische romans en Het Huis Lauernesse. Neerlandistiek.nl, artikel 07.06d, 1-8. Geraadpleegd op 7 december, 2010, via www.neerlandistiek.nl.

Mauthner, N. (1999). "Feeling low and feeling really bad about feeling low": women's experiences of motherhood and postpartum depression (Elektronische versie). Canadian Psychology, 40(2), pp. 143-161.

Maxi-Cosi (2006). Urban Safari: the new limited edition by Maxi-Cosi [Reclame]. Helmond: Dorel Netherlands/Maxi-Cosi.

Maxi-Cosi (2007). Maxi-Cosi consumentenbrochure collectie 2008. Helmond: Dorel Netherlands/MaxiCosi.

Maxi-Cosi (2008). Maxi-Cosi consumentenbrochure collectie 2009. Helmond: Dorel Netherlands/MaxiCosi.

Maxi-Cosi (2009a). Persflyer Maxi-Cosi 25 years NL. Helmond: Dorel Netherlands/Maxi-Cosi.

Maxi-Cosi. (2009b). Maxi-Cosi consumentenbrochure collectie 2010. Helmond: Dorel Netherlands/MaxiCosi.

Maxi-Cosi (2010). Maxi-Cosi consumentenbrochure collectie 2011. Helmond: Dorel Netherlands/MaxiCosi.

Meer, V. van der (1985). Het limonadegevoel en andere verhalen. Amsterdam: Uitgeverij Contact.

Meer, V. van der (1989). De reis naar het kind. Amsterdam: Pandora.

Meer, V. van (1995). Spookliefde. Een lers verhaal. Amsterdam: Uitgeverij Contact.

Meer, V. van der (1999). Eilandgasten. Amsterdam: Uitgeverij Contact.

Meer, V. van der (2001). De avondboot. Amsterdam: Uitgeverij Contact.

Meer, V. van der. (2002). Laatste seizoen. Amsterdam: Uitgeverij Contact.

Meer, V. van der (2002/1989). De reis naar het kind. Amsterdam: Pandora. 
Mees, H. (2007). Weg met het deeltijdfeminisme. Over vrouwen, ambitie, en carrière. Amsterdam: Nieuw Amsterdam.

Meijer, M. (1988). De lust tot lezen. Nederlandse dichteressen en het literaire systeem. Amsterdam: Sara/Van Gennep.

Meijer, M. (1993). [Bespreking van E. van Boven, Een hoofdstuk apart. 'Vrouwenromans' in de literaire kritiek 1989-1930. Amsterdam: Sara/Van Gennep (1992)]. De Nieuwe taalgids, 86(2), 120-126.

Meijer, M. (1996a). In tekst gevat. Inleiding tot een kritiek van representatie. Amsterdam: Amsterdam University Press.

Meijer, I.C. (1996b). Het persoonlijke wordt politiek. Feministische bewustwording in Nederland 19651980. Amsterdam: Het Spinhuis.

Meinkema, H. (1988). Het kind en de rekening. Amsterdam: Uitgeverij Contact.

Meinkema, H. (1994). De speeltuin van Teiresias. Amsterdam: Uitgeverij Contact.

Met onbekende bestemming (geen datum). Geraadpleegd op 29 november 29, 2010 via www.mayarasker.com

Mesters, B. (1997a, 17 januari), Zeldzaam fenomeen kindermoord kwam nog nooit zo vaak voor. De Volkskrant, Kunst, p. 12. Geraadpleegd 10 september, 2007, via LexisNexis.

Mesters, B. (1997b, 2 juli), Straf Hoofddorp-zaak hard voor ouders. De Volkskrant, p. 4. Geraadpleegd op 10 september, 2007, via LexisNexis.

Meulenberg, F., Meer, J. van der \& Oderwald, A. (2002). Ziektebeelden - essays over literatuur en geneeskunde. Utrecht: Uitgeverij Lemma.

Mills, S. (2004). Discourse (2e herz. druk). Oxon/New York: Routledge.

Min, N. M. (2004/1966). Familieberichten I. In J. Deleu (red.), Vijfhonderd gedichten over leven liefde, en dood (p. 71). Tielt: Lannoo/Meulenhoff.

Ministerie van Justitie. (2008, 29 mei). Commissie-Kalsbeek: verhoging leeftijdsgrens bij interlandelijke adoptie. Persbericht. Geraadpleegd op 25 februari, 2009, via www.justitie.nl

Ministerie van VROM. (1990). Vierde nota ruimtelijke ordening extra (VINEX). Den Haag: VROM.

Moerman, J. (2000). Interview: het verlies van souvereiniteit. Maya Rasker in gesprek met Jacob Moerman. Geraadpleegd op 10 november, 2010, via www.mayarasker.com

Montrose, L. (1983). "Shaping fantasies": figurations of gender and power in Elizabethan Culture. Representations, 2, 61-94.

Moore, D.S. \& McCabe, G.P. (1998). Introduction to the practice of statistics (3e druk). New York: W.H. Freeman and Company.

Mourits, B. (2007, 31 augustus). Het einde van de literatuur; waarom thrillerschrijvers zich tooien met een klassiek etiket. NRC Handelsblad, Boeken, p. 27. Geraadpleegd op 10 januari, 2010, via LexisNexis.

Mul, J. de (2006). De domesticatie van het noodlot. De wedergeboorte van de tragedie uit de geest van de technologie. Kampen: Uitgeverij Klement, Pelckmans.

Mul, J. de, Müller, E., \& Nusselder, A. (2001). Menselijke autonomie (Elektronische versie). In ICT de baas. Informatietechnologie en menselijke autonomie. Onderzoeksprogramma internet en openbaar bestuur 2001 (pp. 15-26). Den Haag: Ministerie van Buitenlandse Zaken.

Mulder, R. (1992, 13 november). Een mens ziet wat hij weet. NRC Handelsblad.

Mulisch, H. (1998). De procedure. Amsterdam: de Bezige Bij.

Münstermann, H. (2006). De bekoring. Amsterdam: Nieuw Amsterdam.

Nederlands Instituut voor Oorlogsdocumentatie (2002). Srebrebica, een 'veilig' gebied: reconstructie, achtergronden, gevolgen en analyses van de val van een safe area. Amsterdam: NIOD.

Nederlands Jeugdinstituut (2008). Opvoeding en ontwikkeling. Literatuurlijst voor ouders. Geraadpleegd op 16 oktober, 2010, via www.nji.nl/publicaties/LiteratuurlijstOpvoedingenOntwikkeling.pdf

Nederlands Uitgeversverbond (2009). Nederlandse Uniforme Rubriekscodering. Geraadpleegd op 24 november, 2009, via www.nuv.nl/contenttypes/Artikelen/Artikel977.aspx?Source=http\%3a\%2\%2 fww.nuv. nl\%2fPages\%2fZoek.aspx\%3fk\%3dnur

Nederlands Uitgeversverbond (2008). NUR-lijst. Geraadpleegd op 24 november, 2009, via www.nuv.nl 
Nelson, M.K. (2010). Parenting out of control: anxious parents in uncertain times. New York and London: New York University Press.

Nicolson, P. (1998). Post-natal depression. Psychology, science and the transition to motherhood. London: Routledge.

Nio, I. (2006). Vinex: tussen identificatie en onthechting. In Ruimte in debat volume 5 (pp. 2-13). Den Haag: Ruimtelijk Planbureau.

Niphuis-Nell, M., \& Beer, P. de (1997). Verdeling van arbeid en zorg (Elektronische versie). In C.S. van Praag \& M. Niphuis-Nell (red.), Het gezinsrapport (pp. 43-108). Den Haag: Sociaal en Cultureel Planbureau.

Noort, S. (2006). Nieuwe buren. Amsterdam: Uitgeverij Anthos.

Nooteboom, C. (1980). Rituelen. Amsterdam: Arbeiderspers.

Novy, M. (2008). Reading adoption. Family and difference in fiction and drama. Michigan: The University of Michigan Press.

Novy, M. (red.). (2007). Imagining adoption. Essays on literature and culture. Michigan: The University of Michigan Press.

Oakley, A. (1979). Becoming a mother. New York: Schocken Book.

Oakley, A. (1980). Women confined: towards a sociology of childbirth. New York: Schocken Books.

Oakley, A. (1984). The captured womb: a history of the medical care of pregnant women. Oxford: Blackwell.

Obema, F., \& Ockhuysen, R. (1997, 22 februari). Een geheime behoefte aan breidel. De Volkskrant. Geraadpleegd op 10 september, 2007, via LexisNexis.

Oderwald, A., Meulenberg, F., \& Tilburg, W. van (red.). (2003). De taal van het gevoel, essays over literatuur en psychiatrie. Amsterdam/Antwerpen: Atlas.

Oever, R. van (forthcoming). Dominant mothers, queer sons: undoing momism in American culture, 19491969. Maastricht: Universitaire Pers Maastricht.

Ohio College Library Center (2010). Picarta. Geraadpleegd op 9 november, 2010, via www.oclc.org/ $\mathrm{nl} / \mathrm{nl} /$ gii/ picarta/default.htm

Ohio College Library Center (geen datum a). Advanced search. Geraadpleegd op 20 januari, 2010, via http://picarta.pica.nl/DB=2.41/SET=1/TTL=1/ADVANCED_SEARCHFILTER

Ohio College Library Center (geen datum b). [Bespreking van K. Peters, De zoon van Sofie. Hoorn: Westfriesland (2007)]. Geraadpleegd op 20 januari, 2010, via http://picarta.pica.nl/DB=2.41/SET=1/TTL $=1 / \mathrm{SHW}$ ?FRST $=2$

Ohio College Library Center (geen datum c). [Bespreking van A. Sterk, Het eiland van mijn vader. Amsterdam: Bakker (2003)]. Geraadpleegd op 20 januari, 2010, via http://picarta.pica.nl/DB=2.41/$\mathrm{SET}=1 / \mathrm{TTL}=2 / \mathrm{CMD}$ ?ACT=SRCHA\&IKT=101\&ST=YOP\&TRM=het+eiland+van+mijn+vader

Ohio College Library Center (geen datum d). [Bespreking van R. Dorrestein (2006). Mijn zoon heeft een seksleven en ik lees mijn moeder roodkapje voor. Amsterdam: Contact (2006)]. Geraadpleegd op 20 januari, 2010, via http://picarta. pica.nl/DB=2.41/SET=3/TTL=1/SHW?FRST=1

Ohio College Library Center (geen datum e). [Review van F. van Ouweland, Verdoken vader. Vlaardingen: Paquito Publishers (2007)]. Geraadpleegd op 20 januari, 2010, via http://picarta.pica.nl/DB=2.41/ $\mathrm{SET}=3 / \mathrm{TTL}=1 / \mathrm{CMD}$ ?ACT=SRCHA\&IKT=101 \&ST=YOP\&TRM=verdoken+vader

O'Reilly, Andrea. (2006). Rocking the cradle. Thoughts on motherhood, feminism and the possibility of empowered mothering. Toronto, Ontario: Demeter Press.

Otter, H. (2005, 11 oktober). Met een titel op de bank als de ultieme vrucht van de emancipatie. Trouw, deGIDS, V09.

Oudejans, F. (1997). De actuele geschiedenis van twee grote kranten. Ons Erfdeel, 40. Geraadpleegd op 29 mei, 2011, via www.dbnl.org/tekst/_ons003199701_01/_ons003199701_01_0141.php

Ouders kindermoord Hoofddorp volledig ontoerekeningsvatbaar (1997, 18 juni). Trouw, p. 9. Geraadpleegd op 10 september, 2007, via LexisNexis.

Oudshoorn, N. (1994). Beyond the natural body. An archeology of sex hormones. London: Routledge.

Ouweland, F. van (2007). Verdoken vader. Vlaardingen: Paquito Publishers. 
Ouwendijk, C. (1979). Happy Service wil kersverse moeder dynamisch bejegenen (Elektronische versie). Ariadne, 34(2).

Palmen, C. (1991). De wetten. Amsterdam: Prometheus.

Peters, K. (2000). Geef je dromen niet op. Kampen: Kok.

Peters, K. (2007). De zoon van Sofie. Hoorn: Westfriesland.

Peters, P., Bleijenbergh, I., Pas, B., \& Gremmen, I. (2010). De deeltijdval. Beeldvorming over ambitie en deeltijdwerk bij Nederlandse vrouwen en hun leidinggevenden. Tijdschrift voor genderstudies, 13(4), 21-32.

Pieters, J. (1996). Van oude dingen, de zaken die voorbijgaan. Het New Historicism en de paradigmawissel in het historisch literatuuronderzoek. TvL: tijdschrift voor literatuurwetenschap, 4, 276-288.

Pieters, J. (2007). Literatuur als bron; bij wijze van inleiding. Neerlandistiek.nl, artikel 07.06. Geraadpleegd op 7 december, 2010, via www.neerlandistiek.nl.

Pieters, J., \& Vandevoorde, H. (2003a). De armoede van de praktijk: over de moeizame relatie tussen literatuuronderzoek en cultuurgeschiedenis. Feit \& fictie, 5(4), 8-15.

Pieters, J., \& Vandevoorde, H. (2003b). Over de rand van de tekst. Literatuur en representatie. Feit \& fictie, 5(4), 86-106.

Plasterk, R. (2007). Kabinetsnota over het emancipatiebeleid 2008-2010: 'meer kansen voor vrouwen' (Elektronische versie). Den Haag: Ministerie van Onderwijs, Cultuur en Wetenschap.

Pol, M. (1997, 28 juni). Ziek of schuldig: moordenaars in het Pieter Baan Centrum. NRC Handelsblad, Binnenland, p. 2. Geraadpleegd op 10 september, 2007, via LexisNexis.

Polak, C. (2004). Salka. Amsterdam: Meulenhoff.

Poorthuis, F. (1997, 10 juli). Ook biologen hebben weet van het beest in de mens. De Volkskrant, p. 21. Geraadpleegd op 10 september, 2007, via LexisNexis.

Portegijs, W. (2008). Geen kleine kinderen, toch een deeltijdbaan (Elektronische versie). In W. Portegijs, M. Cloïn, S. Keuzenkamp, A. Merens en E. Steenvoorden (red.), Verdeelde tijd. Waarom vrouwen in deeltijd werken (pp. 84-108). Den Haag: Sociaal en Cultureel Planbureau.

Portegijs, W. (2009). Vrouwen met een kleine deeltijdbaan (Elektronische versie). In S. Keuzenkamp, C. Hillebrink, W. Portegijs \& B. Pouwels (red.), Deeltijd (g)een probleem. Mogelijkheden om de arbeidsduur van vrouwen met een kleine deeltijdbaan te vergroten (pp. 63-93). Den Haag: Sociaal en Cultureel Planbureau.

Portegijs, W., Cloïn, M., Keuzenkamp, S., Merens, A. \& Steenvoorden, E. (red.). (2008). Verdeelde tijd. Waarom vrouwen in deeltijd werken (Elektronische versie). Den Haag: Sociaal en Cultureel Planbureau.

Porter Abbott, H. (2002). The Cambridge introduction to narrative. Cambridge: Cambridge University Press.

Pouwels, B. (2011). Work, family, and happiness. Essays on interdependencies within families, life events, and time allocation decisions. Geraadpleegd op 2 februari, 2011, via http://igiturarchive.library.uu.nl/ dissertations/2011-0119200309/pouwels.pdf

Praag, C.S. van (1997). Demografie (Elektronische versie). In C.S. van Praag \& M. Niphuis-Nell (red.), Het gezinsrapport (pp. 13-43). Den Haag: Sociaal en Cultureel Planbureau.

Prénatal Moeder en Kind BV (2008). Prénatal magazine 2008-2009. Almere: Prénatal Moeder en Kind BV.

Prénatal Moeder en Kind BV (2010a). Een feest van herkenning. Noot voor de redactie: over Prénatal. Geraadpleegd op 19 september, 2010, via www.prenatal.nl/pers

Prénatal Moeder en Kind BV (2010b). Wij Special Media nu 100\% eigendom van Prénatal. Geraadpleegd op 19 september, 2010, via www.prenatal.nl/WSM_nu_voor_100_procent_eigendom_van_Prenatal

Prénatal Moeder en Kind BV (2010c). Zo is Prénatal geboren. Geraadpleegd op 19 september, 2010, via www.prenatal.nl/Zo_is_Prenatal_geboren

Prénatal Moeder en Kind BV (geen datum). Folder 'Mama worden is leuker dan ooit'. Almere: Prénatal Moeder en Kind BV. 
Prints \& Proms (1978). Prints \& Proms. Thuis in àlles "below the line" (Elektronische versie). Ariadne/Revue der Reclame Bureaubijlage, 4(2).

Pronk, I. (2006). Uitgesproken vrouwen. Vrouwenpraatgroepen in Nederland 1970-1980. Themanummer: De tweede feministische golf. Tijdschrift voor Genderstudies, 9(2), 26-36.

Pronk, I. (2007, 25 juni 2007). Vergeet je lezer niet! Trouw, pp. 10-11.

Propp, V. (1997/1939). De morfologie van het toversprookje. Vormleer van een genre (M. Louwerse, vert.). Utrecht: Uitgeverij Het Spectrum.

Punter, D., \& Byron, G. (2004). The gothic. Malden, Mass. [etc.]: Blackwell.

Quasimodo, S. (1971/1930). Terugkeer. In S. Quasimodo, S. Perse, Y. Séferis, Gedichten (H. van den Bergh, J. Th. Stakenburg \& M. Blijstra-van der Meulen, vert.) (p. 71). Hasselt: Uitgeverij HeidelandOrbis.

Rasker, M. (2000). Met onbekende bestemming. Amsterdam: Pockethuis.

Reclamearsenaal (geen datum a). Reclamearsenaal. Geraadpleegd op 19 september, 2010, via www.reclame- arsenaal.nl/index.php?id=2

Reclamearsenaal (geen datum b). Collecties. Geraadpleegd op 19 september, 2010, via www.reclamearsenaal.nl/index. php?id=48

Reen, T. van (1986). Winterjaar. Amsterdam: Contact.

Rees, C.J. van (1987). How reviewers reach consensus on the value of literary works (Elektronische versie). Poetics, 16, 275-294.

Rees, C.J. van, \& Dorleijn, G.J. (2006). Het Nederlandse literaire veld 1800-2000. In G.J. Dorleijn \& C.J. van Rees (red.), De productie van literatuur. Het Nederlandse literaire veld 1800-2000 (pp. 15-38). Nijmegen: Uitgeverij Vantilt.

Rees, C.J. van, Janssen, S., \& Verboord, M. (2006). Classificatie in het culturele en literaire veld 19752000. Diversificatie en nivellering van grenzen tussen culturele genres. In G.J. Dorleijn \& C.J. van Rees (red.), De productie van literatuur. Het Nederlandse literaire veld 1800-2000 (pp. 239-284). Nijmegen: Uitgeverij Vantilt.

Regeling inzake de opneming in Nederland van buitenlandse kinderen met het oog op adoptie. Oorspronkelijke tekst van het voorstel van wet en van de memorie van toelichting zoals voorgelegd aan de raad van state en voor zover nadien gewijzigd. Vergaderjaar 1986-1987, Kamerstuk 20046. (1987). Den Haag: Tweede Kamer der Staten Generaal.

Reijndorp, A., Kompier, V., Metaal, S., Pilet, B., \& Verwij, L. (1998). Buitenwijk. Stedelijkheid op afstand. Rotterdam: NAi Uitgevers.

Rhijn, P. van (2007). Weg van Lila. Een autobiografische roman over de strijd van een vader om zijn kind. Uithoorn: Karakter.

Rhijn, P. van (2009). Vaderstad. Uithoorn: Karakter.

Ribberink, A. (1998). Leidsvrouwen en zaakwaarneemsters. Een geschiedenis van de Aktiegroep Man Vrouw Maatschappij, 1968-1973. Hilversum: Verloren.

Rich, A. (1976). Of women born. Motherhood as experience and institution. New York: Norton.

Riffaterre, M. (1978). Semiotics of poetry. Bloomington/London: Methuen.

Riffaterre, M. (1984). Intertextual representation: on mimesis as interpretive discourse. Critical Inquiry 11, 141-162

Rijswijk, K. van (2006). It's about time. Flextime, and a healthy work-home balance. Tilburg: Universiteit van Tilburg.

Rijt, H. van de \& Plooij, F.X. (1992). Oei, Ik groei! Utrecht: Uitgeverij Kosmos.

Rijt, H. van de \& Plooij, F.X. (2010). Oei, Ik groei! (56ste druk).Utrecht: Uitgeverij Kosmos.

Romito, P. (1990). Postpartum depression and the experience of motherhood (Elektronische versie). Acta Obstetricia et Gynecologica Scandinavica, 69(154), 7-37.

Royen, H. (2000). De gelukkige huisvrouw. HVR.

Rubin, M. (1999). Thrillers. Cambridge: Cambridge University Press.

Runia, E. (2004). "Forget about it": parallel processing in the Srebrenica report. History and Theory, 43(Oktober), 295-320. 
Salomo's Wijsheid (2004). In N. Bijbelgenootschap \& D. K. Bijbelstichting (red.), De nieuwe Bijbelvertaling (Vol. 1 Koningen 3, pp. 16-28). Geraadpleegd op 24 februari, 2009, via www.biblija.net/biblija.cgi?lang=nl

Sana, S. (2000). Zij, mijn moeder mijn land. Amsterdam: Wereldbibliotheek.

Sanoma Uitgevers (2005). Bijlage Oei, ik groei. Ouders van Nu, 11.

Sanoma Uitgevers (2006). Cover. Ouders van $\mathrm{Nu}, 10$.

Sanoma Uitgevers (2008). Ouders van Nu. Adverteren Jongegezinnen. Geraadpleegd op 10 mei, 2008, via www.sanoma-adverteren.nl

Sanoma Uitgevers (2009). Margriet Kids 2009. Geraadpleegd 22 augustus, 2010, via http://producten. zester.nl/Kids-Special/

Sanoma Uitgevers (2010a). Margriet. Geraadpleegd op 1 september 1, 2010, via www.sanomaadverteren.nl/nl-web-Onze_media-m-Margriet-print-Profiel-Merk_profiel.php

Sanoma Uitgevers (2010b). Libelle. Geraadpleegd op 1 september 1, 2010, via www.sanomaadverteren.nl/nl-web-Onze_media-I-Libelle-print-Profiel-Merk_profiel.php

Sanoma Uitgevers (2010c). Ouders van Nu. Geraadpleegd op 1 september 1, 2010, via www.sanomaadverteren. $\mathrm{nl} / \mathrm{nl}$-web-Onze_media-o-Ouders_van_nu-print-Profiel-Merk_profiel.php

Sardar, Z. (1999). Orientalism. Concepts in the social sciences. Buckingham, Philadelphia: Open University Press.

Sas, R. 't (1986, 31 mei). Schrijfster en regisseuse Vonne van der Meer 'Je hele leven bezweer je een soort paranoia'. HN-Magazine/Hervormd Nederland. Geraadpleegd op 8 juni, 2008, via Literom [CD-ROM].

Schenke, M. (2006, 31 mei). Thriller met nijpend gebrek aan spanning. Algemeen Dagblad, p. 19. Geraadpleegd op 15 november, 2007, via LexisNexis.

Schipper, M. (1979). Realisme. De illusie van werkelijkheid in de literatuur (Vol. 3). Assen/brugge: Van Gorcum/Uitgeverij Orion.

Schnabel, P. (2006). Veel over geluk (Elektronische versie). In Sociaal Cultureel Planbureau (2006), Veel geluk in 2007 (pp. 5-9). Den Haag: Sociaal en Cultureel Planbureau.

Schottelndreier, M. (1997, 8 februari). 'Dan kunnen we maar beter samen gaan'. De Volkskrant. Geraadpleegd op 10 september, 2007, via LexisNexis.

Schouten, D. (1989, 11 november). Alleen een dwaas zoekt 's winters vijgen. Gesprek met Vonne van der Meer, schrijfster van morele vertellingen. Vrij Nederland, 3.

Serdijn, D. (2000, 8 november). Verontrustend moederschap. Het Parool. Geraadpleegd op 8 augustus, 2008, via Literom [Cd-rom].

Serrat, M.J. (2006/1972). Nanas de la cebolla. Op Miguel Hernandez [cd]. BMG.

Shelley, M. (2003/1818). Frankenstein: or the modern Prometheus. London: Penguin.

Silk, M. (1996). Tragedy and the tragic. Greek theatre and beyond. Oxford: Oxford University Press.

Singer, E. (1989). Kinderopvang en de moeder-kindrelatie. Utrecht: van Loghum Slaterus.

Sion, L. (2007). Reinterpreting combat masculinity. Dutch peacekeeping in Bosnia and Kosovo. Sociologie, 3(1), 95-110

Smedman, M. S. (1990). Like me, like me not: Gulliver's Travels as children's book. In F. N. Smith (red.), The genres of "Gulliver's Travels". Newark: University of Delaware Press.

Smit, J. (1967). Het onbehagen bij de vrouw (Elektronische versie). De Gids, 130(9/10), 267-281.

Snellen, D. (2003). Vinex en mobiliteit: best succesvol. Den Haag: Ruimtelijk Planbureau.

Soest, M. van (2002, 9 oktober). Je moet het leven niet schuwen. Vrij Nederland. Geraadpleegd op 8 juni, 2008, via Literom [CD-ROM].

Sophocles (2009/406 v.Chr.). Oedipus at Colonus. In The Theban plays: Oedipus the king, Oedipus at Colonus, Antigone (pp. 65-136) (R. Fainlight \& R.J. Littman, vert.). Baltimore, MD: Johns Hopkins University Press.

Sorgdrager: zuinig met informatie bij kindermoorden (1997, 13 februari). Algemeen Dagblad, p. 2. Geraadpleegd op 10 september, 2007, via LexisNexis. 
Spee, S., Lefever, K., \& VanHoof, S. (1999). Stereotypen en rollenpatronen. In M. Michielsen, D. Mortelmans, S. Spee \& M. Nillet (red.), Bouw een vrouw. Sociale Constructie van vrouwbeelden in de media (pp. 25-50). Gent: Academia Press.

Spock, B. (1946). The common sense book of baby and child care. New York: Duell, Sloan and Pearce.

Spock, B. (1950). Baby- en kleuterverzorging (B. Willing, vert.). Amsterdam: Uitgeverij De Driehoek. (Oorspronkelijke uitgave 1946).

Spock, B. (1978). Baby- en kinderverzorging (B. Willing, vert.) (31ste herz. dr.). Amsterdam: Uitgeverij Bert Bakker. (Oorspronkelijke uitgave 1946).

Spock, B. (1984). Baby-en kinderverzorging en opvoeding. (B. Willing, vert.) (34 ${ }^{\text {ste }}$ herz. dr.). Amsterdam: Uitgeverij Bert Bakker. (Oorspronkelijke uitgave 1946).

Spock, B., \& Parker, S. (2000). Baby- en kinderverzorging en opvoeding (W. van Andel, vert.) (46ste herz. dr.). Utrecht: Kosmos Uitgevers. (Oorspronkelijke uitgave 1946).

Spock, B., \& Parker, S. (2007). Baby- en kinderverzorging en opvoeding (W. van Andel, vert.) (53ste herz. dr.). Utrecht: Kosmos Uitgevers. (Oorspronkelijke uitgave 1946).

Spock, B., \& Parker, S. (2010). Baby- en kinderverzorging en opvoeding (W. van Andel, vert.) (56ste herz. dr.). Utrecht: Kosmos Uitgevers. (Oorspronkelijke uitgave 1946).

Steenhuis, P. H. (2001). Renate Dorrestein maakt het zo erg, dat het niet meer 'verontrustend' is; 'Laat ik dan maar meteen zeggen dat ik zelf niet zo'n grafzitter ben'. Trouw, p. 32.

Sterk, A. (2003). Het eiland van mijn vader. Amsterdam: Bakker.

Stroeve, A., Van der Meer, A., Meulenbelt, A., Lambalk, A., et al. (1976). Moederboek (Elektronische versie). Amsterdam: De Bonte Was.

Stulemeijer, P.H. (2003). Bespiegelingen over honderd seizoenen, van land tot stand. Breda: Uitgeverij De Geus.

Süskind, P. (1985). Das Parfum: die Geschichte eines Mörders. Zürich: Diogenes

Sutherland, M. \& Sylvester, A. K. (2000). Reclamewerking ontrafeld: wat werkt, wat niet werkt en waarom (vert.). Deventer: Kluwer/Stichting Wetenschappelijk Onderzoek Commerciële Communicatie. (Oorspronkelijke uitgave 1993).

Swann Jones, P. (2002). The fairy tale. The magic mirror of imagination. London: Routledge.

Swierstra, T., \& Tonkens, E. (2004). Kiezen, een burgerplicht? In M. Hurenkamp \& M. Kremer (red.), Vrijheid verplicht. Over tevredenheid en de grenzen van keuzevrijheid (pp. 207-218). Amsterdam: TSS/Van Gennep.

Swift, J. (1757/1726). Travels into several remote nations of the world, in four parts. By Lemuel Gulliver, first a surgeon, and then a captain of several ships. London: C. Barthurst.

Swinnen, A. (2006). Het slot ontvlucht. De vrouwelijke Bildungsroman in de Nederlandse literatuur. Amsterdam: Amsterdam University Press.

Thijs, G. (1984). De huilende man. Amsterdam: De Harmonie.

Thijssen, W. (1997, 13 februari). Kindermoorden leiden volgens vertrouwensarts tot angst. De Volkskrant. Geraadpleegd op 10 september, 2007, via LexisNexis.

Thijssing-Boer, H. (1983). In de schaduw van een kind. Haarlem: Gottmer.

Throsby, K., \& Gill, R. (2004). "It's different for men": masculinity and IVF. Men and Masculinities, 6(4), $330-348$

Tinknell, E. (2005). Mediating the family. Gender, culture and representation. London: Hodder Arnold.

Tolstoj, L. (1960/1876). Anna Karenina (A.M. Wasilsjikow, vert.). Blaricum: Bigot \& Van Rossum.

Tompkins, J. (1985). Sensational designs. The cultural work of American fiction 1790-1860. Oxford: Oxford University Press.

Tompkins, J. (1992). West of everything. The inner life of Westerns. Oxford: Oxford University Press.

Tonkens, E. (2004). Mondige burgers, getemde professionals. Marktwerking, vraagsturing en professionaliteit in de publieke sector (4e dr.). Utrecht: NIZW uitgeverij.

Treurnis over dood broertjes (1997, 27 januari). Trouw, p. 1. Geraadpleegd op 10 september, 2007, via LexisNexis. 
Trigt, A. M. van (1991). Geneesmiddelen, zwangerschap en de lekenpers. Tijdschrift voor de sociale gezondheidszorg, gezondheid en samenleving, 69(11), 453-457.

Truijens, A. (1998, 4 februari). Voor altijd gestold tot kind. Renate Dorresteins 'Hart van steen' krachtig en vol compassie. De Volkskrant. Geraadpleegd op 19 februari, 2011, via www.volkskrant.nl/vk/nl/2676 /Cultuur/archief/article/detail/454955/1998/02/04/Voor-altijd-gestold-tot-kind-RENATEDORRES TEINS-HART-VAN-STEEN-KRACHTIG-EN-VOL-COMPASSIE.dhtml

Uffelen, H. van (1992). Niederländische Achtziger in Berliner Verlag (Rezension). Juni, 6, 136-140.

Uitgeverij Contact (geen datum a). Boeken buitenland. Geraadpleegd op 29 november, 2010, via www.renatedor restein. $\mathrm{nl} /$ index.php?id=14

Uitgeverij Contact (geen datum b). Prijzen en nominaties. Geraadpleegd op 29 november, 2010, via www.renate dorrestein.nl/index.php?id=33

Uphoff, M. (2005). Koudvuur. Amsterdam: De Bezige Bij.

U2 (2005). How to dismantle an atomic bomb [cd]. Mercury Music Group.

Vader verdacht van vermoorden twee kinderen (1997, 7 februari). De Volkskrant. Geraadpleegd op 10 september, 2007, via LexisNexis.

Vaessens, T. (2009). De revanche van de roman. Literatuur, autoriteit en engagement. Nijmegen: Vantilt.

VARA (2009, 16 april). De wereld draait door, schrijfstersdebat [tv-programma]. Geraadpleegd op 1 december, 2010, via http://dewerelddraaitdoor.vara.nl/Videodetail.628.0.html?\&tx_ttnews[tt_ news]=268\&txttnews[backPid]=626\&tx_ttnws[ct]=148\&cHash=fbf35cacf1ca42a01c1 9d76949a6730

Verboord, M., Janssen, S., \& Rees, C.J. van (2006). Indicatoren voor classificatie in het culturele en literaire veld. In G.J. Dorleijn \& Van Rees, C.J. van (red.), De productie van literatuur. Het Nederlandse literaire veld 1800-2000 (pp. 285-310). Nijmegen: Uitgeverij Vantilt.

Verenging Samenwerkende Ouder- en Patiëntenorganisaties (2003). Een wereld te winnen. Migranten en (para)medici voorlichten over erfelijke en aangeboren aandoeningen. Bevindingen van het VSOP project voorlichting over erfelijke en aangeboren aandoeningen gericht op migranten met een Turkse of Marokkaanse achtergrond 1999-2002. Soestdijk: VSOP/ZONMW. Geraadpleegd op 12 september, 2010, via www.erfocentrum.nl/pdf/onderzoeksverslagen/030700\%20Ervaringen\%20met\%20migrant envoorlichting \%20Een\%20wereld\%20te\%20winnen.pdf

Verhagen, L. (2000). De verloren vader. Kampen: VCL West-Friesland.

Verheijen, C. (1986). Moederschap; gecontroleerde zelfbeschikking. Jeugd en Samenleving, 16(3/4), 131138.

Verhulst, F.C. (2005). De ontwikkeling van het kind. Assen: Koninklijke Van Gorcum BV.

Voorbij, H.J., \& Douma, P.J.M. (1996). Hoe volledig is het Depot: een onderzoek naar de volledigheid van de collectie van het Depot van Nederlandse Publicaties. Den Haag: Koninklijke Bibliotheek.

Vos, L. (2008). Uitzondering op de regel. De positie van vrouwelijke auteurs in het naoorlogse Nederlandse literaire veld. Groningen: uitgave in eigen beheer.

Vreeken, R. (1997, 17 mei). Hoofddorp. De Volkskrant. Geraadpleegd op 10 september, 2007, via LexisNexis.

Vries, P. de (2006). De tweede feministische golf in herinnering. Inleiding op het thema. Themanummer: De tweede feministische golf. Tijdschrift voor Genderstudies. 9(2), 2-11.

Warmerdam, J.N. (2007). Opgroeien tot evenwichtige mensen. Kinderen van homoseksuele en lesbische ouders (Elektronische versie). Maatwerk, 8(2), 64-67.

Warmerdam, J.N. (2010). Homeseksuele en lesbische ouders. In A. Autrique, J.E. Baggerman, F. Boer, P. Cuijpers, E.J. Knorth et al., Gezin. Reeks Kinderen en adolescenten: problemen en risicosituaties (pp. 87-107). Houten: Bohn Stafleu van Loghum.

Weijers, I. (1991). Terug naar het behouden huis: romanschrijvers en wetenschappers in de jaren vijftig. Amsterdam: SUA.

Welles, O. (Director, Producer) (2003/1941). Citizen Kane [DVD]. UK: Universal Pictures.

Wellershoff, M. (2001, 8 Oktober). Doppelter Verlust. Die Niederländerin Maya Rasker lotet die Gefühle in einer Kleinfamilie aus. Der Spiegel, 41, 250.

Werners, J. (1990). Zuigend moeras. Amsterdam: Furie. 
Weusten, J.L. (2009). Een dodelijke kritiek op een geromantiseerd vertoog over moederschap. De moordende moeders in Dorresteins 'Een hart van steen' en Raskers 'Met onbekende bestemming'. Tijdschrift voor Genderstudies, 12(2), 314.

Weusten, J.L. (2010a). Dutch literary fiction post WWII. In B, Bechtold \& D. Cooper (red.), An encyclopedia of infanticide. New York: Edwin Mellen Press

Weusten, J.L. (2010b). An attack on a romanticized discourse on motherhood? Representations of murderous mothers in Dutch novels. Journal of the Motherhood Initiative for Research and Community Involvement, 1(1), 185 -195.

Wesseling, E. (2001). Geleerde moeders. Amsterdam: de Balie.

Wetenschappelijk Onderzoek- en Documentatiecentrum van het Ministerie van Justitie (2006). Integratiekaart 2006 (Elektronische versie). Den Haag/Heerlen: CentraalBureau voor de Statistiek/Wetenschappelijk Onderzoek- en Documentatiecentrum van het Ministerie van Justitie.

Weverling, A. (2006). Politiek gevangene. Amsterdam: Meulenhoff.

Wij Special Media BV (geen datum a). Wie zijn wij. Geraadpleegd op 19 september, 2010, via www.wijspecialmedia.nl/?m=wiezijnwij\&s=wiezijnwij

Wij Special Media BV (geen datum b). Producten van Wij. Geraadpleegd op 19 september, 2010, via www.wijspecial media.nl/?m=productenvanwij

Wiley, J. (2000). Rewriting "Cinderella": envisioning the empowering mother-daughter romance. In A. O'Reilly \& S. Abbey, Mothers and daughters. Connection, empowerment, and transformation (pp. 91-102). Boston: Rowman \& Littlefield Publishers.

Willems, J. (2009). Bibliografie. Geraadpleegd op 25 februari, 2009, via www.vonnevandermeer.nl

Wineke, B. (1992). Ontpopping. Baarn: De Prom.

Wobma. E., \& Graaf, A. de (2009). Scheiden en weer samenwonen. Bevolkingstrends, 4 e kwartaal 2009. Den Haag/Heerlen: Centraal Bureau voor de Statistiek. Geraadpleegd op 6 september, 2010, via www.cbs.nl/NR/rdonlyres/69C3FF3A-D853-46CE-A2D5-37A0D19DD4/0/2009k4b15p14art.pdf

Wolf, N. (2002). Misconceptions. Truth, lies and the unexpected on the journey to motherhood (2e druk). London: Vintage.

Wolfenstein, M. (1974/1955). Fun morality: an analysis of recent American child training literature. In M. Mead \& M. Wolfenstein (red.), Childhood in contemporary cultures (pp. 168-179). Chicago: University of Chicago Press.

Woodward, K. (red.). (1999). Figuring age. Women, bodies, generations. Bloomington \& Indianapolis: Indiana University Press.

Wouters, G., \& Gyselen, P. (2007). Altijd iemands dochter. De moeder-dochterrelatie in het werk van Nederlandstalige romanschrijfsters. In H. M. Müller \& I. Arteel (red.), Een vrouw die schrijft!: literatuur en literatoren feministisch bekeken (pp. 99-124). Brussel: ASP/VUBPRESS.

Wubs, J. (2000). Vaders gezin, moeders verantwoordelijkheid. Opvoedingsvoorlichting in Nederland over moeders en vaders, 1945-1995. Pedagogiek, 20(1). Geraadpleegd op 27 augustus, 2010, via www.pedagogiek-online.nl

Wubs, J. (2004). Luisteren naar deskundigen: opvoedingsadvies aan Nederlandse ouders 1945-1999. Assen: Koninklijke van Gorcum.

Zandbergen, J. (1989). Vrouwen doen 't beter. Intermagazine, 10, 68-70.

Zoonen, L. van (2006). Feminist media studies ( $3^{\mathrm{e}}$ druk). London: Sage.

Zuckerman, M. (1993). Almost chosen people. Oblique biographies in the American grain. Berkeley: University of California Press. 


\section{Summary}

Motherhood seems to be anything but a pleasurable experience in contemporary Dutch literature. Many novels about motherhood published in the past three decades focus on mothers in problematic situations. They depict mothers who loose control and go off the rails. Some of these mothers even batter, misuse, or murder their own children. Motherhood seems to be a terrible and severe ordeal in current Dutch literary fiction. It seems that on the whole mostly female authors publish such novels. Renate Dorrestein is known for writing fiction about disrupted families, as are Hannes Meinkema, Vonne Van der Meer, Saskia Noort, and Maya Rasker. Several of these authors seem to prefer pre-modern genres and elements in their depiction of motherhood.

In contrast to this literary preference for problematizing motherhood, contemporary Dutch society has a tendency to idealize motherhood in quite a normative manner. Motherhood is considered a conscious choice and it is generally believed that the practice of mothering can be molded, changed and controlled as one sees fit. In this context, mothers are expected to enjoy motherhood. It should be fun, as it is no longer something which just happens to women. It is determined by choice and an experience over which women have control. This particular image of motherhood has become prominent in the Netherlands since the 1980s. Due to the coercive presence of this idyllic notion of motherhood, many mothers find it difficult to openly discuss less pleasant experiences and aspects of motherhood. This seems to be taboo. However, since the 1980s Dutch novels have taken a different trajectory: they have focused on mothers who do not, or cannot, live up to this modern ideal.

The tension that results from this contrast is the central subject matter of this dissertation. The main research question is how literary representations of motherhood relate to the normative social ideal mentioned above. The current study mostly deals with the way in which Dutch literature represents motherhood in relation to this social construction of rosy-spectacled motherhood. I am referring to consciously chosen, white, middle-class motherhood in the context of a heterosexual nuclear family with young children. Do these novels criticize this norm? Do they initiate debates about this subject? Does Dutch literature produce new or alternative images of motherhood in the process, or is the norm of enjoyment (re)produced? In answering these questions, this thesis centers on original Dutch fiction from the period 1980-2010.

Literature is demarcated broadly in this study: it includes all novels and novellas that can be considered literature according to their Nederlandse Uniforme Rubriek- 
sindelings-code (Dutch Uniform Classification-code) also known as NUR-code. Literature is considered an integral part of society, as an imaginative force that partly informs our idea of motherhood. It is the social function of literature, which is analyzed here. That is why the literary school New Historicism, in particular the work of Jane Tompkins $(1985,1993)$ serves as the theoretical background to this study. Following Tompkins $(1985,1993)$ I will argue that novels can perform 'cultural work'. Tompkins uses this concept to refer to the way in which literature reflects on society, "defining certain aspects of a social reality which their authors and their readers shared, dramatizing its conflicts, and recommending solutions" (1985, p. 200). In doing so, literature can work to undermine existing social norms, but it can also confirm and reproduce them, and/or introduce new norms. Tompkins (1985) is mainly interested in the meanings that have (most likely) been attributed to novels by critics and readers. This study also takes an interest in the cultural work of literature. It is, however, not chiefly concerned with the meanings that readers and critics have assigned to novels. Although the reception of literature will be discussed, it is the disentanglement of the potential meanings of the novels themselves which is central to this book. This dissertation explores what is called the cultural work potential of novels. This term is also introduced to give voice to the fact that a researcher inevitably plays a part in the meanings that can be assigned to texts. By interpreting literary and non-literary texts from the vantage point of particular questions about motherhood, one does after all activate a specific part of their cultural potential. As such, they are in fact put to work in a particular manner.

In order to analyze the cultural work potential of literature about motherhood, methods from the sociology of literature and different methods of textuel interpretation of novels are combined in an innovative manner. This thesis contains a quantitative analysis of the production of novels on motherhood, and an in-depth structuralist, intertextual interpretation of four well-known novels on motherhood by female authors. Two of them deal with unwanted childlessness: De reis naar het kind (The journey to the child, 1989) by Vonne van der Meer, and Nieuwe buren (New neighbours, 2006) by Saskia Noort. The other two centre on infanticide: Een hart van steen (A heart of stone, 1998) by Renate Dorrestein, and Met onbekende bestemming (Unknown destination, 2000) by Maya Rasker. In the interpretation of these four novels ample attention is given to aspects of genre, as knowledge of the way in which particular genres are mobilized helps me to evaluate the relationship of the novels with its social context(s), for instance the effects of pre- and antimodern genres in these novels. It is particularly interesting to examine what kind of work these genres can do potentially, as they contrast with the modern signature of the social idealization of motherhood. Fatherhood also receives attention throughout this study, as the meanings we tend to assign to motherhood are often tied up with the way we look at fatherhood, and vice versa. 
In order to explore how literature relates to the modern polished image of motherhood, it is necessary to examine the idealization of motherhood over the past thirty years. The first chapter contains such a historical analysis. The dominant presence and the coercive character of today's idyllic image of motherhood is ascertained through a discussion of the representation of motherhood in educational self help books for parents, in commercial glossy magazines for women, in popular educational magazines for parents, and in advertisements and other promotional activities for baby products. For this discussion mostly sociological research on motherhood is used. This is complemented with a new analysis of, amongst others, the glossy Dutch magazine for parents Ouders van nu, and advertizing practices of Prénatal Moeder en Kind BV, the largest Dutch specialized store for pregnant women, mothers and their babies, and Maxi Cosi, a Dutch brand of car safety seats that are distributed world wide. In addition, the historical emergence and development of the modern hedonistic outlook on motherhood is embedded into larger social developments in the Netherlands.

This research shows that the current rosy-spectacled discourse of motherhood emerged at the beginning of the 1970s and has become dominant since the 1980s. It consists of the tacit assumption that the ideal mother is white and that she does not work full-time. In addition, she is believed to belong to the middle class; she has made a conscious choice to have children; and she is a member of a nuclear family household with young, healthy children. The relationship with her young children is symbiotic. Mothers who do not meet this implied typification, are not necessarily expected to enjoy their motherhood. It is, however, different for a mother who does: she is supposed to be blissfully happy because she is a mother. If she does experience any unpleasantness in this position, she is expected to call upon professional services that enable her to become happy after all. Thus, the idyllic discourse of motherhood emphasizes that white, middle class, consciously chosen motherhood in the context of a heterosexual, nuclear family with young and healthy children is a manageable and therefore pleasurable experience. Enjoyment is central to it. The normative character of what I henceforth call the 'discourse of enjoyment' becomes particularly visible when it is disrupted; when one cannot live up to it. A few of the larger social, historical developments, which provide fertile soil for the present rosy-spectacled notion of motherhood are: the emergence of a hedonistic life style, a modern notion of subjectivity, and a dominant outlook on life in Western societies, called the 'psychology of choice', which is grounded in the idea that happiness results from the right choices in life, and that one has control over one's life and luck.

This research demonstrates that the sources under discussion, as well as Dutch society as a whole, do not display motherhood monolithically. There are social, political, and scientific spaces in which negative aspects of motherhood are articulated. Many of these negative images, however, seem to strengthen the white, 
middle class, heterosexual character of the discourse of enjoyment 'ex negativo', as they usually revolve around types of motherhood, which are non-white, nonheterosexual, and non-middle class. Dominant ideas about the mothering practices of migrant women are, for instance, rather negative. Their motherhood is often problematized in political and public debates. The same is true for lesbian mothers or mothers from the 'lower' socio-economic classes. Still, negative representations of white, middle class, heterosexual, and consciously chosen motherhood also exist. However, many of these also seem to be dictated by the normative ideal. The discussion of problems is, for example, not completely absent from educational self help books and magazines, but they are depicted as relatively easy to manage. The overall gist of the argument remains sanguine: it may not be going well now, but there is no cause for worry. Motherhood will be a happy affair in no time, provided that you make the right choices. The normative influence of the idyllic discourse can thus even be felt in cases in which problematic sides of motherhood are brought into the limelight.

My discussion of various types of representations of motherhood simultaneously shows that representations of fatherhood are still relatively scarce in Dutch society. Some of the sources under discussion contain indications that fatherhood is on the verge of representation by the end of the research period, that is 2010 . Still, the invisibility of fathers in educational self help books, magazines, and advertorials is striking. What becomes clear as well is that the types of idealizations of motherhood and fatherhood differ. The combination of a (nearly) full-time career and fatherhood is for instance generally depicted as enriching, while the same combination is generally viewed as wearing out mothers.

Several important hypotheses about Dutch literature on motherhood are put to the test in chapter 2. This chapter is empirical in nature, following the institutional analyses of the production of literature by sociologists of literature such as Pierre Bourdieu (1994) and Susanne Janssen (1994, 1997, 1998, 1999). With the help of descriptive statistics, it maps the production of Dutch fictional novels and novellas on parenthood between January 11980 and December 31 2009. The abstracts and reviews of fictional novels and novellas on parenthood in the Nederlandse Centrale Catalogus (Dutch Central Catalogue) or NCC are analyzed. This database contains descriptions of nearly every book published in the Netherlands with an ISBNnumber. The total number of works which could be inventoried is 549. Of these, 148 were explicitly related to motherhood. Both sets of books were analysed separately. By taking all fictional prose on parenthood on board, the net is thus cast wider in this chapter than in the remainder of this book, which is limited to literary work in which motherhood is the most central topic. By also paying attention to works on fatherhood in this second chapter, it becomes possible to gain an insight into the larger prosaic context of which books on motherhood are part. Moreover, the em- 
pirical analysis is not restricted to literary works of fictions. Other fictional genres for adults are included as well to obtain a better impression of the relative position of the literary genres that depict motherhood and parenthood. The NUR serves as a guideline for a demarcation of the different types of genres. The NUR-genres 'literaire roman, novelle' ('literary novel, novella') and the 'streek- en familieromans' ('regional novels and family sagas') turn out to be largest genres by far. This is valid for works on parenthood in general, as for books on motherhood.

The major objective of this chapter is to find out whether motherhood in literary fiction is mainly depicted in relation to problems. There are strong indications that this is indeed the case. A thorough examination of the NCC-abstracts and reviews of the 148 works on motherhood reveals that motherhood is problematized in the majority of these books, namely $91,2 \%$, regardless of their NUR-genre. This is no different for the largest literary genre, the 'literary novel/novella': motherhood is depicted as problematic in $89,9 \%$ of the 99 works in this genre. This representational tendency is not limited to books on motherhood, but extends to works on parenthood, and henceforth also fatherhood. In 90,0\% of the 549 books under discussion parenthood is not depicted as a rosy affair. It can thus be concluded that Dutch, fictional prose is generally a domain in which parenthood, and motherhood, is systematically linked to misfortune. The descriptions of the novels and novellas show furthermore that there are recurrent themes which emerge in these works, such as the death and/or illness of a parent, the absence of a parent, single parenthood, religion, adoptive parenthood, foster parenthood and step parenthood, war, and pregnancies and children (born) out of wedlock.

Secondly, this second chapter aims to provide insight into the gender of the authors who write on parenthood and motherhood. Literary criticism has claimed that mainly female authors write about these subjects, but the opposite position has been taken as well. An analysis of the gender of the writers of the novels and novellas on parenthood in general and motherhood in particular indicates that female authors outnumber male authors: $59,9 \%$ of the 549 works on parenthood have female authors and $68,2 \%$ of the 148 books on motherhood were written by women. Of the largest literary genre of the books on motherhood - the 'literary novel/novelle' - $60,6 \%$ was written by women. These percentages are comparatively large, as women in general tend to produce a much smaller part of fiction in the Netherlands than men. Research has shown that in 1987 the percentage of fictional prose published by women was, for instance, only 27,0\%, and in 1995 it was 29,0\% (Van Rees, Janssen \& Verboord, 2006).

Finally, this chapter aims to achieve a first impression of the cultural scope of fictional prose on parenthood and motherhood, and of literary fiction on motherhood in particular. This was done through a quantitative analysis of the exposure of the books that have been published from 1995 onwards, in five Dutch newspapers: Algemeen Dagblad, de Volkskrant, Het Parool, NRC Handelsblad and Trouw. In addi- 
tion, the influence of the gender of the author on the exposure in the newspapers is analyzed. In debates about the attention given to and appreciation of female and male authors it is still claimed that women structurally receive less media attention than men. I examine whether this holds for fictional prose on parenthood and motherhood in the five newspapers mentioned above. With that, attention is paid to the influence of the NUR-genre of a book on its exposure. The analysis shows, first of all, that $43,1 \%$ of all prose on parenthood is mentioned in one of the newspapers $(n=343)$. This turns out to be $51,0 \%(n=96)$ for the works on motherhood. The gender of the author does not seem to affect the exposure books on parenthood receive, but genre does. 'Literary novels/novelles' are mentioned more frequently in newspapers than 'regional novels and family sagas'. There is, though, a strong indication for a connection between the number of times a book on parenthood is mentioned in the newspapers and the gender of the author. Men have the advantage here. Their books are cited far more frequently than those written by women. As far as the books on motherhood are concerned, little can be said about the possible connections between sex, genre and exposure because of the few books that could be taken into account. Although a direct relationship between media exposure and the gender of the author could not always be found, it might still be the case that gender indirectly influences the exposure of fictional prose on parenthood and motherhood in the newspapers under scrutiny.

The quantitative analysis in this chapter limits possible answers to the questions that are central to this book. First, the analysis seems to provide an incomplete image of the themes that are dealt with in prose on motherhood. Infanticide, for example, was not a topic in the abstracts and reviews, while several literary critics and literary scholars have pointed at this theme in contemporary prose on motherhood. Moreover, they feel that books on this topic are important and telling in light of the existence of a rosy picture of motherhood in Dutch society. In addition, the NUR-genre of 'literaire thriller' ('literary thriller') is absent in my inventory of the NUR-genres. This is striking, considering that this genre has been connected to parenthood and family life by critics. One of the most important restrictions is, however, that barely anything can be said about the relationship between the prose under analysis and the discourse of enjoyment. The abstracts and reviews in the NCC are hardly indicative of such a relationship. That is why in-depth interpretations of novels themselves are needed. Chapters 4, 5, 6 and 7 contain these interpretations.

Chapter 3 explains in more detail the relation between the sociology of literature and the practice of interpreting novels, the selection of the four case studies, and the method used in interpreting them. I argue that quantitative methods from literary sociology and the methods used to interpret novels share an interpretative quality. Moreover, I suggest that these methods complement each other in this 
research. The largely quantitative analysis of the production of literature makes it possible to gain insight into trends in the literary field enabling me to test some of the research assumptions of chapter 2 . It also makes it possible to situate the four individual case studies and their meanings in a larger context. The interpretations of those cases make it in turn possible to study the cultural work potential of novels vis à vis the social context.

The selection of the novels under analysis has been largely determined by their central theme: white, middle class, heterosexual, consciously chosen motherhood in a nuclear family. As mentioned before, although infanticide does not appear as a topic in the NCC abstracts and reviews, literary scholars and critics have explicitly connected novels about infanticide with the rosy-spectacled norm of motherhood. There seems to be a strained relationship between these books and this particular social norm, which makes them highly interesting cases. Een hart van steen (Dorrestein, 1998) and Met onbekende bestemming (Rasker, 2000) were selected for this reason. This also holds for the two novels on unwanted childlessness. The authors of these novels and literary critics have associated De reis naar het kind (Van der Meer, 1989) and Nieuwe buren (Noort, 2006) with certain elements of the discourse of enjoyment on motherhood. Unwanted childlessness was, for that matter, revealed as a recurring, albeit inconspicuous, theme in the quantitative analysis of the NCC- abstracts and reviews. Narrations about unwanted childlessness do not only depict an (unfulfilled) desire to have a child, but also frequently represent ideas about the desired object - motherhood - itself. The question what it means to be a mother becomes pressing after all when it is difficult to fulfill one's longing for a child. All four novels are by female writers and, thus, they are representative of the gender distinction mentioned in chapter 2. Another selection criterion has to do with genre: these novels are literary fiction for adults according to their NUR-codes. Three of them are 'literary novels/novelles'. These are De reis naar het kind (Van der Meer, 1989), Een hart van steen (Dorrestein, 1998) and Met onbekende bestemming (Rasker, 2000). They belong to the largest NUR-genre that was revealed in the quantitative analysis of prose on motherhood in the NCC. Nieuwe buren (Noort, 2006) is a 'literary thriller', a genre which was strikingly absent from my analysis in chapter 2. The selection of Nieuwe buren (Noort, 2006) is complementary to this analysis. Another reason for assessing Nieuwe buren is the scarcity of interpretative research on Dutch thriller novels. In addition, these novels were chosen because they have had a large cultural scope. They have been read and reviewed both inside and outside the Netherlands. Finally, selecting novels on unwanted childlessness and infanticide means that a choice was made for works of fiction that potentially contain alternative representations of motherhood. Representations which differ from those foregrounded by the discourse of enjoyment. Unwanted childlessness is an experience which sits uneasy with the notion that we can simply choose to have children and that motherhood is a manageable affair. That a mother who kills her 
child presents an extremely disturbing, cultural image of motherhood that seems to be at odds with a hedonistic outlook, is self-evident. Selecting novels about such themes was done in a conscious effort to compensate the normative influence of the discourse of enjoyment. As such, this dissertation is in keeping with gender studies, which provides insight into the cultural construction of gender. The goal of which is to produce knowledge, which makes it possible to call inequalities between both men and women into question.

Attention to intertextuality and the structure of the novels are pivotal ingredients of the method of interpretation used in this dissertation. The latter gives ample attention to genre-aspects of the four novels, letting go of the strict use of the NURgenres. More specifically, the method is based on Maaike Meijer's (1996a) notion of intertextuality, and structuralistist narratology as developed by Mieke Bal (2007, 1980).

Chapter 4 contains the analysis of De reis naar het kind (1989) by Vonne Van der Meer. In this novel Julia and Max, who are unable to have children, try to adopt a child via illegal means. The plot takes a rather absurd turn, as the tormented Julia and Max adopt an old man, Pablo, instead of a baby. De reis naar het kind (Van der Meer, 1989) counters a hedonistic outlook on the mother-child relationship, and the idea that we are free to choose if and when to have children. Instead the novel pleads for a type of motherhood that includes greater self-sacrifice. In addition, the book can be read as a critical exploration of intercontinental adoption. As such, the novel foregrounds the agony, pain and despair that can be caused by being childless by default, as well as of having to raise a child in poverty. This cultural work potential is activated when the novel is approached as a fairy tale. An approach legitimized by the interplay of several intertextual references in the novel. These concern amongst others the pre-modern genre of the fairy tale, the fantastic travel story Gulliver's travels by Jonathan Swift, Orson Welles, the Bible passage Solomon's Wisdom, and Miguel Hernandéz's poems.

The 'literary thriller' Nieuwe buren (2006) by Saskia Noort is analyzed in chapter 5. The central theme of this novel is Peter and Eva's unfulfilled longing for a child. More importantly, the novel deals with the lethal consequences of the couple's, and particularly Eva's, quest for a child. Nieuwe buren (Noort, 2006) relates to the discourse of enjoyment in a contradictory manner. On the one hand, the modern, idyllic image of family life and motherhood is subverted in a thrilleresque way. However, the novel can also invite a reading that leaves crucial parts of this picture in place. This ambivalence is the result of the genres mobilized: the male and female version of the a-heroic crime novel and the homely gothic novel. Although they give the book a thrilling quality, they may also make the novel's criticism of modern family life more superficial. This is possibly due to the fact that the genres mobilized 
in the book are not pre-modern, although they can help to introduce archaic elements.

Een hart van steen (1998) by Renate Dorrestein is discussed in chapter 6. Margje van Bemmel, the novel's main character, massacres nearly her entire family after the birth of her fifth child Ida in 1972 and and then commits suicide. Only 12-year old Ellen and her little brother Michiel have a narrow escape and survive. Twentyfive years later, Ellen, now pregnant, discloses this tragic family history. The novel is interspersed with intertextual references to the genre of the homely gothic novel, to Greek tragedy and Christianity. The use of gothic elements undermines the modern image of the autonomous, rational, self-restrained subject. References to Greek tragedy introduce an outlook on fate that diverges from the modern belief in the manipulability of our lives. This holds for the references to Christianity as well. All in all, the novel produces a range of meanings that can erode the idealized modern norm of motherhood that is immersed in modern ideas about subject, choice and manipulability. This is mainly the result of the introduction of anti- and pre-modern genres and discourses, of which the Greek tragedy is the most important one. There are, however, limits to this disrupting potential of the novel. These limits are partly drawn by the reproduction of the medical-psychological discourse on postpartum depression.

Met onbekende bestemming (2000) by Maya Rasker is at the heart of chapter 7 . This novel focuses on the struggle of Raya Mira Salomon, who is a writer by profession, with her newly acquired status as a mother. This finally culminates in her murder of her little daughter Lizzy on the morning of the latter's fifth birthday. Motherhood and fatherhood are represented in a relational manner, with the help of intertextual references to evolutionary-biological ideas about gender, and to gendered discourses on combining work and parenthood. My analysis shows that the interplay of these discourses generates different and even competing meanings. The novel does, however, question the idyllic picture of motherhood that is held up in contemporary educational self help books, magazines, and advertisements. For Raya kills her child, because she feels suffocated by the symbiotic type of motherhood that is prescribed by these sources. The novel's ambivalent character is enhanced by the overabundance of references to the genre of poetry. These concern explicit quotes from poems, as well as a poetic use of prose in the way Raya's history is told. In the end these references legitimize a reading in which a poststructuralist view on reality and language is called upon. That is how the novel makes a stand against the modern idealization of motherhood. The book can above all be read as a poem in itself, in which experiences of motherhood, fatherhood, infanticide, loss, and death are depicted in an indirect manner. 
In my conclusion at the end of this dissertation I argue that the modern idea of enjoyment, which surrounds motherhood nowadays, is questioned in a critical manner in all four novels. The coercive character of this discourse of enjoyment becomes visible in these books as well. As such, the structuralist, intertextual interpretations of the novels add to knowledge of the presence and the functioning of the hedonistic perspective on motherhood.

The major result of this research is that pre-modern and/or anti-modern perspectives turn out to play a pivotal role in the undermining force of the novels. All books contain intertextual references to genres that open up pre-modern or antimodern representations of motherhood. Van der Meer's novel contains intertextual references to the fairy tale, Noort refers to the a-heroic crime novel; we find references to the (homely) gothic novel in Noort (2006), Dorrestein (1998) and Rasker (2000); to Greek tragedies in Dorrestein (1998) and Rasker (2000), and poetry in Rasker's Met onbekende bestemming (2000). These references often, though not always, unlatch meanings, which make it possible to read the novels as critical commentaries on the modern discourse of enjoyment.

In addition, it is concluded that the combination of quantitative methods from literary sociology and methods that serve the interpretation of novels can be productive in a project that aims to unravel the cultural work potential of novels. The quantitative approach enabled us to map trends, to test some general assumptions about Dutch contemporary literature on motherhood, and helped us to situate the individual case studies. Structualist, intertextual interpretation consequently made it possible to unravel in detail the way novels can work: the meanings they can produce, and how these relate to social developments. Moreover, through these interpretations it proved to be possible to put the novels at hand at work, in order to undercut the modern, normative idealization of motherhood. 


\section{curriculum vitae}

Jos Leonarda (Josje) Weusten (Heerlen, 1980) behaalt in juli 1998 haar atheneumdiploma aan het Bernardinuscollege te Heerlen (cum laude). Aansluitend studeert ze cultuur- en wetenschapsstudies aan de Faculteit der Cultuur- en Maatschappijwetenschappen van de Universiteit Maastricht. Ze legt zich tijdens haar studie voornamelijk toe op gender- en diversiteitsstudies, literatuurwetenschap en filosofie. Ze studeert in juli 2003 af op een doctoraalscriptie over de constructie van moederschap in persoonlijke verhalen van moeders van kinderen die autisme hebben.

$\mathrm{Na}$ haar afstuderen werkt Weusten als communicatiemedewerker wetenschap bij de Universiteit Maastricht en verschijnen van haar verscheidene journalistieke artikelen. Sinds 2004 is ze werkzaam als docent en onderzoeker bij het Centrum voor Gender en Diversiteit en de capaciteitsgroep Letteren en Kunst van de Faculteit der Cultuur- en Maatschappijwetenschappen, Universiteit Maastricht, waar zij sinds 2007 ook haar promotieonderzoek heeft uitgevoerd. Zij heeft de Talentenbeurs van de Faculteit der Cultuur- en Maatschappijwetenschappen gekregen om dit onderzoek op te starten. Deze beurs wordt jaarlijks toegekend aan een talentvolle, veelbelovende jonge onderzoeker. Daarnaast doceert Weusten sinds 2004 aan het University College Maastricht. Namens het Centrum voor Gender en Diversiteit is ze betrokken geweest bij verschillende maatschappelijke en culturele projecten over gender, zoals Internationale Vrouwendag Maastricht, het artistiek, euriogonale project Planet Gender en het festival Women in Science, Education and Research (WISER).

Weusten mengt zich ook in publieke debatten over gender en met name ouderschap, door journalistieke publicaties in bijvoorbeeld het tijdschrift Lover en Dagblad de Limburger en interviews op L1 Radio en L1 TV. Ze heeft haar onderzoek onder meer op conferenties aan Standford University (VS) en York University (Canada) gepresenteerd en ze publiceerde over de verbeelding van moederschap in (peer viewed) wetenschappelijke tijdschriften, zoals het Journal of Literary and Cultural Disability Studies, het Journal of the Motherhood Initiative en het Tijdschrift voor Genderstudies. Weusten is lid van het European Network in Aging Studies en van The Motherhood Initiative for Research and Community Involvement. 



\section{Publicatieoverzicht}

\section{Wetenschappelijke publicaties}

Weusten, J.L. (2011). Narrative constructions of motherhood and autism. Reading embodied language beyond binary oppositions. Journal of Literary and Cultural Disability Studies, 5(1), 53-70.

Weusten, J.L. (2010). An attack on a romanticized discourse on motherhood? Representations of murderous mothers in Dutch novels. Journal of the Motherhood Initiative for Research and Community Involvement, 1(1), 185-195.

Weusten, J.L. (2010). [Recensie van Vall, R. van de \& Zwijnenberg, R. The body within. Art, medicine and visualization. Leiden: Uitgeverij Brill (2009)]. Tijdschrift voor Genderstudies,13(3), 53-56.

Weusten, J.L. (2010). Dutch literary fiction post WWII. In B, Bechtold \& D. Cooper (red.), An encyclopedia of infanticide. New York: Edwin Mellen Press.

Weusten, J.L. (2009). Unraveling the mechanisms of the beauty industry. Concretizing discourse analysis. Transformations: The Journal of Inclusive Scholarship and Pedagogy, xix(2), 129-134.

Weusten, J.L. (2009). Een dodelijke kritiek op een geromantiseerd vertoog over moederschap. De moordende moeders in Dorresteins Een hart van steen en Raskers Met onbekende bestemming. Tijdschrift voor Gendestudies, 12(2), 3-14.

Weusten, J.L. (2006). Voorbij de grenzen van taal. Narratieve identiteiten van moeders van kinderen met autisme. Tijdschrift voor Genderstudies, 9(4) 16-27.

\section{Professionele publicaties (selectie)}

Weusten, J.L. (2009). Oproep tot een feministische ouderschapsbeweging. Lover. Tijdschrift over feminisme, cultuur en wetenschap, www.tijdschriftlover.nl, 3 maart, 2009.

Weusten, J.L. (2007). Eindeloze buien. Rachel Cusk en de donkere kanten van het moederschap. Lover. Tijdschrift over feminisme, cultuur en wetenschap, 34 (4), pp 20-21.

Weusten, J.L. \& Mast, A. van der (2007). De groene omkleedcabine. Turkse studentes manoeuvreren tussen secularisme en islam. Lover. Tijdschrift over feminisme, cultuur en wetenschap, 34(2), pp. 26-27.

Weusten, J.L. (2007, 6 oktober). Emancipatie kan niet zonder mannen. Dagblad de Limburger, p. 3.

Verscheidene andere publicaties in het Research Magazine van de Universiteit Maastricht en in Observant, de universiteitskrant van de Universiteit Maastricht.

\section{Conference Papers (selectie)}

Weusten, J.L. (2009). Beyond a fairytale of motherhood? Motherhood and adoption in the Dutch novel De reis naar het kind. 7th European Feminist Research Conference, Universiteit Utrecht, Nederland, 4-7 juni 2009.

Weusten, J.L. (2008). Forced to enjoy? An analysis of representations of mothers who commit infanticide in Dutch literary fiction. Mothering, Violence, Militarism, War and Social Justice Conference, The Association for Research on Mothering (ARM), York University, Toronto, Canada, 23-26 oktober 2008.

Weusten, J.L. (2008). Forced to enjoy? An analysis of literary representations of mothers who commit infanticide. 2nd Annual Joint Student and Alumni Symposium, Stanford University, Calfornië, VS, 29 juni 2008.

Weusten, J.L. (2008). De dwang tot genieten. Literaire ruimte voor de donkere kanten van ouderschap. 'Achter de Verhalen', Radboud Universiteit Nijmegen, Nederland, 27 maart 2008. 


\section{In de media}

Németh, Kris (2011, Juni 8). Kinderopvang gekort. Interview over de bezuinigingen op de kinderopvangtoeslag. L1Laat (L1 TV).

Priems, Lubert (2009, 6 maart). Interview over Internationale Vrouwendag. Balkon van Limburg (L1 Radio).

Simoen, Ray (2008, 5 juli). Moederhart is vaak loodzwaar. Dagblad de Limburger.

Paulus, Kirsten (2007, 3 december). Interview over de seksualisering van de Nederlandse samenleving. Balkon van Limburg (L1 Radio). 